UNIVERSIDADE DE SÃO PAULO

FACULDADE DE MEDICINA DE RIBEIRÃO PRETO

DEPARTAMENTO DE FISIOLOGIA

FERNANDA BROGNARA PENTEADO DIAS

Papel do sistema nervoso autônomo na modulação da resposta inflamatória sistêmica em ratos não anestesiados

Ribeirão Preto 
Papel do sistema nervoso autônomo na modulação da resposta inflamatória sistêmica em ratos não anestesiados

Tese apresentada à Faculdade de Medicina de Ribeirão Preto, Universidade de São Paulo, para obtenção do título de Doutora em Ciências.

Área de concentração: Fisiologia

Orientador: Prof. Dr. Helio Cesar Salgado

\section{Versão corrigida}

A versão original encontra-se disponível tanto na Biblioteca da Unidade que aloja o Programa, quanto na Biblioteca Digital de Teses e Dissertações da USP (BDTD). 


\section{FICHA CATALOGRÁFICA}

Autorizo a reprodução e divulgação total ou parcial deste trabalho, por qualquer meio convencional ou eletrônico, para fins de estudo e pesquisa, desde que citada a fonte.

Brognara, Fernanda

Papel do sistema nervoso autônomo na modulação da resposta inflamatória sistêmica em ratos não anestesiados. Ribeirão Preto, 2021.

290 p. : il.; $30 \mathrm{~cm}$

Tese de Doutorado, apresentada à Faculdade de Medicina de Ribeirão Preto/USP. Área de concentração: Fisiologia.

Orientador: Salgado, Helio Cesar.

1. Barorreflexo. 2. Quimiorreflexo. 3. Estimulação elétrica. 4. Oclusão da carótida. 5. Inflamação sistêmica. 6 . Sistema nervoso autônomo. 


\section{FOLHA DE AVALIAÇÃO}

Aluna: Fernanda Brognara Penteado Dias

Título: Papel do sistema nervoso autônomo na modulação da resposta inflamatória sistêmica em ratos não anestesiados

Tese apresentada à Faculdade de Medicina de Ribeirão Preto, Universidade de São Paulo, para obtenção do título de Doutora em Ciências.

Área de concentração: Fisiologia

\section{Banca Examinadora:}

Prof. Dr. Eduardo Moacyr Krieger

Instituição: Faculdade de Medicina (FM-USP)

Assinatura:

Prof. Dr. Fernando Silva Carneiro

Instituição: Faculdade de Medicina de Ribeirão Preto (FMRP-USP)

Assinatura:

\section{Prof. ${ }^{a}$ Dr. ${ }^{a}$ Fernanda Luciano Rodrigues}

Instituição: Universidade Federal de Mato Grosso do Sul (UFMS)

Assinatura:

Prof. Dr. Helio Cesar Salgado (Orientador)

Instituição: Faculdade de Medicina de Ribeirão Preto (FMRP-USP)

Assinatura: 
Dedico esta tese aos meus pais, Edgard e Cecília, que com amor incondicional não mediram esforços para que eu realizasse todos os meus sonhos. 


\section{AGRADECIMENTOS}

Aos meus pais, Edgard Brognara Júnior e Maria Cecília Rocha Brognara, e aos meus irmãos, Gustavo Brognara e Gabriel Brognara, por sempre acreditarem no meu potencial, pelos conselhos, suporte, incentivo, auxílio, companheirismo, compreensão, amizade e amor diários. Sempre serão minha base, inspiração e responsáveis pelas minhas conquistas.

Ao meu esposo, Daniel Penteado Martins Dias, o qual admiro muito, por estar sempre ao meu lado com seu amor e amizade, por compartilhar a vida e os sonhos comigo, por me fazer feliz e me incentivar a ser melhor a cada dia, e pelo apoio essencial para o desenvolvimento e finalização desta tese.

Aos meus sogros, Angélica Maria Penteado Martins Dias e Manoel Martins Dias Filho, pelo grande apoio e incentivo sempre.

Ao meu orientador, Prof. Dr. Helio Cesar Salgado, por me receber em seu laboratório e possibilitar que eu descobrisse a vocação pela pesquisa científica, por todos os ensinamentos e inúmeras oportunidades singulares proporcionadas ao longo desses anos desde a iniciação científica.

Ao meu supervisor no estágio na Nova Zelândia, Prof. Dr. Julian Francis Richmond Paton, um pesquisador admirável, pelas oportunidades, apoio, paciência e conhecimento repassado.

Ao Prof. Dr. Rubens Fazan Júnior, pelas conversas, auxílio e contribuições com a minha formação.

Ao Sr. Jaci Airton Castania, meu grande mestre, amigo, conselheiro e parceiro nos experimentos desde a iniciação científica, pela alegre companhia diária, pelo apoio de sempre e pela valiosa contribuição com a minha formação acadêmico-científica e com o desenvolvimento desta tese. 
Ao Dr. Alexandre Kanashiro, pelo conhecimento científico e valores de um bom cientista repassados, além da amizade que cultivamos ao longo desses anos.

Aos técnicos Sr. Mauro de Oliveira, Sr. Carlos Alberto Aguiar da Silva, Sr. Leonardo

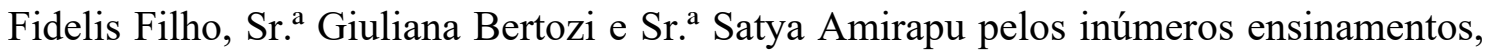
auxílio, apoio e amizade.

Aos amigos e colegas de laboratório, Dr. Pedro L. Katayama, Prof. ${ }^{a}$ Dr. ${ }^{a}$ Fernanda L. Rodrigues, Prof. ${ }^{\text {a Dr. }}$ ' Renata M. Lataro, Prof. Dr. Fábio N. Gava, Dr. Luiz Eduardo V. da Silva, Ms. Thaís C. P. Costa, Ms. Igor S. A. Felippe, Dr. ${ }^{a}$ Aline B. Ribeiro, Ms. Thaís M. da Silva, Rafael R. dos Santos e Amanda R. A. Barboza, que acompanharam diariamente a rotina de experimentos. Em especial, à Dr. ${ }^{a}$ Ana Carolina M. Omoto, que foi paciente em me ouvir nos momentos difíceis e compartilhou aqueles de felicidade tornando a jornada mais leve.

Aos colegas que cursaram junto comigo as disciplinas compulsórias da Pós-Graduação, pois finalizamos juntos uma das etapas mais difíceis desse processo. Em especial à Ms. Natany Garcia Reis, a qual admiro muito pela pessoa e pesquisadora que é, e que sempre se manteve ao meu lado.

Aos docentes do curso de Pós-Graduação em Fisiologia da Faculdade de Medicina de Ribeirão Preto da Universidade de São Paulo, por contribuírem com a minha formação.

Aos funcionários da secretaria da Fisiologia, Sr. ${ }^{a}$ Cláudia de Barcellos Vanzela, Sr. ${ }^{\text {a Elisa }}$ Maria Aleixo, Sr. Fernando C. Rastello e Sr. Igor Mateu Silva, sempre dispostos a ajudar, pelo eficiente trabalho e amizade.

À Faculdade de Medicina de Ribeirão Preto da Universidade de São Paulo, pela infraestrutura necessária ao desenvolvimento deste trabalho.

Às agências de fomento, FAPESP, CAPES e CNPq, que permitiram a realização desta pesquisa. 
“Não há lugar para a sabedoria onde não há paciência." 
Este trabalho foi desenvolvido com o apoio financeiro da Fundação de Amparo à Pesquisa do Estado de São Paulo (FAPESP), processos n. 2017/05163-6 e 2018/16953-0, da Coordenação de Aperfeiçoamento de Pessoal de Nível Superior (CAPES-PROEX), processo n. 88887.505419/2020-00 e do Conselho Nacional de Desenvolvimento Científico e Tecnológico (CNPq), processo n. 870308/1997-1. 


\section{RESUMO}

BROGNARA, F. Papel do sistema nervoso autônomo na modulação da resposta inflamatória sistêmica em ratos não anestesiados. 2021. Tese (Doutorado) - Faculdade de Medicina de Ribeirão Preto, Universidade de São Paulo, Ribeirão Preto, 2021.

Ambos os ramos do sistema nervoso autônomo (parassimpático e simpático) têm sido associados à regulação da inflamação. No entanto, há muito a ser investigado. A fim de explorar o papel do sistema nervoso autônomo na modulação da resposta inflamatória sistêmica, o presente estudo avaliou: (i) os efeitos da ativação parassimpática em ratos endotoxêmicos não anestesiados usando a estimulação elétrica do nervo depressor aórtico; (ii) os efeitos da ativação simpática reflexa por meio da oclusão bilateral carotídea (OBC), uma abordagem fisiológica que envolve os mecanismos barorreflexo e quimiorreflexo; (iii) a influência dos barorreceptores e quimiorreceptores periféricos na resposta inflamatória, por meio da denervação cirúrgica seletiva. Ratos Wistar Hannover foram utilizados em todos os protocolos e a inflamação sistêmica foi induzida pela administração de lipopolissacarídeo (LPS). Antes de iniciar os protocolos principais, foi realizado um estudo das doses de LPS. Quatro doses diferentes foram testadas por via intravenosa: 0,06 mg/kg; $20 \mathrm{mg} / \mathrm{kg} ; 30 \mathrm{mg} / \mathrm{kg}$; e $40 \mathrm{mg} / \mathrm{kg}$. Todas as doses examinadas induziram taquicardia ao longo do tempo, mas apenas a dose mais baixa $(0,06 \mathrm{mg} / \mathrm{kg})$ reduziu a pressão arterial, como geralmente visto na inflamação sistêmica. Além disso, o LPS diminuiu a sensibilidade barorreflexa e alterou o equilíbrio autonômico, independentemente da dose usada. Portanto, os protocolos seguintes foram conduzidos com 0,06 mg/kg (i.v.) de LPS a fim de mimetizar melhor as respostas hemodinâmicas clássicas observadas durante a inflamação. Em ambos os protocolos, amostras de sangue foram coletadas ao longo de 360 min após a administração de LPS para análise dos níveis de citocinas em diferentes momentos, e todos os experimentos foram realizados com ratos não anestesiados. No protocolo de ativação parassimpática, o barorreflexo foi estimulado com sucesso, mas não foi capaz de atenuar o aumento das citocinas plasmáticas induzidas por LPS em nenhum dos momentos avaliados. Além disso, o desequilíbrio autonômico e a diminuição da sensibilidade barorreflexa induzidos pelo LPS não foram evitados pela ativação barorreflexa. No protocolo com ativação simpática, a OBC induziu ativação reflexa do sistema nervoso simpático, reduziu os níveis de citocinas inflamatórias no plasma, incluindo o fator de necrose tumoral (TNF) e a interleucina (IL)-1 $\beta$, e aumentou 
a citocina anti-inflamatória IL-10, 90 min após a administração de LPS. Além disso, a denervação dos barorreceptores ou quimiorreceptores, por si só, diminuiu a liberação de citocinas induzida por LPS, destacando o papel desses receptores periféricos como imunossensores durante um desafio imunológico. Além disso, a desnervação dos barorreceptores aumentou o nível de IL-10 no plasma. No entanto, a OBC também não preveniu alterações no equilíbrio autonômico e na sensibilidade barorreflexa decorrentes da administração de LPS. Em conclusão, esses achados indicam que a ativação parassimpática associada à inibição simpática não tem efeito anti-inflamatório sistêmico em ratos endotoxêmicos não anestesiados. Por outro lado, a ativação reflexa global do sistema simpático é capaz de modular a resposta inflamatória sistêmica. Finalmente, este estudo também sugere uma nova função para os barorreceptores como imunossensores durante um desafio imunológico.

Palavras-chave: Barorreflexo. Quimiorreflexo. Estimulação elétrica. Oclusão da carótida. Inflamação sistêmica. Sistema nervoso autônomo. 


\begin{abstract}
BROGNARA, F. Role of the autonomic nervous system in the systemic inflammatory response modulation in unanesthetized rats. 2021. Thesis (Ph.D.) - Ribeirão Preto Medical School. University of São Paulo, Ribeirão Preto, 2021.
\end{abstract}

Both branches of the autonomic nervous system (parasympathetic and sympathetic) have been associated with the regulation of inflammation. However, there is much to be investigated. In order to explore the role of the autonomic nervous system in the systemic inflammatory response modulation, the present study evaluated: (i) the effects of parasympathetic activation in unanesthetized endotoxemic rats using the aortic depressor nerve electrical stimulation; (ii) the effects of reflex sympathetic activation using the bilateral carotid occlusion (BCO), a physiological approach which involves the baroreflex and chemoreflex mechanisms; (iii) the influence of the baroreceptors and peripheral chemoreceptors, in the systemic inflammatory response, through selective surgical denervation. Male Wistar Hannover rats were used in all protocols, and the systemic inflammation was induced by lipopolysaccharide (LPS) administration. Before start the main protocols, a study of the LPS doses was conducted. Four different doses were tested intravenously: $0.06 \mathrm{mg} / \mathrm{kg} ; 20 \mathrm{mg} / \mathrm{kg} ; 30 \mathrm{mg} / \mathrm{kg}$; and $40 \mathrm{mg} / \mathrm{kg}$. All doses examined induced tachycardia over time, but only the lowest dose $(0.06 \mathrm{mg} / \mathrm{kg})$ reduced the arterial pressure, as generally seen in systemic inflammation. In addition, LPS decreased baroreflex sensitivity and changed the autonomic balance regardless of the dose used. Therefore, the next protocols were conducted using $0.06 \mathrm{mg} / \mathrm{kg}$ (i.v.) of LPS in order to mimic better the classic hemodynamic responses observed during inflammation. In both protocols, blood samples were collected over $360 \mathrm{~min}$ after LPS administration to analyze the cytokines levels in different moments, and all the experiments were performed in unanesthetized rats. In the protocol comprising the parasympathetic activation, the baroreflex was successfully stimulated but was unable to attenuate the increase in plasma cytokines induced by LPS at any of the evaluated moments. Moreover, the autonomic imbalance and the baroreflex sensitivity reduction induced by LPS were not prevented by the baroreflex activation. In the protocol involving the sympathetic activation, the BCO elicited reflex activation of the sympathetic nervous system, reduced the levels of inflammatory cytokines in plasma, including the tumoral necrosis factor (TNF) and the interleukin (IL)-1 $\beta$, and increased the anti-inflammatory cytokine IL-10, 90 min after LPS 
administration. In addition, either baroreceptor or chemoreceptor denervation, by itself, decreased the LPS-induced cytokine release, highlighting the role of these peripheral receptors as immunosensors during an immune challenge. Moreover, baroreceptor denervation increased the level of IL-10 in the plasma. Nevertheless, the BCO also did not avoid changes in the autonomic balance and baroreflex sensitivity over time, resulting from the LPS administration. In conclusion, these findings indicate that the parasympathetic activation associated with sympathetic inhibition has no systemic antiinflammatory effects in unanesthetized endotoxemic rats. On the other hand, global reflex activation of the sympathetic system is able to modulate the systemic inflammatory response. Finally, this study also suggests a novel function for the baroreceptors as immunosensors during an immune challenge.

Keywords: Baroreflex. Chemoreflex. Electrical stimulation. Carotid occlusion. Systemic inflammation. Autonomic nervous system. 


\section{LISTA DE FIGURAS}

Figura 1. Diagrama ilustrando as interações entre as células imunes e e eixo hipotálamo-hipófise-adrenal. As setas sólidas indicam estimulação e as tracejadas indicam inibição. CRH: hormônio liberador de corticotrofina; ACTH: hormônio adrenocorticotrófico. Figura adaptada e retirada do Computers in Biology and Medicine (MALEK et al., 2015) 28

Figura 2. Diagrama resumido do reflexo inflamatório. A: representação do reflexo inflamatório inicialmente proposto por Tracey (TRACEY, 2002). Citocinas próinflamatórias liberadas pelo macrófago ativam o nervo vago aferente, resultando em ativação reflexa vagal eferente, regulando a inflamação ao inibir a liberação de novas citocinas pelos macrófagos por meio da acetilcolina. B: representação do modelo revisado do reflexo inflamatório. A via aferente continua a mesma, porém o ramo eferente do nervo vago ativa os nervos esplênicos, os quais, por sua vez, estimulam os linfócitos $\mathrm{T}$ sintetizadores de acetilcolina, e esta acetilcolina inibe a liberação de novas citocinas, atenuando o processo inflamatório. Figura retirada do Physiological Reviews (DANTZER, 2018). 30

Figura 3. Esquema representativo do barorreflexo. A regulação da pressão arterial pelo barorreflexo é realizada por meio dos mecanorreceptores que detectam distensões nos respectivos vasos, resultando na ativação, ou desativação, dos ramos do sistema nervoso autônomo. NTS: núcleo do trato solitário; NA: núcleo ambíguo; CVLM: região caudal ventrolateral bulbar; RVLM: região rostral ventrolateral bulbar. Figura criada a partir de imagens disponibilizadas na plataforma online Smart Servier Medical Art (disponível em: https://smart.servier.com). 32

Figura 4. Diferentes propostas da via do reflexo inflamatório. A: Via colinérgica antiinflamatória, na qual os ramos aferente e eferente do nervo vago possuem participação na inibição da liberação de citocinas no baço. B: Via esplâncnica anti-inflamatória, na qual o nervo esplâncnico é o ramo eferente da via, inibindo a liberação excessiva de citocinas inflamatórias no baço e em outros órgãos que são inervados pelos neurônios pósganglionares simpáticos. Figura retirada do Experimental Physiology (MARTELLI; FARMER; YAO, 2016). 35 
Figura 5. Evolução temporal da pressão arterial média (PAM) e da frequência cardíaca (FC) em resposta a diferentes doses de lipopolissacarídeo em ratos não anestesiados. Salina: painéis (A, F); 0,06 mg/kg de LPS: painéis (B, G); $20 \mathrm{mg} / \mathrm{kg}$ de LPS: painéis $(\mathrm{C}, \mathrm{H}) ; 30 \mathrm{mg} / \mathrm{kg}$ de LPS: painéis (D, I); $40 \mathrm{mg} / \mathrm{kg}$ de LPS: painéis (E, J). Salina: $\mathrm{n}=5 ; 0,06 \mathrm{mg} / \mathrm{kg}: \mathrm{n}=7 ; 20 \mathrm{mg} / \mathrm{kg}: \mathrm{n}=4 ; 30 \mathrm{mg} / \mathrm{kg}: \mathrm{n}=3.40 \mathrm{mg} / \mathrm{kg}: \mathrm{n}=5$. Os dados são expressos como média \pm erro padrão da média. ${ }^{*} p<0,05$ vs. basal; $\uparrow p<0,05$ vs. $90 \mathrm{~min} ; \#$ p $<0,05$ vs. $180 \mathrm{~min}$. ANOVA de uma via para medidas repetidas seguida do pós-teste de Student-Newman-Keuls.

Figura 6. Efeitos das diferentes doses de lipopolissacarídeo sobre a variabilidade do intervalo cardíaco e da pressão arterial sistólica de ratos não anestesiados. Os parâmetros avaliados foram: banda de LF (LF), banda de HF (HF), razão LF/HF, e LF da pressão arterial sistólica (LF-PAS). Salina: painéis (A, F, K, P); 0,06 mg/kg de LPS: painéis $(\mathrm{B}, \mathrm{G}, \mathrm{L}, \mathrm{Q}) ; 20 \mathrm{mg} / \mathrm{kg}$ de LPS: painéis $(\mathrm{C}, \mathrm{H}, \mathrm{M}, \mathrm{R}) ; 30 \mathrm{mg} / \mathrm{kg}$ de LPS: painéis (D, I, N, S); $40 \mathrm{mg} / \mathrm{kg}$ de LPS: painéis (E, J, O, T). Salina: $\mathrm{n}=5 ; 0,06 \mathrm{mg} / \mathrm{kg}: \mathrm{n}=7 ; 20$ mg/kg: $\mathrm{n}=3 ; 30 \mathrm{mg} / \mathrm{kg}: \mathrm{n}=3.40 \mathrm{mg} / \mathrm{kg}: \mathrm{n}=5$. Barras são expressas como média \pm erro padrão da média. $* \mathrm{p}<0,05$ vs. basal; $\# \mathrm{p}<0,05$ vs. 90 min. LF: baixa frequência; HF: alta frequência. ANOVA de uma via para medidas repetidas seguido do pós-teste de Student-Newman-Keuls.

Figura 7. Efeitos das diferentes doses de lipopolissacarídeo na sensibilidade barorreflexa de ratos não anestesiados. Sensibilidade barorreflexa após a administração de salina ou LPS. Salina (A); 0,06 mg/kg de LPS (B); 20 mg/kg (C); 30 $\mathrm{mg} / \mathrm{kg}$ de LPS (D); $40 \mathrm{mg} / \mathrm{kg}$ de LPS (E). Salina: $\mathrm{n}=5 ; 0,06 \mathrm{mg} / \mathrm{kg}: \mathrm{n}=7 ; 20 \mathrm{mg} / \mathrm{kg}: \mathrm{n}$ $=3 ; 30 \mathrm{mg} / \mathrm{kg}: \mathrm{n}=3.40 \mathrm{mg} / \mathrm{kg}: \mathrm{n}=5$. Barras são expressas como média \pm erro padrão da média. * $\mathrm{p}<0,05$ vs. basal; $\# \mathrm{p}<0,05$ vs. $90 \mathrm{~min}$. ANOVA de uma via para medidas repetidas, seguida do pós-teste de Student-Newman-Keuls

Figura 8. Nervo depressor aórtico posicionado no eletrodo. A seta amarela mostra o segmento do nervo depressor aórtico de um rato, o qual foi isolado e posicionado sobre o eletrodo para realizar a estimulação elétrica. Figura criada utilizando a plataforma online Mind the Graph (disponível em: www.mindthegraph.com).

Figura 9. Fotografia dos eletrodos utilizados no protocolo. A: fios do eletrodo encapados. B: fios do eletrodo decapados. A seta amarela destaca o material que mantem 
os fios encapados. Na foto à direita (B) é possível notar a ausência do material envolvendo os fios 58

Figura 10. Registro representativo das respostas hemodinâmicas de um rato não anestesiado durante a estimulação elétrica do nervo depressor aórtico. Barra horizontal representa o período de 20 minutos referente à estimulação elétrica do nervo depressor aórtico e a linha branca representa a pressão arterial média. Registro de um animal do grupo LPS+ENDA (+). PAP: pressão arterial pulsátil; FC: frequência cardíaca.

Figura 11. Respostas hemodinâmicas à estimulação do nervo depressor aórtico (ENDA) em ratos não anestesiados. PAS: pressão arterial sistólica; PAD: pressão arterial diastólica; PAM: pressão arterial média; FC: frequência cardíaca. Períodos: basal (barras brancas) e 5 segundos após o início da estimulação (barras cinzas). ENDA (-): sem queda de pressão arterial; ENDA $(+)$ : com queda de pressão arterial. LPS+ENDA (): $\mathrm{n}=11 ; \operatorname{LPS}+\operatorname{ENDA}(+): \mathrm{n}=7$. As barras representam média \pm erro padrão $* \mathrm{p}<0,05$. ANOVA de duas vias para medidas repetidas, seguida do pós-teste Tukey....

Figura 12. Efeitos da ativação barorreflexa sobre a variabilidade do intervalo cardíaco e da pressão arterial sistólica de ratos endotoxêmicos não anestesiados ao longo do tempo. Os parâmetros avaliados foram: banda de baixa frequência (LF; painéis A, B, C D e E), banda de alta frequência (HF; painéis F, G, H, I e J), razão LF/HF (painéis $\mathrm{K}, \mathrm{L}, \mathrm{M}, \mathrm{N}$ e O), e LF da pressão arterial sistólica (LF-PAS; painéis P, Q, R, S e T), em diferentes momentos: basal, $90 \mathrm{~min}, 180 \mathrm{~min}, 270 \mathrm{~min}$ e $360 \mathrm{~min}$ após LPS ou salina. Salina: $\mathrm{n}=6-9$; LPS: $\mathrm{n}=6-8$; LPS+ENDA (-): $\mathrm{n}=8-11$; LPS+ENDA $(+): \mathrm{n}=5-7$. As barras representam média \pm erro padrão, ${ }^{*} \mathrm{p}<0,05$ vs. salina; $\# \mathrm{p}<0,05$ vs. LPS; $\uparrow \mathrm{p}<$ 0,05 vs. LPS+ENDA (-). ANOVA de uma via, seguida do pós-teste de Tukey. 64

Figura 13. Efeito da estimulação do nervo depressor aórtico na sensibilidade barorreflexa de ratos não anestesiados. Sensibilidade barorreflexa em diferentes momentos [basal (A), $90 \mathrm{~min}(\mathrm{~B}), 180 \mathrm{~min}(\mathrm{C}), 270 \mathrm{~min}(\mathrm{D})$ e $360 \mathrm{~min}(\mathrm{E})$ ] após a administração de LPS ou salina. Salina: $\mathrm{n}=6-9$; LPS: $\mathrm{n}=7-8$; LPS+ENDA (-): $\mathrm{n}=10$ 11; LPS+ENDA $(+): \mathrm{n}=7$. As barras representam média \pm erro padrão, ${ }^{*} \mathrm{p}<0,05$ vs. salina. ANOVA de uma via, seguida do pós-teste de Tukey. 
Figura 14. Níveis plasmáticos de citocinas 90 min após LPS. Níveis plasmáticos de TNF $(A)$, IL-6 $(B)$, IL-1 $\beta(C)$ e IL-10 $(D) 90$ min após a administração de LPS ou salina. LPS: lipopolissacarídeo; ENDA: estimulação do nervo depressor aórtico sem (-) e com $(+)$ alteração hemodinâmica. Salina: $\mathrm{n}=9$; LPS: $\mathrm{n}=8$; $\operatorname{LPS}+\operatorname{ENDA}(-): \mathrm{n}=11$; LPS+ENDA (+): $\mathrm{n}=7$. As barras representam média \pm erro padrão, $* \mathrm{p}<0,05$ vs. Salina; $\# \mathrm{p}<0,05$ vs. LPS; $\uparrow \mathrm{p}<0,05$ vs. LPS+ENDA (-). ANOVA de uma via, seguida do pósteste Student-Newman-Keuls ou Kruskal-Wallis seguido do pós-teste Dunn. 66

Figura 15. Fotografia do oclusor pneumático utilizado nos experimentos. A: vista lateral do oclusor; B: detalhes do balão no oclusor com o balão em repouso; C: detalhe do balão no oclusor durante a injeção de água. 72

Figura 16. Desnervação seletiva dos barorreceptores. A: Diagrama ilustrativo do método de desnervação seletiva dos barorreceptores. B: Fotografia da bifurcação da carótida de um rato, com destaque para a região onde os barorreceptores carotídeos são cortados (círculo branco). BA: aferências barorreceptoras; CB: corpo carotídeo; CBA: artéria do corpo carotídeo; CCA: artéria carótida comum; CS: seio carotídeo; CNS: nervo do seio carotídeo; ECA: artéria carótida externa; GPN: nervo glossofaríngeo; ICA: artéria carótida interna; OA: artéria occipital. Figura retirada do Experimental Physiology (CASTANIA et al., 2019)..... 74

Figura 17. Representação esquemática do método utilizado para realizar a oclusão da carótida bilateralmente. A: período basal, no qual não há oclusão da carótida comum. O fluxo sanguíneo flui normalmente. B: período durante a manobra para promover a oclusão da carótida comum. O balão dentro do oclusor foi inflado com água utilizando-se uma seringa com agulha sem ponta conectada à cânula de polietileno. Note que o fluxo de sangue, bem como o diâmetro das carótidas, está reduzido na região acima do local da oclusão, desativando os barorreceptores carotídeos. .75

Figura 18. Registro representativo das respostas hemodinâmicas de um rato intacto não anestesiado durante a manobra de oclusão bilateral da carótida (OBC). Barra horizontal representa o período de 20 segundos referente à $\mathrm{OBC}$ e a linha branca representa a pressão arterial média. PAP: pressão arterial pulsátil; FC: frequência cardíaca. 78 
Figura 19. Respostas hemodinâmicas à oclusão bilateral da carótida $(\mathrm{OBC}) \mathrm{em}$ animais intactos, ou com desnervação dos barorreceptores (BARO-X) ou dos quimiorreceptores (QUIMIO-X). PAS: pressão arterial sistólica (A); PAD: pressão arterial diastólica (B); PAM: pressão arterial média (C); FC: frequência cardíaca (D). Períodos: basal (barras brancas) e no pico da resposta à $\mathrm{OBC}$ (barras cinzas). Intacto $(\mathrm{OBC}+\mathrm{LPS}): \mathrm{n}=8$; BARO-X: $\mathrm{n}=9$; QUIMIO-X: $\mathrm{n}=9$. As barras representam média \pm erro padrão $* \mathrm{p}<0,05$. ANOVA de duas vias para medidas repetidas seguida do pós-teste Tukey..... 79

Figura 20. Resposta autonômica à oclusão bilateral da carótida $(\mathrm{OBC}) \mathrm{em}$ animais intactos e com desnervação dos barorreceptores (BARO-X) ou dos quimiorreceptores (QUIMIO-X). Períodos: basal (barras brancas) e no período da OBC (barras cinzas). LF-PAS: banda de alta frequência da pressão arterial sistólica. Intacto (OBC+LPS): $\mathrm{n}=8$; BARO-X: $\mathrm{n}=8$; QUIMIO-X: $\mathrm{n}=9$. As barras representam média \pm erro padrão $* \mathrm{p}<0,05$. ANOVA de duas vias para medidas repetidas seguida do pós-teste Tukey. 80

Figura 21. Variabilidade do intervalo cardíaco e da pressão arterial sistólica de ratos endotoxêmicos, intactos e desnervados, ao longo do tempo. Os parâmetros avaliados foram: banda de baixa frequência (LF; painéis A, B, C D e E), banda de alta frequência (HF; painéis F, G, H, I e J), razão LF/HF (painéis K, L, M, N e O), e LF da pressão arterial sistólica (LF-PAS; painéis P, Q, R, S e T), em diferentes momentos: basal, 90 min, 180 min, 270 min e 360 min após LPS ou salina. Salina: $\mathrm{n}=6-9$; LPS: $\mathrm{n}=6-8$; OBC+LPS: $\mathrm{n}=6-8$; BARO-X+LPS: $\mathrm{n}=6-7$; BARO-X+OBC+LPS: $\mathrm{n}=6-8$; QUIMIO-X+LPS: $\mathrm{n}=$ 4-6; QUIMIO-X+OBC+LPS: $\mathrm{n}=7-9$. As barras representam média \pm erro padrão, * $\mathrm{p}<$ 0,05 vs. Salina; $\# \mathrm{p}<0,05$ vs. LPS; $\uparrow \mathrm{p}<0,05$ vs. OBC+LPS; $\$ \mathrm{p}<0,05$ vs. BARO$\mathrm{X}+\mathrm{LPS} ; \S \mathrm{p}<0,05$ vs. BARO-X+OBC+LPS; $+\mathrm{p}<0,05$ vs. QUIMIO-X+LPS. ANOVA de uma via, seguida do pós-teste de Tukey.

Figura 22. Efeito da oclusão bilateral da carótida na sensibilidade barorreflexa de ratos não anestesiados. Sensibilidade barorreflexa em diferentes momentos [basal (A), $90 \min (\mathrm{B}), 180 \min (\mathrm{C}), 270 \min (\mathrm{D})$ e $360 \min (\mathrm{E})]$ após a administração de LPS ou salina. Salina: $\mathrm{n}=6-9$; LPS: $\mathrm{n}=7-8$; OBC+LPS: $\mathrm{n}=8$. As barras representam média \pm erro padrão, * $\mathrm{p}<0,05$ vs. salina. ANOVA de uma via, seguida do pós-teste de Tukey. 
Figura 23. Níveis plasmáticos de citocinas 90 min após a administração de LPS. Níveis plasmáticos de TNF (A), IL-6 (B), IL-1 $\beta$ (C) e IL-10 (D) 90 min após a administração de LPS ou salina. LPS: lipopolissacarídeo; OBC: oclusão bilateral da carótida; BARO-X: desnervação dos barorreceptores; QUIMIO-X: desnervação dos quimiorreceptores. Salina: $\mathrm{n}=9$; LPS: $\mathrm{n}=8$; OBC+LPS: $\mathrm{n}=8$; BARO-X+LPS: $\mathrm{n}=8$; BARO-X+OBC+LPS: $\mathrm{n}=$ 9; QUIMIO-X+LPS: $\mathrm{n}=7$; QUIMIO-X+OBC+LPS: $\mathrm{n}=9$. As barras representam média \pm erro padrão, $* \mathrm{p}<0,05$ vs. LPS. ANOVA de uma via seguida do pós-teste Student-Newman-Keuls. 86

Figura 24. A ativação barorreflexa atenua apenas a inflamação central em ratos com endotoxemia. A estimulação elétrica do nervo depressor aórtico promove ativação do barorreflexo culminando com um aumento da atividade parassimpática e inibição da atividade simpática. Essa resposta promove inibição da liberação de citocinas no hipotálamo, mas não altera os níveis de citocinas encontrados no baço, no coração e no plasma decorrentes do processo inflamatório sistêmico induzido pela administração de LPS em ratos não anestesiados. RVLM: região ventrolateral rostral bulbar. A linha tracejada indica inibição. Linhas em azul indicam inervação parassimpática e linhas em vermelho indicam inervação simpática. Figura criada a partir de imagens disponibilizadas na plataforma online Smart Servier Medical Art (disponível em: https://smart.servier.com).

Figura 25. Mecanismo molecular proposto para a interação imune-sensorial-neural envolvendo os quimiorreceptores periféricos e os barorreceptores aórticos e carotídeos. A infecção decorrente da administração de LPS, por exemplo, resulta na liberação de mediadores inflamatórios (ex.: IL-6, TNF e IL-1 $\beta$ ) pelas células do sistema imune. Os terminais axonais periféricos de neurônios sensoriais, neste caso representado pelo nervo depressor aórtico, expressam receptores para citocinas e o receptor Toll-like 4 (TLR-4), responsável pelo reconhecimento do LPS. Assim, tanto o LPS quanto as citocinas interagem no terminal axonal do nervo depressor aórtico levando à geração de segundos-mensageiros como o cálcio $\left(\mathrm{Ca}^{2+}\right)$ e a adenosina monofosfato cíclico (AMPc) ativando a cascata que leva à geração do potencial de ação no nervo resultando na sinalização da região do núcleo do trato solitário (NTS). Da mesma forma, as células glomus presentes no corpo carotídeo também expressam receptores para citocinas e o TLR-4, e culminam com a geração de potencial de ação quando ativados. Além disso, a interação do LPS com seu receptor ativa MyD88 o qual induz a translocação do NF-kB 
para o núcleo das células glomus resultando na síntese e liberação de citocinas, como o TNF. Assim, as células do próprio corpo carotídeo secretam citocinas que vão atuar de maneira parácrina e autócrina alterando a sensibilidade dos quimiorreceptores e enviando sinais ao NTS de forma a contribuir com a comunicação neuro-imune. Figura criada a partir de imagens disponibilizadas na plataforma online Smart Servier Medical Art (disponível em: https://smart.servier.com). 98

Figura 26. Ativação simpática reflexa atenua a resposta inflamatória sistêmica. Diagrama mostrando como os barorreceptores e quimiorreceptores atuam para reduzir a liberação de citocinas pró-inflamatórias decorrente da oclusão bilateral da carótida (OBC) em um desafio imune induzido por LPS. Quando as carótidas comuns são ocluídas, os quimiorreceptores carotídeos são ativados e, ao mesmo tempo, os barorreceptores carotídeos são desativados. Assim, a influência inibitória dos barorreceptores no sistema nervoso simpático é prejudicada, e simultaneamente, neurônios da região ventrolateral rostral bulbar (RVLM) são estimulados pela ativação dos quimiorreceptores, determinando o aumento significativo da atividade simpática. Consequentemente, a inervação simpática do baço é estimulada, inibindo a produção de citocinas pelas células imunes do baço. O diagrama também destaca que os barorreceptores e quimiorreceptores poderiam ser ativados por citocinas pró-inflamatórias liberadas pelas células imunes. CVLM: região caudal ventrolateral bulbar; GC: gânglio celíaco; GN: gânglio nodoso; GP: gânglio petroso; GS: gânglio simpático; IML: coluna intermédio lateral; LPS: lipopolissacarídeo; NA: núcleo ambíguo; NTS: núcleo do trato solitário 103 


\section{LISTA DE TABELAS}

Tabela 1. Evolução temporal da pressão arterial média (PAM) e frequência cardíaca (FC) em resposta a diferentes doses de lipopolissacarídeo.

Tabela 2. Análise temporal das respostas hemodinâmicas no protocolo com estimulação do nervo depressor aórtico.

Tabela 3. Análise temporal das citocinas plasmáticas no protocolo com estimulação do nervo depressor aórtico.

Tabela 4. Análise temporal das respostas hemodinâmicas no protocolo com oclusão bilateral da carótida $(\mathrm{OBC})$. 81

Tabela 5. Análise temporal das citocinas plasmáticas no protocolo com oclusão bilateral da carótida $(\mathrm{OBC})$. 


\section{LISTA DE ABREVIATURAS}

$\mathrm{ACTH}$

ANOVA

AMPc

BARO-X

bpm

$\mathrm{Ca}^{2+}$

$\mathrm{CRH}$

CVLM

ELISA

ENDA

FC

$\mathrm{g}$

GC

GN

GP

GS

$\mathrm{h}$

HF

$\mathrm{Hz}$

IFN- $\gamma$

IL-1 $\beta$

IL-4

IL-6

IL-8

IL-10

IL-13

IML

i.p.

i.v.

$\mathrm{kg}$

$\mathrm{kHz}$
Hormônio adrenocorticotrófico

Análise de variância

Adenosina monofosfato cíclico

Desnervação seletiva dos barorreceptores aórticos e carotídeos

Batimentos por minuto

Cálcio

Hormônio liberador de corticotrofina

Região caudal ventrolateral bulbar

Enzyme Linked ImmunonoSorbent Assay

Estimulação do nervo depressor aórtico

Frequência cardíaca

Grama

Gânglio celíaco

Gânglio nodoso

Gânglio petroso

Gânglio simpático

Hora

Alta frequência

Hertz

Interferon-gama

Interleucina-1 beta

Interleucina-4

Interleucina-6

Interleucina-8

Interleucina-10

Interleucina-13

Coluna intermédio lateral

Intraperitoneal

Intravenoso

Kilograma

Kilohertz 


\begin{tabular}{|c|c|}
\hline $\mathrm{LF}$ & Baixa frequência \\
\hline LPS & Lipopolissacarídeo \\
\hline $\mathrm{mA}$ & Miliampere \\
\hline $\mathrm{mg}$ & Miligrama \\
\hline $\min$ & Minuto \\
\hline $\mathrm{mL}$ & Mililitro \\
\hline $\mathrm{mm}$ & Milímetro \\
\hline $\mathrm{mmHg}$ & Milímetro de mercúrio \\
\hline $\mathrm{ms}$ & Milissegundo \\
\hline NA & Núcleo ambíguo \\
\hline NDA & Nervo depressor aórtico \\
\hline NF-kB & Fator de transcrição nuclear kappa B \\
\hline nu & Unidades normalizadas \\
\hline NTS & Núcleo do trato solitário \\
\hline $\mathrm{OBC}$ & Oclusão bilateral da carótida \\
\hline PAD & Pressão arterial diastólica \\
\hline PAM & Pressão arterial média \\
\hline PAS & Pressão arterial sistólica \\
\hline QUIMIO-X & Desnervação seletiva dos quimiorreceptores periféricos \\
\hline rpm & Rotações por minuto \\
\hline RVLM & Região rostral ventrolateral bulbar \\
\hline $\mathrm{s}$ & Segundo \\
\hline s.c. & Subcutâneo \\
\hline TGF- $\beta$ & Fator de transformação do crescimento-beta \\
\hline TLR-4 & Receptor Toll-like 4 \\
\hline TNF- $\alpha$ & Fator de necrose tumoral-alfa \\
\hline UI & Unidades internacionais \\
\hline$\mu \mathrm{g}$ & Micrograma \\
\hline$\mu \mathrm{L}$ & Microlitro \\
\hline$\mu \mathrm{m}$ & Micrômetro \\
\hline${ }^{\circ} \mathrm{C}$ & Grau Celsius \\
\hline$\Delta$ & Delta \\
\hline
\end{tabular}




\section{SUMÁRIO}

1. Introdução.

2. Hipótese.

3.1. Objetivos 42

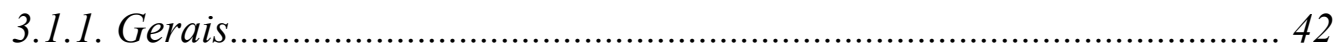

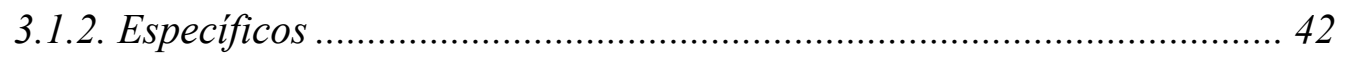

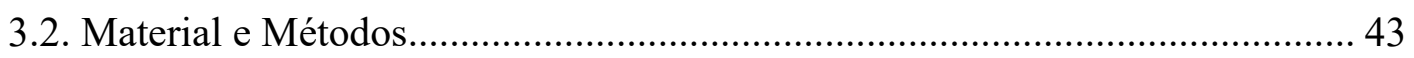

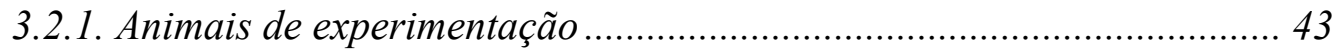

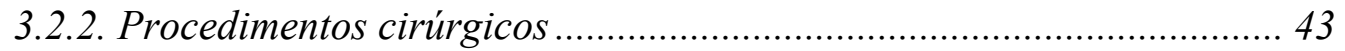

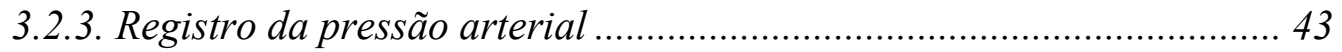

3.2.4. Grupos e procedimentos experimentais ................................................ 44

3.2.5. Análise da variabilidade da pressão arterial sistólica e do intervalo

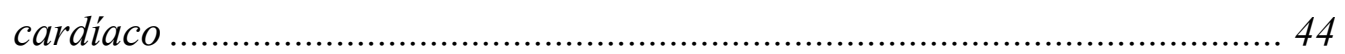

3.2.6. Análise da sensibilidade barorreflexa .............................................. 45

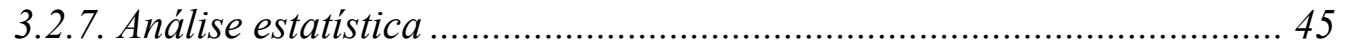

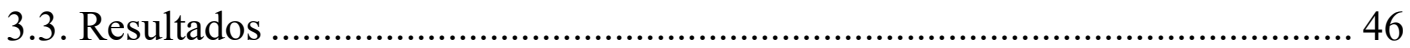

3.3.1. Resposta temporal da pressão arterial à administração de LPS .......... 46

3.3.2. Evolução temporal da frequência cardíaca após a administração de LPS

46

3.3.3. Resposta temporal da variabilidade cardiocirculatória à administração

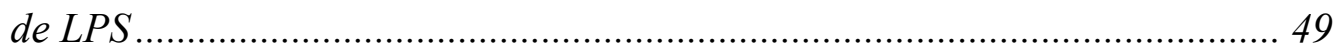

3.3.4. Resposta temporal da sensibilidade barorreflexa à administração de LPS

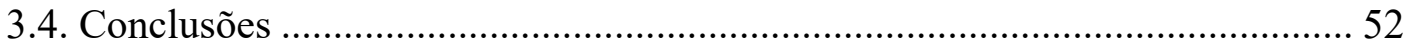

4. Ativação Barorreflexa e a Resposta Inflamatória Sistêmica ..................................... 53

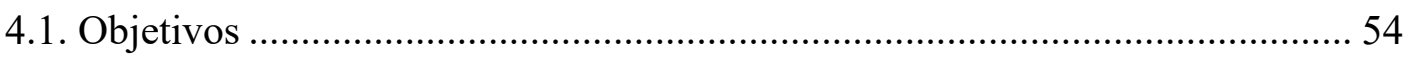

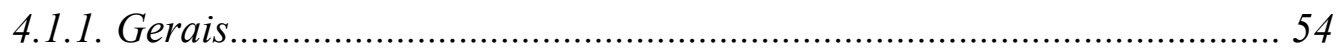

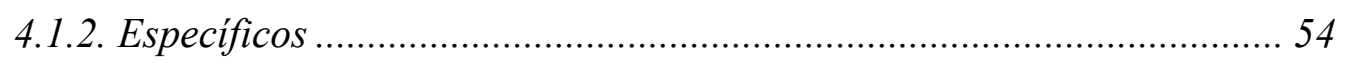

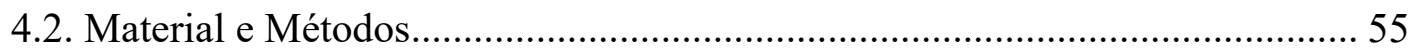


4.2.1. Animais de experimentação

4.2.2. Grupos experimentais ................................................................................. 55

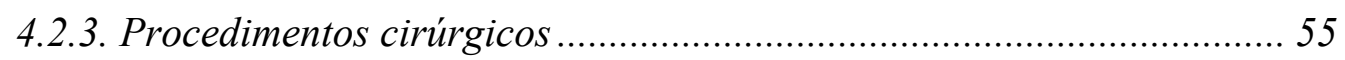

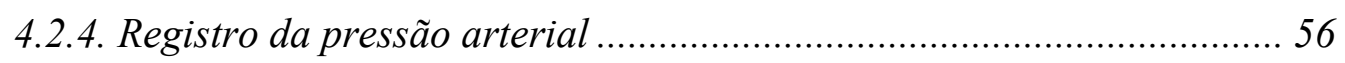

4.2.5. Análise da variabilidade da pressão arterial sistólica e do intervalo

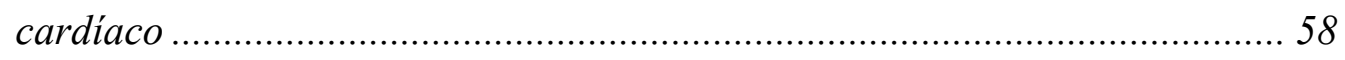

4.2.6. Análise da sensibilidade barorreflexa ................................................ 58

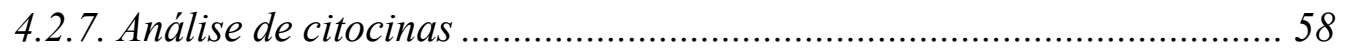

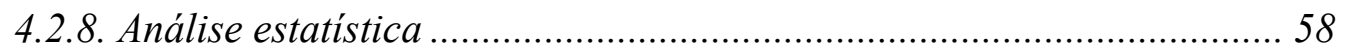

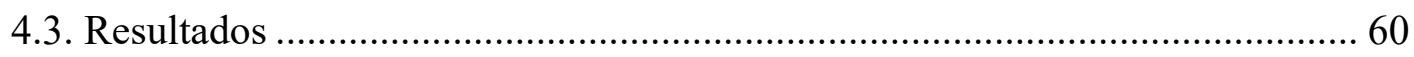

4.3.1. Respostas hemodinâmicas à estimulação elétrica do nervo depressor

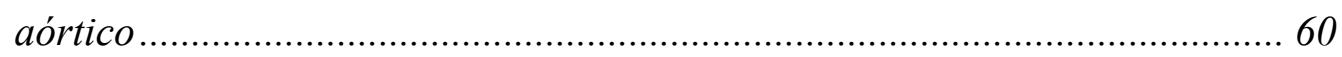

4.3.2. Análise temporal das respostas hemodinâmicas ............................... 61

4.3.3. Ativação barorreflexa e a variabilidade cardiocirculatória em ratos

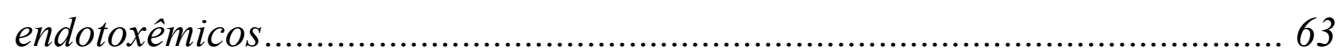

4.3.4. Ativação barorreflexa e a sensibilidade barorreflexa em ratos endotoxêmicos.

4.3.5. A estimulação do nervo depressor aórtico não modula a inflamação

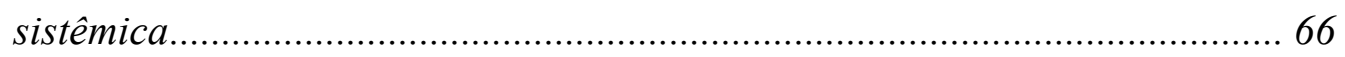

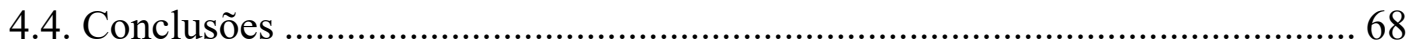

5. Ativação Simpática Reflexa e a Resposta Inflamatória Sistêmica ..............................69

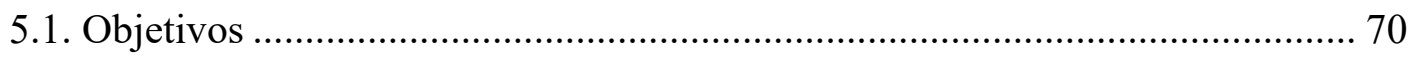

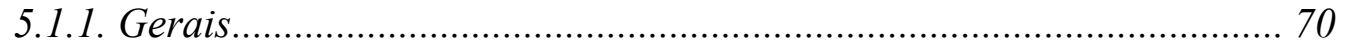

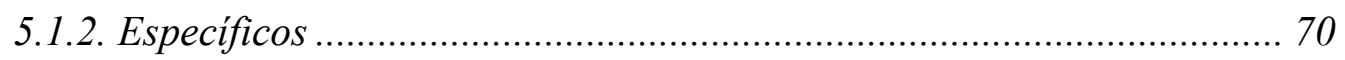

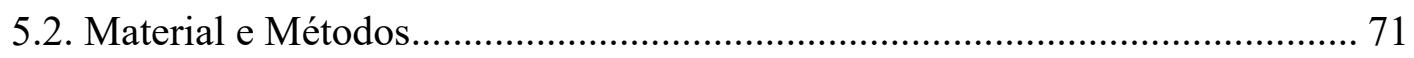

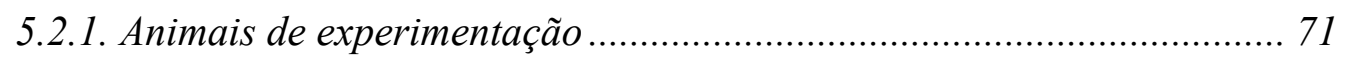

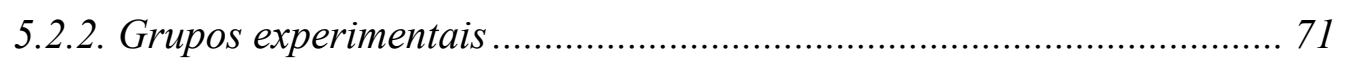

5.2.3. Confecção dos oclusores pneumáticos ............................................. 71

5.2.4. Procedimentos cirúrgicos ................................................................ 72

5.2.5. Registro da pressão arterial .................................................................. 74

5.2.6. Análise da variabilidade da pressão arterial sistólica e do intervalo

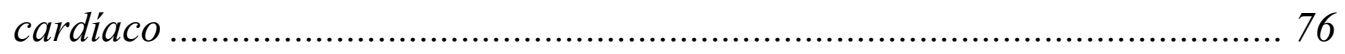

5.2.7. Análise da sensibilidade do barorreflexo ............................................. 76 
5.2.8. Análise de citocinas

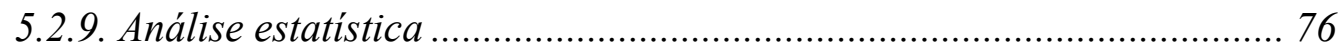

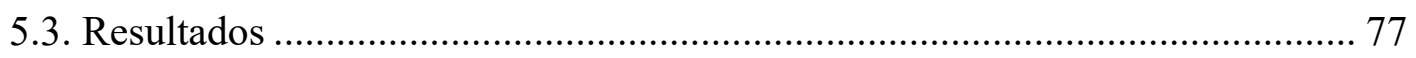

5.3.1. Respostas hemodinâmicas e autonômicas à oclusão bilateral da carótida

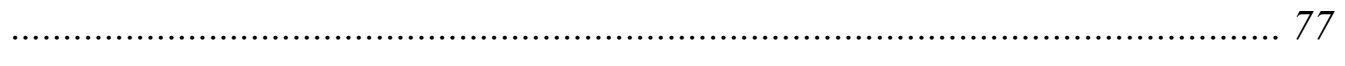

5.3.2. Análise temporal das respostas hemodinâmicas ............................... 77

5.3.3. Variabilidade cardiocirculatória em ratos endotoxêmicos intactos e

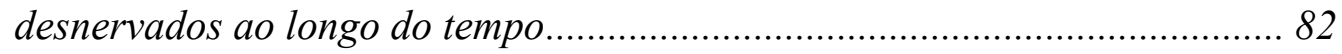

5.3.4. Efeito da oclusão bilateral da carótida na sensibilidade barorreflexa em

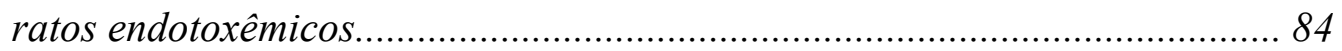

5.3.5. A oclusão bilateral da carótida reduz a inflamação sistêmica.............. 85

5.3.6. Desnervação seletiva dos barorreceptores e quimiorreceptores modula a resposta inflamatória sistêmica .............................................................. 85

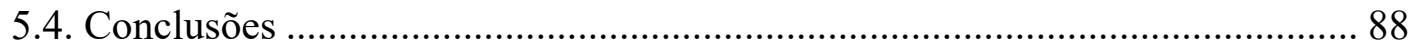

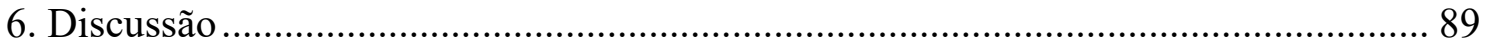

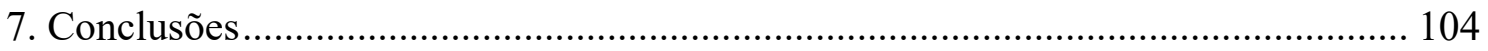

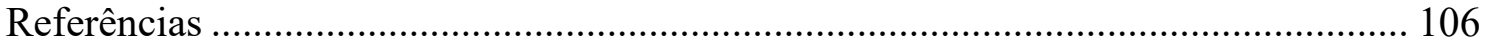

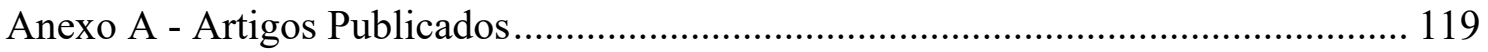

Anexo B - Artigos Aceitos para Publicação .................................................................. 183

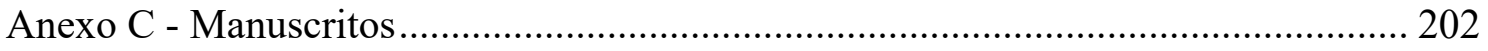




\section{Introdução}




\section{INTRODUÇÃO}

No final do século XIX e início do século XX, muitos estudos foram conduzidos, principalmente na Europa, para compreender a relação entre o sistema nervoso e o sistema imune (BERCZI; SZENTIVANYI, 2008). As primeiras investigações datam de 1898 quando os médicos e bacteriologistas dinamarqueses Carl Julius Salomonsen, considerado o pai da bacteriologia dinamarquesa, e Thorvald Madsen, pesquisavam sobre alergias (SALOMONSEN; MADSEN, 1898, apud BERCZI; SZENTIVANYI, 2008). Pouco mais de dez anos depois, em 1910, Eppinger e Hess publicaram o livro "Die Vagotonie" (em português "A Vagotonia"), propondo que doenças alérgicas e o fenômeno da anafilaxia ocorriam devido ao aumento anormal na taxa de disparo do nervo vago (EPPINGER; HESS, 1910, apud BERCZI; SZENTIVANYI, 2008). Entretanto, até então (1910), nenhum estudo havia sido realizado para identificar áreas específicas no cérebro que pudessem contribuir com a interação desses dois sistemas (neural e imune). Assim, o médico húngaro, Andor Szentivanyi, identificou a ausência dessas informações na literatura, e na década de 50 passou a se dedicar ao estudo de áreas cerebrais, como a região anterior do hipotálamo, que poderiam estar relacionadas ao efeito anafilático e a produção de anticorpos (FILIPP; SZENTIVANYI, 1958; FILIPP; SZENTIVANYI; MESS, 1952; SZENTIVANYI; FILIPP, 1958; SZENTIVANYI; SZEKELY, 1956). Esses e outros estudos mostraram que lesões hipotalâmicas inibem o desenvolvimento do choque anafilático em animais pré-imunizados (KORNEVA; KHAI, 1964), sugerindo a participação do hipotálamo na resposta imune. Além disso, o tratamento prévio com capsaicina (composto que causa dessensibilização dos nervos sensoriais) preveniu a resposta inflamatória, indicando que a estimulação de fibras sensoriais responsáveis pela dor pode induzir a resposta inflamatória (JANCSO, 1960, 1968).

Em 1949, o endocrinologista húngaro, Hans Selye, responsável por introduzir o conceito de estresse na medicina, sugeriu que os corticoides poderiam regular a resposta inflamatória (SELYE, 1949). Como Selye estudava a fisiopatologia do estresse, ele propôs uma associação entre este e o sistema imune, na qual o hormônio adrenocorticotrófico (induzido pelo estresse) por si só, ou em cooperação com outros hormônios, estimularia o córtex adrenal a liberar corticoides, o qual, por sua vez, reduziria a inflamação (SELYE, 1955). Entretanto, segundo ele, por esse mesmo motivo os corticoides abririam caminho para a disseminação da infecção (SELYE, 1955). Posteriormente, com o avanço da ciência, inúmeros estudos comprovaram que, de fato, 
cronicamente, o estresse promove imunossupressão favorecendo o desenvolvimento e progressão de diversas doenças (COHEN et al., 2012; DHABHAR, 2014; REICHE; NUNES; MORIMOTO, 2004; SOUNG; KIM, 2015; STERNBERG et al., 1989; THAKER et al., 2006). No mesmo ano (1949), o fisiologista americano, Philip Showalter Hench, o bioquímico, também americano, Edward Calvin Kendall, e outros dois pesquisadores demostraram, pela primeira vez, os efeitos imunossupressores dos glicocorticoides, assim como do hormônio adrenocorticotrófico em um paciente com artrite reumatoide (HENCH et al., 1949). Esta descoberta resultou a Hench e Kendall o prêmio Nobel em Fisiologia ou Medicina de 1950. A partir desses estudos, a comunicação bidirecional entre o sistema nervoso central e o sistema imune foi consolidada por meio do eixo hipotálamo-hipófise-adrenal e seus hormônios (Fig. 1).

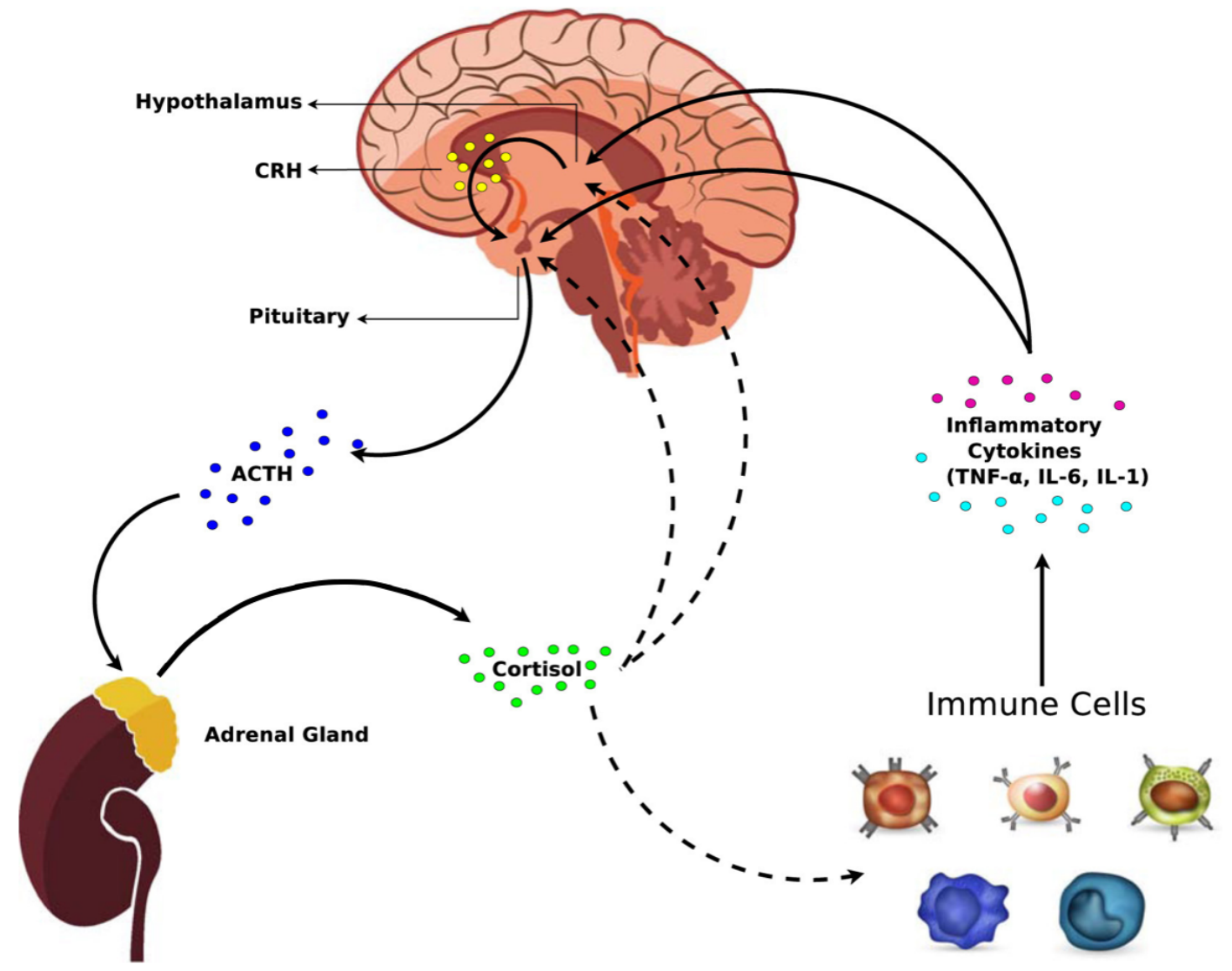

Figura 1. Diagrama ilustrando as interações entre as células imunes e o eixo hipotálamo-hipófiseadrenal. As setas sólidas indicam estimulação e as tracejadas indicam inibição. CRH: hormônio liberador de corticotrofina; ACTH: hormônio adrenocorticotrófico. Figura adaptada e retirada do Computers in Biology and Medicine (MALEK et al., 2015). 
Posteriormente, em 1975, Robert Ader e Nicholas Cohen também mostraram interação do sistema nervoso central com o sistema imune, mas dessa vez associada ao comportamento (ADER; COHEN, 1975). Eles utilizaram uma técnica parecida com a que o fisiologista russo, Ivan Petrovich Pavlov, havia utilizado para estudar o comportamento condicionado de cães, os quais salivavam ao ouvir o som de um sininho. Ader e Cohen demonstraram que o sistema imune possui aprendizado condicionado, assim como outros sistemas do organismo, ao combinar a ingestão de sacarina com a administração de ciclofosfamida, um imunossupressor (ADER; COHEN, 1975). Os ratos passaram a associar o sabor da água com sacarina aos efeitos da ciclofosfamida, que se manifestavam nos animais mesmo sem sua administração. Ou seja, os ratos apresentavam imunossupressão, apenas, com a ingestão de sacarina. Desde então, ficou claro que o sistema nervoso havia sido "selecionado" para controlar a homeostase fisiológica, e que este processo também envolve a habilidade de regular a imunidade inata e modular a inflamação.

Nas décadas de 80 e 90, diversos trabalhos comprovaram, e destacaram, a eficácia do eixo hipotálamo-hipófise-adrenal em regular o processo inflamatório em doenças como artrite reumatoide, síndrome de Cushing, doença autoimune da tireoide, e a encefalomielite alérgica, tanto em humanos quanto em modelos animais (BECK et al., 1993; HARBUZ; REES; LIGHTMAN, 1993; MASON; MACPHEE; ANTONI, 1990; PANAYI, 1992; STERNBERG et al., 1989; TAKASU et al., 1990; YAKUSHIJI et al., 1995). O uso de corticoides é utilizado, até hoje, no tratamento de diversas doenças inflamatórias e autoimunes, apesar dos seus efeitos colaterais (DUBOIS-CAMACHO et al., 2017; JÄGER et al., 2019; WALJEE et al., 2016; ZHANG et al., 2019). Entretanto, novos alvos terapêuticos passaram a ser investigados para melhorar o tratamento das doenças inflamatórias. Ainda na década de 90, começaram a surgir evidências de que o nervo vago poderia estar envolvido na comunicação entre o cérebro e o sistema imune (WATKINS et al., 1995). Entretanto, foi somente no início do século XXI que a interação do sistema nervoso autônomo com o sistema imune foi, de fato, enfatizada. O estudo de Borovikova et al. (2000), liderado pelo neurocirurgião Kevin J. Tracey, demonstrou que a estimulação elétrica do nervo vago eferente inibe a síntese do fator de necrose tumoral (TNF) no fígado e no baço, além de atenuar as concentrações dessa citocina no soro de animais com endotoxemia. Foi então que surgiu a nova via neural de controle da resposta inflamatória denominada de "via colinérgica anti-inflamatória", descrita em 2002 por Kevin Tracey (TRACEY, 2002; Fig. 2A). Este nome foi escolhido uma vez que a 
modulação das reações inflamatórias nessa nova via é dependente da ação da acetilcolina, o principal neurotransmissor do sistema nervoso parassimpático, por meio da ativação do nervo vago. A grande vantagem apresentada pela nova via de interação do sistema nervoso com o sistema imune é que esta apresenta uma resposta muito mais rápida do que as vias anti-inflamatórias humorais, até então conhecidas. A partir deste estudo, iniciouse uma nova linha de pesquisa envolvendo a ativação colinérgica neural como ferramenta para atenuar a resposta inflamatória sistêmica.

Ao longo dos anos, com o crescimento dos estudos na área, a via proposta por Kevin J. Tracey foi revisada em relação ao seu ramo eferente (Fig. 2B), o qual inicialmente era constituído, apenas, pelo nervo vago. Atualmente, essa eferência é descrita com o nervo vago eferente ativando primeiro o nervo esplênico, o qual, por sua vez, estimula os linfócitos T sintetizadores de acetilcolina no baço, por meio da liberação de noradrenalina; assim, a acetilcolina inibe a liberação de novas citocinas ao se ligar ao receptor nicotínico de acetilcolina do tipo alfa-7 nos macrófagos, inibindo a inflamação (DANTZER, 2018; ROSAS-BALLINA et al., 2011; TRACEY, 2010; WANG et al., 2003).

A

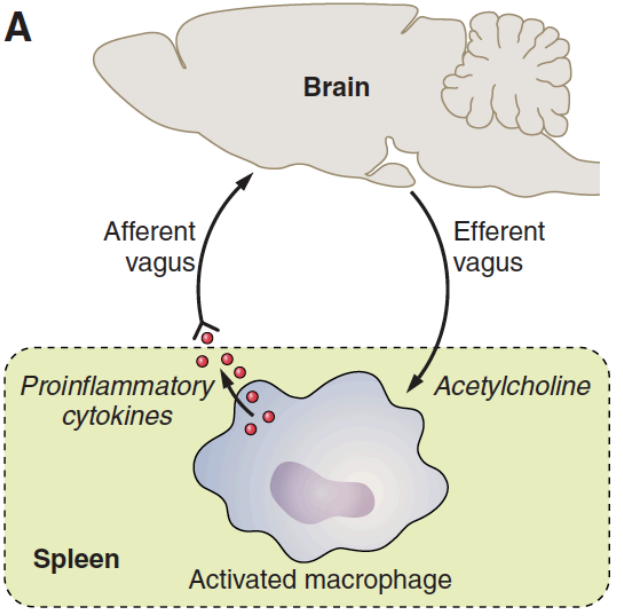

B

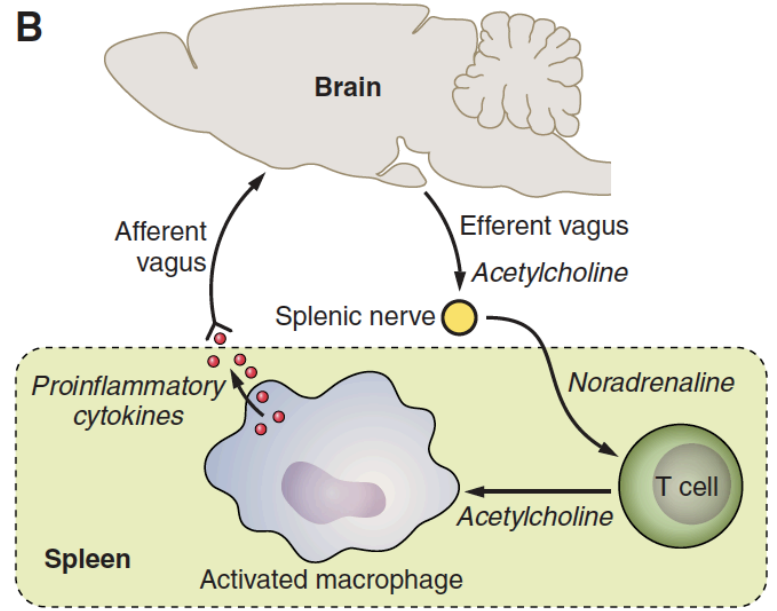

Figura 2. Diagrama resumido do reflexo inflamatório. A: representação do reflexo inflamatório inicialmente proposto por Tracey (TRACEY, 2002). Citocinas pró-inflamatórias liberadas pelo macrófago ativam o nervo vago aferente, resultando em ativação reflexa vagal eferente, regulando a inflamação ao inibir a liberação de novas citocinas pelos macrófagos por meio da acetilcolina. B: representação do modelo revisado do reflexo inflamatório. A via aferente continua a mesma, porém o ramo eferente do nervo vago ativa os nervos esplênicos, os quais, por sua vez, estimulam os linfócitos $\mathrm{T}$ sintetizadores de acetilcolina, e esta acetilcolina inibe a liberação de novas citocinas, atenuando o processo inflamatório. Figura retirada do Physiological Reviews (DANTZER, 2018). 
Assim como o nervo vago, o nervo depressor aórtico (NDA) é um potente ativador do sistema nervoso parassimpático. Ele atua no barorreflexo arterial (Fig. 3) contribuindo com a manutenção da pressão arterial em uma faixa estreita de variação (CHAPLEAU; HAJDUCZOK; ABBOUD, 1988; KRIEGER; SALGADO; MICHELINI, 1982). Os impulsos aferentes provenientes da estimulação dos mecanorreceptores localizados no seio carotídeo trafegam pelo nervo de Hering (ramo do glossofaríngeo), enquanto que os do arco aórtico o fazem por meio do NDA, junto ao vago, dirigindo-se para o bulbo, localizado no tronco cerebral, fazendo a primeira sinapse no núcleo do trato solitário (NTS) (DAMPNEY, 1994). Assim, a partir do núcleo do trato solitário, neurônios se projetam para outras estruturas bulbares, onde ocorre a segunda sinapse, tais como a região caudal ventrolateral bulbar (CVLM) e o núcleo ambíguo (NA); e, em seguida, a partir da CVLM, ocorre a terceira sinapse com a região rostral ventrolateral bulbar (RVLM), a qual apresenta neurônios com atividade espontânea e responsáveis pela geração da atividade eferente simpática (STUESSE; FISH, 1984; URBANSKI; SAPRU, 1988). Quando os barorreceptores são ativados, uma projeção excitatória do NTS é enviada para CVLM, a qual, quando ativada, promove a inibição dos neurônios da RVLM. Simultaneamente, uma projeção excitatória é enviada do NTS para o NA, no qual estão localizados os neurônios pré-ganglionares parassimpáticos, os quais inervam as células do marca-passo cardíaco. Sendo assim, a ativação dos barorreceptores provoca uma resposta neural, a qual compreende a inibição da atividade simpática e concomitante ativação parassimpática (CHAPLEAU; HAJDUCZOK; ABBOUD, 1988; KRIEGER; SALGADO; MICHELINI, 1982).

Levando-se em consideração os achados na literatura destacando o potencial antiinflamatório do nervo vago, a ativação do NDA também poderia ter papel significativo na ativação do reflexo inflamatório inibindo a resposta imune. Nosso laboratório tem ampla experiência no estudo do barorreflexo, por meio da estimulação elétrica do NDA, em ratos não anestesiados. Sendo assim, em 2015, nós testamos esta hipótese em um modelo experimental de artrite reumatoide (BASSI et al., 2015). Esse trabalho mostrou que a ativação do barorreflexo, por meio da estimulação elétrica do NDA, reduziu o recrutamento de neutrófilos, o edema articular, e os níveis de citocinas inflamatórias sinoviais na articulação femorotibial de ratos não anestesiados (BASSI et al., 2015). Deste modo, foi demonstrado pela primeira vez na literatura que o barorreflexo, até então visto como importante regulador da pressão arterial, também é capaz de modular a resposta inflamatória local (BASSI et al., 2015). Assim, esses resultados sugerem um novo 
mecanismo fisiológico de neuromodulação do sistema imune inato por meio da estimulação do barorreflexo.

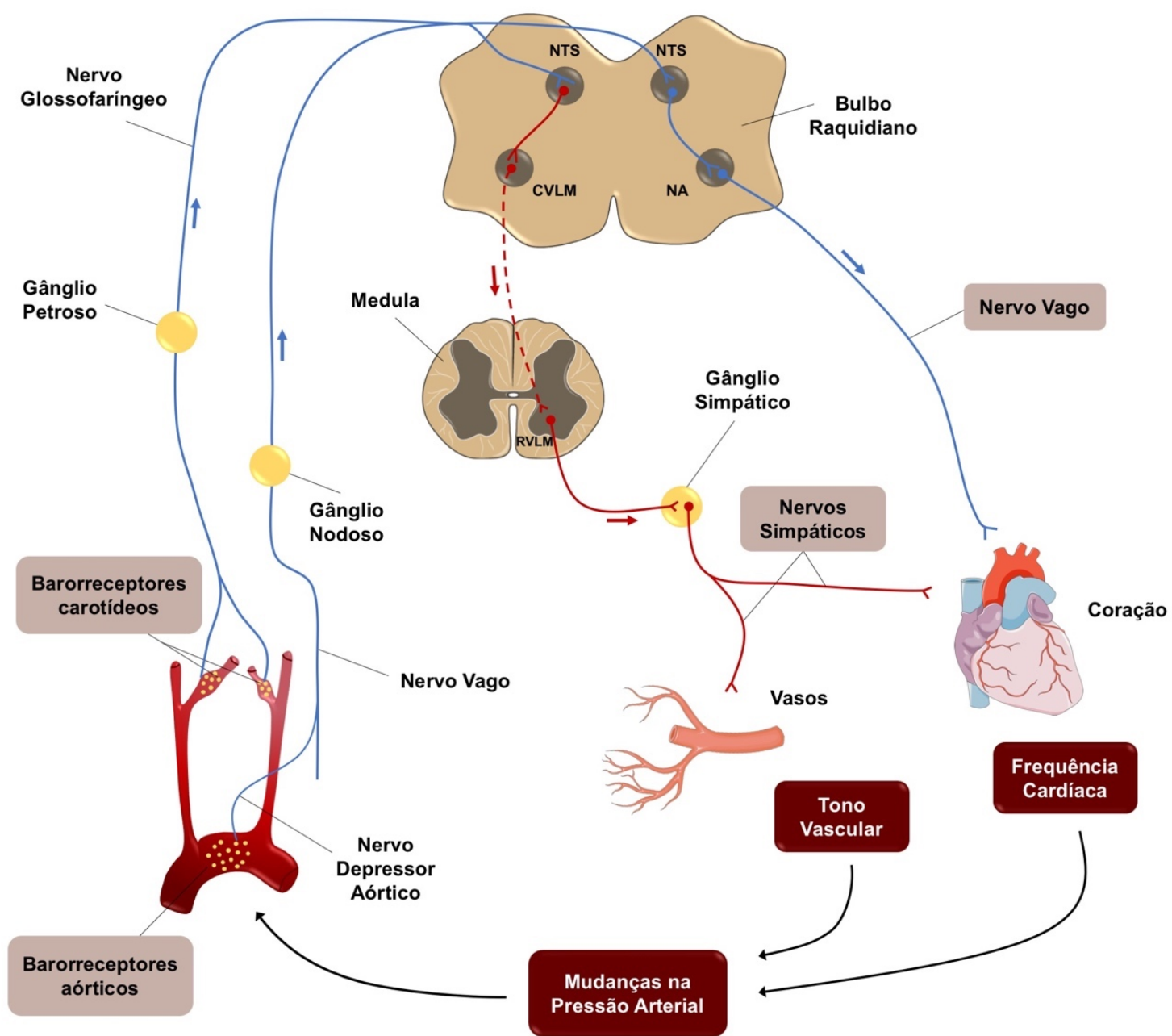

Figura 3. Esquema representativo do barorreflexo. A regulação da pressão arterial pelo barorreflexo é realizada por meio dos mecanorreceptores que detectam distensões nos respectivos vasos, resultando na ativação, ou desativação, dos ramos do sistema nervoso autônomo. NTS: núcleo do trato solitário; NA: núcleo ambíguo; CVLM: região caudal ventrolateral bulbar; RVLM: região rostral ventrolateral bulbar. Figura criada a partir de imagens disponibilizadas na plataforma online Smart Servier Medical Art (disponível em: https://smart.servier.com). 
Apesar dos dados promissores destacando o papel anti-inflamatório do barorreflexo, até então, ainda não se sabia se o mesmo era capaz de atenuar, também, a inflamação sistêmica em modelos endotoxêmicos. Assim, em 2018, um estudo do nosso laboratório mostrou que a ativação barorreflexa, por meio da estimulação elétrica do NDA, não alterou a liberação de citocinas plasmáticas de ratos com endotoxemia induzida pela administração de lipopolissacarídeo (LPS) (BROGNARA et al., 2018). Por outro lado, a estimulação elétrica reduziu as citocinas encontradas no hipotálamo, evidenciando um papel anti-inflamatório central do barorreflexo, até então desconhecido (BROGNARA et al., 2018). Entretanto, no estudo de Brognara et al. (2018) a avaliação dos mediadores inflamatórios foi feita somente 90 min após a indução do desafio imunológico com LPS. É possível que o efeito anti-inflamatório da ativação do barorreflexo atue mais tardiamente na atenuação sistêmica da resposta inflamatória, sendo pertinente explorar melhor esses efeitos em outros momentos que sucedem o início da resposta inflamatória. Além disso, há evidências de que a resposta do organismo ao LPS pode variar, em alguns aspectos, de acordo com a via de administração utilizada (COPELAND et al., 2005). Sendo assim, seria pertinente realizar o estudo do papel da ativação barorreflexa na resposta inflamatória sistêmica utilizando-se uma via de administração de LPS diferente da já utilizada no estudo de Brognara et al. (2018). Vale destacar que há uma diversidade muito grande de doses de LPS utilizadas na literatura, e a escolha da mesma também poderia interferir na resposta anti-inflamatória decorrente da ativação do barorreflexo.

Embora vários estudos demonstrem a importância da ativação do sistema parassimpático no controle da função imune, o papel do sistema nervoso simpático também foi colocado em foco. Em 2014, Martelli et al. (2014a) propuseram outra via neural de regulação do sistema imune, desta vez, envolvendo o sistema nervoso simpático. Nesse trabalho, os autores demonstraram que os níveis plasmáticos de TNF, em ratos anestesiados que receberam LPS, não foram afetados pela vagotomia cervical bilateral. Entretanto, os níveis de TNF no plasma aumentaram quando o nervo simpático esplâncnico maior foi cortado. Assim, os autores sugeriram que o braço eferente desse reflexo seria, na verdade, o nervo simpático esplâncnico, e não o nervo vago como proposto anteriormente (HUSTON et al., 2006; ROSAS-BALLINA; TRACEY, 2009; TRACEY, 2002). Uma vez que a nova via proposta envolve a participação dos nervos simpáticos esplâncnicos, a mesma foi nomeada de "via esplâncnica anti-inflamatória" (MARTELLI et al., 2014a; Fig. 4). Outros estudos também destacaram as propriedades 
anti-inflamatórias do sistema nervoso simpático (KEES et al., 2003; STRAUB et al., 2011; VIDA et al., 2011). Entretanto, até o momento, nenhum trabalho avaliou se esses efeitos também ocorrem ao se realizar uma ativação simpática reflexa, e não uma ativação direta.

A oclusão bilateral da carótida (OBC) é uma técnica usada, também, para promover ativação reflexa global do sistema nervoso simpático, tanto em animais não anestesiados (DICARLO et al., 1989; LATARO et al., 2010; PARRA et al., 2005; SALGADO; SALGADO; KRIEGER, 1986) quanto anestesiados (REISON et al., 1983; WANG et al., 1970). Durante a OBC há importante redução da pressão arterial e do fluxo sanguíneo na região do seio carotídeo, culminando com a desativação dos barorreceptores carotídeos. A inativação dos barorreceptores carotídeos induz aumento da atividade simpática para o coração e para os vasos (aumento da resistência periférica global) com concomitante redução da atividade parassimpática para o coração, resultando, assim, no aumento da pressão arterial (BEDRAN-DE-CASTRO; MOREIRA; KRIEGER, 1986; KRIEGER, 1963). É importante destacar que com o aumento da pressão arterial, decorrente da $\mathrm{OBC}$, há ativação dos barorreceptores aórticos, os quais, por sua vez, promovem aumento da atividade parassimpática para o coração e redução da atividade simpática para o coração e vasos, buscando restaurar a pressão arterial para o seu nível basal. Portanto, existem ações antagônicas dos barorreceptores arteriais e carotídeos durante a OBC. Entretanto, apesar da ativação dos barorreceptores aórticos, a redução da pressão arterial no seio carotídeo promovida pela OBC também promove maior liberação de adrenalina e noradrenalina nas terminações nervosas simpáticas do coração e dos rins (REISON et al., 1983), contribuindo com o aumento significativo da pressão arterial e evidenciando, de fato, o aumento predominante da atividade simpática. Além disso, simultaneamente, há ativação dos quimiorreceptores carotídeos decorrente da hipóxia ocasionada pela redução do fluxo sanguíneo no seio carotídeo, contribuindo com o aumento da atividade simpática durante a OBC (BEDRAN-DE-CASTRO; MOREIRA; KRIEGER, 1986; KRIEGER, 1963). Assim, como a OBC é uma técnica que promove ativação simpática generalizada, e passível de ser utilizada em animais não anestesiados, esta é uma ferramenta que pode auxiliar no estudo da influência do sistema nervoso autônomo, particularmente do seu ramo simpático, no controle da inflamação sistêmica. 

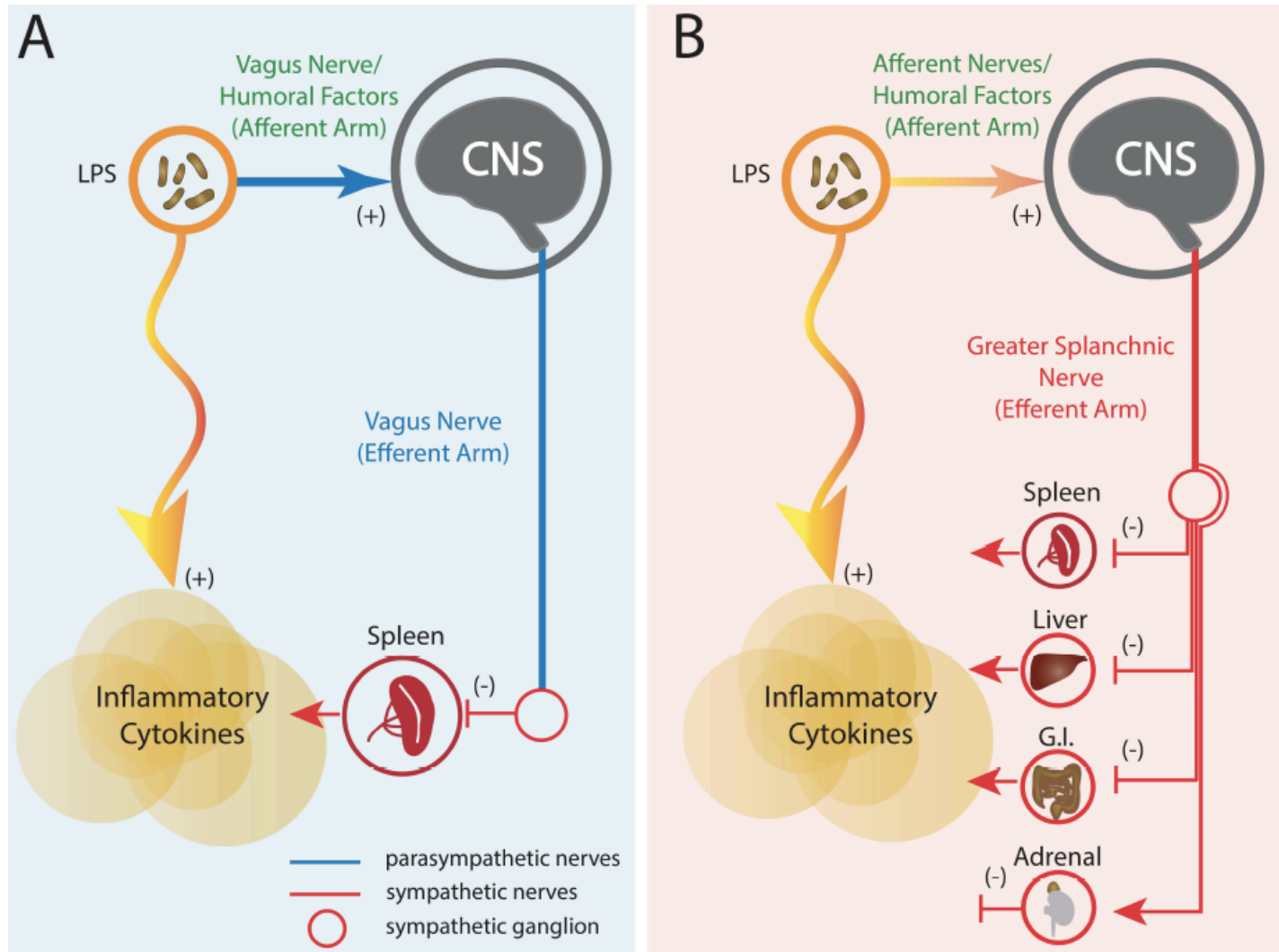

Figura 4. Diferentes propostas da via do reflexo inflamatório. A: Via colinérgica anti-inflamatória, na qual os ramos aferente e eferente do nervo vago possuem participação na inibição da liberação de citocinas no baço. B: Via esplâncnica anti-inflamatória, na qual o nervo esplâncnico é o ramo eferente da via, inibindo a liberação excessiva de citocinas inflamatórias no baço e em outros órgãos que são inervados pelos neurônios pós-ganglionares simpáticos. Figura retirada do Experimental Physiology (MARTELLI; FARMER; YAO, 2016).

Para explorar a imunidade inata do hospedeiro envolvida na resposta inflamatória, e buscar abordagens terapêuticas para o tratamento de doenças inflamatórias, modelos experimentais de endotoxemia têm sido amplamente utilizados. O modelo de endotoxemia induzida pela administração de LPS é bem conhecido e tem sido vastamente usado em estudos recentes (ÁVILA et al., 2020; BROGNARA et al., 2018, 2019; CHEN et al., 2019; XIE et al., 2017). Esse modelo contribui para uma melhor compreensão das manifestações fisiopatológicas encontradas em infecções e doenças inflamatórias, simulando sinais clínicos como hipo ou hipertermia, taquicardia, hipotensão e taquipneia (CAFÉ-MENDES et al., 2017; CAI; DEITCH; ULLOA, 2010a; KOMEGAE et al., 2018; WASILCZUK et al., 2019). Além disso, é um modelo prático e reproduzível em várias espécies, como camundongos (HUANG et al., 2018), ratos (ÁVILA et al., 2020), coelhos (HE et al., 2018), cães (EASLEY et al., 2020) e ovelhas (PÉREZ-FERNÁNDEZ et al., 
2017). O LPS é um componente da membrana externa das bactérias Gram-negativas, o qual, após ser reconhecido pelo receptor Toll-like 4 (AKIRA; TAKEDA; KAISHO, 2001), se configura como potente ativador da imunidade inata (BEUTLER; RIETSCHEL, 2003; RAETZ; WHITFIELD, 2002). Esse receptor é responsável pela ativação da via do fator de transcrição nuclear-kB (NF-kB) o qual leva à síntese e liberação, pelas células imunes, de mediadores inflamatórios, como as citocinas (BEUTLER; RIETSCHEL, 2003; CAFÉ-MENDES et al., 2017).

A síntese e liberação de citocinas é uma característica fundamental do sistema imune inato. Sabe-se que as citocinas são moduladores do processo inflamatório e estão associadas à patogênese de doenças agudas e crônicas como a sepse, bem como doenças autoimunes e neurodegenerativas (AKIYAMA et al., 2000; ALLAN; ROTHWELL, 2001). Elas medeiam a comunicação das células imunes com outras células de diferentes tecidos evocando atividade biológica específica, após se ligarem ao receptor da célula alvo (WYSS-CORAY; MUCKE, 2002). Sabe-se que neurônios possuem receptores para citocinas, sugerindo, novamente, a interação dos sistemas imune e nervoso (WYSSCORAY; MUCKE, 2002). Além disso, as citocinas apresentam diferentes funções no sistema nervoso central, que podem ser importantes nas doenças neurodegenerativas, apresentando um caráter neurotóxico (citocinas pró-inflamatórias) ou neuroprotetor (citocinas anti-inflamatórias) (ALLAN; ROTHWELL, 2001; CORSI-ZUELLI et al., 2017; DANTZER et al., 2008). Em 1975 foi descoberta a primeira molécula derivada do sistema imune, capaz de promover interação com o sistema nervoso, ou seja, a interleucina-1 (IL-1), a qual foi, inicialmente, descrita como mediador endógeno de leucócitos (WANNEMACHER et al., 1975). Em 1986, o professor Kevin J. Tracey e seu grupo de pesquisa mostraram que o TNF, anteriormente conhecido em inglês como "cachectin", era capaz de induzir, por si só, muitos dos efeitos deletérios causados por uma endotoxina durante uma inflamação sistêmica (TRACEY et al., 1986), sugerindo um possível alvo terapêutico nas doenças inflamatórias (MCCANN et al., 1994). Posteriormente, citocinas como a interleucina-6 (IL-6), interferon-gama (IFN- $\gamma$ ), IL-1 e TNF foram associadas à regulação da secreção de hormônios hipofisários diante de uma inflamação sistêmica (BERKENBOSCH et al., 1987; MCCANN et al., 1994; SAPOLSKY, 1998).

De um modo geral, as citocinas podem ser divididas entre aquelas com ações, predominantemente, pró-inflamatórias, a saber, IL-6, TNF- $\alpha$, IL-1 $\beta$, interleucina- 8 (IL8), e aquelas com ações anti-inflamatórias, as quais incluem interleucina-4 (IL-4), 
interleucina-10 (IL-10), interleucina-13 (IL-13) e fator de transformação do crescimento$\beta$ (TGF- $\beta$ ) (BLACKWELL; CHRISTMAN, 1996; CHACHKHIANI et al., 2005). Sabese que $1 \mathrm{~h}$ após a indução do processo inflamatório, em ratos, inicia-se um aumento das concentrações plasmáticas de citocinas pró-inflamatórias (IL-1 $\beta$, IL-6 e TNF- $\alpha$ ) com retorno aos níveis normais 5 h após a sua indução (GIVALOIS et al., 1994). Por esse motivo, vários estudos têm avaliado os níveis de citocinas plasmáticas 90 min após a administração de LPS (BROGNARA et al., 2018; NARDOCCI et al., 2015), com a finalidade de mensurá-las durante o pico do processo inflamatório. Assim, fica claro que a dosagem de citocinas em estudos envolvendo o reflexo inflamatório é uma excelente ferramenta para avaliar a inflamação local, e sistêmica, e se os estímulos aplicados são eficazes, ou não, em atenuar a resposta inflamatória.

Além da avaliação de mediadores do sistema imune, como citado acima, a avaliação do equilíbrio autonômico também tem se mostrado um importante instrumento de análise em diferentes condições clínicas, incluindo doenças inflamatórias e autoimunes. Estudos clínicos e experimentais mostraram alterações do sistema nervoso autônomo em afecções inflamatórias periféricas e crônicas (PONGRATZ; STRAUB, 2013; ZUBCEVIC et al., 2014). Pacientes com artrite reumatoide crônica, por exemplo, apresentam redução da modulação parassimpática e aumento da simpática (KOOPMAN; STOOF, 2011; PONGRATZ; STRAUB, 2014), mostrando uma relação entre o desequilíbrio autonômico e a doença inflamatória. Assim como ocorre na artrite reumatoide, muitas doenças apresentam um aumento da atividade simpática a qual, frequentemente, está associada à gravidade e progressão da doença (AYDEMIR et al., 2010; BORMAN et al., 2008; SHARMA et al., 2009). Além disso, esse desequilíbrio autonômico presente nas doenças inflamatórias, resulta em redução da variabilidade da frequência cardíaca e da sensibilidade barorreflexa, apresentando uma relação inversa com os níveis de citocinas pró-inflamatórias (ARONSON; MITTLEMAN; BURGER, 2001; HAMAAD et al., 2005; HELWIG et al., 2008; JANSZKY et al., 2004; LANZA et al., 2006; NIIJIMA et al., 1991). Ou seja, quanto maior o nível de citocinas próinflamatórias, menor a variabilidade da frequência cardíaca e a sensibilidade barorreflexa (FAIRCHILD et al., 2009; TAKAGISHI et al., 2010). Vale destacar que a variabilidade da frequência cardíaca e da pressão arterial são facilmente mensuradas por meio análise no domínio da frequência (análise espectral), na qual as oscilações de alta frequência (HF) do intervalo cardíaco correspondem à modulação vagal sobre o coração (AKSELROD et al., 1981; JAPUNDZIC et al., 1990; JULIEN et al., 1995) e as oscilações de baixa 
frequência (LF), tanto do intervalo cardíaco quanto da pressão arterial sistólica, refletem a modulação simpática sobre o coração e os vasos, respectivamente (AKSELROD et al., 1981; CERUTTI et al., 1991; ELGHOZI; JULIEN, 2007; JULIEN, 2006).

Destaca-se, ainda, a importância da condução de experimentos utilizando animais não anestesiados, uma vez que a anestesia pode interferir, tanto do ponto de vista neural quanto imunológico, sub ou superestimando o real efeito da estimulação neural na resposta inflamatória (PICQ et al., 2013). Vários estudos têm demonstrado que a Ketamina e o isoflurano, por exemplo, possuem potente propriedade anti-inflamatória (CRUZ; ROCCO; PELOSI, 2017; FLONDOR et al., 2008; QIN et al., 2015; TANIGUCHI; YAMAMOTO, 2005). Além disso, Vatner et al. (1971) mostraram que a anestesia afeta, apreciavelmente, grande parte do controle do sistema nervoso central sobre o sistema cardiovascular. 
2. Hipótese 


\section{HIPÓTESE}

Com o objetivo de caracterizar a participação, individual ou conjunta, dos sistemas nervoso simpático e parassimpático no controle da resposta inflamatória, o presente estudo teve duas hipóteses principais:

a) A ativação parassimpática, por meio da estimulação elétrica do barorreflexo, reduz a inflamação sistêmica em ratos não anestesiados.

b) A ativação simpática reflexa, por um mecanismo fisiológico, reduz a inflamação sistêmica em ratos não anestesiados.

Em atenção aos protocolos utilizados optou-se em dividir a tese em três seções:

a) "Respostas Hemodinâmicas a diferentes doses de LPS";

b) "Ativação Barorreflexa e a Resposta Inflamatória Sistêmica";

c) "Ativação Simpática Reflexa e a Resposta Inflamatória Sistêmica".

Desta forma, os objetivos, material e métodos, bem como os resultados de cada seção são apresentados separadamente; e, em seguida, há uma discussão em comum para os dados obtidos. 
3. Respostas Hemodinâmicas a Diferentes Doses de LPS 


\section{RESPOSTAS HEMODINÂMICAS A DIFERENTES DOSES DE LPS}

\subsection{Objetivos}

\subsubsection{Gerais}

A literatura indica que diferentes doses de LPS têm sido utilizadas em diversos estudos, mas a resposta hemodinâmica decorrente da administração de LPS nem sempre é mostrada, ou mesmo considerada, especialmente em animais não anestesiados. Considerando que, no presente estudo, é desejável que a administração de LPS mimetize os efeitos hemodinâmicos comumente descritos na inflamação sistêmica (hipotensão e taquicardia), o objetivo do presente estudo foi avaliar a pressão arterial, a frequência cardíaca, a variabilidade do intervalo cardíaco e da pressão arterial sistólica, bem como a sensibilidade barorreflexa de ratos não anestesiados, ao longo do tempo, submetidos a diferentes doses de LPS com a finalidade de obter-se a dose ideal para os protocolos a serem estudados. Ressalta-se que os dados descritos nesta seção foram publicados na revista Frontiers in Physiology (BROGNARA et al., 2019).

\subsubsection{Específicos}

Os objetivos específicos deste estudo foram:

a) Analisar a pressão arterial, a frequência cardíaca, a variabilidade do intervalo cardíaco, a variabilidade da pressão arterial sistólica, e a sensibilidade barorreflexa ao longo do tempo, em diferentes momentos após a administração de diversas doses de LPS em ratos não anestesiados;

b) Verificar se existe relação entre as alterações na pressão arterial e na frequência cardíaca, associadas a modificações na sensibilidade barorreflexa, e na variabilidade do intervalo cardíaco e da pressão arterial sistólica decorrentes da administração de LPS. 


\subsection{Material e Métodos}

\subsubsection{Animais de experimentação}

Foram utilizados ratos Wistar Hannover pesando 210-280 g provenientes do Biotério Central do Campus da Universidade de São Paulo de Ribeirão Preto (Campus de Ribeirão Preto; Ribeirão Preto, SP, Brasil), acondicionados em caixas individuais e mantidos sob temperatura controlada $\left(22^{\circ} \mathrm{C}\right)$, ciclo claro-escuro constante de $12 \mathrm{~h}$, com livre acesso a água e ração. Todos os procedimentos foram revisados e aprovados pelo Comitê de Ética no Uso de Animais de Experimentação da Faculdade de Medicina de Ribeirão Preto - Universidade de São Paulo.

\subsubsection{Procedimentos cirúrgicos}

Os animais foram anestesiados com uma mistura de Ketamina e Xilazina (50 $\mathrm{mg} / \mathrm{kg}$ e $10 \mathrm{mg} / \mathrm{kg}$, i.p.) e, então, submetidos ao procedimento cirúrgico de canulação da artéria e veia femorais, para registro da pressão arterial pulsátil e administração de LPS (ou salina), respectivamente. Resumidamente, foi realizada uma pequena incisão cirúrgica na região da artéria femoral esquerda para então realizar a canulação da mesma com um tubo de polietileno (PE-50 soldado ao PE-10; Intramedic, Clay Adams, Parsippany, NJ, EUA). No mesmo local, outra cânula (PE-50 soldado ao PE-10; Intramedic, Clay Adams, Parsippany, $N J, E U A$ ) foi inserida na veia femoral esquerda para administração de LPS, derivado de Escherichia coli (0111: B4), purificado pela extração de fenol (Sigma-Aldrich, St. Louis, MO, EUA). A cânula implantada na artéria femoral foi preenchida com $100 \mathrm{UI} / \mathrm{mL}$ de heparina em salina. As cânulas foram conduzidas, subcutaneamente, até o pescoço do animal e exteriorizadas na parte posterior do mesmo, e, em seguida, as incisões cirúrgicas foram suturadas. Imediatamente após o final da cirurgia foi realizada a injeção de analgésico (cloridrato de tramadol $2 \mathrm{mg} / \mathrm{kg}$, s.c.).

\subsubsection{Registro da pressão arterial}

Para o registro da pressão arterial, o cateter da artéria femoral foi conectado ao transdutor de pressão (MLT844; ADInstruments, Bella Vista, Austrália), o sinal amplificado (ML224; ADInstruments, Bella Vista, Austrália), e amostrado a $2 \mathrm{kHz}$ por um computador (Core 2 Duo, $2.2 \mathrm{GHz}, 4 \mathrm{~GB} R A M$ ) interligado a uma interface analógicodigital (PowerLab, ADInstruments, Bella Vista, Austrália). Os experimentos foram 
conduzidos com os animais se movimentando livremente em suas próprias caixas (um animal por caixa) e silêncio foi mantido para se evitar o estresse ambiental. O registro da pressão arterial pulsátil foi processado por um software computacional (LabChart 7.0, ADInstruments, Bella Vista, Austrália) capaz de detectar os pontos de inflexão, e gerar séries temporais com valores de pressão arterial média e de frequência cardíaca, batimento a batimento.

\subsubsection{Grupos e procedimentos experimentais}

Vinte e quatro horas após os procedimentos cirúrgicos os ratos foram divididos em quatro grupos com diferentes doses de LPS, e um grupo com administração de salina:

I) $0,06 \mathrm{mg} / \mathrm{kg}(\mathbf{n}=\mathbf{7})$ : administração de LPS (i.v) na dose de $0,06 \mathrm{mg} / \mathrm{kg}$;

II) $20 \mathrm{mg} / \mathrm{kg}(\mathbf{n}=\mathbf{4})$ : administração de LPS (i.v) na dose de $20 \mathrm{mg} / \mathrm{kg}$;

III) $30 \mathrm{mg} / \mathbf{k g}(\mathbf{n}=\mathbf{3})$ : administração de LPS (i.v) na dose de $30 \mathrm{mg} / \mathrm{kg}$;

IV) 40 mg/kg (n= 5): administração de LPS (i.v) na dose de $40 \mathrm{mg} / \mathrm{kg}$;

V) Salina (n= 5): administração de Salina (i.v.).

Com os animais não anestesiados e se movimentando livremente, o protocolo experimental consistiu do registro basal da pressão arterial pulsátil, seguido da administração de LPS ou salina. A pressão arterial foi registrada 90, 180 e 360 min após a injeção de LPS, ou salina, para avaliação temporal dos parâmetros hemodinâmicos.

\subsubsection{Análise da variabilidade da pressão arterial sistólica e do intervalo cardíaco}

Séries temporais, batimento-a-batimento, com valores de pressão arterial sistólica e intervalo cardíaco foram extraídas de períodos de aproximadamente $10 \mathrm{~min}$, a partir dos traçados de pressão arterial pulsátil. As séries foram analisadas no domínio da frequência por meio da análise espectral (Transformada Rápida de Fourier), utilizando-se um software computacional, personalizado, de livre acesso (CardioSeries v2.7, www.danielpenteado.com). Resumidamente, as séries temporais, batimento-a-batimento, foram re-amostradas em $10 \mathrm{~Hz}$ por meio de interpolação cúbica do tipo spline. As séries interpoladas foram divididas em segmentos sequenciais de 512 pontos, sobrepostos em $50 \%$. Após inspeção visual criteriosa, todos os segmentos com transientes que pudessem afetar o cálculo dos espectros foram excluídos da análise final. Em seguida, um janelamento do tipo Hanning foi aplicado aos segmentos e seus espectros foram calculados, inspecionados visualmente e integrados em bandas de LF $(0,20-0,75 \mathrm{~Hz})$ e 
HF (0,75-3,00 Hz). Os resultados são expressos em unidades absolutas $\left(\mathrm{ms}^{2}\right.$ e $\left.\mathrm{mmHg}^{2}\right)$ ou normalizadas (nu). A razão LF/HF também foi calculada.

\subsubsection{Análise da sensibilidade barorreflexa}

As mesmas séries temporais batimento-a-batimento, selecionadas para a análise da variabilidade da pressão arterial sistólica e do intervalo cardíaco, foram utilizadas para avaliação da sensibilidade espontânea do barorreflexo. As análises foram realizadas utilizando-se o método da sequência (BERTINIERI et al., 1985; DI RIENZO et al., 1985). Séries temporais foram examinadas pelo software CardioSeries, procurando-se sequências de valores com, no mínimo, quatro batimentos consecutivos, nos quais aumentos da pressão arterial sistólica foram seguidos por prolongamentos do intervalo cardíaco; assim como reduções da pressão arterial sistólica foram seguidas por encurtamento do intervalo cardíaco. Uma sequência barorreflexa foi considerada quando o coeficiente de correlação $(r)$ entre os valores de pressão arterial sistólica e intervalo cardíaco foi maior ou igual a 0,80. A média da inclinação da reta da regressão linear entre os valores de pressão arterial sistólica e intervalo cardíaco, de cada sequência barorreflexa, foi tomada como a sensibilidade do barorreflexo.

\subsubsection{Análise estatística}

Os dados foram submetidos à análise de variância (ANOVA) de uma via, e à ANOVA de uma via para medidas repetidas seguidas do pós-teste Student-NewmanKeuls, quando indicado. Diferenças foram consideradas estatisticamente significativas se $\mathrm{p}<0,05$. Os resultados são apresentados como média \pm erro padrão da média. A análise estatística foi realizada utilizando-se o software SigmaPlot 12.0 (Systat Software, San Jose, CA, EUA). 


\subsection{Resultados}

\subsubsection{Resposta temporal da pressão arterial à administração de LPS}

Não foram observadas alterações na pressão arterial média ao longo do tempo no grupo salina (Fig. 5A e Tabela 1). Em comparação ao basal, a dose de 0,06 mg/kg de LPS diminuiu a pressão arterial média aos 360 min após a sua administração (116 \pm 3 vs. 109 $\pm 2 \mathrm{mmHg}$; Fig. 5B e Tabela 1). Por outro lado, as doses de 20, 30 e $40 \mathrm{mg} / \mathrm{kg}$ aumentaram a pressão arterial média ao longo do tempo (Fig. 5C - E e Tabela 1). As doses de 20 e 30 $\mathrm{mg} / \mathrm{kg}$ atingiram o pico da resposta pressora aos $360 \mathrm{~min}$, enquanto a dose de $40 \mathrm{mg} / \mathrm{kg}$ atingiu aos $180 \mathrm{~min}$ (Fig. 5C - E e Tabela 1). Além disso, a dose de $20 \mathrm{mg} / \mathrm{kg}$ foi capaz de aumentar a pressão arterial média já nos primeiros 90 min após o LPS, enquanto as doses de 40 e $30 \mathrm{mg} / \mathrm{kg}$ só foram capazes de aumentar a pressão arterial aos 180 e 360 min, respectivamente (Fig. 5C - E e Tabela 1).

\subsubsection{Evolução temporal da frequência cardíaca após a administração de LPS}

Não foram observadas alterações na frequência cardíaca ao longo do tempo no grupo salina (Fig. 5F e Tabela 1). Todas as doses de LPS testadas aumentaram a frequência cardíaca ao longo do tempo, em comparação com os valores basais, atingindo o pico aos 360 min após administração do LPS (Fig. 5G - J e Tabela 1). No entanto, a dose de $0,06 \mathrm{mg} / \mathrm{kg}$ promoveu menor taquicardia em comparação com as outras doses avaliadas (0,06 mg/kg: $\Delta 84 \pm 23$ bpm vs. $20 \mathrm{mg} / \mathrm{kg}: \Delta 200 \pm 26$ bpm; $30 \mathrm{mg} / \mathrm{kg}: \Delta 202$ $\pm 29 \mathrm{bpm} ; 40 \mathrm{mg} / \mathrm{kg}: \Delta 180 \pm 29 \mathrm{bpm})$. Além disso, todas as doses de LPS testadas foram capazes de aumentar a frequência cardíaca, já nos primeiros 90 min após a sua administração (Fig. 5G - J e Tabela 1). 

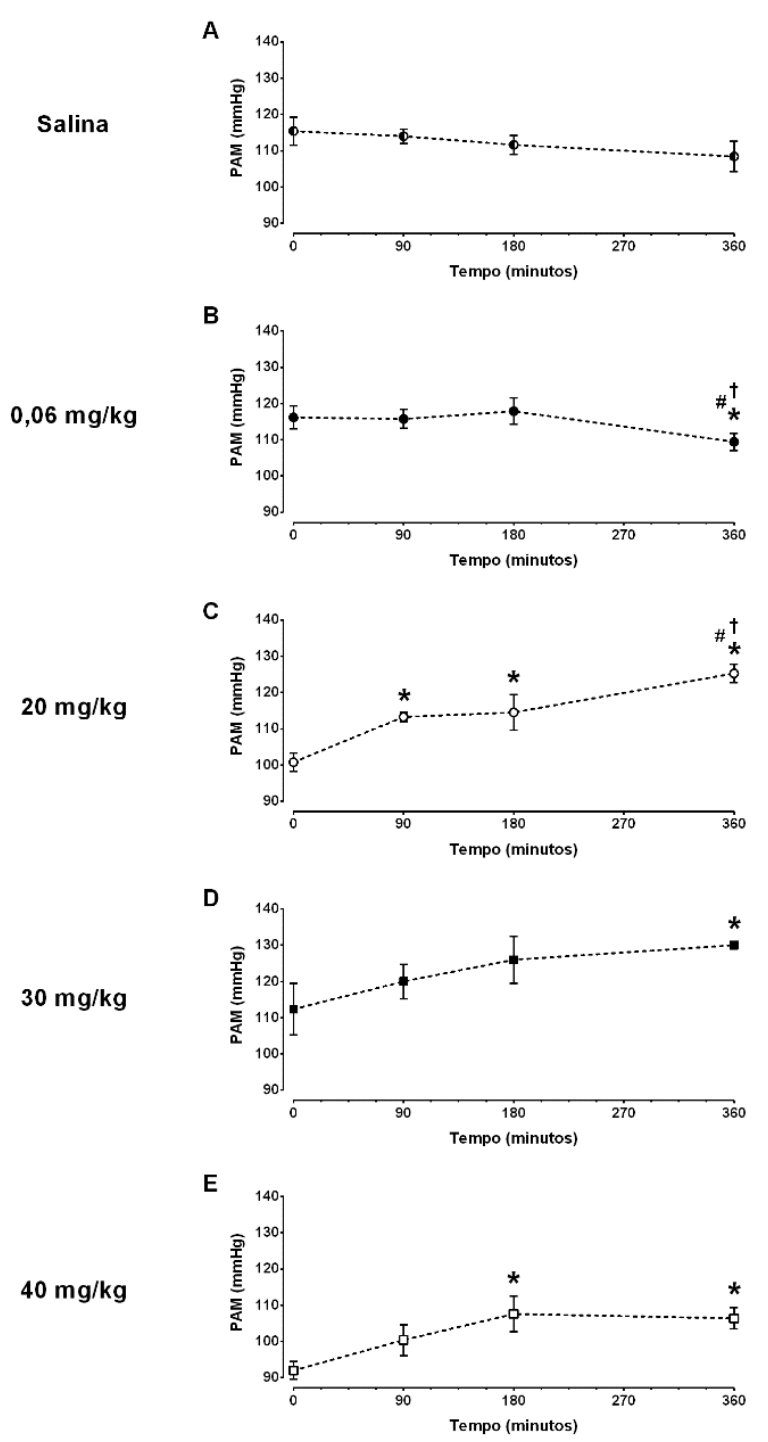

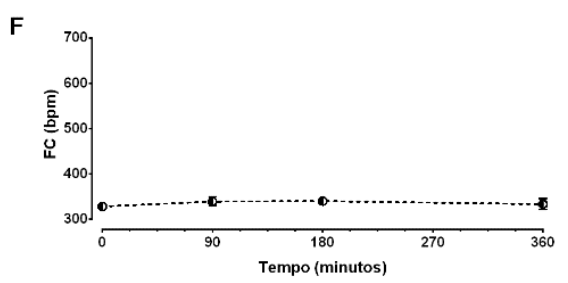

G
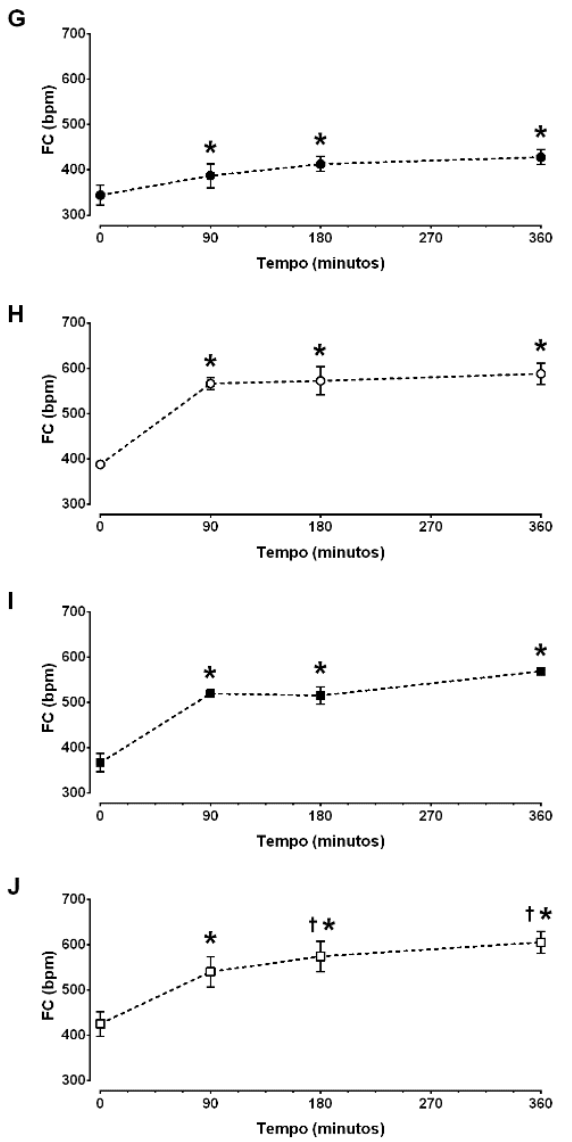

Figura 5. Evolução temporal da pressão arterial média (PAM) e da frequência cardíaca (FC) em resposta a diferentes doses de lipopolissacarídeo em ratos não anestesiados. Salina: painéis (A, F); 0,06 $\mathrm{mg} / \mathrm{kg}$ de LPS: painéis (B, G); $20 \mathrm{mg} / \mathrm{kg}$ de LPS: painéis (C, H); $30 \mathrm{mg} / \mathrm{kg}$ de LPS: painéis (D, I); $40 \mathrm{mg} / \mathrm{kg}$ de LPS: painéis (E, J). Salina: $\mathrm{n}=5 ; 0,06 \mathrm{mg} / \mathrm{kg}: \mathrm{n}=7 ; 20 \mathrm{mg} / \mathrm{kg}: \mathrm{n}=4 ; 30 \mathrm{mg} / \mathrm{kg}: \mathrm{n}=3.40 \mathrm{mg} / \mathrm{kg}: \mathrm{n}=$ 5. Os dados são expressos como média \pm erro padrão da média. * $\mathrm{p}<0,05$ vs. basal; $\uparrow \mathrm{p}<0,05$ vs. 90 min; $\# \mathrm{p}<0,05$ vs. 180 min. ANOVA de uma via para medidas repetidas seguida do pós-teste de StudentNewman-Keuls. 
Tabela 1. Evolução temporal da pressão arterial média (PAM) e frequência cardíaca (FC) em resposta a diferentes doses de lipopolissacarídeo.

\begin{tabular}{|c|c|c|c|c|c|}
\hline & $\begin{array}{l}\text { Salina } \\
(\mathrm{n}=5)\end{array}$ & $\begin{array}{c}0,06 \mathrm{mg} / \mathrm{kg} \\
(\mathrm{n}=7)\end{array}$ & $\begin{array}{c}20 \mathrm{mg} / \mathrm{kg} \\
(\mathrm{n}=4)\end{array}$ & $\begin{array}{c}30 \mathrm{mg} / \mathrm{kg} \\
(\mathrm{n}=3)\end{array}$ & $\begin{array}{c}40 \mathrm{mg} / \mathrm{kg} \\
(\mathrm{n}=5)\end{array}$ \\
\hline \multicolumn{6}{|c|}{ PAM (mmHg) } \\
\hline Basal & $115 \pm 4$ & $116 \pm 3$ & $101 \pm 2$ & $112 \pm 7$ & $92 \pm 2$ \\
\hline $90 \mathrm{~min}$ & $114 \pm 2$ & $116 \pm 3$ & $113 \pm 1 *$ & $120 \pm 5$ & $100 \pm 4$ \\
\hline $180 \mathrm{~min}$ & $112 \pm 3$ & $118 \pm 4$ & $114 \pm 5^{*}$ & $126 \pm 6$ & $108 \pm 5^{*}$ \\
\hline $360 \mathrm{~min}$ & $108 \pm 4$ & $109 \pm 2^{* \# \dagger}$ & $121 \pm 4^{* \# \dagger}$ & $130 \pm 0.4^{*}$ & $107 \pm 3^{*}$ \\
\hline \multicolumn{6}{|l|}{ FC (bpm) } \\
\hline Basal & $328 \pm 5$ & $344 \pm 22$ & $388 \pm 6$ & $367 \pm 21$ & $426 \pm 27$ \\
\hline $90 \mathrm{~min}$ & $339 \pm 10$ & $387 \pm 27^{*}$ & $566 \pm 13^{*}$ & $520 \pm 6^{*}$ & $540 \pm 34^{*}$ \\
\hline $180 \mathrm{~min}$ & $340 \pm 8$ & $413 \pm 16^{*}$ & $572 \pm 31^{*}$ & $516 \pm 18^{*}$ & $574 \pm 33^{* \dagger}$ \\
\hline $360 \mathrm{~min}$ & $333 \pm 12$ & $428 \pm 17^{*}$ & $588 \pm 24^{*}$ & $569 \pm 9^{*}$ & $606 \pm 24 * \dagger$ \\
\hline$\overline{\text { Dados expres }}$ & édia $\pm \mathrm{e}$ & drão da m & $* \mathrm{p}<0,0$ & basal; $\uparrow \mathrm{p}<$ & 5 vs. $90 \mathrm{~m}$ \\
\hline
\end{tabular}




\subsubsection{Resposta temporal da variabilidade cardiocirculatória à administração de LPS}

A análise realizada em vários momentos (basal, 90, 180 e 360 min) após a administração de LPS, ou salina, não revelou diferença na potência da banda de LF no espectro do intervalo cardíaco nos grupos salina, 0,06, 20 ou $30 \mathrm{mg} / \mathrm{kg}$ de LPS, apesar de forte tendência em aumentar a potência de LF nos grupos com 20 ou $30 \mathrm{mg} / \mathrm{kg}$ (Fig. 6A - D). No entanto, os ratos que receberam $40 \mathrm{mg} / \mathrm{kg}$ mostraram um aumento na potência da banda de LF no espectro do intervalo cardíaco aos 180 e 360 min após a administração do LPS (Fig. 6E). A análise da potência de HF não mostrou alterações no grupo salina (Fig. 6F); mas, a injeção de LPS reduziu, drasticamente, a potência de HF ao longo do tempo, iniciando aos 90 min após sua administração (Fig. 6G - J). Em todos os grupos não foram encontradas diferenças na relação LF/HF ao longo do tempo (Fig. 6K - O). No entanto, a dose de $40 \mathrm{mg} / \mathrm{kg}$ apresentou grande tendência ao aumento aos 180 e $360 \mathrm{~min}$ após o LPS (Fig. 6O). A potência da banda de LF do espectro da pressão arterial sistólica aumentou ao longo do tempo em ambos os grupos, tratados com salina ou LPS (Fig. 6P $-\mathrm{T})$. 


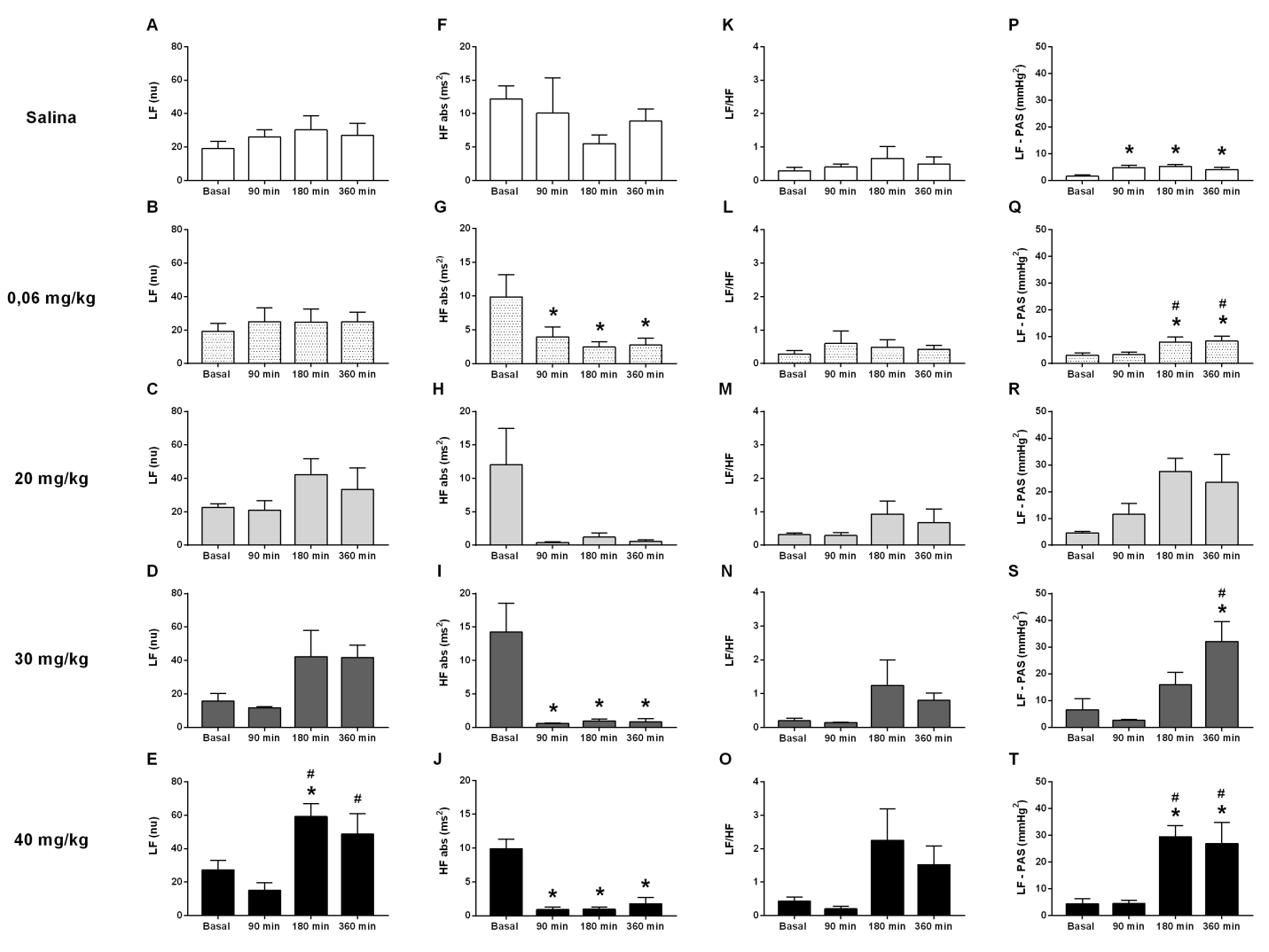

Figura 6. Efeitos das diferentes doses de lipopolissacarídeo sobre a variabilidade do intervalo cardíaco e da pressão arterial sistólica de ratos não anestesiados. Os parâmetros avaliados foram: banda de LF (LF), banda de HF (HF), razão LF/HF, e LF da pressão arterial sistólica (LF-PAS). Salina: painéis (A, F, K, P); 0,06 mg/kg de LPS: painéis (B, G, L, Q); $20 \mathrm{mg} / \mathrm{kg}$ de LPS: painéis (C, H, M, R); $30 \mathrm{mg} / \mathrm{kg}$ de LPS: painéis (D, I, N, S); $40 \mathrm{mg} / \mathrm{kg}$ de LPS: painéis (E, J, O, T). Salina: $\mathrm{n}=5 ; 0,06 \mathrm{mg} / \mathrm{kg}: \mathrm{n}=7 ; 20$ $\mathrm{mg} / \mathrm{kg}: \mathrm{n}=3 ; 30 \mathrm{mg} / \mathrm{kg}: \mathrm{n}=3.40 \mathrm{mg} / \mathrm{kg}: \mathrm{n}=5$. Barras são expressas como média \pm erro padrão da média. $* \mathrm{p}<0,05$ vs. basal; \# $\mathrm{p}<0,05$ vs. 90 min. LF: baixa frequência; HF: alta frequência. ANOVA de uma via para medidas repetidas seguido do pós-teste de Student-Newman-Keuls. 


\subsubsection{Resposta temporal da sensibilidade barorreflexa à administração de LPS}

A análise da sensibilidade barorreflexa revelou que a administração de salina não alterou a sensibilidade barorreflexa ao longo do tempo (Fig. 7A). Por outro lado, todas as doses de LPS promoveram diminuição da sensibilidade barorreflexa, ao longo do tempo (Fig. 7B - E). Vale destacar que essa alteração foi observada já no primeiro momento avaliado (90 min) após a administração de LPS, e foi mantida até o final do protocolo (360 $\mathrm{min})$.
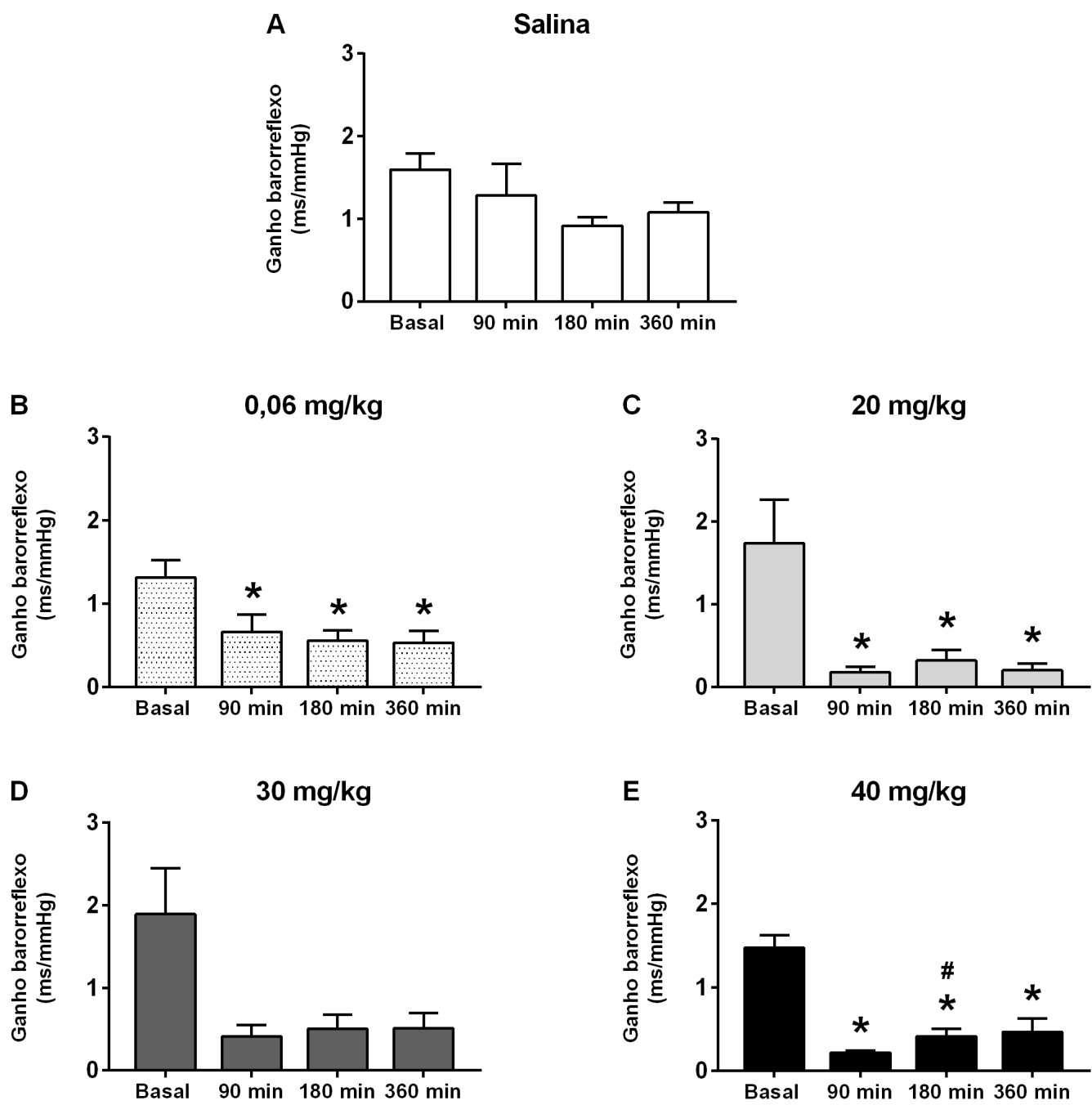

Figura 7. Efeitos das diferentes doses de lipopolissacarídeo na sensibilidade barorreflexa de ratos não anestesiados. Sensibilidade barorreflexa após a administração de salina ou LPS. Salina (A); 0,06 mg/kg de LPS (B); 20 mg/kg (C); 30 mg/kg de LPS (D); 40 mg/kg de LPS (E). Salina: $\mathrm{n}=5 ; 0,06 \mathrm{mg} / \mathrm{kg}: \mathrm{n}=7 ; 20$ $\mathrm{mg} / \mathrm{kg}: \mathrm{n}=3 ; 30 \mathrm{mg} / \mathrm{kg}: \mathrm{n}=3.40 \mathrm{mg} / \mathrm{kg}: \mathrm{n}=5$. Barras são expressas como média \pm erro padrão da média. $* \mathrm{p}<0,05$ vs. basal; \# p $<0,05$ vs. $90 \mathrm{~min}$. ANOVA de uma via para medidas repetidas, seguida do pósteste de Student-Newman-Keuls. 


\subsection{Conclusões}

Os dados apresentados neste protocolo indicam que altas doses de LPS promovem aumento da pressão arterial ao longo do tempo, enquanto que uma dose baixa reduz a pressão arterial. Ainda, tanto doses altas quanto baixas provocam taquicardia nos animais ao longo do tempo. Além disso, alterações na variabilidade do intervalo cardíaco e na sensibilidade barorreflexa, causadas pela administração de LPS, talvez não estejam associadas com a resposta de pressão arterial apresentada na endotoxemia. Por outro lado, as diferenças observadas na resposta da pressão arterial entre os grupos com doses altas e baixas de LPS, podem ser atribuídas ao aumento exacerbado da potência da banda de LF no espectro da pressão arterial sistólica, ao longo do tempo, nos grupos que receberam doses altas de LPS. 
4. Ativação Barorreflexa e a Resposta Inflamatória Sistêmica 


\section{ATIVAÇÃO BARORREFLEXA E A RESPOSTA INFLAMATÓRIA SISTÊMICA}

\subsection{Objetivos}

\subsubsection{Gerais}

Após o estudo das alterações cardiovasculares decorrentes da administração de diferentes doses de LPS, optou-se por utilizar a dose de $0,06 \mathrm{mg} / \mathrm{kg}$ (i.v.) nos próximos protocolos, uma vez que esta foi a dose, dentre as avaliadas, que mimetizou melhor as alterações hemodinâmicas classicamente observadas na inflamação sistêmica. Além disso, doses muito altas poderiam mascarar a possível resposta anti-inflamatória da ativação do barorreflexo e comprometer as análises por induzirem, também, danos sistêmicos maiores. Sendo assim, optou-se por uma dose de LPS considerada baixa, mas capaz de ativar o sistema imune de ratos, como já demonstrado em trabalhos também envolvendo o controle neural da resposta inflamatória (MARTELLI et al., 2014a, 2014b).

Uma vez que a ativação barorreflexa atenua a inflamação local em um modelo experimental de artrite reumatoide (BASSI et al., 2015) e os níveis hipotalâmicos de citocinas em um modelo de endotoxemia (BROGNARA et al., 2018), para expandir o conhecimento sobre o potencial anti-inflamatório da ativação elétrica do barorreflexo, o presente protocolo teve como objetivo avaliar, ao longo de um período maior de tempo, se a estimulação elétrica do NDA reduz a inflamação sistêmica em ratos endotoxêmicos não anestesiados.

\subsubsection{Específicos}

Os objetivos específicos deste estudo foram:

a) Analisar a pressão arterial, a frequência cardíaca, a variabilidade do intervalo cardíaco, a variabilidade da pressão arterial sistólica, e a sensibilidade do barorreflexo em diferentes momentos ao longo de 360 min após a administração de LPS, ou salina, nos diferentes grupos;

b) Quantificar os níveis plasmáticos das citocinas pró-inflamatórias (TNF- $\alpha$, IL-1 $\beta$ e IL-6) e anti-inflamatória (IL-10), em diferentes momentos ao longo de $360 \mathrm{~min}$ após a administração de LPS, ou salina, afim de examinar se a ativação parassimpática e inibição simpática, por meio da estimulação do NDA, previne o aumento das citocinas induzido pelo LPS. 


\subsection{Material e Métodos}

\subsubsection{Animais de experimentação}

Foram utilizados ratos Wistar Hannover pesando 230-300 g, provenientes do Biotério Central do Campus da Universidade de São Paulo de Ribeirão Preto (Campus de Ribeirão Preto; Ribeirão Preto, SP, Brasil), acondicionados em caixas individuais e mantidos sob temperatura controlada $\left(22^{\circ} \mathrm{C}\right)$, ciclo claro-escuro constante de $12 \mathrm{~h}$, com livre acesso a água e ração. Todos os procedimentos foram revisados e aprovados pelo Comitê de Ética no Uso de Animais de Experimentação da Faculdade de Medicina de Ribeirão Preto - Universidade de São Paulo (Protocolo n. 194/2016).

\subsubsection{Grupos experimentais}

Antes de serem submetidos aos procedimentos cirúrgicos, os animais foram divididos em quatro grupos experimentais:

I) Salina (n = 9): cirurgia fictícia e administração de salina;

II) LPS $(\mathbf{n}=\mathbf{8})$ : implante do eletrodo com os fios encapados no NDA sem estimulação elétrica, porém com administração de LPS.

III) LPS + ENDA (-) $(\mathbf{n}=\mathbf{1 1})$ : implante do eletrodo no NDA associado à estimulação elétrica sem efeito hemodinâmico, porém com administração de LPS;

IV) LPS + ENDA (+) $(\mathbf{n}=7)$ : implante do eletrodo no NDA associado à estimulação elétrica com efeito hemodinâmico, porém com administração de LPS.

\subsubsection{Procedimentos cirúrgicos}

Os animais foram anestesiados com uma mistura de Ketamina e Xilazina (50 $\mathrm{mg} / \mathrm{kg}$ e $10 \mathrm{mg} / \mathrm{kg}$, i.p.), e submetidos aos procedimentos cirúrgicos para isolar o NDA esquerdo para implante do eletrodo, e canulação da artéria e veia femorais para registro da pressão arterial e administração de LPS (ou salina), respectivamente. Para o implante do eletrodo foi realizada uma cervicotomia mediana anterior, para, cuidadosamente, com o auxílio do microscópio, isolar o NDA esquerdo, abaixo da sua junção com o nervo laríngeo superior, e colocá-lo sobre o par de eletrodos bipolares. O eletrodo utilizado era bipolar de aço inoxidável confeccionado com dois fios de $40 \mathrm{~mm}$ de comprimento, e uma distância entre os fios de $2 \mathrm{~mm}$ (diâmetro: $127 \mu \mathrm{m}$ descoberto e 203,2 $\mu \mathrm{m}$ coberto com Teflon; modelo 791400; A-M Systems, Sequim, WA, EUA) associados a um pequeno 
conector (GF-6; Microtech, Boothwyn, PA, EUA). As pontas descobertas do eletrodo consistiam em comprimentos de $2 \mathrm{~mm}$, em formato de gancho ao redor do NDA. Primeiramente, o eletrodo foi posicionado através do músculo esternocleidomastoideo e o pequeno conector foi exteriorizado na região posterior do pescoço do animal. Em seguida, o segmento isolado do NDA foi posicionado sobre o eletrodo de aço inoxidável (Fig. 8) e cuidadosamente coberto com um material siliconado para isolar a região (KwikSil silicone elastomer; World Precision Instruments, Sarasota, FL, EUA). Após alguns min para completa polimerização do silicone, a região foi suturada. Os animais do grupo II passaram pelos mesmos procedimentos, mas o eletrodo no NDA tinha os seus fios encapados (Fig. 9). Já nos animais do grupo I foi realizado apenas a cervicotomia, ou seja, os animais não tiveram o NDA isolado e o eletrodo não foi implantado ao seu redor. Na mesma cirurgia, a artéria e veia femorais esquerdas foram canuladas com tubo de polietileno (tubo de polietileno PE-50 soldado ao PE-10; Intramedic, Clay Adams, Parsippany, NJ, EUA). Tanto o conector do eletrodo, quanto os cateteres vasculares, foram exteriorizados na parte posterior do pescoço dos ratos, e as incisões cirúrgicas foram devidamente suturadas. Imediatamente após o término da cirurgia foi feita a administração de analgésico (cloridrato de tramadol $2 \mathrm{mg} / \mathrm{kg}$, s.c.).

\subsubsection{Registro da pressão arterial}

Após o período de recuperação cirúrgica de $24 \mathrm{~h}$, os animais se movimentando livremente (não anestesiados) foram conectados ao sistema de registro, o qual consistiu de um transdutor de pressão (MLT844; ADInstruments, Sydney, Austrália) ligado ao amplificador (ML224; ADInstruments, Bella Vista, Austrália) conectado a um computador (Core 2 Duo, $2.2 \mathrm{GHz}, 4 \mathrm{~GB}$ RAM) e a uma interface analógico-digital (PowerLab, ADInstruments, Bella Vista, Austrália) para registrar o sinal da pressão arterial pulsátil, e, a partir dele, obter a pressão arterial média, sistólica, diastólica e a frequência cardíaca. Os experimentos foram conduzidos com os animais se movimentando livremente em sua própria caixa (um animal por caixa), e silêncio foi mantido na sala para minimizar o estresse ambiental. No caso dos grupos III e IV, o conector do eletrodo foi ligado a um estimulador elétrico, o qual foi, também, interligado ao sistema de registro digital para monitoramento. O estimulador gerava um estímulo elétrico com onda quadrada em regime de pulso contínuo seguindo os seguintes parâmetros de estimulação: frequência de $15 \mathrm{~Hz}$, largura do pulso de $0,25 \mathrm{~ms}$, intensidade de $0,5 \mathrm{~mA}$. 
Para todos os animais, o protocolo experimental inicial consistiu na coleta de amostra de sangue em condições basais e registro da pressão arterial pulsátil por $30 \mathrm{~min}$. Em seguida, para os grupos I e II foi realizada a administração de salina, ou LPS, imediatamente após término do período basal. Então, a pressão arterial foi registrada continuamente durante 360 min após a administração de LPS ou salina. Para os grupos III e IV, após o período basal, o estimulador elétrico foi ligado e a estimulação elétrica do NDA foi realizada por $10 \mathrm{~min}$, antes e $10 \mathrm{~min}$ depois da administração de LPS [0,06 mg/kg (i.v.); Escherichia coli - 0111: B4; Sigma-Aldrich, St. Louis, MO, EUA], totalizando 20 min de estímulo elétrico. Em seguida, a pressão arterial também foi registrada continuamente durante 360 min após a administração de LPS. Nesse período foram feitas coletas de sangue seriadas ( $250 \mu \mathrm{L}$ por amostra) aos 90, 180, 270 e $360 \mathrm{~min}$ após a administração de LPS, ou salina, através da cânula na artéria femoral esquerda em todos os grupos experimentais. As amostras de sangue foram coletadas com heparina e mantidas no gelo até serem centrifugadas a $4^{\circ} \mathrm{C}$, durante $15 \mathrm{~min}$, utilizando-se $5000 \mathrm{rpm}$. Logo após, o plasma foi coletado e armazenado a $-80^{\circ} \mathrm{C}$ até o dia do processamento da amostra.

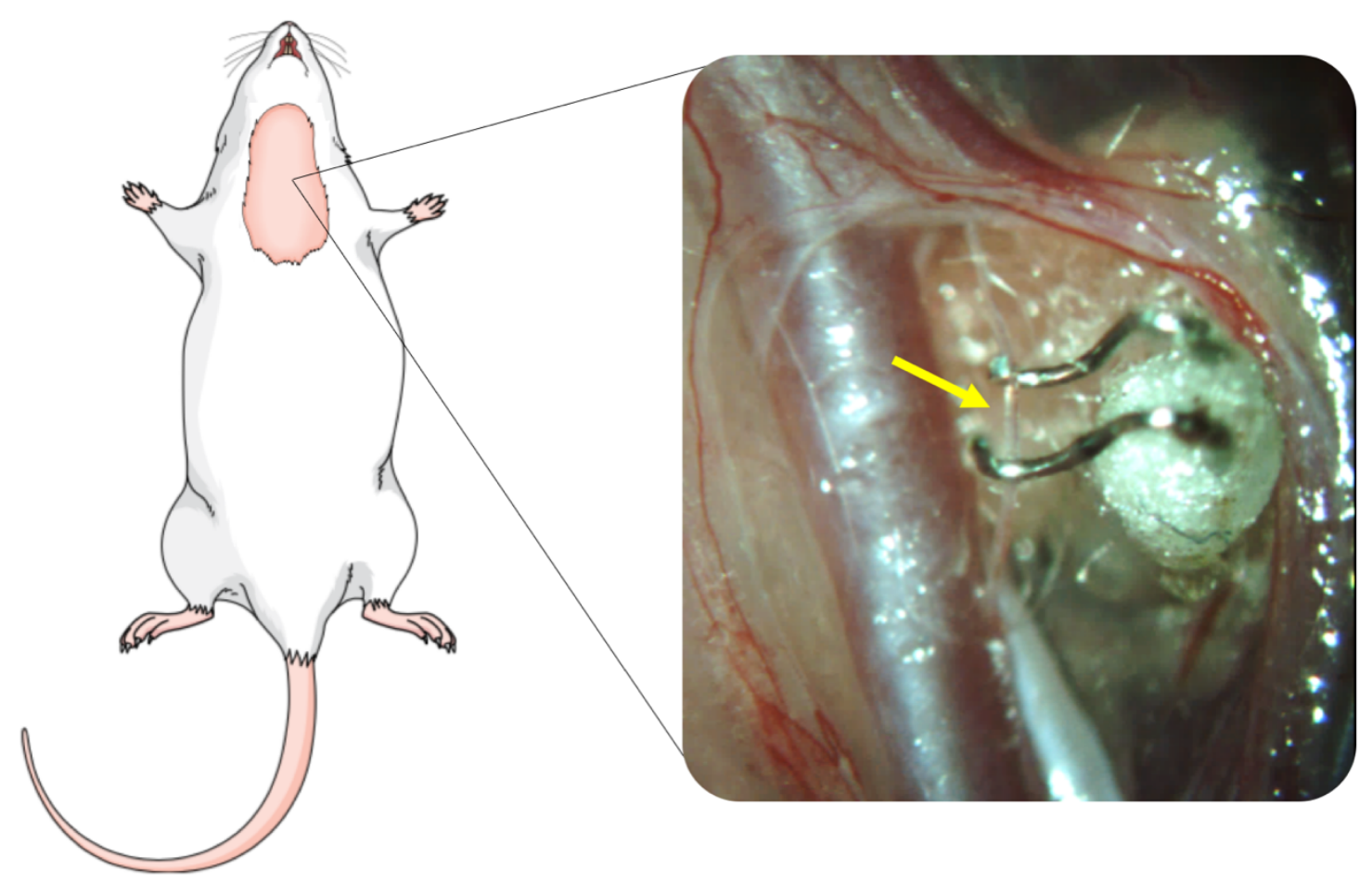

Figura 8. Nervo depressor aórtico posicionado no eletrodo. A seta amarela mostra o segmento do nervo depressor aórtico de um rato, o qual foi isolado e posicionado sobre o eletrodo para realizar a estimulação elétrica. Figura criada utilizando a plataforma online Mind the Graph (disponível em: www.mindthegraph.com). 

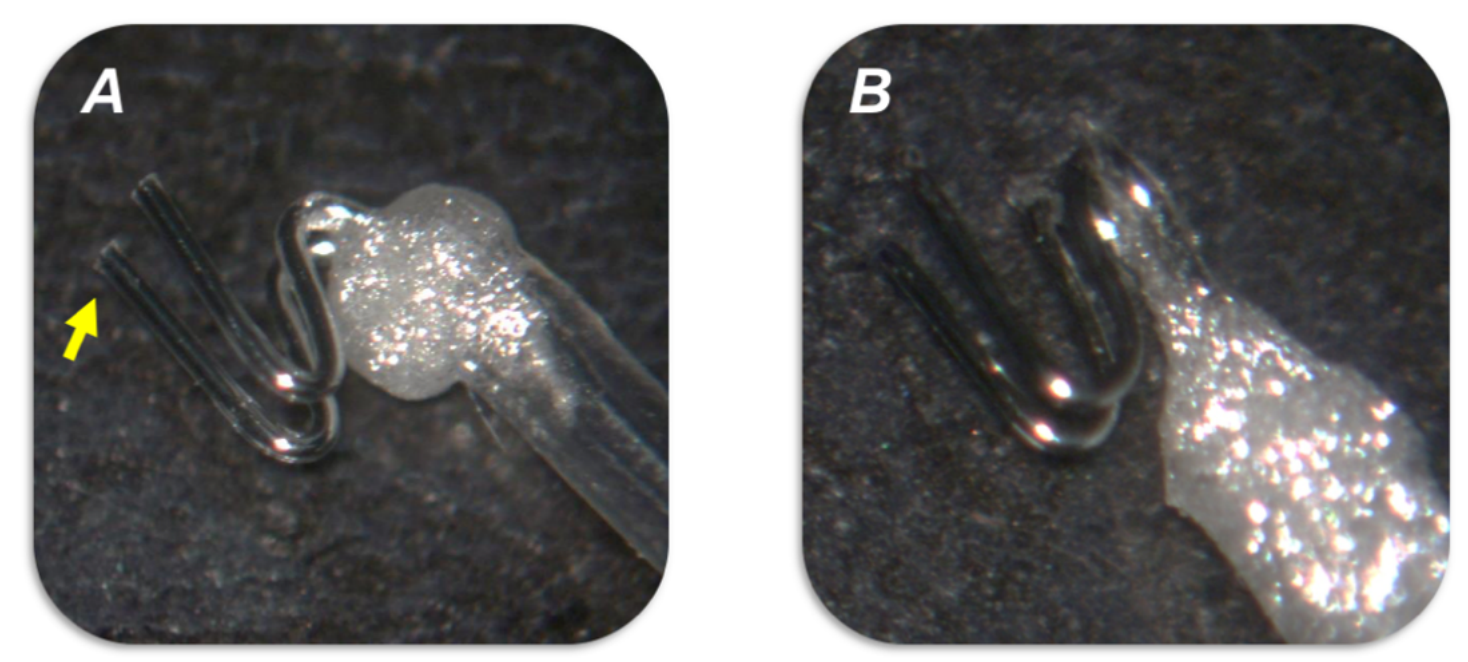

Figura 9. Fotografia dos eletrodos utilizados no protocolo. A: fios do eletrodo encapados. B: fios do eletrodo decapados. A seta amarela destaca o material que mantem os fios encapados. Na foto à direita (B) é possível notar a ausência do material envolvendo os fios.

\subsubsection{Análise da variabilidade da pressão arterial sistólica e do intervalo cardíaco}

A análise da variabilidade da pressão arterial sistólica e do intervalo cardíaco foi realizada como descrito na subseção 3.2.5.

\subsubsection{Análise da sensibilidade barorreflexa}

A análise da sensibilidade barorreflexa foi realizada como descrito na subseção 3.2.6.

\subsubsection{Análise de citocinas}

Os níveis plasmáticos das citocinas (TNF- $\alpha$, IL-1 $\beta$, IL-6 e IL-10) foram determinados por meio do método imunoenzimático Enzyme Linked ImmunonoSorbent Assay (ELISA) utilizando kits (Duo set R\&D Systems, Minneapolis, MN, EUA), seguindo as instruções do fabricante.

\subsubsection{Análise estatística}

Os parâmetros hemodinâmicos foram analisados pela ANOVA de duas vias para medidas repetidas, seguida do pós-teste Tukey, quando indicado. As análises da variabilidade cardiocirculatória e da sensibilidade barorreflexa foram feitas pela ANOVA 
de uma via, seguida do pós-teste de Tukey. Os dados obtidos a partir do plasma foram analisados pela ANOVA de uma via, seguida do pós-teste de Student-Newman-Keuls e Kruskal-Wallis, seguido do pós-teste Dunn, quando indicado, e, também pela ANOVA de duas vias para medidas repetidas seguida do pós-teste Tukey. Diferenças foram consideradas estatisticamente significativas se $\mathrm{p}<0,05$. Os resultados são apresentados como média \pm erro padrão da média. A análise estatística foi realizada utilizando-se o software SigmaPlot 12.0 (Systat Software, San Jose, CA, EUA). 


\subsection{Resultados}

\subsubsection{Respostas hemodinâmicas à estimulação elétrica do nervo depressor aórtico}

Logo após o seu início (primeiros 5 segundos), a estimulação do NDA (ENDA) reduziu a pressão arterial e a frequência cardíaca dos animais [Fig. 10 e Fig. 11; grupo ENDA (+)], resposta esperada quando o barorreflexo é ativado. Entretanto, a ENDA não alterou a pressão arterial em 11 dos 18 animais que receberam a estimulação elétrica [Fig. 11; grupo ENDA (-)]. Ou seja, com o mesmo estímulo, alguns animais não apresentaram a resposta hemodinâmica clássica decorrente da ativação barorreflexa, por isso, o conjunto dos animais foi separado em dois grupos: um com resposta hemodinâmica $(+)$, e o outro sem a resposta (-).
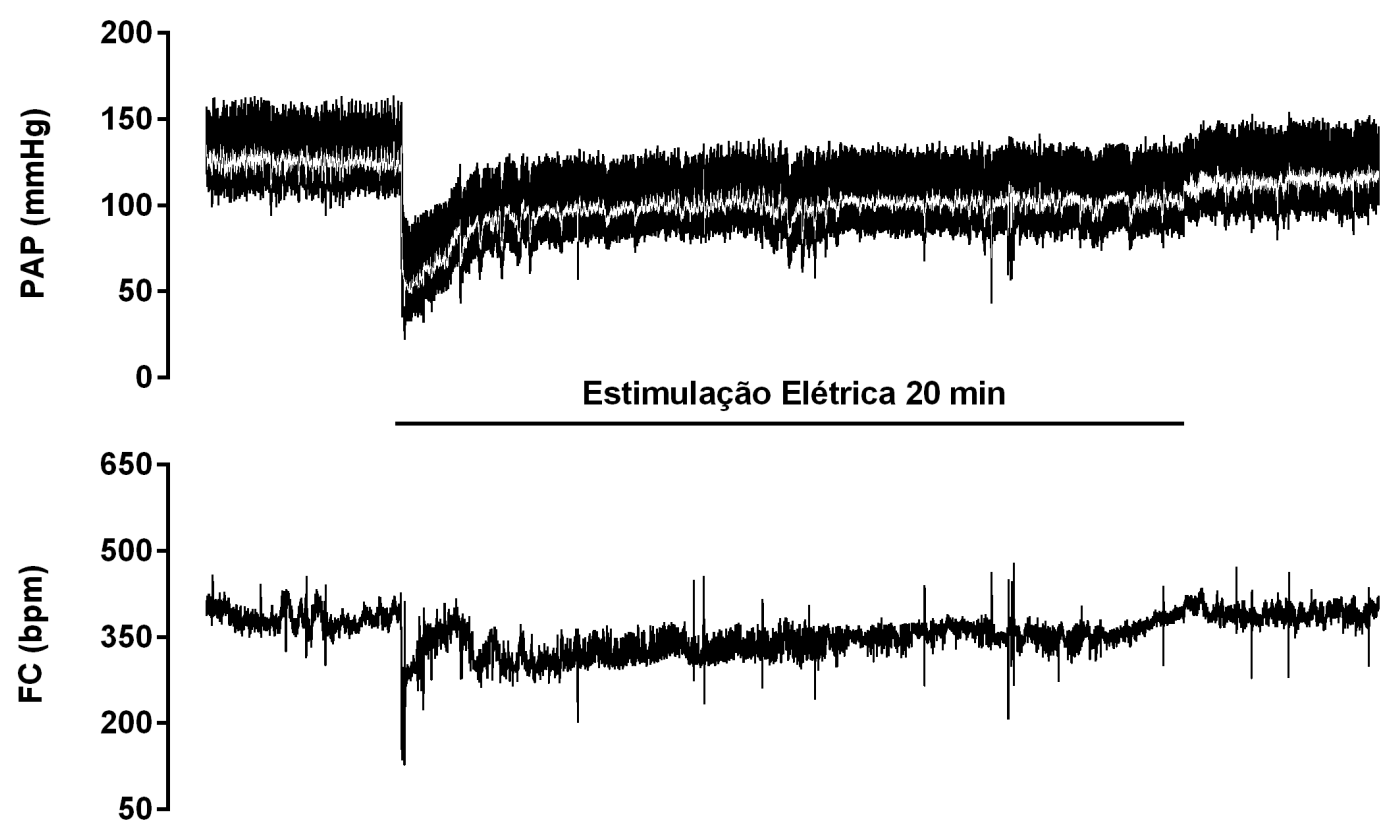

Figura 10. Registro representativo das respostas hemodinâmicas de um rato não anestesiado durante a estimulação elétrica do nervo depressor aórtico. Barra horizontal representa o período de 20 minutos referente à estimulação elétrica do nervo depressor aórtico e a linha branca representa a pressão arterial média. Registro de um animal do grupo LPS+ENDA (+). PAP: pressão arterial pulsátil; FC: frequência cardíaca. 
A

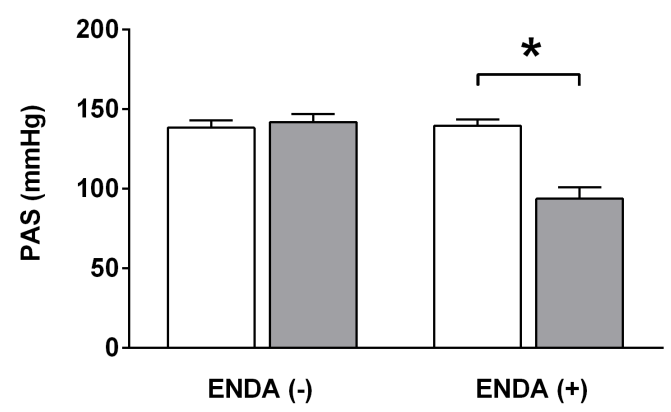

C

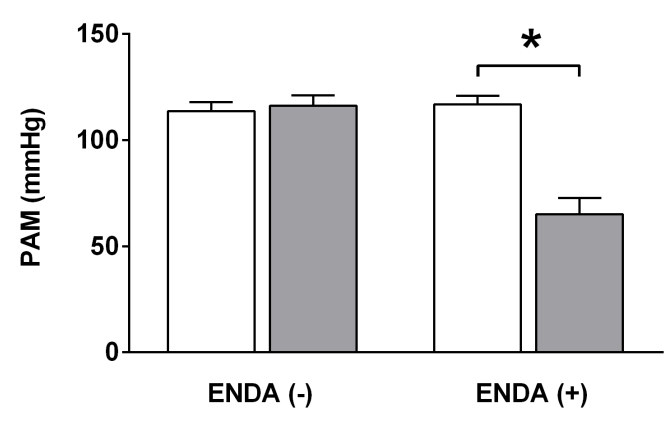

B

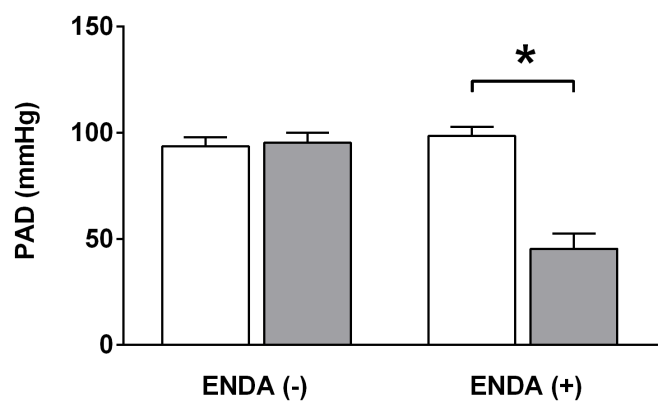

D

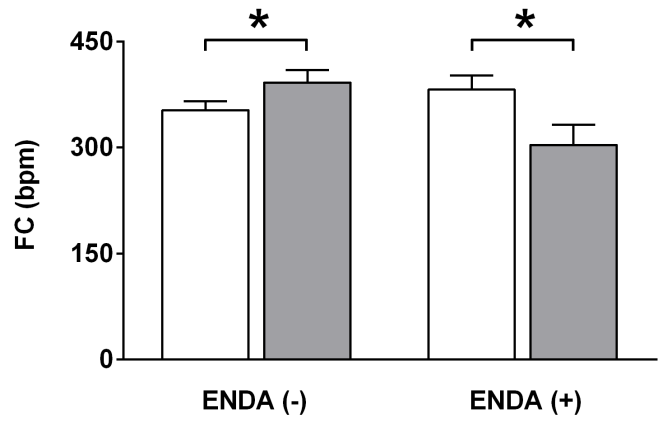

Figura 11. Respostas hemodinâmicas à estimulação do nervo depressor aórtico (ENDA) em ratos não anestesiados. PAS: pressão arterial sistólica; PAD: pressão arterial diastólica; PAM: pressão arterial média; FC: frequência cardíaca. Períodos: basal (barras brancas) e 5 segundos após o início da estimulação (barras cinzas). ENDA (-): sem queda de pressão arterial; ENDA (+): com queda de pressão arterial. LPS+ENDA $(-): n=11 ; \operatorname{LPS}+\operatorname{ENDA}(+): \mathrm{n}=7$. As barras representam média \pm erro padrão $* \mathrm{p}<0,05$. ANOVA de duas vias para medidas repetidas, seguida do pós-teste Tukey.

\subsubsection{Análise temporal das respostas hemodinâmicas}

A análise temporal mostrou que todos os grupos apresentaram valores similares no período basal (0 $\mathrm{min})$, tanto para pressão arterial quanto para a frequência cardíaca (Tabela 2). Ao longo do tempo, a pressão arterial não diferiu entre os grupos avaliados (Tabela 2). Por outro lado, houve um aumento expressivo da frequência cardíaca ao longo do tempo, em todos os grupos que receberam LPS, já a partir do primeiro momento avaliado após sua administração (Tabela 2). Entretanto, não houve diferença nos valores de frequência cardíaca entre esses grupos em nenhum dos momentos que sucederam a administração de LPS (Tabela 2). O grupo controle (salina) não apresentou alterações na frequência cardíaca durante o período estudado (Tabela 2). 
Tabela 2. Análise temporal das respostas hemodinâmicas no protocolo com estimulação do nervo depressor aórtico.

\begin{tabular}{|c|c|c|c|c|}
\hline & $\begin{array}{c}\text { Salina } \\
(\mathrm{n}=9)\end{array}$ & $\begin{array}{c}\text { LPS } \\
(\mathrm{n}=8)\end{array}$ & $\begin{array}{c}\text { LPS+ENDA (-) } \\
\quad(\mathrm{n}=11)\end{array}$ & $\begin{array}{c}\text { LPS }+ \text { ENDA }(+) \\
(\mathrm{n}=7)\end{array}$ \\
\hline \multicolumn{5}{|l|}{ PAS (mmHg) } \\
\hline $0 \mathrm{~min}$ & $137 \pm 3$ & $136 \pm 3$ & $139 \pm 4$ & $140 \pm 4$ \\
\hline $90 \mathrm{~min}$ & $133 \pm 3$ & $148 \pm 3$ & $142 \pm 3$ & $144 \pm 3$ \\
\hline $180 \mathrm{~min}$ & $132 \pm 2$ & $142 \pm 3$ & $135 \pm 3$ & $132 \pm 3$ \\
\hline $270 \mathrm{~min}$ & $130 \pm 2$ & $146 \pm 4^{*}$ & $138 \pm 4$ & $133 \pm 7$ \\
\hline $360 \mathrm{~min}$ & $126 \pm 3$ & $140 \pm 7$ & $134 \pm 4$ & $133 \pm 8$ \\
\hline \multicolumn{5}{|l|}{ PAD (mmHg) } \\
\hline $0 \mathrm{~min}$ & $97 \pm 3$ & $97 \pm 3$ & $94 \pm 4$ & $99 \pm 4$ \\
\hline $90 \mathrm{~min}$ & $94 \pm 2$ & $105 \pm 3$ & $96 \pm 4$ & $99 \pm 4$ \\
\hline $180 \mathrm{~min}$ & $92 \pm 2$ & $104 \pm 3$ & $93 \pm 4$ & $92 \pm 5$ \\
\hline $270 \mathrm{~min}$ & $87 \pm 3$ & $119 \pm 3$ & $90 \pm 4$ & $91 \pm 8$ \\
\hline $360 \mathrm{~min}$ & $83 \pm 4$ & $113 \pm 6$ & $88 \pm 5$ & $91 \pm 8$ \\
\hline \multicolumn{5}{|c|}{ PAM (mmHg) } \\
\hline $0 \mathrm{~min}$ & $115 \pm 3$ & $114 \pm 3$ & $114 \pm 4$ & $117 \pm 4$ \\
\hline $90 \mathrm{~min}$ & $112 \pm 2$ & $123 \pm 2$ & $115 \pm 4$ & $117 \pm 4$ \\
\hline $180 \mathrm{~min}$ & $110 \pm 2$ & $120 \pm 3$ & $110 \pm 3$ & $108 \pm 4$ \\
\hline $270 \mathrm{~min}$ & $107 \pm 2$ & $119 \pm 3$ & $110 \pm 4$ & $108 \pm 7$ \\
\hline $360 \mathrm{~min}$ & $103 \pm 3$ & $113 \pm 6$ & $107 \pm 4$ & $109 \pm 8$ \\
\hline \multicolumn{5}{|l|}{ FC (bpm) } \\
\hline $0 \mathrm{~min}$ & $336 \pm 8$ & $333 \pm 12$ & $353 \pm 12$ & $382 \pm 20$ \\
\hline $90 \mathrm{~min}$ & $344 \pm 8$ & $415 \pm 22^{*}$ & $421 \pm 22^{*}$ & $463 \pm 14^{*}$ \\
\hline $180 \mathrm{~min}$ & $357 \pm 11$ & $445 \pm 24^{*}$ & $465 \pm 19^{*}$ & $498 \pm 7^{*}$ \\
\hline $270 \mathrm{~min}$ & $361 \pm 14$ & $456 \pm 19^{*}$ & $474 \pm 14^{*}$ & $492 \pm 14^{*}$ \\
\hline $360 \mathrm{~min}$ & $351 \pm 12$ & $432 \pm 20^{*}$ & $447 \pm 17^{*}$ & $484 \pm 18^{*}$ \\
\hline
\end{tabular}

Dados expressos como média \pm erro padrão da média. PAS: pressão arterial sistólica; PAD: pressão arterial diastólica; PAM: pressão arterial média; FC: frequência cardíaca; ENDA: estimulação do nervo depressor aórtico sem (-) e com (+) alteração hemodinâmica. * p $<0,05$ vs. Salina no mesmo momento. ANOVA de duas vias para medidas repetidas, seguida do pós-teste Tukey. 


\subsubsection{Ativação barorreflexa e a variabilidade cardiocirculatória em ratos endotoxêmicos}

A análise da variabilidade do intervalo cardíaco revelou que no período basal, o grupo LPS+ENDA $(+)$ apresentou maior potência na banda de LF e menor potência na banda de HF no espectro do intervalo cardíaco comparado com os grupos Salina e LPS (Fig. 12A e F, respectivamente). Esses achados também refletiram em uma maior razão LF/HF no período basal no grupo LPS+ENDA (+) (Fig. 12K). Entretanto, essas diferenças deixaram de existir ao longo do tempo. Com relação à potência da banda de LF ao longo do tempo, aos 360 min foi observado aumento da banda de LF no grupo LPS+ENDA (-) comparado aos outros grupos avaliados (Fig. 12E). Já os dados referentes à potência da banda de HF mostraram que a partir do momento 90 min, todos os grupos que receberam LPS apresentaram redução da potência da banda de HF comparado ao grupo salina (Fig. 12G - J). Em decorrência do aumento da potência da banda de LF e redução da banda de HF aos 360 min, o grupo LPS+ENDA (-) apresentou aumento na razão LF/HF (Fig. 12O).

A análise da variabilidade da pressão arterial sistólica mostrou que 90 min após a administração de LPS houve um aumento na banda de LF e que a estimulação elétrica do NDA, (com ou sem efeito hemodinâmico), reduziu esse aumento (Fig. 12Q). Entretanto, ao final do protocolo (momento $360 \mathrm{~min}$ ) não foram observadas diferenças entre os grupos estudados (Fig. 12T). 


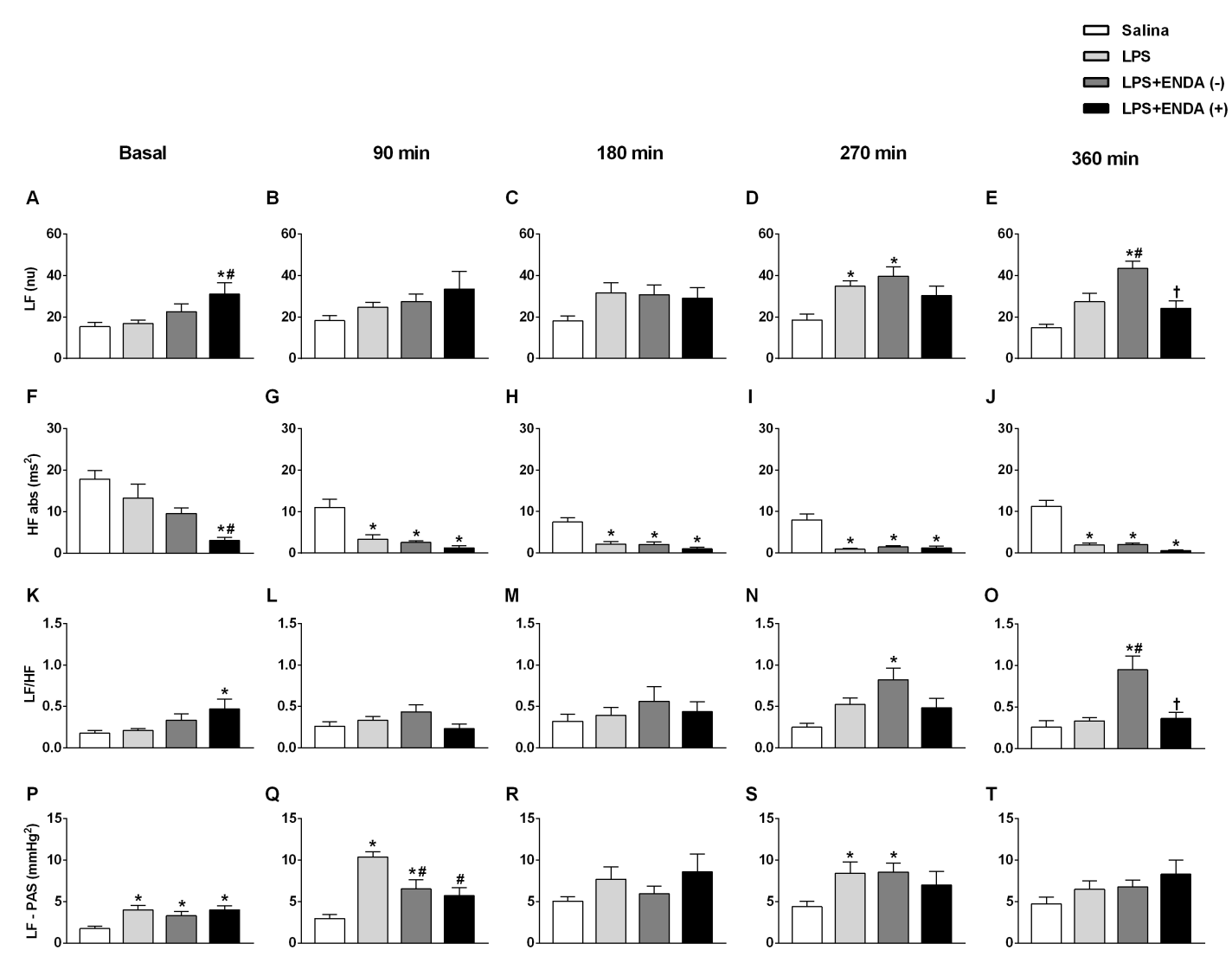

Figura 12. Efeitos da ativação barorreflexa sobre a variabilidade do intervalo cardíaco e da pressão arterial sistólica de ratos endotoxêmicos não anestesiados ao longo do tempo. Os parâmetros avaliados foram: banda de baixa frequência (LF; painéis A, B, C D e E), banda de alta frequência (HF; painéis F, G, H, I e J), razão LF/HF (painéis K, L, M, N e O), e LF da pressão arterial sistólica (LF-PAS; painéis P, Q, R, S e T), em diferentes momentos: basal, $90 \mathrm{~min}, 180 \mathrm{~min}, 270$ min e 360 min após LPS ou salina. Salina: $\mathrm{n}=6-9$; LPS: $\mathrm{n}=6-8$; LPS+ENDA (-): $\mathrm{n}=8-11$; LPS+ENDA (+): $\mathrm{n}=5-7$. As barras representam média \pm erro padrão, ${ }^{*} \mathrm{p}<0,05$ vs. salina; $\# \mathrm{p}<0,05$ vs. LPS; $\uparrow \mathrm{p}<0,05$ vs. LPS+ENDA (-). ANOVA de uma via, seguida do pós-teste de Tukey. 


\subsubsection{Ativação barorreflexa e a sensibilidade barorreflexa em ratos endotoxêmicos}

No período basal, todos os grupos apresentaram valores similares de ganho barorreflexo (Fig. 13A). Entretanto, a partir do momento $180 \mathrm{~min}$ (Fig. 13C), assim como visto no primeiro protocolo descrito nesta tese, que avaliou as diferentes doses de LPS, a sensibilidade barorreflexa diminuiu ao longo do tempo, após a indução do desafio imune (Fig. 13). Além disso, a ativação barorreflexa (com ou sem efeito hemodinâmico) não preveniu essa redução (Fig. 13C - E).

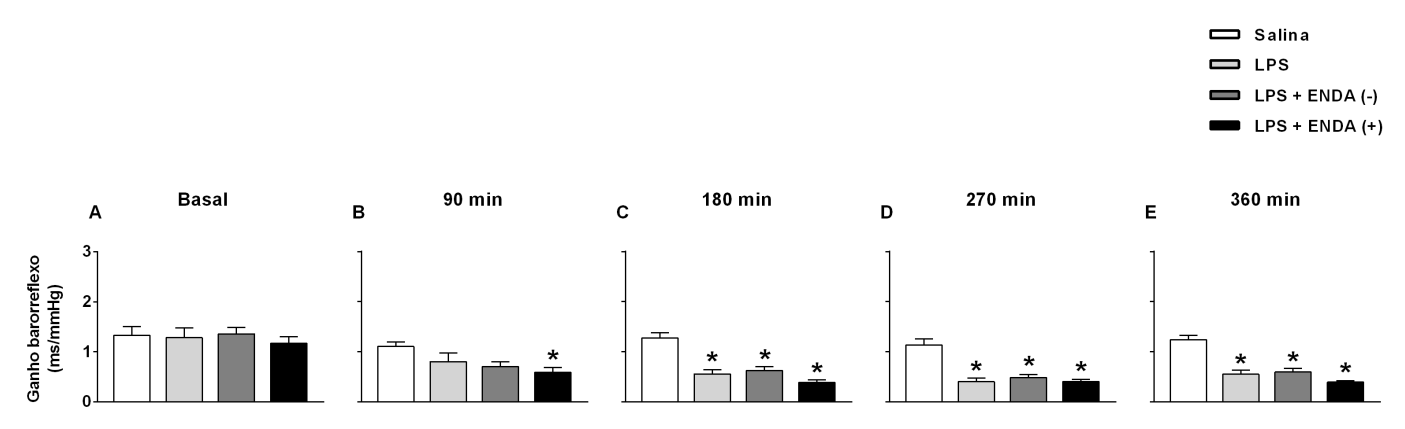

Figura 13. Efeito da estimulação do nervo depressor aórtico na sensibilidade barorreflexa de ratos não anestesiados. Sensibilidade barorreflexa em diferentes momentos [basal (A), 90 min (B), $180 \mathrm{~min}$ (C), $270 \min (\mathrm{D})$ e $360 \min (\mathrm{E})$ ] após a administração de LPS ou salina. Salina: $\mathrm{n}=6-9$; LPS: $\mathrm{n}=7-8$; LPS+ENDA (-): $\mathrm{n}=10-11 ;$ LPS+ENDA $(+): \mathrm{n}=7$. As barras representam média \pm erro padrão, ${ }^{*} \mathrm{p}<0,05$ vs. salina. ANOVA de uma via, seguida do pós-teste de Tukey. 


\subsubsection{A estimulação do nervo depressor aórtico não modula a inflamação sistêmica}

A estimulação do NDA não reduziu os níveis das citocinas avaliadas neste estudo (TNF, IL-6, IL-1ß e IL-10), tanto 90 min após a administração de LPS (Fig. 14), quanto nos outros momentos analisados (Tabela 3). O grupo com estimulação elétrica do NDA sem efeito hemodinâmico [LPS+ENDA (-)] aumentou os níveis de IL-10 aos 90 min, quando comparado aos outros dois grupos que receberam LPS (Fig. 14D; Tabela 3). A estimulação do NDA com efeito hemodinâmico [(LPS+ENDA (+)] aumentou os níveis de IL-1 $\beta$ aos 360 min quando comparado ao grupo LPS (Tabela 3). De uma maneira geral, os níveis de citocinas aumentaram logo após a administração de LPS, enquanto que a partir dos 90 min os mesmos tenderam a se reduzir (Tabela 3).

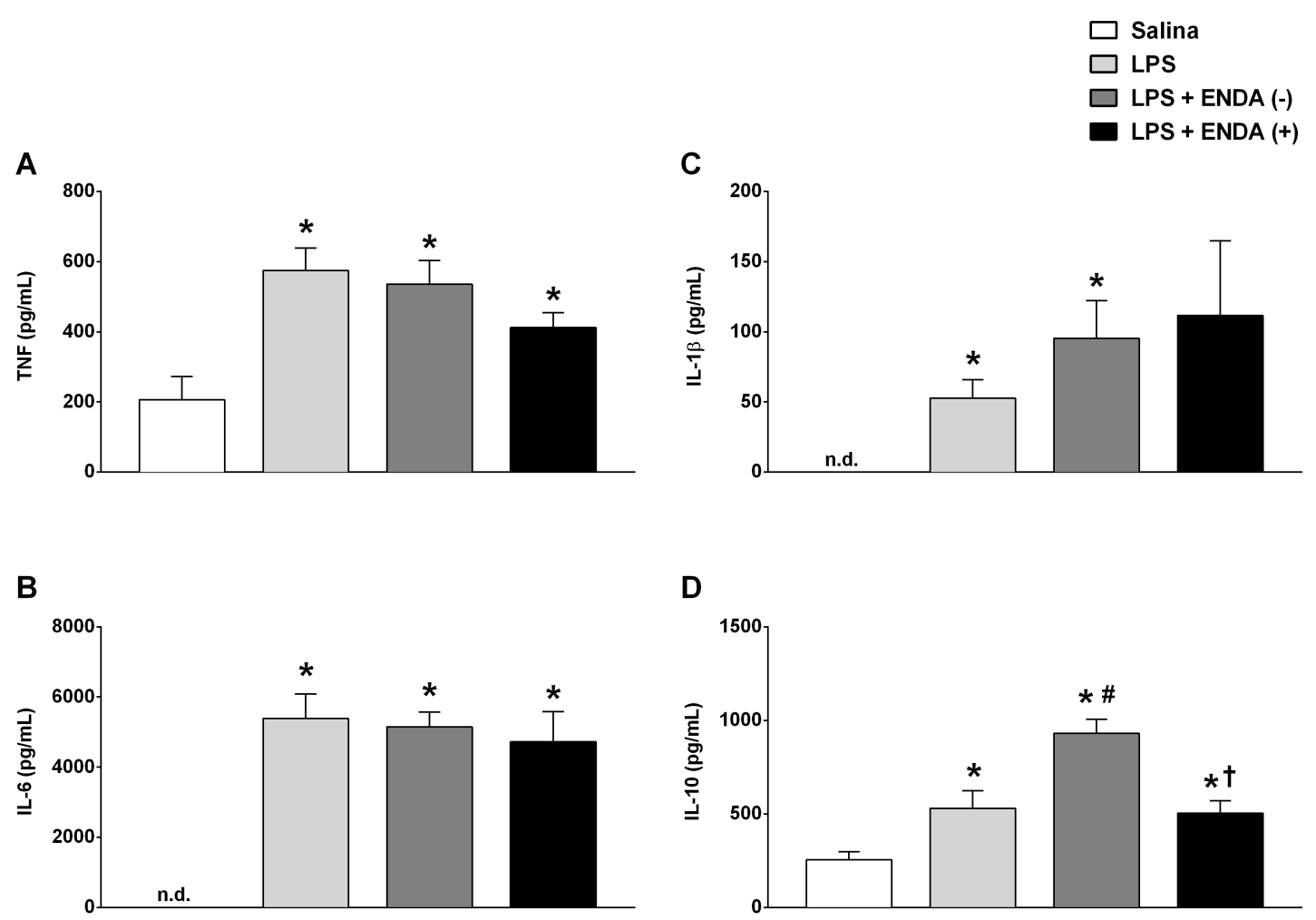

Figura 14. Níveis plasmáticos de citocinas 90 min após LPS. Níveis plasmáticos de TNF $(A)$, IL-6 (B), IL-1 $\beta(C)$ e IL-10 (D) 90 min após a administração de LPS ou salina. LPS: lipopolissacarídeo; ENDA: estimulação do nervo depressor aórtico sem (-) e com (+) alteração hemodinâmica. Salina: $\mathrm{n}=9$; LPS: $\mathrm{n}=$ 8; LPS+ENDA (-): $\mathrm{n}=11$; LPS+ENDA $(+): \mathrm{n}=7$. As barras representam média \pm erro padrão, ${ }^{*} \mathrm{p}<0,05$ vs. Salina; \# p $<0,05$ vs. LPS; $\uparrow \mathrm{p}<0,05$ vs. LPS+ENDA (-). ANOVA de uma via, seguida do pós-teste Student-Newman-Keuls ou Kruskal-Wallis seguido do pós-teste Dunn. 
Tabela 3. Análise temporal das citocinas plasmáticas no protocolo com estimulação do nervo depressor aórtico.

\begin{tabular}{|c|c|c|c|c|}
\hline & $\begin{array}{c}\text { Salina } \\
(\mathrm{n}=9)\end{array}$ & $\begin{array}{c}\text { LPS } \\
(\mathrm{n}=8)\end{array}$ & $\begin{array}{c}\text { LPS+ENDA (-) } \\
\quad(\mathrm{n}=12)\end{array}$ & $\underset{(\mathrm{n}=8)}{\operatorname{LPS}+\text { ENDA }}(+)$ \\
\hline \multicolumn{5}{|l|}{ TNF (pg/mL) } \\
\hline $0 \min$ & $503 \pm 89$ & $259 \pm 55^{*}$ & $303 \pm 65^{*}$ & $190 \pm 47^{*}$ \\
\hline $90 \min$ & $207 \pm 66$ & $574 \pm 64^{*}$ & $536 \pm 67^{*}$ & $412 \pm 42^{*}$ \\
\hline $180 \mathrm{~min}$ & $117 \pm 36$ & $117 \pm 7$ & $141 \pm 30$ & $88 \pm 16$ \\
\hline $270 \mathrm{~min}$ & $105 \pm 25$ & $50 \pm 7$ & $54 \pm 9$ & $43 \pm 10$ \\
\hline $360 \mathrm{~min}$ & $89 \pm 20$ & $52 \pm 6$ & $42 \pm 8$ & $40 \pm 10$ \\
\hline \multicolumn{5}{|l|}{ IL-6 (pg/mL) } \\
\hline $0 \mathrm{~min}$ & $0 \pm 0$ & $0 \pm 0$ & $0 \pm 0$ & $0 \pm 0$ \\
\hline $90 \mathrm{~min}$ & $0 \pm 0$ & $5384 \pm 703^{*}$ & $5144 \pm 430^{*}$ & $4727 \pm 856^{*}$ \\
\hline $180 \mathrm{~min}$ & $0 \pm 0$ & $637 \pm 229$ & $657 \pm 213$ & $92 \pm 67$ \\
\hline $270 \mathrm{~min}$ & $0 \pm 0$ & $0 \pm 0$ & $0 \pm 0$ & $0 \pm 0$ \\
\hline $360 \mathrm{~min}$ & $0 \pm 0$ & $0 \pm 0$ & $0 \pm 0$ & $0 \pm 0$ \\
\hline \multicolumn{5}{|c|}{ IL-1ß (pg/mL) } \\
\hline $0 \min$ & $0 \pm 0$ & $5 \pm 4$ & $2 \pm 2$ & $24 \pm 17$ \\
\hline $90 \mathrm{~min}$ & $0 \pm 0$ & $53 \pm 13$ & $86 \pm 28^{*}$ & $112 \pm 53^{*}$ \\
\hline $180 \mathrm{~min}$ & $2 \pm 1$ & $43 \pm 20$ & $56 \pm 14$ & $74 \pm 29$ \\
\hline $270 \mathrm{~min}$ & $0 \pm 0$ & $17 \pm 6$ & $58 \pm 36$ & $86 \pm 35^{*}$ \\
\hline $360 \mathrm{~min}$ & $0 \pm 0$ & $6 \pm 2$ & $34 \pm 13$ & $114 \pm 43^{* \#}$ \\
\hline \multicolumn{5}{|c|}{ IL-10 (pg/mL) } \\
\hline $0 \mathrm{~min}$ & $543 \pm 29$ & $549 \pm 188$ & $513 \pm 120$ & $386 \pm 132 *$ \\
\hline $90 \mathrm{~min}$ & $287 \pm 34$ & $530 \pm 93$ & $930 \pm 75^{* \#}$ & $504 \pm 67^{\dagger}$ \\
\hline $180 \mathrm{~min}$ & $198 \pm 18$ & $586 \pm 147^{*}$ & $594 \pm 96^{*}$ & $347 \pm 55$ \\
\hline $270 \mathrm{~min}$ & $105 \pm 12$ & $136 \pm 50$ & $381 \pm 76$ & $117 \pm 41$ \\
\hline $360 \mathrm{~min}$ & $43 \pm 11$ & $14 \pm 9$ & $87 \pm 44$ & $96 \pm 44$ \\
\hline
\end{tabular}

Dados expressos como média \pm erro padrão da média. TNF: fator de necrose tumoral; IL-6: interleucina 6; IL-1 $\beta$ : interleucina 1 $\beta$; IL-10: interleucina 10; LPS: lipopolissacarídeo; ENDA: estimulação do nervo depressor aórtico sem (-) e com (+) alteração hemodinâmica. * p < 0,05 vs. Salina dentro do mesmo momento; $\# \mathrm{p}<0,05$ vs. LPS dentro do mesmo momento; $\uparrow \mathrm{p}<0,05$ vs. LPS+ENDA (-) dentro do mesmo momento. ANOVA de duas vias para medidas repetidas, seguida do pós-teste Tukey. 


\subsection{Conclusões}

Os dados apresentados neste protocolo sugerem que a ativação do barorreflexo, por meio da estimulação elétrica do NDA, não possui efeito anti-inflamatório sistêmico, uma vez que os níveis de citocinas pró-inflamatórias não foram reduzidos com o estímulo elétrico deste nervo. Além disso, essa resposta é independente da alteração cardiovascular causada pela estimulação elétrica do NDA (com e sem efeito hemodinâmico), bem como do momento avaliado após a indução do processo inflamatório. Por outro lado, a estimulação elétrica do NDA (com e sem efeito hemodinâmico) atenuou o aumento da banda de LF no espectro da pressão arterial sistólica induzido pela administração de LPS em curto prazo (90 min), mas não preveniu a redução na sensibilidade barorreflexa observada ao longo do tempo. 


\section{Ativação Simpática Reflexa e a Resposta Inflamatória Sistêmica}




\section{ATIVAÇÃO SIMPÁTICA REFLEXA E A RESPOSTA INFLAMATÓRIA SISTÊMICA}

\subsection{Objetivos}

\subsubsection{Gerais}

Após avaliar se a ativação do barorreflexo possuía efeito anti-inflamatório sistêmico, o próximo passo foi investigar o papel, ao longo do tempo, da ativação reflexa do sistema nervoso simpático, por meio da OBC, na modulação da inflamação sistêmica induzida por LPS em ratos não anestesiados.

\subsubsection{Específicos}

Os objetivos específicos deste estudo foram:

a) Analisar a pressão arterial, a frequência cardíaca, a variabilidade do intervalo cardíaco, a variabilidade da pressão arterial sistólica, e a sensibilidade do barorreflexo, ao longo do tempo, em diferentes momentos após a administração de LPS, ou salina, em diversos grupos experimentais;

b) Quantificar os níveis plasmáticos das citocinas pró-inflamatórias (TNF- $\alpha$, IL-1 $\beta$ e IL-6) e anti-inflamatória (IL-10), em diferentes momentos ao longo de $360 \mathrm{~min}$ após a administração de LPS, ou salina, a fim de examinar se a ativação simpática por meio da OBC previne o aumento das citocinas induzido por LPS;

c) Avaliar o papel dos barorreceptores (aórticos e carotídeos) e dos quimiorreceptores periféricos na resposta inflamatória sistêmica induzida por LPS, associada ou não à $\mathrm{OBC}$, em ratos não anestesiados. 


\subsection{Material e Métodos}

\subsubsection{Animais de experimentação}

Foram utilizados ratos Wistar Hannover pesando 250-320 g provenientes do Biotério Central do Campus da Universidade de São Paulo de Ribeirão Preto (Campus de Ribeirão Preto; Ribeirão Preto, SP, Brasil), acondicionados em caixas individuais, e mantidos sob temperatura controlada $\left(22^{\circ} \mathrm{C}\right)$, ciclo claro-escuro constante de $12 \mathrm{~h}$, com livre acesso a água e ração. Todos os procedimentos foram revisados, e aprovados, pelo Comitê de Ética no Uso de Animais de Experimentação da Faculdade de Medicina de Ribeirão Preto - Universidade de São Paulo (Protocolo n. 194/2016).

\subsubsection{Grupos experimentais}

Antes de serem submetidos aos procedimentos cirúrgicos, os animais foram divididos em sete grupos experimentais:

I) Salina (n = 9): cirurgia fictícia e administração de salina;

II) LPS (n = 8): implante dos oclusores, sem OBC, e administração de LPS;

III) OBC + LPS $(\mathbf{n}=\mathbf{8})$ : implante dos oclusores, OBC por 20s, e administração de LPS;

IV) BARO-X + LPS (n = 7): desnervação seletiva dos barorreceptores aórticos e carotídeos, implante dos oclusores, sem OBC, e administração de LPS;

V) BARO-X + OBC + LPS (n = 9): desnervação seletiva dos barorreceptores aórticos e carotídeos, com OBC por 20s, e administração de LPS;

VI) QUIMIO-X + LPS (n= 7): desnervação seletiva dos quimiorreceptores carotídeos, implante dos oclusores, sem OBC, e administração de LPS;

VII) QUIMIO-X + OBC + LPS (n = 9): desnervação seletiva dos quimiorreceptores carotídeos, com OBC por 20s, e administração de LPS.

\subsubsection{Confecção dos oclusores pneumáticos}

Os oclusores pneumáticos foram confeccionados seguindo a técnica descrita por Maio et al. (1981). Resumidamente, as duas bordas externas do tubo de polietileno (PE320) com $0,5 \mathrm{~cm}$ de comprimento foram dilatadas por aquecimento, e em seguida o tubo foi cortado ao longo do seu eixo longitudinal. Utilizando-se uma agulha hipodérmica 16G1 1/2 (40x16 mm), fez-se um orifício no centro da parede oposta ao corte anterior. Um 
outro tubo de polietileno de menor calibre (PE-50) com $10 \mathrm{~cm}$ de comprimento também teve uma de suas extremidades dilatada por meio de aquecimento, e em seguida, com o auxílio de um mandril dentro do tubo PE-50, recebeu uma membrana de látex, a qual foi amarrada por um fio de algodão. Ao ser inflada com ar ou água, esta membrana se torna um balão. O tubo com a membrana em sua extremidade foi introduzido no orifício do tubo PE-320, concluindo-se, então, a confecção do oclusor (Fig. 15).

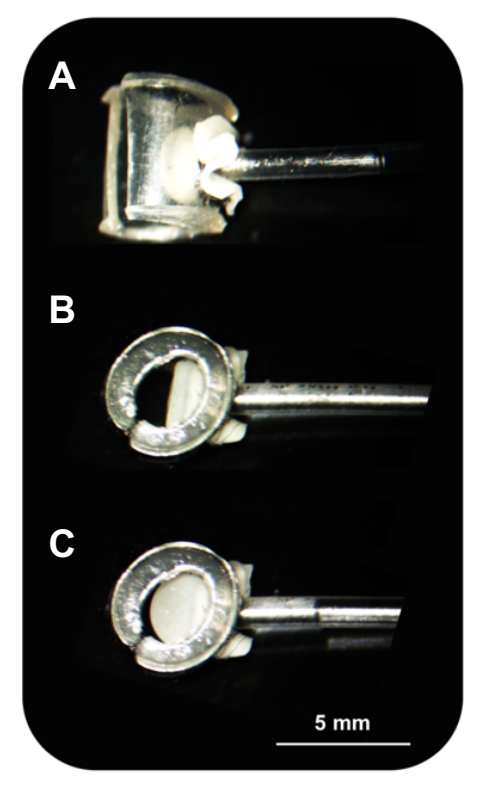

Figura 15. Fotografia do oclusor pneumático utilizado nos experimentos. A: vista lateral do oclusor; B: detalhes do balão no oclusor com o balão em repouso; C: detalhe do balão no oclusor durante a injeção de água.

\subsubsection{Procedimentos cirúrgicos}

Os animais foram anestesiados com uma mistura de Ketamina e Xilazina (50 $\mathrm{mg} / \mathrm{kg}$ e $10 \mathrm{mg} / \mathrm{kg}$, i.p.), e, então, submetidos ao procedimento cirúrgico de canulação da artéria e veia femorais para registro da pressão arterial e administração de LPS (ou salina), respectivamente, como descrito na seção anterior. Na mesma cirurgia, com exceção do grupo salina, todos os outros animais tiveram oclusores implantados ao redor das carótidas comuns (bilateralmente). Para tanto, por meio de uma cervicotomia mediana anterior, os músculos esternoioideo e esternocleidomastoideo foram identificados e afastados, expondo a carótida comum e o seio carotídeo. Para implantar os oclusores pneumáticos, as carótidas comuns foram cuidadosamente isoladas, e os oclusores fixados ao redor das mesmas com fios de algodão. Os cateteres para enchimento dos balões foram 
exteriorizados, e fixados no dorso do animal, bem como os cateteres vasculares. As incisões cirúrgicas foram devidamente suturadas e, imediatamente após o término da cirurgia, foi feita a administração de analgésico (cloridrato de tramadol $2 \mathrm{mg} / \mathrm{kg}$, s.c.).

Para os grupos IV e V, antes do implante dos oclusores, na mesma cirurgia, foi realizado um procedimento para desnervação das aferências barorreceptoras com o objetivo de prevenir a atenuação da atividade simpática pelos barorreceptores, durante a elevação da pressão arterial decorrente da $\mathrm{OBC}$; e, também, eliminar a possível influência do barorreflexo na resposta anti-inflamatória causada pela ativação simpática. Para tanto, foi realizada, bilateralmente, a desnervação dos barorreceptores aórticos e carotídeos. A desnervação das aferências barorreceptoras carotídeas foi realizada segundo a técnica descrita por Castania et al. (2019). Resumidamente, os ratos foram submetidos a uma incisão na região cervical anterior, permitindo a exposição da região da carótida comum e da bifurcação da carótida. Com o auxílio de uma lupa, a área da bifurcação da carótida foi cuidadosamente isolada. Próximo ao nervo glossofaríngeo é possível identificar duas ramificações, geralmente separadas por uma pequena artéria. Um desses ramos, o qual possui as fibras aferentes dos barorreceptores carotídeos, foi cuidadosamente seccionado (Fig. 16). Já a desnervação dos barorreceptores aórticos foi realizada seguindo a técnica descrita por Krieger (1964), na qual o nervo laríngeo superior e o gânglio cervical superior foram isolados e seccionados. O tronco simpático cervical também foi seccionado em sua porção caudal ao gânglio cervical superior, o qual foi dissecado e removido. $O$ procedimento foi realizado em ambos os lados. Por outro lado, os grupos VI e VII foram submetidos à desnervação dos quimiorreceptores carotídeos para estudar sua influência na resposta inflamatória sistêmica durante a OBC. O procedimento também foi realizado bilateralmente e seguindo a técnica descrita por Franchini e Krieger (1992). Para isso, foi realizada uma cervicotomia mediana anterior, seguida pela exposição da carótida comum e da bifurcação da mesma. A artéria do corpúsculo carotídeo foi cuidadosamente isolada com auxílio de uma lupa, ligada com fio de sutura, e seccionada distalmente à ligadura. 

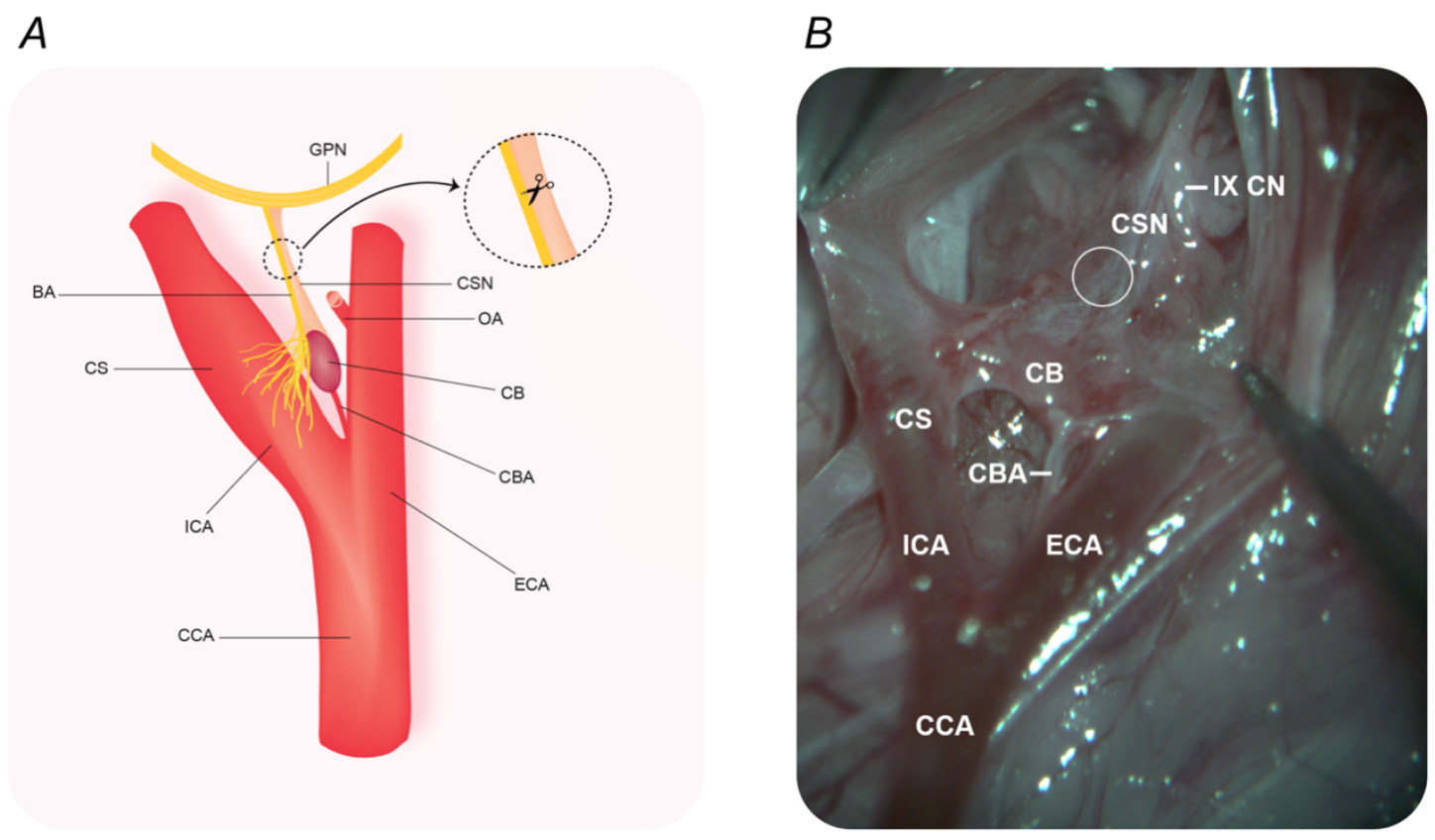

Figura 16. Desnervação seletiva dos barorreceptores. A: Diagrama ilustrativo do método de desnervação seletiva dos barorreceptores. B: Fotografia da bifurcação da carótida de um rato, com destaque para a região onde os barorreceptores carotídeos são cortados (círculo branco). BA: aferências barorreceptoras; CB: corpo carotídeo; CBA: artéria do corpo carotídeo; CCA: artéria carótida comum; CS: seio carotídeo; CNS: nervo do seio carotídeo; ECA: artéria carótida externa; GPN: nervo glossofaríngeo; ICA: artéria carótida interna; OA: artéria occipital. Figura retirada do Experimental Physiology (CASTANIA et al., 2019).

\subsubsection{Registro da pressão arterial}

Após o período de recuperação da cirurgia, o qual que foi de 24 h, os animais não anestesiados e se movimentando livremente, foram conectados ao sistema de registro da pressão arterial já descrito nas seções 3 e 4 . No caso dos grupos com $\mathrm{OBC}$ os dois cateteres para enchimento dos balões foram conectados a uma seringa com água, através de uma cânula em Y, personalizada para que a oclusão acontecesse simultaneamente dos dois lados, reduzindo o fluxo sanguíneo no seio carotídeo (Fig. 17). Posteriormente, a coleta de sangue basal e ao registro basal da pressão arterial pulsátil durante $30 \mathrm{~min}$, as carótidas foram ocluídas durante $20 \mathrm{~s}$, injetando-se água nos balões dos oclusores, bilateralmente, para insuflá-los e promover a OBC com consequente ativação simpática. Após esse período, para a desoclusão, os balões foram desinsuflados para reestabelecer o fluxo de sangue nas bifurcações das carótidas. Imediatamente após o término da oclusão, foi feita a administração de LPS [0,06 mg/kg (i.v.); Escherichia coli - 0111: B4; SigmaAldrich, St. Louis, $M O, E U A]$. Para os outros grupos, sem OBC, a administração de salina 
ou LPS foi feita imediatamente após término do período basal.

A pressão arterial foi registrada continuamente durante $360 \mathrm{~min}$ após a administração de LPS, ou salina, em todos os grupos. Nesse período foram feitas coletas de sangue seriadas ( $250 \mu \mathrm{L}$ por amostra) aos 90, 180, 270 e 360 min após a administração de LPS, ou salina, através da cânula introduzida na artéria femoral esquerda. As amostras de sangue (foram coletadas com heparina e mantidas no gelo até serem centrifugadas a $4^{\circ} \mathrm{C}$, por $15 \mathrm{~min}$, utilizando-se $5000 \mathrm{rpm}$. Em seguida, o plasma foi coletado e armazenado a $-80^{\circ} \mathrm{C}$ até o seu processamento. Nos grupos com desnervação, ao final da última coleta de sangue, foram realizados testes com Fenilefrina ( $2 \mu \mathrm{g}$ em $0,1 \mathrm{~mL}$, i.v.) e Cianeto de Potássio ( $40 \mu \mathrm{g}$ em 0,1 mL, i.v.), para confirmar a correta desnervação de cada animal. Os animais que não estavam corretamente desnervados, foram excluídos do trabalho.

$\boldsymbol{A}$

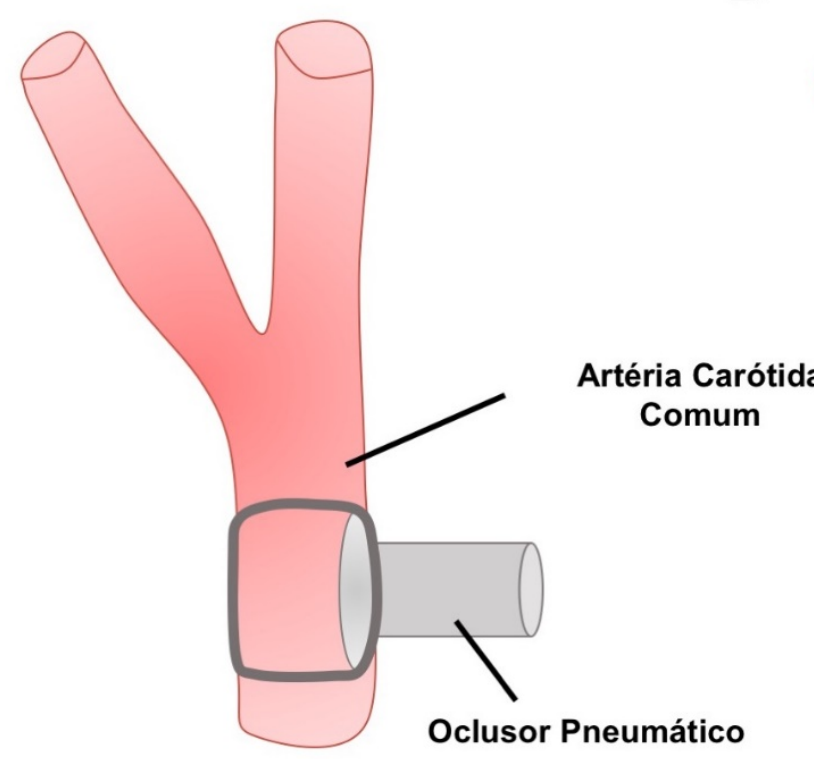

$\boldsymbol{B}$

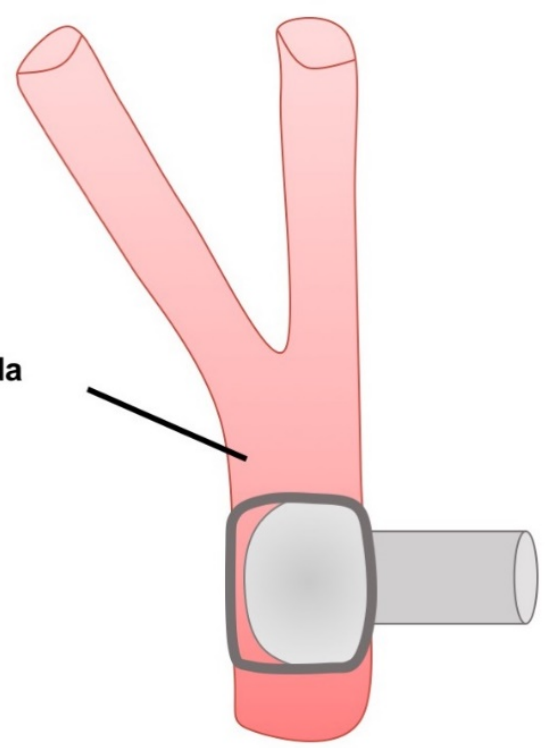

Figura 17. Representação esquemática do método utilizado para realizar a oclusão da carótida bilateralmente. A: período basal, no qual não há oclusão da carótida comum. O fluxo sanguíneo flui normalmente. B: período durante a manobra para promover a oclusão da carótida comum. O balão dentro do oclusor foi inflado com água utilizando-se uma seringa com agulha sem ponta conectada à cânula de polietileno. Note que o fluxo de sangue, bem como o diâmetro das carótidas, está reduzido na região acima do local da oclusão, desativando os barorreceptores carotídeos. 


\subsubsection{Análise da variabilidade da pressão arterial sistólica e do intervalo cardíaco}

A análise da variabilidade da pressão arterial sistólica e do intervalo cardíaco foi realizada como descrito anteriormente na subseção 3.2.5. Para a análise da variabilidade da pressão arterial sistólica durante o período da OBC foi utilizado somente o primeiro minuto após o início da OBC.

\subsubsection{Análise da sensibilidade do barorreflexo}

A análise da sensibilidade do barorreflexo foi realizada como descrito anteriormente na subseção 3.2.6.

\subsubsection{Análise de citocinas}

A análise das citocinas plasmáticas foi realizada como descrito anteriormente na subseção 4.2.7.

\subsubsection{Análise estatística}

Os parâmetros hemodinâmicos foram analisados pela ANOVA de duas vias para medidas repetidas, seguida do pós-teste Tukey, quando indicado. As análises da variabilidade cardiocirculatória e da sensibilidade barorreflexa foram feitas pela ANOVA de uma via ou ANOVA de duas vias para medidas repetidas, seguida do pós-teste de Tukey. Os dados obtidos a partir do plasma foram analisados pela ANOVA de uma via, seguida do pós-teste Student-Newman-Keuls, quando indicado, e, também, pela ANOVA de duas vias para medidas repetidas, seguida do pós-teste Student-Newman-Keuls. Diferenças foram consideradas estatisticamente significativas se $\mathrm{p}<0,05$. Os resultados são apresentados como média \pm erro padrão da média. A análise estatística foi realizada utilizando-se o software SigmaPlot 12.0 (Systat Software, San Jose, CA, EUA). 


\subsection{Resultados}

\subsubsection{Respostas hemodinâmicas e autonômicas à oclusão bilateral da carótida}

Como esperado, a OBC promoveu aumento da pressão arterial pulsátil nos animais intactos (Fig. 18). Assim, houve aumento da pressão arterial sistólica, diastólica e média (Fig. 19A - C), tanto nos animais intactos quanto nos animais que tiveram os barorreceptores (BARO-X) ou os quimiorreceptores (QUIMIO-X) desnervados durante a manobra de $\mathrm{OBC}$, indicando um aumento da resistência periférica decorrente do aumento da atividade simpática. Entretanto, a resposta pressora decorrente da OBC foi menor nos animais QUIMIO-X comparado com os animais intactos e BARO-X (PAM: Intacto $\Delta 61 \pm 3 \mathrm{mmHg}$; BARO-X $\Delta 61 \pm 3 \mathrm{mmHg}$; QUIMIO-X $\Delta 47 \pm 3 \mathrm{mmHg} ; \mathrm{p}<$ $0,05)$, destacando a importância da integridade dos quimiorreceptores periféricos no pico da resposta pressora durante a OBC, como previamente descrito (BEDRAN-DECASTRO; MOREIRA; KRIEGER, 1986). Além disso, enquanto a OBC não promoveu alteração na frequência cardíaca dos animais intactos e BARO-X, nos animais QUIMIOX promoveu bradicardia (Fig. 19D), sugerindo uma resposta reflexa da ativação dos barorreceptores aórticos, durante a $\mathrm{OBC}$, para o coração.

Vale ressaltar que aumento da potência da banda de LF da pressão arterial sistólica durante o período da OBC (Fig. 20) confirmou o aumento da modulação simpática para os vasos decorrente da manobra de oclusão, tanto nos animais intactos quanto nos desnervados (BARO-X e QUIMIO-X).

\subsubsection{Análise temporal das respostas hemodinâmicas}

A análise dos parâmetros hemodinâmicos mostrou que os grupos em estudo apresentaram valores similares de pressão arterial no período basal ( $0 \mathrm{~min})$, apesar da tendência observada, nos grupos com desnervação dos barorreceptores, em apresentar a pressão arterial mais elevada (Tabela 4). Com relação à avaliação temporal da pressão arterial, novamente, não foram observadas diferenças na pressão arterial entre os grupos em nenhum dos momentos avaliado (Tabela 4). Com relação à frequência cardíaca no período basal, como esperado e já relatado na literatura (FAZAN JÚNIOR; MACHADO; SALGADO, 1997; VASQUES; KRIEGER, 1980), os grupos com desnervação dos barorreceptores apresentaram valores maiores de frequência cardíaca do que a maioria dos grupos (Tabela 4). Ao longo do tempo, todos os grupos que receberam LPS apresentaram taquicardia quando comparado ao grupo Salina (Tabela 4). Essa taquicardia 
foi acentuada aos $180 \mathrm{~min}$, mas se manteve até o final do protocolo (aos $360 \mathrm{~min}$ ) em todos os grupos com endotoxemia (Tabela 4). Além disso, aos 180 e 270 min os valores de frequência cardíaca eram similares entre os grupos com LPS, mas aos 360 min o grupo BARO-X+LPS apresentou taquicardia comparado a todos os outros grupos, com exceção do grupo BARO-X+OBC+LPS - que apresentou valores ainda maiores do que os animais do grupo BARO-X+LPS (Tabela 4).
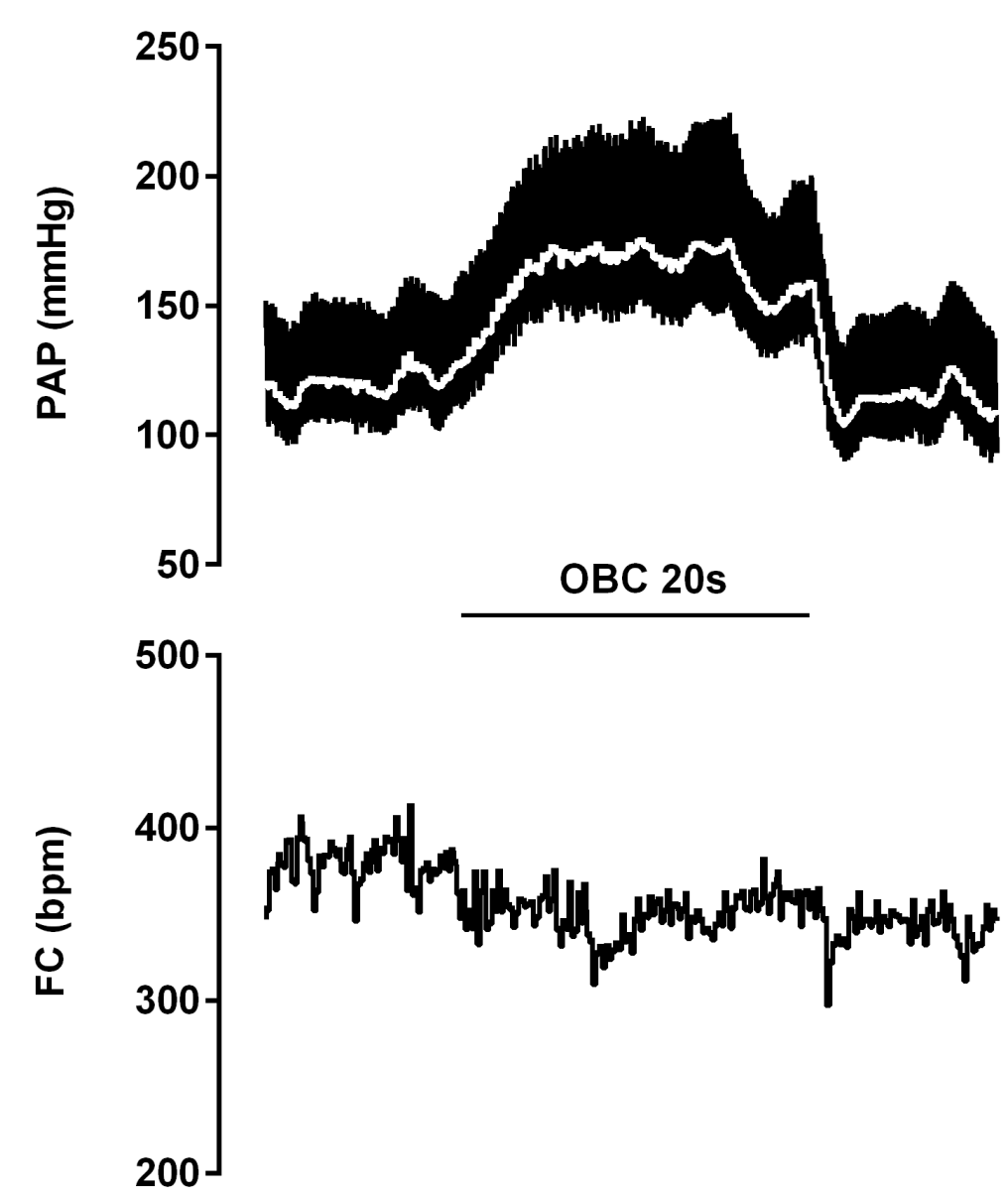

Figura 18. Registro representativo das respostas hemodinâmicas de um rato intacto não anestesiado durante a manobra de oclusão bilateral da carótida (OBC). Barra horizontal representa o período de 20 segundos referente à $\mathrm{OBC}$ e a linha branca representa a pressão arterial média. PAP: pressão arterial pulsátil; FC: frequência cardíaca. 
A

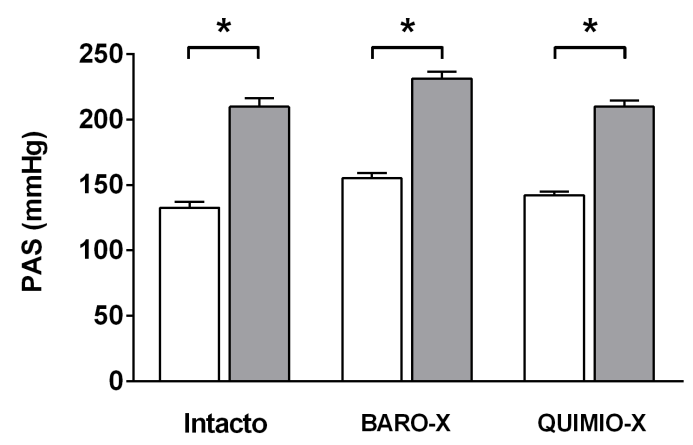

C

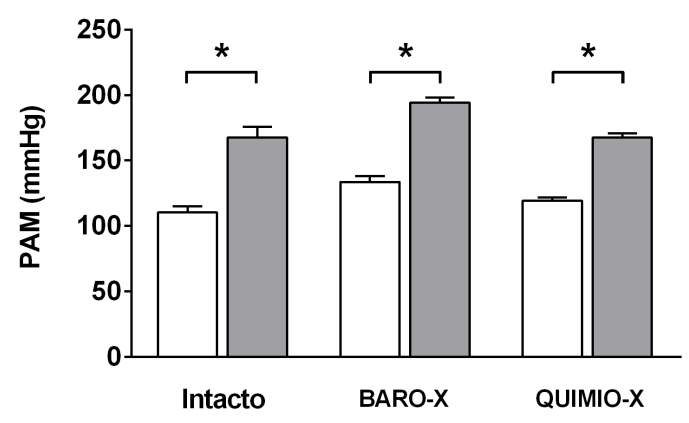

B

$\square$ Basal

$\square \mathrm{OBC}$

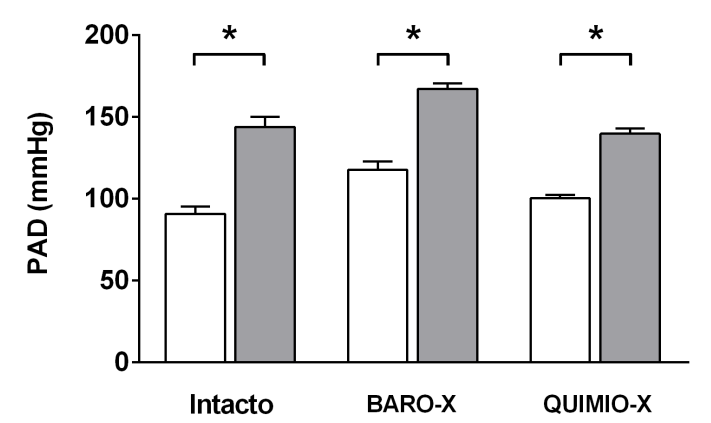

D

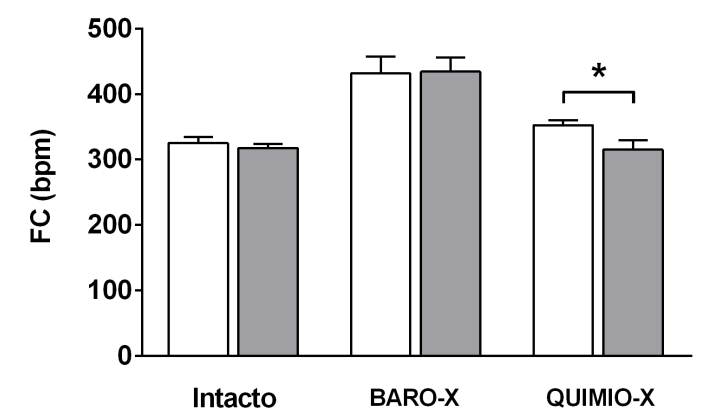

Figura 19. Respostas hemodinâmicas à oclusão bilateral da carótida (OBC) em animais intactos, ou com desnervação dos barorreceptores (BARO-X) ou dos quimiorreceptores (QUIMIO-X). PAS: pressão arterial sistólica (A); PAD: pressão arterial diastólica (B); PAM: pressão arterial média (C); FC: frequência cardíaca (D). Períodos: basal (barras brancas) e no pico da resposta à $\mathrm{OBC}$ (barras cinzas). Intacto (OBC+LPS): $\mathrm{n}=8$; BARO-X: $\mathrm{n}=9$; QUIMIO-X: $\mathrm{n}=9$. As barras representam média \pm erro padrão $* \mathrm{p}<0,05$. ANOVA de duas vias para medidas repetidas seguida do pós-teste Tukey. 


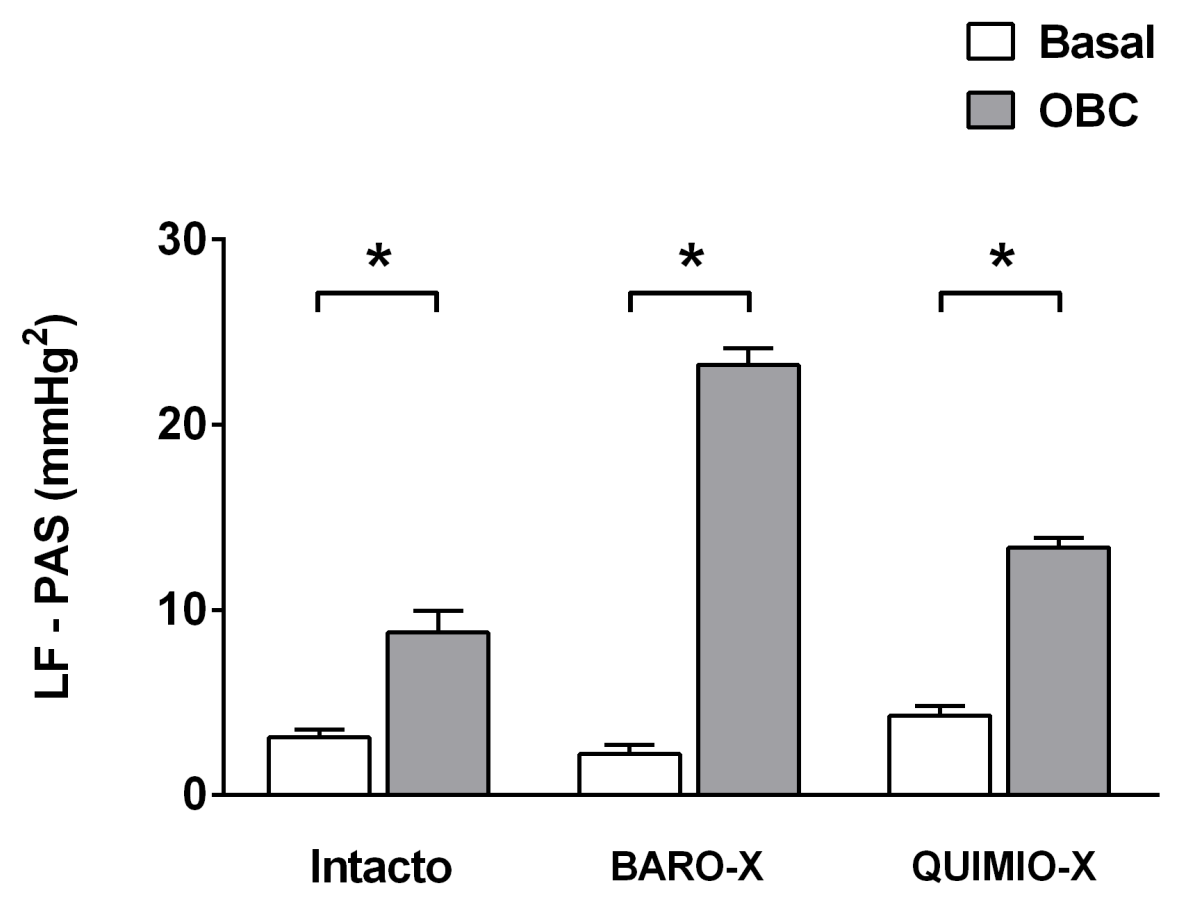

Figura 20. Resposta autonômica à oclusão bilateral da carótida (OBC) em animais intactos e com desnervação dos barorreceptores (BARO-X) ou dos quimiorreceptores (QUIMIO-X). Períodos: basal (barras brancas) e no período da OBC (barras cinzas). LF-PAS: banda de alta frequência da pressão arterial sistólica. Intacto (OBC+LPS): $\mathrm{n}=8$; BARO-X: $\mathrm{n}=8$; QUIMIO-X: $\mathrm{n}=9$. As barras representam média \pm erro padrão $* \mathrm{p}<0,05$. ANOVA de duas vias para medidas repetidas seguida do pós-teste Tukey. 
Tabela 4. Análise temporal das respostas hemodinâmicas no protocolo com oclusão bilateral da carótida (OBC).

\begin{tabular}{|c|c|c|c|c|c|c|c|}
\hline & $\begin{array}{c}\text { Salina } \\
(\mathrm{n}=9)\end{array}$ & $\begin{array}{c}\text { LPS } \\
(\mathrm{n}=8)\end{array}$ & $\begin{array}{c}\mathrm{OBC}+\mathrm{LPS} \\
(\mathrm{n}=\mathbf{8})\end{array}$ & $\begin{array}{c}\text { BARO-X } \\
+ \text { +LPS } \\
(\mathbf{n}=7)\end{array}$ & $\begin{array}{c}\text { BARO-X+ } \\
\text { OBC+LPS } \\
\quad(n=9)\end{array}$ & $\begin{array}{c}\text { QUIMIO-X } \\
+ \text { LPS } \\
(n=7)\end{array}$ & $\begin{array}{c}\text { QUIMIO-X } \\
\text { +OBC+LPS } \\
(\mathbf{n}=9)\end{array}$ \\
\hline \multicolumn{8}{|c|}{ PAS (mmHg) } \\
\hline $0 \mathrm{~min}$ & $137 \pm 3$ & $138 \pm 4$ & $133 \pm 5$ & $157 \pm 11$ & $155 \pm 4$ & $137 \pm 7$ & $140 \pm 3$ \\
\hline $90 \mathrm{~min}$ & $133 \pm 3$ & $136 \pm 5$ & $136 \pm 4$ & $145 \pm 10$ & $141 \pm 5$ & $140 \pm 5$ & $143 \pm 6$ \\
\hline $180 \mathrm{~min}$ & $132 \pm 2$ & $134 \pm 6$ & $128 \pm 4$ & $135 \pm 8$ & $122 \pm 8$ & $132 \pm 7$ & $139 \pm 6$ \\
\hline $270 \mathrm{~min}$ & $130 \pm 2$ & $129 \pm 6$ & $130 \pm 5$ & $130 \pm 9$ & $140 \pm 4$ & $129 \pm 8$ & $137 \pm 7$ \\
\hline $360 \mathrm{~min}$ & $126 \pm 3$ & $128 \pm 6$ & $125 \pm 6$ & $141 \pm 8$ & $137 \pm 9$ & $123 \pm 9$ & $130 \pm 7$ \\
\hline \multicolumn{8}{|c|}{ PAD (mmHg) } \\
\hline $0 \mathrm{~min}$ & $97 \pm 3$ & $93 \pm 4$ & $91 \pm 5$ & $113 \pm 8$ & $118 \pm 5^{\#} \dagger$ & $97 \pm 5$ & $98 \pm 3$ \\
\hline $90 \mathrm{~min}$ & $94 \pm 2$ & $92 \pm 5$ & $92 \pm 5$ & $101 \pm 7$ & $107 \pm 5$ & $102 \pm 3$ & $101 \pm 4$ \\
\hline $180 \mathrm{~min}$ & $92 \pm 2$ & $97 \pm 6$ & $96 \pm 6$ & $102 \pm 7$ & $95 \pm 7$ & $99 \pm 4$ & $102 \pm 5$ \\
\hline $270 \mathrm{~min}$ & $87 \pm 3$ & $87 \pm 7$ & $90 \pm 6$ & $93 \pm 8$ & $106 \pm 4$ & $95 \pm 5$ & $94 \pm 5$ \\
\hline $360 \mathrm{~min}$ & $83 \pm 4$ & $83 \pm 8$ & $85 \pm 7$ & $100 \pm 7$ & $100 \pm 7$ & $89 \pm 7$ & $86 \pm 6$ \\
\hline \multicolumn{8}{|c|}{ PAM (mmHg) } \\
\hline $0 \mathrm{~min}$ & $115 \pm 3$ & $113 \pm 4$ & $110 \pm 5$ & $132 \pm 9$ & $134 \pm 4 \dagger$ & $114 \pm 6$ & $118 \pm 3$ \\
\hline $90 \mathrm{~min}$ & $112 \pm 2$ & $111 \pm 5$ & $112 \pm 4$ & $119 \pm 7$ & $120 \pm 5$ & $118 \pm 3$ & $119 \pm 5$ \\
\hline $180 \mathrm{~min}$ & $110 \pm 2$ & $112 \pm 6$ & $110 \pm 5$ & $115 \pm 7$ & $106 \pm 7$ & $113 \pm 5$ & $117 \pm 5$ \\
\hline $270 \mathrm{~min}$ & $107 \pm 2$ & $105 \pm 7$ & $107 \pm 6$ & $108 \pm 8$ & $119 \pm 3$ & $109 \pm 5$ & $112 \pm 5$ \\
\hline $360 \mathrm{~min}$ & $103 \pm 3$ & $103 \pm 7$ & $106 \pm 6$ & $117 \pm 7$ & $115 \pm 7$ & $104 \pm 7$ & $105 \pm 6$ \\
\hline \multicolumn{8}{|l|}{ FC (bpm) } \\
\hline $0 \min$ & $336 \pm 8$ & $342 \pm 19$ & $325 \pm 9$ & $402 \pm 27$ & $432 \pm 25^{* \#} \dagger$ & $373 \pm 23$ & $352 \pm 6^{\S}$ \\
\hline $90 \mathrm{~min}$ & $344 \pm 8$ & $382 \pm 24$ & $370 \pm 17$ & $413 \pm 28$ & $457 \pm 26^{*} \dagger$ & $401 \pm 23$ & $380 \pm 10^{\S}$ \\
\hline $180 \mathrm{~min}$ & $357 \pm 11$ & $416 \pm 15$ & $427 \pm 17$ & $447 \pm 20^{*}$ & $475 \pm 25^{*}$ & $449 \pm 23 *$ & $478 \pm 17^{*}$ \\
\hline $270 \mathrm{~min}$ & $361 \pm 14$ & $447 \pm 15^{*}$ & $462 \pm 15^{*}$ & $448 \pm 26^{*}$ & $493 \pm 21^{*}$ & $427 \pm 26$ & $464 \pm 13^{*}$ \\
\hline $360 \mathrm{~min}$ & $351 \pm 12$ & $435 \pm 16^{*}$ & $432 \pm 11^{*}$ & $443 \pm 33^{* *} \dagger$ & $479 \pm 23 * \$$ & $426 \pm 17^{\$}$ & $430 \pm 16^{* \$}$ \\
\hline
\end{tabular}

Dados expressos como média \pm erro padrão da média. PAS: pressão arterial sistólica; PAD: pressão arterial diastólica; PAM: pressão arterial média; FC: frequência cardíaca; QUIMIO-X: desnervação dos quimiorreceptores; BARO-X: desnervação dos barorreceptores. ${ }^{*} \mathrm{p}<0,05$ vs. Salina; \# $\mathrm{p}<0,05$ vs. LPS; $\uparrow \mathrm{p}<0,05$ vs. OBC+LPS; $\$ \mathrm{p}<0,05$ vs. BARO-X+LPS; $\S \mathrm{p}<0,05$ vs. BARO-X+OBC+LPS. Todas as comparações são referentes entre os grupos dentro do mesmo momento. ANOVA de duas vias para medidas repetidas seguida do pós-teste Tukey. 


\subsubsection{Variabilidade cardiocirculatória em ratos endotoxêmicos intactos e desnervados ao longo do tempo}

A análise da variabilidade do intervalo cardíaco não revelou diferença na potência da banda de LF no espectro do intervalo cardíaco entre os grupos avaliados ao longo do tempo (Fig. 21A - E). O mesmo foi observado para a relação LF/HF ao longo do tempo (Fig. $21 \mathrm{~K}-\mathrm{O}$ ). Com relação à potência da banda de HF, já no período basal foi observado redução desse parâmetro nos animais com desenervação seletiva dos barorreceptores comparado aos ratos controles intactos (Fig. 21F). O grupo com desnervação seletiva dos quimiorreceptores também apresentou valores menores da potência da banda de HF já no momento basal (Fig. 21F). Entretanto, o grupo com desnervação seletiva dos quimiorreceptores associada à $\mathrm{OBC}$, apresentou um aumento da banda de $\mathrm{HF}$ comparado ao grupo BARO-X+OBC+LPS nos momentos basal e 90 min (Fig. 21F e G). Ao longo do tempo, todos os grupos que receberam LPS apresentaram redução da potência da banda de HF comparado ao grupo salina, como visto nos momentos 270 min e $360 \mathrm{~min}$ (Fig. 21I e J).

Já a análise da variabilidade da pressão arterial sistólica mostrou que a OBC reduziu a potência na banda de LF do espectro da pressão arterial sistólica, comparado ao grupo LPS, aos $180 \mathrm{~min}$ (Fig. 21R). Além disso, a partir do momento $180 \mathrm{~min}$, os animais com desnervação seletiva dos barorreceptores apresentaram menor potência da banda de LF da pressão arterial (Fig. 21R - T). Ainda, aos 270 min, o grupo QUIMIO$\mathrm{X}+\mathrm{OBC}+\mathrm{LPS}$ apresentou maior potência na banda de LF da pressão arterial que a maioria dos grupos avaliados (Fig. 21S). 


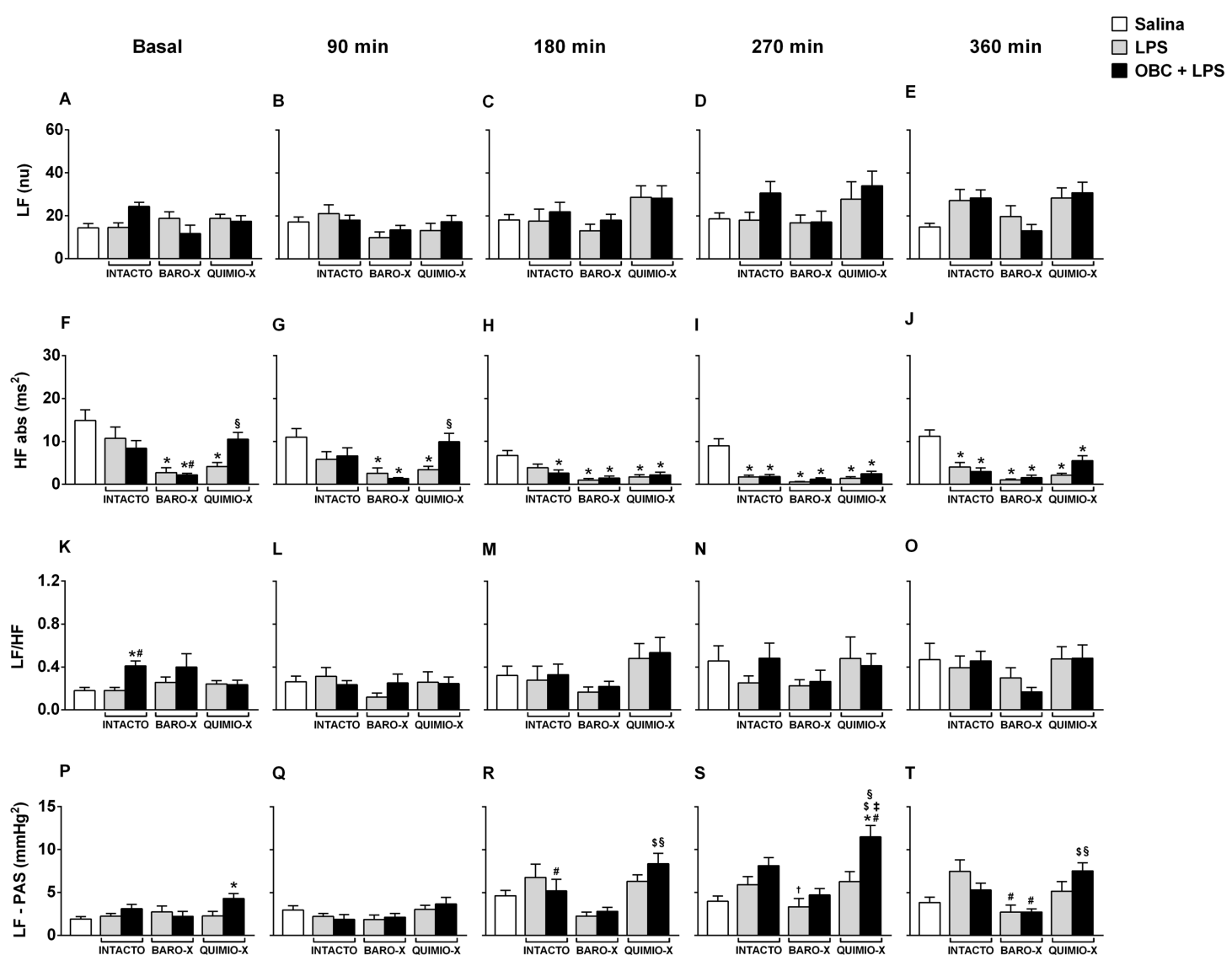

Figura 21. Variabilidade do intervalo cardíaco e da pressão arterial sistólica de ratos endotoxêmicos, intactos e desnervados, ao longo do tempo. Os parâmetros avaliados foram: banda de baixa frequência (LF; painéis A, B, C D e E), banda de alta frequência (HF; painéis F, G, H, I e J), razão LF/HF (painéis K, L, M, N e O), e LF da pressão arterial sistólica (LF-PAS; painéis P, Q, R, S e T), em diferentes momentos: basal, $90 \mathrm{~min}, 180 \mathrm{~min}, 270 \mathrm{~min}$ e $360 \mathrm{~min}$ após LPS ou salina. Salina: $\mathrm{n}=6-9$; LPS: $\mathrm{n}$ =6-8; OBC+LPS: $\mathrm{n}=6$ 6-8; BARO-X+LPS: $\mathrm{n}=6$ 6-7; BARO-X+OBC+LPS: $\mathrm{n}=6$ 6-8; QUIMIO-X+LPS: $\mathrm{n}=$ 4-6; QUIMIO$\mathrm{X}+\mathrm{OBC}+\mathrm{LPS}: \mathrm{n}=7-9$. As barras representam média \pm erro padrão, $* \mathrm{p}<0,05$ vs. Salina; \# $\mathrm{p}<0,05$ vs. LPS; $\uparrow \mathrm{p}<0,05$ vs. OBC+LPS; $\$ \mathrm{p}<0,05$ vs. BARO-X+LPS; $\S \mathrm{p}<0,05$ vs. BARO-X+OBC+LPS; $+\mathrm{p}<$ 0,05 vs. QUIMIO-X+LPS. ANOVA de uma via, seguida do pós-teste de Tukey. 


\subsubsection{Efeito da oclusão bilateral da carótida na sensibilidade barorreflexa em ratos endotoxêmicos}

No período basal, todos os grupos apresentaram valores similares de ganho barorreflexo (Fig. 22A). Entretanto, a partir do momento $180 \mathrm{~min}$ (Fig. 22C), assim como descrito no protocolo anterior desta tese, a sensibilidade barorreflexa diminuiu ao longo do tempo, após a administração de LPS (Fig. 22). Do mesmo modo, a OBC não preveniu essa alteração (Fig. 22C - E).

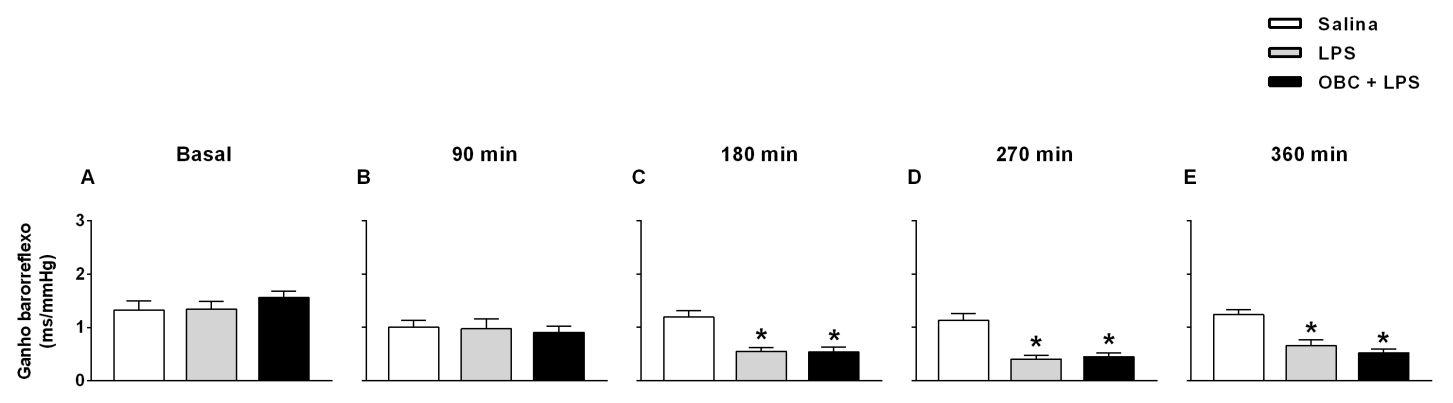

Figura 22. Efeito da oclusão bilateral da carótida na sensibilidade barorreflexa de ratos não anestesiados. Sensibilidade barorreflexa em diferentes momentos [basal (A), 90 min (B), 180 min (C), 270 $\min (\mathrm{D})$ e $360 \min (\mathrm{E})$ ] após a administração de LPS ou salina. Salina: $\mathrm{n}=6-9$; LPS: n = 7-8; OBC+LPS: $\mathrm{n}=8$. As barras representam média \pm erro padrão, $* \mathrm{p}<0,05$ vs. salina. ANOVA de uma via, seguida do pós-teste de Tukey. 


\subsubsection{A oclusão bilateral da carótida reduz a inflamação sistêmica}

A OBC reduziu os níveis plasmáticos de TNF e IL-1 $\beta$, tanto nos animais intactos quanto naqueles com desnervação seletiva dos barorreceptores e quimiorreceptores, aos 90 min após a administração do LPS (Fig. 23A e C). Para a IL-1 $\beta$ esse efeito foi mantido até os 180 min depois da administração do LPS nos animais intactos, e até 270 min nos animais desnervados (Tabela 5). Além disso, a OBC aumentou os níveis de IL-10 no plasma dos animais intactos, assim como dos animais com desnervação dos quimiorreceptores, aos $90 \mathrm{~min}$ e aos $180 \mathrm{~min}$, respectivamente (Fig. 23D; Tabela 5). Em outras palavras, os níveis plasmáticos da citocina anti-inflamatória aumentam quando os barorreceptores carotídeos são desativados. Além disso, a OBC não promoveu alteração nos níveis de IL-10, aos 90 min, nos animais com desnervação dos barorreceptores (Fig. 23D), mas aumentou aos 180 min comparado com o grupo LPS (Tabela 5), sugerindo uma possível interferência transitória da ativação dos quimiorreceptores na liberação de IL-10. Além disso, a OBC reduziu os níveis de IL-6 apenas nos animais com desnervação dos quimiorreceptores, aos 90 e 180 min após a administração do LPS (Fig. 23B; Tabela 5). Entretanto, a OBC não foi eficaz em reduzir a IL-6 nos animais intactos, assim como naqueles com desnervação dos barorreceptores (Fig. 23B; Tabela 5).

\subsubsection{Desnervação seletiva dos barorreceptores e quimiorreceptores modula a resposta inflamatória sistêmica}

A desnervação dos barorreceptores aórticos e carotídeos, por si só, atenuou a liberação de TNF, IL-6 e IL-1 $\beta$, no plasma, 90 min após a administração de LPS (Fig. $23 \mathrm{~A}-\mathrm{C}$ ). Esse efeito permaneceu até $180 \mathrm{~min}$ após o desafio imune para os níveis de IL6 , e até 270 min após para os níveis de IL-1 $\beta$ (Tabela 5). O mesmo foi observado nos animais que passaram pela desnervação seletiva dos quimiorreceptores (Fig. 23A - C; Tabela 5), sugerindo uma possível comunicação entre ambos, barorreceptores e quimiorreceptores, e o sistema imune. Já com relação aos níveis de IL-10, em comparação ao grupo LPS, a desnervação seletiva dos barorreceptores estimulou a sua liberação, já no período basal (Tabela 5); e a mesma resposta foi mantida 90 min após a administração de LPS (Fig. 23D), e durante todo o período avaliado (Tabela 5). Por outro lado, nenhuma diferença foi observada nos valores de IL-10, em nenhum dos momentos avaliados, entre o grupo com desnervação seletiva dos quimiorreceptores e o grupo LPS (Tabela 5). 


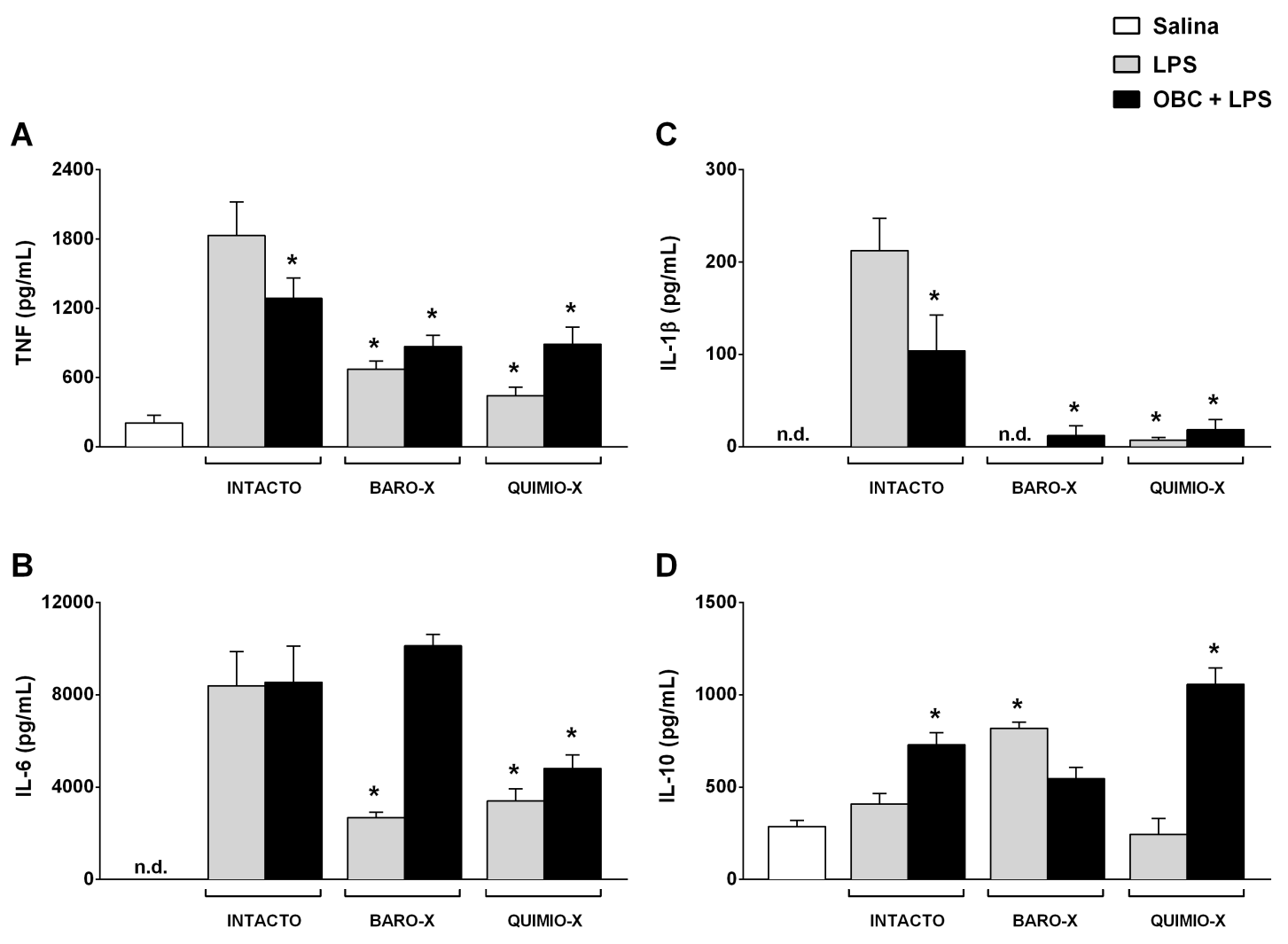

Figura 23. Níveis plasmáticos de citocinas 90 min após a administração de LPS. Níveis plasmáticos de TNF (A), IL-6 (B), IL-1ß (C) e IL-10 (D) 90 min após a administração de LPS ou salina. LPS: lipopolissacarídeo; OBC: oclusão bilateral da carótida; BARO-X: desnervação dos barorreceptores; QUIMIO-X: desnervação dos quimiorreceptores. Salina: $\mathrm{n}=9$; LPS: $\mathrm{n}=8$; OBC+LPS: $\mathrm{n}=8$; BAROX+LPS: $\mathrm{n}=8$; BARO-X+OBC+LPS: $\mathrm{n}=9$; QUIMIO-X+LPS: $\mathrm{n}=7$; QUIMIO-X+OBC+LPS: $\mathrm{n}=9$. As barras representam média \pm erro padrão, ${ }^{*}$ p $<0,05$ vs. LPS. ANOVA de uma via seguida do pós-teste Student-Newman-Keuls. 
Tabela 5. Análise temporal das citocinas plasmáticas no protocolo com oclusão bilateral da carótida (OBC).

\begin{tabular}{|c|c|c|c|c|c|c|c|}
\hline & $\begin{array}{c}\text { Salina } \\
(n=9)\end{array}$ & $\begin{array}{c}\text { LPS } \\
(n=8)\end{array}$ & $\begin{array}{c}\text { OBC+LPS } \\
(n=8)\end{array}$ & $\begin{array}{c}\text { BARO-X } \\
\quad+\text { LPS } \\
\quad(n=8)\end{array}$ & $\begin{array}{c}\text { BARO-X+ } \\
\text { OBC+LPS } \\
(\mathbf{n}=9)\end{array}$ & $\begin{array}{c}\text { QUIMIO-X } \\
\text { +LPS } \\
(n=7)\end{array}$ & $\begin{array}{c}\text { QUIMIO-X+ } \\
\text { OBC+LPS } \\
(\mathbf{n}=9)\end{array}$ \\
\hline \multicolumn{8}{|l|}{$\begin{array}{c}\text { TNF } \\
(\mathrm{pg} / \mathrm{mL})\end{array}$} \\
\hline $0 \mathrm{~min}$ & $503 \pm 89$ & $183 \pm 60^{*}$ & $145 \pm 32 *$ & $290 \pm 60$ & $359 \pm 63$ & $160 \pm 41^{*}$ & $177 \pm 32 *$ \\
\hline $90 \mathrm{~min}$ & $207 \pm 66$ & $1831 \pm 290 *$ & $1326 \pm 180^{* \#}$ & $671 \pm 72^{* \# \dagger}$ & $873 \pm 96^{* \# \dagger}$ & $442 \pm 75^{* \#+} \uparrow \S$ & $889 \pm 146^{* \#+\dagger}$ \\
\hline $180 \mathrm{~min}$ & $117 \pm 36$ & $275 \pm 40$ & $206 \pm 19$ & $222 \pm 15$ & $299 \pm 21$ & $69 \pm 9$ & $213 \pm 22$ \\
\hline $270 \mathrm{~min}$ & $105 \pm 25$ & $120 \pm 18$ & $100 \pm 8$ & $114 \pm 18$ & $226 \pm 18$ & $30 \pm 7$ & $121 \pm 8$ \\
\hline $360 \mathrm{~min}$ & $89 \pm 20$ & $99 \pm 12$ & $76 \pm 5$ & $92 \pm 14$ & $181 \pm 12$ & $24 \pm 8$ & $97 \pm 9$ \\
\hline \multicolumn{8}{|l|}{$\begin{array}{c}\text { IL-6 } \\
\text { (pg/mL) }\end{array}$} \\
\hline $0 \mathrm{~min}$ & $0 \pm 0$ & $0 \pm 0$ & $0 \pm 0$ & $0 \pm 0$ & $0 \pm 0$ & $0 \pm 0$ & $0 \pm 0$ \\
\hline $90 \mathrm{~min}$ & $0 \pm 0$ & $8389 \pm 1480 *$ & $8546 \pm 1560^{*}$ & $2684 \pm 225^{* \#+}$ & $10120 \pm 502^{* \#+}$ & $3398 \pm 533^{* *} \uparrow \S$ & $4810 \pm 587^{* \#+\$} \S$ \\
\hline $180 \mathrm{~min}$ & $0 \pm 0$ & $2977 \pm 588^{*}$ & $3048 \pm 1191 *$ & $252 \pm 92^{\# \dagger}$ & $3888 \pm 695^{* \$}$ & $0 \pm 0^{\#} \dagger \S$ & $398 \pm 49^{\#} \dagger \S$ \\
\hline $270 \mathrm{~min}$ & $0 \pm 0$ & $14 \pm 12$ & $22 \pm 19$ & $0 \pm 0$ & $0 \pm 0$ & $0 \pm 0$ & $0 \pm 0$ \\
\hline $360 \mathrm{~min}$ & $0 \pm 0$ & $0 \pm 0$ & $0 \pm 0$ & $0 \pm 0$ & $0 \pm 0$ & $0 \pm 0$ & $0 \pm 0$ \\
\hline \multicolumn{8}{|l|}{$\begin{array}{c}\text { IL-1及 } \\
(\mathrm{pg} / \mathrm{mL})\end{array}$} \\
\hline $0 \mathrm{~min}$ & $0 \pm 0$ & $10 \pm 9$ & $3 \pm 3$ & $0 \pm 0$ & $12 \pm 11$ & $21 \pm 18$ & $0 \pm 0$ \\
\hline $90 \mathrm{~min}$ & $0 \pm 0$ & $212 \pm 35^{*}$ & $104 \pm 39^{* \#}$ & $0 \pm 0^{\#} \uparrow$ & $12 \pm 11^{\#} \dagger$ & $7 \pm 3^{\#} \uparrow$ & $19 \pm 11^{\#} \dagger$ \\
\hline $180 \mathrm{~min}$ & $2 \pm 1$ & $178 \pm 26^{*}$ & $116 \pm 50^{* \#}$ & $18 \pm 12^{\#} \dagger$ & $0 \pm 0^{\#} \dagger$ & $4 \pm 2^{\#+}$ & $19 \pm 11^{\#} \dagger$ \\
\hline $270 \min$ & $0 \pm 0$ & $82 \pm 18^{*}$ & $47 \pm 20$ & $0 \pm 0^{\#}$ & $23 \pm 14^{\#}$ & $0 \pm 0^{\#}$ & $8 \pm 5^{\#}$ \\
\hline $360 \mathrm{~min}$ & $0 \pm 0$ & $39 \pm 35$ & $11 \pm 7$ & $0 \pm 0$ & $2 \pm 1$ & $0 \pm 0$ & $3 \pm 2$ \\
\hline \multicolumn{8}{|l|}{$\begin{array}{c}\text { IL-10 } \\
(\mathrm{pg} / \mathrm{mL})\end{array}$} \\
\hline $0 \min$ & $543 \pm 29$ & $181 \pm 31 *$ & $286 \pm 70^{*}$ & $505 \pm 78^{\#}$ & $440 \pm 82^{\#}$ & $245 \pm 65^{*}$ & $513 \pm 75^{\#+t}$ \\
\hline $90 \min$ & $287 \pm 34$ & $410 \pm 55$ & $730 \pm 66^{* \#}$ & $819 \pm 33^{* \#}$ & $546 \pm 63 * \uparrow \$$ & $245 \pm 86 \dagger^{\$} \S$ & $1057 \pm 88^{* \#+\$} \S \ddagger$ \\
\hline $180 \mathrm{~min}$ & $198 \pm 18$ & $474 \pm 51 *$ & $523 \pm 56^{*}$ & $989 \pm 173^{* *_{\dagger}}$ & $730 \pm 70^{* \#+}$ & $307 \pm 94^{\$} \S$ & $900 \pm 108^{* \#} \dagger t$ \\
\hline $270 \min$ & $105 \pm 12$ & $229 \pm 38$ & $295 \pm 39$ & $539 \pm 49^{* *} \uparrow$ & $328 \pm 40 * \$_{\ddagger}^{+}$ & $14 \pm 13 \uparrow^{\$}$ & $349 \pm 48 * \$+$ \\
\hline $360 \mathrm{~min}$ & $43 \pm 11$ & $122 \pm 31$ & $137 \pm 13$ & $415 \pm 50^{* *} \dagger$ & $222 \pm 42^{\S}$ & $0 \pm 0^{\$}$ & $188 \pm 29^{\$}$ \\
\hline
\end{tabular}

Dados expressos como média \pm erro padrão da média. TNF: fator de necrose tumoral; IL-6: interleucina 6; IL-1 $\beta$ : interleucina $1 \beta$; IL-10: interleucina $10 .{ }^{*} \mathrm{p}<0,05$ vs. Salina; $\# \mathrm{p}<0,05$ vs. LPS; $\dagger \mathrm{p}<0,05$ vs. OBC+LPS; $\$ \mathrm{p}<0,05$ vs. BARO-X+LPS; $\S \mathrm{p}<0,05$ vs. BARO$\mathrm{X}+\mathrm{OBC}+\mathrm{LPS} ;+\mathrm{p}<0,05$ vs. QUIMIO-X+LPS. Todas as comparações são referentes entre os grupos dentro do mesmo momento. ANOVA de duas vias para medidas repetidas seguida do pósteste Student-Newman-Keuls. 


\subsection{Conclusões}

Os dados apresentados neste protocolo indicam que os barorreceptores (aórticos e carotídeos) e os quimiorreceptores periféricos contribuem para o desenvolvimento da resposta inflamatória sistêmica, induzida por LPS, uma vez que na ausência dos mesmos a liberação de citocinas pró-inflamatórias, no plasma, é atenuada. Além disso, os dados decorrentes da OBC mostram que a ativação simpática reflexa diminui a resposta inflamatória induzida por LPS. Ou seja, a ativação do sistema nervoso simpático promove efeitos anti-inflamatórios sistêmicos em um modelo de endotoxemia em ratos. E por fim, que a administração de LPS reduz a potência da banda de HF no espectro do intervalo cardíaco ao longo do tempo, mas que a OBC ou as desnervações seletivas de barorreceptores e quimiorreceptores não modificam esse efeito. A OBC também não foi capaz de prevenir a diminuição da sensibilidade barorreflexa induzida pelo LPS ao longo do tempo. 


\section{Discussão}




\section{DISCUSSÃO}

Nas últimas duas décadas, diversos grupos de pesquisa, incluindo o nosso, contribuíram para o entendimento do papel individual dos ramos do sistema nervoso autônomo (simpático e parassimpático) na resposta inflamatória (ABE et al., 2017; BASSI et al., 2015; BOROVIKOVA et al., 2000; BROGNARA et al., 2018; KOOPMAN et al., 2016; MARTELLI et al., 2014a; VIDA et al., 2011). No entanto, há muito ainda a ser investigado nesse contexto. Assim, o presente estudo teve como objetivo explorar os efeitos da estimulação elétrica do barorreflexo, da ativação simpática reflexa (OBC), bem como dos barorreceptores e quimiorreceptores periféricos em ratos não anestesiados com inflamação sistêmica. Para tanto, o modelo escolhido para induzir a inflamação sistêmica nos animais nos diferentes protocolos, foi a administração de LPS.

O modelo de endotoxemia tem sido amplamente utilizado para explorar a imunidade inata do hospedeiro, envolvida na resposta inflamatória, e buscar abordagens terapêuticas para o tratamento de diversas doenças. O modelo de endotoxemia induzida pela administração de LPS é bem conhecido, e tem sido vastamente usado em estudos recentes (BROGNARA et al., 2019; CHEN et al., 2019; EL-LAKANY et al., 2020; ZHAO et al., 2020). Por ser um modelo muito utilizado, diferentes doses de LPS são encontradas na literatura; mas as respostas hemodinâmicas ao LPS nem sempre são destacadas, ou mesmo consideradas pertinentes nos estudos. Classicamente, a administração de LPS promove hipotensão e taquicardia (CAFÉ-MENDES et al., 2017; CAI; DEITCH; ULLOA, 2010b; KOMEGAE et al., 2018; WASILCZUK et al., 2019); porém, na literatura essas respostas não são descritas com precisão em relação às diferentes doses empregadas, principalmente ao se tratar de estudos em animais não anestesiados.

Assim, antes de iniciar os protocolos com ativação parassimpática ou simpática, foi feito um estudo avaliando o efeito promovido por diferentes doses de LPS na pressão arterial, na frequência cardíaca, na variabilidade cardiocirculatória e na sensibilidade barorreflexa. Foram escolhidas quatro doses para realização deste estudo: 0,06 mg/kg, 20 $\mathrm{mg} / \mathrm{kg}, 30 \mathrm{mg} / \mathrm{kg}$ e $40 \mathrm{mg} / \mathrm{kg}$, todas administradas via intravenosa em ratos não anestesiados. A dose de $0,06 \mathrm{mg} / \mathrm{kg}$ tem sido amplamente utilizada em ratos para investigar os mecanismos envolvidos no reflexo inflamatório (KOMEGAE et al., 2018; MARTELLI et al., 2014b, 2019), bem como para avaliar a regulação barorreflexa durante a inflamação sistêmica (TOHYAMA et al., 2018). Com relação à pressão arterial, assim 
como em estudos anteriores (MARTELLI et al., 2019), os resultados do presente estudo, os quais estão publicados na revista científica Frontiers in Physiology (BROGNARA et al., 2019), demonstraram que esta dose reduz a pressão arterial média ao longo do tempo. Entretanto, no estudo de Martelli et al. (2014b) a mesma dose promoveu um aumento transitório da pressão arterial média, 2 e 3 h após a administração de LPS, com retorno para o nível basal 4 a 6 h após.

Estudos anteriores usando uma dose mais alta de LPS (ex.: $20 \mathrm{mg} / \mathrm{kg}$ ) para desencadear o processo inflamatório, demonstraram que essa abordagem promoveu hipotensão (ALTAVILLA et al., 2002; DOURSOUT et al., 2013, 2016). Doursout et al. (2016), por exemplo, observaram diminuição na pressão arterial média $1 \mathrm{~h}$ após a administração de $20 \mathrm{mg} / \mathrm{kg}$ de LPS em ratos não anestesiados, seguida de recuperação para os níveis basais 2 e $3 \mathrm{~h}$ depois. Um outro estudo (ALTAVILLA et al., 2002) avaliou a pressão arterial média por 360 min após a administração de LPS. Os resultados obtidos mostraram redução sustentada desse parâmetro hemodinâmico em ratos anestesiados, ao longo do tempo, iniciando 30 min após a administração de LPS (ALTAVILLA et al., 2002). No entanto, o presente estudo não provê suporte para esse achado, uma vez que a administração intravenosa de doses mais altas de LPS (20, 30 e 40 mg/kg) não reduziu a pressão arterial média em ratos não anestesiados; a qual aumentou com o passar do tempo, algumas vezes já se apresentando aumentada 90 min após a injeção de LPS (como foi o caso da dose de $20 \mathrm{mg} / \mathrm{kg}$ ). Muitos fatores como o sexo dos animais, a qualidade do LPS (pureza, fonte e via de administração), e as cepas dos ratos podem influenciar as alterações cardiovasculares induzidas pela inflamação (FERGUSON et al., 2013; MARRIOTT; BOST; HUET-HUDSON, 2006; SIMONS et al., 1998; STERNBERG et al., 1989), e poderiam explicar essas discrepância entre os estudos, justificando novas investigações no futuro.

Vale ressaltar que alguns estudos relatam alterações na pressão arterial após a administração de doses intermediárias de LPS (isto é, 5 e $10 \mathrm{mg} / \mathrm{kg}$, i.v.) em ratos não anestesiados. Mehanna et al. (2007) descreveram três fases para a resposta da pressão arterial na primeira hora após a administração de LPS (5 mg/kg, i.v.): diminuição inicial (fase 1); recuperação rebote (fase 2); e diminuição duradoura (fase 3). Outros estudos também mostraram que a dose de $10 \mathrm{mg} / \mathrm{kg}$ (i.v.) promove redução na pressão arterial ao longo do tempo, ou seja, até 180 min (SALLAM et al., 2017, 2018). No entanto, Lee et al. (2005), em uma análise mais ampla em ratos não anestesiados, ou seja, até 24 h após a administração de LPS, observaram que as alterações da pressão arterial consistiam em 
uma resposta hipotensora inicial, entre 30 e $60 \mathrm{~min}$, seguida de redução da pressão arterial, de 1 a 9 h, e, finalmente, por um aumento da pressão arterial, de 9 a 24 h após a administração de $5 \mathrm{mg} / \mathrm{kg}$ de LPS (i.v.). Assim, parece que a resposta da pressão arterial ao LPS é bastante variável, ao longo do tempo, e vários elementos podem influenciar esse resultado, como mencionado anteriormente. Com relação às alterações na frequência cardíaca, todas as doses avaliadas no presente estudo promoveram taquicardia ao longo do tempo, como usualmente observado na literatura (ALTAVILLA et al., 2002; MARTELLI et al., 2014b).

A análise da variabilidade do intervalo cardíaco mostrou claramente que doses mais altas de LPS aumentaram a potência do espectro da banda LF e diminuíram a potência do espectro da banda HF ao longo do tempo. Em outras palavras, o LPS aumentou a modulação simpática e reduziu a modulação vagal para o coração em ratos não anestesiados. É sabido que a administração de LPS influencia a variabilidade da frequência cardíaca de ratos (HUANG et al., 2010; ZILA et al., 2015). No entanto, ao que se sabe, nenhum estudo anterior descreveu os efeitos de diferentes doses de LPS na variabilidade da frequência cardíaca, ao longo do tempo, em ratos não anestesiados. Uma vez que todos os grupos tratados com LPS (doses baixas e altas) apresentaram diminuição da potência de HF (redução da modulação vagal), e apenas a dose mais baixa diminuiu a pressão arterial ao longo do tempo, enquanto as demais promoveram a resposta oposta, parece que a hipotensão provocada pela dose mais baixa de LPS não depende de aumento, ou manutenção, da modulação vagal ao longo do tempo. Entretanto, as diferenças observadas na resposta da pressão arterial entre os grupos com doses altas e baixas de LPS, podem ser atribuídas ao aumento exacerbado da potência da banda de LF no espectro da pressão arterial sistólica, ao longo do tempo, nos grupos que receberam doses altas de LPS. Vale ressaltar que a banda de LF da pressão arterial sistólica está relacionada à resistência periférica dos vasos sanguíneos (JULIEN, 2006). Assim, a resistência periférica aumentada pode ter contribuído para o aumento da pressão arterial nos animais que receberam altas doses de LPS.

A função barorreflexa também tem sido examinada após a administração de LPS (RADAELLI et al., 2013; SHEN et al., 2004; TOHYAMA et al., 2018). No presente estudo, a análise da função barorreflexa revelou diminuição na sensibilidade barorreflexa em todos os grupos tratados com LPS, ao longo do tempo, independentemente da dose utilizada. Esse comprometimento foi observado já no primeiro momento avaliado, ou seja, 90 min depois do LPS, e foi mantido até o final do protocolo, ou seja, $360 \mathrm{~min}$ 
depois. Corroborando com os resultados do presente estudo, Radaelli et al. (2013) mostraram sustentada redução na sensibilidade barorreflexa, a qual começou logo após o início (10 min depois) da infusão de LPS em ratos. Além disso, Shen et al. (2004) concluíram que um barorreflexo arterial eficiente é essencial para determinar a sobrevida durante o choque letal induzido por LPS. O comprometimento do barorreflexo tem consequências significativas em relação à pressão arterial, pois na ausência do controle reflexo da mesma, o sistema cardiovascular perde o seu controle adequado, podendo culminar em aumento ou redução da pressão arterial durante a endotoxemia. Como todos os grupos que receberam LPS apresentaram comprometimento da função barorreflexa ao longo do tempo, não podem ser feitas correlações entre comprometimento do barorreflexo e alterações da pressão arterial, uma vez que ratos que receberam uma dose baixa de LPS exibiram uma diminuição na pressão arterial, enquanto os ratos que receberam doses altas de LPS apresentaram aumento na pressão arterial.

Portanto, esses dados mostram que que nem sempre a administração de LPS promove as alterações hemodinâmicas clássicas esperadas em um modelo de endotoxemia. Levando em consideração os achados desse estudo inicial das doses de LPS, a dose escolhida para os estudos seguintes foi a dose de $0,06 \mathrm{mg} / \mathrm{kg}$ uma vez que foi a dose que melhor mimetizou as respostas de pressão arterial e frequência cardíaca esperadas durante a inflamação sistêmica em ratos.

Com a dose de LPS definida e dando sequência aos estudos, o presente trabalho avaliou se o efeito anti-inflamatório da ativação barorreflexa observado no modelo de artrite reumatoide (BASSI et al., 2015) também seria observado, ao longo do tempo, em um modelo de inflamação sistêmica em ratos não anestesiados. Vale destacar que o estudo prévio de Brognara et al. (2018), mostrou que a estimulação elétrica do NDA, um nervo aferente responsável pelo controle da homeostase cardiovascular, promove efeitos antiinflamatórios centrais em ratos endotoxêmicos 90 min após a administração de LPS, inibindo os níveis hipotalâmicos de todas as citocinas analisadas (TNF, IL-6, IL-1 $\beta$ e IL10). Outros estudos já relataram que a estimulação elétrica de nervos periféricos e a estimulação direta do cérebro, induzem efeitos protetores na isquemia cerebral, na lesão traumática do cérebro, bem como, na isquemia e reperfusão cerebral (JIANG et al., 2014; MENESES et al., 2016; SCHWEIGHÖFER et al., 2016). Meneses et al. (2016), mostraram que a estimulação elétrica do vago reduziu os níveis de citocinas próinflamatórias (TNF, IL-6 e IL-1 $\beta$ ), centrais, em camundongos com inflamação sistêmica induzida por LPS. 
Entretanto, embora a estimulação barorreflexa tenha atenuado os níveis de citocinas centralmente (hipotálamo), as citocinas periféricas (coração, baço e plasma) não foram afetadas nos animais endotoxêmicos não anestesiados (BROGNARA et al., 2018). De fato, como apresentado na presente tese, mesmo alterando a via de administração de LPS (de intraperitoneal para intravenoso), a dose (de $5 \mathrm{mg} / \mathrm{kg}$ para 0,06 $\mathrm{mg} / \mathrm{kg}$ ) e até mesmo a cepa dos ratos (Wistar para Wistar Hannover) em comparação ao estudo de Brognara et al. (2018), a ativação do barorreflexo, por meio da estimulação elétrica do NDA, não promoveu efeitos anti-inflamatórios sistêmicos (plasma) em curto (90 min após o LPS) ou longo prazo (até 360 min após o LPS). Uma vez que o baço é a principal fonte de TNF, o qual é liberado na corrente sanguínea durante a endotoxemia, e é o órgão alvo do reflexo inflamatório (HUSTON et al., 2006), é surpreendente que a estimulação barorreflexa não tenha afetado os níveis de citocinas plasmáticas. No entanto, os achados do presente estudo corroboram dados anteriores, os quais mostraram que a ativação do barorreflexo - via estimulação elétrica do NDA - inibe os níveis de citocinas no líquido sinovial na artrite experimental, por meio de um mecanismo independente do baço (BASSI et al., 2015).

Vale destacar que, neste protocolo, a administração de LPS também reduziu a potência da banda HF no espectro do intervalo cardíaco ao longo do tempo, refletindo uma diminuição na modulação vagal mesmo nos animais que receberam a ativação elétrica do barorreflexo. Além disso, a função barorreflexa também reduziu ao longo do tempo em todos os grupos que receberam LPS. Ou seja, a alteração causada pelo processo inflamatório sistêmico na função barorreflexa não foi prevenido ou atenuado pela ativação elétrica do NDA. Sendo assim, é possível que sistemicamente, o potencial antiinflamatório da ativação barorreflexa esteja comprometido, uma vez que tanto a função barorreflexa quanto a modulação parassimpática estão drasticamente afetadas. Portanto, ainda não está claro quais são os mecanismos por trás dos efeitos anti-inflamatórios da ativação barorreflexa e qual o seu alcance em modelos de inflamação sistêmica, mas parece que seus efeitos se restringem a locais específicos.

Os dados apresentados nesta tese destacam que alguns animais não respondem à ativação barorreflexa com alterações hemodinâmicas frente aos mesmos parâmetros de estimulação. Isso pode ser explicado pelo fato de que alguns nervos podem necessitar de um estímulo elétrico mais intenso para apresentar respostas hemodinâmicas. Alguns estudos utilizando estimulação elétrica do nervo vago, e do seio carotídeo, são conduzidos com parâmetros especificamente ajustados para cada animal; justamente com a finalidade 
de padronizar a alteração hemodinâmica decorrente da estimulação elétrica (KAWADA et al., 2014; LI et al., 2004; LOHMEIER et al., 2010). Como no presente estudo os parâmetros de estimulação elétrica do NDA foram fixados para todos os animais, pode ser que aqueles que não responderam com alterações hemodinâmicas, apenas precisassem de estímulos mais intensos para desencadear esses efeitos. Entretanto, como observado no estudo de Brognara et al. (2018), o mecanismo anti-inflamatório central do barorreflexo parece ser independente de alterações cardiovasculares (BROGNARA et al., 2018). Ou seja, mesmo que não ocorra alteração na pressão arterial durante a estimulação barorreflexa, é possível que, mesmo assim, a via de resposta anti-inflamatória seja ativada.

O diagrama apresentado na figura 24 sintetiza os achados provenientes da estimulação elétrica do NDA apresentados nesta tese em conjunto com dados obtidos previamente em nosso laboratório com o mesmo grupo de pesquisa (BROGNARA et al., 2018). Em suma, a estimulação elétrica do NDA promove ativação do barorreflexo resultando em aumento da atividade parassimpática, e inibição da atividade simpática. Essa resposta promove inibição da liberação de citocinas no hipotálamo, mas não altera os níveis de citocinas encontrados no baço, no coração, e no plasma, decorrentes do processo inflamatório sistêmico induzido pela administração de LPS em ratos não anestesiados.

Apesar da ativação dos barorreceptores, pela estimulação elétrica do NDA, não ter apresentado efeito anti-inflamatório periférico, a desnervação seletiva dos barorreceptores aórticos e carotídeos, por si só, reduziu os níveis das citocinas próinflamatórias no plasma de ratos com inflamação sistêmica induzida por LPS. Mais especificamente, nos ratos sem os barorreceptores, os níveis de TNF e IL-6 estavam significativamente mais baixos do que nos animais intactos (somente LPS), e a liberação de IL-1 $\beta$ induzida pelo LPS foi abolida nos animais sem os barorreceptores. A mesma resposta foi observada nos animais que tiveram apenas os seus quimiorreceptores carotídeos removidos. Ou seja, esses dados sugerem que tanto os barorreceptores quanto os quimiorreceptores contribuem com a sinalização da resposta inflamatória, favorecendo a liberação de citocinas durante o desafio imune.

Com relação ao papel dos quimiorreceptores na resposta inflamatória, vários estudos demonstraram que as células glomus do corpo carotídeo de ratos possuem receptores para citocinas pró-inflamatórias, como TNF, IL-6 e IL-1 (FERNANDEZ et al., 2014; FERNÁNDEZ et al., 2011; FUNG, 2014; LAM et al., 2008; WANG et al., 2002, 
2006). O estudo de Fernández et al. (2011), conduzido em ratos Sprague-Dawley, mostrou que o tratamento com LPS aumentou a expressão de TNF e de seu receptor no corpo carotídeo, e que além de apresentar receptores para citocinas, o mesmo possui o receptor Toll-like 4, responsável por reconhecer o LPS. Assim, durante a resposta inflamatória, as citocinas liberadas pelo próprio corpo carotídeo podem atuar de maneira periférica (aumentando a resposta imune), parácrina ou autócrina diretamente nas células do corpo carotídeo, alterando, também, a sua sensibilidade (FERNÁNDEZ et al., 2011). Sendo assim, os autores sugerem que o quimiorreceptor carotídeo pode servir como sensor periférico para a presença de agentes imunogênicos no sangue, contribuindo para a comunicação entre o sistema imune e o cérebro durante a endotoxemia (FERNANDEZ et al., 2014; FERNÁNDEZ et al., 2011; Fig. 25). É importante destacar que outros estudos já demonstraram que o corpo carotídeo de humanos também possui receptores para citocinas (TNF, IL-6, IL-1 $\beta$ e IL-10) e o receptor Toll-like (KAHLIN et al., 2015; MKRTCHIAN et al., 2012), sugerindo uma função imunossensora do corpo carotídeo (FUNG, 2014).

Pouco se sabe sobre o papel dos barorreceptores influenciando a sinalização da resposta inflamatória. Um estudo recente mostrou que a desnervação sino-aórtica atenuou a liberação de IL-6 e IL-10 no plasma de ratos endotoxêmicos (AMORIM et al., 2020). Entretanto, levando-se em consideração que a desnervação sino-aórtica inclui a remoção dos quimiorreceptores carotídeos (FRANCHINI; KRIEGER, 1992; KRIEGER, 1964; SILVA et al., 2015; ZHANG; BARRÈS; JULIEN, 1995), pode ser que a resposta observada no estudo citado tenha ocorrido pela ausência dos quimiorreceptores e não, necessariamente, dos barorreceptores. Sabe-se que tanto os receptores Toll-like 4, quanto os receptores para citocinas são expressos em neurônios (CHAVAN; PAVLOV; TRACEY, 2017; DE LARTIGUE et al., 2011; HOSOI et al., 2005; LI et al., 2005; MA; ZHANG; WESTLUND, 2009). Além disso, o estudo de Hosoi et al. (2005) concluiu que o gânglio nodoso (responsável por enviar as projeções do nervo vago ao sistema nervoso central) expressa o receptor Toll-like 4; e, portanto, o LPS poderia ativar esses neurônios e desencadear o processo inflamatório também por meio desta via. Juntos, esses dados sugerem que, assim como outros neurônios, as terminações nervosas dos barorreceptores também podem possuir receptores Toll-like 4 e/ou receptores para citocinas, contribuindo com a comunicação entre o sistema imune e o cérebro durante a endotoxemia (Fig. 25). Vale ressaltar que além de reduzir as citocinas pró-inflamatórias, o presente estudo também mostrou que a ausência dos barorreceptores aumentou a liberação de IL-10 
(citocina anti-inflamatória) durante o desafio imune induzido por LPS. Esse resultado pode indicar que além de sinalizar para o sistema nervoso central, os barorreceptores podem possuir papel na atividade dos macrófagos do tipo II, que estão associados com a liberação de marcadores como a IL-10, dentre outros (LAWRENCE; NATOLI, 2011). $\mathrm{Na}$ ausência dos barorreceptores, os macrófagos do tipo II poderiam atuar, livremente, na liberação de citocinas pró-inflamatórias (como a IL-10), auxiliando no controle da resposta inflamatória. Entretanto, estudos futuros são necessários para confirmar essas hipóteses.

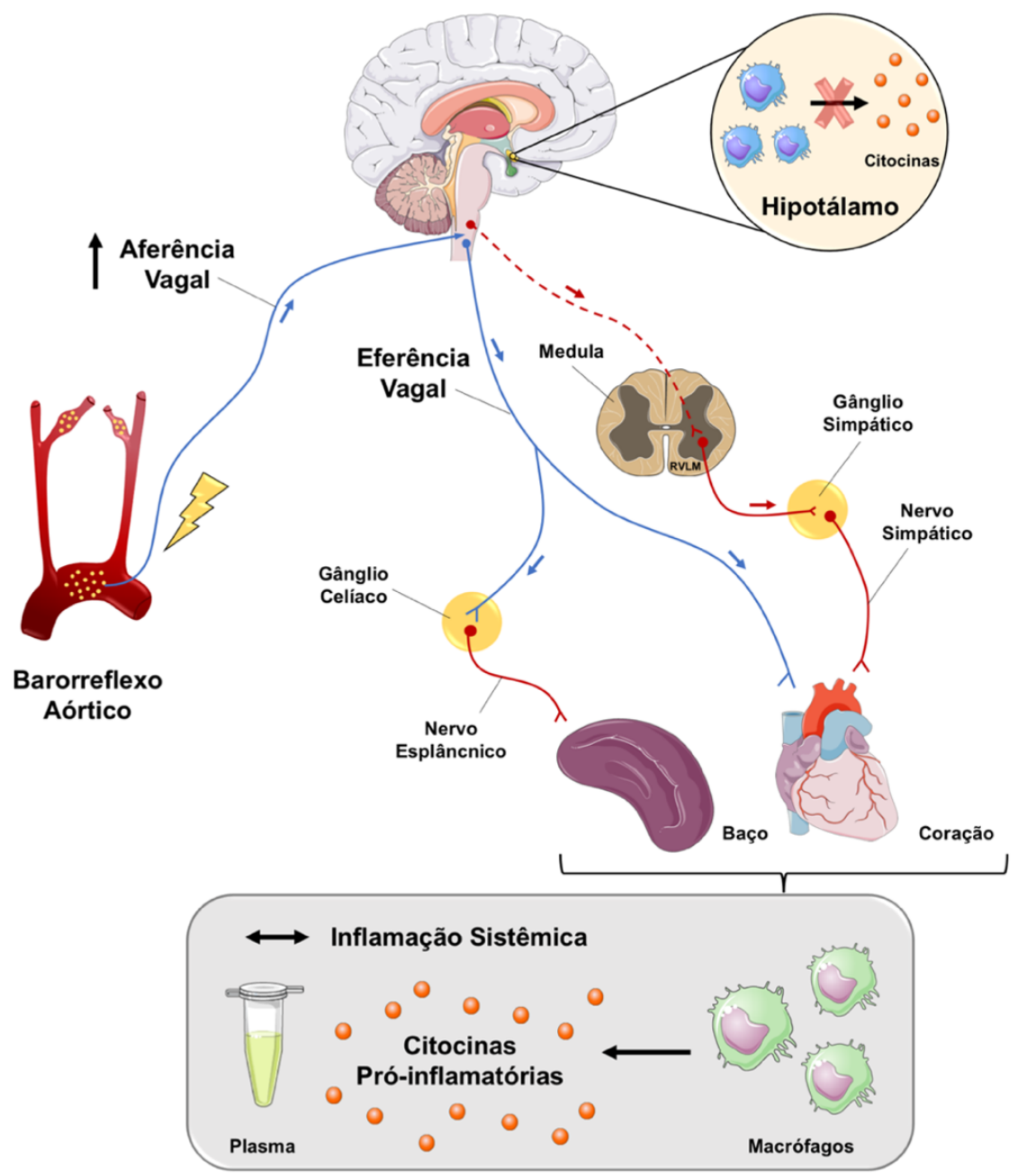

Figura 24. A ativação barorreflexa atenua apenas a inflamação central em ratos com endotoxemia.

A estimulação elétrica do nervo depressor aórtico promove ativação do barorreflexo culminando com um aumento da atividade parassimpática e inibição da atividade simpática. Essa resposta promove inibição da liberação de citocinas no hipotálamo, mas não altera os níveis de citocinas encontrados no baço, no coração e no plasma decorrentes do processo inflamatório sistêmico induzido pela administração de LPS em ratos não anestesiados. RVLM: região ventrolateral rostral bulbar. A linha tracejada indica inibição. Linhas em azul indicam inervação parassimpática e linhas em vermelho indicam inervação simpática. Figura criada a partir de imagens disponibilizadas na plataforma online Smart Servier Medical Art (disponível em: https://smart.servier.com). 


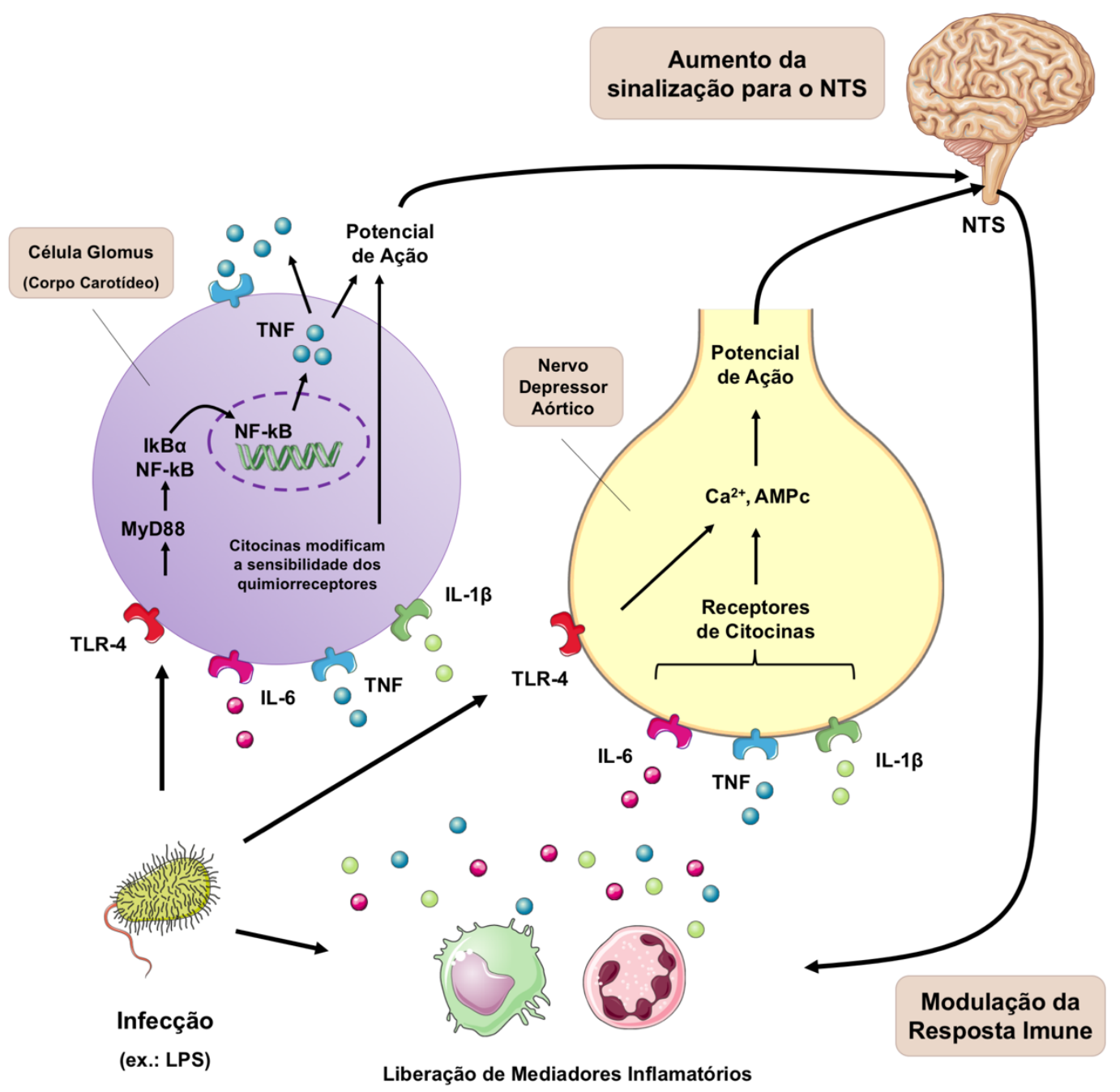

Figura 25. Mecanismo molecular proposto para a interação imune-sensorial-neural envolvendo os quimiorreceptores periféricos e os barorreceptores aórticos e carotídeos. A infecção decorrente da administração de LPS, por exemplo, resulta na liberação de mediadores inflamatórios (ex.: IL-6, TNF e IL1ß) pelas células do sistema imune. Os terminais axonais periféricos de neurônios sensoriais, neste caso representado pelo nervo depressor aórtico, expressam receptores para citocinas e o receptor Toll-like 4 (TLR-4), responsável pelo reconhecimento do LPS. Assim, tanto o LPS quanto as citocinas interagem no terminal axonal do nervo depressor aórtico levando à geração de segundos-mensageiros como o cálcio $\left(\mathrm{Ca}^{2+}\right)$ e a adenosina monofosfato cíclico (AMPc) ativando a cascata que leva à geração do potencial de ação no nervo resultando na sinalização da região do núcleo do trato solitário (NTS). Da mesma forma, as células glomus presentes no corpo carotídeo também expressam receptores para citocinas e o TLR-4, e culminam com a geração de potencial de ação quando ativados. Além disso, a interação do LPS com seu receptor ativa MyD88 o qual induz a translocação do NF-kB para o núcleo das células glomus resultando na síntese e liberação de citocinas, como o TNF. Assim, as células do próprio corpo carotídeo secretam citocinas que vão atuar de maneira parácrina e autócrina alterando a sensibilidade dos quimiorreceptores e enviando sinais ao NTS de forma a contribuir com a comunicação neuro-imune. Figura criada a partir de imagens disponibilizadas na plataforma online Smart Servier Medical Art (disponível em: https://smart.servier.com). 
Após estudar a ativação do ramo parassimpático com concomitante inibição do ramo simpático do sistema nervoso autônomo, por meio da estimulação elétrica do NDA, o próximo passo foi avaliar o papel da ativação reflexa generalizada do sistema nervoso simpático. Como apresentado anteriormente, a OBC tem sido utilizada como manobra para promover ativação reflexa, global, do sistema nervoso simpático (BEDRAN-DECASTRO; MOREIRA; KRIEGER, 1986; KRIEGER, 1963; WANG et al., 1970). Resumidamente, a inativação dos barorreceptores carotídeos durante a OBC induz aumento da atividade simpática para o coração e para os vasos (aumento da resistência periférica global) com concomitante redução da atividade parassimpática para o coração, resultando, assim, no aumento da pressão arterial (BEDRAN-DE-CASTRO; MOREIRA; KRIEGER, 1986; KRIEGER, 1963). Os dados obtidos no presente estudo estão de acordo com a literatura, uma vez que todos os animais submetidos à $\mathrm{OBC}$ apresentaram aumento expressivo da pressão arterial e da potência da banda de LF da pressão arterial sistólica durante o período da $\mathrm{OBC}$, confirmando o aumento da modulação simpática para os vasos e da resistência periférica. Assim, o aumento da pressão arterial observado durante a OBC, tanto nos ratos intactos quanto nos desnervados (BARO-X e QUIMIO-X), sugere que a $\mathrm{OBC}$, de fato, promoveu aumento da resistência periférica decorrente da ativação simpática. No caso dos animais intactos, a ativação simpática pode ter sido decorrente da inibição dos barorreceptores carotídeos e ativação dos quimiorreceptores periféricos. Já nos animais com desnervação dos barorreceptores, pode-se atribuir o aumento da atividade simpática à ativação dos quimiorreceptores, enquanto que nos ratos com desnervação dos quimiorreceptores, esse aumento se deve, provavelmente, pela inativação dos barorreceptores carotídeos.

Com relação à resposta da frequência cardíaca à $\mathrm{OBC}$, a literatura apresenta divergência de resultados dependendo da espécie avaliada. Cães podem apresentar taquicardia ou inalteração da frequência cardíaca (KIRBY; VATNER, 1987; VATNER; MANDERS, 1979), enquanto que coelhos apresentam um leve aumento da frequência cardíaca (KUMAGAI; REID, 1994). Já em camundongos, há redução da frequência cardíaca durante a OBC (LATARO et al., 2010). No presente estudo, ratos intactos, e também aqueles que tiveram os barorreceptores desnervados, não apresentaram alteração na frequência cardíaca, enquanto que os animais que tiveram os quimiorreceptores desnervados exibiram bradicardia durante a OBC. Essa redução da frequência cardíaca nos animais sem quimiorreceptores pode ser explicada pela ativação dos barorreceptores aórticos durante a $\mathrm{OBC}$, contribuindo para o aumento da atividade parassimpática para $\mathrm{o}$ 
coração. Já no estudo de Lataro et al. (2010), nenhuma alteração na frequência cardíaca foi observada em camundongos com desnervação do seio carotídeo. Portanto, esses dados indicam que ainda não há consenso quanto aos efeitos da $\mathrm{OBC}$ na frequência cardíaca, em diferentes espécies.

A avaliação das citocinas plasmáticas mostrou que a ativação simpática (promovida pela $\mathrm{OBC}$ ), nos ratos intactos, resultou em redução das citocinas próinflamatórias (TNF e IL-1 $\beta$ ) e aumento da citocina anti-inflamatória avaliada (IL-10) 90 min após a administração de LPS, contribuindo para o controle e redução da resposta inflamatória sistêmica em ratos não anestesiados. O possível mecanismo pelo qual a OBC reduziu a liberação de citocinas pró-inflamatórias pode estar relacionado com a ativação dos quimiorreceptores carotídeos e inativação dos barorreceptores carotídeos, que resultam em aumento da atividade simpática eferente. Quando as carótidas comuns são ocluídas, os quimiorreceptores carotídeos são ativados e, ao mesmo tempo, os barorreceptores carotídeos são desativados. Assim, a influência inibitória dos barorreceptores no sistema nervoso simpático é prejudicada, e simultaneamente, neurônios da RVLM são estimulados pela ativação dos quimiorreceptores, determinando o aumento significativo da atividade simpática. Consequentemente, a inervação simpática do baço é estimulada, inibindo a produção de citocinas pelas células imunes do baço pela via já descrita na literatura que envolve a participação de linfócitos $\mathrm{T}$ sintetizadores de acetilcolina, acetilcolina e receptores nicotínicos de acetilcolina do tipo alfa-7 (DANTZER, 2018; TRACEY, 2010; WANG et al., 2003). Vale ressaltar que o efeito anti-inflamatório decorrente da $\mathrm{OBC}$, observado no presente estudo, não é dependente da integridade da função barorreflexa, uma vez que a OBC não preveniu ou atenuou a diminuição da sensibilidade barorreflexa induzida pela administração de LPS ao longo do tempo.

Outros estudos já mostraram que o sistema nervoso simpático possui propriedades anti-inflamatórias (KEES et al., 2003; MARTELLI et al., 2014a; STRAUB et al., 2011; VIDA et al., 2011), corroborando com os dados apresentados no presente trabalho. Entretanto, este é o primeiro estudo que mostra esses efeitos por meio de uma ativação simpática reflexa. A figura 26 resume os possíveis mecanismos pelos quais a ativação simpática reflexa atenua a resposta inflamatória sistêmica, destacando os achados do presente estudo.

Nos animais com desnervação dos barorreceptores, ou dos quimiorreceptores, a OBC não alterou o efeito já promovido pela própria desnervação, por si só, nas citocinas 
pró-inflamatórias, com exceção da IL-6 nos animais com desnervação dos barorreceptores, a qual aumentou com a OBC. Este último dado sugere que a ativação quimiorreflexa decorrente da $\mathrm{OBC}$, nos animais sem barorreceptores, aumenta a liberação de IL-6 no plasma, contribuindo com o aumento da resposta inflamatória. Ao observar os níveis da citocina anti-inflamatória, IL-10, a resposta foi ligeiramente diferente entre os grupos desnervados com, e sem, OBC. Nos animais com desnervação dos barorreceptores a OBC elevou os níveis de IL-10, apenas, 180 min após a administração de LPS, retornando aos níveis basais logo em seguida. Já nos animais com desnervação de quimiorreceptores, a OBC aumentou os níveis de IL-10, no plasma, 90, 180 e $270 \mathrm{~min}$ após a administração de LPS. Ou seja, a desativação dos barorreceptores carotídeos promovida pela $\mathrm{OBC}$, nos animais sem quimiorreceptores, contribuiu com uma maior liberação de IL-10 no plasma, em longo prazo, corroborando os dados discutidos anteriormente nesta tese, sobre a possível relação entre os barorreceptores e os macrófagos do tipo II. Juntos, esses dados sugerem que a ativação simpática reflexa atenua a resposta inflamatória sistêmica, e que ambos, barorreceptores e quimiorreceptores, apresentam papel importante na comunicação neuroimune.

Assim como demonstrado nos estudos das doses de LPS (BROGNARA et al., 2019) e da estimulação barorreflexa, apresentados no presente trabalho, o protocolo com OBC também evidenciou redução na potência da banda de HF no espectro do intervalo cardíaco, ao longo do tempo, em todos os grupos que receberam LPS. Além disso, os grupos com desnervação de barorreceptores já apresentava diminuição da potência da banda de HF no período basal. Esses achados demonstram que a inflamação sistêmica e a ausência dos barorreceptores aórticos e carotídeos diminuem a modulação vagal para o coração. Além disso, como também exposto no estudo das doses (BROGNARA et al., 2019), a dose de LPS $0,06 \mathrm{mg} / \mathrm{kg}$ utilizada no protocolo com OBC não alterou a potência da banda de LF no espectro do intervalo cardíaco. Da mesma forma, nenhuma das manobras utilizadas neste protocolo (OBC, BARO-X ou QUIMIO-X) alterou a potência da banda de LF no espectro do intervalo cardíaco ao longo do tempo. Esses dados indicam que durante a inflamação sistêmica, a remoção dos barorreceptores aórticos e carotídeos ou quimiorreceptores periféricos não afeta significativamente a modulação simpática para o coração no período avaliado neste estudo. Corroborando com esses resultados, estudos prévios também demonstraram que a inflamação sistêmica induzida por LPS em ratos não anestesiados reduziu a modulação vagal sem alterar a modulação simpática para o coração (AMORIM et al., 2019, 2020). 
É importante ressaltar que a avaliação temporal das citocinas permitiu analisar o efeito de cada tratamento, não apenas no pico da resposta inflamatória (90 min), mas também em outros três momentos ao longo de $360 \mathrm{~min}$, revelando possíveis respostas tardias ou prolongadas. Outro aspecto importante do presente estudo é o fato de que todos os experimentos foram conduzidos em animais não anestesiados, simulando situações clínicas e condições fisiológicas. É sabido que os anestésicos interferem particularmente nos mecanismos neurais que modulam o sistema imunológico (PICQ et al., 2013). Vários estudos mostraram que a Ketamina e o isoflurano, bem como outros anestésicos amplamente utilizados, exibem potentes propriedades anti-inflamatórias (CRUZ; ROCCO; PELOSI, 2017; FLONDOR et al., 2008; QIN et al., 2015; TANIGUCHI; YAMAMOTO, 2005). Estudos anteriores investigando a estimulação elétrica neural em modelos de inflamação foram conduzidos, principalmente, em roedores anestesiados. Uma exceção significativa pode ser atribuída ao estudo de Martelli et al. (2014b), os quais demonstraram, em ratos não anestesiados, que a via esplâncnica anti-inflamatória tem influência inibidora expressiva, e sustentada, nos processos inflamatórios. Sendo assim, os dados apresentados nesta tese se destacam por fornecer informações significativas sobre a regulação autonômica do processo inflamatório, sem os efeitos indesejados da anestesia. 


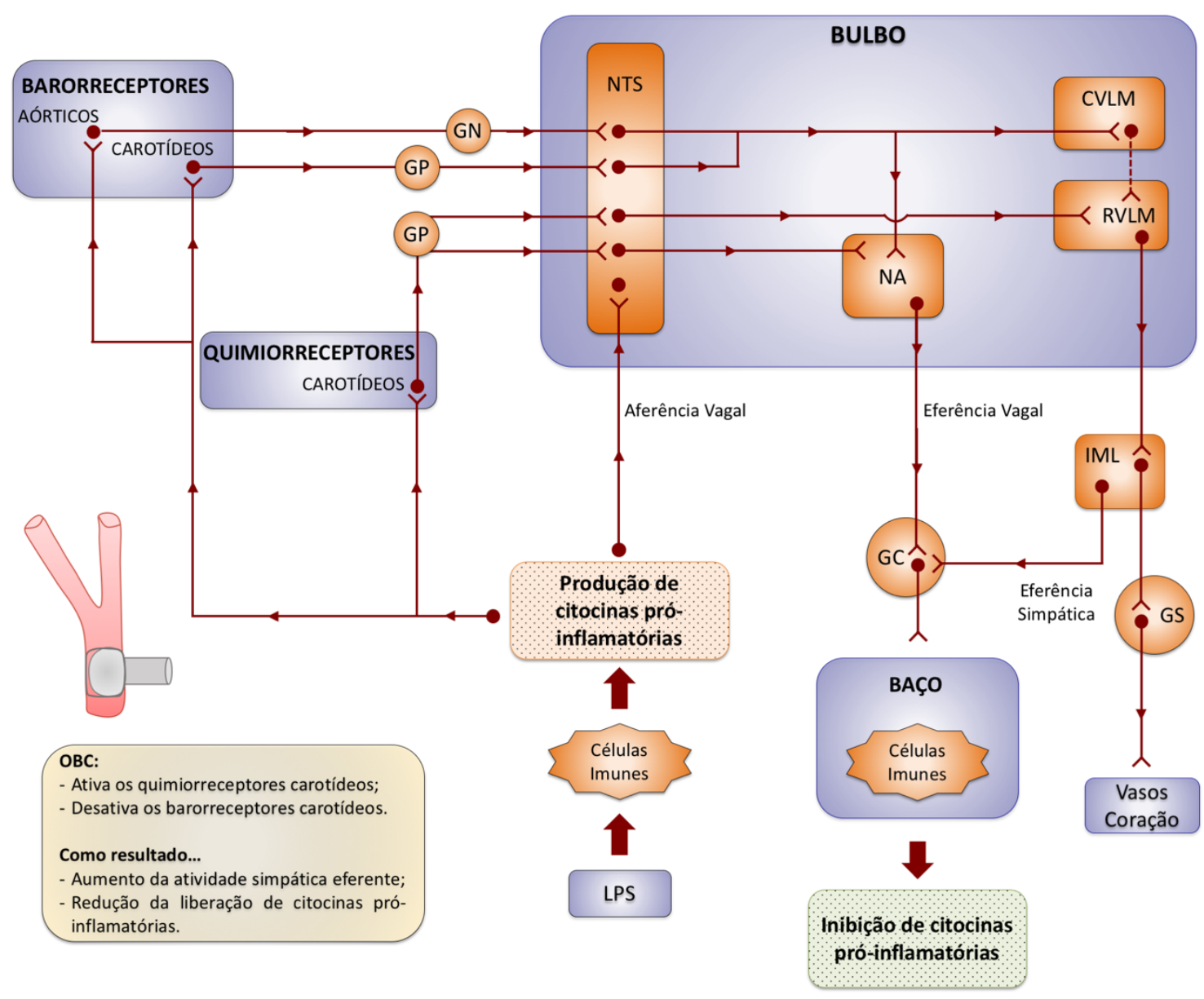

Figura 26. Ativação simpática reflexa atenua a resposta inflamatória sistêmica. Diagrama mostrando como os barorreceptores e quimiorreceptores atuam para reduzir a liberação de citocinas pró-inflamatórias decorrente da oclusão bilateral da carótida (OBC) em um desafio imune induzido por LPS. Quando as carótidas comuns são ocluídas, os quimiorreceptores carotídeos são ativados e, ao mesmo tempo, os barorreceptores carotídeos são desativados. Assim, a influência inibitória dos barorreceptores no sistema nervoso simpático é prejudicada, e simultaneamente, neurônios da região ventrolateral rostral bulbar (RVLM) são estimulados pela ativação dos quimiorreceptores, determinando o aumento significativo da atividade simpática. Consequentemente, a inervação simpática do baço é estimulada, inibindo a produção de citocinas pelas células imunes do baço. O diagrama também destaca que os barorreceptores e quimiorreceptores poderiam ser ativados por citocinas pró-inflamatórias liberadas pelas células imunes. CVLM: região caudal ventrolateral bulbar; GC: gânglio celíaco; GN: gânglio nodoso; GP: gânglio petroso; GS: gânglio simpático; IML: coluna intermédio lateral; LPS: lipopolissacarídeo; NA: núcleo ambíguo; NTS: núcleo do trato solitário. 
7. Conclusões 


\section{CONCLUSÕES}

O conjunto de resultados apresentados nesta tese mostrou que a caracterização da dose de LPS escolhida para o estudo da interação do sistema nervoso autônomo com o sistema imune é muito importante, uma vez que nem sempre a administração de LPS promove as alterações hemodinâmicas clássicas esperadas em um modelo de endotoxemia. Em ratos não anestesiados, altas doses de LPS podem promover aumento da pressão arterial ao longo do tempo, enquanto que uma dose mais baixa pode reduzir a pressão arterial, também ao longo do tempo. Por outro lado, tanto doses altas quanto baixas de LPS produzem aumento da frequência cardíaca ao longo do tempo. Assim, é preciso identificar quais parâmetros são importantes para cada estudo, e buscar a dose de LPS mais adequada.

Adicionalmente, os dados obtidos neste trabalho fornecem evidências de que a ativação parassimpática associada a inibição simpática (por meio da estimulação elétrica do NDA) não possui efeitos anti-inflamatórios sistêmicos (plasma) em ratos endotoxêmicos não anestesiados. Por outro lado, apesar da ativação barorreflexa não ter se mostrado efetiva no controle da resposta inflamatória sistêmica, a ativação reflexa do sistema nervoso simpático, por meio da $\mathrm{OBC}$, atenuou a liberação de citocinas plasmáticas pró-inflamatórias em ratos não anestesiados. Esses dados sugerem que a ativação reflexa global do sistema simpático é capaz de modular a resposta inflamatória sistêmica.

Por fim, o presente estudo também sugere que, assim como os quimiorreceptores periféricos, os barorreceptores aórticos e carotídeos, também possuem importante papel na sinalização da resposta inflamatória, possivelmente desempenhando uma função imunossensora e contribuindo com a comunicação neuroimune frente ao desafio imune induzido por LPS em ratos não anestesiados. 
Referências 


\section{REFERÊNCIAS}

ABE, C. et al. C1 neurons mediate a stress-induced anti-inflammatory reflex in mice. Nature Neuroscience, v. 20, n. 5, p. 700-707, maio 2017.

ADER, R.; COHEN, N. Behaviorally Conditioned Immunosuppression. Psychosomatic Medicine, v. 37, n. 4, p. 333-340, ago. 1975.

AKIRA, S.; TAKEDA, K.; KAISHO, T. Toll-like receptors: critical proteins linking innate and acquired immunity. Nature Immunology, v. 2, n. 8, p. 675-680, ago. 2001.

AKIYAMA, H. et al. Inflammation and Alzheimer's disease. Neurobiology of Aging, v. 21, n. 3, p. 383-421, jun. 2000.

AKSELROD, S. et al. Power spectrum analysis of heart rate fluctuation: a quantitative probe of beat-to-beat cardiovascular control. Science (New York, N.Y.), v. 213, n. 4504, p. 220-222, 10 jul. 1981.

ALLAN, S. M.; ROTHWELL, N. J. Cytokines and acute neurodegeneration. Nature Reviews. Neuroscience, v. 2, n. 10, p. 734-744, out. 2001.

ALTAVILLA, D. et al. Inhibition of nuclear factor-kappaB activation by IRFI 042, protects against endotoxin-induced shock. Cardiovascular Research, v. 54, n. 3, p. 684693, jun. 2002.

AMORIM, M. R. et al. Neuroinflammation in the NTS is associated with changes in cardiovascular reflexes during systemic inflammation. Journal of Neuroinflammation, v. 16, n. 1, p. 125, 20 jun. 2019.

AMORIM, M. R. et al. Baroreceptor denervation reduces inflammatory status but worsens cardiovascular collapse during systemic inflammation. Scientific Reports, v. 10, n. 1, p. 6990, 24 abr. 2020.

ARONSON, D.; MITTLEMAN, M. A.; BURGER, A. J. Interleukin-6 levels are inversely correlated with heart rate variability in patients with decompensated heart failure. Journal of Cardiovascular Electrophysiology, v. 12, n. 3, p. 294-300, mar. 2001.

ÁVILA, P. R. M. et al. Protective effects of fecal microbiota transplantation in sepsis are independent of the modulation of the intestinal flora. Nutrition (Burbank, Los Angeles County, Calif.), v. 73, p. 110727, 18 jan. 2020.

AYDEMIR, M. et al. Cardiac autonomic profile in rheumatoid arthritis and systemic lupus erythematosus. Lupus, v. 19, n. 3, p. 255-261, mar. 2010.

BASSI, G. S. et al. Baroreflex activation in conscious rats modulates the joint inflammatory response via sympathetic function. Brain, Behavior, and Immunity, 15 maio 2015.

BECK, R. W. et al. The effect of corticosteroids for acute optic neuritis on the subsequent development of multiple sclerosis. The Optic Neuritis Study Group. The New England Journal of Medicine, v. 329, n. 24, p. 1764-1769, 9 dez. 1993. 
BEDRAN-DE-CASTRO, M.; MOREIRA, E.; KRIEGER, E. Reflex and central components of carotid occlusion in conscious rats: effect of lesion of the medial forebrain bundle. Hypertension, v. 8, n. 4, abr. 1986.

BERCZI, I.; SZENTIVANYI, A. The History of Neuroimmune Biology. Cytokines and the Brain. Amsterdam: Elsevier Academic Press, v. 6. 2008.

BERKENBOSCH, F. et al. Corticotropin-releasing factor-producing neurons in the rat activated by interleukin-1. Science (New York, N.Y.), v. 238, n. 4826, p. 524-526, 23 out. 1987.

BERTINIERI, G. et al. A new approach to analysis of the arterial baroreflex. Journal of Hypertension. Supplement: Official Journal of the International Society of Hypertension, v. 3, n. 3, p. S79-81, dez. 1985.

BEUTLER, B.; RIETSCHEL, E. T. Innate immune sensing and its roots: the story of endotoxin. Nature Reviews. Immunology, v. 3, n. 2, p. 169-176, fev. 2003.

BLACKWELL, T. S.; CHRISTMAN, J. W. Sepsis and cytokines: current status. British Journal of Anaesthesia, v. 77, n. 1, p. 110-117, jul. 1996.

BORMAN, P. et al. The autonomic dysfunction in patients with ankylosing spondylitis: a clinical and electrophysiological study. Clinical Rheumatology, v. 27, n. 10, p. 12671273, out. 2008.

BOROVIKOVA, L. V. et al. Vagus nerve stimulation attenuates the systemic inflammatory response to endotoxin. Nature, v. 405, n. 6785, p. 458-462, 25 maio 2000.

BROGNARA, F. et al. Baroreflex stimulation attenuates central but not peripheral inflammation in conscious endotoxemic rats. Brain Research, v. 1682, p. 54-60, 1 mar. 2018.

BROGNARA, F. et al. Time Course of Hemodynamic Responses to Different Doses of Lipopolysaccharide in Unanesthetized Male Rats. Frontiers in Physiology, v. 10, p. 771, 2019.

CAFÉ-MENDES, C. C. et al. Chronic nicotine treatment decreases LPS signaling through NF- $\mathrm{kB}$ and TLR-4 modulation in the hippocampus. Neuroscience Letters, v. 636, p. 218-224, 012017.

CAI, B.; DEITCH, E. A.; ULLOA, L. Novel insights for systemic inflammation in sepsis and hemorrhage. Mediators of Inflammation, v. 2010, p. 642462, 2010a.

CAI, B.; DEITCH, E. A.; ULLOA, L. Novel insights for systemic inflammation in sepsis and hemorrhage. Mediators of Inflammation, v. 2010, p. 642462, 2010 b.

CASTANIA, J. A. et al. Selective denervation of the aortic and carotid baroreceptors in rats. Experimental Physiology, v. 104, n. 9, p. 1335-1342, set. 2019.

CERUTTI, C. et al. Autonomic nervous system and cardiovascular variability in rats: a spectral analysis approach. The American Journal of Physiology, v. 261, n. 4 Pt 2, p. H1292-1299, out. 1991. 
CHACHKHIANI, I. et al. The postoperative stress response and its reflection in cytokine network and leptin plasma levels. Physiological Research / Academia Scientiarum Bohemoslovaca, v. 54, n. 3, p. 279-285, 2005.

CHAPLEAU, M. W.; HAJDUCZOK, G.; ABBOUD, F. M. Mechanisms of resetting of arterial baroreceptors: an overview. The American Journal of the Medical Sciences, v. 295, n. 4, p. 327-334, abr. 1988.

CHAVAN, S. S.; PAVLOV, V. A.; TRACEY, K. J. Mechanisms and Therapeutic Relevance of Neuro-immune Communication. Immunity, v. 46, n. 6, p. 927-942, 20 2017.

CHEN, W. et al. Enhanced Macrophage Pannexin 1 Expression and Hemichannel Activation Exacerbates Lethal Experimental Sepsis. Scientific Reports, v. 9, n. 1, p. 160, 17 jan. 2019.

COHEN, S. et al. Chronic stress, glucocorticoid receptor resistance, inflammation, and disease risk. Proceedings of the National Academy of Sciences of the United States of America, v. 109, n. 16, p. 5995-5999, 17 abr. 2012.

COPELAND, S. et al. Acute inflammatory response to endotoxin in mice and humans. Clinical and Diagnostic Laboratory Immunology, v. 12, n. 1, p. 60-67, jan. 2005.

CORSI-ZUELLI, F. M. DAS G. et al. Neuroimmune Interactions in Schizophrenia: Focus on Vagus Nerve Stimulation and Activation of the Alpha-7 Nicotinic Acetylcholine Receptor. Frontiers in Immunology, v. 8, p. in press, 2017.

CRUZ, F. F.; ROCCO, P. R. M.; PELOSI, P. Anti-inflammatory properties of anesthetic agents. Critical Care (London, England), v. 21, n. 1, p. 67, 212017.

DAMPNEY, R. A. Functional organization of central pathways regulating the cardiovascular system. Physiological Reviews, v. 74, n. 2, p. 323-364, abr. 1994.

DANTZER, R. et al. From inflammation to sickness and depression: when the immune system subjugates the brain. Nature Reviews. Neuroscience, v. 9, n. 1, p. 46-56, jan. 2008.

DANTZER, R. Neuroimmune Interactions: From the Brain to the Immune System and Vice Versa. Physiological Reviews, v. 98, n. 1, p. 477-504, 012018.

DE LARTIGUE, G. et al. Diet-induced obesity leads to the development of leptin resistance in vagal afferent neurons. American Journal of Physiology. Endocrinology and Metabolism, v. 301, n. 1, p. E187-195, jul. 2011.

DHABHAR, F. S. Effects of stress on immune function: the good, the bad, and the beautiful. Immunologic Research, v. 58, n. 2-3, p. 193-210, maio 2014.

DI RIENZO, M. et al. A new method for evaluating the baroreflex role by a joint pattern analysis of pulse interval and systolic blood pressure series. Medical and Biological Engineering and Computing, v. 23, n. 1 Suppl, p. 313-314, 1985.

DICARLO, S. E. et al. The role of vasopressin in the pressor response to bilateral carotid occlusion. Journal of the Autonomic Nervous System, v. 27, n. 1, p. 1-10, 1989. 
DOURSOUT, M.-F. et al. Lactoferrin moderates LPS-induced hypotensive response and gut injury in rats. International Immunopharmacology, v. 15, n. 2, p. 227-231, fev. 2013.

DOURSOUT, M.-F. et al. Active hexose correlated compound modulates LPS-induced hypotension and gut injury in rats. International Immunopharmacology, v. 39, p. 280286, out. 2016.

DUBOIS-CAMACHO, K. et al. Glucocorticosteroid therapy in inflammatory bowel diseases: From clinical practice to molecular biology. World Journal of Gastroenterology, v. 23, n. 36, p. 6628-6638, 28 set. 2017.

EASLEY, F. et al. Serum procalcitonin concentrations in dogs with induced endotoxemia. Journal of Veterinary Internal Medicine, v. 34, n. 2, p. 653-658, mar. 2020.

ELGHOZI, J.-L.; JULIEN, C. Sympathetic control of short-term heart rate variability and its pharmacological modulation. Fundamental \& Clinical Pharmacology, v. 21, n. 4, p. 337-47, 2007.

EL-LAKANY, M. A. et al. Ovariectomy provokes inflammatory and cardiovascular effects of endotoxemia in rats: Dissimilar benefits of hormonal supplements. Toxicology and Applied Pharmacology, p. 114928, 21 fev. 2020.

EPPINGER, H.; HESS, L. Die Vagotonie. Hirschwald, Berlin, 1910.

FAIRCHILD, K. D. et al. Endotoxin depresses heart rate variability in mice: cytokine and steroid effects. American Journal of Physiology. Regulatory, Integrative and Comparative Physiology, v. 297, n. 4, p. R1019-1027, out. 2009.

FAZAN JÚNIOR, R.; MACHADO, B. H.; SALGADO, H. C. Hemodynamic responses to acute aortic coarctation in conscious sinoaortic denervated rats. Brazilian Journal of Medical and Biological Research, v. 30, n. 10, p. 1249-1255, out. 1997.

FERGUSON, J. F. et al. Race and gender variation in response to evoked inflammation. Journal of Translational Medicine, v. 11, p. 63, 12 mar. 2013.

FERNÁNDEZ, R. et al. Lipopolysaccharide signaling in the carotid chemoreceptor pathway of rats with sepsis syndrome. Respiratory Physiology and Neurobiology, v. 175, n. 3, p. 336-348, 2011.

FERNANDEZ, R. et al. Neural reflex regulation of systemic inflammation: Potential new targets for sepsis therapy. Frontiers in Physiology, v. 5, p. 1-9, 2014.

FILIPP, G.; SZENTIVANYI, A. Anaphylaxis and the nervous system. III. Annals of Allergy, v. 16, n. 3, p. 306-311, jun. 1958.

FILIPP, G.; SZENTIVANYI, A.; MESS, B. Anaphylaxis and the nervous system. Acta Medica Academiae Scientiarum Hungaricae, v. 3, n. 2, p. 163-173, 1952.

FLONDOR, M. et al. Isoflurane inhalation after induction of endotoxemia in rats attenuates the systemic cytokine response. European Surgical Research. Europaische Chirurgische Forschung. Recherches Chirurgicales Europeennes, v. 40, n. 1, p. 1-6, 2008. 
FRANCHINI, K. G.; KRIEGER, E. M. Carotid chemoreceptors influence arterial pressure in intact and aortic-denervated rats. The American Journal of Physiology, v. 262, n. 4 Pt 2, p. R677-683, abr. 1992.

FUNG, M. L. Pathogenic roles of the carotid body inflammation in sleep apnea. Mediators of Inflammation, v. 2014, p. 354279, 2014.

GIVALOIS, L. et al. Temporal cascade of plasma level surges in ACTH, corticosterone, and cytokines in endotoxin-challenged rats. The American Journal of Physiology, v. 267, n. 1 Pt 2, p. R164-170, jul. 1994.

HAMAAD, A. et al. Markers of inflammation in acute coronary syndromes: association with increased heart rate and reductions in heart rate variability. Clinical Cardiology, v. 28, n. 12, p. 570-576, dez. 2005.

HARBUZ, M. S.; REES, R. G.; LIGHTMAN, S. L. Hypothalamo- pituitary responses to acute stress and changes in circulating glucocorticoids during chronic adjuvant-induced arthritis in the rat. American Journal of Physiology, v. 264, p. R179-185, 1993.

HE, H. et al. The Pannexin-1 Channel Inhibitor Probenecid Attenuates Skeletal Muscle Cellular Energy Crisis and Histopathological Injury in a Rabbit Endotoxemia Model. Inflammation, v. 41, n. 6, p. 2030-2040, dez. 2018.

HELWIG, B. G. et al. Central nervous system administration of interleukin-6 produces splenic sympathoexcitation. Autonomic Neuroscience: Basic \& Clinical, v. 141, n. 12, p. 104-111, 18 ago. 2008.

HENCH, P. S. et al. The effect of a hormone of the adrenal cortex (17-hydroxy-11dehydrocorticosterone: compound E) and of pituitary adrenocortical hormone in arthritis: preliminary report. Annals of the Rheumatic Diseases, v. 8, n. 2, p. 97-104, jun. 1949.

HOSOI, T. et al. Novel pathway for LPS-induced afferent vagus nerve activation: possible role of nodose ganglion. Autonomic Neuroscience: Basic \& Clinical, v. 120, n. 1-2, p. 104-107, 15 jun. 2005.

HUANG, J. et al. The sympathetic-vagal balance against endotoxemia. Journal of Neural Transmission (Vienna, Austria: 1996), v. 117, n. 6, p. 729-735, jun. 2010.

HUANG, L.-Y. et al. Aggravated intestinal apoptosis by ClC-3 deletion is lethal to mice endotoxemia. Cell Biology International, v. 42, n. 10, p. 1445-1453, set. 2018.

HUSTON, J. M. et al. Splenectomy inactivates the cholinergic antiinflammatory pathway during lethal endotoxemia and polymicrobial sepsis. The Journal of Experimental Medicine, v. 203, n. 7, p. 1623-1628, 2006.

JÄGER, U. et al. Diagnosis and treatment of autoimmune hemolytic anemia in adults: Recommendations from the First International Consensus Meeting. Blood Reviews, p. 100648, 5 dez. 2019.

JANCSO, N. Role of the nerve terminals in the mechanism of inflammatory reactions. Bull Millard Fillmore Hosp, p. 7-53, 1960.

JANCSO, N. Desensitization with capsaicin and related acylamides as tool for studying the function of pain receptors. Pharmacology of Pain, 1968. 
JANSZKY, I. et al. Inflammatory markers and heart rate variability in women with coronary heart disease. Journal of Internal Medicine, v. 256, n. 5, p. 421-428, nov. 2004.

JAPUNDZIC, N. et al. Spectral analysis of blood pressure and heart rate in conscious rats: effects of autonomic blockers. Journal of the Autonomic Nervous System, v. 30, n. 2, p. 91-100, jun. 1990.

JIANG, Y. et al. Vagus nerve stimulation attenuates cerebral ischemia and reperfusion injury via endogenous cholinergic pathway in rat. PloS One, v. 9, n. 7, p. e102342, 2014.

JULIEN, C. et al. Hemodynamic analysis of arterial pressure oscillations in conscious rats. Journal of the Autonomic Nervous System, v. 50, n. 3, p. 239-252, 3 jan. 1995.

JULIEN, C. The enigma of Mayer waves: Facts and models. Cardiovascular Research, v. 70, n. 1 , p. 12-21, 1 abr. 2006.

KAHLIN, J. et al. The Human Carotid Body Gene Expression and Function in Signaling of Hypoxia and Inflammation. Advances in Experimental Medicine and Biology, v. 860, p. 371-377, 2015.

KAWADA, T. et al. Chronic vagal nerve stimulation improves baroreflex neural arc function in heart failure rats. Journal of Applied Physiology (Bethesda, Md.: 1985), v. 116, n. 10, p. 1308-1314, 15 maio 2014.

KEES, M. G. et al. Via $\beta$-adrenoceptors, stimulation of extrasplenic sympathetic nerve fibers inhibits lipopolysaccharide-induced TNF secretion in perfused rat spleen. Journal of Neuroimmunology, v. 145, n. 1-2, p. 77-85, 2003.

KIRBY, D. A.; VATNER, S. F. Enhanced responsiveness to carotid baroreceptor unloading in conscious dogs during development of perinephritic hypertension. Circulation Research, v. 61, n. 5, p. 678-686, nov. 1987.

KOMEGAE, E. N. et al. Vagal afferent activation suppresses systemic inflammation via the splanchnic anti-inflammatory pathway. Brain, Behavior, and Immunity, v. 73, p. 441-449, 2018.

KOOPMAN, F. A. et al. Vagus nerve stimulation inhibits cytokine production and attenuates disease severity in rheumatoid arthritis. Proceedings of the National Academy of Sciences of the United States of America, v. 113, n. 29, p. 8284-8289, 19 jul. 2016.

KOOPMAN, F.; STOOF, S. Restoring the Balance of the Autonomic Nervous System as an Innovative Approach to the Treatment of Rheumatoid Arthritis. Molecular Medicine, v. 17, n. 9-10, p. 1, 2011.

KORNEVA, E. A.; KHAI, L. M. Effect of destruction of hypothalamic areas on immunogenesis. Federation Proceedings. Translation Supplement; Selected Translations from Medical-Related Science, v. 23, p. 88-92, fev. 1964.

KRIEGER, E. M. Carotid occlusion in the rat: circulatory and respiratory effects. Acta Physiologica Latino Americana, v. 13, p. 350-357, 1963. 
KRIEGER, E. M. Neurogenic hypertension in the rat. Circulation Research, v. 15, p. 511-521, dez. 1964.

KRIEGER, E. M.; SALGADO, H. C.; MICHELINI, L. C. Resetting of the baroreceptors. International Review of Physiology, v. 26, p. 119-146, 1982.

KUMAGAI, K.; REID, I. A. Losartan inhibits sympathetic and cardiovascular responses to carotid occlusion. Hypertension (Dallas, Tex.: 1979), v. 23, n. 6 Pt 2, p. 827-831, jun. 1994.

LAM, S.-Y. et al. Chronic hypoxia upregulates the expression and function of proinflammatory cytokines in the rat carotid body. Histochemistry and Cell Biology, v. 130, n. 3, p. 549-559, set. 2008.

LANZA, G. A. et al. Relation of heart rate variability to serum levels of C-reactive protein in patients with unstable angina pectoris. The American Journal of Cardiology, v. 97, n. 12, p. 1702-1706, 15 jun. 2006.

LATARO, R. M. et al. Baroreceptor and chemoreceptor contributions to the hypertensive response to bilateral carotid occlusion in conscious mice. American Journal of Physiology. Heart and Circulatory Physiology, v. 299, n. 6, p. H1990-1995, dez. 2010.

LAWRENCE, T.; NATOLI, G. Transcriptional regulation of macrophage polarization: enabling diversity with identity. Nature Reviews. Immunology, v. 11, n. 11, p. 750-761, 25 out. 2011.

LEE, C.-C. et al. Inducible nitric oxide synthase inhibition potentiates multiple organ dysfunction induced by endotoxin in conscious rats. Journal of Cardiovascular Pharmacology, v. 45, n. 5, p. 396-403, maio 2005.

LI, M. et al. Vagal nerve stimulation markedly improves long-term survival after chronic heart failure in rats. Circulation, v. 109, n. 1, p. 120-124, 6 jan. 2004.

LI, M. et al. Effects of complete Freund's adjuvant on immunohistochemical distribution of IL-1beta and IL-1R I in neurons and glia cells of dorsal root ganglion. Acta Pharmacologica Sinica, v. 26, n. 2, p. 192-198, fev. 2005.

LOHMEIER, T. E. et al. Sustained suppression of sympathetic activity and arterial pressure during chronic activation of the carotid baroreflex. American Journal of Physiology. Heart and Circulatory Physiology, v. 299, n. 2, p. H402-409, ago. 2010.

MA, F.; ZHANG, L.; WESTLUND, K. N. Reactive oxygen species mediate TNFR1 increase after TRPV1 activation in mouse DRG neurons. Molecular Pain, v. 5, p. 31, 17 jun. 2009.

MAIO, A. et al. Cardiovascular responses of conscious rats due to arterial occlusion. Brazilian Journal of Medical and Biological Research, v. 14, p. 115, 1981.

MALEK, H. et al. Dynamics of the HPA axis and inflammatory cytokines: Insights from mathematical modeling. Computers in Biology and Medicine, v. 67, p. 1-12, 1 dez. 2015.

MARRIOTT, I.; BOST, K. L.; HUET-HUDSON, Y. M. Sexual dimorphism in expression of receptors for bacterial lipopolysaccharides in murine macrophages: a 
possible mechanism for gender-based differences in endotoxic shock susceptibility. Journal of Reproductive Immunology, v. 71, n. 1, p. 12-27, ago. 2006.

MARTELLI, D. et al. Reflex control of inflammation by sympathetic nerves, not the vagus. The Journal of physiology, v. 592, n. 7, p. 1677-86, 2014a.

MARTELLI, D. et al. Reflex control of inflammation by the splanchnic antiinflammatory pathway is sustained and independent of anesthesia. American Journal of Physiology. Regulatory, Integrative and Comparative Physiology, v. 307, n. 9, p. R1085-1091, 1 nov. 2014b.

MARTELLI, D. et al. Anti-inflammatory reflex action of splanchnic sympathetic nerves is distributed across abdominal organs. American Journal of Physiology. Regulatory, Integrative and Comparative Physiology, v. 316, n. 3, p. R235-R242, 1 mar. 2019.

MARTELLI, D.; FARMER, D. G. S.; YAO, S. T. The splanchnic anti-inflammatory pathway: could it be the efferent arm of the inflammatory reflex? Experimental physiology, v. 101, n. 10, p. 1245-1252, 2016.

MASON, D.; MACPHEE, I.; ANTONI, F. The role of the neuroendocrine system in determining genetic susceptibility to experimental allergic encephalomyelitis in the rat. Immunology, v. 70, n. 1, p. 1-5, maio 1990.

MCCANN, S. M. et al. Induction by cytokines of the pattern of pituitary hormone secretion in infection. Neuroimmunomodulation, v. 1, n. 1, p. 2-13, jan. 1994.

MEHANNA, A. et al. Cardiovascular and pulmonary effects of NOS inhibition in endotoxemic conscious rats subjected to swimming training. Life Sciences, v. 81, n. 16, p. 1301-1308, 29 set. 2007.

MENESES, G. et al. Electric stimulation of the vagus nerve reduced mouse neuroinflammation induced by lipopolysaccharide. Journal of Inflammation (London, England), v. 13, p. 33, 2016.

MKRTCHIAN, S. et al. The human carotid body transcriptome with focus on oxygen sensing and inflammation--a comparative analysis. The Journal of Physiology, v. 590, n. 16 , p. $3807-3819,15$ ago. 2012.

NARDOCCI, G. et al. Sepsis progression to multiple organ dysfunction in carotid chemo/baro-denervated rats treated with lipopolysaccharide. Journal of Neuroimmunology, v. 278, p. 44-52, 2015.

NIIJIMA, A. et al. The effects of interleukin-1 beta on the activity of adrenal, splenic and renal sympathetic nerves in the rat. Journal of the Autonomic Nervous System, v. 36, n. 3, p. 183-192, dez. 1991.

PANAYI, G. S. Neuroendocrine modulation of disease expression in rheumatoid arthritis. EULAR Congress Reports, v. 2, p. 2-12, 1992.

PARRA, R. S. et al. Pressure response to carotid occlusion in diabetic rats: Effect of insulin therapy. Diabetes Research and Clinical Practice, v. 68, n. 1, p. 12-17, 2005. 
PÉREZ-FERNÁNDEZ, R. et al. Plasma and tissue disposition of florfenicol in Escherichia coli lipopolysaccharide-induced endotoxaemic sheep. Xenobiotica; the Fate of Foreign Compounds in Biological Systems, v. 47, n. 5, p. 408-415, maio 2017.

PICQ, C. A. et al. Impact of Anesthetics on Immune Functions in a Rat Model of Vagus Nerve Stimulation. PloS One, v. 8, n. 6, p. e67086, 2013.

PONGRATZ, G.; STRAUB, R. H. Role of peripheral nerve fibres in acute and chronic inflammation in arthritis. Nature Reviews. Rheumatology, v. 9, n. 2, p. 117-126, fev. 2013.

PONGRATZ, G.; STRAUB, R. H. The sympathetic nervous response in inflammation. Arthritis Research \& Therapy, v. 16, n. 504, p. 1-12, 2014.

QIN, M.-Z. et al. Ketamine effect on HMGB1 and TLR4 expression in rats with acute lung injury. International Journal of Clinical and Experimental Pathology, v. 8, n. 10, p. 12943-12948, 2015.

RADAELLI, A. et al. Infusion of Escherichia coli lipopolysaccharide toxin in rats produces an early and severe impairment of baroreflex function in absence of blood pressure changes. Shock (Augusta, Ga.), v. 39, n. 2, p. 204-209, fev. 2013.

RAETZ, C. R. H.; WHITFIELD, C. Lipopolysaccharide endotoxins. Annual Review of Biochemistry, v. 71, p. 635-700, 2002.

REICHE, E. M. V.; NUNES, S. O. V.; MORIMOTO, H. K. Stress, depression, the immune system, and cancer. The Lancet. Oncology, v. 5, n. 10, p. 617-625, out. 2004.

REISON, D. S. et al. Release of norepinephrine from sympathetic nerve efferents by bilateral carotid occlusion. The American Journal of Physiology, v. 245, n. 4, p. H635639, out. 1983.

ROSAS-BALLINA, M. et al. Acetylcholine-synthesizing T cells relay neural signals in a vagus nerve circuit. Science (New York, N.Y.), v. 334, n. 6052, p. 98-101, 7 out. 2011.

ROSAS-BALLINA, M.; TRACEY, K. J. The neurology of the immune system: neural reflexes regulate immunity. Neuron, v. 64, n. 1, p. 28-32, 15 out. 2009.

SALGADO, H. C.; SALGADO, M. C.; KRIEGER, E. M. Cardiovascular reflexes in conscious sodium-depleted rats. Brazilian Journal of Medical and Biological Research, v. 19, n. 2, p. 319-325, 1986.

SALLAM, M. Y. et al. Cyclosporine counteracts endotoxemia-evoked reductions in blood pressure and cardiac autonomic dysfunction via central sGC/MAPKs signaling in rats. European Journal of Pharmacology, v. 797, p. 143-152, 15 fev. 2017.

SALLAM, M. Y. et al. Additive counteraction by $\alpha 7$ and $\alpha 4 \beta 2-n A C h R s$ of the hypotension and cardiac sympathovagal imbalance evoked by endotoxemia in male rats. European Journal of Pharmacology, v. 834, p. 36-44, 5 set. 2018.

SALOMONSEN, C. J.; MADSEN, T. Influence de quelques poisons sur le pouvoir antitoxiquen du sang. Comt Rend Acad Sci, v. 125, p. 1229-33, 1898. 
SAPOLSKY, R. M. The stress of Gulf War syndrome. Nature, v. 393, n. 6683, p. 308309, 28 maio 1998.

SCHWEIGHÖFER, $H$. et al. Modulatory effects of vagal stimulation on neurophysiological parameters and the cellular immune response in the rat brain during systemic inflammation. Intensive Care Medicine Experimental, v. 4, n. 1, p. 19, dez. 2016.

SELYE, H. Effect of ACTH and cortisone upon an anaphylactoid reaction. Canadian Medical Association Journal, v. 61, n. 6, p. 553-556, illust, dez. 1949.

SELYE, H. Stress and disease. Science (New York, N.Y.), v. 122, n. 3171, p. 625-631, 7 out. 1955.

SHARMA, P. et al. Autonomic dysfunctions in patients with inflammatory bowel disease in clinical remission. Digestive Diseases and Sciences, v. 54, n. 4, p. 853-861, abr. 2009.

SHEN, F.-M. et al. Arterial baroreflex function determines the survival time in lipopolysaccharide-induced shock in rats. Shock (Augusta, Ga.), v. 21, n. 6, p. 556-560, jun. 2004.

SILVA, E. F. et al. Involvement of sinoaortic afferents in renal sympathoinhibition and vasodilation induced by acute hypernatremia. Clinical and Experimental Pharmacology \& Physiology, v. 42, n. 11, p. 1135-1141, nov. 2015.

SIMONS, C. T. et al. Signaling the brain in systemic inflammation: which vagal branch is involved in fever genesis? The American Journal of Physiology, v. 275, n. 1, p. R6368, 1998.

SOUNG, N. K.; KIM, B. Y. Psychological stress and cancer. Journal of Analytical Science and Technology, v. 6, n. 1, p. 1-6, dez. 2015.

STERNBERG, E. M. et al. Inflammatory mediator-induced hypothalamic-pituitaryadrenal axis activation is defective in streptococcal cell wall arthritis-susceptible Lewis rats. Proceedings of the National Academy of Sciences of the United States of America, v. 86, n. 7, p. 2374-2378, abr. 1989.

STRAUB, R. H. et al. Sympathetic inhibition of IL-6, IFN- $\gamma$, and KC/CXCL1 and sympathetic stimulation of TGF- $\beta$ in spleen of early arthritic mice. Brain, Behavior, and Immunity, v. 25, n. 8, p. 1708-1715, nov. 2011.

STUESSE, S. L.; FISH, S. E. Projections to the cardioinhibitory region of the nucleus ambiguus of rat. The Journal of Comparative Neurology, v. 229, n. 2, p. 271-278, 20 out. 1984.

SZENTIVANYI, A.; FILIPP, G. Anaphylaxis and the nervous system. II. Annals of Allergy, v. 16, n. 2, p. 143-151, abr. 1958.

SZENTIVANYI, A.; SZEKELY, J. Effect of injury to, and electrical stimulation of, hypothalamic areas on anaphylactic and histamine shock of the guinea pig; a preliminary report. Annals of Allergy, v. 14, n. 3, p. 259-260, jun. 1956.

TAKAGISHI, M. et al. IL-6 microinjected in the nucleus tractus solitarii attenuates cardiac baroreceptor reflex function in rats. American Journal of Physiology. 
Regulatory, Integrative and Comparative Physiology, v. 298, n. 1, p. R183-190, jan. 2010 .

TAKASU, N. et al. Exacerbation of autoimmune thyroid dysfunction after unilateral adrenalectomy in patients with Cushing's syndrome due to an adrenocortical adenoma. The New England Journal of Medicine, v. 322, n. 24, p. 1708-1712, 14 jun. 1990.

TANIGUCHI, T.; YAMAMOTO, K. Anti-inflammatory effects of intravenous anesthetics on endotoxemia. Mini Reviews in Medicinal Chemistry, v. 5, n. 3, p. 241245, mar. 2005.

THAKER, P. H. et al. Chronic stress promotes tumor growth and angiogenesis in a mouse model of ovarian carcinoma. Nature Medicine, v. 12, n. 8, p. 939-944, ago. 2006.

TOHYAMA, T. et al. Impact of lipopolysaccharide-induced acute inflammation on baroreflex-controlled sympathetic arterial pressure regulation. PloS One, v. 13, n. 1, p. e0190830, 2018.

TRACEY, K. J. et al. Shock and tissue injury induced by recombinant human cachectin. Science (New York, N.Y.), v. 234, n. 4775, p. 470-474, 24 out. 1986.

TRACEY, K. J. The inflammatory reflex. Nature, v. 420, n. 6917, p. 853-859, 19 dez. 2002.

TRACEY, K. J. Understanding immunity requires more than immunology. Nature Immunology, v. 11, n. 7, p. 561-564, jul. 2010.

URBANSKI, R. W.; SAPRU, H. N. Evidence for a sympathoexcitatory pathway from the nucleus tractus solitarii to the ventrolateral medullary pressor area. Journal of the Autonomic Nervous System, v. 23, n. 2, p. 161-174, ago. 1988.

VASQUES, E.; KRIEGER, E. Regulatory, integrative and comparative physiology sequence of tachycardia following baroreceptor denervation in the rat. n. Arterial Baroreceptors and Hypertension, p. 413-417, 1980.

VATNER, S. F.; FRANKLIN, D.; BRAUNWALD, E. Effects of anesthesia and sleep on circulatory response to carotid sinus nerve stimulation. The American Journal of Physiology, v. 220, n. 5, p. 1249-1255, maio 1971.

VATNER, S. F.; MANDERS, W. T. Depressed responsiveness of the carotid sinus reflex in conscious newborn animals. The American Journal of Physiology, v. 237, n. 1, p. H40-43, jul. 1979.

VIDA, G. et al. 2-Adrenoreceptors of regulatory lymphocytes are essential for vagal neuromodulation of the innate immune system. The FASEB Journal, v. 25, n. 12, p. 4476-4485, 2011.

WALJEE, A. K. et al. Corticosteroid Use and Complications in a US Inflammatory Bowel Disease Cohort. PloS One, v. 11, n. 6, p. e0158017, 2016.

WANG, H. et al. Nicotinic acetylcholine receptor alpha7 subunit is an essential regulator of inflammation. Nature, v. 421, n. 6921, p. 384-388, 23 jan. 2003. 
WANG, H. H. et al. Participation of cardiac and peripheral sympathetics in carotid occlusion response. The American Journal of Physiology, v. 218, n. 6, p. 1548-1554, jun. 1970.

WANG, X. et al. Strong expression of interleukin-1 receptor type I in the rat carotid body. The Journal of Histochemistry and Cytochemistry: Official Journal of the Histochemistry Society, v. 50, n. 12, p. 1677-1684, dez. 2002.

WANG, X. et al. Morphological evidence for existence of IL-6 receptor alpha in the glomus cells of rat carotid body. The Anatomical Record. Part A, Discoveries in Molecular, Cellular, and Evolutionary Biology, v. 288, n. 3, p. 292-296, mar. 2006.

WANNEMACHER, R. W. et al. A protein from polymorphonuclear leukocytes (LEM) which affects the rate of hepatic amino acid transport and synthesis of acute-phase globulins. Endocrinology, v. 96, n. 3, p. 651-661, mar. 1975.

WASILCZUK, K. M. et al. Modulating the Inflammatory Reflex in Rats Using LowIntensity Focused Ultrasound Stimulation of the Vagus Nerve. Ultrasound in Medicine \& Biology, v. 45, n. 2, p. 481-489, 2019.

WATKINS, L. R. et al. Blockade of interleukin-1 induced hyperthermia by subdiaphragmatic vagotomy: evidence for vagal mediation of immune-brain communication. Neuroscience Letters, v. 183, n. 1-2, p. 27-31, 2 jan. 1995.

WYSS-CORAY, T.; MUCKE, L. Inflammation in neurodegenerative disease--a doubleedged sword. Neuron, v. 35, n. 3, p. 419-432, 2002.

XIE, X. et al. Rat BMSC infusion was unable to ameliorate inflammatory injuries in tissues of mice with LPS-induced endotoxemia. Bio-Medical Materials and Engineering, v. 28, n. s1, p. S129-S138, 2017.

YAKUSHIJI, F. et al. Exacerbation of rheumatoid arthritis after removal of adrenal adenoma in Cushing's syndrome. Endocrine Journal, v. 42, n. 2, p. 219-223, abr. 1995.

ZHANG, C. et al. The efficacy and safety of different doses of glucocorticoid for autoimmune hepatitis: A systematic review and meta-analysis. Medicine, v. 98, n. 52, p. e18313, dez. 2019.

ZHANG, Z. Q.; BARRÈS, C.; JULIEN, C. Involvement of vasodilator mechanisms in arterial pressure lability after sino-aortic baroreceptor denervation in rat. The Journal of Physiology, v. 482 ( Pt 2), p. 435-448, 15 jan. 1995.

ZHAO, J. et al. Low-Dose Ketamine Improves LPS-Induced Depression-like Behavior in Rats by Activating Cholinergic Anti-inflammatory Pathways. ACS chemical neuroscience, v. 11, n. 5, p. 752-762, 4 mar. 2020.

ZILA, I. et al. Heart rate variability and inflammatory response in rats with lipopolysaccharide-induced endotoxemia. Physiological Research, v. 64 Suppl 5, p. S669-676, 2015.

ZUBCEVIC, J. et al. Altered inflammatory response is associated with an impaired autonomic input to the bone marrow in the spontaneously hypertensive rat. Hypertension (Dallas, Tex.: 1979), v. 63, n. 3, p. 542-550, mar. 2014. 
Anexo A - Artigos Publicados 


\title{
Time Course of Hemodynamic Responses to Different Doses of Lipopolysaccharide in Unanesthetized Male Rats
}

\author{
Fernanda Brognara', Jaci Airton Castania', Daniel Penteado Martins Dias², \\ Alexandre Kanashiro ${ }^{3}$ and Helio Cesar Salgado ${ }^{1 *}$
}

'Department of Physiology, Ribeirão Preto Medical School, University of São Paulo, Ribeirão Preto, Brazil, ${ }^{2}$ Barão de Mauá University Center, Ribeirão Preto, Brazil, ${ }^{3}$ Department of Neurosciences and Behavior, Ribeirão Preto Medical School, University of São Paulo, Ribeirão Preto, Brazil

\section{OPEN ACCESS}

Edited by:

Ovidiu Constantin Baltatu Anhembi Morumbi University,

Brazil

Reviewed by: Katarzyna Kaczynska, Mossakowski Medical Research

Centre (PAN), Poland Marli Cardoso Martins-Pinge, State University of Londrina, Brazi

*Correspondence: Helio Cesar Salgado hcsalgado@fmrp.usp.br

Specialty section: This article was submitted to Integrative Physiology, a section of the journal Frontiers in Physiology

Received: 16 April 2019 Accepted: 03 June 2019 Published: 25 June 2019

Citation:

Brognara F, Castania JA, Dias DPM Kanashiro A and Salgado HC (2019)

Time Course of Hemodynamic

Responses to Different Doses of Lipopolysaccharide in Unanesthetized Male Rats.

Front. Physiol. 10:771. doi: 10.3389/fphys.2019.00771
Lipopolysaccharide (LPS) administration is a well-known method to induce systemic inflammation widely used for investigating new therapeutic strategies for sepsis treatment, which is characterized by clinical manifestations such as tachycardia and hypotension. However, there are different doses of LPS used in several studies, and the hemodynamic responses were not always well characterized. Thus, the present study aimed to evaluate the arterial pressure, heart rate, heart rate variability, and baroreflex function from rats, over time, to different doses of LPS. Femoral artery and vein catheters were inserted into anesthetized Wistar-Hannover male rats for arterial pressure recording and LPS administration, respectively. On the next day, the arterial pressure was recorded before and after (90, 180, and $360 \mathrm{~min}$ ) LPS injection $(0.06,20,30$, and $40 \mathrm{mg} / \mathrm{kg})$. All doses of LPS tested increased the heart rate and decreased baroreflex sensitivity over time. In addition, while LPS administration of 20,30 , and $40 \mathrm{mg} / \mathrm{kg}$ increased the mean arterial pressure over time, $0.06 \mathrm{mg} / \mathrm{kg}$ decreased the mean arterial pressure at $360 \mathrm{~min}$, as compared to baseline values. Furthermore, high doses of LPS decreased the power of the HF band of the cardiac interval spectrum over time, and the higher dose increased the power of the LF band. Our data indicate that high doses of LPS promote hypertensive response over time, while a low dose decreases arterial pressure. Moreover, the changes in heart rate variability and baroreflex function elicited by LPS may be not associated with arterial pressure response produced by the endotoxemia.

Keywords: lipopolysaccharide, arterial pressure, heart rate, heart rate variability, baroreflex sensitivity, unanesthetized rats

\section{INTRODUCTION}

Models of endotoxemia have been used to explore the host innate immunity involved in the inflammatory response and searching therapeutic approaches for the treatment of inflammatory diseases (Borovikova et al., 2000; Bassi et al., 2015; Halbach et al., 2017). The well-known experimental model of endotoxemia elicited by lipopolysaccharide (LPS) administration has 
been widely used (Brognara et al., 2018; Chen et al., 2019). LPS is a component of the outer membrane of Gram-negative bacteria, which is a potent activator of the innate immunity, after being recognized by toll-like receptor 4 (Raetz and Whitfield, 2002; Beutler and Rietschel, 2003). This receptor is responsible for the activation of the nuclear factor- $\kappa B$ pathway that leads the synthesis and release of some pro-inflammatory mediators such as cytokines by macrophages (Beutler and Rietschel, 2003; Café-Mendes et al., 2017). Furthermore, this model of inflammation contributes for better understanding of the pathophysiological manifestations found in infection and inflammatory diseases, such as sepsis, mimicking clinical signs including hypo or hyperthermia, tachycardia, hypotension, and tachypnea (Cai et al., 2010; Café-Mendes et al., 2017; Komegae et al., 2018; Wasilczuk et al., 2019).

The literature indicates that different doses of LPS have been used in several studies, but the hemodynamic responses involved are not always shown or even considered. Usually, LPS administration promotes hypotension and tachycardia; but, in the literature, these responses are not precisely described concerning the different doses employed, especially in unanesthetized animals. Therefore, the present study aimed to evaluate the arterial pressure, heart rate, and the heart rate variability responses from unanesthetized rats, over time, to different doses of LPS.

\section{MATERIALS AND METHODS}

\section{Experimental Animals}

The experiments were performed on male Wistar-Hannover rats weighing 210-280 g obtained from the Main Animal Facility of the University of São Paulo (Campus of Ribeirão Preto; Ribeirão Preto, SP, Brazil), maintained under controlled temperature $\left(22^{\circ} \mathrm{C}\right)$ and constant $12 \mathrm{~h}$ light-dark cycle, and provided with food and water ad libitum. All procedures were reviewed and approved by the Committee of Ethics in Animal Research of the Ribeirão Preto Medical School - University of São Paulo (protocol number 194/2016).

\section{Surgical Procedures}

Animals were anesthetized with a cocktail of ketamine and xylazine $(50 \mathrm{mg} / \mathrm{kg}$ and $10 \mathrm{mg} / \mathrm{kg}$, i.p.) and then subjected to surgical procedures to catheterization of the femoral artery and vein for arterial pressure recording and LPS administration, respectively. Briefly, the left femoral artery was catheterized with polyethylene tubing (PE-50 soldered to PE-10 polyethylene tube; Intramedic, Clay Adams, Parsippany, NJ, USA) for arterial pressure recording. The catheter implanted into the femoral artery was filled with $100 \mathrm{IU} / \mathrm{ml}$ heparin in saline. Additionally, a catheter (PE-50 polyethylene tube; Intramedic, Clay Adams, Parsippany, NJ, USA) was inserted into the left femoral vein for the administration of LPS from Escherichia coli 0111: B4 purified by phenol extraction (Sigma-Aldrich, St. Louis, MO, USA). The catheters were pulled up through a subcutaneous track to the animal's neck and exteriorized in the back of the nape, and the surgical incisions were sutured.
Analgesic (tramadol hydrochloride: $2 \mathrm{mg} / \mathrm{kg}$, s.c.) was injected immediately after the end of surgery.

\section{Arterial Pressure Recording}

To record the pulsatile arterial pressure, the arterial catheter was connected to a pressure transducer (MLT844; ADInstruments, Bella Vista, Australia) and the signal was amplified (ML224; ADInstruments, Bella Vista, Australia) and sampled at $2 \mathrm{kHz}$ by an IBM/PC computer (Core 2 Duo, $2.2 \mathrm{GHz}, 4$ GB RAM) attached to an analog-to-digital interface (PowerLab, ADInstruments, Bella Vista, Australia). The experiment was conducted with the animals moving freely in their own cage (one rat per cage) and silence was maintained to minimize environment stress. Arterial pressure recordings were processed with computer software (LabChart 7.0, ADInstruments, Bella Vista, Australia) capable of detecting inflection points and generate mean arterial pressure and heart rate beat-by-beat time series.

\section{Experimental Procedures}

Twenty-four hours after the surgical procedures, the rats were assigned into five groups with different doses of LPS: (1) $0.06 \mathrm{mg} / \mathrm{kg}(n=7),(2) 20 \mathrm{mg} / \mathrm{kg}(n=4)$, (3) $30 \mathrm{mg} / \mathrm{kg}$ $(n=3),(4) 40 \mathrm{mg} / \mathrm{kg}(n=5)$, and (5) with saline administration (control, $n=5$ ). With the unanesthetized animals moving freely, the experimental protocol consisted of basal recordings of pulsatile arterial pressure, followed by administration of LPS or saline. The arterial pressure was also recorded 90, 180, and $360 \mathrm{~min}$ after LPS or saline injection to evaluate the time course of the hemodynamic parameters.

\section{Heart Rate and Systolic Arterial Pressure Variability Analysis}

Beat-by-beat time series with systolic arterial pressure and cardiac interval values were extracted from periods of approximately $10 \mathrm{~min}$ from each moment (basal, 90, 180, and $360 \mathrm{~min}$ after LPS or saline) from pulsatile arterial pressure tracings. The series were analyzed in the frequency domain by means of spectral analysis using open access custom computer software (CardioSeries v2.7, www.danielpenteado.com). Briefly, the beat-by-beat time series were resampled using cubic spline interpolation $(10 \mathrm{~Hz})$ and the interpolated series were split in half-overlapping sequential segments of 512 data points. All segments were visually inspected looking for transients that could affect the calculation of the power spectral density (Fast Fourier Transform), and the spectra were integrated in low(LF: $0.20-0.75 \mathrm{~Hz}$ ) and high-frequency (HF: 0.75-3.0 Hz) bands. Results are expressed in absolute $\left(\mathrm{ms}^{2}\right)$ and normalized (nu) units. LF/HF ratio was also calculated.

\section{Baroreflex Sensitivity Analysis}

The same beat-by-beat time series selected for heart rate and systolic arterial pressure variability analysis were used for assessment of spontaneous baroreflex sensitivity. In the time domain, analysis was carried out using the sequence method (Bertinieri et al., 1985; Di Rienzo et al., 1985). Time series were scanned by the CardioSeries software, searching for 
sequences of data values with at least four consecutive beats in which rises in systolic arterial pressure were followed by cardiac interval lengthening and decreases in systolic arterial pressure were followed by cardiac interval shortening, with a calculated linear correlation higher than 0.85 . The average of the slopes of the linear regression lines between systolic arterial pressure and cardiac interval values was taken as the baroreflex sensitivity. In addition, spontaneous baroreflex sensitivity was assessed into the frequency domain using cross-spectral analysis through the Fast Fourier Transform. In brief, beat-by-beat time series were interpolated $(10 \mathrm{~Hz})$, split into half-overlapping sequential sets of 512 points, and had cross-spectra calculated. When a coherence function returned values greater than 0.5 , the average gain of the transfer function into the LF band $(0.20-0.75 \mathrm{~Hz})$ was taken as a measure of the baroreflex gain.

\section{Statistical Analysis}

The data were analyzed by one-way analysis of variance and one-way analysis of variance for repeated measures followed by a Student-Newman-Keuls's or Dunn's post hoc test when indicated. Differences were considered statistically significant if $p<0.05$. The results are shown as the mean \pm standard error of the mean. Statistical analysis was performed using SigmaPlot 12.0 software (Systat Software, San Jose, CA, USA).

\section{RESULTS}

\section{Time Course of the Arterial Pressure to Lipopolysaccharide Administration}

No changes in mean arterial pressure were observed over time in the saline group (Figure $\mathbf{1 A}$ and Table 1). As compared to baseline, the dose of $0.06 \mathrm{mg} / \mathrm{kg}$ of LPS decreased the mean arterial pressure at $360 \mathrm{~min}$ after its administration $(116 \pm 3$ vs. $109 \pm 2 \mathrm{mmHg}, p=0.025$; Figure $1 \mathrm{~B}$ and Table 1). In contrast, the doses of 20,30 and $40 \mathrm{mg} / \mathrm{kg}$ increased the mean arterial pressure over time (Figures 1C-E and Table 1). The doses of 20 and $30 \mathrm{mg} / \mathrm{kg}$ reached the hypertensive peak at $360 \mathrm{~min}$ and the dose of $40 \mathrm{mg} / \mathrm{kg}$ at $180 \mathrm{~min}$ (Figures 1C-E and Table 1). In addition, the dose of $20 \mathrm{mg} / \mathrm{kg}$ was able to increase the mean arterial pressure already in the first $90 \mathrm{~min}$ after LPS, while the doses of 40 and $30 \mathrm{mg} / \mathrm{kg}$ were only able to increase the arterial pressure 180 and $360 \mathrm{~min}$, respectively (Figures 1C-E and Table 1).

\section{Time Course of the Heart Rate to Lipopolysaccharide Administration}

No changes in heart rate were observed over time in the saline group (Figure 1F and Table 1). All doses of LPS tested in this study increased the heart rate over time, compared to baseline values and reached a peak at $360 \mathrm{~min}$ after LPS administration Figures 1G-J and Table 1). Nevertheless, the dose of $0.06 \mathrm{mg} / \mathrm{kg}$ promoted a smaller tachycardia as compared to the other doses evaluated $(0.06 \mathrm{mg} / \mathrm{kg}: \Delta 84 \pm 23 \mathrm{bpm}$ vs. $20 \mathrm{mg} / \mathrm{kg}: \Delta 200 \pm 26 \mathrm{bpm}$, $p=0.007 ; 30 \mathrm{mg} / \mathrm{kg}: \Delta 202 \pm 29 \mathrm{bpm}, p=0.023 ; 40 \mathrm{mg} / \mathrm{kg}$ :
$\Delta 180 \pm 29 \mathrm{bpm}, \mathrm{p}=0.007)$. Moreover, all doses of LPS tested were able to increase the heart rate already in the first 90 min after their administration (Figures 1G-J and Table 1).

\section{Time Course of the Heart Rate Variability to Lipopolysaccharide Administration}

The analysis performed over several time points (basal, 90, 180 , and $360 \mathrm{~min}$ ) following LPS administration, revealed no differences in the power of the LF band of the cardiac interval spectrum in saline, $0.06,20$, or $30 \mathrm{mg} / \mathrm{kg}$ LPS groups, despite a strong trend toward enhanced LF power in 20 or $30 \mathrm{mg} / \mathrm{kg}$ groups (Figures 2A-D). However, the rats that received $40 \mathrm{mg} / \mathrm{kg}$ showed an increased LF power of the cardiac interval spectrum at 180 and 360 min following LPS administration (Figure 2E). The analysis of HF power depicted no changes in the saline group (Figure 2F); but LPS injection drastically reduced the HF power over time, starting at $90 \mathrm{~min}$ after its administration (Figures 2G-J). In all groups, no differences were found in the LF/HF ratio over time (Figures $2 \mathbf{K}-\mathbf{O}$ ). Nevertheless, the dose of $40 \mathrm{mg} / \mathrm{kg}$ presented a great trend toward an increase at 180 and $360 \mathrm{~min}$ after LPS (Figure 20). The power of the LF band of systolic arterial pressure spectra increased over time in either, saline and LPS treated groups (Figures 2P-T).

\section{Time Course of the Baroreflex Sensitivity to Lipopolysaccharide Administration}

In general, both methods of analysis (i.e., cross-spectral analysis and the sequence method) revealed a decrease in baroreflex sensitivity in all LPS groups over time (Figures $\mathbf{3 B}-\mathbf{E}, \mathbf{G}-\mathbf{J}$ ). This change was observed early in the first moment evaluated (90 $\mathrm{min}$ ) and was kept until the end of the protocol (360 $\mathrm{min}$ ). In the saline group, no changes were observed over time, when baroreflex sensitivity was evaluated by the sequence method (Figure 3F); while a slight reduction was shown by the cross-spectral analysis approach (Figure 3A)

\section{DISCUSSION}

In the current study, we described the changes in arterial pressure and heart rate as well as the heart rate variability, over time, elicited by different doses of LPS administration. Concerning the heart rate, we observed that all doses tested increased this hemodynamic parameter, over time, supporting previous observation (Altavilla et al., 2002). Moreover, in agreement with previous studies (Martelli et al., 2019), our findings demonstrated that the lowest dose tested $(0.06 \mathrm{mg} / \mathrm{kg})$ reduces the mean arterial pressure over time. However, it has been described a transient increase in mean arterial pressure, 2 and $3 \mathrm{~h}$ after LPS administration, with the return of this hemodynamic parameter to baseline, $4-6 \mathrm{~h}$ later, using the same dose $(0.06 \mathrm{mg} /$ kg) (Martelli et al., 2014). Apropos, this dose of LPS has been extensively used in rats for investigating the mechanisms involved in the inflammatory reflex pathway (Martelli et al., 2014, 2019; Komegae et al., 2018), as well as for evaluating the baroreflex regulation during systemic inflammation (Tohyama et al., 2018). 


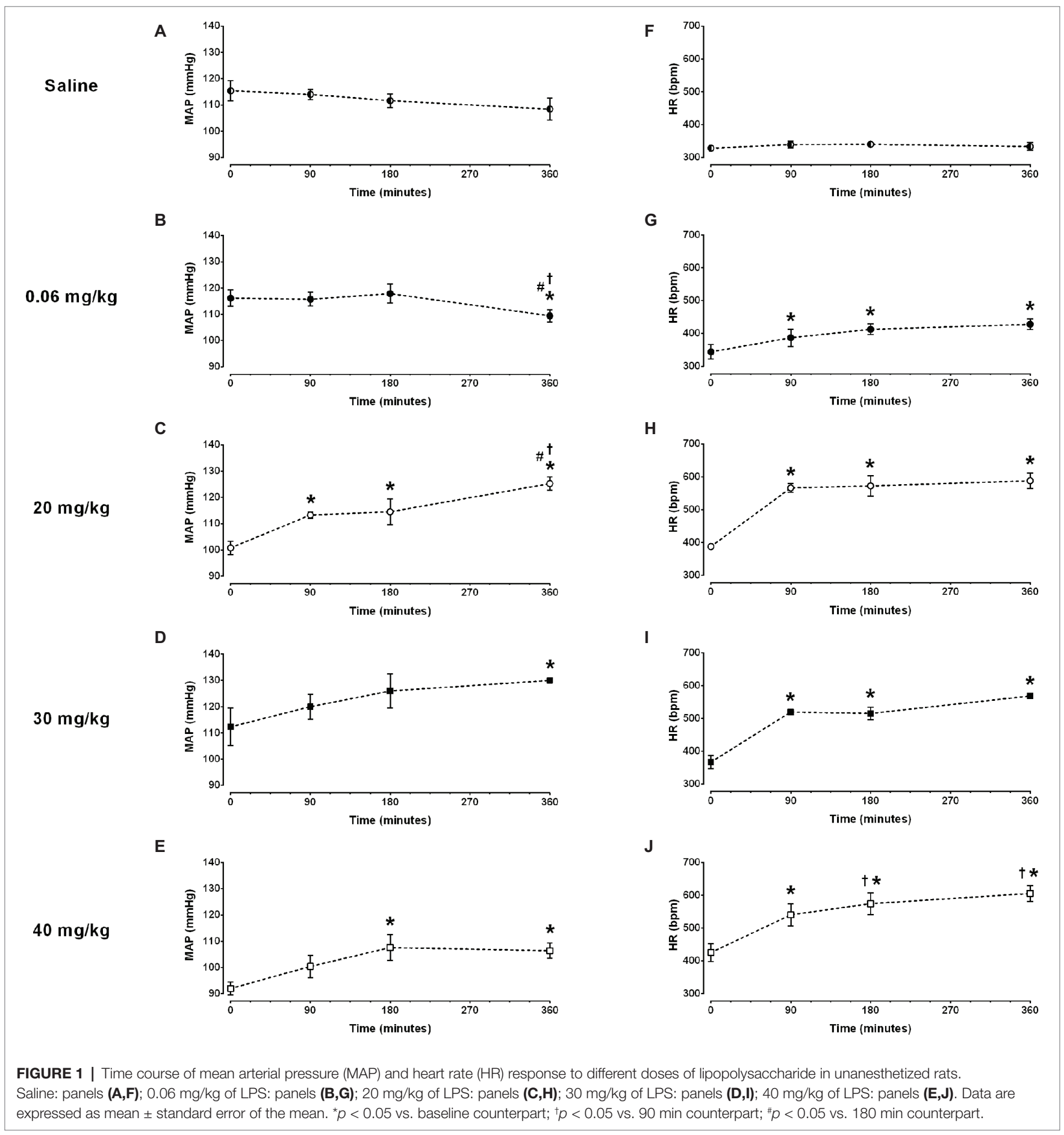

Previous studies using higher doses of LPS, for eliciting the inflammatory process, demonstrated that this approach promoted a hypotensive response (Altavilla et al., 2002; Doursout et al., 2016). For instance, Dourtsout and coworkers (Doursout et al., 2016) observed a decrease in mean arterial pressure, $1 \mathrm{~h}$ after the administration of a high dose of LPS, in conscious rats, followed by the recover to baseline levels 2 and $3 \mathrm{~h}$ later. Another study evaluated the time course of the mean arterial pressure for $360 \mathrm{~min}$, after LPS administration, displaying a sustained reduction of this hemodynamic parameter in anesthetized rats, over time, initiating $30 \mathrm{~min}$ after the injection (Altavilla et al., 2002). However, the current study did not provide support to this finding, since the intravenous administration of higher doses of LPS $(20,30$, and $40 \mathrm{mg} / \mathrm{kg}$ ) did not reduce the mean arterial pressure in unanesthetized rats, but increased over time, starting sometimes $90 \mathrm{~min}$ after 
their administration (as was the case of the dose of $20 \mathrm{mg} / \mathrm{kg}$ ). Many factors can influence the inflammation-induced

TABLE 1 | Time course of mean arterial pressure (MAP) and heart rate (HR) response to different doses of lipopolysaccharide.

\begin{tabular}{|c|c|c|c|c|c|}
\hline & $\begin{array}{l}\text { Saline } \\
(n=5)\end{array}$ & $\begin{array}{c}0.06 \mathrm{mg} / \mathrm{kg} \\
(n=7)\end{array}$ & $\begin{array}{c}20 \mathrm{mg} / \mathrm{kg} \\
(n=4)\end{array}$ & $\begin{array}{c}30 \mathrm{mg} / \mathrm{kg} \\
(n=3)\end{array}$ & $\begin{array}{c}40 \mathrm{mg} / \mathrm{kg} \\
(n=5)\end{array}$ \\
\hline \multicolumn{6}{|c|}{ MAP $(\mathrm{mmHg})$} \\
\hline $\begin{array}{l}\text { Baseline } \\
90 \text { min } \\
180 \text { min } \\
360 \text { min }\end{array}$ & $\begin{array}{l}115 \pm 4 \\
114 \pm 2 \\
112 \pm 3 \\
108 \pm 4\end{array}$ & $\begin{array}{c}116 \pm 3 \\
116 \pm 3 \\
118 \pm 4 \\
109 \pm 2^{\star,+, \#}\end{array}$ & $\begin{array}{c}101 \pm 2 \\
113 \pm 1^{\star} \\
114 \pm 5^{\star} \\
121 \pm 4^{\star,+, \#}\end{array}$ & $\begin{array}{c}112 \pm 7 \\
120 \pm 5 \\
126 \pm 6 \\
130 \pm 0.4^{\star}\end{array}$ & $\begin{array}{c}92 \pm 2 \\
100 \pm 4 \\
108 \pm 5^{\star} \\
107 \pm 3^{\star}\end{array}$ \\
\hline \multicolumn{6}{|c|}{ HR (bpm) } \\
\hline $\begin{array}{l}\text { Baseline } \\
90 \mathrm{~min} \\
180 \mathrm{~min} \\
360 \mathrm{~min}\end{array}$ & $\begin{array}{c}328 \pm 5 \\
339 \pm 10 \\
340 \pm 8 \\
333 \pm 12\end{array}$ & $\begin{array}{l}344 \pm 22 \\
387 \pm 27^{\star} \\
413 \pm 16^{\star} \\
428 \pm 17^{\star}\end{array}$ & $\begin{array}{c}388 \pm 6 \\
566 \pm 13^{*} \\
572 \pm 31^{*} \\
588 \pm 24^{*}\end{array}$ & $\begin{array}{c}367 \pm 21 \\
520 \pm 6^{\star} \\
516 \pm 18^{\star} \\
569 \pm 9^{\star}\end{array}$ & $\begin{array}{c}426 \pm 27 \\
540 \pm 34^{*} \\
574 \pm 33^{*, \dagger} \\
606 \pm 24^{*, \dagger}\end{array}$ \\
\hline
\end{tabular}

Data are expressed as mean \pm standard error of the mean. ${ }^{*} p<0.05$ vs. baseline counterpart; ${ }^{\dagger} p<0.05$ vs. 90 min counterpart; $" p<0.05$ vs. 180 min counterpart. cardiovascular alterations that could explain these discrepancies between the studies, deserving an investigation in the future, including the gender of the subjects, quality of the LPS (i.e., purity, source, and route of administration) and rat strains (Sternberg et al., 1989; Simons et al., 1998; Marriott et al., 2006; Ferguson et al., 2013).

It is noteworthy to mention that some studies report changes in the arterial pressure after administration of intermediate (i.e., 5 and $10 \mathrm{mg} / \mathrm{kg}$ ) doses of LPS in unanesthetized rats. Mehanna and coworkers (Mehanna et al., 2007) described three phases for the arterial pressure response within the first hour after LPS $(5 \mathrm{mg} / \mathrm{kg}$ ) which consisted of an initial decrease (phase 1), rebound recovery (phase 2), and a long-lasting decrease (phase 3). Other studies also showed that the dose of $10 \mathrm{mg} / \mathrm{kg}$ promoted a reduction in arterial pressure over time (i.e., up to $180 \mathrm{~min}$ ) (Sallam et al., 2017, 2018). Nevertheless, Lee et al. (2005) in an extended analysis (i.e., up to $24 \mathrm{~h}$ after LPS administration), observed that the arterial pressure changes consisted of an initial hypotensive response (i.e., at 30-60 $\mathrm{min}$ ), followed by a

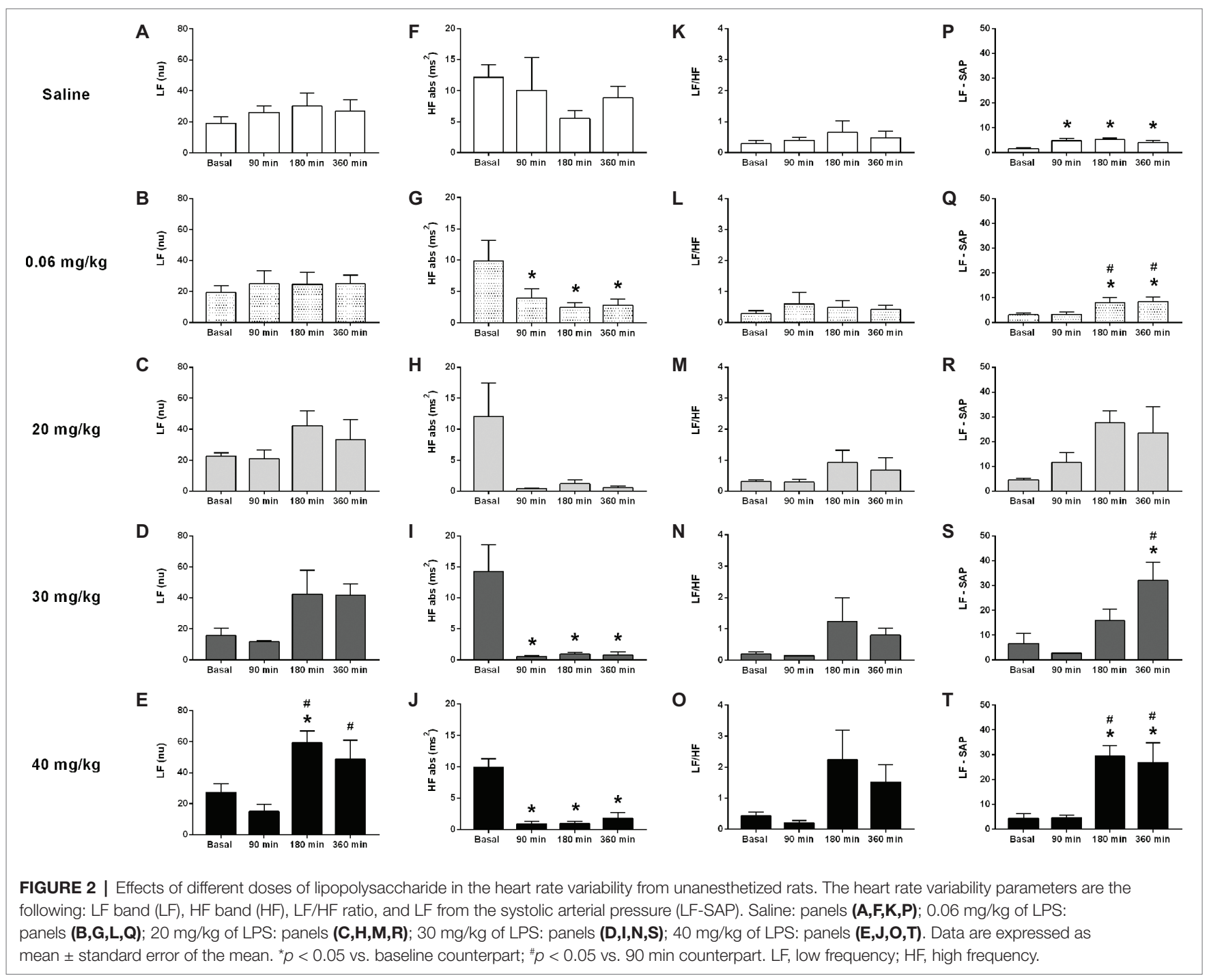




\section{Cross-spectral Method}

A

Saline
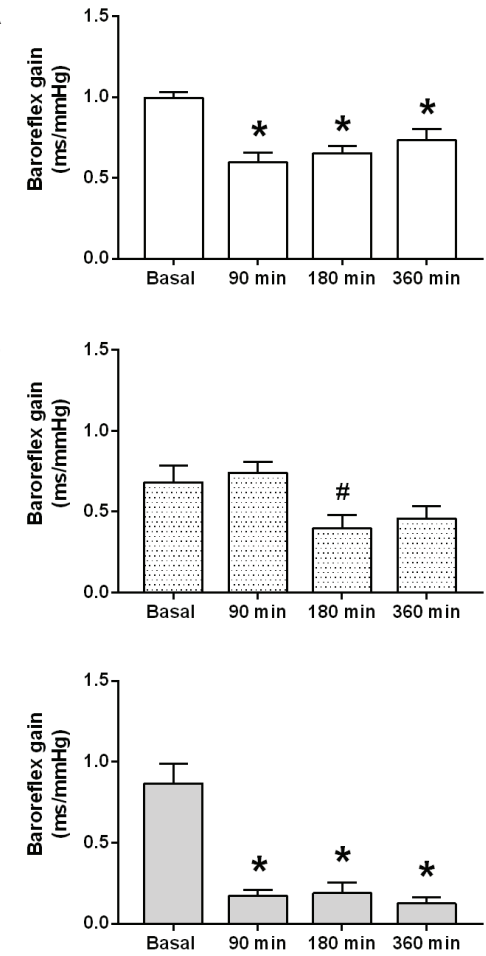

$30 \mathrm{mg} / \mathrm{kg}$

D

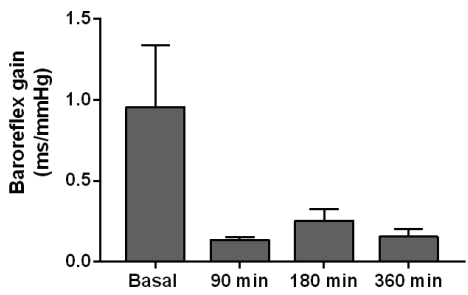

$40 \mathrm{mg} / \mathrm{kg}$

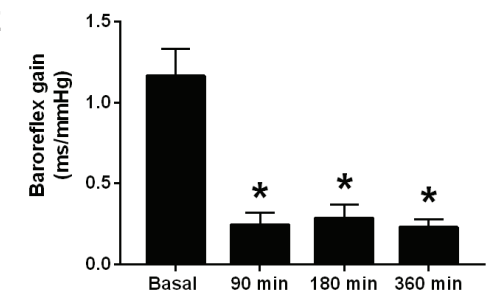

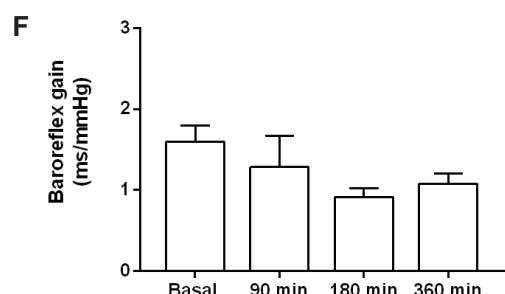

G

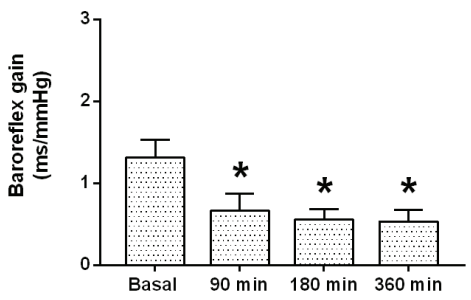

$\mathrm{H}$

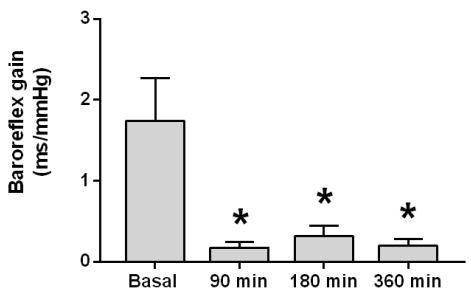

I

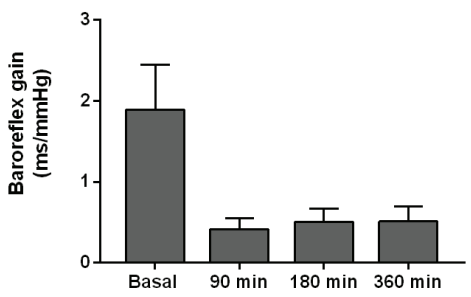

J

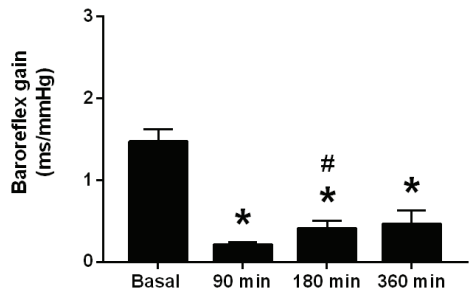

FIGURE 3 | Effects of different doses of lipopolysaccharide in the baroreflex sensitivity in unanesthetized rats. Baroreflex sensitivity analysis by cross-spectral (panels (A-E)) and the sequence method (panels (F-J)), after saline or LPS administration. Saline: panels (A,F); 0.06 mg/kg of LPS: panels (B,G); 20 mg/kg of LPS: panels $(\mathbf{C}, \mathbf{H}) ; 30 \mathrm{mg} / \mathrm{kg}$ of LPS: panels (D,I); $40 \mathrm{mg} / \mathrm{kg}$ of LPS: panels $\mathbf{( E , J ) . ~ D a t a ~ a r e ~ e x p r e s s e d ~ a s ~ m e a n ~} \pm$ standard error of the mean. ${ }^{*} p<0.05$ vs. baseline counterpart; $\# p<0.05$ vs. 90 min counterpart.

hypertensive response (i.e., from 1 to $9 \mathrm{~h}$ ), and finally by a second hypotensive response (i.e., from 9 to $24 \mathrm{~h}$ ) after the administration of $5 \mathrm{mg} / \mathrm{kg}$ of LPS in unanesthetized rats. Thus, it seems that the response of the arterial pressure to LPS is quite variable over time, and several elements may influence this outcome, as mentioned previously.
In addition, the results of the present study clearly showed that higher doses of LPS increased the power of the LF band and decreased the power of the HF band spectra over time (i.e., following LPS administration). In other words, LPS enhanced the sympathetic tone and reduced the vagal tone in unanesthetized rats. It is well known that LPS administration influences the 
heart rate variability of rats (Huang et al., 2010; Zila et al., 2015). Nevertheless, to the best of our knowledge, no previous study has described the effects of different doses of LPS on heart rate variability, over time, in unanesthetized rats. Since all LPS-treated groups (i.e., low and higher doses) showed a decrease in the HF power (i.e., reduction of the vagal tone), and only the lower dose diminished the arterial pressure over time, while the others promoted the opposite response, it seems that the hypotensive response elicited by the lower dose of LPS is not dependent of an increase, or maintenance, of the vagal tone over time. However, differences observed in the arterial pressure response among groups injected with high and low doses of LPS could be attributed to the exacerbated increase in the power of the LF band of the systolic arterial pressure over time in the groups received high doses of LPS, since this parameter is related to peripheral resistance of blood vessels (Julien, 2006). Thus, the enhanced peripheral resistance may have contributed to the hypertensive response from the high LPS dose groups.

The baroreflex function has been explored after LPS administration (Shen et al., 2004; Radaelli et al., 2013; Tohyama et al., 2018). In the present study, the analysis of the baroreflex function revealed a decrease in baroreflex sensitivity in all LPS-treated groups, over time, regardless of the dose used. This impairment was observed early in the first moment and was sustained until the end of the protocol. In agreement with our results, Radaelli et al. (2013) showed a sustained reduction in baroreflex sensitivity, which starting right after the beginning of the infusion of LPS in rats (i.e., $10 \mathrm{~min}$ later). Furthermore, Shen et al., (2004) concluded that an efficient arterial baroreflex is essential to determine survival during the LPS-induced lethal shock. Baroreflex impairment has meaningful consequences in arterial pressure because, under the absence of the reflex control of arterial pressure, the cardiovascular system loses the ability to control appropriately the arterial pressure, leading to hypotensive or hypertensive responses during endotoxemia. Since all groups receiving LPS showed impairment of baroreflex function over time, correlations between baroreflex impairment and arterial pressure changes cannot be made, since rats receiving a low dose of LPS had a decrease in arterial pressure, while the rats receiving high doses of LPS had an increase in arterial pressure.

\section{REFERENCES}

Altavilla, D., Squadrito, G., Minutoli, L., Deodato, B., Bova, A., Sardella, A., et al. (2002). Inhibition of nuclear factor-kappaB activation by IRFI 042, protects against endotoxin-induced shock. Cardiovasc. Res. 54, 684-693. doi: 10.1016/S0008-6363(02)00276-6

Bassi, G. S., Brognara, F., Castania, J. A., Talbot, J., Cunha, T. M., Cunha, F. Q., et al. (2015). Baroreflex activation in conscious rats modulates the join inflammatory response via sympathetic function. Brain Behav. Immun. 49, 140-147. doi: 10.1016/j.bbi.2015.05.002

Bertinieri, G., di Rienzo, M., Cavallazzi, A., Ferrari, A. U., Pedotti, A., and Mancia, G. (1985). A new approach to analysis of the arterial baroreflex. J. Hypertens. Suppl. 3, S79-S81.

Beutler, B., and Rietschel, E. T. (2003). Innate immune sensing and its roots: the story of endotoxin. Nat. Rev. Immunol. 3, 169-176. doi: 10.1038/nri1004
In conclusion, our data show that while opposite changes of the arterial pressure responses are dependent on the dose of LPS administrated, the tachycardic response seems to be independent of the dose. We suggest that changes in the heart rate variability and baroreflex function elicited by LPS may not be associated with the arterial pressure response produced by the endotoxemia.

\section{DATA AVAILABILITY}

All datasets generated for this study are included in the manuscript and/or the supplementary files.

\section{ETHICS STATEMENT}

This study was carried out in accordance with the recommendations of Committee of Ethics in Animal Research of the Ribeirão Preto Medical School - University of São Paulo. The protocol was approved by the Committee of Ethics in Animal Research of the Ribeirão Preto Medical School University of São Paulo (protocol number 194/2016).

\section{AUTHOR CONTRIBUTIONS}

FB conceived and designed the research study, performed experiments, analyzed data, interpreted results, prepared figures and table, and wrote the manuscript. JC performed experiments. DD analyzed data, commented, and edited the manuscript. AK and HS commented and edited the manuscript. All the authors reviewed and approved the final version of manuscript before submission.

\section{FUNDING}

This work was supported by the Fundação de Amparo à Pesquisa do Estado de São Paulo (FAPESP) process \#2013/20549-7, \#2011/20343-4, and FB holds a PhD Scholarships from FAPESP, process \#2017/05163-6.

Borovikova, L. V., Ivanova, S., Zhang, M., Yang, H., Botchkina, G. I., Watkins, L. R., et al. (2000). Vagus nerve stimulation attenuates the systemic inflammatory response to endotoxin. Nature 405, 458-462. doi: $10.1038 / 35013070$

Brognara, F., Castania, J. A., Dias, D. P. M., Lopes, A. H., Fazan, R., Kanashiro, A., et al. (2018). Baroreflex stimulation attenuates central but not peripheral inflammation in conscious endotoxemic rats. Brain Res. 1682, 54-60. doi: 10.1016/j.brainres.2018.01.003

Café-Mendes, C. C., Garay-Malpartida, H. M., Malta, M. B., de Sá Lima, L., Scavone, C., Ferreira, Z. S., et al. (2017). Chronic nicotine treatment decreases LPS signaling through NF- $\mathrm{kB}$ and TLR-4 modulation in the hippocampus. Neurosci. Lett. 636, 218-224. doi: 10.1016/j.neulet.2016.10.056

Cai, B., Deitch, E. A., and Ulloa, L. (2010). Novel insights for systemic inflammation in sepsis and hemorrhage. Mediat. Inflamm. 2010, 1-10. doi: $10.1155 / 2010 / 642462$ 
Chen, W., Zhu, S., Wang, Y., Li, J., Qiang, X., Zhao, X., et al. (2019). Enhanced macrophage pannexin 1 expression and hemichannel activation exacerbates lethal experimental sepsis. Sci. Rep. 9:160. doi: 10.1038/s41598-018-37232-z

Di Rienzo, M., Bertinieri, G., Mancia, G., and Pedotti, A. (1985). A new method for evaluating the baroreflex role by a joint pattern analysis of pulse interval and systolic blood pressure series. Med. Biol. Eng. Comput. 23, 313-314.

Doursout, M.-F., Liang, Y., Sundaresan, A., Wakame, K., Fujii, H., Takanari, J., et al. (2016). Active hexose correlated compound modulates LPS-induced hypotension and gut injury in rats. Int. Immunopharmacol. 39, 280-286. doi: $10.1016 /$ j.intimp.2016.07.023

Ferguson, J. F., Patel, P. N., Shah, R. Y., Mulvey, C. K., Gadi, R., Nijjar, P. S., et al. (2013). Race and gender variation in response to evoked inflammation. J. Transl. Med. 11:63. doi: 10.1186/1479-5876-11-63

Halbach, J. L., Wang, A. W., Hawisher, D., Cauvi, D. M., Lizardo, R. E., Rosas, J., et al. (2017). Why antibiotic treatment is not enough for sepsis resolution an evaluation in an experimental animal model. Infect. Immun. 85:e00664-17. doi: 10.1128/IAI.00664-17

Huang, J., Wang, Y., Jiang, D., Zhou, J., and Huang, X. (2010). The sympathetic vagal balance against endotoxemia. J. Neural Transm. 117, 729-735. doi: 10.1007/s00702-010-0407-6

Julien, C. (2006). The enigma of Mayer waves: facts and models. Cardiovasc. Res. 70, 12-21. doi: 10.1016/j.cardiores.2005.11.008

Komegae, E. N., Farmer, D. G. S., Brooks, V. L., McKinley, M. J., McAllen, R. M., and Martelli, D. (2018). Vagal afferent activation suppresses systemic inflammation via the splanchnic anti-inflammatory pathway. Brain Behav. Immun. 73, 441-449. doi: 10.1016/j.bbi.2018.06.005

Lee, C.-C., Lin, N.-T., Hsu, Y. H., and Chen, H. I. (2005). Inducible nitric oxide synthase inhibition potentiates multiple organ dysfunction induced by endotoxin in conscious rats. J. Cardiovasc. Pharmacol. 45, 396-403. doi 10.1097/01.fjc.0000157438.72483.ae

Marriott, I., Bost, K. L., and Huet-Hudson, Y. M. (2006). Sexual dimorphism in expression of receptors for bacterial lipopolysaccharides in murine macrophages: a possible mechanism for gender-based differences in endotoxic shock susceptibility. J. Reprod. Immunol. 71, 12-27. doi: 10.1016/j.jri.2006.01.004

Martelli, D., Farmer, D. G. S., McKinley, M. J., Yao, S. T., and McAllen, R. M. (2019). Anti-inflammatory reflex action of splanchnic sympathetic nerves is distributed across abdominal organs. Am. J. Phys. Regul. Integr. Comp. Phys. 316, R235-R242. doi: 10.1152/ajpregu.00298.2018

Martelli, D., Yao, S. T., Mancera, J., McKinley, M. J., and McAllen, R. M. (2014). Reflex control of inflammation by the splanchnic anti-inflammatory pathway is sustained and independent of anesthesia. Am. J. Phys. Regul. Integr. Comp. Phys. 307, R1085-R1091. doi: 10.1152/ajpregu.00259.2014

Mehanna, A., Vitorino, D. C., Panis, C., Blanco, E. E. A., Pinge-Filho, P., and Martins-Pinge, M. C. (2007). Cardiovascular and pulmonary effects of NOS inhibition in endotoxemic conscious rats subjected to swimming training. Life Sci. 81, 1301-1308. doi: 10.1016/j.lfs.2007.09.006

Radaelli, A., Castiglioni, P., Cerrito, M. G., De Carlini, C., Soriano, F., Di Rienzo, M., et al. (2013). Infusion of Escherichia coli lipopolysaccharide toxin in rats produces an early and severe impairment of baroreflex function in absence of blood pressure changes. Shock 39, 204-209. doi: 10.1097/ SHK.0b013e3182767daf

Raetz, C. R. H., and Whitfield, C. (2002). Lipopolysaccharide endotoxins. Annu. Rev. Biochem. 71, 635-700. doi: 10.1146/annurev.biochem.71. 110601.135414

Sallam, M. Y., El-Gowilly, S. M., Abdel-Galil, A.-G. A., and El-Mas, M. M. (2017). Cyclosporine counteracts endotoxemia-evoked reductions in blood pressure and cardiac autonomic dysfunction via central sGC/MAPKs signaling in rats. Eur. J. Pharmacol. 797, 143-152. doi: 10.1016/j.ejphar. 2017.01.023

Sallam, M. Y., El-Gowilly, S. M., El-Gowelli, H. M., El-Lakany, M. A., and El-Mas, M. M. (2018). Additive counteraction by $\alpha 7$ and $\alpha 4 \beta 2$-nAChRs of the hypotension and cardiac sympathovagal imbalance evoked by endotoxemia in male rats. Eur. J. Pharmacol. 834, 36-44. doi: 10.1016/j.ejphar.2018.07.008

Shen, F.-M., Guan, Y.-F., Xie, H.-H., and Su, D.-F. (2004). Arterial baroreflex function determines the survival time in lipopolysaccharide-induced shock in rats. Shock 21, 556-560. doi: 10.1097/01.shk.0000126647.51109.5c

Simons, C. T., Kulchitsky, V. A., Sugimoto, N., Homer, L. D., Székely, M., and Romanovsky, A. A. (1998). Signaling the brain in systemic inflammation: which vagal branch is involved in fever genesis? Am. J. Phys. 275, R63-R68. doi: 10.1152/ajpregu.1998.275.1.R63

Sternberg, E. M., Hill, J. M., Chrousos, G. P., Kamilaris, T., Listwak, S. J., Gold, P. W., et al. (1989). Inflammatory mediator-induced hypothalamicpituitary-adrenal axis activation is defective in streptococcal cell wall arthritissusceptible Lewis rats. Proc. Natl. Acad. Sci. USA 86, 2374-2378.

Tohyama, T., Saku, K., Kawada, T., Kishi, T., Yoshida, K., Nishikawa, T., et al. (2018). Impact of lipopolysaccharide-induced acute inflammation on baroreflexcontrolled sympathetic arterial pressure regulation. PLoS One 13:e0190830. doi: 10.1371/journal.pone.0190830

Wasilczuk, K. M., Bayer, K. C., Somann, J. P., Albors, G. O., Sturgis, J., Lyle, L. T., et al. (2019). Modulating the inflammatory reflex in rats using low-intensity focused ultrasound stimulation of the vagus nerve. Ultrasound Med. Biol. 45, 481-489. doi: 10.1016/j.ultrasmedbio.2018.09.005

Zila, I., Mokra, D., Kopincova, J., Kolomaznik, M., Javorka, M., and Calkovska, A. (2015). Heart rate variability and inflammatory response in rats with lipopolysaccharide-induced endotoxemia. Physiol. Res. 64(Suppl. 5), S669-S676.

Conflict of Interest Statement: The authors declare that the research was conducted in the absence of any commercial or financial relationships that could be construed as a potential conflict of interest.

Copyright (c) 2019 Brognara, Castania, Dias, Kanashiro and Salgado. This is an open-access article distributed under the terms of the Creative Commons Attribution License (CC BY). The use, distribution or reproduction in other forums is permitted, provided the original author(s) and the copyright owner(s) are credited and that the original publication in this journal is cited, in accordance with accepted academic practice. No use, distribution or reproduction is permitted which does not comply with these terms. 


\title{
Selective denervation of the aortic and carotid baroreceptors in rats
}

\author{
Jaci A. Castania ${ }^{1}$ | Pedro L. Katayama ${ }^{1}$ (D) | Fernanda Brognara ${ }^{1}$ \\ Davi J.A. Moraes $^{1}$ | João Paulo J.Sabino ${ }^{2}$ | Helio C. Salgado ${ }^{1}$
}

${ }^{1}$ Department of Physiology, Ribeirão Preto Medical School, University of São Paulo, Ribeirão Preto, São Paulo, Brazil

${ }^{2}$ Department of Biophysics and Physiology, Federal University of Piauí, Teresina, Piauí, Brazil

\section{Correspondence}

Helio C. Salgado, Department of Physiology, Ribeirão Preto Medical School, University of São Paulo, Av. Bandeirantes 3900, 14049-900 Ribeirão Preto, São Paulo, Brazil.

Email:hcsalgado@fmrp.usp.br

\section{Edited by: Robert Brothers}

Funding information

This work was supported by São Paulo Research Foundation (FAPESP; grants \#2013/205497,\#2013/10484-5,\#2015/18511-7 and \#2017/05163-6) and National Council for Scientific and Technological Development (CNPq;\#475715/2012-8).

\begin{abstract}
Studies have demonstrated that the traditional surgical approach for sino-aortic denervation in rats leads to simultaneous carotid baroreceptor and chemoreceptor deactivation. The present study reports a new surgical approach to denervate the aortic and the carotid baroreceptors selectively, keeping the carotid bodies (peripheral chemoreceptors) intact. Wistar rats were subjected to specific aortic and carotid baroreceptor denervation (BAROS-X) or sham surgery (SHAM). Baroreflex activation was achieved by I.V. administration of phenylephrine, whereas peripheral chemoreflex activation was produced by I.V. administration of potassium cyanide. The SHAM and BAROS-X rats displayed significant hypertensive responses to phenylephrine administration. However, the reflex bradycardia following the hypertensive response caused by phenylephrine was remarkable in SHAM, but not significant in the BAROS-X animals, confirming the efficacy of the surgical procedure to abolish the baroreflex. In addition, the baroreflex activation elicited by phenylephrine increased carotid sinus nerve activity only in SHAM, but not in the BAROS-X animals, providing support to the notion that the baroreceptor afferents were absent. Instead, the classical peripheral chemoreflex hypertensive and bradycardic responses to potassium cyanide were similar in both groups, suggesting that the carotid body chemoreceptors were preserved after BAROS-X. In summary, we describe a new surgical approach in which only the baroreceptors are eliminated, while the carotid chemoreceptors are preserved. Therefore, it is understood that this procedure is potentially a useful tool for examining the relative roles of the arterial baroreceptors versus the chemoreceptors in several pathophysiological conditions, for instance, arterial hypertension and heart failure.
\end{abstract}

KEYWORDS

autonomic nervous system, baroreflex, haemodynamics, phenylephrine

\section{1 | INTRODUCTION}

The arterial baroreflex is the main regulatory system responsible for the maintenance of arterial pressure within a relatively narrow range of oscillation (Chapleau, Hajduczock, \& Abboud, 1988; Krieger, Salgado, \& Michelini, 1982). Basically, the arterial baroreflex comprises the baroreceptors (sensory neurons located within the aortic arch and carotid sinuses), central components situated particularly in the brainstem, and autonomic sympathetic and parasympathetic efferents. Activation of the baroreceptors, i.e. the afferent arm of the baroreflex, determines a neural response characterized by inhibition of sympathetic nerves and concomitant activation of parasympathetic efferents innervating key organs involved in cardiovascular regulation (Chapleau et al., 1988; Krieger et al., 1982). In contrast, the activation of afferents from the peripheral chemoreceptors, located especially in the carotid sinus, causes increased activity of sympathetic and parasympathetic efferents, characterizing the chemoreflex function (Franchini \& Krieger 1993; Guyenet, 2006).

Krieger (1964) first described sino-aortic denervation (SAD) in rats. Since then, several studies have examined the effects of the

(c) 2019 The Authors. Experimental Physiology (c) 2019 The Physiological Society 
absence of aortic and carotid baroreceptors in experimental models in physiological and pathological conditions (Ceroni, Chaar, Bombein, \& Michelini, 2009; Flues et al., 2012; Miao \& Su, 2002; Miao, Xie, Zhan, \& Su, 2006; Miao, Yuan, \& Su, 2003; Potts, Polson, Hirooka, \& Dampney, 1997; Sirvente et al., 2014; Van Vliet, Chafe, \& Montani, 1999). Some studies attributed their findings only to unloading of the baroreceptors, showing the importance of the baroreflex mechanism in cardiovascular neural regulation. However, besides the disruption of the carotid and aortic baroreceptor afferents, resulting in baroreflex dysfunction, the traditional SAD model also includes denervation of the carotid body chemoreceptors (Krieger, 1964). Although, in physiological conditions, the carotid body chemoreceptors do not contribute significantly to the arterial pressure regulation, recent studies have proposed that these receptors are involved not only in the pathophysiology of a number of cardiovascular diseases, but also in respiratory and metabolic disturbances (Abdala et al., 2012; Del Rio, Marcus, \& Schultz, 2013; Marcus, Del Rio, Schultz, Xia, \& Schultz, 2014; Paton et al., 2013; Prabhakar, 2016; Ribeiro et al., 2013; Schultz, Marcus, \& Del Rio, 2013).

Thus, to allow a better understanding of the relative role played by the baroreceptors or by the chemoreceptors in several experimental situations, the objective of the present study was to describe a new surgical technique in which only the baroreceptors are knocked out, whilst the carotid chemoreceptors are preserved.

\section{2 | METHODS}

\section{1 | Ethical approval}

All experimental procedures were approved by the Ethical Committee on Animal Experimentation of the Ribeirão Preto Medical School, University of São Paulo (protocol no. 143/2013). The authors are in agreement with the Experimental Physiology ethical principles and guidelines; hence, the present study was performed in accordance with the animal ethics checklist reported by Grundy (2015).

\section{2 | Animals}

Experiments were conducted in male Wistar rats $(270-310 \mathrm{~g})$ provided by the Animal Care Facility of the University of São Paulo at Ribeirão Preto, São Paulo, Brazil. All animals were maintained in a room with controlled temperature $\left(22^{\circ} \mathrm{C}\right)$ and constant $12 \mathrm{~h}-12 \mathrm{~h}$ light-dark cycle, receiving food and water ad libitum.

\section{3 | Surgical procedures}

Rats were anaesthetized with a mixture of ketamine $\left(50 \mathrm{mg} \mathrm{kg}^{-1}\right)$ and xylazine $\left(10 \mathrm{mg} \mathrm{kg}^{-1}\right.$ ) given I.P. and separated into two experimental groups, as follows: (a) baroreceptor-denervated group (BAROS-X; carotid and aortic baroreceptor denervation); and (b) control group (SHAM; sham surgery).

\section{New Findings}

- What is the central question of this study?

The traditional surgical approach for sino-aortic denervation in rats leads to simultaneous carotid baroreceptor and chemoreceptor deactivation, which does not permit their individual study in different situations.

- What is the main finding and its importance?

We have described a new surgical approach capable of selective denervation of the arterial (aortic and carotid) baroreceptors, keeping the carotid bodies (chemoreceptors) intact. It is understood that this technique might be a useful tool for investigating the relative role of the baro- and chemoreceptors in several physiological and pathophysiological conditions.

In the BAROS-X group, the rats were subjected to a mid-line ventral neck incision, allowing exposure of the right common carotid artery and right carotid bifurcation. Under microscope magnification, the area of the carotid bifurcation was carefully isolated and exposed. Close to the pterygopalatine and internal carotid arteries, the carotid sinus nerve projects towards the glossopharyngeal nerve. At this point, it was possible to identify two different branches, usually separated by a tiny artery. One of these branches, which carries the carotid baroreceptor afferent fibres, was carefully cut (Figure 1). An identical procedure was performed on the left side of the neck. For the aortic baroreceptor denervation, the technique described by Krieger (1964) was used. Briefly, the superior laryngeal nerve and the superior cervical ganglion were isolated and resected bilaterally (Amorim, Bonagamba, Souza, Moraes, \& Machado, 2017; Krieger, 1964). The SHAM animals were subjected to the same manipulation of the carotid sinus bifurcation and aortic regions, but all structures were kept intact.

Under the same anaesthesia, the femoral artery and vein were catheterized with polyethylene tubing (PE-50 attached to a PE-10; Becton Dickinson, Sparks, MD, USA) for recording pulsatile arterial pressure (PAP) and for I.V. drug administration. Catheters were exteriorized on the back of the nape, and the surgical incision was closed by sutures. Postoperatively, the animals received a single dose of flunixin meglumine $\left(2.5\right.$ mg kg ${ }^{-1}$, I.M.; Schering-Plough, Cotia, SP, Brazil).

\subsection{Experimental protocols}

\subsubsection{Haemodynamic measurements}

These protocols were carried out $24 \mathrm{~h}$ after the surgical procedures and recovery from anaesthesia, following the same time frame reported by previous studies using the traditional SAD (Krieger et al., 2006, Silva et al., 2015, Zhang, Barrès, \& Julien, 1995). Freely moving rats from both SHAM $(n=9)$ and BAROS-X $(n=8)$ groups had the arterial catheter connected to a pressure 
FIGURE 1 (a) Drawing illustrating the baroreceptor selective denervation method. (b) Photograph of the carotid bifurcation of the rat. The white circle shows where the carotid baroreceptor afferents were cut. Abbreviations: $B A$, baroreceptor afferents; $C B$, carotid body; CBA, carotid body artery; CCA, common carotid artery; $\mathrm{CS}$, carotid sinus; $\mathrm{CSN}$, carotid sinus nerve; ECA, external carotid artery; GPN, glossopharyngeal nerve; ICA, internal carotid artery; and OA, occipital artery (a)

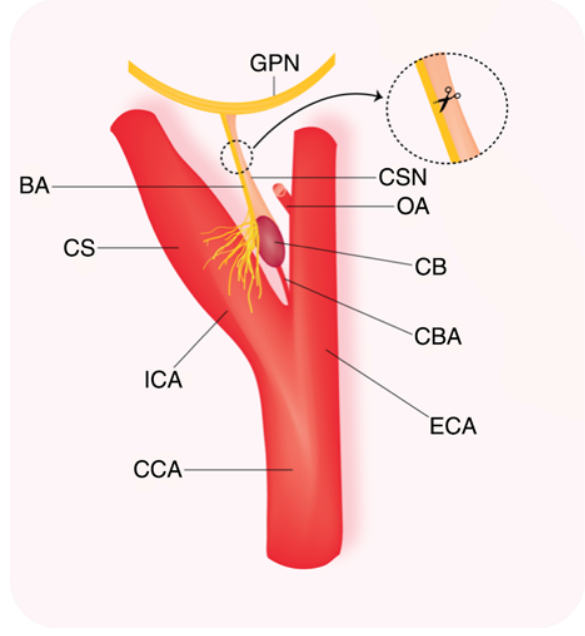

(b)

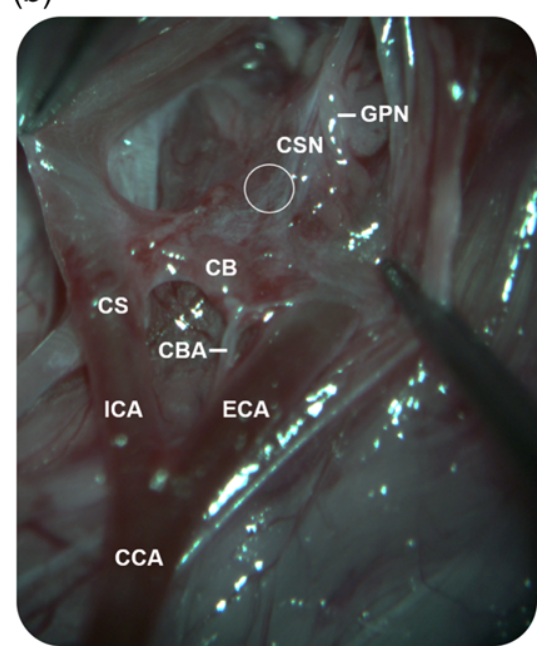

transducer (MLT844; ADInstruments, Bella Vista, NSW, Australia). The PAP signal was amplified (ML224; ADInstruments) and sampled by an IBM/PC computer (Core 2 duo, $2.2 \mathrm{GHz}, 4 \mathrm{~GB}$ ram) equipped with an analog-to-digital interface (2 kHz, ML866; ADInstruments). Recordings of PAP were processed with computer software (LabChart v.7.0; ADInstruments) capable of detecting inflection points and generating systolic, diastolic and mean arterial pressure (MAP) and heart rate (HR) time series.

The experimental protocol consisted of a basal recording of the cardiovascular parameters for $15 \mathrm{~min}$, followed by baroreflex activation by means of phenylephrine administration ( $2 \mu \mathrm{g}$ in $0.1 \mathrm{ml}$, I.V.). Ten minutes after phenylephrine administration, the peripheral chemoreflex was stimulated by the injection of potassium cyanide ( $\mathrm{KCN} ; 40 \mu \mathrm{g}$ in $0.1 \mathrm{ml}$, I.V.), in order to confirm the integrity of the peripheral chemoreceptors. All protocols were carried out between 1.00 and $14.00 \mathrm{~h}$, during the inactive phase.

\subsubsection{Carotid sinus nerve recordings}

Animals were anaesthetized with a mixture of ketamine $\left(50 \mathrm{mg} \mathrm{kg}^{-1}\right)$ and xylazine $\left(10 \mathrm{mg} \mathrm{kg}^{-1}\right)$ I.P., placed in the supine position in a heating pad (ALB 200 RA; Bonther, Ribeirão Preto, Brazil), and core body temperature was monitored and maintained at a minimum of $37^{\circ} \mathrm{C}$ via a thermocouple (MLT1403; Harvard Apparatus, Holliston, MA, USA). Polyethelene catheters were inserted into the femoral artery and vein for recording PAP and for I.V. administration of fluids and drugs, as previously described. The neck was opened through the mid-line and the carotid bifurcation exposed. The carotid sinus nerve was separated from surrounding tissue, close to its origin in the glossopharyngeal nerve, placed in a bipolar electrode, connected in turn to an amplifier (1700 amplifier; A-M Systems, Sequim, WA, USA) and covered with warm mineral oil. The recorded signal was bandpass filtered ( $10 \mathrm{~Hz}-5 \mathrm{kHz}$ ), amplified and acquired by a data acquisition system (5 kHz; ML866; ADInstruments) controlled by a computer running LabChart software (v.7.0; ADInstruments). Animals breathed spontaneously throughout the experiments and were submitted to baroreflex activation by means of phenylephrine administration, whereas the peripheral chemoreflex was stimulated by $\mathrm{KCN}$. The recorded signal was fed to a spike amplitude discriminator and counter, which digitally counted in $1 \mathrm{~s}$ intervals to assess the discharge frequency of carotid sinus nerve (in spikes per second). At the end of the experiments, the animals were killed by an overdose of ketamine and xylazine given I.V.

\section{5 | Statistical analysis}

Data are expressed as means \pm SD. The Kolmogorov-Smirnov test was applied to verify the normal distribution of the variables involved. The haemodynamic parameters at baseline were compared between SHAM and BAROS-X groups using Student's unpaired $t$ test or the Mann-Whitney $U$ test when required. Comparisons of MAP, HR and carotid sinus nerve activity between SHAM and BAROS$\mathrm{X}$ groups, before and after phenylephrine or $\mathrm{KCN}$ administration, were performed with two-way ANOVA followed by Tukey's multiple comparison test. The significance level was set at $P<0.05$. Statistical analyses were performed using SigmaStat v.3.5 software (Systat Software Inc., San Jose, CA, USA).

\section{3 | RESULTS}

\section{1 | Baseline haemodynamics}

The selective denervation of arterial baroreceptors caused a significant increase in baseline arterial pressure, as shown by the higher values of systolic, diastolic and mean arterial pressure in the BAROS-X compared with the SHAM group $(P<0.001)$; the HR was not significantly affected by the surgical procedure (Table 1 ).

\subsection{Haemodynamic responses to baroreflex and peripheral chemoreflex activation}

Baroreflex activation elicited by I.V. administration of phenylephrine significantly increased arterial pressure in both SHAM and BAROS-X 
TABLE 1 Baseline haemodynamics

$\begin{array}{lcl}\text { Parameter } & \operatorname{SHAM}(n=9) & \text { BAROS-X }(n=8) \\ \text { SAP }(\mathrm{mmHg}) & 121 \pm 6 & 146 \pm 17^{* * *} \\ \text { DAP }(\mathrm{mmHg}) & 90 \pm 3 & 114 \pm 20^{* * *} \\ \text { MAP }(\mathrm{mmHg}) & 105 \pm 3 & 129 \pm 17^{* * *} \\ \left.\text { HR (beats min }{ }^{-1}\right) & 384 \pm 36 & 423 \pm 62\end{array}$

Data are expressed as the mean \pm SD systolic arterial pressure (SAP), diastolic arterial pressure (DAP), mean arterial pressure (MAP) and heart rate (HR). Abbreviations: BAROS-X, aortic and carotid baroreceptordenervated group; and SHAM, sham surgery group.

${ }^{* * *} P<0.001$ compared with SHAM group.

groups, as shown by the representative traces of PAP and MAP (Figure $2 a$ ) and by the individual and grouped data of MAP (Figure $2 b$ ). In the SHAM group, phenylephrine increased MAP from $108 \pm 6$ to
$154 \pm 9 \mathrm{mmHg}(P<0.001)$, and in the BAROS- $X$ group the increase in MAP was from $131 \pm 18$ to $169 \pm 16 \mathrm{mmHg}(P<0.001)$. The MAP at the peak response to phenylephrine was also higher in the BAROS-X group than in the SHAM group $(P=0.032)$.

Regarding the HR, baroreflex activation by phenylephrine caused a marked reflex bradycardia in the SHAM group but did not affect the HR in the BAROS-X group, as demonstrated by Figure 2a,b. In the SHAM group, HR decreased from $397 \pm 54$ beats $\min ^{-1}$ at baseline to $338 \pm 49$ beats $\mathrm{min}^{-1}$ in response to phenylephrine $(P=0.04)$, whereas in the BAROS-X group HR remained unchanged $(419 \pm 67$ versus $414 \pm 68$ beats $\min ^{-1}, P=0.87$ ), confirming the efficacy of the procedure for baroreceptor denervation.

To test whether the surgical procedure was selective for baroreceptor denervation and preserved the integrity of the carotid body chemoreceptors, activation of the peripheral chemoreflex (a)

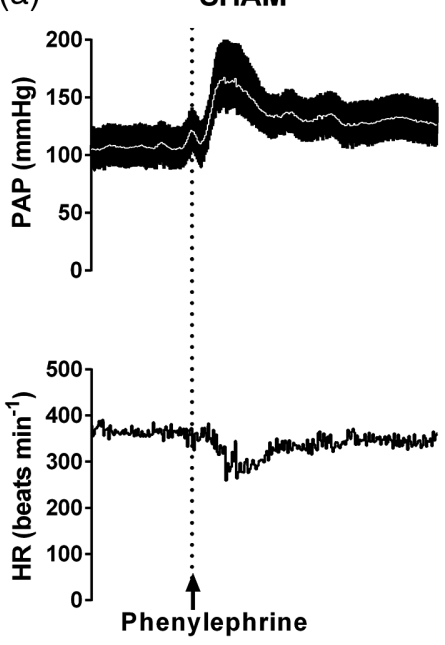

(c)

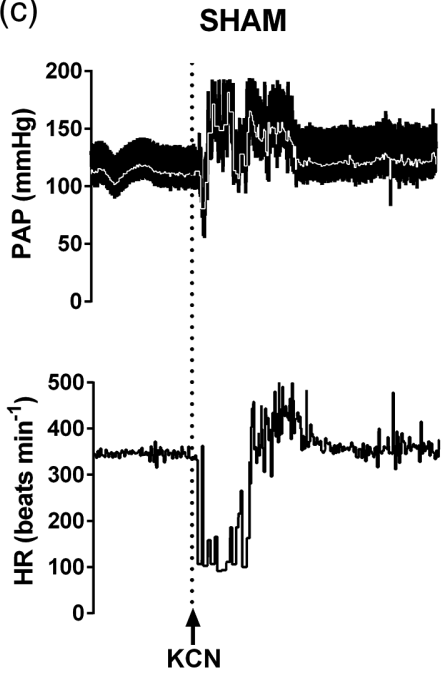

BAROS-X

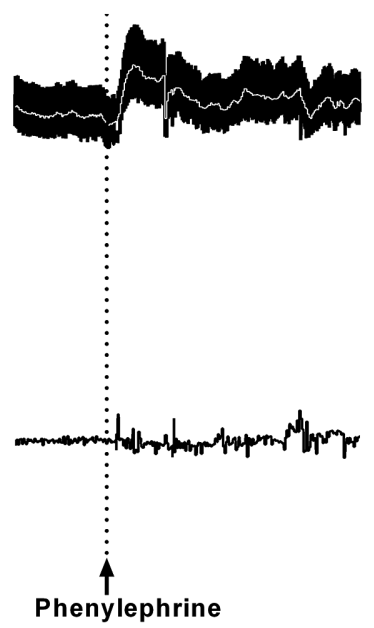

BAROS-X

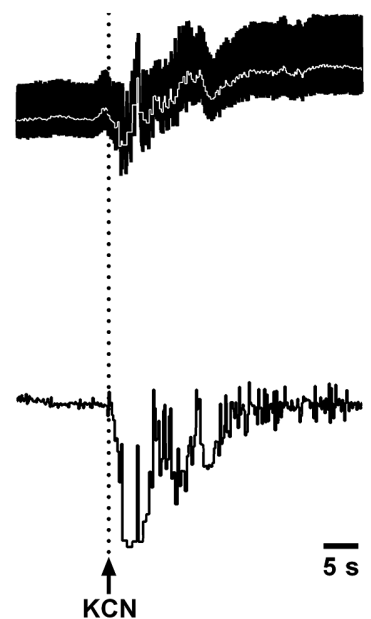

(b)
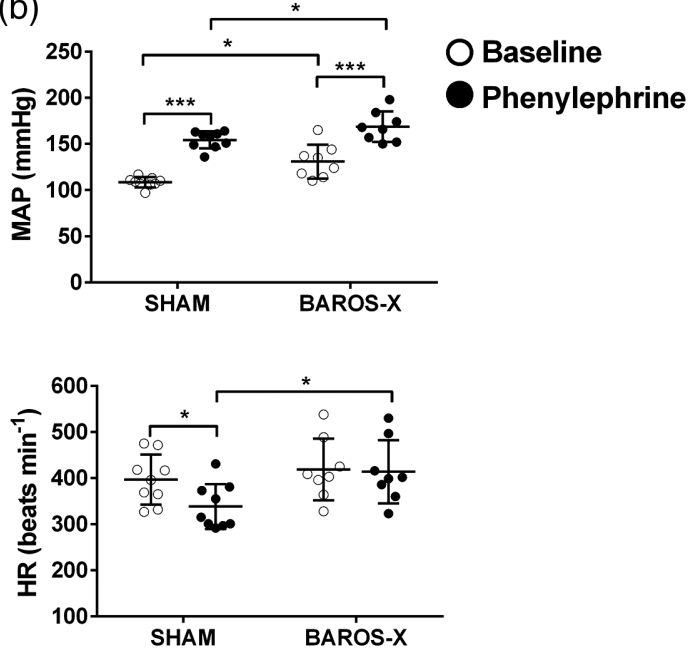

(d)
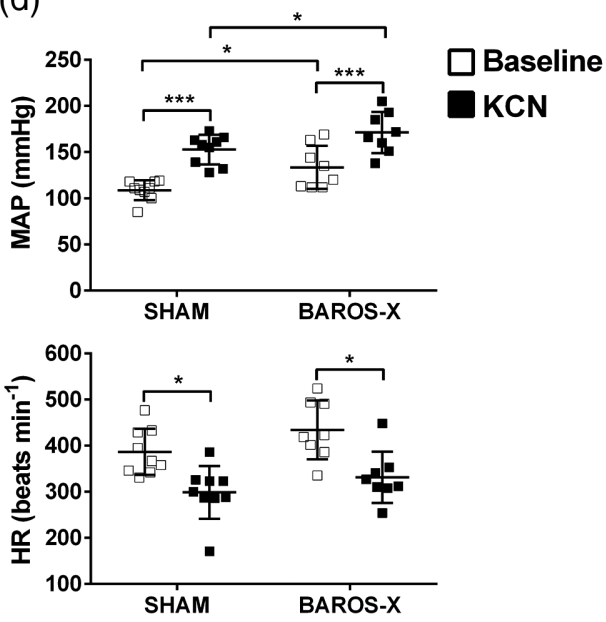

FIGURE 2 Cardiovascular responses to phenylephrine and potassium cyanide (KCN) in conscious baroreceptor-denervated (BARO-X) and sham-operated (SHAM) rats. (a, c) Representative traces of the arterial pressure [pulsatile arterial pressure (PAP); white line indicates mean arterial pressure] and heart rate (HR), showing the responses to I.V. administration of phenylephrine (a) or KCN (c) in SHAM and BAROS-X rats. (b, d) Individual and grouped data showing the mean arterial pressure (MAP) and HR during baseline conditions and the peak responses to I.V. administration of phenylephrine (b) or KCN (d) in SHAM and BAROS-X groups. ${ }^{*} P<0.05,{ }^{* * *} P<0.001$ 
was elicited by I.V. administration of $\mathrm{KCN}$. As illustrated by the representative traces in Figure $2 \mathrm{c}, \mathrm{KCN}$ caused typical peripheral chemoreflex activation, determining hypertensive and bradycardic responses in both the SHAM and the BAROS-X group. In the SHAM group, the MAP increased from $109 \pm 11$ to $153 \pm 16 \mathrm{mmHg}$ $(P<0.001)$, and in the BAROS- $X$ group it increased from $133 \pm 23$ to $171 \pm 22 \mathrm{mmHg}(P<0.001)$, as illustrated in Figure $2 \mathrm{~d}$. In addition, in the SHAM group KCN caused a remarkable decrease in HR from $386 \pm 50$ to $299 \pm 57$ beats $\min ^{-1}(P=0.003)$, and in the BAROS-X group a decrease from $434 \pm 64$ to $332 \pm 55$ beats $\mathrm{min}^{-1}(P=0.001)$, as illustrated in Figure $2 \mathrm{~d}$.

\section{3 | Carotid sinus nerve responses to baroreflex and peripheral chemoreflex activation}

To demonstrate the selectivity of removal of the carotid baroreceptor fibres and the integrity of the fibres arising from the carotid peripheral chemoreceptors, we also evaluated responses of the carotid sinus nerve (close to its origin in the glossopharyngeal nerve) to either baroreflex or chemoreflex activation in anaesthetized rats. Intravenous administration of phenylephrine produced similar increases in arterial pressure in SHAM (147 \pm 5 versus $97 \pm 7 \mathrm{mmHg}$; $n=6 ; P<0.001)$ and BAROS-X (159 \pm 9 versus $112 \pm 4 \mathrm{mmHg}$; $n=5 ; P<0.0001$ ) anaesthetized rats (Figure 3a). The reflex bradycardic response was present in the SHAM group ( $322 \pm 46$ versus $380 \pm 27$ beats $\min ^{-1} ; P=0.02$ ), but not in the BAROS-X group $\left(361 \pm 38\right.$ versus $369 \pm 49$ beats $\left.\min ^{-1}\right)$. Likewise, the carotid sinus nerve activity increased from $26 \pm 5$ spikes $\mathrm{s}^{-1}$ at baseline to $69 \pm 12$ spikes $s^{-1}$ in response to phenylephrine in SHAM rats (Figure $3 a, b$ ), whereas its activity in the BAROS-X group remained unchanged ( $27 \pm 7$ versus $27 \pm 9$ spikes $\mathrm{s}^{-1}$; Figure $3 a$,b), confirming the effectiveness of the baroreceptor denervation.

To demonstrate the integrity of carotid body chemoreceptors, peripheral chemoreflex activation was elicited by I.V. administration of $\mathrm{KCN}$ in the same group of anaesthetized rats. Peripheral chemoreflex activation produced similar increases in MAP (SHAM, $158 \pm 17$ versus $96 \pm 12 \mathrm{mmHg} ; n=6 ; P<0.0001$; and BAROS-X, $170 \pm 16$ versus $115 \pm 13 \mathrm{mmHg} ; n=5 ; P=0.0001$ ) and reductions in HR (SHAM, $177 \pm 66$ versus $376 \pm 54$ beats $\min ^{-1} ; P=0.0002$; and BARO-X, $185 \pm 56$ versus $390 \pm 42$ beats $\min ^{-1} ; P<0.0001$ ) in anaesthetized rats from both SHAM and BAROS-X groups (Figure 3c). Likewise, $\mathrm{KCN}$ caused similar and significant increases in carotid sinus nerve activity from both SHAM and BAROS-X groups (SHAM, $26 \pm 5$ versus $106 \pm 7$ spikes s $^{-1}$; and BAROS-X, $28 \pm 7$ versus $110 \pm 11$ spikes s $^{-1}$; Figure 3c,d).

\section{4 | DISCUSSION}

In the present study, a new technique is described for selective denervation of the aortic and carotid baroreceptors, while keeping the carotid bodies, i.e. the chemoreceptor afferents, intact. To the best of our knowledge, this is the first study to describe and test the efficacy of such a technique dealing with haemodynamic (arterial pressure and heart rate) responses in unanaesthetized and anaesthetized rats. This new surgical approach will allow characterization of the relative role played by the baro- and chemoreceptors in rats in several experimental situations.

The validation of this technique was accomplished through pharmacological activation of the baroreflex and the chemoreflex. Baroreflex activation was induced by I.V. administration of phenylephrine, a selective $\alpha_{1}$-adrenergic receptor agonist. Phenylephrine administration caused a hypertensive response associated with baroreflex-mediated bradycardia in SHAM rats. However, in the absence of the arterial baroreceptors, i.e. in the BAROS-X group, the phenylephrine-induced hypertension did not produce reflex bradycardia, providing support to the notion that the arterial baroreceptors (aortic and carotid) were absent in these circumstances. Next, chemoreflex activation was obtained by I.V. administration of $\mathrm{KCN}$. In normal conditions, the haemodynamic responses to $\mathrm{KCN}$ administration are characterized by hypertension combined with bradycardia (Barros et al., 2002; Franchini \& Krieger 1993). Thus, in both groups, i.e. SHAM and BAROS-X, $\mathrm{KCN}$ elicited these classical haemodynamic responses (hypertension and bradycardia), indicating that the carotid chemoreceptors were intact. Therefore, the aforementioned protocols demonstrated that the BAROS-X group exhibited denervated aortic and carotid baroreceptors combined with intact carotid chemoreceptors, providing functional support to the efficacy of the new surgical approach described.

As is widely known, the traditional approach for SAD results not only in denervation of the aortic and carotid baroreceptors, but also in elimination of the carotid chemoreceptors (Franchini \& Krieger, 1992; Krieger, 1964; Silva et al., 2015; Zhang et al., 1995). For instance, Silva et al. (2015) verified that traditional SAD abolished the reflex bradycardia in response to I.V. administration of phenylephrine, indicating successful denervation of the aortic and carotid baroreceptors. As expected, the I.V. administration of $\mathrm{KCN}$, to activate the chemoreflex, did not produce any cardiovascular response in these animals, confirming the concomitant denervation of carotid chemoreceptors resulting from SAD.

In the present study, besides the haemodynamic measurements, we evaluated the carotid sinus nerve activity in response to baro- and chemoreflex activation. It is well known that the carotid sinus nerve contains activity from the carotid chemoreceptors and baroreceptors (Seagard et al., 1990; Porzionato et al., 2019). Therefore, we performed recordings from the whole carotid sinus nerve, close to its origin in the glossopharyngeal nerve, in anaesthetized rats to provide further support to the efficacy of denervation of the aortic and carotid baroreceptors at the neural level. In this regard, carotid sinus nerve discharges increased when arterial pressure increased in response to phenylephrine in the SHAM group. In contrast, a similar increase in arterial pressure did not change the carotid sinus nerve discharges in the BARO-X group. Furthermore, activation of the peripheral chemoreceptors produced increases in carotid sinus nerve discharges in both SHAM and BARO-X groups. Thus, the hypertensive and bradycardic 

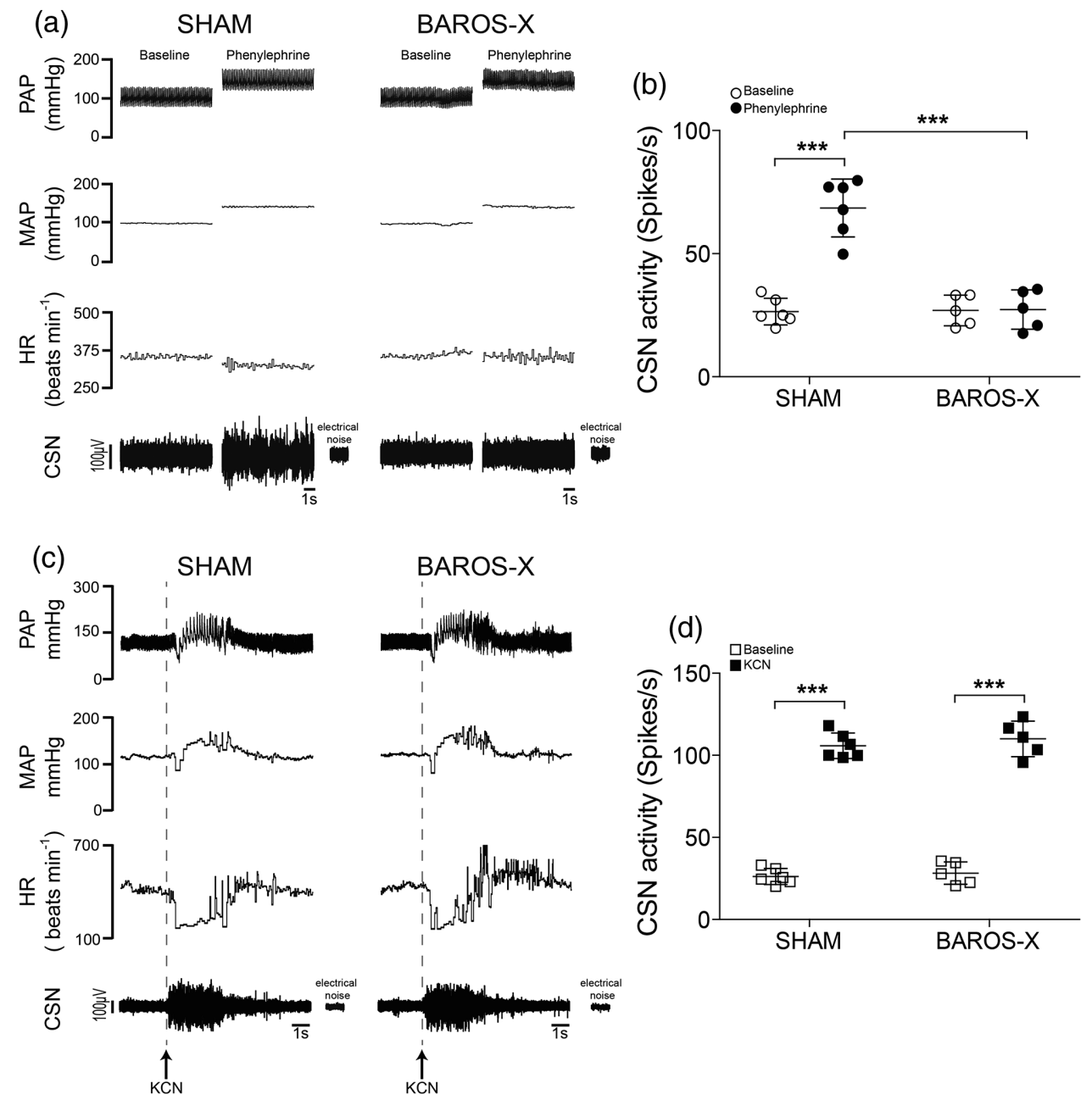

FIGURE 3 Carotid sinus nerve responses to phenylephrine and potassium cyanide (KCN) in baroreceptor-denervated (BARO-X) and sham-operated (SHAM) rats. (a) Typical traces of pulsatile arterial pressure (PAP), mean arterial pressure (MAP), heart rate (HR) and carotid sinus nerve (CSN) activity recordings from SHAM and BAROS-X groups during baseline conditions and after I.V. administration of phenylephrine. (b) Individual and grouped data showing the CSN activity during baseline and in response to phenylephrine. (c) Representative traces of PAP, MAP, HR and CSN activity recordings from SHAM and BAROS-X groups during baseline conditions and in response to I.V. administration of KCN. (d) Individual and grouped data showing the CSN activity during baseline and after I.V. administration of $\mathrm{KCN}$. ${ }^{* *} \mathrm{P}<0.001$

responses to KCN in SHAM and BARO-X groups are likely to be related to activation of the carotid body peripheral chemoreceptors.

Studies have already highlighted that traditional SAD leads to concomitant carotid chemoreceptor denervation. Ceroni et al. (2009) investigated the role of the baroreceptors on the physical traininginduced reduction in arterial pressure and resting bradycardia in spontaneously hypertensive rats and normotensive Wistar-Kyoto rats. These authors concluded that the beneficial physical traininginduced cardiovascular effects were dependent on baroreceptor integrity. Additionally, these authors emphasized that because SAD also leads to carotid chemoreceptor removal, it does not allow a distinction to be made between the effects caused by baroreceptor resection and those caused by chemoreceptor removal. Moreover, aiming to study the relative role of the baroreceptors and chemoreceptors in ventricular hypertrophy caused by SAD in rats, Van Vliet et al. (1999) developed a modified SAD technique aiming to keep the carotid body chemoreceptors and their innervations intact. However, these authors did not test the efficacy of the method by confirming the absence of baroreceptors and the integrity of carotid body chemoreceptors.

Using the technique described in the present study, our group demonstrated the role played by the carotid chemoreceptors in the haemodynamic (arterial pressure and heart rate) responses to electrical stimulation of the left carotid sinus in conscious rats (Katayama et al., 2015). These authors assessed the relative role of the carotid chemoreceptors by means of selective denervation of the left carotid baroreceptors, maintaining the integrity of the carotid chemoreceptors. However, in the study by Katayama et al. (2015), because the right carotid baroreceptors and aortic baroreceptors on both sides were kept intact, the efficacy of the selective baroreceptor denervation was based on the lack of haemodynamic responses to progressive changes in pressure of the isolated left carotid sinus. Importantly, recent studies have proposed that the carotid body chemoreceptors are involved in the pathophysiology of cardiovascular, 
respiratory and metabolic diseases (Abdala et al., 2012; Del Rio et al., 2013; Marcus et al., 2014; Paton et al., 2013; Prabhakar, 2016; Ribeiro et al., 2013; Schultz et al., 2013) showing, from the translational point of view, the importance of studying the individual roles of these receptors.

In summary, we have described a new surgical approach capable of selectively denervating the arterial (aortic and carotid) baroreceptors, while keeping the carotid bodies (chemoreceptors) intact. It is understood that this technique might be a useful tool for investigating the relative role of the baro- and chemoreceptors in several physiological and pathophysiological conditions.

\section{ACKNOWLEDGEMENTS}

The authors are grateful to Ludmila Lima Silveira for the design of Figure 1a.

\section{COMPETING INTERESTS}

None declared.

\section{AUTHOR CONTRIBUTIONS}

Conception of the work: J.A.C and H.C.S. Acquisition, analysis and interpretation of data: J.A.C., P.L.K., F.B., D.J.A.M. and J.P.J.S. Drafting the manuscript: P.L.K., F.B. and D.J.A.M. Revising the manuscript critically for intellectual comment: J.P.J.S. and H.C.S. All authors approved the final version of the manuscript and agree to be accountable for all aspects of the work in ensuring that questions related to the accuracy or integrity of any part of the work are appropriately investigated and resolved. All persons designated as authors qualify for authorship, and all those who qualify for authorship are listed.

\section{ORCID}

Pedro L. Katayama (iD https://orcid.org/0000-0001-5641-7305

Fernanda Brognara (D) https://orcid.org/0000-0002-5042-1319

\section{REFERENCES}

Abdala, A. P., McBryde, F. D., Marina, N., Hendy, E. B., Engelman, Z. J., Fudim, M., \& Paton, J. F. R. (2012). Hypertension is critically dependent on the carotid body input in the spontaneously hypertensive rat. The Journal of Physiology, 590, 4269-4277.

Amorim, M. R., Bonagamba, L. G. H., Souza, G. M. P. R., Moraes, D. J. A., \& Machado, B. H. (2017). Changes in the inspiratory pattern contribute to modulate the sympathetic activity in sino-aortic denervated rats. Experimental Physiology, 102, 1100-1117

Barros, R. C., Bonagamba, L. G., Okamoto-Canesin, R., de Oliveira, M., Branco, L. G., \& Machado, B. H. (2002). Cardiovascular responses to chemoreflex activation with potassium cyanide or hypoxic hypoxia in awake rats. Autonomic Neuroscience, 97, 110-115.

Ceroni, A., Chaar, L. J., Bombein, R. L., \& Michelini, L. C. (2009). Chronic absence of baroreceptor inputs prevents training-induced cardiovascular adjustments in normotensive and spontaneously hypertensive rats. Experimental Physiology, 94, 630-640.
Chapleau, M. W., Hajduczock, G., \& Abboud, F. M. (1988). Mechanism of resetting of arterial baroreceptors: An overview. American Journal of the Medical Sciences, 295, 327-334.

Del Rio, R., Marcus, N. J., \& Schultz, H. D. (2013). Carotid chemoreceptor ablation improves survival in heart failure: Rescuing autonomic control of cardiorespiratory function. Journal of the American College of Cardiology, 62, 2422-2430.

Flues, K., Moraes-Silva, I. C., Mostarda, C., Souza, P. R., Diniz, G. P., Moreira, E. D., ... Caldini, E. G. (2012). Cardiac and pulmonary arterial remodeling after sinoaortic denervation in normotensive rats. Autonomic Neuroscience, 166, 47-53.

Franchini, K. G., \& Krieger, E. M. (1992). Carotid chemoreceptors influence arterial pressure in intact and aortic-denervated rats. American Journal of Physiology-Regulatory, Integrative and Comparative Physiology, 262, R677-R683.

Franchini, K. G., \& Krieger, E. M. (1993). Cardiovascular responses of conscious rats to carotid body chemoreceptor stimulation by intravenous KCN. Journal of the Autonomic Nervous System, 42, 63-69.

Grundy, D. (2015). Principles and standards for reporting animal experiments in The Journal of Physiology and Experimental Physiology. The Journal of Physiology, 593, 2547-2549.

Guyenet, P. G. (2006). The sympathetic control of blood pressure. Nature Reviews Neuroscience, 7, 335-346.

Katayama, P. L., Castania, J. A., Dias, D. P. M., Patel, K. P., Fazan, R., \& Salgado, H. C. (2015). Role of chemoreceptor activation in hemodynamic responses to electrical stimulation of the carotid sinus in conscious rats. Hypertension, 66, 598-603.

Krieger, E. M. (1964). Neurogenic hypertension in the rat. Circulation Research, 15, 511-521.

Krieger, E. M., Salgado, H. C., \& Michelini, L. C. (1982). Resetting of the baroreceptors. International Review of Physiology, 26, 119-146.

Krieger, M. H., Moreira, E. D., Oliveira, E. M., Oliveira, V. L. L., Krieger, E. M., $\&$ Krieger, J. E. (2006). Dissociaton of blood pressure and sympathetic activation of renin release in sinoaortic-denervated rats. Clinical and Experimental Pharmacology and Physiology, 33, 471-476.

Marcus, N. J., Del Rio, R., Schultz, E. P., Xia, X.-H., \& Schultz, H. D. (2014). Carotid body denervation improves autonomic and cardiac function and attenuates disordered breathing in congestive heart failure. The Journal of Physiology, 592, 391-408.

Miao, C.-Y., \& Su, D.-F. (2002). The importance of blood pressure variability in rat aortic and left ventricular hypertrophy produced by sinoaortic denervation. Hypertension, 20, 1865-1872.

Miao, C.-Y., Xie, H.-H., Zhan, L.-S., \& Su, D.-F. (2006). Blood pressure variability is more important than blood pressure level in determination of end-organ damage in rats. Journal of Hypertension, 24, 1125-1135.

Miao, C.-Y., Yuan, W.-J., \& Su, D.-F. (2003). Comparative study of sinoaortic denervated rats and spontaneously hypertensive rats. American Journal of Hypertension, 16, 585-591.

Paton, J. F. R., Ratcliffe, L., Hering, D., Wolf, J., Sobotka, P. A., \& Narkiewicz, K. (2013). Revelations about carotid body function through its pathological role in resistant hypertension. Current Hypertension Reports, 15, 273-280.

Porzionato, A., Macchi, V., Stecco, C., \& De Caro, R. (2019). The carotid sinus nerve-structure, function, and clinical implications. Anatomical Record, 302, 575-587.

Potts, P. D., Polson, J. W., Hirooka, Y., \& Dampney, R. A. L. (1997). Effects of sinoaortic denervation on Fos expression in the brain evoked by hypertension and hypotension in conscious rabbits. Neuroscience, 77, 503520.

Prabhakar, N. R. (2016). Carotid body chemoreflex: A driver of autonomic abnormalities in sleep apnoea. Experimental Physiology, 101, 975-985.

Ribeiro, M. J., Sacramento, J. F., Gonzalez, C., Guarino, M. P., Monteiro, E. C., \& Conde, S. V. (2013). Carotid body denervation prevents the development of insulin resistance and hypertension induced by hypercaloric diets. Diabetes, 62, 2905-2916. 
Schultz, H. D., Marcus, N. J., \& Del Rio, R. (2013). Role of the carotid body in the pathophysiology of heart failure. Current Hypertension Reports, 15 , 356-362.

Seagard, J. L., van Brederode, J. F., Dean, C., Hopp, F. A., Gallenberg, L. A., \& Kampine, J. P. (1990). Firing characteristics of single-fiber carotid sinus baroreceptors. Circulation Research, 66, 1499-1509.

Silva, E. F., Sera, C. T. N., Mourão, A. A., Lopes, P. R., Moreira, M. C. S., Ferreira-Neto, M. L., ... Pedrino, G. R. (2015). Involvement of sinoaortic afferents in renal sympathoinhibition and vasodilation induced by acute hypernatremia. Clinical and Experimental Pharmacology and Physiology, 42, 1135-1141.

Sirvente, R. A., Irigoyen, M. C., Souza, L. E., Mostarda, C., La Fuente, R. N., Candido, G. O., ... Salemi, V. M. C. (2014). Cardiac impairment evaluated by transesophageal echocardiography and invasive measurements in rats undergoing sinoaortic denervation. PLoS ONE, 9, e87935.
Van Vliet, B. N., Chafe, L. L., \& Montani, J. P. (1999). Contribution of baroreceptors and chemoreceptors to ventricular hypertrophy produced by sino-aortic denervation in rats. The Journal of Physiology, 516, 885-895.

Zhang, Z. Q., Barrès, C., \& Julien, C. (1995). Involvement of vasodilator mechanisms in arterial pressure lability after sino-aortic baroreceptor denervation in rat. The Journal of Physiology, 482, 435-448.

How to cite this article: Castania JA, Katayama PL, Brognara F, Moraes DJA, Sabino JPJ, Salgado HC. Selective denervation of the aortic and carotid baroreceptors in rats. Experimental Physiology. 2019;104:1335-1342. https://doi.org/10.1113/ EP087764 
Research report

\title{
Baroreflex stimulation attenuates central but not peripheral inflammation in conscious endotoxemic rats
}

\author{
Fernanda Brognara ${ }^{a}$, Jaci A. Castania ${ }^{a}$, Daniel P.M. Dias ${ }^{a}$, Alexandre H. Lopes ${ }^{b}$, Rubens Fazan Jr. ${ }^{a}$, \\ Alexandre Kanashiro $^{c}$, Luis Ulloa ${ }^{\mathrm{d}, *}$, Helio C. Salgado ${ }^{\mathrm{a}, *}$
}

${ }^{a}$ Department of Physiology, Ribeirão Preto Medical School, University of São Paulo, Ribeirão Preto, SP, Brazil

${ }^{\mathrm{b}}$ Department of Pharmacology, Ribeirão Preto Medical School, University of São Paulo, Ribeirão Preto, SP, Brazil

${ }^{\mathrm{c}}$ Department of Physiological Sciences, Federal University of São Carlos, São Carlos, SP, Brazil

d Department of Surgery, Center for Immunology and Inflammation, Rutgers University - New Jersey Medical School, Newark, NJ 07103, USA

\section{A R T I C L E I N F O}

\section{Article history:}

Received 8 September 2017

Received in revised form 16 December 2017

Accepted 2 January 2018

Available online 6 January 2018

\section{Keywords:}

Baroreflex

Aortic depressor nerve

Neuroimmunomodulation

Inflammation

Lipopolysaccharide

Hypothalamus

\begin{abstract}
A B S T R A C T
We previously reported that activation of the baroreflex, a critical physiological mechanism controlling cardiovascular homeostasis, through electrical stimulation of the aortic depressor nerve attenuates joint inflammation in experimental arthritis. However, it is unknown whether baroreflex activation can control systemic inflammation. Here, we investigate whether baroreflex activation controls systemic inflammation in conscious endotoxemic rats. Animals underwent sham or electrical aortic depressor nerve stimulation initiated 10 min prior to a lipopolysaccharide (LPS) challenge, while inflammatory cytokine levels were measured in the blood, spleen, heart and hypothalamus 90 min after LPS treatment. Baroreflex activation did not affect LPS-induced levels of pro-inflammatory (tumor necrosis factor, interleukin $1 \beta$ and interleukin 6) or anti-inflammatory (interleukin 10) cytokines in the periphery (heart, spleen and blood). However, baroreflex stimulation attenuated LPS-induced levels of all these cytokines in the hypothalamus. Notably, these results indicate that the central anti-inflammatory mechanism induced by baroreflex stimulation is independent of cardiovascular alterations, since aortic depressor nerve stimulation that failed to induce hemodynamic changes was also efficient at inhibiting inflammatory cytokines in the hypothalamus. Thus, aortic depressor nerve stimulation might represent a novel therapeutic strategy for neuroprotection, modulating inflammation in the central nervous system.
\end{abstract}

(c) 2018 Elsevier B.V. All rights reserved.

\section{Introduction}

The nervous system has been selected through evolution to control physiological homeostasis. One of the most critical processes of neuromodulation is the ability of the nervous system to regulate innate immunity and modulate inflammation. There are three major pathways of neuromodulation: the hypothalamic-pit uitaryadrenal axis (Sternberg et al., 1989), the cholinergic vagal anti-inflammatory pathway (Tracey, 2002; Ulloa, 2005), and the sympathetic splanchnic anti-inflammatory pathway (Martelli et al., 2014b). We recently reported that baroreflex activation through electrical stimulation of the aortic depressor nerve (ADN) attenuates, via sympathetic innervation, joint inflammation

* Corresponding authors at: Department of Physiology, Ribeirão Preto Medical School, University of São Paulo. Av. Bandeirantes, 3900, 14049-900, Ribeirão Preto SP, Brazil (H.C. Salgado). Medical Science Building (MSB) 185 South Orange Avenue Room, Newark, NJ 07101, USA (L. Ulloa).

E-mail addresses: ulloalu@njms.rutgers.edu (L. Ulloa), hcsalgado@fmrp.usp.br (H.C. Salgado). in a rat model of arthritis. Our results depicted the baroreflex antiinflammatory pathway as a new physiological mechanism of neuromodulation of inflammation and the innate immune system (Bassi et al., 2015).

Baroreceptors are sensory neurons monitoring the arterial pressure in the aortic arch, carotid sinuses and major blood vessels (Chapleau et al., 1988; Krieger et al., 1982). These mechanoreceptors induce reflex responses increasing parasympathetic and decreasing sympathetic drive to maintain the blood pressure at nearly constant levels (Chapleau et al., 1988; Krieger et al., 1982). Baroreflex activation is considered a promising therapeutic approach for patients with resistant hypertension (Alnima et al., 2014; Bisognano et al., 2011; Halbach et al., 2015; Hoppe et al., 2012). Clinical studies showed that hypertensive patients have attenuated baroreflex function (Ding et al., 2011; Huang et al., 2017; Subha et al., 2016) associated with a high inflammatory profile (Harrison et al., 2011; Mattace-Raso et al., 2010; Sesso et al., 2007; Solak et al., 2016). These results suggest that baroreflex dysfunction may facilitate inflammation in hypertensive subjects. 
We recently reported that baroreflex activation attenuates local inflammation in arthritic knee joints (Bassi et al., 2015). This mechanism significantly inhibits neutrophil recruitment, articular edema and inflammatory cytokine levels in the synovial fluid (Bassi et al., 2015). This anti-inflammatory mechanism involves sympathetic modulation (Bassi et al., 2015); however, it is unknown whether baroreflex activation can control systemic inflammation. To expand knowledge about the anti-inflammatory potential of electrical stimulation of the baroreflex, we analyze, in the present study, whether baroreflex activation by electrical ADN stimulation controls systemic inflammation in endotoxemic rats.

\section{Results}

\subsection{Time course of cardiovascular responses to bacterial endotoxin}

Intraperitoneal administration of either saline or lipopolysaccharide (LPS) did not affect the mean arterial pressure (MAP) (Fig. 1). However, LPS induced tachycardia $45 \mathrm{~min}$ after its administration, which lasted up to 90 min compared to the saline treatment (Fig. 1).

\subsection{Baroreflex activation and hemodynamic responses}

Electrical ADN stimulation quickly (within the first $5 \mathrm{~s}$ ) decreased MAP and heart rate (HR) (Fig. 2A and B). These effects were transient because the hemodynamic parameters had returned to baseline levels at the 20th min of electrical ADN stimulation. However, electrical ADN stimulation did not affect cardiocirculatory hemodynamics in 12 of 25 animals. Even with electrical stimulation, these animals did not present a decrease in MAP and HR (Fig. 2C and D). Moreover, the animals in the LPS + ADNs (-)
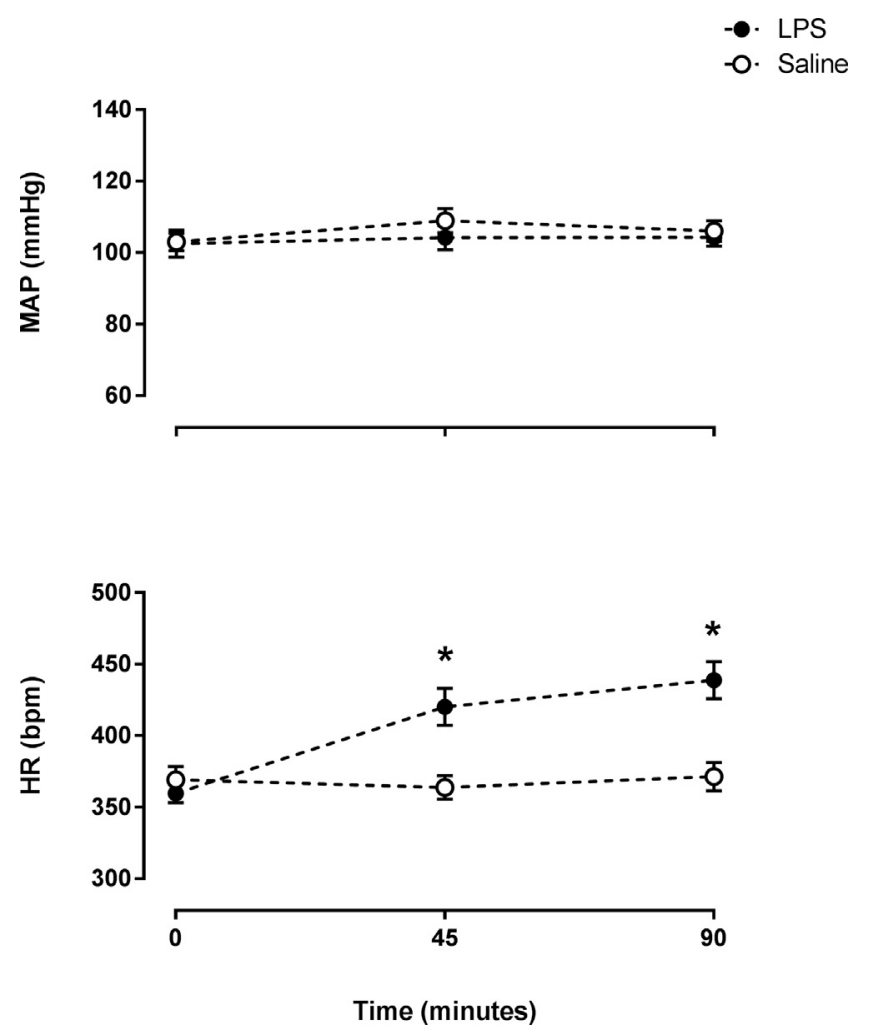

Fig. 1. LPS increased heart rate but did not affect the mean arterial pressure. Time course of mean arterial pressure (MAP) and heart rate (HR) at baseline (time zero), 45 and 90 min after the administration of LPS $(n=13)$ or saline $(n=12) .{ }^{*} \mathrm{P}<.05$ vs. Saline. group showed a statistical increase of $9 \%$ in HR at the 20th min of electrical ADN stimulation (10 min after LPS injection) without affecting MAP (Fig. 2D). Nevertheless, all endotoxemic animals exhibited an increased HR by the end of the experimental protocol at the 90th min after the LPS challenge (Fig. 3).

\subsection{Baroreflex stimulation did not affect peripheral cytokine levels in endotoxemic rats}

Intraperitoneal injection of bacterial LPS increased the plasma levels of all cytokines analyzed, including pro-inflammatory cytokines [tumor necrosis factor (TNF), interleukin $1 \beta$ (IL-1 $\beta$ ) and interleukin 6 (IL-6)] and anti-inflammatory cytokine [interleukin 10 (IL-10)] (Fig. 4A-D). Baroreflex stimulation did not affect the levels of any of these cytokines in the blood (Fig. 4A-D). LPS also increased the levels of TNF and IL-6 in the heart and spleen (Fig. 4E, G, I and K). In addition, LPS specifically increased IL-1 $\beta$ levels in the heart but not in the spleen (Fig. 4F and J). LPS also induced anti-inflammatory cytokine IL-10 in the blood, but not in the heart or the spleen (Fig. 4D, H, L). Thus, ADN stimulation did not change the peripheral levels of any of these cytokines in the blood, spleen or heart. These results indicate that baroreflex stimulation did not regulate peripheral cytokine levels in endotoxemia. It is important to highlight that despite the short recovery time from surgery, the subjects did not exhibit any sign of sickness behavior until the beginning of the experiment.

\subsection{Baroreflex stimulation attenuated central cytokine levels in the hypothalamus}

Intraperitoneal LPS administration also increased the levels of all the cytokines in the hypothalamus, including inflammatory (TNF, IL-1 $\beta$, IL-6) and anti-inflammatory (IL-10) cytokines (Fig. 5A-D). Baroreflex activation attenuated the LPS-induced levels of all the cytokines in the hypothalamus (Fig. 5A-D) independent of the cardiovascular effects.

\section{Discussion}

The present results show that electrical stimulation of the ADN, a known afferent nerve responsible for controlling cardiovascular homeostasis, induced central anti-inflammatory effects inhibiting LPS-induced hypothalamic levels of all cytokines analyzed. This effect is due to a direct central, but not peripheral, mechanism because ADN stimulation did not affect the levels of any of these cytokines in the peripheral blood or organs. In the present study, we injected LPS intraperitoneally and studied whether baroreflex stimulation can control systemic inflammation. This experimental model of systemic inflammation has been widely used in the literature to investigate new therapeutic strategies for sepsis (Cai et al., 2010).

It is well-established that cytokines control inflammation and induce cellular damage and organ failure contributing to the pathogenesis of multiple acute and chronic disorders such as sepsis and autoimmune diseases (Akiyama et al., 2000; Allan and Rothwell, 2001; Mennicken et al., 1999). Inflammatory cytokines mediate communication between the immune and other systems inducing particular biological activities after binding to the receptors of the targeted cells (Wyss-Coray and Mucke, 2002). Neurons also have cytokine receptors, suggesting an active bidirectional crosstalk between the immune and nervous systems (WyssCoray and Mucke, 2002). Additionally, cytokines have different functions in the central nervous system and can induce neurotoxicity, which appears to contribute to the physiopathology of psychiatric [depression, schizophrenia] and neurodegenerative 
LPS + ADNs

A

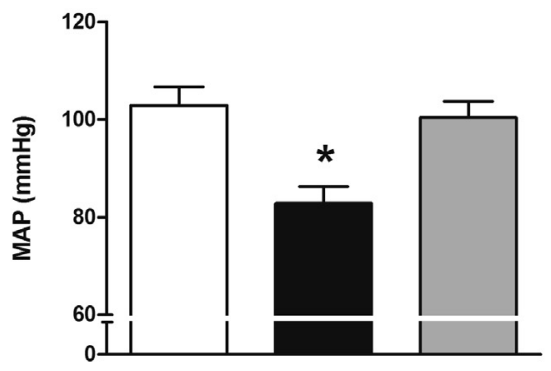

B

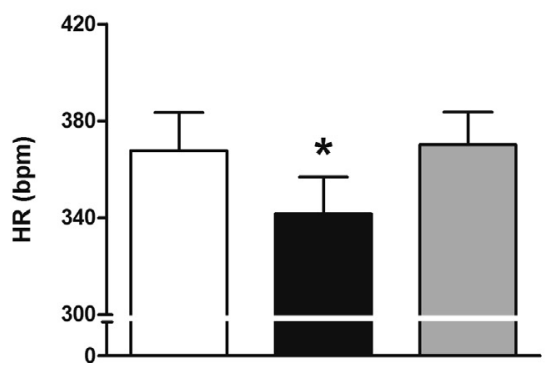

LPS + ADNs (-)

C

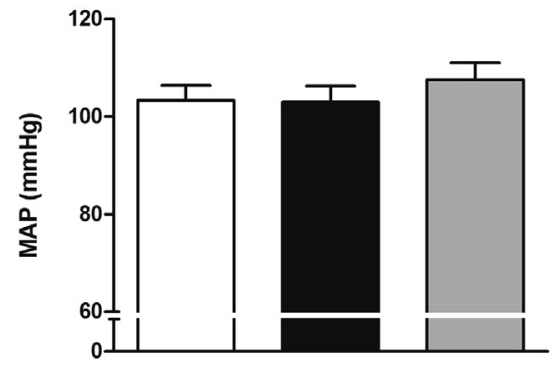

D

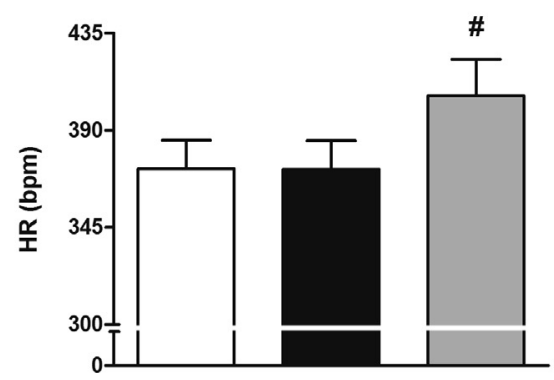

Fig. 2. Hemodynamic responses to electrical stimulation of the aortic depressor nerve. Bar graphs represent the mean arterial pressure (MAP; A and C) and heart rate (HR; B and $\mathrm{D}$ ) at baseline; at $5 \mathrm{~s}$ after initiating electrical stimulation of the aortic depressor nerve (ADNs), with (LPS + ADNs) or without [LPS + ADNs ( - )] hemodynamic changes; and at the end of electrical stimulation ( 5 s). LPS + ADNs: $n=13$; LPS + ADNs $(-): n=12$. Bars represent mean \pm standard error. ${ }^{*} P<.05$ vs. baseline; ${ }^{*} \mathrm{P}<.05$ vs. baseline and first $5 \mathrm{~s}$ of ADNs.

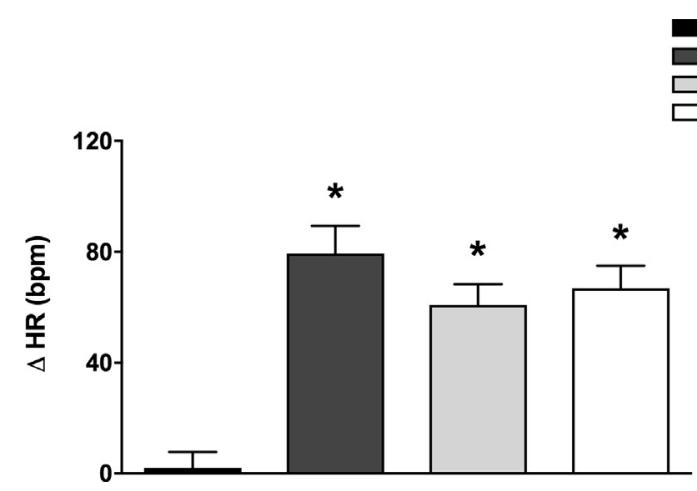

Fig. 3. Ninety minutes after the LPS injection, aortic depressor nerve stimulation did not attenuate the increase in heart rate induced by LPS. Bar graphs show the changes in heart rate $(\triangle \mathrm{HR}) 90 \mathrm{~min}$ after the administration of saline or LPS, or LPS combined or not combined with previous aortic depressor nerve stimulation (ADNs), with or without hemodynamic changes. Bars represent mean \pm standard error, $\mathrm{n}=12$ to $13 .{ }^{*} \mathrm{P}<.05$ vs. saline.

diseases [Parkinson's and Alzheimer's diseases] (Allan and Rothwell, 2003; Corsi-Zuelli et al., 2017; Dantzer et al., 2008). Moreover, since inflammation in the central nervous system, particularly in the hypothalamus, has recently been shown to be intricately involved in the development and maintenance of hypertension (Khor and Cai, 2017), we suggest that the selective and central anti-inflammatory potential of ADN stimulation could be an additional mechanism involved in the baroreflex antihypertensive effects.

Current studies highlight the need to develop innovative therapies based on electrical neural stimulation for treating diseases with non-pharmacological approaches (De Ferrari et al., 2011; Famm et al., 2013; Schwartz, 2013). "Electroceuticals" have been considered a promising future for treating a number of diseases including central inflammatory and neurological disorders (Famm et al., 2013). Recent studies showed that electrical stimulation of peripheral nerves (including vagus) or direct brain stimulation, induces protective effects in ischemic stroke, traumatic brain injury, as well as in experimental cerebral ischemia and reperfusion (Jiang et al., 2014; Meneses et al., 2016; Notturno et al., 2014; Schweighöfer et al., 2016).

Our study shows that baroreflex stimulation inhibits LPSinduced inflammatory cytokines in the brain (hypothalamus). Surprisingly, electrical ADN stimulation that failed to induce hemodynamic changes was also efficient at inhibiting inflammatory cytokines in the hypothalamus. These findings suggest that the central baroreflex anti-inflammatory mechanism is independent of cardiovascular alterations. In line with our results, vagal stimulation at high intensity produces hemodynamic alterations but not anti-inflammatory effects, while low intensity vagal stimulation induces immunomodulatory properties without promoting hemodynamic alterations (Bassi et al., 2017). Thus, our results indicate that during parasympathetic activation, it is not essential for changes in the hemodynamic parameters to occur in order for an anti-inflammatory effect to occur.

Although baroreflex stimulation attenuated central cytokine levels, it did not affect peripheral cytokines in endotoxemic animals. In fact, electrical ADN stimulation did not change the levels of inflammatory cytokines (TNF, IL-1 $\beta$ and IL-6) and antiinflammatory cytokine IL-10 in the plasma, spleen or heart. Of note, the baroreflex acts by reducing sympathetic and increasing parasympathetic drive (Chapleau et al., 1988; Krieger et al., 
PLASMA

A

\section{TNF}

(\% Control)

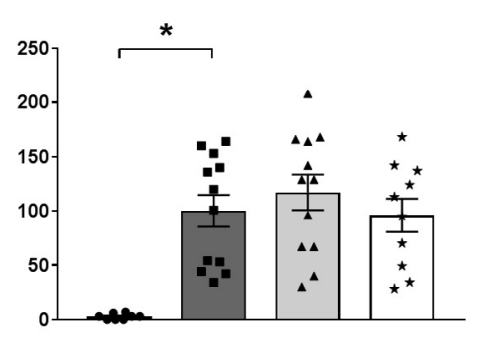

B

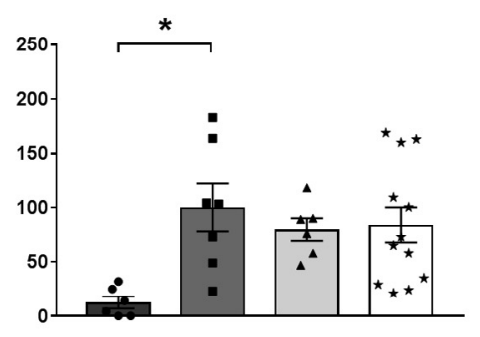

C

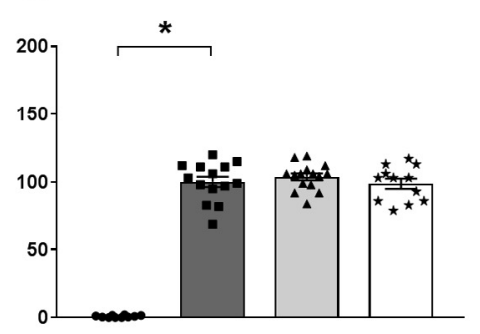

D

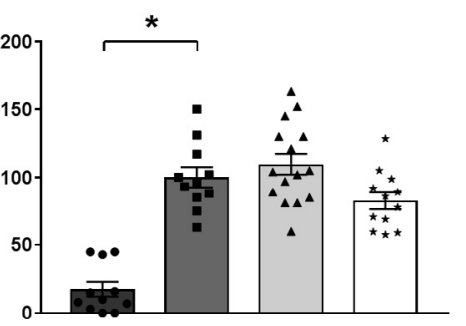

E

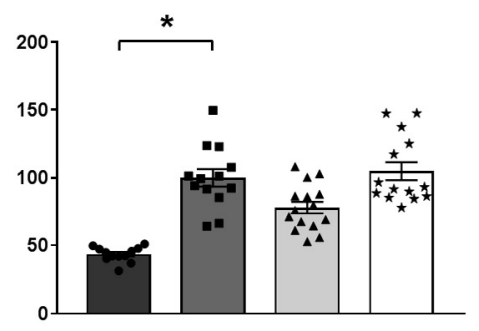

F

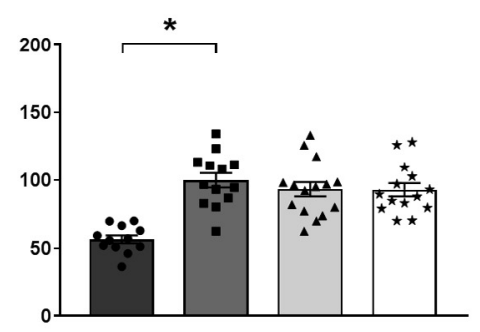

G

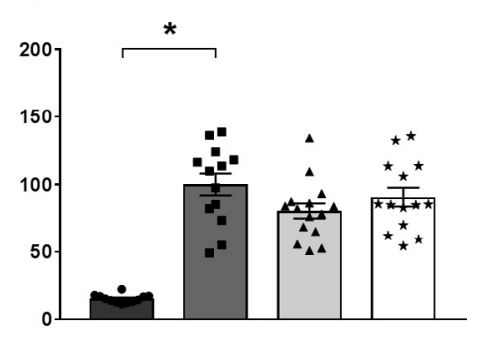

$\mathrm{H}$

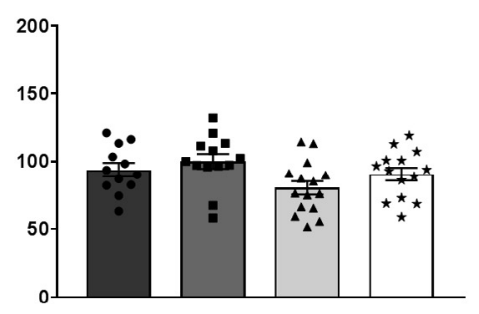

I

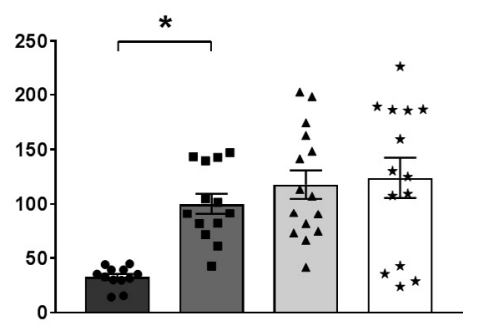

J

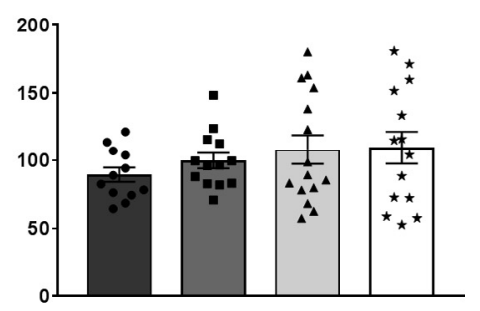

K

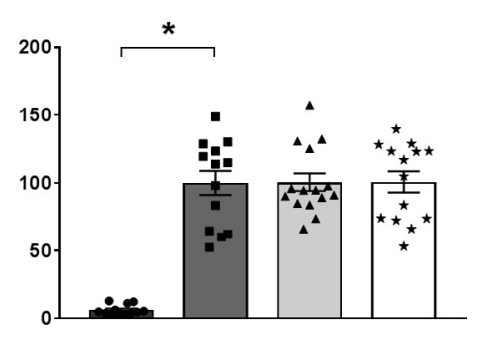

L

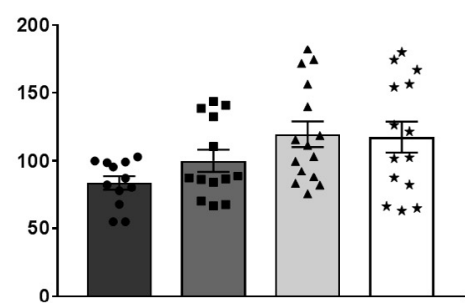

Fig. 4. Aortic depressor nerve stimulation did not affect plasma and peripheral organ (heart and spleen) levels of cytokines in response to LPS administration. Plasma (A, B, C and D) and tissue (heart: E, F, G, H and spleen: I, J, K and L) levels of pro-inflammatory and anti-inflammatory cytokines 90 min after the administration of saline or LPS, or LPS combined or not combined with electrical stimulation of the aortic depressor nerve (ADNs), with or without hemodynamic changes. Tumor necrosis factor (TNF): plasma (A),

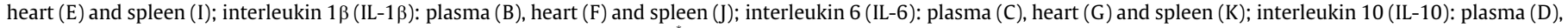
heart $(\mathrm{H})$ and spleen $(\mathrm{L})$. Bars represent mean \pm standard error, $\mathrm{n}=6-15{ }^{*} \mathrm{P}<.05$.

1982), a well-known autonomic network controlling inflammation (Huston et al., 2006; Martelli et al., 2016; Tracey, 2002). It is wellestablished that the spleen is the main source of peripheral TNF, which is released into the bloodstream during endotoxemia (Huston et al., 2006). However, taking into account that the spleen is also the targeted organ of the "inflammatory reflex" (Huston et al., 2006) and that the sympathetic splanchnic nerve inhibits the inflammatory response in the spleen (Martelli et al., 2016), it is surprising that baroreflex stimulation did not affect systemic cytokine levels. However, it is possible that simultaneous activation of the parasympathetic nervous system (anti-inflammatory) and inhibition of the sympathetic nervous system (proinflammatory) following electrical activation of the baroreflex accounted for the lack of effect on systemic inflammation. Never- 


\section{HYPOTHALAMUS}

A

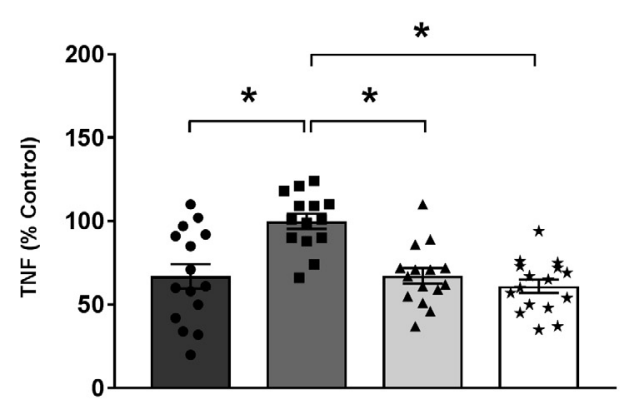

C

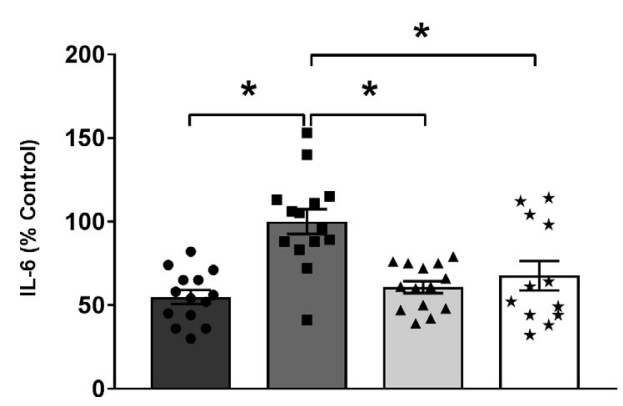

B

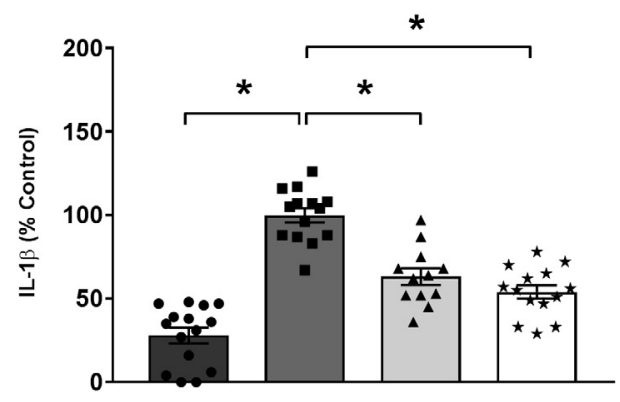

D

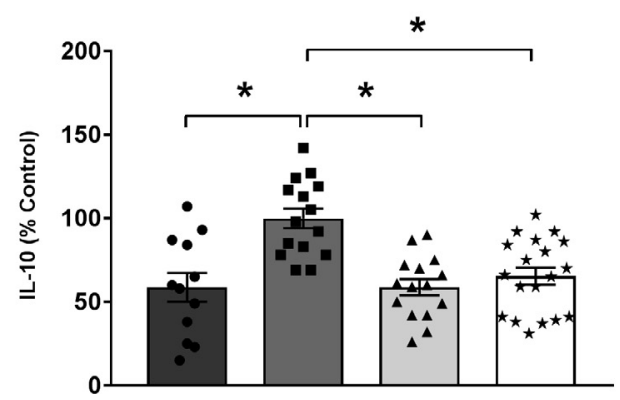

Fig. 5. Aortic depressor nerve stimulation decreases the LPS-induced production of cytokines in the hypothalamus. Hypothalamic levels of tumor necrosis factor (TNF, $A$ ), interleukin $1 \beta$ (IL-1 $\beta, B$ ), interleukin 6 (IL-6,C) and interleukin 10 (IL-10, D) 90 min after the administration of saline or LPS, or LPS combined or not combined with stimulation of the aortic depressor nerve (ADNs), with or without hemodynamic changes. Bars represent mean \pm standard error, $\mathrm{n}=12$ to 19 . " $\mathrm{P}<.05$.

theless, our present results concur with previous studies of our group showing that baroreflex activation via ADN stimulation inhibits joint cytokine levels in experimental arthritis by sympathetic modulation, but, again, through a mechanism independent of the spleen (Bassi et al., 2015).

An important aspect of our study is that the experiments were performed in unanesthetized animals, mimicking clinical settings and physiological conditions (De Paula et al., 1999; Salgado et al., 2006). Previous studies investigating neural electrical stimulation were conducted primarily in anesthetized rodents. A significant exception can be attributed to Martelli and colleagues (Martelli et al., 2014a) who demonstrated, in conscious rats, that the splanchnic anti-inflammatory pathway has a powerful and sustained inhibitory influence on inflammatory processes. It is well known that anesthetics interfere particularly with the neural mechanisms modulating the immune system (Picq et al., 2013). For instance, several studies showed that ketamine and isoflurane exhibit potent anti-inflammatory properties (Flondor et al., 2008; Hofstetter et al., 2005; Qin et al., 2015). Notably, our laboratory studies of neural cardiocirculatory control in conscious rodents has provided significant information concerning the neural regulation of inflammation (Bassi et al., 2015), particularly under physiological conditions without the interference of anesthesia, as conducted in the present study.

\section{Conclusions}

Baroreflex activation could be used as a novel therapeutic strategy for treating inflammatory diseases involving the central ner- vous system, such as stroke, brain trauma, amyotrophic lateral sclerosis, Parkinson's and Alzheimer's disease and even hypertension. However, future studies are required to investigate the neural pathways and molecular mechanisms mediating these neuroprotective properties, as well as the optimal parameters for activating the ADN under different inflammatory conditions.

\section{Experimental procedure}

\subsection{Experimental animals}

The experiments were performed on male Wistar rats weighing 250-300 g obtained from the Main Animal Facility of the University of São Paulo (Campus of Ribeirão Preto; Ribeirão Preto, SP, Brazil), maintained under controlled temperature $\left(22^{\circ} \mathrm{C}\right)$ and constant $12 \mathrm{~h}$ light-dark cycle and provided with food and water ad libitum. All procedures were reviewed and approved by the Committee of Ethics in Animal Research of the Ribeirão Preto Medical School University of São Paulo (Protocol number 161/2016).

\subsection{Surgical procedures}

Animals were anesthetized with a cocktail of ketamine and xylazine (50 $\mathrm{mg} / \mathrm{kg}$ and $10 \mathrm{mg} / \mathrm{kg}$, i.p.) and then subjected to surgical procedures to isolate the left ADN for the implantation of electrodes, catheterization of the femoral artery and insertion of a peritoneal catheter. The catheter implanted into the femoral artery was filled with $100 \mathrm{IU} / \mathrm{ml}$ heparin in saline. The ADN group was implanted with a bipolar stainless-steel electrode with an inter- 
leads distance of $2 \mathrm{~mm}$. The electrodes were constructed by attaching two $40 \mathrm{~mm}$ long stainless-steel wires (0.008 in. bare, $0.011 \mathrm{in}$. Teflon coated; model 791,400; A-M Systems, Sequim, WA, USA) to a small plug (GF-6; Microtech, Boothwyn, PA, USA). The bared tips of the electrodes consisted of $2 \mathrm{~mm}$ lengths, forming hooks that were implanted around the ADN. First, the electrode was tunneled through the sternocleidomastoid muscle and the small plug was exteriorized in the nape of the neck. Next, the short segment of the ADN that was implanted with the bipolar stainless-steel electrodes was carefully covered with silicone impression material (Kwik-Sil silicone elastomer; World Precision Instruments, Sarasota, FL, USA). A few minutes were allowed for complete polymerization of the silicone impression material. In the "sham surgery" groups, the animals were subjected to the same surgical procedures, but the electrodes were not implanted around the nerve.

Under the same anesthesia, the left femoral artery was catheterized with polyethylene tubing (PE-50 soldered to PE-10 polyethylene tube; Intramedic, Clay Adams, Parsippany, NJ, USA) for arterial pressure recording. Additionally, a catheter (PE-50 polyethylene tube; Intramedic, Clay Adams, Parsippany, NJ, USA) was inserted into the abdominal cavity for the administration of LPS from Escherichia coli 0111: B4 (Sigma-Aldrich, St. Louis, MO, USA) or sterile saline (vehicle). The catheters were pulled up through a subcutaneous track to the animal's neck and exteriorized in the back of the nape; next, the surgical incisions were sutured. Flunixin meglumine (Banamine, $2.5 \mathrm{mg} / \mathrm{kg}$, i.m.; Schering-Plough, Cotia, SP, Brazil) was injected immediately after the end of surgery.

\subsection{Assessment of the hemodynamic parameters and electrical} stimulation of the aortic depressor nerve

Twenty-four hours after the surgical procedures, arterial pressure and HR from conscious rats were recorded. Briefly, the arterial catheter was connected to a pressure transducer (MLT844; ADInstruments, Bella Vista, Australia) and the signal was amplified (ML224; ADInstruments, Bella Vista, Australia) and sampled by an IBM/PC computer (Core 2 Duo, $2.2 \mathrm{GHz}, 4 \mathrm{~GB}$ RAM) attached to an analog-to-digital interface (PowerLab, ADInstruments, Bella Vista, Australia). The experiment was conducted with the animals moving freely in their own cage (one rat per cage) and silence was maintained to minimize environment stress. Only rats that showed no signs of distress during electrical stimulation of the ADN were assigned to the study. The electrodes were connected to an external square pulse generator to activate the $\operatorname{ADN}(0.5 \mathrm{~mA}, 0.25 \mathrm{~ms}$, $15 \mathrm{~Hz}$ ). Arterial pressure recordings were processed with computer software (LabChart 7.0, ADInstruments, Bella Vista, Australia) capable of detecting inflection points and systolic, diastolic and mean arterial pressure, as well as HR beat-by-beat time series.

\subsection{Experimental procedures}

The rats were assigned into four groups:

1) Saline: Sham surgery of electrode implantation around the ADN and vehicle administration;

2) LPS: Sham surgery of electrode implantation around the ADN and LPS administration;

3) $\mathrm{LPS}+\mathrm{ADNs}(-)$ : Electrode implantation around the ADN, electrical stimulation combined with failure to promote hemodynamic effects and LPS administration;

4) LPS + ADNs: Electrode implantation around the ADN, electrical stimulation showing hemodynamic effects and LPS administration.

The experimental protocol consisted of basal recordings of arterial pressure and HR for $30 \mathrm{~min}$, followed by electrical stimulation of the $\mathrm{ADN}$ for $10 \mathrm{~min}$ before and $10 \mathrm{~min}$ after intraperitoneal administration of LPS ( $5 \mathrm{mg} / \mathrm{kg}$, i.p.) or vehicle ( $5 \mathrm{~mL} / \mathrm{kg}$, i.p.). LPS was sonicated for $30 \mathrm{~min}$ before the injection. The hemodynamic parameters were recorded throughout $90 \mathrm{~min}$ after LPS injection, and then the blood samples were collected through the catheter from the femoral artery before the rats were killed by decapitation for rapid collection of the spleen, heart and hypothalamus. The entire hypothalamus was dissected from the brain taking into account the following limits: the anterior border of the optic chiasma, the anterior border of the mammillary bodies, and the lateral hypothalamic sulci with a depth of $2 \mathrm{~mm}$. The samples of spleen, heart and hypothalamus were immediately frozen in liquid nitrogen. Blood samples were maintained on ice until centrifugation at $3500 \mathrm{rpm}$ for $15 \mathrm{~min}$ at $4{ }^{\circ} \mathrm{C}$. The plasma was then collected, and all biological material was frozen at $-80^{\circ} \mathrm{C}$ and stored until analysis.

\subsection{Cytokine measurements}

On the day of the assay, the samples were thawed and maintained on ice. The hypothalamus, spleen, and heart were homogenized in $0.5 \mathrm{~mL}$ of PBS using a Politron-PT-3100 (Evisa; Kinematica, Luzern, Switzerland) and then centrifuged at $1.000 \mathrm{rpm}$ for $10 \mathrm{~min}$ at $4{ }^{\circ} \mathrm{C}$. The plasma and tissue supernatant samples were used to measure the cytokine (TNF, IL-1 $\beta$, IL-6, and IL-10) levels by an immune-enzymatic ELISA method using Duo set kits from R\&D Systems (Minneapolis, MN, USA) according to the manufacturer's instructions. Plasma and tissue cytokine levels are expressed as percentages compared to the control group (LPS).

\subsection{Statistical analysis}

The hemodynamic parameters were analyzed by one-way analysis of variance (ANOVA) for repeated measures followed by Student-Newman-Keuls post hoc test when indicated, two-way ANOVA for repeated measures followed by Student-NewmanKeuls post hoc test, or one-way ANOVA followed by Dunn's post hoc test. The data obtained from the tissues and plasma were analyzed either by one-way ANOVA with Student-Newman-Keuls post hoc test or by Kruskal-Wallis - a nonparametric statistical test followed by Dunn's post hoc test when the data did not pass the Shapiro-Wilk test of normality. Differences were considered statistically significant if $\mathrm{P}<.05$. The results are shown as the mean $\pm \mathrm{s}$ tandard error of the mean.

\section{Acknowledgements}

FB held a Scholarship for Scientific Initiation from FAPESP (Fundação de Amparo à Pesquisa do Estado de São Paulo - Brazil), Process \# 2014/15386-4; and now holds a PhD Scholarship from FAPESP, Process \# 2017/05163-6. This work received financial support from FAPESP, Process \# 2013/20549-7 and \# 2011/20343-4.

\section{References}

Akiyama, H., Barger, S., Barnum, S. Bradt B. Bauer, J., Cole, G.M., Cooper, N.R., Eikelenboom, P., Emmerling, M., Fiebich, B.L., Finch, C.E., Frautschy, S., Griffin, W.S., Hampel, H., Hull, M., Landreth, G., Lue, L., Mrak, R., Mackenzie, I.R., McGeer, P.L., O’Banion, M.K., Pachter, J., Pasinetti, G., Plata-Salaman, C., Rogers, J., Rydel, R., Shen, Y., Streit, W., Strohmeyer, R., Tooyoma, I., Van Muiswinkel, F. L., Veerhuis, R., Walker, D., Webster, S., Wegrzyniak, B., Wenk, G., Wyss-Coray, T., 2000. Inflammation and Alzheimer's disease. Neurobiol. Aging 21, 383-421. Allan, S.M., Rothwell, N.J., 2003. Inflammation in central nervous system injury. Philos. Trans. R. Soc. Lond., B Biol. Sci. 358, 1669-1677. https://doi.org/10.1098/ rstb.2003.1358

Allan, S.M., Rothwell, N.J., 2001. Cytokines and acute neurodegeneration. Nat. Rev. Neurosci. 2, 734-744. https://doi.org/10.1038/35094583. 
Alnima, T., Kroon, A.A., de Leeuw, P.W., 2014. Baroreflex activation therapy for patients with drug-resistant hypertension. Expert Rev. Cardiovasc. Ther. 12 955-962. https://doi.org/10.1586/14779072.2014.931226.

Bassi, G.S., Brognara, F., Castania, J.A., Talbot, J., Cunha, T.M., Cunha, F.Q., Ulloa, L., Kanashiro, A., Dias, D.P.M., Salgado, H.C., 2015. Baroreflex activation in conscious rats modulates the joint inflammatory response via sympathetic function. Immun. Brain Behav. https://doi.org/10.1016/j.bbi.2015.05.002.

Bassi, G.S., Dias, D.P.M., Franchin, M., Talbot, J., Reis, D.G., Menezes, G.B., Castania, J A., Garcia-Cairasco, N., Resstel, L.B.M., Salgado, H.C., Cunha, F.Q., Cunha, T.M. Ulloa, L., Kanashiro, A., 2017. Modulation of experimental arthritis by vagal sensory and central brain stimulation. Brain Behav. Immun. 64, 330-343. https://doi.org/10.1016/j.bbi.2017.04.003.

Bisognano, J.D., Bakris, G., Nadim, M.K., Sanchez, L., Kroon, A.A., Schafer, J., de Leeuw, P.W., Sica, D.A., 2011. Baroreflex activation therapy lowers blood pressure in patients with resistant hypertension: results from the double-blind, randomized, placebo-controlled rheos pivotal trial. J. Am. Coll. Cardiol. 58, 765-773. https://doi.org/10.1016/j.jacc.2011.06.008.

Cai, B., Deitch, E.A., Ulloa, L., 2010. Novel insights for systemic inflammation in sepsis and hemorrhage. Mediators Inflamm. 2010, 642462. https://doi.org/ $10.1155 / 2010 / 642462$

Chapleau, M.W. Hajduczok, G., Abboud, F.M., 1988. Mechanisms of resetting of arterial baroreceptors: an overview. Am. J. Med. Sci. 295, 327-334.

Corsi-Zuelli das, F.M., Brognara, G., Quirino, F., da, G.F., Hiroki, S., Fais, C.H., Del-Ben, R.S., Ulloa, C.M., Salgado, L., Kanashiro, H.C., Loureiro, A., 2017. Neuroimmune interactions in Schizophrenia: focus on vagus nerve stimulation and activation of the alpha-7 nicotinic acetylcholine receptor. Front. Immunol. 8. https://doi. org/10.3389/fimmu.2017.00618.

Dantzer, R., O’Connor, J.C., Freund, G.G., Johnson, R.W., Kelley, K.W., 2008. From inflammation to sickness and depression: when the immune system subjugates the brain. Nat. Rev. Neurosci. 9, 46-56. https://doi.org/10.1038/nrn2297.

De Ferrari, G.M., Crijns, H.J.G.M., Borggrefe, M., Milasinovic, G., Smid, J., Zabel, M., Gavazzi, A., Sanzo, A., Dennert, R., Kuschyk, J., Raspopovic, S., Klein, H. Swedberg, K., Schwartz, P.J., 2011. Chronic vagus nerve stimulation: a new and promising therapeutic approach for chronic heart failure. Eur. Heart J. 32 847-855. https://doi.org/10.1093/eurheartj/ehq391.

De Paula, P.M., Castania, J.A., Bonagamba, L.G., Salgado, H.C., Machado, B.H., 1999. Hemodynamic responses to electrical stimulation of the aortic depressor nerve in awake rats. Am. J. Physiol. 277, R31-R38.

Ding, W., Zhou, L., Bao, Y., Zhou, L., Yang, Y., Lu, B., Wu, X., Hu, R., 2011. Autonomic nervous function and baroreflex sensitivity in hypertensive diabetic patients. Acta Cardiol. 66, 465-470. https://doi.org/10.2143/AC.66.4.2126595.

Famm, K., Litt, B., Tracey, K.J., Boyden, E.S., Slaoui, M., 2013. Drug discovery: a jumpstart for electroceuticals. Nature 496, 159-161. https://doi.org/10.1038/ 496159a.

Flondor, M., Hofstetter, C., Boost, K.A., Betz, C., Homann, M., Zwissler, B., 2008 Isoflurane inhalation after induction of endotoxemia in rats attenuates the systemic cytokine response. Eur. Surg. Res. 40, 1-6. https://doi.org/10.1159/ 000107614

Halbach, M. Hickethier, T., Madershahian, N., Reuter, H., Brandt, M.C. Hoppe, U.C Müller-Ehmsen, J., 2015. Acute on/off effects and chronic blood pressure reduction after long-term baroreflex activation therapy in resistant hypertension. J. Hypertens. 33, 1697-1703. https://doi.org/10.1097| HJH.0000000000000586.

Harrison, D.G., Guzik, T.J., Lob, H.E., Madhur, M.S., Marvar, P.J., Thabet, S.R., Vinh, A Weyand, C.M., 2011. Inflammation, immunity, and hypertension. Hypertension 57, 132-140. https://doi.org/10.1161/HYPERTENSIONAHA.110.163576.

Hofstetter, C., Flondor, M., Boost, K.A., Koehler, P., Bosmann, M., Pfeilschifter, J., Zwissler, B., Mühl, H., 2005. A brief exposure to isoflurane (50 s) significantly impacts on plasma cytokine levels in endotoxemic rats. Int Immunopharmacol. 5, 1519-1522. https://doi.org/10.1016/j.intimp.2005.04.008.

Hoppe, U.C., Brandt, M.-C., Wachter, R., Beige, J., Rump, L.C., Kroon, A.A., Cates, A.W., Lovett, E.G., Haller, H., 2012. Minimally invasive system for baroreflex activation therapy chronically lowers blood pressure with pacemaker-like safety profile: results from the Barostim neo trial. J. Am. Soc. Hypertens. 6, 270 276. https://doi.org/10.1016/j.jash.2012.04.004.

Huang, D., Zhou, J., Su, D., Yu, W., Chen, J., 2017. Variations of perioperative baroreflex sensitivity in hypertensive and normotensive patients. Clin. Exp. Hypertens. 39, 74-79. https://doi.org/10.1080/10641963.2016.1210624.

Huston, J.M., Ochani, M., Rosas-Ballina, M., Liao, H., Ochani, K., Pavlov, V.A. Gallowitsch-Puerta, M., Ashok, M., Czura, C.J., Foxwell, B., Tracey, K.J., Ulloa, L. 2006. Splenectomy inactivates the cholinergic antiinflammatory pathway during lethal endotoxemia and polymicrobial sepsis. J. Exp. Med. 203, 1623 1628. https://doi.org/10.1084/jem.20052362.
Jiang, Y., Li, L., Liu, B., Zhang, Y., Chen, Q., Li, C., 2014. Vagus nerve stimulation attenuates cerebral ischemia and reperfusion injury via endogenous cholinergic pathway in rat. PLoS ONE 9, e102342. https://doi.org/10.1371/journal. pone.0102342.

Khor, S., Cai, D., 2017. Hypothalamic and inflammatory basis of hypertension. Clin. Sci. 131, 211-223. https://doi.org/10.1042/CS20160001.

Krieger, E.M., Salgado, H.C., Michelini, L.C., 1982. Resetting of the baroreceptors. Int. Rev. Physiol. 26, 119-146.

Martelli, D., Farmer, D.G.S., Yao, S.T., 2016. The splanchnic anti-inflammatory pathway: could it be the efferent arm of the inflammatory reflex? Exp. Physiol. 101, 1245-1252. https://doi.org/10.1113/EP085559.

Martelli, D., Yao, S.T., Mancera, J., McKinley, M.J., McAllen, R.M., 2014a. Reflex control of inflammation by the splanchnic anti-inflammatory pathway is sustained and independent of anesthesia. Am. J. Physiol. Regul. Integr. Comp. Physiol. 307, R1085-R1091. https://doi.org/10.1152/ajpregu.00259.2014.

Martelli, D., Yao, S.T., McKinley, M.J., McAllen, R.M., 2014b. Reflex control of inflammation by sympathetic nerves, not the vagus. J. Physiol. 592, 1677-1686. https://doi.org/10.1113/jphysiol.2013.268573.

Mattace-Raso, F.U.S., Verwoert, G.C., Hofman, A., Witteman, J.C.M., 2010 Inflammation and incident-isolated systolic hypertension in older adults: the Rotterdam study. J. Hypertens. 28, 892-895. https://doi.org/10.1097/ HJH.0b013e328336ed26.

Meneses, G., Bautista, M., Florentino, A., Díaz, G., Acero, G., Besedovsky, H., Meneses D., Fleury, A., Del Rey, A., Gevorkian, G., Fragoso, G., Sciutto, E., 2016. Electric stimulation of the vagus nerve reduced mouse neuroinflammation induced by lipopolysaccharide. J. Inflamm. (Lond.) 13, 33. https://doi.org/10.1186/s12950016-0140-5.

Mennicken, F., Maki, R., de Souza, E.B., Quirion, R., 1999. Chemokines and chemokine receptors in the CNS: a possible role in neuroinflammation and patterning. Trends Pharmacol. Sci. 20, 73-78.

Notturno, F., Pace, M., Zappasodi, F., Cam, E., Bassetti, C.L., Uncini, A., 2014 Neuroprotective effect of cathodal transcranial direct current stimulation in a rat stroke model. J. Neurol. Sci. 342, 146-151. https://doi.org/10.1016/j. ins.2014.05.017.

Picq, C.A., Clarençon, D., Sinniger, V.E., Bonaz, B.L., Mayol, J.-F.S., 2013. Impact of anesthetics on immune functions in a rat model of vagus nerve stimulation. PLoS ONE 8, e67086. https://doi.org/10.1371/journal.pone.0067086.

Qin, M.-Z., Gu, Q.-H., Tao, J., Song, X.-Y., Gan, G.-S., Luo, Z.-B., Li, B.-X., 2015 Ketamine effect on HMGB1 and TLR4 expression in rats with acute lung injury. Int. J. Clin. Exp. Pathol. 8, 12943-12948.

Salgado, M.C.O., Justo, S.V.S., Joaquim, L.F., Fazan Jr, R., Salgado, H.C., 2006. Role of nitric oxide and prostanoids in attenuation of rapid baroreceptor resetting. Am. J. Physiol. Heart Circ. Physiol. 290, H1059-H1063. https://doi.org/10.1152/ ajpheart.00219.2005.

Schwartz, P.J., 2013. Vagal stimulation for heart diseases: from animals to men. An example of translational cardiology. Neth. Heart J. 21, 82-84. https://doi.org/ 10.1007/s12471-012-0368-5.

Schweighöfer, H., Rummel, C., Roth, J., Rosengarten, B., 2016. Modulatory effects of vagal stimulation on neurophysiological parameters and the cellular immune response in the rat brain during systemic inflammation. Int. Care Med. Exp. 4 19. https://doi.org/10.1186/s40635-016-0091-4.

Sesso, H.D., Wang, L., Buring, J.E., Ridker, P.M., Gaziano, J.M., 2007. Comparison of interleukin-6 and C-reactive protein for the risk of developing hypertension in women. Hypertension 49, 304-310. https://doi.org/10.1161/01. HYP.0000252664.24294.ff.

Solak, Y., Afsar, B., Vaziri, N.D., Aslan, G., Yalcin, C.E., Covic, A., Kanbay, M., 2016 Hypertension as an autoimmune and inflammatory disease. Hypertens. Res. 39 567-573. https://doi.org/10.1038/hr.2016.35.

Sternberg, E.M. Hill, J.M., Chrousos, G.P. Kamilaris, T, Listwak, S.J. Gold, P.W. Wilder, R.L., 1989. Inflammatory mediator-induced hypothalamic-pituitaryadrenal axis activation is defective in streptococcal cell wall arthritissusceptible Lewis rats. Proc. Natl. Acad. Sci. U.S.A. 86, 2374-2378.

Subha, M. Pal, P. Pal, G.K, Habeebullah, S, Adithan, C, Sridhar, M.G, 2016. Decreased baroreflex sensitivity is linked to sympathovagal imbalance, lowgrade inflammation, and oxidative stress in pregnancy-induced hypertension. Clin. Exp. Hypertens. 38, 666-672. https://doi.org/10.1080/ 10641963.2016.1200596.

Tracey, K.J., 2002. The inflammatory reflex. Nature 420, 853-859. https://doi.org/ 10.1038 /nature 01321.

Ulloa, L., 2005. The vagus nerve and the nicotinic anti-inflammatory pathway. Nat. Rev. Drug Discov. 4, 673-684. https://doi.org/10.1038/nrd1797.

Wyss-Coray, T., Mucke, L., 2002. Inflammation in neurodegenerative disease-a double-edged sword. Neuron 35, 419-432. 


\title{
Changes in the Complexity of Heart Rate Variability with Exercise Training Measured by Multiscale Entropy-Based Measurements
}

\author{
Frederico Sassoli Fazan ${ }^{1}$, Fernanda Brognara ${ }^{1}{ }^{(\mathbb{D}}$, Rubens Fazan Junior ${ }^{1}$, \\ Luiz Otavio Murta Junior 2 (D) and Luiz Eduardo Virgilio Silva 1,3,* (D) \\ 1 Department of Physiology, School of Medicine of Ribeirão Preto, University of São Paulo, Ribeirão Preto, \\ SP 14049-900, Brazil; frederico.fazan@usp.br (F.S.F.); fernanda.brognara@usp.br (F.B.); rfazan@usp.br (R.F.J.) \\ 2 Department of Computing and Mathematics, School of Philosophy, Sciences and Languages of Ribeirão \\ Preto, University of São Paulo, Ribeirão Preto, SP 14040-901, Brazil; murta@usp.br \\ 3 Department of Computer Science, Institute of Mathematics and Computer Sciences, University of São Paulo, \\ São Carlos, SP 13566-590, Brazil \\ * Correspondence: luizeduardo@usp.br
}

Received: 12 December 2017; Accepted: 8 January 2018; Published: 17 January 2018

\begin{abstract}
Quantifying complexity from heart rate variability (HRV) series is a challenging task, and multiscale entropy (MSE), along with its variants, has been demonstrated to be one of the most robust approaches to achieve this goal. Although physical training is known to be beneficial, there is little information about the long-term complexity changes induced by the physical conditioning. The present study aimed to quantify the changes in physiological complexity elicited by physical training through multiscale entropy-based complexity measurements. Rats were subject to a protocol of medium intensity training $(n=13)$ or a sedentary protocol $(n=12)$. One-hour HRV series were obtained from all conscious rats five days after the experimental protocol. We estimated MSE, multiscale dispersion entropy (MDE) and multiscale $\mathrm{SDiff}_{q}$ from HRV series. Multiscale $\mathrm{SDiff}_{q}$ is a recent approach that accounts for entropy differences between a given time series and its shuffled dynamics. From SDiff $f_{q}$, three attributes ( $q$-attributes) were derived, namely SDiff $q_{\max }, q_{\max }$ and $q_{z e r o}$. MSE, MDE and multiscale $q$-attributes presented similar profiles, except for SDiff $q_{\max } . q_{\max }$ showed significant differences between trained and sedentary groups on Time Scales 6 to 20. Results suggest that physical training increases the system complexity and that multiscale $q$-attributes provide valuable information about the physiological complexity.
\end{abstract}

Keywords: sample entropy; dispersion entropy; multiscale entropy; complexity; heart rate variability; rat; exercise; physical training; conditioning

\section{Introduction}

The study of system complexity is very challenging and has attracted much attention in the past few years [1-3]. Physiological complexity reflects the interoperability and correct functioning of regulatory processes as a whole, so the higher the complexity, the higher the system ability to adapt to different situations in daily life [4].

Heart rate variability (HRV) series, derived from the electrocardiogram (ECG) or arterial pressure signals, is one of the most important sources of information about system physiological status. Heart rate is actively controlled by the autonomic nervous system and can respond to many situations when the organism is challenged. A number of studies demonstrated that many indices extracted from HRV are powerful risk predictors of morbidity and death, for cardiac and non-cardiac diseases [5-7].

One of the most substantial challenges in the quantification of complexity from HRV time series is the difficulty in finding out a single measurement capable of doing this task consistently. 
In other words, most of the complexity measurements are capable of extracting some properties that regard complexity itself, but none of them are enough to characterize all the complex traits of a system. Mono- and multi-fractal measurements [8,9], irreversibility estimations [10,11], symbolic methods [12,13], network analysis [14,15], as well as entropy-based approaches [16,17] have been proposed to infer the system complexity.

Multiscale entropy (MSE) is an important example of an approach that has been shown to be quite robust and consistent to characterize the system complexity from HRV time series. Like many other approaches, it has some limitations depending on the situation, and improvements or refinements have been proposed since MSE has emerged [18]. For example, the entropy estimator used in MSE (sample entropy) can be replaced by other estimators, such as permutation entropy [19], fuzzy entropy [20], distribution entropy [21], dispersion entropy [22], Rényi entropy [23] and bubble entropy [24], among others. Some other entropy-based proposals, such as entropy of entropy [25] and multiscale $\mathrm{SDiff}_{q}$ (a measure of entropic differences) [26], are markedly different from the MSE original framework, although notably inspired by MSE.

Mild intensity aerobic exercise has been shown to improve several systemic functions and prepare the organism for sudden changes in the body. Experimental models using physical training have demonstrated that gaining physical conditioning, before an induced pathology, can reduce the disturbances caused by the disease $[27,28]$. In other words, physical conditioning seems to increase the system physiological complexity level. However, controversial findings have been reported about complexity and exercise, and scarce studies applied multiscale complexity approaches to identify how the aerobic training can increase the complexity in healthy subjects [29-33].

In the present study, we applied MSE and two other complexity measurements derived from MSE, namely multiscale dispersion entropy and multiscale SDiff $f_{q}$, to quantify the increase of complexity with physical training in experimental models of healthy rats. Results show that all measurements point to the same direction, but significant findings were obtained only with multiscale SDiff ${ }_{q}$.

\section{Materials and Methods}

\subsection{Experimental Protocol}

Male Wistar rats (210 g on average) were obtained from the Animal Care Facility at the Campus of Ribeirão Preto of the University of São Paulo. The animals' usage was according to the Ethical Principles in Animal Research adopted by the National Council for the Control of Animal Experimentation, approved by the Local Animal Ethical Committee from the School of Medicine of Ribeirão Preto of the University of São Paulo.

The study divided animals into trained $(n=13)$ and sedentary groups $(n=12)$. Since animals could have distinct initial physical conditioning, they were individually tested for maximum velocity $\left(V_{\max }\right)$. For the $V_{\max }$ test, the animals were placed on a treadmill, with no inclination, and the speed was increased in steps of $3 \mathrm{~m} / \mathrm{s}$ every $3 \mathrm{~min}$. The stage where the animal fatigued, as well as the time spent on the incomplete stage were noted to calculate the $V_{\max }$ of each rat [34].

The trained group underwent a physical training protocol on the treadmill with no inclination for 9 consecutive weeks, 5 days per week. The training protocol consisted of a medium intensity training that initiated at $50 \%$ of $V_{\max }$ for $20 \mathrm{~min}$ and ended, at the ninth week, at $70 \%$ of $V_{\max }$ for $60 \mathrm{~min}$ (Adapted from [35]). At the fifth week, the trained group underwent a new $V_{\max }$ test to adjust the training protocol as some animals acquire physical conditioning quicker than others. The sedentary group followed the same protocol, but the treadmill was kept off.

\subsection{Data Acquisition and Processing}

Two to three days after the end of the physical training protocol, rats were anesthetized with a mixture of ketamine and xylazine (50 and $10 \mathrm{mg} / \mathrm{kg}$, ip) and implanted with subcutaneous electrodes for ECG recordings. Two days after surgery, with the animals conscious and under free 
movement conditions, the electrodes were connected to a bioelectric amplifier (Animal BioAmp FE136, ADInstruments, Bella Vista, Australia), and ECG recordings were acquired $(2 \mathrm{kHz})$ by an IBM/PC coupled to an analog-to-digital interface (ML866 PowerLab 4/30, ADInstruments, Bella Vista, Australia).

ECG was recorded during one hour, so that multiscale measurements could be confidently estimated from HRV series. ECG recordings were processed using computer software (LabChart Pro, ADInstruments, Bella Vista, Australia) that creates HRV series as the sequence of R-R intervals, i.e., the time interval between adjacent $\mathrm{R}$ waves. All ECG recordings were carefully inspected, and missing beat detections and artifacts were manually corrected. HRV series are 20,000 beats in length, on average.

\subsection{Multiscale Sample Entropy}

Multiscale sample entropy (MSE) is a widely-known procedure to quantify the irregularity of time series within a time-scale range [36,37]. The MSE algorithm consists of creating multiple scaled versions of the original time series and calculating sample entropy (SampEn) from each scaled time series.

Consider a time series given by $u(1), u(2), \ldots, u(N)$. Let $x_{m}(i)$ be the set of consecutive samples in $u$ from $i$ to $i+m-1$, i.e., $x_{m}(i)=[u(i), u(i+1), u(i+2), \ldots, u(i+m-1)]$. Thus, SampEn is defined as [38]:

$$
\operatorname{SampEn}(m, r, N)=-\ln \frac{U^{m+1}(r)}{U^{m}(r)}
$$

where:

$$
\begin{gathered}
U^{m}(r)=\frac{1}{N-m} \sum_{i=1}^{N-m} U_{i}^{m} \\
U_{i}^{m}=\frac{\left[\# \text { of } x_{m} \mid d\left[x_{m}(i), x_{m}(j)\right] \leq r\right]}{N-m-1}
\end{gathered}
$$

and:

$$
\begin{gathered}
U^{m+1}(r)=\frac{1}{N-m} \sum_{i=1}^{N-m} U_{i}^{m+1} \\
U_{i}^{m+1}=\frac{\left[\# \text { of } x_{m+1} \mid d\left[x_{m+1}(i), x_{m+1}(j)\right] \leq r\right]}{N-m-1} .
\end{gathered}
$$

The distance function $d$ is given by:

$$
d\left[x_{m}(i), x_{m}(j)\right]=\max _{k=1, \ldots, m}(|u(i+k-1)-u(j+k-1)|) .
$$

In Equations (3) and (5), $1 \leq j \leq N-m, j \neq i$. In SampEn equations, $m$ is the pattern length or embedding dimension and $r$ is the tolerance factor assumed for similarity between samples.

To estimate MSE, multiple scaled versions of $u$ are created by a coarse-graining procedure, where each element $j$ in a $\tau$-scaled series is defined by:

$$
u^{\tau}(j)=\frac{1}{\tau} \sum_{i=(j-1) \tau+1}^{j \tau} u(i), \quad 1 \leq j \leq N / \tau .
$$

Next, SampEn is calculated from each scaled time series $u^{\tau}$, resulting in a curve of entropy versus scale. It is worth noting that the higher the time scale $(\tau)$, the slower the dynamics that the scaled time series is representing. Importantly, the tolerance factor $(r)$ of SampEn is kept fixed for all time scales $(\tau)$ in MSE.

In the present study, we calculated MSE with the most widely-used parameter setting, i.e., $m=2$ and $r=15 \%$ of the original time series standard deviation. The maximum scale calculated was $\tau=20$. 


\subsection{Multiscale Dispersion Entropy}

Multiscale dispersion entropy (MDE) is similar to MSE and also quantifies the complexity of time series [39]. However, instead of calculating SampEn for each scaled time series, dispersion entropy (DispEn) is used to estimate irregularity.

Consider the same time series given before $(u)$. First, $u$ is filtered by a normal cumulative distribution function (NCDF) with mean $\mu$ and standard deviation $\sigma$, resulting in a filtered time series $u_{f}$, which ranges from 0 to 1 . This procedure is intended to better treat outliers. Next, $u_{f}$ is mapped into $c$ classes $(1$ to $c)$, according to $z^{c}(j)=\operatorname{round}\left(c * u_{f}(j)+0.5\right)$, a function that linearly maps the range $[0,1]$ to $[1, c]$.

Now, let $y_{m}(i)$ be the set of consecutive samples in $z^{c}$ from $i$ to $i+m-1$, i.e., $y_{m}(i)=$ $\left[z^{c}(i), z^{\mathcal{C}}(i+1), z^{c}(i+2), \ldots, z^{c}(i+m-1)\right], i=1,2, \ldots, N-m+1$. Each vector $y_{m}(i)$ represents a dispersion pattern. Considering that each value in $y_{m}$ can assume one of the $c$ possible classes, there will be $c^{m}$ potential dispersion patterns.

The probability of occurrence of each dispersion pattern $y_{m}(i)$ in $z^{\mathcal{C}}$ can be calculated as the number of times the pattern $y_{m}(i)$ appears on $z^{\mathcal{c}}$, divided by the total number of patterns in $z^{\mathcal{c}}$ (i.e., $N-m+1)$. This procedure will result in a probability distribution for all possible dispersion patterns, $p\left[y_{m}(i)\right]$. Finally, the DispEn is defined as the Shannon entropy of $p\left[y_{m}(i)\right][22]:$

$$
\operatorname{DispEn}(m, c)=-\sum_{i=1}^{c^{m}} p\left[y_{m}(i)\right] \log \left(p\left[y_{m}(i)\right]\right)
$$

MDE uses the same coarse-graining procedure of MSE. Thus, MDE estimation consists of the creation of scaled versions of the original time series using Equation (7) and the calculation of DispEn from each scaled time series. However, the NCDF function applied to each scaled version is the same as that applied to the first scale, i.e., the original time series. This procedure has a similar effect of keeping $r$ fixed at all time scales in MSE and can be achieved choosing the same $\mu$ and $\sigma$ of the NCDF function at all scales.

Parameters of MDE were set as $m=2, c=6$ and maximum time scale $\tau=20$. NCDF was generated with $\mu$ and $\sigma$ as the mean and standard deviation of the original time series, respectively.

\subsection{Multiscale SDiff,}

An alternative proposal for multiscale complexity measurement is the multiscale $\mathrm{SDiff}_{q}$ analysis [26]. Although still inspired by MSE in the sense of multiscale analysis, multiscale SDiff ${ }_{q}$ do not use the entropy values over scales directly to characterize complexity. Instead, differences of entropy between the time series and its uncorrelated version, i.e., surrogate data, are used to represent the complexity. The difference of entropy is evaluated for a range of $q$-values, which is a parameter derived from nonadditive mechanical statistics $[40,41]$. The so-called nonadditive $q$-entropy has three regimes, namely classic additive when $q=1$, sub-additive when $q>1$ and super-additive when $q<1$.

SDiff $_{q}$ accounts for the difference between the $\operatorname{SampEn}_{q}$ of a given time series and the mean $\mathrm{SampEn}_{q}$ of a set of surrogate series. SampEn $q$ is a generalization of SampEn inspired by nonadditive statistics, which introduces the nonadditive parameter $q$ to SampEn. Its equation is given by [42]:

$$
\operatorname{SampEn}_{q}(m, r, N)=\log _{q} U^{m}(r)-\log _{q} U^{m+1}(r)
$$

where $\log _{q}$ is defined as [43]:

$$
\log _{q}(x)=\frac{x^{1-q}-1}{1-q},\left[x \in \mathbb{R}_{+}^{*} ; q \in \mathbb{R} ; \log _{1}(x)=\log (x)\right]
$$

and $[Z]_{+}=\max \{Z, 0\}$. The definitions of $U^{m}(r)$ and $U^{m+1}(r)$ are the same as presented in Equations (2) and (4) for SampEn. 
To calculate $\operatorname{SDiff}_{q}$, one has to follow the steps:

- From a given time series $u, S$ surrogate series are generated from $u$. The surrogate series is obtained by simply shuffling $u$ [44];

- $\quad$ Next, values $A=U^{m}(r)$ and $B=U^{m+1}(r)$ are calculated from $u$;

- Values of $U^{m}(r)$ and $U^{m+1}(r)$ are also calculated from each surrogate instance, obtaining their mean values $C=\overline{U^{m}(r)}$ and $D=\overline{U^{m+1}(r)}$;

- Finally, $\mathrm{SDiff}_{q}$ is defined by Equation (11) below:

$$
\begin{aligned}
\text { SDiff }_{q} & =\log _{q}(A)-\log _{q}(B)-\left[\log _{q}(C)-\log _{q}(D)\right] \\
& =\log _{q}(A)+\log _{q}(D)-\log _{q}(B)-\log _{q}(C) .
\end{aligned}
$$

Both $\operatorname{SampEn}_{q}$ and $\mathrm{SDiff}_{q}$ are parametrized in $q$ so that they represent a curve of entropy, or entropy difference, as a function of $q$. From SDiff $q$ curves, three attributes ( $q$-attributes) are obtained to characterize the time series dynamics, namely SDiff $q_{\max }, q_{\max }$ and $q_{z e r o}$. The SDiff $q_{\max }$ represents the maximum value for SDiff $q$ in the range of $q$. The $q_{\max }$ and $q_{z e r o}$ represent the $q$-value where SDiff $q$ finds its maximum and zero values, respectively. $q_{\max }$ is the $q$ parameter that gives the largest entropic separation between the actual time series and its surrogate versions, whereas $q_{\text {zero }}$ is the $q$ parameter where original and shuffled dynamics have the same entropy. For more details on the calculation of $q$-attributes, please refer to [26,42].

The extension of $\mathrm{SDiff}_{q}$ to a multiscale measurement is straightforward. Scaled versions of the original time series are created using the same coarse-graining procedure of MSE, given by Equation (7). Then, for each scaled time series, the $\mathrm{SDiff}_{q}$ curve is calculated and $q$-attributes are obtained, so that it ends up with multiscale $q$-attributes.

Multiscale $\operatorname{SDiff}_{q}$ parameters were set with the same values chosen for MSE, i.e., $m=2, r=0.15$ and maximum time scale $\tau=20$. The number of surrogate instances generated for each time scale was $S=20$, and the nonadditive $q$ parameter ranged from -2 to 2 to estimate the $q$-attributes.

It is worth emphasizing the fact that $q$-attributes represent the SDiff $_{q}$ behavior. Furthermore, the $q$ parameter comes with the power law equation proposed for nonadditive entropy ( $q$-entropy) [40,43]. Therefore, one can say that $q_{\max }$ and $q_{\text {zero }}$ indicate where this power law results in maximum entropy differences regarding surrogates and where this difference is null (zero-crossing), respectively.

\subsection{Statistical Analysis}

We assessed mean MSE, MDE and multiscale $q$-attributes values in two range segments: short ( 1 to 5 ) and long (6 to 20 ) time scales. Those variables were checked for normality by the Shapiro-Wilk test. Differences between trained and sedentary groups were verified by Student's $t$-test or the Mann-Whitney rank sum test when required. Significance was assumed when $p<0.05$.

\section{Results}

The curve profiles of MSE and MDE were very similar for both trained and sedentary rats (Figure 1A,B). Likewise, no difference was found between the groups in the mean values of MSE and MDE grouped by short (1 to 5) and long (6 to 20) time scales (Figure 1C,D), although for higher scales, there was a tendency of increasing differences among groups (Figure 1A,B).

The curve profiles of $q_{\max }$ and $q_{\text {zero }}$ were very similar to each other (Figure 2B,C), which in turn were also very similar to MSE and MDE (Figure 1A,B), regardless of the experimental group. On the other hand, those curves are entirely different from the profile of SDiff $q_{\max }$ (Figure 2A). For $q_{\max }$ and $q_{\text {zero }}$, the curve values decrease for the first two or three scales; after that, they start to increase (Figure 2B,C). However, in the case of SDiff $q_{\max }$, values increase for, approximately, the first six scales, and then, the values are virtually stable (Figure 2A). A significant difference was found between trained and sedentary rats in the mean $q_{\max }$ at long time scales (6-20) (Figure 2E). No difference was observed among groups in the mean $\mathrm{SDiff}_{q_{\max }}$ (Figure 2D) or mean $q_{\text {zero }}$ (Figure 2F). 
A
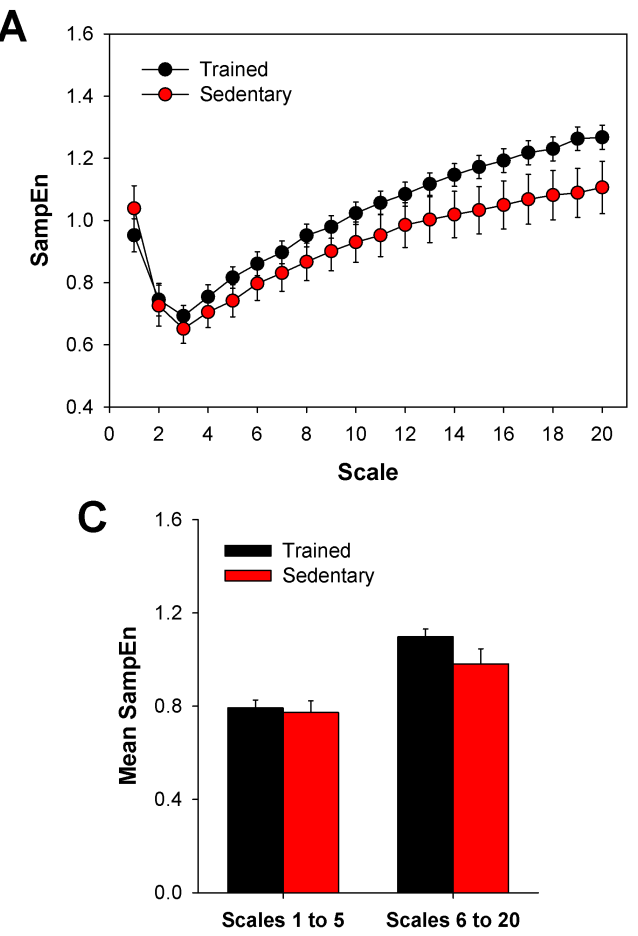
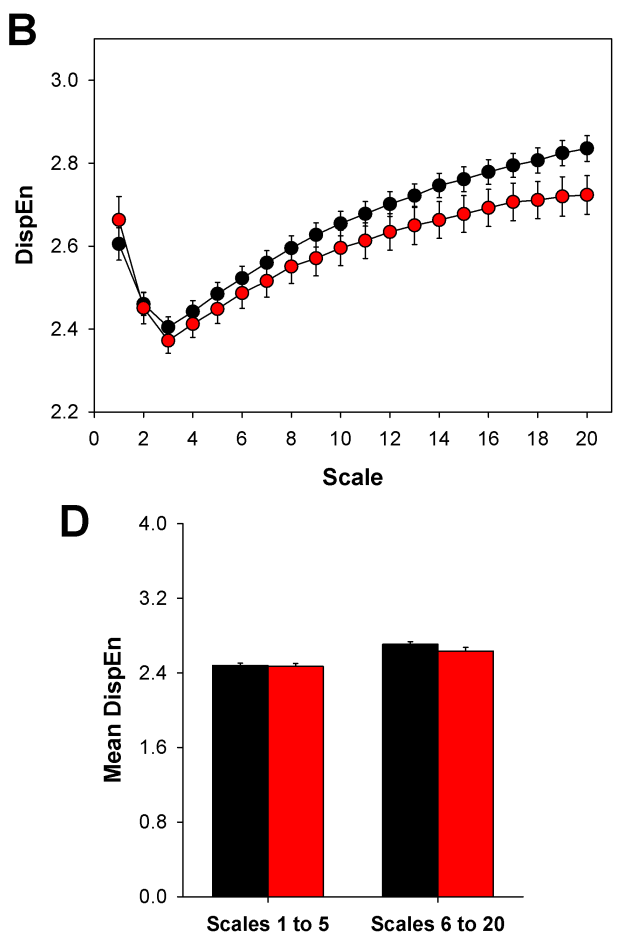

Figure 1. MSE or MDE did not detect differences between HRV complexity from trained and sedentary rats. Curve profiles are presented for MSE (A) and MDE (B), obtained from trained and sedentary groups. Bar graphs show mean entropy values obtained from MSE (C) and MDE (D) curves, grouped by short (1 to 5) and long (6 to 20) time scales. MSE: multiscale sample entropy; MDE: multiscale dispersion entropy; SampEn: sample entropy; DispEn: dispersion entropy; HRV: heart rate variability. Bars represent the mean \pm standard error.
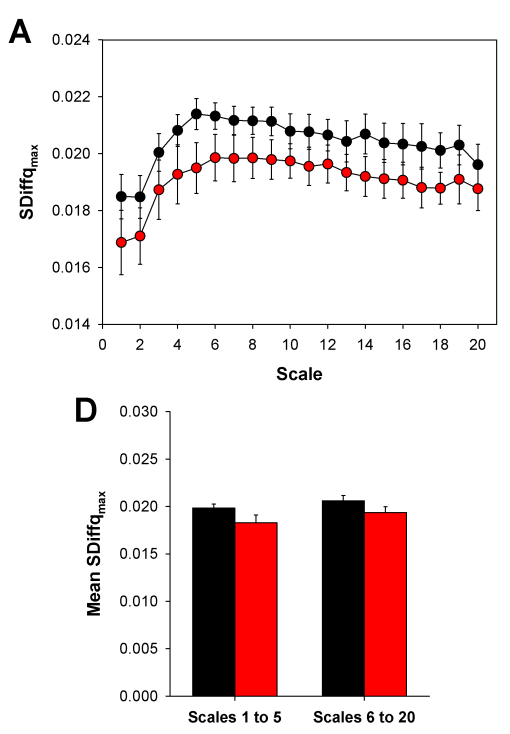
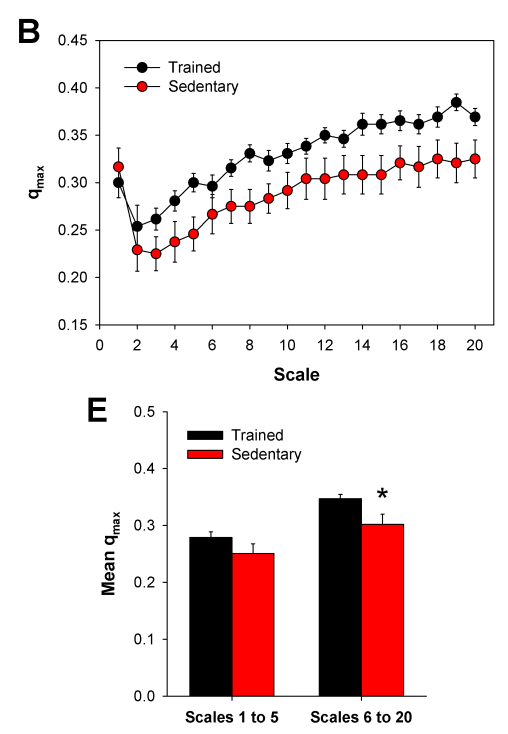
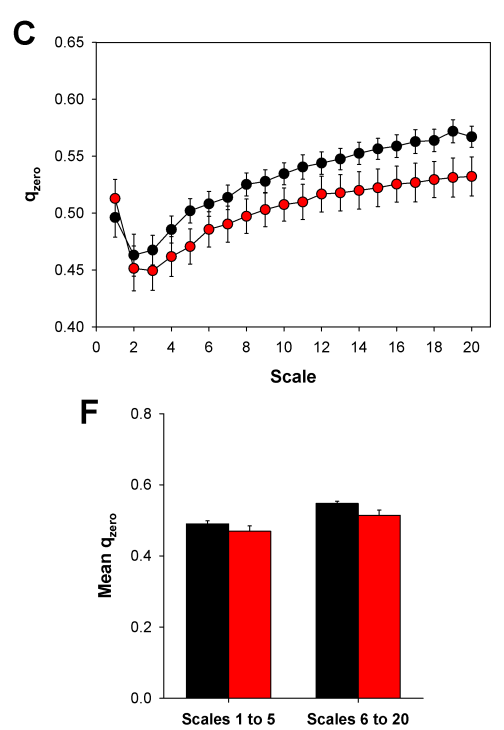

Figure 2. Multiscale $q$-attributes calculated from HRV series of trained and sedentary rats. Curve profiles are presented for SDiff $q_{\max }(\mathbf{A}), q_{\max }(\mathbf{B})$ and $q_{\text {zero }}(\mathbf{C})$, obtained from trained and sedentary rats. Bar graphs show mean $q$-attributes values, obtained from $\operatorname{SDiff}_{q_{\max }}(\mathbf{D}), q_{\max }(\mathbf{E})$ and $q_{\text {zero }}(\mathbf{F})$, grouped by short ( 1 to 5 ) and long (6 to 20 ) time scales. SDiff $q_{\max }$ : maximal SDiff $q q_{\text {max }}: q$ value where SDiff $q$ is maximal; $q_{\text {zero }}: q$ value where $\mathrm{SDiff}_{q}$ is zero; HRV: heart rate variability. Bars represent the mean \pm standard error. ${ }^{*} p<0.05$ when compared to the trained group. 


\section{Discussion}

The characterization of system physiological complexity from a univariate variable, such as HRV, is a hard task. Previous studies have reported on MSE as a powerful tool to assess the complexity of HRV [37,45-48]. Many studies have proposed and evaluated modifications in MSE, given its success in characterizing complex dynamics. Some of them are based on the replacement of sample entropy by another entropy measurement, such as MDE, attempting to improve the accuracy of MSE in specific situations. In the present study, we applied MSE and MDE to account for the complexity changes due to physical training in rats. However, neither MSE nor MDE were able to detect any difference between HRV complexity from trained and sedentary rats.

On the other hand, multiscale $\mathrm{SDiff}_{q}$ is a recent proposal of complexity measurements ( $q$-attributes), inspired by MSE, but with a different theoretical background. It relies on nonadditive statistics and uses the difference of $q$-entropy between the actual and surrogate HRV time series to characterize the complexity. Interestingly, from all the multiscale measurements studied, only $q_{\max }$ was able to distinguish the complexity of HRV between trained and sedentary animals. Moreover, the difference was found only at long time scales (6 to 20). Recent studies have pointed out that short time scales of MSE are more associated with the vagal control of HRV, whereas long time scales seem to be more related (although not exclusively) to the sympathetic control of HRV [46,49], reinforcing the existence of long-term memory in the components of the autonomic nervous system. Extending this interpretation to SDiff $_{q}$, one could say that the difference between sedentary and trained $\mathrm{HRV}$ is more related to differences in the sympathetic control. This seems a reasonable assumption, given that (1) $q$-attributes use the same coarse-graining procedure of MSE to create the scaled time series and (2) physical training promotes, among other benefits, a lower sympathetic activity and modulation [50,51].

Even though there is a significant difference in $q_{\max }$ between trained and sedentary groups, the difference is not huge. An interesting question to ask is: how much is changed in the physiological complexity with physical training? Another question would be: how do the interactions between physiological systems change in a physically trained animal? One has to bear in mind that all those multiscale measurements represent a general view of the system function. In other words, those complexity measurements extract the overall complexity of the system, which is the result of several mechanisms contributing to the homeostasis. Considering that the sedentary animals are healthy, a tremendous increase would not be expected in the complexity after physical training, given that most of the regulatory mechanisms are supposed to be already working at a high complexity level. Therefore, results suggest that systemic changes induced by physical training increase the system complexity to a slightly higher level.

The ability of those multiscale measurements to quantify the overall system complexity of HRV is a distinguishing feature. Many classical HRV indices seek to extract information related to the sympathetic or vagal autonomic modulation, not to mention that they are all linear models. Those indices are usually very sensitive to the environment and behavioral conditions and cannot represent the physiological complexity [4]. For example, during one hour of ECG recording, the rat may explore, sleep, groom, dig and other typical rat behaviors. All those situations will change the autonomic balance, and it is difficult to say what is the real sympathetic and vagal modulation of the rat during the whole one-hour period. On the other hand, applying the multiscale complexity measurements during the whole period, it was possible to identify that the dynamics of HRV has higher complexity in the trained rat compared to the sedentary one, even though the rat can change its physiological state several times during the recording. It is worth noting that all multiscale approaches were also applied to differential HRV series, but no difference was found between trained and sedentary animals, for any measurement [52].

The classical concept of entropy, e.g., SampEn and DispEn, relies on the quantification of the irregularity of a given series. The more irregular (unpredictable) the series, the higher the entropy. Thus, the entropy of any series is supposed to be lower than the entropy of its shuffled version 
(surrogate), even though the correlation properties of the dynamics were broken when samples are shuffled. However, with $q$-entropy, it is possible to achieve the same entropy values for both situations $\left(q_{\text {zero }}\right)$. Therefore, if we consider the classical entropy $(q=1)$, surrogate data will always be assigned to a higher entropy value, but if we consider $q$ near 0.5 (super-additive), the two dynamics will be assigned the same $q$-sample entropy. More interestingly, there are some values of $q$ where the actual dynamics is assigned higher entropy regarding its surrogate (also for super-additive $q$ ). Hence, $q_{\max }$ can be interpreted as the nonadditive parameter that maximizes the complex properties present in the actual dynamics.

In summary, results with multiscale $\mathrm{SDiff}_{q}$ confirmed previous findings that $q_{\max }$ and $q_{\text {zero }}$ provide similar, although not equivalent information, which is quite different from SDiff $q_{\max }$. Furthermore, MSE, $\mathrm{MDE}, q_{\max }$ and $q_{\text {zero }}$ presented very similar curve profiles, despite their different theoretical definitions, and $q_{\max }$ was the only measurement that detected differences in the physiological complexity after physical training. There is no doubt that MSE represents a relevant tool for complexity analysis. This study reinforces that multiscale $\mathrm{SDiff}_{q}$ is an alternative tool for characterizing the complexity of HRV time series, which can add information in some situations where MSE is not accurate enough. Multiscale SDiff $_{q}$ could also be used to help to characterize the complexity of HRV time series in different pathophysiological conditions, as well as in situations where the signal source is other than HRV.

Acknowledgments: This work was supported by CNPq (Grant 113) and CAPES (Grant PNPD20131672) and FAPESP (Grant 2017/05163-6).

Author Contributions: F.S.F., R.F.J. and L.E.V.S. conceived of the study. F.S.F. designed and performed the experiments. F.B., R.F.J. and L.E.V.S. collected the data. F.B., L.E.V.S. and L.O.M.J. analyzed the data. L.E.V.S. drafted the paper. All authors revised and approved the paper.

Conflicts of Interest: The authors declare no conflict of interest.

\section{References}

1. Boccara, N. Modeling Complex Systems; Springer: New York, NY, USA, 2004.

2. Baranger, M. Chaos, Complexity, and Entropy: A Physics Talk for Non-Physicists; New England Complex Systems Institute: Cambridge, MA, USA, 2001.

3. Goldberger, A. Giles f. Filley lecture. Complex systems. Proc. Am. Thorac. Soc. 2006, 3, 467-471.

4. Goldberger, A.L.; Peng, C.K.; Lipsitz, L.A. What is physiologic complexity and how does it change with aging and disease? Neurobiol. Aging 2002, 23, 23-26.

5. Seely, A.J.E.; Macklem, P.T. Complex systems and the technology of variability analysis. Crit. Care 2004, 8, R367-R384.

6. Ahmad, S.; Ramsay, T.; Huebsch, L.; Flanagan, S.; McDiarmid, S.; Batkin, I.; McIntyre, L.; Sundaresan, S.R.; Maziak, D.E.; Shamji, F.M.; et al. Continuous multi-parameter heart rate variability analysis heralds onset of sepsis in adults. PLoS ONE 2009, 4, e6642.

7. Arab, C.; Dias, D.P.M.; de Almeida Barbosa, R.T.; de Carvalho, T.D.; Valenti, V.E.; Crocetta, T.B.; Ferreira, M.; de Abreu, L.C.; Ferreira, C. Heart rate variability measure in breast cancer patients and survivors: A systematic review. Psychoneuroendocrinology 2016, 68, 57-68.

8. Peng, C.K.; Havlin, S.; Stanley, H.E.; Goldberger, A.L. Quantification of Scaling Exponents and Crossover Phenomena In Nonstationary Heartbeat Time-series. Chaos 1995, 5, 82-87.

9. Ivanov, P.C.; Amaral, L.A.N.; Goldberger, A.L.; Havlin, S.; Rosenblum, M.G.; Struzik, Z.R.; Stanley, H.E. Multifractality in human heartbeat dynamics. Nature 1999, 399, 461-465.

10. Porta, A.; Casali, K.R.; Casali, A.G.; Gnecchi-Ruscone, T.; Tobaldini, E.; Montano, N.; Lange, S.; Geue, D.; Cysarz, D.; Van Leeuwen, P. Temporal asymmetries of short-term heart period variability are linked to autonomic regulation. Am. J. Physiol. Regul. Integr. Comp. Physiol. 2008, 295, R550-R557.

11. Costa, M.D.; Peng, C.K.; Goldberger, A.L. Multiscale analysis of heart rate dynamics: Entropy and time irreversibility measures. Cardiovasc. Eng. 2008, 8, 88-93. 
12. Porta, A.; Tobaldini, E.; Guzzetti, S.; Furlan, R.; Montano, N.; Gnecchi-Ruscone, T. Assessment of cardiac autonomic modulation during graded head-up tilt by symbolic analysis of heart rate variability. Am. J. Physiol. Heart Circ. Physiol. 2007. 293, H702-H708.

13. Costa, M.D.; Davis, R.; Goldberger, A. Heart Rate Fragmentation: A Symbolic Dynamical Approach. Front. Physiol. 2017, 8, 827.

14. Bashan, A.; Bartsch, R.P.; Kantelhardt, J.W.; Havlin, S.; Ivanov, P.C. Network physiology reveals relations between network topology and physiological function. Nat. Commun. 2012, 3, 702.

15. Hou, F.Z.; Wang, J.; Wu, X.C.; Yan, F.R. A dynamic marker of very short-term heartbeat under pathological states via network analysis. EPL (Europhys. Lett.) 2014, 107, 58001.

16. Chen, C.; Jin, Y.; Lo, I.L.; Zhao, H.; Sun, B.; Zhao, Q.; Zheng, J.; Zhang, X.D. Complexity Change in Cardiovascular Disease. Int. J. Biol. Sci. 2017, 13, 1320-1328.

17. Xiong, W.; Faes, L.; Ivanov, P.C. Entropy measures, entropy estimators, and their performance in quantifying complex dynamics: Effects of artifacts, nonstationarity, and long-range correlations. Phys. Rev. E 2017, 95, 062114.

18. Humeau-Heurtier, A. The Multiscale Entropy Algorithm and Its Variants: A Review. Entropy 2015, 17, 3110-3123.

19. Bandt, C.; Pompe, B. Permutation entropy: A natural complexity measure for time series. Phys. Rev. Lett. 2002, 88, 174102.

20. Chen, W.; Wang, Z.; Xie, H.; Yu, W. Characterization of surface EMG signal based on fuzzy entropy. IEEE Trans. Neural Syst. Rehabil. Eng. 2007, 15, 266-272.

21. Li, P.; Liu, C.; Li, K.; Zheng, D.; Liu, C.; Hou, Y. Assessing the complexity of short-term heartbeat interval series by distribution entropy. Med. Biol. Eng. Comput. 2015, 53, 77-87.

22. Rostaghi, M.; Azami, H. Dispersion Entropy: A Measure for Time-Series Analysis. IEEE Signal Process. Lett. 2016, 23, 610-614.

23. Rényi, A. On measures of entropy and information. In Proceedings of the Fourth Berkeley Symposium on Mathematical Statistics and Probability, Volume 1: Contributions to the Theory of Statistics; The Regents of the University of California: Berkeley, CA, USA, 1961.

24. Manis, G.; Aktaruzzaman, M.; Sassi, R. Bubble Entropy: An Entropy Almost Free of Parameters. IEEE Trans. Biomed. Eng. 2017, 64, 2711-2718.

25. Hsu, C.F.; Wei, S.Y.; Huang, H.P.; Hsu, L.; Chi, S.; Peng, C.K. Entropy of Entropy: Measurement of Dynamical Complexity for Biological Systems. Entropy 2017, 19, 550.

26. Silva, L.E.V.; Cabella, B.C.T.; Neves, U.P.d.C.; Murta Junior, L.O. Multiscale entropy-based methods for heart rate variability complexity analysis. Phys. A Stat. Mech. Its Appl. 2015, 422, 143-152.

27. Amaral, L.S.d.B.; Silva, F.A.; Correia, V.B.; Andrade, C.E.F.; Dutra, B.A.; Oliveira, M.V.; de Magalhães, A.C.M.; Volpini, R.A.; Seguro, A.C.; Coimbra, T.M.; et al. Beneficial effects of previous exercise training on renal changes in streptozotocin-induced diabetic female rats. Exp. Biol. Med. 2016, 241, 437-445.

28. Faleiros, C.M.; Francescato, H.D.C.; Papoti, M.; Chaves, L.; Silva, C.G.A.; Costa, R.S.; Coimbra, T.M. Effects of previous physical training on adriamycin nephropathy and its relationship with endothelial lesions and angiogenesis in the renal cortex. Life Sci. 2017, 169, 43-51.

29. Weippert, M.; Behrens, K.; Rieger, A.; Kumar, M.; Behrens, M. Effects of breathing patterns and light exercise on linear and nonlinear heart rate variability. Appl. Physiol. Nutr. Metab. 2015, 40, 762-768.

30. Soares-Miranda, L.; Sandercock, G.; Vale, S.; Silva, P.; Moreira, C.; Santos, R.; Mota, J. Benefits of achieving vigorous as well as moderate physical activity recommendations: Evidence from heart rate complexity and cardiac vagal modulation. J. Sports Sci. 2011, 29, 1011-1018.

31. Karavirta, L.; Costa, M.D.; Goldberger, A.L.; Tulppo, M.P.; Laaksonen, D.E.; Nyman, K.; Keskitalo, M.; Häkkinen, A.; Häkkinen, K. Heart rate dynamics after combined strength and endurance training in middle-aged women: Heterogeneity of responses. PLOS ONE 2013, 8, e72664.

32. Goulopoulou, S.; Fernhall, B.; Kanaley, J.A. Hemodynamic responses and linear and non-linear dynamics of cardiovascular autonomic regulation following supramaximal exercise. Eur. J. Appl. Physiol. 2009, 105, 525-531.

33. Platisa, M.M.; Mazic, S.; Nestorovic, Z.; Gal, V. Complexity of heartbeat interval series in young healthy trained and untrained men. Physiol. Meas. 2008, 29, 439-450. 
34. Kuipers, H.; Verstappen, F.; Keizer, H.; Geurten, P.; Van Kranenburg, G. Variability of aerobic performance in the laboratory and its physiologic correlates. Int. J. Sports Med. 1985, 6, 197-201.

35. Silva, K.A.d.S.; Luiz, R.S.; Rampaso, R.R.; de Abreu, N.P.; Moreira, E.D.; Mostarda, C.T.; De Angelis, K.; Teixeira, V.d.P.C.; Irigoyen, M.C.; Schor, N. Previous exercise training has a beneficial effect on renal and cardiovascular function in a model of diabetes. PLOS ONE 2012, 7, e48826.

36. Costa, M.; Goldberger, A.L.; Peng, C.K. Multiscale Entropy Analysis of Complex Physiologic Time Series. Phys. Rev. Lett. 2002, 89, 068102.

37. Costa, M.; Goldberger, A.L.; Peng, C.K. Multiscale entropy analysis of biological signals. Phys. Rev. E 2005, 71, 021906.

38. Richman, J.S.; Moorman, J.R. Physiological time-series analysis using approximate entropy and sample entropy. Am. J. Physiol. Heart Circ. Physiol. 2000, 278, H2039-H2049.

39. Azami, H.; Rostaghi, M.; Abasolo, D.; Escudero, J. Refined Composite Multiscale Dispersion Entropy and Its Application to Biomedical Signals. IEEE Trans. Biomed. Eng. 2017, 64, 2872-2879.

40. Tsallis, C. Possible generalization of Boltzmann-Gibbs statistics. J. Stat. Phys. 1988, 52, 479-487.

41. Tsallis, C. Introduction to Nonextensive Statistical Mechanics; Springer: New York, NY, USA, 2009.

42. Silva, L.E.V.; Murta, L.O. Evaluation of physiologic complexity in time series using generalized sample entropy and surrogate data analysis. Chaos 2012, 22, 043105.

43. Borges, E.P. A possible deformed algebra and calculus inspired in nonextensive thermostatistics. Phys. A Stat. Mech. Its Appl. 2004, 340, 95-101.

44. Theiler, J.; Eubank, S.; Longtin, A.; Galdrikian, B.; Doyne Farmer, J. Testing for nonlinearity in time series: The method of surrogate data. Phys. D Nonlinear Phenom. 1992. 58, 77-94.

45. Silva, L.E.V.; Lataro, R.M.; Castania, J.A.; da Silva, C.A.A.; Valencia, J.F.; Murta, L.O.; Salgado, H.C.; Fazan, R.; Porta, A. Multiscale entropy analysis of heart rate variability in heart failure, hypertensive, and sinoaortic-denervated rats: Classical and refined approaches. Am. J. Physiol. Regul. Integr. Comp. Physiol. 2016, 311, R150-R156.

46. Silva, L.E.V.; Silva, C.A.A.; Salgado, H.C.; Fazan, R. The role of sympathetic and vagal cardiac control on complexity of heart rate dynamics. Am. J. Physiol. Heart Circ. Physiol. 2017, 312, H469-H477.

47. Silva, L.E.V.; Rodrigues, F.L.; de Oliveira, M.; Salgado, H.C.; Fazan, R. Heart rate complexity in sinoaortic-denervated mice. Exp. Physiol. 2015, 100, 156-163.

48. Ho, Y.L.; Lin, C.; Lin, Y.H.; Lo, M.T. The Prognostic Value of Non-Linear Analysis of Heart Rate Variability in Patients with Congestive Heart Failure-A Pilot Study of Multiscale Entropy. PLoS ONE 2011, 6, e18699.

49. Bari, V.; Valencia, J.F.; Vallverdú, M.; Girardengo, G.; Marchi, A.; Bassani, T.; Caminal, P.; Cerutti, S.; George, A.L.; Brink, P.A.; et al. Multiscale complexity analysis of the cardiac control identifies asymptomatic and symptomatic patients in long QT syndrome type 1. PLoS ONE 2014, 9, e93808.

50. Pardo, Y.; Merz, N.; Bairey, C.; Velasquez, I.; Paul-Labrador, M.; Agarwala, A.; Peter, C.T. Exercise conditioning and heart rate variability: Evidence of a threshold effect. Clin. Cardiol. 2000, 23, 615-620.

51. Mueller, P.J. Exercise training and sympathetic nervous system activity: evidence for physical activity dependent neural plasticity. Clin. Exp. Pharmacol. Physiol. 2007, 34, 377-384.

52. Liu, C.; Gao, R. Multiscale Entropy Analysis of the Differential RR Interval Time Series Signal and Its Application in Detecting Congestive Heart Failure. Entropy 2017, 19, 251.

(C) 2018 by the authors. Licensee MDPI, Basel, Switzerland. This article is an open access article distributed under the terms and conditions of the Creative Commons Attribution (CC BY) license (http://creativecommons.org/licenses/by/4.0/). 


\section{Neuroimmune Interactions in Schizophrenia: Focus on Vagus Nerve Stimulation and Activation of the Alpha-7 Nicotinic Acetylcholine Receptor}

\section{OPEN ACCESS}

Edited by:

Valentin A. Pavlov

Northwell Health at Manhasset,

United States

Reviewed by:

Bruno Bonaz,

Grenoble Faculty of

Medicine and Hospital, France

Mauricio Rosas-Ballina,

University of Basel, Switzerland

Maryna Skok

Palladin Institute of Biochemistry

(NAN Ukraine), Ukraine

${ }^{*}$ Correspondence:

Fabiana Maria das Graças

Corsi-Zuelli

fabiana.zuelli@usp.br;

Camila Marcelino Loureiro

camila.loureiro@usp.br

Specialty section This article was submitted to Inflammation,

a section of the journal

Frontiers in Immunology

Received: 08 February 2017

Accepted: 10 May 2017

Published: 31 May 2017

Citation

Corsi-Zuelli FMG, Brognara F Quirino GFS, Hiroki $\mathrm{CH}$, Fais RS, Del-Ben CM, Ulloa L,

Salgado HC, Kanashiro A and Loureiro CM (2017) Neuroimmune Interactions in Schizophrenia: Focus

on Vagus Nerve Stimulation and

Activation of the Alpha-7 Nicotinic Acetylcholine Receptor

Front. Immunol. 8:618.

doi: 10.3389/fimmu.2017.00618
Fabiana Maria das Graças Corsi-Zuelli ${ }^{*}$, Fernanda Brognara ${ }^{2}$, Gustavo Fernando da Silva Quirino ${ }^{3}$, Carlos Hiroji Hiroki ${ }^{4}$, Rafael Sobrano Fais ${ }^{4}$, Cristina Marta Del-Ben ${ }^{1}$, Luis Ulloa ${ }^{5}$, Helio Cesar Salgado ${ }^{2}$, Alexandre Kanashiro ${ }^{6}$ and Camila Marcelino Loureiro ${ }^{7 *}$

\begin{abstract}
Department of Neuroscience and Behavior, Ribeirão Preto Medical School, University of São Paulo, São Paulo, Brazil, ${ }^{2}$ Department of Physiology, Ribeirão Preto Medical School, University of São Paulo, São Paulo, Brazil, ${ }^{3}$ Department of Cellular and Molecular Biology, Ribeirão Preto Medical School, University of São Paulo, São Paulo, Brazil, ${ }^{4}$ Department of Pharmacology, Ribeirão Preto Medical School, University of São Paulo, São Paulo, Brazil, ${ }^{5}$ Department of Surgery, Center of Immunology and Inflammation, Rutgers University-New Jersey Medical School, Newark, NJ, United States, ${ }^{6}$ Department of Physiological Sciences, Federal University of São Carlos, São Carlos, Brazil, ${ }^{7}$ Department of Internal Medicine, Ribeirão Preto Medical School, University of São Paulo, São Paulo, Brazil
\end{abstract}

Schizophrenia is one of the most debilitating mental disorders and is aggravated by the lack of efficacious treatment. Although its etiology is unclear, epidemiological studies indicate that infection and inflammation during development induces behavioral, morphological, neurochemical, and cognitive impairments, increasing the risk of developing schizophrenia. The inflammatory hypothesis of schizophrenia is also supported by clinical studies demonstrating systemic inflammation and microglia activation in schizophrenic patients. Although elucidating the mechanism that induces this inflammatory profile remains a challenge, mounting evidence suggests that neuroimmune interactions may provide therapeutic advantages to control inflammation and hence schizophrenia. Recent studies have indicated that vagus nerve stimulation controls both peripheral and central inflammation via alpha-7 nicotinic acetylcholine receptor ( $\alpha 7 \mathrm{nAChR})$. Other findings have indicated that vagal stimulation and $\alpha 7 n A C h R$-agonists can provide therapeutic advantages for neuropsychiatric disorders, such as depression and epilepsy. This review analyzes the latest results regarding: (I) the immune-to-brain pathogenesis of schizophrenia; (II) the regulation of inflammation by the autonomic nervous system in psychiatric disorders; and (III) the role of the vagus nerve and $\alpha 7 \mathrm{nAChR}$ in schizophrenia.

Keywords: schizophrenia, immune system, cytokines, inflammation, microglia, vagus nerve stimulation, alpha-7 nicotinic acetylcholine receptor, cholinergic anti-inflammatory pathway

Abbreviations: ACh, acetylcholine; BBB, blood-brain barrier; CNS, central nervous system; GABA, gamma-aminobutyric acid; HRV, heart rate variability; IL, interleukin; IFN, interferon; KYNA, kynurenic acid; NMDAR, $N$-methyl-D-aspartate receptor; M1, microglia type 1; M2, microglia type 2; TGF, transforming growth factor; Th1, T helper cells type 1; Th2, T helper cells type 2; TNF, tumor necrosis factor; VNS, vagus nerve stimulation; tVNS, transcutaneous vagus nerve stimulation; $\alpha 7 \mathrm{nAChR}$, alpha-7 nicotinic acetylcholine receptor. 


\section{INTRODUCTION}

Mental disorders are a major clinical and scientific challenge in modern medicine with an estimated prevalence of approximately $17 \%$ of the population $(1,2)$. Schizophrenia is one of the most debilitating psychotic disorders due to the lack of effective treatment $(3,4)$. Schizophrenia is a chronic psychiatric disorder characterized by faulty perception and withdrawal from reality. Schizophrenia symptomatology comprises positive (delusions, hallucinations), negative symptoms (social withdrawal, apathy) cognitive alterations, disorganized thinking, and psychomotor disturbances (2). The average life expectancy of schizophrenia patients is $10-25$ years less than the normal population due to health problems and a higher suicide rate (5-7). Despite its significant social implications, schizophrenia is neglected worldwide $(3,4,8)$.

Current treatments for schizophrenia are inefficacious, and there is an unmet clinical need for new and safe therapeutic strategies (9-12). Schizophrenia is usually treated with typical or atypical antipsychotics. Typical antipsychotics often induce significant psychomotor side effects. Atypical antipsychotics are the usual first-line treatment, although they are associated with metabolic syndrome and an increased cardiovascular risk of death $(11,12)$. An explanation for the inefficacious treatments is the insufficient knowledge about the etiology of schizophrenia. Both groups of antipsychotics are believed to be antagonists for dopamine receptors in the brain, and thus, previous studies mostly focused on the dopaminergic system (13). Although dopaminergic dysfunction contributes to schizophrenia, the mechanisms leading to this dysfunction are unknown. Recent studies demonstrate an abnormal inflammatory profile that can cause neurotransmission dysfunction in schizophrenia $(14,15)$. Early infections and other immune alterations during pregnancy and development can contribute to schizophrenia and other neurological disorders (16-19). These studies are contemporary with recent investigations demonstrating that vagal stimulation controls both central and peripheral inflammation (20-24) and that vagal stimulation can provide therapeutic advantages for neuropsychiatric disorders, such as depression and epilepsy $(25,26)$. However, little is known about the potential of this mechanism for treating schizophrenia (27). We reasoned that vagal stimulation may control inflammation and provide novel therapeutic advantages for schizophrenia. In this article, we evaluate this hypothesis by reviewing autonomic vagal dysfunction in psychiatric disorders and discussing the potential of vagal stimulation and alpha-7 cholinergic receptor $(\alpha 7 \mathrm{nAChR})$ agonists for treating schizophrenia.

\section{IMMUNE-TO-BRAIN PATHOGENESIS: FROM HOMEOSTASIS TO INFLAMMATION}

Unregulated inflammation induced by infection or trauma results in excessive production of inflammatory cytokines, such as tumor necrosis factor (TNF), interferon- $\gamma$ (IFN- $\gamma$ ), and interleukins (IL-1 $\beta$, IL-6, etc.). These cytokines influence the homeostasis of several organs, as well as the central nervous system (CNS) (28).

Despite the traditional view of the brain as an immunologically privileged site, multiple studies have demonstrated that the
CNS interacts with peripheral inflammatory cytokines through several pathways, described as follows (29). First, the humoral pathway: peripheral cytokines diffuse into the CNS through circumventricular organs and structures lacking the blood-brain barrier (BBB). Second, the cellular pathway: peripheral immune cells enter the CNS due to alterations in the BBB permeability and through the actions of chemoattractant mediators. Third, the microbiota-gut-brain axis: the microbiota-gut can transmit signals to the brain via the vagus nerve, immune mediators, and microbial metabolites, thereby altering neurotransmission in the CNS $(30,31)$. Fourth, the recently discovered central lymphatic pathway or the glymphatic system: mediated by functional lymphatic vessels in the CNS (32). In this pathway, extracellular fluids (the cerebrospinal fluid and interstitial fluid) draining from the brain parenchyma to the cervical and lumbar lymph nodes facilitate the traffic of antigens and immune cells affecting peripheral and central inflammation (33). Finally, the neural pathway: the afferent vagus nerve detects peripheral inflammatory cytokines (TNF, IL-1 $\beta$, IL-6) and transmits signals to the nucleus tractus solitarius, and thereby to the hypothalamus $(29,34)$. All these pathways serve as immune-to-brain cross talk that facilitate central inflammation and behavioral changes.

\section{THE INFLAMMATORY HYPOTHESES OF SCHIZOPHRENIA}

A balance between the pro- and anti-inflammatory cytokines is critical for proper brain development (35). Epidemiological studies indicate that infections during development increase the risk of schizophrenia in adulthood (36-39). These studies report an association between elevated maternal inflammatory cytokines levels (especially IL-8 and TNF) and risk of schizophrenia in adult offspring $(16,37)$. It has been observed in preclinical studies that maternal immune activation in rodents induces inflammatory cytokines (IL-1 $\beta$, IL-6, TNF) and reduces anti-inflammatory cytokines (IL-10) in both the maternal fluids and in the fetal brain, inducing schizophrenia-like behaviors in the offspring $(35,40)$. Likewise, direct IL-6 inoculation into pregnant rodents also induces schizophrenia-like abnormalities in the offspring. This effect is prevented by neutralizing IL- 6 antibodies, genetic depletion of the IL-6 gene (IL-6 knockout) (35), or overexpression of anti-inflammatory cytokines (IL-10) in the macrophages of pregnant dams (41).

Genetic studies have demonstrated the implications of immune-related genes in schizophrenia (42). A Danish cohort study reported a significant relationship between severe infections and the risk of schizophrenia. A previous history of autoimmune disorders increases the risk of schizophrenia by $36 \%$. This risk of schizophrenia increases up to $60 \%$ in patients with a previous history of infection and hospitalization (19). Several clinical studies demonstrate a chronic low-grade inflammation in schizophrenia (43-46). Early studies suggested that this chronic low-grade inflammation may be due to chronically activated macrophages that fail to properly control T-lymphocytes in the so called "macrophage-T-lymphocyte hypothesis" (47). Thereafter, Schwarz et al. (48) suggested that psychotic patients have a T helper cells type 2-profile (Th2) characterized by increased Th2-produced 
IL-4 and decreased T helper cells type 1 (Th1)-produced IFN$\gamma$ (48). In contrast, a shift away from Th2-produced IL-4 and toward Th1-produced IFN- $\gamma$ was later highlighted, suggesting the involvement of transforming growth factor (TGF)- $\beta$ in the Th1/ Th2 regulation of schizophrenia. Although contradictory, these hypotheses concur that an inflammatory imbalance is involved in schizophrenia (49).

Recent meta-analyses indicate that acute and chronically ill patients demonstrate a low-grade inflammatory profile that correlates with the clinical symptoms of schizophrenia $(43,45$, 46) (Table 1). This inflammatory profile was also reported in drug-naive patients in the first episode of psychosis (45). Since these patients were drug-naïve and in the first manifestation of the disease, it is unlikely that inflammation was related to antipsychotics or duration of illness. Thus, inflammatory cytokines in the peripheral blood were suggested to be either state or trait biomarkers. State biomarkers refer to specific cytokines elevated in schizophrenia and normalized with antipsychotics. Trait biomarkers are cytokines that are elevated in schizophrenia and are not normalized following antipsychotic treatment (43).

The association between biological and environmental factors can have significant implications in schizophrenia (50). In this respect, Monji et al. (51) shed light on the microglia hypothesis of schizophrenia (51). Microglia are the resident macrophages in the CNS (52), and similar to peripheral macrophages, they show different activation states. Basal state microglia (M0) perform

TABLE 1 | Cytokine profile in schizophrenia.

\begin{tabular}{|c|c|c|c|}
\hline $\begin{array}{l}\text { Meta-analyses } \\
\text { (reference) }\end{array}$ & $\begin{array}{l}\text { Number } \\
\text { of studies } \\
\text { included in } \\
\text { the meta- } \\
\text { analyses }\end{array}$ & $\begin{array}{l}\text { Patients } \\
\text { (status) }\end{array}$ & Peripheral blood cytokines \\
\hline \multirow[t]{3}{*}{ Miller et al. (43) } & \multirow{3}{*}{33} & $\mathrm{AR}$ & $\begin{array}{c}\uparrow \\
\text { IL-6, IL-8, TNF, IFN- } \gamma, \text { TGF- } \beta \text {, } \\
\text { IL-1RA }\end{array}$ \\
\hline & & & $\begin{array}{c}\downarrow \\
\text { IL-10 }\end{array}$ \\
\hline & & $\begin{array}{l}\text { FEP } \\
\text { (drug-näive) }\end{array}$ & $\begin{array}{c}\uparrow \\
\text { IL-1 } \beta, \text { IL-6, IL-12, IFN- } \gamma, \text { TNF, } \\
\text { TGF- } \beta, \text { sIL-2R }\end{array}$ \\
\hline Upthegrove et al. (45) & 14 & $\begin{array}{l}\text { FEP } \\
\text { (drug-näive) }\end{array}$ & $\begin{array}{c}\uparrow \\
\mathrm{IL}-1 \beta, \mathrm{sIL}-2 \mathrm{R}, \mathrm{IL}-6, \mathrm{TNF}\end{array}$ \\
\hline \multirow[t]{2}{*}{ Goldsmith et al. (46) } & 40 & AR/FEP & $\begin{array}{c}\uparrow \\
\text { IFN- } \gamma, \text { IL-1 } \beta, \text { IL-6, IL-8, IL-10a, } \\
\text { IL-12, TNF, TGF- } \beta, \text { IL-1RA, } \\
\text { sIL-2R } \\
\downarrow \\
\text { IL-4, IL-10 }\end{array}$ \\
\hline & 18 & Chronic & $\begin{array}{c}\uparrow \\
\mathrm{IL}-1 \beta, \mathrm{IL}-6, \mathrm{TNF}, \mathrm{sIL}-2 \mathrm{R} \\
\downarrow \\
\mathrm{IFN}-\gamma\end{array}$ \\
\hline
\end{tabular}

Enhanced ( $\uparrow$ ) or decreased ( $\downarrow$ ) cytokines levels in the peripheral blood of patients with schizophrenia; $A R$, acutely relapsed; FEP, first episode psychosis; IL, interleukin; TNF, tumor necrosis factor, IFN- $\gamma$, interferon- $\gamma$; TGF- $\beta$, transforming growth factor- $\beta$; $s / L-2 R$, soluble IL-2 receptor; IL-1RA, IL-1 receptor antagonist.

alL-10, increased in FEP but decreased in AR. phagocytosis and promote neurite outgrowth (53-55). However, both physical (infections) (56) or psychological (early life stress) stressors induce microglial activation (57-62). In response to these events, microglial polarization is triggered, resulting in an inflammatory state (microglia type $1 ; \mathrm{M} 1)(63,64)$. M1 microglia produce large amounts of inflammatory cytokines (TNF, IL-1, IL-6, IL-12) inducing neuronal cytotoxicity $(57,61,62)$. In contrast, anti-inflammatory cytokines (IL-4, IL-10) induce microglial polarization toward an anti-inflammatory state (microglia type 2; M2), critical for homeostasis. The imbalance between these factors affects neurite outgrowth, neuronal connections, and neurotransmitter formation and induces neuronal cytotoxicity, contributing to neuropsychiatric disorders (57, 65-67). Indeed, increased microglial density and microglial activation have been demonstrated in the hippocampus and gray matter of schizophrenic patients, as demonstrated by postmortem and in vivo studies (68-73), and microglial activation has been linked to the pre-suicidal stress associated with schizophrenia (74).

Microglia-produced TNF induces neurotoxicity and neurodegeneration as demonstrated both in vitro $(54,75)$ and in vivo $(76,77)$. A typical example is that abnormal microglia activation alters tryptophan metabolism along the kynurenine pathway, producing metabolites that act as $N$-methyl-D-aspartate receptor (NMDAR)-agonists (quinolinic acid) or -antagonists, such as kynurenic acid (KYNA) $(29,78,79)$. NMDAR dysfunction is associated with schizophrenia (80) and NMDAR-antagonists induce positive, negative, and cognitive symptoms in healthy volunteers, similar to those observed in schizophrenia $(81,82)$. Delusions and hallucinations related to autoantibodies blocking NMDARs were reported in schizophrenic and healthy controls $(83,84)$. The kynurenine pathway is also linked to oxidative stress. Neuronal apoptosis and structural changes in specific areas of the brain, such as the amygdala, hippocampus, and prefrontal cortex, are related to several psychiatric disorders, including schizophrenia (78). Together these studies demonstrate that inflammation of the CNS can contribute to schizophrenia $(43,45,46)$.

The efficacy of antipsychotics may be due to microglial suppression and subsequent neuroprotection (85-87). Atypical antipsychotics inhibit TNF production by the IFN- $\gamma$-stimulated microglia $(86,87)$. Minocycline, a non-psychotic medication with potent effects in inhibiting microglia, has been suggested as an adjuvant in the treatment of schizophrenia (86). However, atypical antipsychotics induce metabolic and cardiovascular dysfunctions $(11,12)$. Thus, there is an unmet clinical need for new therapeutic strategies to control inflammation and the progression of schizophrenia.

\section{DOES AUTONOMIC IMMUNOMODULATION CONTRIBUTE TO THE INFLAMMATORY COMPONENT OF SCHIZOPHRENIA?}

\section{The Autonomic Nervous System}

The autonomic nervous system regulates the immune system through both the sympathetic and parasympathetic networks 
$(21,88,89)$. This regulation is not only critical for physiological homeostasis, such as that in the gastrointestinal tract $(90,91)$, but also in pathological conditions that range from infection to trauma (22, 92-94). Briefly, sympathetic preganglionic neurons that originate from the thoracic and lumbar spinal segments synapse with postganglionic neurons in pre- or paravertebral ganglia. Parasympathetic preganglionic neurons originate from the brainstem and the sacral spinal cord and synapse with postganglionic neurons in terminal ganglia located near target organs. Both preganglionic sympathetic and parasympathetic neurons release acetylcholine (ACh). While all parasympathetic postganglionic neurons release $\mathrm{ACh}$, most sympathetic postganglionic neurons release norepinephrine. Overall, sympathetic activity predominates during the "fight-or-flight" reactions, while parasympathetic activity predominates during "quiet" resting conditions (95). The vagus nerve-the major component of the parasympathetic system-plays a critical role in the communication between the brain and peripheral organs, such as the heart, lungs, and intestine (96).

\section{The Autonomic Nervous System Regulation of Inflammation in Schizophrenia}

Dysfunction of the autonomic nervous system may contribute to the inflammatory profile reported in schizophrenia. The balance between the sympathetic and parasympathetic systems can be determined by the heart rate variability (HRV), which represents the variation of the intervals between heartbeats (97). Parasympathetic nerves slow heart rate and increase HRV by releasing ACh. Sympathetic nerves accelerate heart rate and decrease HRV by releasing epinephrine and norepinephrine $(98,99)$. Lower HRV is a predictor of cardiac morbidity and mortality (100-102). Psychiatric patients tend to have an autonomic imbalance with low HRV suggesting a reduced parasympathetic and increased sympathetic tone (103-105). Low HRV has also been related to psychotic symptoms and depression (106-108); and thus, the vagal tone could serve as an index of the treatment response (109).

The polyvagal theory associates the autonomic neuronal system with affective experiences and contingent social behavior (110). Low vagal activity is associated with reduced social involvement and a less flexible behavioral response to environmental conditions (110). In agreement with this theory, Bylsma and coworkers suggested that "the cardiac autonomic balance may be a useful index that reflects the balance of the autonomic nervous system to respond to aspects of the environment that may be sensitive to psychophysiological abnormalities" (111). Thus, autonomic neuronal dysfunction and low vagal activity could contribute to schizophrenia.

Electrical vagus nerve stimulation (VNS) was approved by the food and drug administration for treating several neuropsychiatric disorders including refractory epilepsy and depression $(25,112-114)$. However, few studies have explored VNS in schizophrenia (27). The only study that addresses VNS in schizophrenia examined the effects of transcutaneous vagal stimulation (tVNS) (115). tVNS is a non-invasive electrical stimulation of the external ear allowing stimulation of the auricular vagal branch (116). tVNS of the cymba conche results in the strongest activation of the vagal afferent pathway in the brainstem, as observed through functional magnetic resonance imaging (117). A bicentric, randomized, sham-controlled and doubleblind clinical investigation was performed in 20 schizophrenic patients, who were randomly assigned to two groups: one received daily active stimulation of the left auricle for 26 weeks; the other group received sham stimulation daily. Regarding efficacy, there was no difference between the sham and tVNS groups (115). However, only half of the patients adhered to the protocol. Given that the vagal stimulation treatment depends on patient adherence, it was not possible to conclude a result due to non-adherence to the protocol and methodological limitations. In contrast, experimental studies demonstrated that VNS significantly reversed hippocampal hyperactivity, mesolimbic dopaminergic dysfunction, and schizophrenia-like symptoms, including cognitive deficits $(118,119)$.

Autonomic dysfunction facilitates immune alterations and increases the susceptibility to infectious and immunological disorders. The vagus nerve directs the "cholinergic anti-inflammatory pathway" modulating inflammation, as reported in preclinical and clinical studies $(21,23,24,26,93,118-124)$. In clinical studies, VNS inhibited cytokine production, improved HRV, and ameliorated low moods and emotional symptoms in depressive patients resistant to pharmacological treatment $(26,124)$. Recent studies demonstrated brain inflammation reduction with VNS applied at a low frequency, a protocol that favors the activation of efferent vagus nerve fibers $(23,24)$. Inhibition of CNS inflammation can be a consequence of peripheral inflammation inhibition $(22,24)$. The vagal anti-inflammatory signals are mediated by $\alpha 7 \mathrm{nAChR}$, suggesting that nicotinic agonists mimic vagal antiinflammatory potential $(22,125,126) . \alpha 7 \mathrm{nAChR}$ were detected in several cell types, including neurons and immune cells. In the CNS, $\alpha 7 \mathrm{nAChR}$ are expressed by pyramidal interneurons $(127,128)$, immature granule cells (129), astrocytes (130), and microglia $(131,132)$. In the periphery, this receptor is expressed in monocytes $(133,134)$, dendritic cells (135), macrophages (120, 136), T-cells (137), and B-cells (138). In this regard, the use of selective $\alpha 7 \mathrm{nAChR}$-agonists in the treatment of psychiatric and neurological patients has been reported (139). Remarkably, activation of $\alpha 7 \mathrm{nAChR}$ in cultured microglia cells inhibits LPSinduced release of cytokines and promotes conversion of M1 microglia to M2 $(132,140)$.

Genetic studies demonstrated that $\alpha 7 \mathrm{nAChR}$ activity is reduced, especially in the hippocampus, thalamus, frontal cortex, brainstem, ventral tegmental area, nucleus accumbens, and the cingulate cortex of schizophrenic patients (141-146). This reduced activity is more remarkable in gamma-aminobutyric acid (GABA) interneurons (142) that are key players in schizophrenia, especially in the cognitive domain (147). In addition, $\alpha 7 \mathrm{nAChR}$ participate in NMDA and $\mathrm{GABA}_{\mathrm{A}}$ receptors activity, and similar to NMDAR, they modulate calcium influx facilitating neurotransmission (148-150). Accordingly, $\alpha 7 n$ AChR has been involved in a myriad of brain functions, including learning, memory, neuroprotection, and synaptic plasticity (151-153). Conversely, $\alpha 7 \mathrm{nAChR}$ dysfunction leads to abnormal NMDAR/ 
$\mathrm{GABA}_{\mathrm{A}}$ function and perturbation of glutamatergic and GABAergic neurotransmission (154).

Kynurenic acid, besides acting as an NMDAR inhibitor, is also a potent non-competitive $\alpha 7 \mathrm{nAChR}$-antagonist (155) and is associated with hypoglutamatergic and hypocholinergic neurotransmission, facilitating cognitive deficits and sensory gating disturbances in schizophrenia (155). $\alpha 7 \mathrm{nAChR}$-agonists restore dopamine signaling in the brain (156) and improve negative symptoms and cognitive function in schizophrenia $(139,157-161)$. Variation in brain KYNA may be related to the nicotinic cholinergic system. It has been observed that nicotine reduces levels of KYNA in clinical trials (162). In rodents, this effect was clear during a 5-day nicotine treatment; however, prolonged treatment enhanced central levels of KYNA (155). Notably, increased brain levels of KYNA are reported in schizophrenia (14); this concurs with data demonstrating a high rate of cigarette smokers with schizophrenia (163). For instance, over $80 \%$ of schizophrenic patients were smokers compared to $20 \%$ of the general population of the USA in 2006 (164). Accordingly, a recent meta-analysis reported that people who smoke are three times more likely to suffer psychosis (165); thus, high cigarette smoking in schizophrenia is suggested as a physiological basis on which patients try to correct cognitive deficits caused by $\alpha 7 \mathrm{nAChR}$ dysfunction (155). In a recent study, chronic nicotine reversed hypofrontality in an animal model of addiction and schizophrenia (166). $\alpha 7 \mathrm{nAChR}$ represents a potential therapeutic target for cognitive deficits and sensory gating disturbances; nevertheless, cigarette smoking is toxic and unspecific with deleterious side effects, and it is critical to find specific and safer therapeutic strategies for schizophrenia (163).

Essentially, the development of schizophrenia is more complex. This condition is influenced by genetic vulnerability interacting synergistically with multiple environmental risk factors, such as infections or stress in early life, drug abuse, besides other environmental adversities occurring at critical periods of neurodevelopment (167-169). This gene-environmental interaction could produce a latent immune vulnerability. Thus, when this vulnerability is manifested, the individuals become more susceptible to immune dysfunctions, increasing their risk of developing schizophrenia (170).

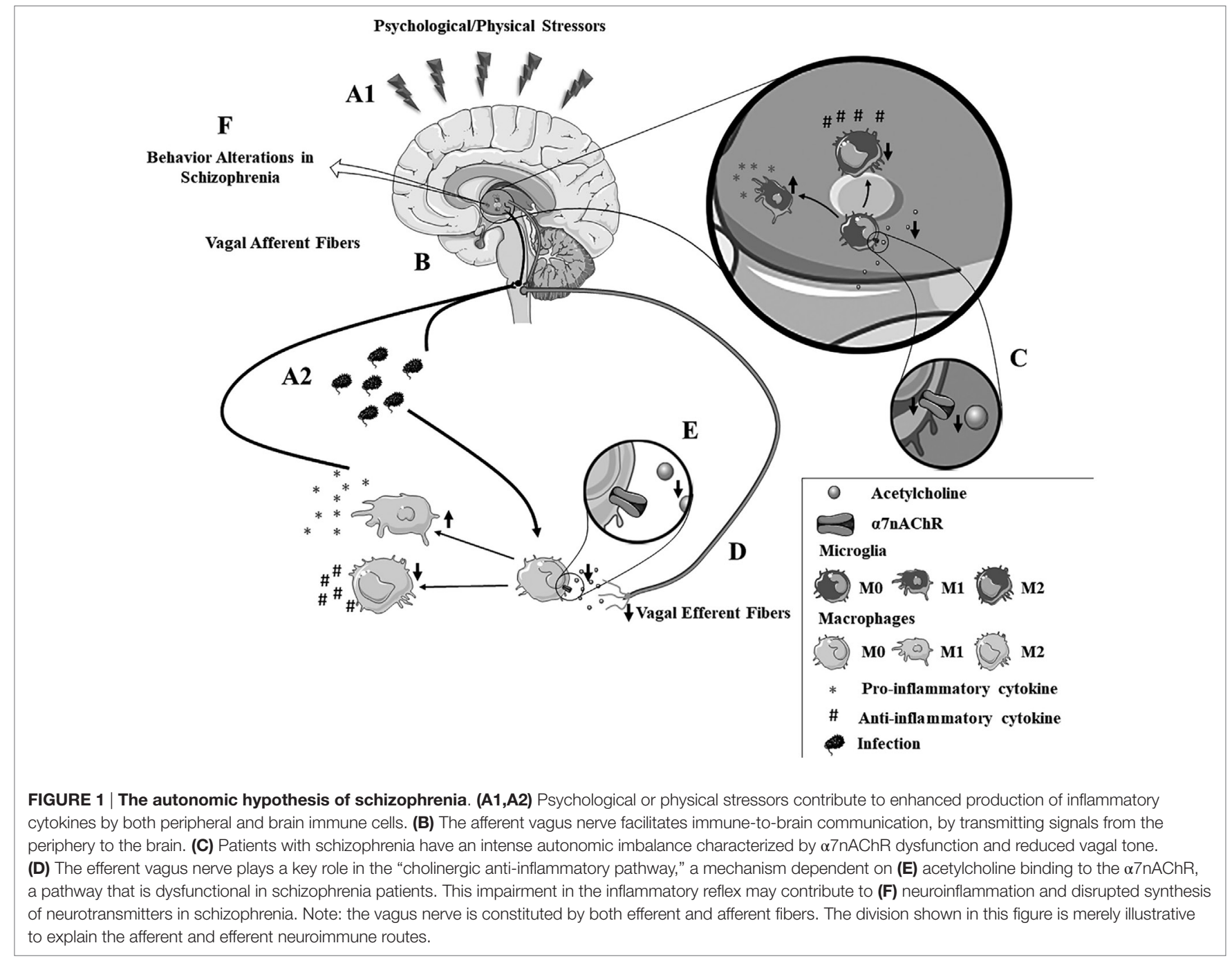


Notably, stressful situations can induce an impairment of the $\alpha 7 \mathrm{nAChR}$ (171-173). Animal models demonstrate an interaction between $\alpha 7 \mathrm{nAChR}$ and the hypothalamic-pituitary-adrenal axis, a primary system responsible for the stress response (172). Prenatal restraint stress decreases $\alpha 7 \mathrm{nAChR}$ expression in the hippocampus and prefrontal cortex in adult rats (173), while VNS reduces conditioned fear in rodents with posttraumatic stress disorder (174). A recent review stated that $\alpha 7 \mathrm{nAChR}$-agonists induce beneficial effects in patients with psychiatric disorders (139) ameliorating cognitive deficits, negative symptoms, and sensory gating disturbances in both preclinical and clinical trials of schizophrenia (139, 157-161). Advantageous effects for the negative symptoms have been reported repeatedly, while improvements in the cognitive domain remain controversial, deserving further exploration $(175,176)$. Together, these studies indicate that the vagus nerve and the $\alpha 7 \mathrm{nAChR}$ may be involved in the inflammatory hypothesis of schizophrenia (Figure 1). Thus, future investigations are critical to determine their clinical potential in schizophrenia and other neurological disorders. Moreover, the consideration of stressful events in future investigations would be of interest. This would help to reduce the discrepancy regarding inflammatory processes in schizophrenia that are observed in data from several studies.

\section{FUTURE PERSPECTIVES}

The inter-relationship between the nervous and the immune systems is critical to understand the pathogenesis of schizophrenia. In brief, a reduced parasympathetic tone could contribute to inflammation observed in schizophrenic patients. This mechanism combined with stress-mediated dysfunctions of the $\alpha 7 \mathrm{nAChR}$ can enhance the impairment of the inflammatory reflex, contributing to schizophrenia's symptoms. In the face of microglial hyperactivation, future investigations controlling microglial activation through innovative approaches, such as VNS and $\alpha 7 \mathrm{nAChR}$ modulation, may provide clinical advantages for treating schizophrenia. As early exposure to stressors induces changes in the inflammatory reflex, a better understanding of the association between biological and environmental factors would potentially improve the diagnosis and treatment of schizophrenia. In this regard, public health interventions controlling stressful

\section{REFERENCES}

1. Steel Z, Marnane C, Iranpour C, Chey T, Jackson JW, Patel V, et al. The global prevalence of common mental disorders: a systematic review and meta-analysis 1980-2013. Int J Epidemiol (2014) 43(2):476-93. doi:10.1093/ije/dyu038

2. American Psychiatric Association. Diagnostic and Statistical Manual of Mental Disorders. 5th ed. Washington, DC: American Psychiatric Association (2013).

3. Whiteford HA, Degenhardt L, Rehm J, Baxter AJ, Ferrari AJ, Erskine HE, et al. Global burden of disease attributable to mental and substance use disorders: findings from the Global Burden of Disease Study 2010. Lancet (2013) 382(9904):1575-86. doi:10.1016/S0140-6736(13)61611-6

4. Collaborators GBoDS. Global, regional, and national incidence, prevalence, and years lived with disability for 301 acute and chronic diseases and injuries in 188 countries, 1990-2013: a systematic analysis for the Global Burden of Disease Study 2013. Lancet (2015) 386(9995):743-800. doi:10.1016/ S0140-6736(15)60692-4 events, such as public education and comprehensive approaches to early treatment focusing on individual, social and environmental factors, might be beneficial for mental health promotion and prevention of future psychiatric disorders.

\section{AUTHOR CONTRIBUTIONS}

AK proposed the review to the authors and together with HS, $\mathrm{LU}$, and CD-B revised the manuscript. FC-Z and CL suggested the topic for this review, coordinated the research group, drafted and revised this manuscript. FB also drafted and revised the manuscript, and together with AK, HS, and LU was essential in the consideration of the autonomic nervous system. GQ and $\mathrm{CH}$ were helpful in providing general information about inflammation. RF participated in the elaboration of the figure. All authors approved the final manuscript.

\section{ACKNOWLEDGMENTS}

This review originated from discussions between graduate students and researchers during the course: "Neural Control of the Inflammatory Response" (RFI5806) from the Department of Physiology, Ribeirão Preto Medical School that was coordinated by HS and AK.

\section{FUNDING}

FC-Z was a recipient from Coordenação de Aperfeiçoamento de Pessoal de Nível Superior (CAPES/PROEX) and now receives a grant from Fundação de Amparo à Pesquisa do Estado de São Paulo (FAPESP), grant number: 2016/12195-9; GQ is a recipient of a fellowship from FAPESP, grant number: 2015/10378-6 and RF receives grants from FAPESP: 2016/11988-5 and 2016/076410 ; $\mathrm{FB}$ and $\mathrm{CH}$ are recipients of fellowships from Conselho Nacional de Desenvolvimento Científico e Tecnológico (CNPq), grant numbers: $154027 / 2016-2$; 830699/1999-6. AK is recipient of a fellowship from CAPES/PNPD and FAPESP, grant number: 2011/20343-4; CL receives a grant from CAPES/PROEX. CD-B receives a grant from the Thematic Project FAPESP Process number 2012/05178-0. This work received financial support from the Department of Physiology, Ribeirão Preto Medical School (Thematic Project FAPESP Process number 2013/20549-7).

5. Laursen TM, Munk-Olsen T, Vestergaard M. Life expectancy and cardiovascular mortality in persons with schizophrenia. Curr Opin Psychiatry (2012) 25(2):83-8. doi:10.1097/YCO.0b013e32835035ca

6. Pompili M, Amador XF, Girardi P, Harkavy-Friedman J, Harrow M, Kaplan K, et al. Suicide risk in schizophrenia: learning from the past to change the future. Ann Gen Psychiatry (2007) 6:10. doi:10.1186/1744-859X-6-10

7. van Os J, Kapur S. Schizophrenia. Lancet (2009) 374(9690):635-45. doi:10.1016/S0140-6736(09)60995-8

8. Whiteford HA, Ferrari AJ, Degenhardt L, Feigin V, Vos T. The global burden of mental, neurological and substance use disorders: an analysis from the Global Burden of Disease Study 2010. PLoS One (2015) 10(2):e0116820. doi:10.1371/ journal.pone.0116820

9. Leucht S, Corves C, Arbter D, Engel RR, Li C, Davis JM. Secondgeneration versus first-generation antipsychotic drugs for schizophrenia: a meta-analysis. Lancet (2009) 373(9657):31-41. doi:10.1016/S0140-6736(08) 61764-X 
10. Agid O, Kapur S, Remington G. Emerging drugs for schizophrenia. Expert Opin Emerg Drugs (2008) 13(3):479-95. doi:10.1517/14728214.13.3.479

11. Grundmann M, Kacirova I, Urinovska R. Therapeutic drug monitoring of atypical antipsychotic drugs. Acta Pharm (2014) 64(4):387-401. doi:10.2478/ acph-2014-0036

12. Gardner-Sood P, Lally J, Smith S, Atakan Z, Ismail K, Greenwood KE, et al. Cardiovascular risk factors and metabolic syndrome in people with established psychotic illnesses: baseline data from the IMPaCT randomized controlled trial. Psychol Med (2015) 45(12):2619-29. doi:10.1017/S0033291715000562

13. Howes $\mathrm{O}, \mathrm{McCutcheon} \mathrm{R}$, Stone J. Glutamate and dopamine in schizophrenia: an update for the 21st century. J Psychopharmacol (2015) 29(2):97-115 doi:10.1177/0269881114563634

14. Kegel ME, Bhat M, Skogh E, Samuelsson M, Lundberg K, Dahl ML, et al. Imbalanced kynurenine pathway in schizophrenia. Int J Tryptophan Res (2014) 7:15-22. doi:10.4137/IJTR.S16800

15. Koola MM. Kynurenine pathway and cognitive impairments in schizophrenia: pharmacogenetics of galantamine and memantine. Schizophr Res Cogn (2016) 4:4-9. doi:10.1016/j.scog.2016.02.001

16. Buka SL, Tsuang MT, Torrey EF, Klebanoff MA, Bernstein D, Yolken RH. Maternal infections and subsequent psychosis among offspring. Arch Gen Psychiatry (2001) 58(11):1032-7. doi:10.1001/archpsyc.58.11.1032

17. Brown AS, Hooton J, Schaefer CA, Zhang H, Petkova E, Babulas V, et al. Elevated maternal interleukin-8 levels and risk of schizophrenia in adult offspring. Am J Psychiatry (2004) 161(5):889-95. doi:10.1176/appi.ajp.161.5.889

18. Brown AS, Schaefer CA, Quesenberry CP, Liu L, Babulas VP, Susser ES Maternal exposure to toxoplasmosis and risk of schizophrenia in adult offspring. Am J Psychiatry (2005) 162(4):767-73. doi:10.1176/appi.ajp.162.4.767

19. Benros ME, Nielsen PR, Nordentoft M, Eaton WW, Dalton SO, Mortensen PB. Autoimmune diseases and severe infections as risk factors for schizophrenia: a 30-year population-based register study. Am J Psychiatry (2011) 168(12): 1303-10. doi:10.1176/appi.ajp.2011.11030516

20. Pavlov VA, Tracey KJ. Neural regulation of immunity: molecular mechanisms and clinical translation. Nat Neurosci (2017) 20(2):156-66. doi:10.1038/ nn. 4477

21. Martelli D, Farmer DG, Yao ST. The splanchnic anti-inflammatory pathway: could it be the efferent arm of the inflammatory reflex? Exp Physiol (2016) 101(10):1245-52. doi:10.1113/EP085559

22. Ulloa L. The vagus nerve and the nicotinic anti-inflammatory pathway. Nat Rev Drug Discov (2005) 4(8):673-84. doi:10.1038/nrd1797

23. Schweighöfer H, Rummel C, Roth J, Rosengarten B. Modulatory effects of vagal stimulation on neurophysiological parameters and the cellular immune response in the rat brain during systemic inflammation. Intensive Care Med $\operatorname{Exp}$ (2016) 4(1):19. doi:10.1186/s40635-016-0091-4

24. Meneses G, Bautista M, Florentino A, Díaz G, Acero G, Besedovsky H, et al. Electric stimulation of the vagus nerve reduced mouse neuroinflammation induced by lipopolysaccharide. J Inflamm (2016) 13:33. doi:10.1186/ s12950-016-0140-5

25. Ardesch JJ, Buschman HP, Wagener-Schimmel LJ, van der Aa HE, Hageman G. Vagus nerve stimulation for medically refractory epilepsy: a long-term followup study. Seizure (2007) 16(7):579-85. doi:10.1016/j.seizure.2007.04.005

26. Nemeroff CB, Mayberg HS, Krahl SE, McNamara J, Frazer A, Henry TR, et al. VNS therapy in treatment-resistant depression: clinical evidence and putative neurobiological mechanisms. Neuropsychopharmacology (2006) 31(7):1345-55. doi:10.1038/sj.npp.1301082

27. Cimpianu CL, Strube W, Falkai P, Palm U, Hasan A. Vagus nerve stimulation in psychiatry: a systematic review of the available evidence. J Neural Transm (2016) 124:145-58. doi:10.1007/s00702-016-1642-2

28. Corbin JG, Kelly D, Rath EM, Baerwald KD, Suzuki K, Popko B. Targeted CNS expression of interferon-gamma in transgenic mice leads to hypomyelination, reactive gliosis, and abnormal cerebellar development. Mol Cell Neurosci (1996) 7(5):354-70. doi:10.1006/mcne.1996.0026

29. Khandaker GM, Cousins L, Deakin J, Lennox BR, Yolken R, Jones PB. Inflammation and immunity in schizophrenia: implications for pathophysiology and treatment. Lancet Psychiatry (2015) 2(3):258-70. doi:10.1016/ S2215-0366(14)00122-9

30. Desbonnet L, Clarke G, Traplin A, O’Sullivan O, Crispie F, Moloney RD, et al. Gut microbiota depletion from early adolescence in mice: implications for brain and behaviour. Brain Behav Immun (2015) 48:165-73. doi:10.1016/j. bbi.2015.04.004
31. De Palma G, Lynch MD, Lu J, Dang VT, Deng Y, Jury J, et al. Transplantation of fecal microbiota from patients with irritable bowel syndrome alters gut function and behavior in recipient mice. Sci Transl Med (2017) 9(379):eaaf6397. doi:10.1126/scitranslmed.aaf6397

32. Louveau A, Smirnov I, Keyes TJ, Eccles JD, Rouhani SJ, Peske JD, et al. Structural and functional features of central nervous system lymphatic vessels. Nature (2015) 523(7560):337-41. doi:10.1038/nature14432

33. Aspelund A, Antila S, Proulx ST, Karlsen TV, Karaman S, Detmar M, et al. A dural lymphatic vascular system that drains brain interstitial fluid and macromolecules. J Exp Med (2015) 212(7):991-9. doi:10.1084/jem.20142290

34. Dantzer R, O'Connor JC, Freund GG, Johnson RW, Kelley KW. From inflammation to sickness and depression: when the immune system subjugates the brain. Nat Rev Neurosci (2008) 9(1):46-56. doi:10.1038/nrn2297

35. Smith SE, Li J, Garbett K, Mirnics K, Patterson PH. Maternal immune activation alters fetal brain development through interleukin-6. J Neurosci (2007) 27(40):10695-702. doi:10.1523/JNEUROSCI.2178-07.2007

36. McGrath J, Saha S, Chant D, Welham J. Schizophrenia: a concise overview of incidence, prevalence, and mortality. Epidemiol Rev (2008) 30:67-76. doi:10.1093/epirev/mxn001

37. Brown AS, Derkits EJ. Prenatal infection and schizophrenia: a review of epidemiologic and translational studies. Am J Psychiatry (2010) 167(3):261-80. doi:10.1176/appi.ajp.2009.09030361

38. Khandaker GM, Zimbron J, Lewis G, Jones PB. Prenatal maternal infection, neurodevelopment and adult schizophrenia: a systematic review of population-based studies. Psychol Med (2013) 43(2):239-57. doi:10.1017/ S0033291712000736

39. Knuesel I, Chicha L, Britschgi M, Schobel SA, Bodmer M, Hellings JA, et al. Maternal immune activation and abnormal brain development across CNS disorders. Nat Rev Neurol (2014) 10(11):643-60. doi:10.1038/nrneurol. 2014.187

40. Oskvig DB, Elkahloun AG, Johnson KR, Phillips TM, Herkenham M. Maternal immune activation by LPS selectively alters specific gene expression profiles of interneuron migration and oxidative stress in the fetus without triggering a fetal immune response. Brain Behav Immun (2012) 26(4):623-34. doi:10.1016/j.bbi.2012.01.015

41. Meyer U. Prenatal poly(I:C) exposure and other developmental immune activation models in rodent systems. Biol Psychiatry (2014) 75(4):307-15. doi:10.1016/j.biopsych.2013.07.011

42. Andreassen OA, Harbo HF, Wang Y, Thompson WK, Schork AJ, Mattingsdal M, et al. Genetic pleiotropy between multiple sclerosis and schizophrenia but not bipolar disorder: differential involvement of immune-related gene loci. $\mathrm{Mol}$ Psychiatry (2015) 20(2):207-14. doi:10.1038/mp.2013.195

43. Miller BJ, Buckley P, Seabolt W, Mellor A, Kirkpatrick B. Meta-analysis of cytokine alterations in schizophrenia: clinical status and antipsychotic effects. Biol Psychiatry (2011) 70(7):663-71. doi:10.1016/j.biopsych.2011.04.013

44. Potvin S, Stip E, Sepehry AA, Gendron A, Bah R, Kouassi E. Inflammatory cytokine alterations in schizophrenia: a systematic quantitative review. Biol Psychiatry (2008) 63(8):801-8. doi:10.1016/j.biopsych.2007.09.024

45. Upthegrove R, Manzanares-Teson N, Barnes NM. Cytokine function in medication-naive first episode psychosis: a systematic review and meta-analysis. Schizophr Res (2014) 155(1-3):101-8. doi:10.1016/j.schres.2014.03.005

46. Goldsmith DR, Rapaport MH, Miller BJ. A meta-analysis of blood cytokine network alterations in psychiatric patients: comparisons between schizophrenia, bipolar disorder and depression. Mol Psychiatry (2016) 21(12):1696-709. doi:10.1038/mp.2016.3

47. Smith RS, Maes M. The macrophage-T-lymphocyte theory of schizophrenia: additional evidence. Med Hypotheses (1995) 45(2):135-41. doi:10.1016/03069877(95)90062-4

48. Schwarz MJ, Müller N, Riedel M, Ackenheil M. The Th2-hypothesis of schizophrenia: a strategy to identify a subgroup of schizophrenia caused by immune mechanisms. Med Hypotheses (2001) 56(4):483-6. doi:10.1054/mehy. 2000.1203

49. Kim YK, Myint AM, Lee BH, Han CS, Lee HJ, Kim DJ, et al. Th1, Th2 and Th3 cytokine alteration in schizophrenia. Prog Neuropsychopharmacol Biol Psychiatry (2004) 28(7):1129-34. doi:10.1016/j.pnpbp.2004.05.047

50. Modai S, Shomron N. Molecular risk factors for schizophrenia. Trends $\mathrm{Mol}$ Med (2016) 22(3):242-53. doi:10.1016/j.molmed.2016.01.006

51. Monji A, Kato TA, Mizoguchi Y, Horikawa H, Seki Y, Kasai M, et al. Neuroinflammation in schizophrenia especially focused on the role of 
microglia. Prog Neuropsychopharmacol Biol Psychiatry (2013) 42:115-21. doi:10.1016/j.pnpbp.2011.12.002

52. Wake H, Moorhouse AJ, Jinno S, Kohsaka S, Nabekura J. Resting microglia directly monitor the functional state of synapses in vivo and determine the fate of ischemic terminals. J Neurosci (2009) 29(13):3974-80. doi:10.1523/ JNEUROSCI.4363-08.2009

53. Kigerl KA, Gensel JC, Ankeny DP, Alexander JK, Donnelly DJ, Popovich PG Identification of two distinct macrophage subsets with divergent effects causing either neurotoxicity or regeneration in the injured mouse spinal cord. J Neurosci (2009) 29(43):13435-44. doi:10.1523/JNEUROSCI.3257-09.2009

54. Cacci E, Claasen JH, Kokaia Z. Microglia-derived tumor necrosis factor-alpha exaggerates death of newborn hippocampal progenitor cells in vitro. J Neurosci Res (2005) 80(6):789-97. doi:10.1002/jnr.20531

55. Wohleb ES, Fenn AM, Pacenta AM, Powell ND, Sheridan JF, Godbout JP. Peripheral innate immune challenge exaggerated microglia activation, increased the number of inflammatory CNS macrophages, and prolonged social withdrawal in socially defeated mice. Psychoneuroendocrinology (2012) 37(9):1491-505. doi:10.1016/j.psyneuen.2012.02.003

56. Häusler KG, Prinz M, Nolte C, Weber JR, Schumann RR, Kettenmann H, et al. Interferon-gamma differentially modulates the release of cytokines and chemokines in lipopolysaccharide- and pneumococcal cell wall-stimulated mouse microglia and macrophages. Eur J Neurosci (2002) 16(11):2113-22. doi:10.1046/j.1460-9568.2002.02287.x

57. de Pablos RM, Villarán RF, Argüelles S, Herrera AJ, Venero JL, Ayala A, et al. Stress increases vulnerability to inflammation in the rat prefrontal cortex. J Neurosci (2006) 26(21):5709-19. doi:10.1523/JNEUROSCI.0802-06.2006

58. Wang HT, Huang FL, Hu ZL, Zhang WJ, Qiao XQ, Huang YQ, et al. Early-life social isolation-induced depressive-like behavior in rats results in microglial activation and neuronal histone methylation that are mitigated by minocycline. Neurotox Res (2017) 31(4):505-20. doi:10.1007/s12640-016-9696-3

59. Roque A, Ochoa-Zarzosa A, Torner L. Maternal separation activates microglial cells and induces an inflammatory response in the hippocampus of male rat pups, independently of hypothalamic and peripheral cytokine levels. Brain Behav Immun (2016) 55:39-48. doi:10.1016/j.bbi.2015.09.017

60. Gracia-Rubio I, Moscoso-Castro M, Pozo OJ, Marcos J, Nadal R, Valverde O. Maternal separation induces neuroinflammation and long-lasting emotional alterations in mice. Prog Neuropsychopharmacol Biol Psychiatry (2016) 65:104-17. doi:10.1016/j.pnpbp.2015.09.003

61. Blandino P, Barnum CJ, Deak T. The involvement of norepinephrine and microglia in hypothalamic and splenic IL-1beta responses to stress. J Neuroimmunol (2006) 173(1-2):87-95. doi:10.1016/j.jneuroim.2005.11.021

62. Shimoda M, Jones VC, Kobayashi M, Suzuki F. Microglial cells from psychologically stressed mice as an accelerator of cerebral cryptococcosis. Immunol Cell Biol (2006) 84(6):551-6. doi:10.1111/j.1440-1711.2006.01466.x

63. Frank MG, Baratta MV, Sprunger DB, Watkins LR, Maier SF. Microglia serve as a neuroimmune substrate for stress-induced potentiation of CNS proinflammatory cytokine responses. Brain Behav Immun (2007) 21(1):47-59. doi:10.1016/j.bbi.2006.03.005

64. Johnson JD, O'Connor KA, Deak T, Stark M, Watkins LR, Maier SF. Prior stressor exposure sensitizes LPS-induced cytokine production. Brain Behav Immun (2002) 16(4):461-76. doi:10.1006/brbi.2001.0638

65. Mahadevan J, Sundaresh A, Rajkumar RP, Muthuramalingam A, Menon V, Negi VS, et al. An exploratory study of immune markers in acute and transient psychosis. Asian J Psychiatr (2017) 25:219-23. doi:10.1016/j.ajp.2016.11.010

66. Lee EE, Hong S, Martin AS, Eyler LT, Jeste DV. Inflammation in schizophrenia: cytokine levels and their relationships to demographic and clinical variables. Am J Geriatr Psychiatry (2017) 25(1):50-61. doi:10.1016/j.jagp.2016.09.009

67. Szymona K, Zdzisińska B, Karakuła-Juchnowicz H, Kocki T, KandeferSzerszeń M, Flis M, et al. Correlations of kynurenic acid, 3-hydroxykynurenine, sIL-2R, IFN- $\alpha$, and IL-4 with clinical symptoms during acute relapse of schizophrenia. Neurotox Res (2017). doi:10.1007/s12640-017-9714-0

68. Busse S, Busse M, Schiltz K, Bielau H, Gos T, Brisch R, et al. Different distribution patterns of lymphocytes and microglia in the hippocampus of patients with residual versus paranoid schizophrenia: further evidence for disease course-related immune alterations? Brain Behav Immun (2012) 26(8):1273-9. doi:10.1016/j.bbi.2012.08.005

69. Bayer TA, Buslei R, Havas L, Falkai P. Evidence for activation of microglia in patients with psychiatric illnesses. Neurosci Lett (1999) 271(2):126-8. doi:10.1016/S0304-3940(99)00545-5
70. Radewicz K, Garey LJ, Gentleman SM, Reynolds R. Increase in HLA-DR immunoreactive microglia in frontal and temporal cortex of chronic schizophrenics. J Neuropathol Exp Neurol (2000) 59(2):137-50. doi:10.1093/ jnen/59.2.137

71. Steiner J, Mawrin C, Ziegeler A, Bielau H, Ullrich O, Bernstein HG, et al. Distribution of HLA-DR-positive microglia in schizophrenia reflects impaired cerebral lateralization. Acta Neuropathol (2006) 112(3):305-16. doi:10.1007/ 00401-006-0090-8

72. Doorduin J, de Vries EF, Willemsen AT, de Groot JC, Dierckx RA, Klein HC. Neuroinflammation in schizophrenia-related psychosis: a PET study. J Nucl Med (2009) 50(11):1801-7. doi:10.2967/jnumed.109.066647

73. van Berckel BN, Bossong MG, Boellaard R, Kloet R, Schuitemaker A, Caspers E, et al. Microglia activation in recent-onset schizophrenia: a quantitative (R)-[11C]PK11195 positron emission tomography study. Biol Psychiatry (2008) 64(9):820-2. doi:10.1016/j.biopsych.2008.04.025

74. Steiner J, Bielau H, Brisch R, Danos P, Ullrich O, Mawrin C, et al. Immunological aspects in the neurobiology of suicide: elevated microglial density in schizophrenia and depression is associated with suicide. J Psychiatr Res (2008) 42(2):151-7. doi:10.1016/j.jpsychires.2006.10.013

75. Monje ML, Toda H, Palmer TD. Inflammatory blockade restores adult hippocampal neurogenesis. Science (2003) 302(5651):1760-5. doi:10.1126/ science. 1088417

76. Iosif RE, Ekdahl CT, Ahlenius H, Pronk CJ, Bonde S, Kokaia Z, et al. Tumor necrosis factor receptor 1 is a negative regulator of progenitor proliferation in adult hippocampal neurogenesis. J Neurosci (2006) 26(38):9703-12. doi:10.1523/JNEUROSCI.2723-06.2006

77. Kaneko N, Kudo K, Mabuchi T, Takemoto K, Fujimaki K, Wati H, et al. Suppression of cell proliferation by interferon-alpha through interleukin-1 production in adult rat dentate gyrus. Neuropsychopharmacology (2006) 31(12):2619-26. doi:10.1038/sj.npp.1301137

78. Meyer U, Schwarz MJ, Müller N. Inflammatory processes in schizophrenia: a promising neuroimmunological target for the treatment of negative/cognitive symptoms and beyond. Pharmacol Ther (2011) 132(1):96-110. doi:10.1016/j. pharmthera.2011.06.003

79. Möller M, Du Preez JL, Emsley R, Harvey BH. Social isolation rearing in rats alters plasma tryptophan metabolism and is reversed by sub-chronic clozapine treatment. Neuropharmacology (2012) 62(8):2499-506. doi:10.1016/j. neuropharm.2012.02.021

80. Bressan RA, Pilowsky LS. [Glutamatergic hypothesis of schizophrenia]. Rev Bras Psiquiatr (2003) 25(3):177-83. doi:10.1590/S1516-44462003000300011

81. Gouzoulis-Mayfrank E, Heekeren K, Neukirch A, Stoll M, Stock C, Obradovic M, et al. Psychological effects of (S)-ketamine and N,N-dimethyltryptamine (DMT): a double-blind, cross-over study in healthy volunteers. Pharmacopsychiatry (2005) 38(6):301-11. doi:10.1055/s-2005-918695

82. Luby ED, Cohen BD, Rosenbaum G, Gottlieb JS, Kelley R. Study of a new schizophrenomimetic drug; sernyl. AMA Arch Neurol Psychiatry (1959) 81(3):363-9. doi:10.1001/archneurpsyc.1959.02340150095011

83. Steiner J, Walter M, Glanz W, Sarnyai Z, Bernstein HG, Vielhaber S, et al. Increased prevalence of diverse N-methyl-D-aspartate glutamate receptor antibodies in patients with an initial diagnosis of schizophrenia: specific relevance of IgG NR1a antibodies for distinction from N-methyl-D-aspartate glutamate receptor encephalitis. JAMA Psychiatry (2013) 70(3):271-8. doi:10.1001/2013.jamapsychiatry. 86

84. Lennox BR, Palmer-Cooper EC, Pollak T, Hainsworth J, Marks J, Jacobson L, et al. Prevalence and clinical characteristics of serum neuronal cell surface antibodies in first-episode psychosis: a case-control study. Lancet Psychiatry (2017) 4(1):42-8. doi:10.1016/S2215-0366(16)30375-3

85. Bian Q, Kato T, Monji A, Hashioka S, Mizoguchi Y, Horikawa H, et al. The effect of atypical antipsychotics, perospirone, ziprasidone and quetiapine on microglial activation induced by interferon-gamma. Prog Neuropsychopharmacol Biol Psychiatry (2008) 32(1):42-8. doi:10.1016/j.pnpbp.2007.06.031

86. Seki Y, Kato TA, Monji A, Mizoguchi Y, Horikawa H, Sato-Kasai M, et al. Pretreatment of aripiprazole and minocycline, but not haloperidol, suppresses oligodendrocyte damage from interferon- $\gamma$-stimulated microglia in co-culture model. Schizophr Res (2013) 151(1-3):20-8. doi:10.1016/j. schres.2013.09.011

87. Kato T, Monji A, Hashioka S, Kanba S. Risperidone significantly inhibits interferon-gamma-induced microglial activation in vitro. Schizophr Res (2007) 92(1-3):108-15. doi:10.1016/j.schres.2007.01.019 
88. Tracey KJ. The inflammatory reflex. Nature (2002) 420(6917):853-9. doi:10.1038/nature01321

89. Andersson U, Tracey KJ. Neural reflexes in inflammation and immunity. J Exp Med (2012) 209(6):1057-68. doi:10.1084/jem.20120571

90. Pellissier S, Dantzer C, Canini F, Mathieu N, Bonaz B. Psychological adjustment and autonomic disturbances in inflammatory bowel diseases and irritable bowel syndrome. Psychoneuroendocrinology (2010) 35(5):653-62. doi:10.1016/j.psyneuen.2009.10.004

91. Bonaz B, Sinniger V, Pellissier S. Anti-inflammatory properties of the vagus nerve: potential therapeutic implications of vagus nerve stimulation. J Physiol (2016) 594(20):5781-90. doi:10.1113/JP271539

92. Cai B, Dong W, Sharpe S, Deitch EA, Ulloa L. Survival and inflammatory responses in experimental models of hemorrhage. JSurg Res (2011) 169(2):257-66. doi:10.1016/j.jss.2009.11.712

93. Ulloa L. The anti-inflammatory potential of selective cholinergic agonists. Shock (2011) 36(1):97-8. doi:10.1097/SHK.0b013e31821820d2

94. Bassi GS, Brognara F, Castania JA, Talbot J, Cunha TM, Cunha FQ, et al. Baroreflex activation in conscious rats modulates the joint inflammatory response via sympathetic function. Brain Behav Immun (2015) 49:140-7. doi:10.1016/j.bbi.2015.05.002

95. McCorry LK. Physiology of the autonomic nervous system. Am J Pharm Educ (2007) 71(4):78. doi:10.5688/aj710478

96. Berthoud HR, Neuhuber WL. Functional and chemical anatomy of the afferent vagal system. Auton Neurosci (2000) 85(1-3):1-17. doi:10.1016/ S1566-0702(00)00215-0

97. Heart Rate Variability. Standards of measurement, physiological interpretation, and clinical use. Task force of the European Society of Cardiology and the North American Society of Pacing and Electrophysiology. Eur Heart J (1996) 17(3):354-81

98. Stauss HM. Physiologic mechanisms of heart rate variability. Rev Bras Hipertens (2007) 14(1):8-15.

99. Squires RW. Defining the high-risk cardiac patient. In: Robertson L, Enderle K, Hambly L, editors. Exercise Prescription for the High-Risk Cardiac Patient. Human Kinetics (1998). p. 1-16.

100. Ponikowski P, Anker SD, Chua TP, Szelemej R, Piepoli M, Adamopoulos S, et al. Depressed heart rate variability as an independent predictor of death in chronic congestive heart failure secondary to ischemic or idiopathic dilated cardiomyopathy. Am J Cardiol (1997) 79(12):1645-50. doi:10.1016/ S0002-9149(97)00215-4

101. La Rovere MT, Pinna GD, Maestri R, Mortara A, Capomolla S, Febo O, et al. Short-term heart rate variability strongly predicts sudden cardiac death in chronic heart failure patients. Circulation (2003) 107(4):565-70. doi:10.1161/01.CIR.0000047275.25795.17

102. Hemingway H, Shipley M, Brunner E, Britton A, Malik M, Marmot M. Does autonomic function link social position to coronary risk? The Whitehall II study. Circulation (2005) 111(23):3071-7. doi:10.1161/CIRCULATIONAHA. 104.497347

103. Bassett D, Bear N, Nutt D, Hood S, Bassett S, Hans D. Reduced heart rate variability in remitted bipolar disorder and recurrent depression. Aust N Z J Psychiatry (2016) 50(8):793-804. doi:10.1177/ 0004867416652734

104. Malaspina D, Bruder G, Dalack GW, Storer S, Van Kammen M, Amador X, et al. Diminished cardiac vagal tone in schizophrenia: associations to brain laterality and age of onset. Biol Psychiatry (1997) 41(5):612-7. doi:10.1016/ S0006-3223(96)00161-8

105. Bär KJ, Letzsch A, Jochum T, Wagner G, Greiner W, Sauer H. Loss of efferent vagal activity in acute schizophrenia. J Psychiatr Res (2005) 39(5):519-27. doi:10.1016/j.jpsychires.2004.12.007

106. Bär KJ, Boettger MK, Berger S, Baier V, Sauer H, Yeragani VK, et al. Decreased baroreflex sensitivity in acute schizophrenia. J Appl Physiol (1985) (2007) 102(3):1051-6. doi:10.1152/japplphysiol.00811.2006

107. Toichi M, Kubota Y, Murai T, Kamio Y, Sakihama M, Toriuchi T, et al. The influence of psychotic states on the autonomic nervous system in schizophrenia. Int J Psychophysiol (1999) 31(2):147-54. doi:10.1016/ S0167-8760(98)00047-6

108. Zahn TP, Pickar D. Autonomic activity in relation to symptom ratings and reaction time in unmedicated patients with schizophrenia. Schizophr Res (2005) 79(2-3):257-70. doi:10.1016/j.schres.2005.05.025
109. Chambers AS, Allen JJ. Vagal tone as an indicator of treatment response in major depression. Psychophysiology (2002) 39(6):861-4. doi:10.1111/14698986.3960861

110. Porges SW. The polyvagal theory: phylogenetic substrates of a social nervous system. Int J Psychophysiol (2001) 42(2):123-46. doi:10.1016/S01678760(01)00162-3

111. Bylsma LM, Yaroslavsky I, Rottenberg J, Jennings JR, George CJ, Kiss E, et al. Juvenile onset depression alters cardiac autonomic balance in response to psychological and physical challenges. Biol Psychol (2015) 110:167-74. doi:10.1016/j.biopsycho.2015.07.003

112. De Benedictis A, Freri E, Rizzi M, Franzini A, Ragona F, Specchio N, et al. Vagus nerve stimulation for drug-resistant epilepsia partialis continua: report of four cases. Epilepsy Res (2013) 107(1-2):163-71. doi:10.1016/j. eplepsyres.2013.07.010

113. Rush AJ, Sackeim HA, Marangell LB, George MS, Brannan SK, Davis SM, et al. Effects of 12 months of vagus nerve stimulation in treatment-resistant depression: a naturalistic study. Biol Psychiatry (2005) 58(5):355-63. doi:10.1016/j.biopsych.2005.05.024

114. Bajbouj M, Merkl A, Schlaepfer TE, Frick C, Zobel A, Maier W, et al. Two-year outcome of vagus nerve stimulation in treatment-resistant depression. J Clin Psychopharmacol (2010) 30(3):273-81. doi:10.1097/JCP.0b013e3181db8831

115. Hasan A, Wolff-Menzler C, Pfeiffer S, Falkai P, Weidinger E, Jobst A, et al. Transcutaneous noninvasive vagus nerve stimulation (tVNS) in the treatment of schizophrenia: a bicentric randomized controlled pilot study. Eur Arch Psychiatry Clin Neurosci (2015) 265(7):589-600. doi:10.1007/ s00406-015-0618-9

116. Frangos E, Komisaruk BR. Access to vagal projections via cutaneous electrical stimulation of the neck: fMRI evidence in healthy humans. Brain Stimul (2017) 10(1):19-27. doi:10.1016/j.brs.2016.10.008

117. Yakunina N, Kim SS, Nam EC. Optimization of transcutaneous vagus nerve stimulation using functional MRI. Neuromodulation (2016) 20:290-300. doi:10.1111/ner.12541

118. Smucny J, Visani A, Tregellas JR. Could vagus nerve stimulation target hippocampal hyperactivity to improve cognition in schizophrenia? Front Psychiatry (2015) 6:43. doi:10.3389/fpsyt.2015.00043

119. Perez SM, Carreno FR, Frazer A, Lodge DJ. Vagal nerve stimulation reverses aberrant dopamine system function in the methylazoxymethanol acetate rodent model of schizophrenia. J Neurosci (2014) 34(28):9261-7. doi:10.1523/JNEUROSCI.0588-14.2014

120. Borovikova LV, Ivanova S, Zhang M, Yang H, Botchkina GI, Watkins LR, et al. Vagus nerve stimulation attenuates the systemic inflammatory response to endotoxin. Nature (2000) 405(6785):458-62. doi:10.1038/35013070

121. Ondicova K, Pecenák J, Mravec B. The role of the vagus nerve in depression. Neuro Endocrinol Lett (2010) 31(5):602-8.

122. Vonck K, Raedt R, Naulaerts J, De Vogelaere F, Thiery E, Van Roost D, et al. Vagus nerve stimulation...25 years later! What do we know about the effects on cognition? Neurosci Biobehav Rev (2014) 45:63-71. doi:10.1016/j. neubiorev.2014.05.005

123. Zhang Y, Popovic ZB, Bibevski S, Fakhry I, Sica DA, Van Wagoner DR, et al. Chronic vagus nerve stimulation improves autonomic control and attenuates systemic inflammation and heart failure progression in a canine high-rate pacing model. Circ Heart Fail (2009) 2(6):692-9. doi:10.1161/ CIRCHEARTFAILURE.109.873968

124. Köhler O, Benros ME, Nordentoft M, Farkouh ME, Iyengar RL, Mors O, et al. Effect of anti-inflammatory treatment on depression, depressive symptoms, and adverse effects: a systematic review and meta-analysis of randomized clinical trials. JAMA Psychiatry (2014) 71(12):1381-91. doi:10.1001/ jamapsychiatry.2014.1611

125. Ulloa L. The cholinergic anti-inflammatory pathway meets microRNA. Cell Res (2013) 23(11):1249-50. doi:10.1038/cr.2013.128

126. Tracey KJ. Reflex control of immunity. Nat Rev Immunol (2009) 9(6):418-28. doi:10.1038/nri2566

127. Hurst R, Rollema H, Bertrand D. Nicotinic acetylcholine receptors: from basic science to therapeutics. Pharmacol Ther (2013) 137(1):22-54. doi:10.1016/j. pharmthera.2012.08.012

128. Dineley KT, Pandya AA, Yakel JL. Nicotinic ACh receptors as therapeutic targets in CNS disorders. Trends Pharmacol Sci (2015) 36(2):96-108. doi:10.1016/j.tips.2014.12.002 
129. John D, Shelukhina I, Yanagawa Y, Deuchars J, Henderson Z. Functional alpha7 nicotinic receptors are expressed on immature granule cells of the postnatal dentate gyrus. Brain Res (2015) 1601:15-30. doi:10.1016/j. brainres.2014.12.041

130. Shen JX, Yakel JL. Functional $\alpha 7$ nicotinic ACh receptors on astrocytes in rat hippocampal CA1 slices. J Mol Neurosci (2012) 48(1):14-21. doi:10.1007/ s12031-012-9719-3

131. Shytle RD, Mori T, Townsend K, Vendrame M, Sun N, Zeng J, et al. Cholinergic modulation of microglial activation by alpha 7 nicotinic receptors. J Neurochem (2004) 89(2):337-43. doi:10.1046/j.1471-4159.2004.02347.x

132. Suzuki T, Hide I, Matsubara A, Hama C, Harada K, Miyano K, et al. Microglial alpha7 nicotinic acetylcholine receptors drive a phospholipase $\mathrm{C} /$ IP3 pathway and modulate the cell activation toward a neuroprotective role. J Neurosci Res (2006) 83(8):1461-70. doi:10.1002/jnr.20850

133. Hamano R, Takahashi HK, Iwagaki H, Yoshino T, Nishibori M, Tanaka N. Stimulation of alpha7 nicotinic acetylcholine receptor inhibits CD14 and the toll-like receptor 4 expression in human monocytes. Shock (2006) 26(4): 358-64. doi:10.1097/01.shk.0000228168.86845.60

134. Rosas-Ballina M, Goldstein RS, Gallowitsch-Puerta M, Yang L, Valdés-Ferrer SI, Patel NB, et al. The selective alpha7 agonist GTS-21 attenuates cytokine production in human whole blood and human monocytes activated by ligands for TLR2, TLR3, TLR4, TLR9, and RAGE. Mol Med (2009) 15(7-8):195-202. doi:10.2119/molmed.2009.00039

135. Sato K, Nagayama H, Tadokoro K, Juji T, Takahashi TA. Extracellular signal-regulated kinase, stress-activated protein kinase/c-Jun $\mathrm{N}$-terminal kinase, and p38mapk are involved in IL-10-mediated selective repression of TNF-alpha-induced activation and maturation of human peripheral blood monocyte-derived dendritic cells. J Immunol (1999) 162(7):3865-72.

136. Wang H, Yu M, Ochani M, Amella CA, Tanovic M, Susarla S, et al. Nicotinic acetylcholine receptor alpha7 subunit is an essential regulator of inflammation. Nature (2003) 421(6921):384-8. doi:10.1038/nature01339

137. Razani-Boroujerdi S, Boyd RT, Dávila-García MI, Nandi JS, Mishra NC, Singh SP, et al. T cells express alpha7-nicotinic acetylcholine receptor subunits that require a functional TCR and leukocyte-specific protein tyrosine kinase for nicotine-induced Ca2+ response. J Immunol (2007) 179(5):2889-98. doi:10.4049/jimmunol.179.5.2889

138. Skok MV, Kalashnik EN, Koval LN, Tsetlin VI, Utkin YN, Changeux JP, et al. Functional nicotinic acetylcholine receptors are expressed in B lymphocyte-derived cell lines. Mol Pharmacol (2003) 64(4):885-9. doi:10.1124/ mol.64.4.885

139. Kalkman HO, Feuerbach D. Modulatory effects of $\alpha 7$ nAChRs on the immune system and its relevance for CNS disorders. Cell Mol Life Sci (2016) 73(13):2511-30. doi:10.1007/s00018-016-2175-4

140. Zhang Q, Lu Y, Bian H, Guo L, Zhu H. Activation of the $\alpha 7$ nicotinic receptor promotes lipopolysaccharide-induced conversion of M1 microglia to M2. Am J Transl Res (2017) 9(3):971-85.

141. Leonard S, Freedman R. Genetics of chromosome 15q13-q14 in schizophrenia. Biol Psychiatry (2006) 60(2):115-22. doi:10.1016/j.biopsych.2006.03.054

142. Freedman R, Adams CE, Leonard S. The alpha7-nicotinic acetylcholine receptor and the pathology of hippocampal interneurons in schizophrenia. J Chem Neuroanat (2000) 20(3-4):299-306. doi:10.1016/S0891-0618(00)00109-5

143. Court J, Spurden D, Lloyd S, McKeith I, Ballard C, Cairns N, et al. Neuronal nicotinic receptors in dementia with Lewy bodies and schizophrenia: alpha-bungarotoxin and nicotine binding in the thalamus. JNeurochem (1999) 73(4):1590-7. doi:10.1046/j.1471-4159.1999.0731590.x

144. Guan ZZ, Zhang X, Blennow K, Nordberg A. Decreased protein level of nic otinic receptor alpha7 subunit in the frontal cortex from schizophrenic brain. Neuroreport (1999) 10(8):1779-82. doi:10.1097/00001756-199906030-00028

145. Woo TU, Kim AM, Viscidi E. Disease-specific alterations in glutamatergic neurotransmission on inhibitory interneurons in the prefrontal cortex in schizophrenia. Brain Res (2008) 1218:267-77. doi:10.1016/j. brainres.2008.03.092

146. Marutle A, Zhang X, Court J, Piggott M, Johnson M, Perry R, et al. Laminar distribution of nicotinic receptor subtypes in cortical regions in schizophrenia. JChem Neuroanat (2001) 22(1-2):115-26. doi:10.1016/ S0891-0618(01)00117-X

147. Lewis DA, Curley AA, Glausier JR, Volk DW. Cortical parvalbumin interneurons and cognitive dysfunction in schizophrenia. Trends Neurosci (2012) 35(1):57-67. doi:10.1016/j.tins.2011.10.004
148. Li S, Nai Q, Lipina TV, Roder JC, Liu F. $\alpha 7 n$ AchR/NMDAR coupling affects NMDAR function and object recognition. Mol Brain (2013) 6:58. doi:10.1186/1756-6606-6-58

149. Shen L, Cui WY, Chen RZ, Wang H. Differential modulation of GABAA and NMDA receptors by $\alpha 7$-nicotinic receptor desensitization in cultured rat hippocampal neurons. Acta Pharmacol Sin (2016) 37(3):312-21. doi:10.1038/ aps.2015.106

150. Liu Z, Conroy WG, Stawicki TM, Nai Q, Neff RA, Berg DK. EphB receptors co-distribute with a nicotinic receptor subtype and regulate nicotinic downstream signaling in neurons. Mol Cell Neurosci (2008) 38(2):236-44. doi:10.1016/j.mcn.2008.02.013

151. Yakel JL. Nicotinic ACh receptors in the hippocampal circuit; functional expression and role in synaptic plasticity. J Physiol (2014) 592(19):4147-53. doi:10.1113/jphysiol.2014.273896

152. Nordman JC, Phillips WS, Kodama N, Clark SG, Del Negro CA, Kabbani N. Axon targeting of the alpha 7 nicotinic receptor in developing hippocampal neurons by Gprin1 regulates growth. J Neurochem (2014) 129(4):649-62. doi:10.1111/jnc.12641

153. Wonnacott S, Barik J, Dickinson J, Jones IW. Nicotinic receptors modulate transmitter cross talk in the CNS: nicotinic modulation of transmitters. J Mol Neurosci (2006) 30(1-2):137-40. doi:10.1385/JMN:30:1:137

154. Lin H, Hsu FC, Baumann BH, Coulter DA, Lynch DR. Cortical synaptic NMDA receptor deficits in $\alpha 7$ nicotinic acetylcholine receptor gene deletion models: implications for neuropsychiatric diseases. Neurobiol Dis (2014) 63:129-40. doi:10.1016/j.nbd.2013.11.021

155. Hilmas C, Pereira EF, Alkondon M, Rassoulpour A, Schwarcz R, Albuquerque EX. The brain metabolite kynurenic acid inhibits alpha7 nicotinic receptor activity and increases non-alpha7 nicotinic receptor expression: physiopathological implications. J Neurosci (2001) 21(19):7463-73.

156. Pichat P, Bergis OE, Terranova JP, Urani A, Duarte C, Santucci V, et al. SSR180711, a novel selective alpha7 nicotinic receptor partial agonist: (II) efficacy in experimental models predictive of activity against cognitive symptoms of schizophrenia. Neuropsychopharmacology (2007) 32(1):17-34. doi:10.1038/sj.npp. 1301188

157. Olincy A, Harris JG, Johnson LL, Pender V, Kongs S, Allensworth D, et al. Proof-of-concept trial of an alpha7 nicotinic agonist in schizophrenia. Arch Gen Psychiatry (2006) 63(6):630-8. doi:10.1001/archpsyc. 63.6.630

158. Freedman R, Olincy A, Buchanan RW, Harris JG, Gold JM, Johnson L, et al. Initial phase 2 trial of a nicotinic agonist in schizophrenia. Am J Psychiatry (2008) 165(8):1040-7. doi:10.1176/appi.ajp.2008.07071135

159. Sinkus ML, Lee MJ, Gault J, Logel J, Short M, Freedman R, et al. A 2-base pair deletion polymorphism in the partial duplication of the alpha7 nicotinic acetylcholine gene (CHRFAM7A) on chromosome $15 \mathrm{q} 14$ is associated with schizophrenia. Brain Res (2009) 1291:1-11. doi:10.1016/j. brainres.2009.07.041

160. Egea J, Buendia I, Parada E, Navarro E, León R, Lopez MG. Antiinflammatory role of microglial alpha7 $\mathrm{nAChRs}$ and its role in neuroprotection. Biochem Pharmacol (2015) 97(4):463-72. doi:10.1016/j. bcp.2015.07.032

161. Keefe RS, Meltzer HA, Dgetluck N, Gawryl M, Koenig G, Moebius HJ, et al. Randomized, double-blind, placebo-controlled study of encenicline, an $\alpha 7$ nicotinic acetylcholine receptor agonist, as a treatment for cognitive impairment in schizophrenia. Neuropsychopharmacology (2015) 40(13):3053-60. doi:10.1038/npp.2015.176

162. Milart P, Młynarczyk M, Sikorski R. Influence of maternal smoking on kynurenic acid concentrations in umbilical cord blood. Ginekol Pol (2000) 71(8):843-7.

163. Sagud M, Mihaljević-Peles A, Mück-Seler D, Pivac N, Vuksan-Cusa B, Brataljenović T, et al. Smoking and schizophrenia. Psychiatr Danub (2009) 21(3):371-5.

164. Keltner NL, Grant JS. Smoke, smoke, smoke that cigarette. Perspect Psychiatr Care (2006) 42(4):256-61. doi:10.1111/j.1744-6163.2006.00085.x

165. Gurillo P, Jauhar S, Murray RM, MacCabe JH. Does tobacco use cause psychosis? Systematic review and meta-analysis. Lancet Psychiatry (2015) 2(8):718-25. doi:10.1016/S2215-0366(15)00152-2

166. Koukouli F, Rooy M, Tziotis D, Sailor KA, O’Neill HC, Levenga J, et al. Nicotine reverses hypofrontality in animal models of addiction and schizophrenia. Nat Med (2017) 23(3):347-54. doi:10.1038/nm.4274 
167. Baharnoori M, Bhardwaj SK, Srivastava LK. Neonatal behavioral changes in rats with gestational exposure to lipopolysaccharide: a prenatal infection model for developmental neuropsychiatric disorders. Schizophr Bull (2012) 38(3):444-56. doi:10.1093/schbul/sbq098

168. Karl T, Arnold JC. Schizophrenia: a consequence of gene-environment interactions? Front Behav Neurosci (2014) 8:435. doi:10.3389/fnbeh.2014. 00435

169. Tournier M. [First-episodes psychosis: clinical and epidemiological news]. Encephale (2013) 39(Suppl 2):S74-8. doi:10.1016/S0013-7006(13) 70099-X

170. Kinney DK, Hintz K, Shearer EM, Barch DH, Riffin C, Whitley K, et al. A unifying hypothesis of schizophrenia: abnormal immune system development may help explain roles of prenatal hazards, post-pubertal onset, stress, genes, climate, infections, and brain dysfunction. Med Hypotheses (2010) 74(3):555-63. doi:10.1016/j.mehy.2009.09.040

171. Holgate JY, Bartlett SE. Early life stress, nicotinic acetylcholine receptors and alcohol use disorders. Brain Sci (2015) 5(3):258-74. doi:10.3390/ brainsci5030258

172. Okada S, Yamaguchi-Shima N, Shimizu T, Arai J, Lianyi L, Wakiguchi H, et al. Role of brain nicotinic acetylcholine receptor in centrally administered corticotropin-releasing factor-induced elevation of plasma corticosterone in rats. Eur J Pharmacol (2008) 587(1-3):322-9. doi:10.1016/j. ejphar.2008.03.005

173. Baier CJ, Pallarés ME, Adrover E, Monteleone MC, Brocco MA, Barrantes FJ, et al. Prenatal restraint stress decreases the expression of alpha-7 nicotinic receptor in the brain of adult rat offspring. Stress (2015) 18(4):435-45. doi:1 $0.3109 / 10253890.2015 .1022148$

174. Peña DF, Engineer ND, McIntyre CK. Rapid remission of conditioned fear expression with extinction training paired with vagus nerve stimulation. Biol Psychiatry (2013) 73(11):1071-7. doi:10.1016/j.biopsych.2012.10.021

175. Boggs DL, Carlson J, Cortes-Briones J, Krystal JH, D’Souza DC. Going up in smoke? A review of nAChRs-based treatment strategies for improving cognition in schizophrenia. Curr Pharm Des (2014) 20(31):5077-92. doi:10. 2174/1381612819666131216121019

176. Rowe AR, Mercer L, Casetti V, Sendt KV, Giaroli G, Shergill SS, et al. Dementia praecox redux: a systematic review of the nicotinic receptor as a target for cognitive symptoms of schizophrenia. J Psychopharmacol (2015) 29(2):197-211. doi:10.1177/0269881114564096

Conflict of Interest Statement: The authors declare that the research was conducted in the absence of any commercial or financial relationships that could be construed as a potential conflict of interest.

Copyright (c) 2017 Corsi-Zuelli, Brognara, Quirino, Hiroki, Fais, Del-Ben, Ulloa, Salgado, Kanashiro and Loureiro. This is an open-access article distributed under the terms of the Creative Commons Attribution License (CC BY). The use, distribution or reproduction in other forums is permitted, provided the original author(s) or licensor are credited and that the original publication in this journal is cited, in accordance with accepted academic practice. No use, distribution or reproduction is permitted which does not comply with these terms. 
ISSN-1809-4260

Julho - Setembro 2017

Volume 20, Número 3

\section{$\mathrm{SBH}$}

Sociedade

Brasileira

de Hipertensão

sbh.org.br

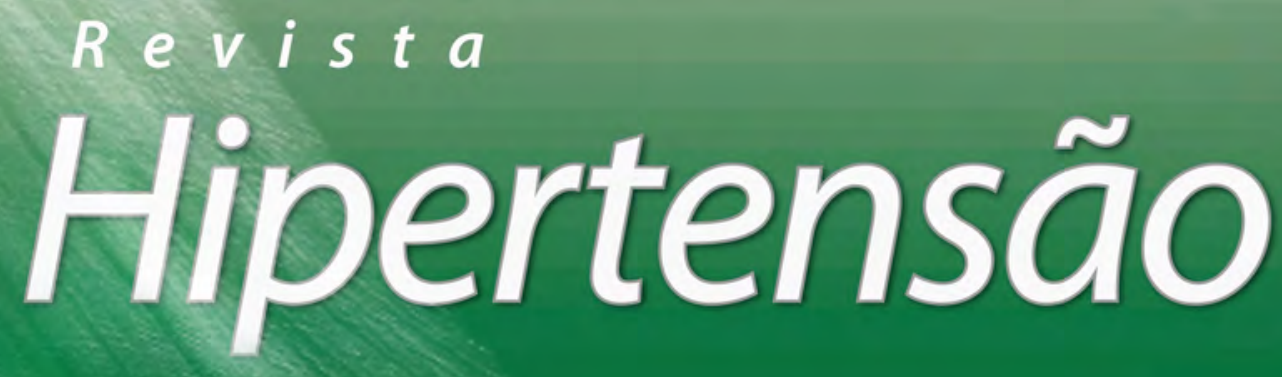

Variabilidade da frequência cardíaca 


\section{Artigo 6 \\ Variabilidade da frequência cardíaca e a resposta inflamatória \\ Heart rate variability and inflammatory response}

\section{Fernanda Brognara}

Departamento de Fisiologia, Faculdade de Medicina de Ribeirão Preto, Universidade de São Paulo (USP) - São Paulo (SP), Brasil.

\section{Fernanda Luciano Rodrigues}

Departamento de Fisiologia, Faculdade de Medicina de Ribeirão Preto, USP - São Paulo (SP), Brasil.

\section{Resumo}

A interação entre o sistema nervoso autônomo e o sistema imune na patogênese de diferentes doenças tem sido amplamente estudada. Alterações na variabilidade da frequência cardíaca refletem um desequilíbrio autonômico, que, quando caracterizado por hiperatividade simpática e/ou diminuição da atividade parassimpática, leva ao aumento das respostas inflamatórias mediadas pelo sistema imune inato e adaptativo, desencadeando, ou acelerando, processos patológicos. Diversos estudos têm demonstrado uma relação inversa entre a variabilidade da frequência cardíaca e os níveis plasmáticos de marcadores inflamatórios em doenças como hipertensão, insuficiência cardíaca, aterosclerose, lúpus eritematoso sistêmico, artrite reumatoide, sepse, choque séptico e endotoxemia. Esses dados indicam uma forte relação entre o aumento das citocinas inflamatórias e a redução da variabilidade da frequência cardíaca nesses indivíduos. Além de atuarem como preditores de morbidade e mortalidade, os índices de variabilidade da frequência cardíaca também podem auxiliar no diagnóstico e no monitoramento de pacientes com sepse, facilitando o tratamento e aumentando a sobrevida. Portanto, a inflamação associada, ou não,

\section{Abstract}

The crosstalk between the autonomic nervous system and the immune system in the pathogenesis of different diseases has been widely studied. Changes in heart rate variability reflect in an autonomic imbalance, which, when characterized by sympathetic overactivity and/ or decreased parasympathetic activity, leads to an increase in the inflammatory responses mediated by the innate and adaptive immune system, triggering, or accelerating, pathological processes. Studies have demonstrated an inverse relationship between heart rate variability and the plasma levels of inflammatory markers in several diseases, such as hypertension, heart failure, atherosclerosis, systemic lupus erythematosus, rheumatoid arthritis, sepsis, septic shock and endotoxemia. These data indicate a strong relationship between the increase in the levels of inflammatory cytokines and the reduced heart rate variability. Besides acting as predictors of morbidity and mortality, the heart rate variability indexes can also help in the diagnosis and monitoring of sepsis patients, facilitating the treatment and increasing survival. Therefore, inflammation

Endereço para correspondência: Fernanda Luciano Rodrigues - Departamento de Fisiologia, Faculdade de Medicina de Ribeirão Preto, Universidade de São Paulo - Avenida Bandeirantes, 3.900 - CEP: 14049-900 Ribeirão Preto (SP), Brasil - E-mail: flrodrigues@usp.br

Fonte de financiamento: Fundação de Amparo à Pesquisa do Estado de São Paulo (FAPESP), processos n. 2015/21976-1 e 2017/05163-6. 
a agentes infecciosos parece contribuir para o desbalanço autonômico e, consequentemente, para a redução da variabilidade da frequência cardíaca. Da mesma forma, o inverso também parece ser verdadeiro: alterações na variabilidade da frequência cardíaca contribuem para um aumento da resposta inflamatória.

\section{Palavras chave:}

frequência cardíaca; cardiovasculares; inflamação. associated or not with infectious agents seems to contribute to autonomic imbalance and, consequently, to a reduction in heart rate variability. Likewise, the reverse also seems to be true: changes in heart rate variability contribute to an increased inflammatory response.

\section{Keywords:}

doenças heart rate; cardiovascular diseases; inflammation.
A interação entre o sistema imune e o sistema nervoso autônomo já está bem estabelecida, sendo o sistema imune capaz de modular o controle autonômico cardiovascular em situações fisiológicas e fisiopatológicas ${ }^{1,2}$. O conceito de que o sistema nervoso autônomo pode modular o sistema imune e contribuir para a patogênese de diferentes doenças tem sido exaustivamente estudado. $\mathrm{O}$ sistema imune inato é o maior ativador da resposta imune adaptativa e seus efeitos resultam em respostas imunológicas sustentadas e prolongadas ${ }^{3}$. $O$ desequilíbrio do sistema nervoso autônomo, com hiperatividade simpática e/ou diminuição da atividade parassimpática, leva ao aumento das respostas inflamatórias do sistema imune inato e adaptativo, desencadeando, ou acelerando, processos patológicos. Além disso, o aumento das respostas inflamatórias em diferentes doenças também pode ser atribuído ao próprio sistema imune, que se torna anormalmente sensível às influências do sistema nervoso autônomo ${ }^{4}$.

O estudo da variabilidade da frequência cardíaca é uma ferramenta muito útil para avaliação da modulação autonômica cardiovascular. Alterações na variabilidade da frequência cardíaca são preditoras de morbidade e mortalidade em diferentes situações. Visto que o sistema nervoso autônomo e o sistema imune estão inti- mamente relacionados e que alterações na variabilidade da frequência cardíaca refletem uma disfunção autonômica, a inflamação pode ser um possível mediador das alterações na variabilidade da frequência cardíaca observadas em diferentes situações patológicas. De fato, estudos distintos sugerem uma relação inversa entre a variabilidade da frequência cardíaca e os níveis plasmáticos de marcadores inflamatórios ${ }^{5-8}$.

Estudos clínicos e experimentais têm demonstrado evidências de que os aspectos inflamatórios e autoimunes são essenciais para o desenvolvimento da hipertensão. A contribuição do sistema imune, particularmente dos linfócitos T, já é bem aceita, porém os mecanismos que precedem a ativação das células imunes, dando início à hipertensão, ainda não são completamente conhecidos. O estresse oxidativo e a infiltração inflamatória no interstício renal e na parede vascular arteriolar podem levar ao aumento da pressão arterial. Entretanto, como o estresse oxidativo e a inflamação estão intimamente relacionados, podendo iniciar e amplificar a resposta um do outro, é difícil determinar quem aparece primeiro 9 . O aumento nos níveis de citocinas pró-inflamatórias circulantes está intimamente relacionado com o aumento da atividade simpática ${ }^{10,11}$, com a diminuição da sensibilidade barorreflexa ${ }^{12}$ e com a redução 
da variabilidade da frequência cardíaca ${ }^{13}$. $\mathrm{Na}$ hipertensão induzida pela gravidez, a redução na sensibilidade do barorreflexo está relacionada com a disfunção autonômica, o estresse oxidativo e a inflamação ${ }^{14}$. A hipertensão é associada com o aumento da atividade simpática, que perpetua e exacerba essa doença. Assim, uma vez que o sistema imune é modulado pelo sistema nervoso autônomo, é possível sugerir que a inflamação participe, pelo menos em parte, das alterações na variabilidade da frequência cardíaca em indivíduos hipertensos, já que estes apresentam um desbalanço autonômico caracterizado pela redução da variabilidade da frequência cardíaca ${ }^{15,16}$.

Além da hipertensão, os índices de variabilidade da frequência cardíaca também estão reduzidos na insuficiência cardíaca, e essa redução é proporcional à extensão da doença ${ }^{17,18}$. A insuficiência cardíaca também apresenta um processo inflamatório associado e estudos mostraram que há uma correlação inversa entre os níveis aumentados de interleucina 6 (citocina pró-inflamatória) e os valores reduzidos de desvio padrão dos intervalos RR normais (SDNN) em pacientes com insuficiência cardíaca ${ }^{5}$. Da mesma forma, os níveis aumentados de fator de necrose tumoral (TNF) foram inversamente correlacionados com a redução dos índices de variabilidade no domínio do tempo e da frequência nesses pacientes ${ }^{19,20}$, sugerindo uma forte relação entre o aumento das citocinas inflamatórias e a redução da variabilidade da frequência cardíaca em indivíduos com insuficiência cardíaca.

A aterosclerose é uma doença na qual o acúmulo de lipídeos na parede das principais artérias resulta em uma estenose ou trombose, causando lesões isquêmicas ou oclusões de artérias para o coração, cérebro, membros inferiores e outros órgãos ${ }^{21}$. A inflamação é um mediador importante na patogênese da aterosclerose, envolvendo tanto o sistema imune inato quanto o sistema imune adaptativo ${ }^{22}$. A área das placas ateroscleróticas carotídeas, por exemplo, apresenta uma correlação positiva com a contagem de células brancas e com os níveis de proteína $C$ reativa circulantes, enquanto que a sensibilidade barorreflexa está inversamente correlacionada com a área de placas na carótida ${ }^{23}$. Ou seja, quanto maior a área das placas, maiores os níveis circulantes de marcadores inflamatórios e menor a sensibilidade do barorreflexo em pacientes com aterosclerose. A contagem de células brancas em indivíduos com aterosclerose está inversamente correlacionada com a sensibilidade do barorreflexo e a variabilidade da frequência cardíaca ${ }^{23}$. Além disso, a severidade e a extensão da aterosclerose coronariana estão relacionadas com alterações na regulação autonômica cardíaca, com prejuízo da atividade parassimpática, já que uma correlação negativa entre a severidade global da estenose da coronária e os índices de variabilidade no domínio do tempo e da frequência (porcentagem de sucessivos intervalos RR que diferem mais de 50 ms - pNN50 - e arritmia respiratória, respectivamente) foi observada em pacientes com aterosclerose ${ }^{24}$. Sendo assim, a função autonômica está associada com a aterosclerose e a inflamação apresenta um papel importante mediando essa relação.

O desbalanço autonômico também tem sido demonstrado nas doenças autoimunes como artrite reumatoide, lúpus eritematoso sistêmico, espondilite anquilosante e doença inflamatória intestinal, onde essa alteração autonômica tem sido associada à inflamação crônica ${ }^{25-27}$. $\mathrm{Na}$ artrite reumatoide, por exemplo, alguns estudos demonstraram uma redu- 
ção na atividade parassimpática cardíaca, enquanto outros observaram uma hiperatividade simpática nesses pacientes $^{28,29}$. O indivíduo com artrite reumatoide apresenta redução na potência da banda de high frequency (HF) e aumento na potência de low frequency (LF) no espectro da variabilidade da frequência cardíaca. Como resultado, a razão LF/HF está aumentada, sugerindo uma hiperatividade simpática nos pacientes com artrite reumatoide ${ }^{30}$. Da mesma forma, a disfunção autonômica observada no lúpus eritematoso sistêmico também é caracterizada por um aumento da atividade simpática e uma redução da atividade parassimpática ${ }^{25,31}$. Essas alterações autonômicas poderiam modular a resposta inflamatória central e periférica, exercendo um papel patogênico. Recentemente foi demonstrado que, em pacientes com lúpus eritematoso sistêmico, existe uma correlação inversa da atividade da doença com os índices de variabilidade da frequência cardíaca no domínio do tempo (pNN50) e da frequência (arritmia respiratória e razão LF/HF) ${ }^{32}$. Além disso, existe uma correlação negativa entre os níveis de citocinas pró-inflamatórias plasmáticas e os índices de variabilidade da frequência cardíaca (raiz quadrada da média da soma dos quadrados das diferenças entre sucessivos valores de intervalo RR - RMSSD -, pNN50, arritmia respiratória e razão $L F / H F)^{32}$. Ou seja, pacientes com lúpus eritematoso sistêmico apresentam reduções nos índices de variabilidade da frequência cardíaca que estão relacionadas com a progressão da doença e parecem estar associadas ao aumento dos níveis plasmáticos de citocinas inflamatórias.

A resposta inflamatória exacerbada observada nas doenças infecciosas como a sepse, o choque e a endotoxemia também está associada com uma redução da variabilidade da frequência car- díaca e o aumento da regularidade do ciclo cardíaco ${ }^{33-37}$. A sepse é definida como uma resposta inflamatória severa à infecção, caracterizada por um estado de inflamação sistêmica e pela lesão de múltiplos órgãos ${ }^{38,39}$. O choque séptico é marcado por uma hipotensão irreversível com falência progressiva de múltiplos órgãos. No choque séptico, o sistema cardiovascular é incapaz de compensar a hipotensão, uma vez que a resposta compensatória normal inclui a ação dos barorreceptores, que, nesse caso, estão comprometidos ${ }^{40}$. Estudos clínicos mostraram que existe uma alteração no balanço autonômico tanto em pacientes com sepse quanto em pacientes em choque séptico, e que a interação entre a atividade simpática e vagal já está alterada no início da sepse grave, com destaque para um aumento da atividade simpáti-

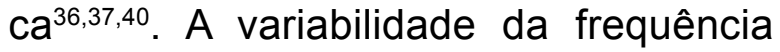
cardíaca estimada pelo SDNN está reduzida durante o desenvolvimento do choque séptico e há uma correlação inversa entre o SDNN e os níveis de proteína C reativa, e o escore de lesão de órgãos. Já os níveis de interleucina 10 (citocina anti-inflamatória) apresentam uma correlação positiva com a potência da banda de HF da variabilidade da frequência cardíaca (tono vagal) ${ }^{41}$.

Além do comprometimento da variabilidade da frequência cardíaca, a sensibilidade barorreflexa também está alterada nas doenças infecciosas. Estudos utilizando o método da sequência em modelos animais de endotoxemia mostraram uma redução da sensibilidade do barorreflexo logo no início da resposta inflamatória. Essa diminuição rápida da sensibilidade barorreflexa ocorre independentemente dos níveis da pressão arterial, uma vez que os animais apresentaram prejuízo da função barorreflexa mesmo na ausência de hipotensão ${ }^{42}$. Outros estudos mostraram uma relação direta entre a sensibi- 
lidade do barorreflexo e o tempo de sobrevivência no choque séptico, ou seja, o tempo de sobrevivência é menor quando a função barorreflexa está reduzida ${ }^{43,44}$.

Além de serem utilizados como marcadores de severidade, os índices de variabilidade da frequência cardíaca também são usados para diagnóstico e monitoramento de pacientes com sepse ${ }^{45-47}$. Atualmente, a hemocultura é considerada padrão ouro para o diagnóstico da sepse. Entretanto, esse exame leva cerca de 48 horas e, em geral, está associado com resultados falso-positivos ou falso-negativos ${ }^{48}$. Assim, muitas vezes a sepse é diagnosticada tardiamente, dificultando o tratamento e aumentando a mortalidade desses pacientes. Pesquisas mostraram que a redução da variabilidade da frequência cardíaca precede o diagnóstico da sepse ${ }^{47}$. Sendo assim, a avaliação da variabilidade da frequência cardíaca nos pacientes ambulatoriais poderia auxiliar no monitoramento do indivíduo antes mesmo da instalação da sepse ou em estágios iniciais da doença, facilitando o tratamento, aumentando a sobrevida e auxiliando nas decisões sobre o início e a interrupção do uso de antibióticos.

Por fim, fica claro que a inflamação associada, ou não, a agentes infecciosos parece influenciar negativamente a variabilidade da frequência cardíaca. Sendo assim, o controle da resposta inflamatória sistêmica poderia contribuir para a normalização dos índices de variabilidade da frequência cardíaca e, consequentemente, para a melhora do quadro clínico de diversas doenças.

\section{Referências}

1. Okun E, Griffioen KJ, Rothman S, 5. Aronson D, Mittleman MA, Burger Wan R, Cong WN, De Cabo R, et al. Toll-like receptors 2 and 4 modulate autonomic control of heart rate and energy metabolism. Brain Behav Immun. 2014;36:90-100. https://dx.doi. org/10.1016\%2Fj.bbi.2013.10.013

2. Rodrigues FL, Silva LE, Hott SC, Bomfim GF, da Silva CA, Fazan R, Jr., et al. Toll-like receptor 9 plays a key role in the autonomic cardiac and baroreflex control of arterial pressure. Am J Physiol Regul Integr Comp Physiol. 2015;308(8):R714-23. https:// doi.org/10.1152/ajpregu.00150.2014

3. Harwani SC, Chapleau MW, Legge $\mathrm{KL}$, Ballas ZK, Abboud FM. Neurohormonal modulation of the innate immune system is proinflammatory in the prehypertensive spontaneously hypertensive rat, a genetic model of essential hypertension. Circulation Res. 2012;111(9):1190-7. https://doi. org/10.1161/CIRCRESAHA.112.277475

4. Abboud FM, Harwani SC, Chapleau MW. Autonomic neural regulation of the immune system: implications for hypertension and cardiovascular disease. Hypertension. 2012;59(4):755-62.https://doi.org/10.1161/ HYPERTENSIONAHA.111.186833
AJ. Interleukin-6 levels are inversely correlated with heart rate variability in patients with decompensated heart failure. J Cardiovascular Electrophysiol. 2001;12(3):294-300. DOI: 10.1046/j.1540-8167.2001.00294.x

6. Hamaad A, Sosin M, Blann AD, Patel J, Lip GY, MacFadyen RJ. Markers of inflammation in acute coronary syndromes: association with increased heart rate and reductions in heart rate variability. Clin Cardiol. 2005;28(12):570-6. DOI: 10.1002 clc. 4960281207

7. Janszky I, Ericson M, Lekander $M$, Blom M, Buhlin K, Georgiades $A$, et al. Inflammatory markers and heart rate variability in women with coronary heart disease. J Internal Med. 2004;256(5):421-8. DOI: 10.1111/j.13652796.2004.01403.x

8. Lanza GA, Sgueglia GA, Cianflone D, Rebuzzi AG, Angeloni G, Sestito A, et al. Relation of heart rate variability to serum levels of C-reactive protein in patients with unstable angina pectoris. Am J Cardiol. 2006;97(12):1702-6. https:// doi.org/10.1016/j.amjcard.2006.01.029
9. Solak Y, Afsar B, Vaziri ND, Aslan G, Yalcin CE, Covic A, et al. Hypertension as an autoimmune and inflammatory disease. Hypertension Res. 2016;39(8):567-73. DOI: 10.1038/ hr.2016.35

10. Helwig BG, Craig RA, Fels RJ, Blecha $F$, Kenney MJ. Central nervous system administration of interleukin-6 produces splenic sympathoexcitation. Autonomic Neuroscience Basic Clin. 2008;141(12):104-11. https://doi.org/10.1016/j. autneu.2008.04.008

11. Niijima A, Hori T, Aou S, Oomura Y. The effects of interleukin-1 beta on the activity of adrenal, splenic and renal sympathetic nerves in the rat. J Auton Nerv Syst. 1991;36(3):183$92 . \quad$ https://doi.org/10.1016/01651838(91)90042-2

12. Takagishi $M$, Waki $H$, Bhuiyan ME, Gouraud SS, Kohsaka A, Cui H, et al. IL-6 microinjected in the nucleus tractus solitarii attenuates cardiac baroreceptor reflex function in rats. Am J Physiol Regul Integr Comp Physiol. 2010;298(1):R183-90. https:// doi.org/10.1152/ajpregu.00176.2009 
13. Fairchild KD, Saucerman JJ, Raynor LL, Sivak JA, Xiao Y, Lake DE, et al. Endotoxin depresses heart rate variability in mice: cytokine and steroid effects. Am J Physiol Regul Integr Comp Physiol. 2009;297(4):R1019-27. https:// doi.org/10.1152/ajpregu.00132.2009

14. Subha M, Pal P, Pal GK, Habeebullah S, Adithan C, Sridhar MG. Decreased baroreflex sensitivity is linked to sympathovagal imbalance, low-grade inflammation, and oxidative stress in pregnancy-induced hypertension. Clin Experim Hypertension. 2016;38(8):66672. https://doi.org/10.1080/10641963.2 016.1200596

15. Schroeder EB, Liao $D$, Chambless LE, Prineas RJ, Evans GW, Heiss G. Hypertension, blood pressure, and heart rate variability: the Atherosclerosis Risk in Communities (ARIC) study. Hypertension. 2003;42(6):1106-11. https://doi. org/10.1161/01.HYP.0000100444.71069.73

16. Virtanen R, Jula A, Kuusela T, Helenius $\mathrm{H}$, Voipio-Pulkki LM. Reduced heart rate variability in hypertension: associations with lifestyle factors and plasma renin activity. J Hum Hypertens. 2003;17(3):171-9. https:// doi.org/10.1038/sj.jhh.1001529

17. Casolo GC, Stroder P, Sulla A, Chelucci A, Freni A, Zerauschek M. Heart rate variability and functional severity of congestive heart failure secondary to coronary artery disease. Eur Heart J. 1995;16(3):360-7. https://doi.org/10.1093/ oxfordjournals.eurheartj.a060919

18. Panina G, Khot UN, Nunziata E, Cody RJ, Binkley PF. Role of spectral measures of heart rate variability as markers of disease progression in patients with chronic congestive heart failure not treated with angiotensinconverting enzyme inhibitors. Am Heart J. 1996;131(1):153-7. https://doi. org/10.1016/S0002-8703(96)90064-2

19. Malave HA, TaylorAA, Nattama J, Deswal A, Mann DL. Circulating levels of tumor necrosis factor correlate with indexes of depressed heart rate variability: a study in patients with mild-to-moderate heart failure. Chest. 2003;123(3):716-24. https://doi.org/10.1378/chest.123.3.716

20. Papaioannou V, Pneumatikos I, Maglaveras N. Association of heart rate variability and inflammatory response in patients with cardiovascular diseases: current strengths and limitations. Front Physiol. 2013;4:174. https://dx.doi. org/10.3389\%2Ffphys.2013.00174

21. Insull W, Jr. The pathology of atherosclerosis: plaque development and plaque responses to medical treatment. Am J Med. 2009;122(1 Suppl):S3-S14. https://doi.org/10.1016/j. amjmed.2008.10.013
22. HanssonGK.Inflammation, atherosclerosis, and coronary artery disease. New Engl $J$ Med. 2005;352(16):1685-95. https://doi. org/10.1056/NEJMra043430

23. Ulleryd MA, Prahl U, Börsbo J, Schmidt C, Nilsson S, Bergström $\mathrm{G}$, et al. The association between autonomic dysfunction, inflammation and atherosclerosis in men unde investigation for carotid plaques. Plos One. 2017;12(4):e0174974. https://doi. org/10.1371/journal.pone.0174974

24. Simula $S$, Vanninen $E$, Lehto $S$ Hedman A, Pajunen P, Syvänne M, et al. Heart rate variability associates with asymptomatic coronary atherosclerosis Clin Auton Res. 2014;24(1):31-7. https:/ doi.org/10.1007/s10286-013-0220-z

25. Aydemir M, Yazisiz V, Basarici I, Avci $A B$, Erbasan F, Belgi A, et al. Cardiac autonomic profile in rheumatoid arthritis and systemic lupus erythematosus. Lupus. 2010;19(3):255-61. https://doi. org/10.1177/0961203309351540

26. Borman P, Gokoglu F, Kocaoglu S YorganciogluZR. Theautonomicdysfunction in patients with ankylosing spondylitis: a clinical and electrophysiological study. Clin Rheumatol. 2008;27(10):1267-73. https:// doi.org/10.1007/s10067-008-0906-0

27. Sharma $P$, Makharia GK, Ahuja V, Dwivedi SN, Deepak KK Autonomic dysfunctions in patients with inflammatory bowel disease in clinical remission. Digestive Diseases Sciences. 2008;54(4):853-61. https:// doi.org/10.1007/s10620-008-0424-6

28. AdlanAM, Lip GY, Paton JF, Kitas GD, Fisher JP. Autonomic function and rheumatoid arthritis: a systematic review. Semin Arthritis Rheum. 2014;44(3):283-304. https://doi. org/10.1016/j.semarthrit.2014.06.003

29. Koopman FA, Stoof SP, Straub RH Van Maanen MA, Vervoordeldonk MJ, Tak PP. Restoring the balance of the autonomic nervous system as an innovative approach to the treatmen of rheumatoid arthritis. Mol Med. 2011;17(9-10):937-48. https://dx.doi org/10.2119\%2Fmolmed.2011.00065

30. Evrengül $H$, Dursunoglu D, Cobankara V, Polat B, Seleci D, Kabukçu S, et al. Heart rate variability in patients with rheumatoid arthritis. Rheumato Int. 2004;24(4):198-202. https://doi. org/10.1007/s00296-003-0357-5

31. Milovanovic B, Stojanovic L, Milicevik $\mathrm{N}$, Vasic K, Bjelakovic B, Krotin M. Cardiac autonomic dysfunction in patients with systemic lupus rheumatoid arthritis and sudden death risk. Srpski arhiv za celokupno lekarstvo. 2010;138(1-2):26-32. DOI: 10.2298/SARH1002026M
32. Thanou A, Stavrakis S, Dyer JW, Munroe ME, James JA, Merrill JT. Impact of heart rate variability, a marker for cardiac health, on lupus disease activity. Arthritis Res Ther. 2016;18:197. https://doi. org/10.1186/s13075-016-1087-x

33. Buchman TG. The community of the self. Nature. 2002;420(6912):246-51. https:// doi.org/10.1038/nature01260

34. Godin PJ, Fleisher LA, Eidsath A, Vandivier RW, Preas HL, Banks SM, et al. Experimental human endotoxemia increases cardiac regularity: results from a prospective, randomized, crossover trial. Crit Care Med. 1996;24(7):1117-24. http://dx.doi. org/10.1097/00003246-199607000-00009

35. Ellenby MS, McNames J, Lai S, McDonald BA, Krieger D, Sclabassi RJ, et al. Uncoupling and recoupling of autonomic regulation of the heart beat in pediatric septic shock. Shock. 2001;16(4):274-7. DOI: 10.1097/00024382-200116040-00007

36. Garrard CS, Kontoyannis DA, Piepoli M. Spectral analysis of heart rate variability in the sepsis syndrome. Clin Auton Res. 1993;3(1):5-13

37. Piepoli M, Garrard CS, Kontoyannis DA, Bernardi L. Autonomic control of the heart and peripheral vessels in human septic shock. Intensive Care Med. 1995;21(2):112-9.

38. Deutschman CS, Tracey KJ. Sepsis: current dogma and new perspectives. Immunity. 2014;40(4):463-75. https://doi. org/10.1016/j.immuni.2014.04.001

39. Tilahun AY, Chowdhary VR, David CS, Rajagopalan G. Systemic inflammatory response elicited by superantigen destabilizes $\mathrm{T}$ regulatory cells, rendering themineffectiveduring toxicshocksyndrome. J Immunol. 2014;193(6):2919-30. https:// doi.org/10.4049/jimmunol.1400980

40. Annane D, Trabold F, Sharshar T, Jarrin I, Blanc AS, Raphael JC, et al. Inappropriate sympathetic activation at onset of septic shock: a spectral analysis approach. Am J Respir Crit Care Med. 1999;160(2):458-65. https://doi. org/10.1164/ajrccm.160.2.9810073

41. Papaioannou VE, Dragoumanis C, Theodorou V, Gargaretas C, Pneumatikos I. Relation of heart rate variability to serum levels of C-reactive protein, interleukin 6 , and 10 in patients with sepsis and septic shock. J Crit Care. 2009;24(4):625.e1-7. https://doi.org/10.1016/j.jcrc.2008.11.010

42. Radaelli A, Castiglioni P, Cerrito MG, De Carlini C, Soriano F, Di Rienzo $M$, et al. Infusion of Escherichia coli lipopolysaccharide toxin in rats produces an early and severe impairment of baroreflex function in absence of blood pressure changes. Shock. 2013;39(2):204-9. https:// doi.org/10.1097/SHK.0b013e3182767daf 
43. Shen FM, Guan YF, Xie HH, Su DF. Arterial baroreflex function determines the survival time in lipopolysaccharideinduced shock in rats. Shock. 2004;21(6):556-60.

44. Shi KY, Shen FM, Liu AJ, Chu ZX, Cao YL, Su DF. The survival time post-cecal ligation and puncture in sinoaortic denervated rats. J Cardiovasc Pharmacol. 2007;50(2):162-7. https://doi. org/10.1097/FJC.0b013e31805c942d
45. Bravi A, Green G, Longtin A, Seely AJ. Monitoring and identification of sepsis development through a composite measure of heart rate variability. PloS One. 2012;7(9):e45666. https://doi. org/10.1371/journal.pone.0045666

46. Bohanon FJ, Mrazek AA, Shabana MT, Mims S, Radhakrishnan GL, Kramer $\mathrm{GC}$, et al. Heart rate variability analysis is more sensitive at identifying neonata sepsis than conventional vital signs. Am J Surg. 2015;210(4):661-7. https://doi. org/10.1016/j.amjsurg.2015.06.002
47. Ahmad S, Ramsay T, Huebsch L, Flanagan S, McDiarmid S, Batkin I, et al. Continuous multiparameter heart rate variability analysis heralds onset of sepsis in adults. PloS One. 2009;4(8):e6642. https://doi.org/10.1371/journal. pone.0006642

48. Dong Y, Speer CP. Late-onset neonatal sepsis: recent developments. Arch Dis Child Fetal Neonatal Ed. 2015;100(3):F257-63. DOI: 10.1136/ archdischild-2014-306213 


\title{
scientific reports
}

\section{OPEN Carotid sinus nerve stimulation attenuates alveolar bone loss and inflammation in experimental periodontitis}

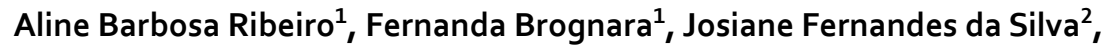
Jaci Airton Castaniaํ, Patrícia Garani Fernandes ${ }^{3}$, Rita C. Tostes ${ }^{2} \&$ Helio Cesar Salgado $^{1 \bowtie}$

Baroreceptor and chemoreceptor reflexes modulate inflammatory responses. However, whether these reflexes attenuate periodontal diseases has been poorly examined. Thus, the present study determined the effects of electrical activation of the carotid sinus nerve (CSN) in rats with periodontitis. We hypothesized that activation of the baro and chemoreflexes attenuates alveolar bone loss and the associated inflammatory processes. Electrodes were implanted around the CSN, and bilateral ligation of the first mandibular molar was performed to, respectively, stimulate the CNS and induce periodontitis. The CSN was stimulated daily for $10 \mathrm{~min}$, during nine days, in unanesthetized animals. On the eighth day, a catheter was inserted into the left femoral artery and, in the next day, the arterial pressure was recorded. Effectiveness of the CNS electrical stimulation was confirmed by hypotensive responses, which was followed by the collection of a blood sample, gingival tissue, and jaw. Long-term (9 days) electrical stimulation of the CSN attenuated bone loss and the histological damage around the first molar. In addition, the CSN stimulation also reduced the gingival and plasma pro-inflammatory cytokines induced by periodontitis. Thus, CSN stimulation has a protective effect on the development of periodontal disease mitigating alveolar bone loss and inflammatory processes.
\end{abstract}

Periodontitis is a chronic inflammatory disease with high prevalence rates, representing a major public health problem ${ }^{1}$. It is associated with the progressive destruction of the supporting structures of the teeth (alveolar bone, periodontal ligament, and cementum) by overactivity of host immune-inflammatory agents in response to dysbiosis biofilm ${ }^{2,3}$. The host responds to microbial challenge activating components of innate and adaptative immunity, followed by the production of inflammatory mediators and generation of an overwhelming proinflammatory response ${ }^{4}$. Pro-inflammatory cytokines are produced by resident cells (epithelial cells, gingival and periodontal ligament fibroblasts, osteoblast, and dendritic cells), phagocytes (neutrophils and macrophages) and lymphocytes. Tumor necrosis factor-alpha (TNFa), one of these pro-inflammatory cytokines, induces inflammatory cells migration to tissue destruction ${ }^{5}$, upregulates the release of interleukin-1 beta (IL-1 $\beta$ ) and interleukin- 6 $(\mathrm{IL}-6)^{6,7}$, and increases osteoclastogenesis ${ }^{8,9}$. The osteoclastogenesis is also controlled by the autonomic nervous system $^{10,11}$. The sympathetic nervous system acts as a negative bone mass regulator, inhibits the proliferation of osteoblasts and promotes osteoclastogenesis ${ }^{12}$. In contrast, the parasympathetic nervous system acts positively in the control of bone mass, promoting apoptosis of osteoclasts ${ }^{11,13}$.

Experimental and clinical evidence indicates an association between the autonomic nervous system and the immune respons $\mathrm{e}^{14,15}$. The brain inhibits inflammation through three pathways: the activation of the hypothalamic-pituitary-adrenal axis releasing glucocorticoids ${ }^{16}$; the cholinergic vagal anti-inflammatory pathway ${ }^{17}$; and the sympathetic splanchnic anti-inflammatory pathway ${ }^{18}$. Over the past twenty years, many studies were performed to better understand the relationship between the immune system and both branches (parasympathetic and sympathetic) of the autonomic system ${ }^{17,19-21}$. Our research group reported that baroreflex activation, through electrical stimulation of the aortic depressor nerve, attenuates the joint (femorotibial) 22 and neural (hypothalamus) inflammation in conscious endotoxemic rats ${ }^{23}$. The simultaneous activation of both the carotid baroreflex and peripheral chemoreflex, by electrical stimulation of the carotid sinus nerve (CSN) and carotid

${ }^{1}$ Department of Physiology, Ribeirão Preto Medical School, University of São Paulo, Avenida dos Bandeirantes, 3900, Ribeirão Preto, SP 14049-900, Brazil. 'Department of Pharmacology, Ribeirão Preto Medical School, University of São Paulo, Ribeirão Preto, SP, Brazil. ${ }^{3}$ University Center North Paulista (Unorp), São José do Rio Preto, SP, Brazil. ${ }^{\bowtie}$ email: hcsalgado@fmrp.usp.br 
sinus, was very effective controlling the innate immune response induced by lipopolysaccharide ${ }^{24}$. It is important to highlight that the carotid sinus electrical activation has been used to treat hypertensive patients resistant to pharmacological therapy ${ }^{25,26}$ and also patients with heart failure ${ }^{27}$. Activation of the carotid baroreflex elicits sympathetic activity inhibition and parasympathetic drive activation to the heart ${ }^{28}$. On the other hand, peripheral chemoreflex activation leads to concomitant sympathetic and parasympathetic activation ${ }^{29}$. Therefore, it is reasonable to expect that simultaneous baroreflex and chemoreflex activation produces a significant antiinflammatory response, inhibiting innate immune system, attenuating the release of pro-inflammatory cytokines and decreasing osteoclastogenesis in other inflammatory diseases, such as periodontitis.

Our laboratory developed a technique to simultaneously stimulate the carotid baroreflex and chemoreflex in unanesthetized rats ${ }^{30}$. This electroceutical approach allows the investigation of autonomic modulation without the undesirable effects of anesthesia under different protocols, particularly those involving inflammatory models ${ }^{24}$. Although the effectiveness of this approach in controlling systemic inflammation has already been described ${ }^{24}$, the influence of simultaneous electrical stimulation of the chemo- and baroreflex, through the CSN stimulation, on periodontitis-associated inflammatory response has not previously been investigated. It is worth to highlight that the impact of periodontal disease (PD) is not restricted to the oral cavity. PD also affects the overall health of individual $\mathrm{s}^{31}$ being associated with cardiovascular diseases, such as arterial hypertension, myocardial infarction, stroke, and atherosclerosis ${ }^{32-35}$. The present study determined the modulatory effects of long-term (9 days) carotid baroreflex and chemoreflex activation on bone resorption, histological damage and inflammatory mediators in rats submitted to ligature-induced periodontitis.

\section{Material and methods}

Animals. Adult male Wistar Hannover rats weighing about $250 \mathrm{~g}$ were obtained from the breeding facility of the University of São Paulo at Ribeirão Preto. The animals were maintained under controlled temperature $\left(24^{\circ} \mathrm{C}\right)$, constant 12 hours (h) light-dark cycle, while food and water were provided ad libitum. The rats were divided into four groups: I: SHAM + Control (fictitious surgery for ligation around the right and left first molars associated with placement of the electrodes around the CSN, but without electrical stimulation); II: SHAM + CSN (fictitious surgery for ligation around the right and left first molars associated with placement of the electrodes plus electrical stimulation of the CSN); III: PD + Control (surgery for ligation around the right and left first molars associated with placement of the electrodes around the CSN, but without electrical stimulation); IV: PD + CSN (surgery for ligation around the right and left first molars associated with placement of the electrodes plus electrical stimulation of the CSN). All experimental procedures were performed following the "Guide for the Care and Use of Laboratory Animals" prepared by the National Academy of Sciences and published by the National Institutes of Health ${ }^{36}$. This study was also approved by the Ethics Committee of the Ribeirão Preto Medical School, University of São Paulo, São Paulo, Brazil (protocol number 252/2017).

Surgical procedures. Rats were anesthetized with a mixture of Ketamine $(50 \mathrm{mg} / \mathrm{kg}$, i.p.) and Xylazine $(10 \mathrm{mg} / \mathrm{kg}$, i.p.) and then submitted to surgical procedures to isolate the left CSN for implantation of electrodes as previously described ${ }^{30}$. Briefly, the rats were subjected to ventral neck surgery, and the left CSN was carefully isolated. The CSN received a bipolar stainless-steel electrode positioned around the left carotid sinus and CSN. The electrode was covered with silicone impression material (Kwik-Sil silicone elastomer; World Precision Instruments, Sarasota, Florida, USA). The ends of the electrode wires were conveyed subcutaneously to the interscapular region of the rats and welded to small outlets. Then, the incision in the cervical area was sutured. Control rats underwent surgery with procedures similar to those described above, but electrodes were not placed on the CSN and carotid sinus.

In the same surgery, a 4-0 sterile silk ligature was placed around the right and left first molars to induce the PD or not (SHAM). At the end of the surgery, all animals received a polyvalent veterinary antibiotic (Pentabiótico, $0.2 \mathrm{~mL}$, i.m., Fort Dodge, Campinas, SP, Brazil) and analgesic (tramadol hydrochloride: $2 \mathrm{mg} / \mathrm{kg}$, s.c., during 3 consecutive days). After 8 days, under anesthesia [Ketamine $(50 \mathrm{mg} / \mathrm{kg}$, i.p.) and Xylazine (10 mg/kg, i.p.)], the left femoral artery was catheterized with polyethene tubing (PE-50 soldered to PE-10 polyethene tube; Intramedic, Clay Adams, Parsippany, NJ, USA) for arterial pressure recording.

Assessment of the hemodynamic parameters and electrical stimulation of the carotid sinus nerve. Twenty-four hours after the femoral artery catheterization, the pulsatile arterial pressure was recorded in unanesthetized freely moving animals placed in individual cage. The arterial catheter was connected to a pressure transducer (MLT844; ADInstruments, Bella Vista, Australia), and the arterial pressure signal was amplified (ML224; ADInstruments, Bella Vista, Australia). The signal was sent to an IBM/ PC computer (Core 2 Duo, 2.2 GHz, 4 GB RAM) attached to an analogue-to-digital interface (PowerLab, ADInstruments, Bella Vista, Australia). The electrodes were connected to an external square pulse generator to stimulate the CNS [1.5-3 V; $1 \mathrm{~ms}$; $30 \mathrm{~Hz}$; for 10 minutes $(\mathrm{min})$ ]. Pulsatile arterial pressure recordings were processed with a computer software (LabChart 8.0, ADInstruments, Bella Vista, Australia) capable of detecting inflexion points, systolic, diastolic and mean arterial pressure (MAP); as well as heart rate (HR) beat-by-beat time series.

Experimental procedures. After the surgical procedures, electrical stimulation of the CSN was performed daily during nine consecutive days in unanesthetized rats, starting the first day of dental ligation (Fig. 1). On the ninth day, the pulsatile arterial pressure was recorded for $30 \mathrm{~min}$, followed by the CSN electrical stimulation to confirm the effectiveness of the electrical stimulation. This effectiveness was confirmed by the hypotensive response caused by the CSN electrical stimulation. Then, a blood sample $(1 \mathrm{~mL})$, gingival tissue (right and left) and the jaw (separated on the right and left) were collected. The blood samples were maintained at $4{ }^{\circ} \mathrm{C}$ and 


\section{Electrical stimulation of the CSN (1.5 - $3 \mathrm{~V} ; 1 \mathrm{~ms} ; 30 \mathrm{~Hz}$ during $10 \mathrm{~min})$}

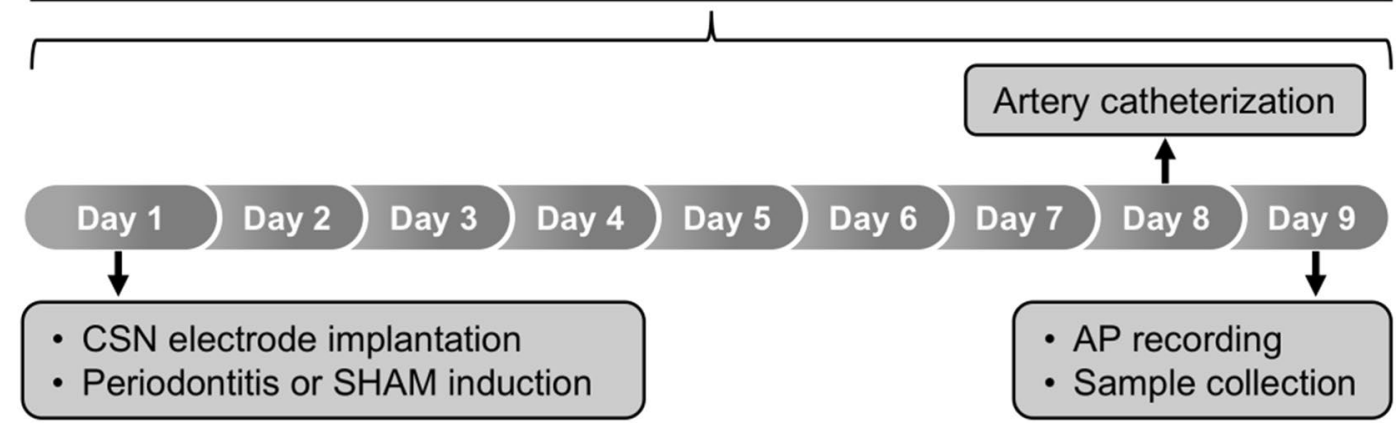

Figure 1. The experimental protocol. On the first day, the electrodes were implanted around the carotid sinus nerve (CSN) combined with the mandibular ligation, around the first lower molars, to induce periodontitis. Electrical stimulation of the CSN was performed for nine days, starting on the first day of dental ligation. On the eighth day, a catheter was inserted into the left femoral artery, while in the next day the arterial pressure (AP) was recorded to confirm the effectiveness of the electrical stimulation of the CSN. Next, a blood sample, the gingival tissue and the jaw were collected for further analysis. SHAM, fictitious ligation.

centrifuged for $20 \mathrm{~min}$ at $3,500 \mathrm{rpm}$. Then, the plasma was frozen at $-80^{\circ} \mathrm{C}$ for further analysis of inflammatory cytokines. The gingival tissue was transferred to a microtube with RNALater reagent (Ambion, Austin, TX, USA) and stored at $4{ }^{\circ} \mathrm{C}$ during $24 \mathrm{~h}$ and then stored at $-80^{\circ} \mathrm{C}$.

Micro-computed tomography analysis. Non-demineralized specimens were scanned by a cone-beam micro-CT system (Skyscan 1176; Bruker, Belgium). The X-ray generator was operated at $50 \mathrm{kV}$ with a source current of $500 \mu \mathrm{A}$ and a $0.5 \mathrm{~mm}$ aluminum filter. A volume of interest from the apexes of all roots of the mandibular first molar (M1) up to the roof of the furcation of M1, touching the roots surfaces (CT-Analyzer; Bruker, Belgium) was selected for bone volume measurement, as previously described ${ }^{37,38}$. The bone volume/tissue volume (BV/TV), porosity, trabecular number $(\mathrm{Tb} . \mathrm{N})$ and trabecular separation $(\mathrm{Tb} . \mathrm{Sp})$ were analyzed in the volume of interested area with CtAn (Bruker, Belgium). The data sets were reconstructed with CTVox (Bruker, Belgium). All micro-CT analyses were performed by one masked and calibrated examiner.

Histological analysis. The jaws were adequately fixed in $10 \%$ buffered formaldehyde, and after decalcified in $4 \%$ ethylenediaminetetraacetic acid solution, buffered with sodium phosphate, $\mathrm{pH}$ 7.4. After complete decalcification, the specimens were immersed into $30 \%$ sucrose solution in PBS, until tissue saturation. Serial Sects. (10 $\mu \mathrm{m}$ thick) were cut, using a cryostat, from the buccal toward the lingual direction. These sections were stained with hematoxylin and eosin for analysis by light microscopy (DM 5500B; Leica Microsystems, Wetzlar, Germany). Two sections, from each sample, representing the central buccal-lingual portion in the furcation area of the first molar, were selected for histopathologic and histometric analysis. The histopathological scores in interdental (between the first and the second molar) region were analyzed under light microscopy, as described previously ${ }^{39}$. The scores were assigned as follows: score $\mathbf{0}$, absence or sparse inflammatory cell infiltration, preserved alveolar process and cementum; score 1, moderate inflammatory cell infiltration in the insert gingival with intact cementum and minor alveolar process resorption; score 2, accentuated cellular infiltration of the gingival and periodontal ligament, and marked degradation of the alveolar process and part of the cementum; and score 3, accentuated cellular infiltrate in both gingival and periodontal ligament, complete alveolar process resorption and severe cementum destruction.

For the histometric alveolar bone analysis, the images of the histologic sections were analyzed using appropriate software (ImageJ 1.50i, a version of Wayne Rasband, National Institutes of Health, USA; https://image j.nih.gov/ij). The furcation region not filled with bone was measured by the linear distance between the area surrounded to the roof of the furcation to alveolar crest in the furcation.

Plasma cytokine measurement. The plasma concentrations of IL-6, TNFa, IL-1 $\beta$ and IL-10 were determined using enzyme-linked immunosorbent assay (ELISA) kits from R\&D Systems (Minneapolis, MN, USA) according to the manufacturer's instructions. The results were expressed as $\mathrm{pg} / \mathrm{mL}$, based on standard curves.

Analysis of gene expression in gingival tissue. Briefly, the total RNA from gingival tissue was extracted using the RNeasy Plus Mini Kit (Qiagen, Hilden, Germany), and 500 ng of total RNA was reverse-transcribed using the QuantiNova Reverse TraNSCription kit (Qiagen, Hilden, Germany) according to the manufacturer's kit instructions. The reactions were performed using TaqMan Gene Expression Assays (Thermo Fischer Scientific, Waltham, MA, USA), according to the manufacturer's recommendations and TaqMan Universal Master Mix II (Thermo Fischer Scientific, Waltham, MA, USA). Undetermined values in SHAM groups were set to a maximum Ct (e.g. 40), because the majority were non-detects, as previously suggested ${ }^{40}$. Data were analyzed by 
A

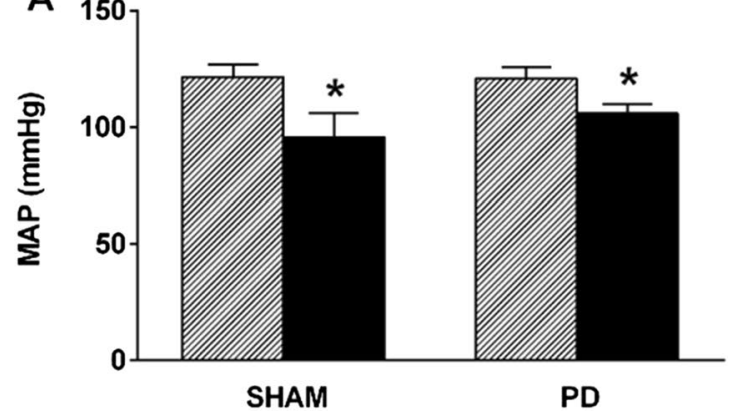

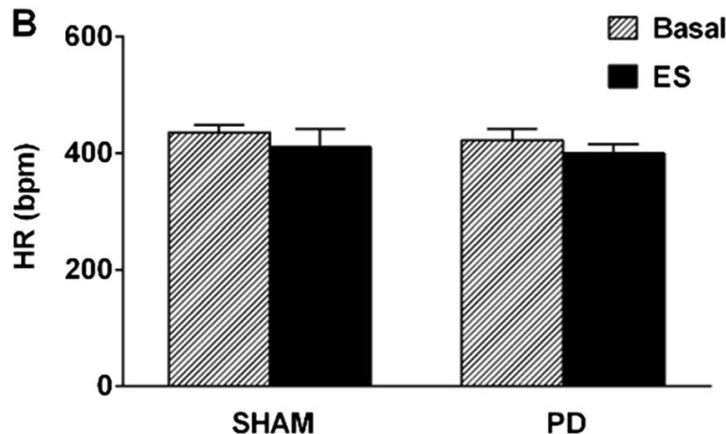

B

SHAM

Figure 2. CSN stimulation elicits a hypotensive response. Mean arterial pressure (MAP; A) and heart rate (HR; B) at baseline and during electrical stimulation (ES) of the carotid sinus nerve in SHAM $(n=5)$ and periodontal disease $(\mathrm{PD})$ rats $(\mathrm{n}=8)$. Bars represent the mean \pm standard error. ${ }^{\star} P<0.05$ versus basal. CSN, carotid sinus nerve; SHAM, fictitious ligation.

the $2^{-\Delta \Delta C t}$ method $^{41}$, and the results expressed in relation to the relatively to control. The data were represented as the difference $\left(2^{-\Delta \Delta C t}\right)$ in TNFa, IL- $\beta$, IL- 6 and IL-10 genes expression, which were normalized by GAPDH.

Statistical analysis. The statistical analysis was performed using two-way analysis of variance (ANOVA) for repeated measures, followed by the Tukey's multiple comparisons post-hoc test. The data obtained from the plasma, gingival tissues and histopathological score were statistically analyzed using the non-parametric KruskalWallis test followed by the Dunn post-test to compare medians. Values are expressed as the mean \pm standard error of the mean (SEM). Differences were considered significant at $P<0.05$.

\section{Results}

Hemodynamic responses to CSN electrical stimulation. The CSN electrical stimulation reduced MAP in both SHAM and PD rats (Fig. 2A). Moreover, this hypotensive response was similar between the groups (Fig. 2A). Electrical stimulation of the CSN did not change HR in SHAM or PD rats (Fig. 2B).

Micro-computed tomography analysis of alveolar bone. The bi-dimensional (coronal and sagittal) and three-dimensional (lingual) views from the micro-computed tomography of the jaw revealed a typical alveolar bone architecture, characterized by the absence of alveolar bone resorption in groups SHAM control and SHAM plus CSN stimulation (Fig. 3A). Likewise, the same analysis showed a higher bone loss in the PD control group, classically observed in PD (Fig. 3A). However, in rats with PD plus CSN stimulation, decreased alveolar bone resorption was observed compared to the PD control group (Fig. 3A).

Quantification of bone in the furcation area showed no changes in the SHAM groups (stimulated or not) (Fig. 3B-E). However, the PD control rats exhibited a decrease in bone volume/tissue volume (BV/TV; Fig. 3B), an increase in porosity (Fig. 3C), and trabecular separation (Tb.Sp; Fig. 3D), compared to all the other groups. On the other hand, CSN stimulation attenuated the bone loss induced by PD (Fig. 3B-D). There was no difference in Th.N (Fig. 3E) among the groups.

Histological analysis of the effects of CSN stimulation. The histological analysis of the excised jaw showed no differences in the alveolar bone level or histological score between the SHAM groups (Fig. 4). Nevertheless, PD control rats exhibited severe inflammatory cellular infiltration, process resorption and severe cementum destruction (Fig. 4A), which was reflected by increased alveolar bone loss levels (Fig. 4B) and histological scores (Fig. 4C) compared to other animals. However, the periodontium of the rats with PD plus CSN stimulation showed considerable preserved alveolar process, well-preserved cementum, and reduced cellular influx (Fig. 4A-B), resulting in lower histological scores (Fig. 4C).

Effects of CSN stimulation on plasma cytokines concentration. In the PD control group, high levels of the proinflammatory cytokine IL-6 were detected in plasma (Fig. 5A). Nevertheless, CSN stimulation reduced the levels of IL-6 induced by PD in the plasma (Fig. 5A). Plasma levels of IL-6 and IL- $1 \beta$ were not detected in SHAM plus CSN stimulated or SHAM control groups (Fig. 5A,C). Moreover, no differences were observed in plasma levels of TNFa, IL-1 $\beta$ or IL-10 among groups (Fig. 5B-D).

Effects of CSN stimulation on gingival cytokines expression. No changes were found in the expression of IL-6 and IL-10 in the gingival tissue among the groups (Fig. 6A,D). However, in addition to alveolar bone loss and histological damage, the ligature induced in the control rats a higher expression of TNFa and IL-1 $\beta$ in the gingival tissue, compared to the SHAM groups (Fig. 6B,C). Importantly, mRNA expressions of gingival TNFa decreased in the PD rats submitted to CSN stimulation when compared to the PD plus control rats (Fig. 6B). Nevertheless, the same was not observed with respect the IL-1 $\beta$ levels (Fig. 6C). 
A

SHAM + Control

$\mathrm{SHAM}+\mathrm{ES}$

PD + Control

$\mathrm{PD}+\mathrm{ES}$

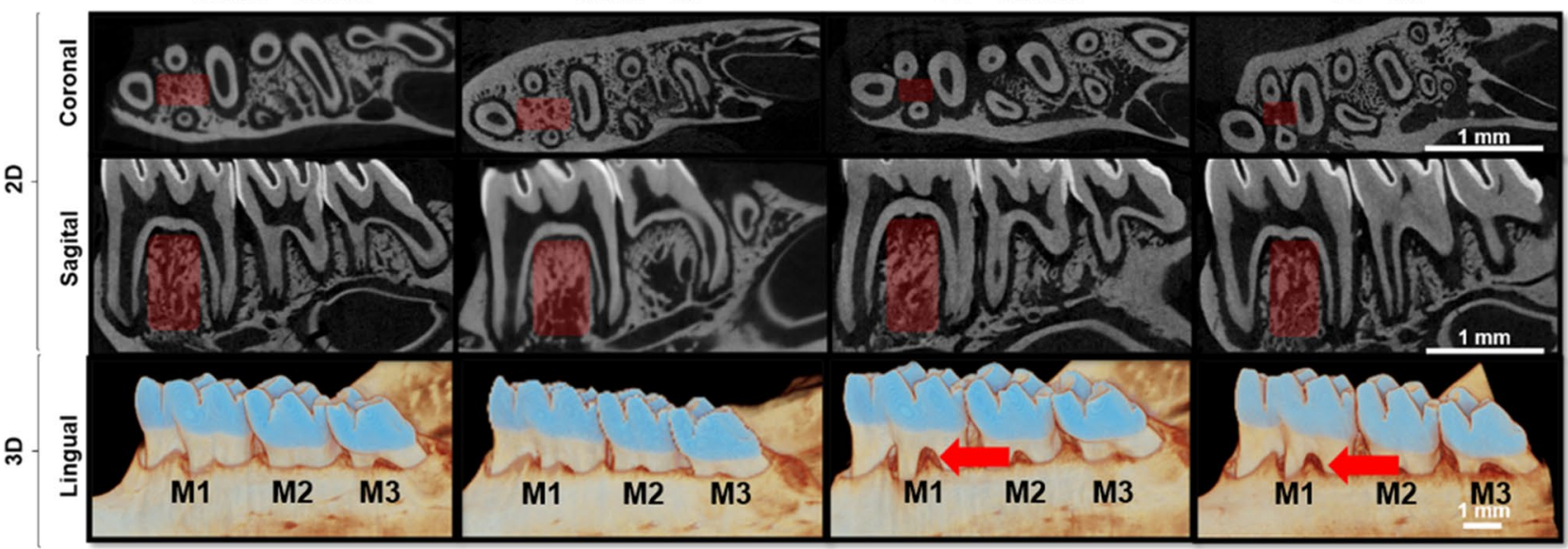

B

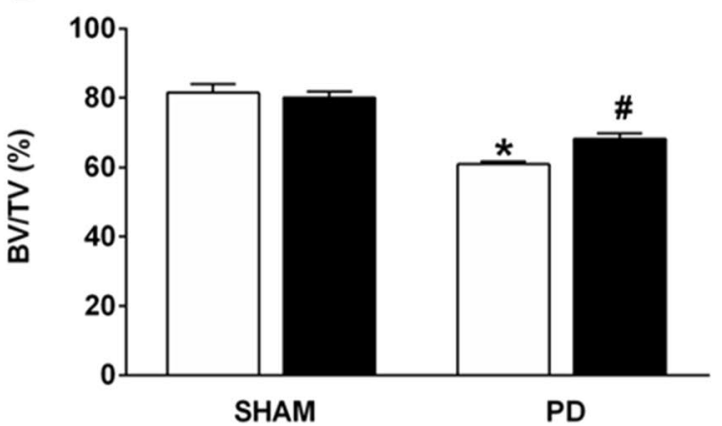

D

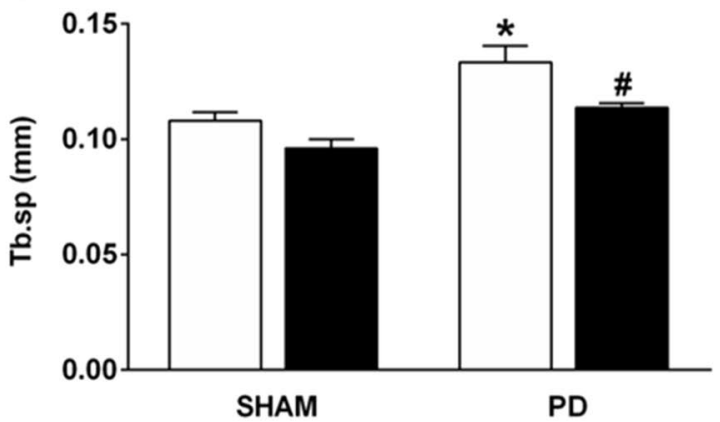

C

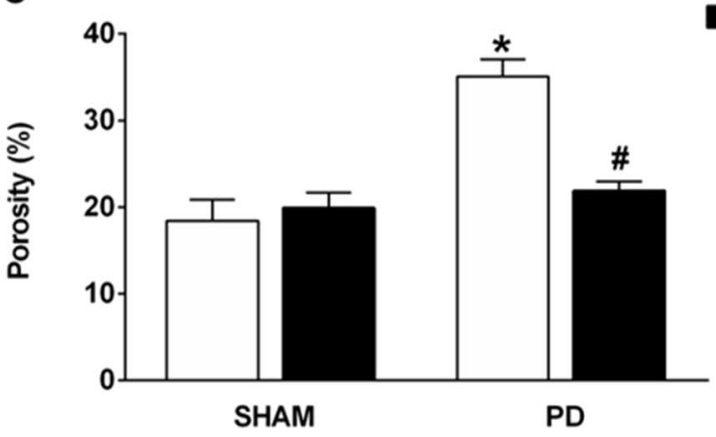

E

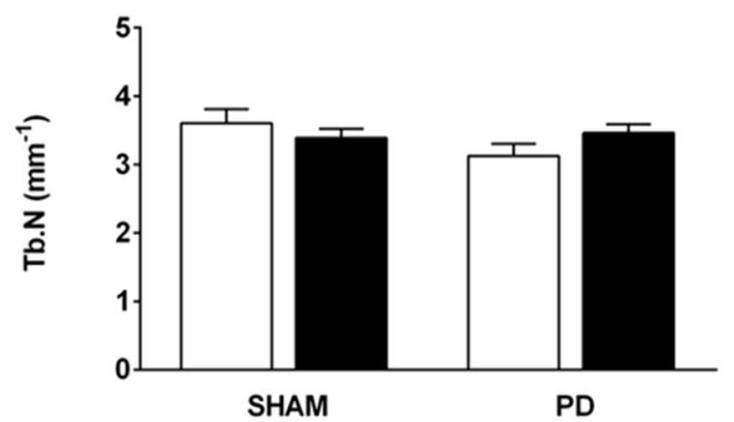

Figure 3. Stimulation of the CSN attenuates the bone loss induced by periodontitis, Evaluation trough $2 \mathrm{D}$ and 3D image analysis. Micro-CT images of the jaw (A) from SHAM rats with $(n=5)$ and without $(n=5)$ CSN stimulation and jaw from PD rats with $(n=8)$ and without $(n=6)$ CSN stimulation. Bar graphs represent bone volume/tissue volume $(\mathbf{B} ; \mathrm{BV} / \mathrm{TV})$, total bone porosity $(\mathbf{C})$, separation of the trabeculae $(\mathbf{D} ; \mathrm{Tb} . \mathrm{Sp})$ and the trabecular number (E; Tb.N) in all evaluated groups. In Panel A, the red color arrow in the image from PD control group highlights the accentuated bone loss in the first molar (M1); the red color arrow in the image from PD plus CSN stimulation highlights the attenuation of the bone loss due to the CSN activation. In contrast, the area highlighted in dark red color indicates the bone volume of interest, where the bone volumetric analysis was performed. Bars represent the mean \pm standard error. ${ }^{\star} P<0.05$ versus $S H A M+$ Control; $\# P<0.05$ versus $\mathrm{PD}+$ Control. ES, electrical stimulation; M2, lower second molar; M3, lower third molar; SHAM, fictitious ligation.

\section{Discussion}

The present study demonstrates, for the first time, that long-term (9 days) CSN electrical stimulation (nine days) in unanesthetized rats attenuates bone loss, histological damage between the first and the second molar, local (gingival) and systemic (plasma) pro-inflammatory cytokines induced by periodontitis. Thus, these results indicate that sympathetic and parasympathetic activation, through the CSN stimulation, can prevent the damage of the ligature-induced periodontitis in rats. 
A

A SHAM + Control

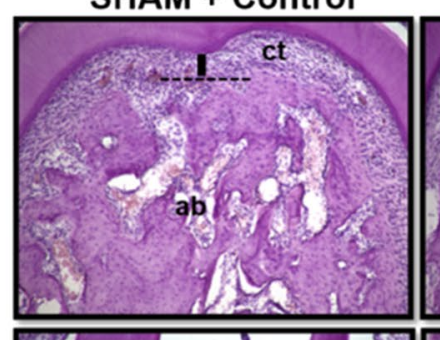

SHAM + ES

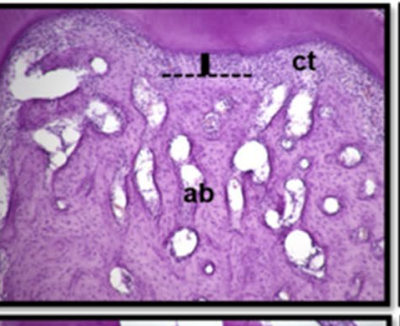

PD + Control

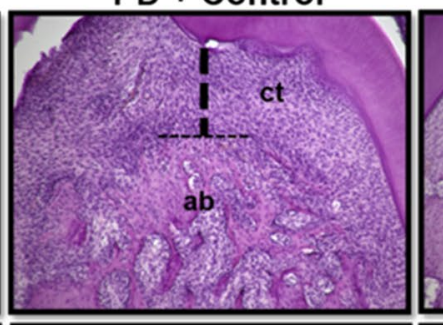

$P D+E S$

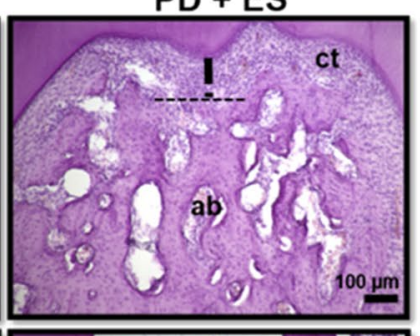

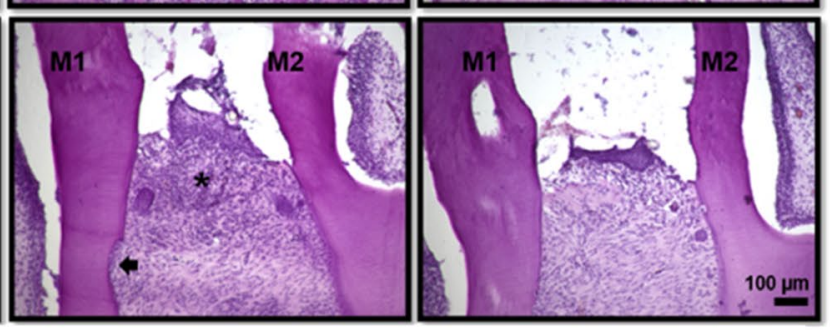

B

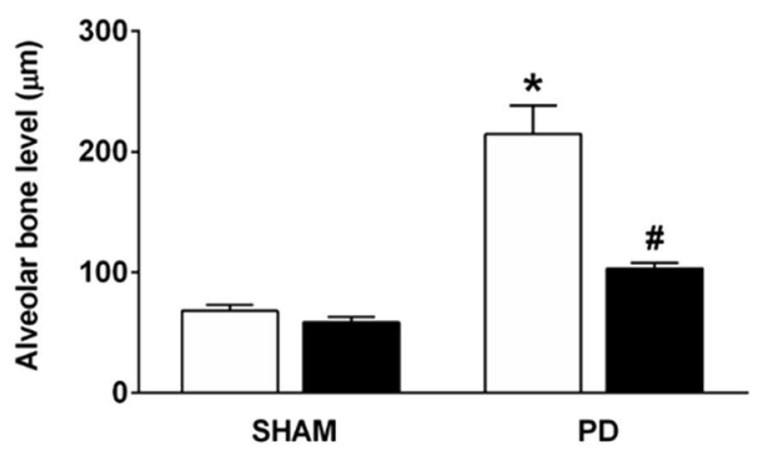

C

Control

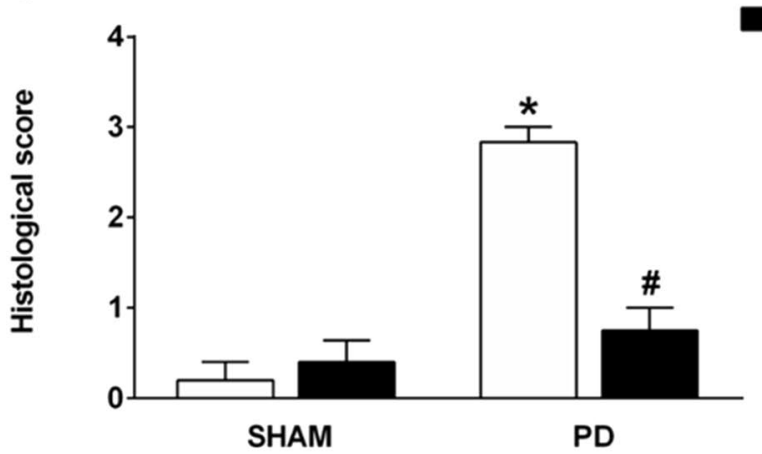

Figure 4. Stimulation of the CSN reduces bone loss and histological damage induced by periodontitis. Histological images of the jaw (A) from SHAM rats with $(n=5)$ and without $(n=5)$ CSN stimulation and from PD rats with $(n=8)$ and without $(n=6)$ CSN stimulation. The horizontal interrupted lines in the furcation area indicate the linear measurements of bone loss; the asterisk $\left(^{*}\right)$ indicates infiltration of inflammatory cells, and arrow indicates the loss of cementum. Bar graphs represent linear alveolar bone loss $(\mathbf{B})$, and histological score (C) represented by bone loss, infiltration of inflammatory cells, and loss of cementum. Quantifications were performed using ImageJ 1.50i software, a version of Wayne Rasband, National Institutes of Health, USA (https:// imagej.nih.gov/ij). Bars represent the mean \pm standard error. ${ }^{\star} P<0.05$ versus $\mathrm{SHAM}+$ Control; $\# P<0.05$ versus $\mathrm{PD}+$ Control. CSN, carotid sinus nerve; ES, electrical stimulation; PD, periodontal disease; SHAM, fictitious ligation; ct, connective tissue; ab, alveolar bone; M1, lower first molar; and M2, second lower molar.

The autonomic nervous system influences the periodontal tissue ${ }^{42}$. Autonomic nerve fibers were found in the cortical bone, endosteum, and periosteum, suggesting a direct effect on bone cell function ${ }^{43,44}$. Moreover, the sympathetic activity inhibits the proliferation of osteoblasts and promotes bone loss trough the norepinephrine release $^{45,46}$. In contrast, parasympathetic activity has anti-inflammatory properties and decreases bone resorption by suppressing the sympathetic activity and increasing the apoptosis of osteoclasts ${ }^{13,47}$. Acetylcholine, the principal neurotransmitter released by the parasympathetic nervous system ${ }^{48}$, is synthesized by periodontium cells, as well as cells of the immune system, such as monocytes/macrophages, B and T cells ${ }^{49-51}$. Previous studies showed that acetylcholine has anti-inflammatory activity through the activation of the alpha 7 nicotinic receptor, acting on immune-competent cells regulating inflammatory processe ${ }^{20,21}$. The cholinergic anti-inflammatory pathway has been extensively investigated with therapeutic purposes to treat chronic inflammatory diseases, such as rheumatoid arthritis, asthma, sepsis, diabetes and psoriasis ${ }^{52}$. However, the effect of this pathway in the treatment of PD is currently unknown. It is possible that the beneficial effects observed in bone loss and inflammation in PD, caused by the simultaneous stimulation of the carotid baroreflex and chemoreflex described in the present study, maybe due to parasympathetic activation. This mechanism may protect the alveolar bone loss by decreasing the inflammation, the osteoclastogenesis and the sympathetic activity induced by PD.

Placement of a ligature around the posterior teeth mimics the development of the human periodontal disease, leading to local cellular inflammatory accumulation, apical migration of junctional epithelium, and bone $\operatorname{loss}^{9,53}$. The development of periodontitis is associated with dysbiotic plaque biofilms and inflammatory response mediated by the host ${ }^{54}$. The inflammatory response results in progressive destruction of the supporting structures of the teeth and loss of periodontal attachment ${ }^{4}$. Therefore, the primary outcome of periodontitis includes 
A

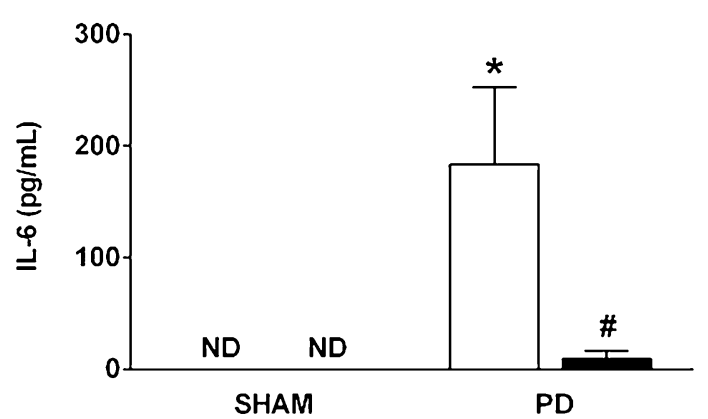

C

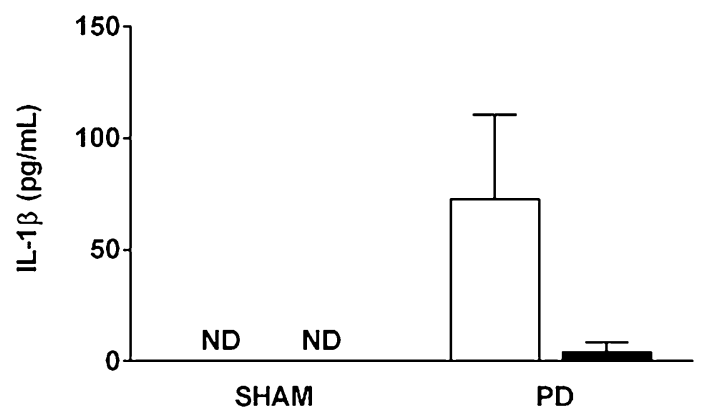

B

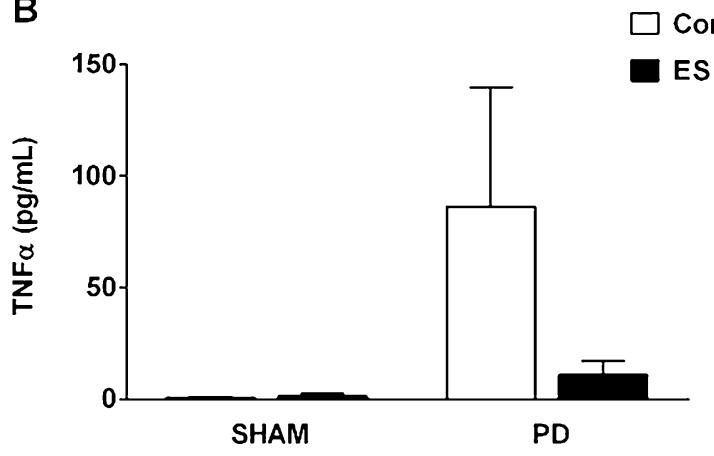

D

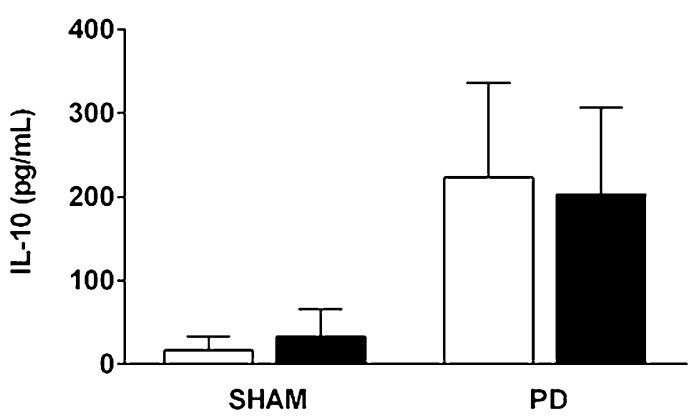

Figure 5. CSN activation decreases plasma levels of IL-6. Plasma concentrations of IL-6 (A), TNF $\alpha$ (B), IL-1 $\beta$ (C) and IL-10 (D) of SHAM rats with $(n=5)$ and without $(\mathrm{n}=5)$ CSN stimulation and of PD rats with $(\mathrm{n}=8)$ and without $(\mathrm{n}=6)$ CSN stimulation. Bars graphs represent the mean \pm standard error. ${ }^{\star} P<0.05$ versus SHAM + Control; $\# P<0.05$ versus DP + Control. CSN, carotid sinus nerve; ES, electrical stimulation; ND, not detected; $\mathrm{PD}$, periodontal disease; SHAM, fictitious ligation.

alveolar bone loss $^{4}$. Beyond alveolar bone loss and gingival inflammation, the literature documents that the production of cytokines in PD can act systemically through oral bacteria and immune cells translocation in the bloodstream reaching distant organs; eliciting, therefore, a generalized inflammatory response ${ }^{55}$. Nevertheless, systemic inflammatory disease impacts the periodontal tissues, such as diabetes and hypertension ${ }^{56,57}$. This notion might explain why the physiopathogenesis of PD is similar, in nature, to other inflammatory diseases. Thus, the ligature experimental periodontal disease model has been widely used in the literature to investigate the pathophysiology and new potential therapeutic strategies for periodontitis 9

In the current study, rats with PD submitted to CSN activation showed lower plasma concentrations of IL- 6 compared to the PD control group. IL-6 is a pro-inflammatory cytokine usually increased in periodontitis patients, and it has been likewise associated with the augmented incidence of myocardial infarction and mortality ${ }^{58}$. Also, PD is associated with cardiovascular diseases ${ }^{32-35}$, and inflammation seems to be the most likely outcome that correlates PD with cardiovascular diseases ${ }^{59}$. Thus, there is a connection between these three conditions: inflammation, cardiovascular diseases and PD. It has been shown that electrical stimulation of the baroreflex is an effective therapeutic approach for cardiovascular diseases, for instance, arterial hypertension and heart failure ${ }^{25-27}$; nevertheless, this electroceutical approach has also attenuated the inflammation in experimental PD, as demonstrated in the present study. Thus, the activation of the carotid baroreflex and chemoreflex in those clinical situations (hypertension and heart failure) would be helpful to counteract the undesirable effects of periodontitis themselves, eventually associated with those morbidities. For this reason, the results of the current study must be cautiously interpreted and carefully extrapolated to a clinical context.

In addition, in the current study, the PD control group exhibited an increase in inflammatory cell infiltration between the first and the second molar and augmentation of pro-inflammatory mediators (IL-1 $\beta$ and TNF $\alpha$ ) along with the alveolar bone loss (volume and linear level). However, the levels of anti-inflammatory cytokine IL-10 and pro-inflammatory IL-6 were closer to the normal range. The increased levels of inflammatory cell infiltration and pro-inflammatory cytokines, and the alveolar bone loss are, in fact, a hallmark of periodontitis ${ }^{2-4,60}$. Nevertheless, the CSN stimulation in the PD reduced the alveolar bone loss and histological damage, combined with a decrease in inflammatory cells in the interproximal area between the first molar and the second molar; nevertheless, with preservation of the cementum covering the dentin.

The TNFa is one of the essential pro-inflammatory cytokines involved in the development of PD. It elicits the migration of inflammatory cells, increasing the production of IL- $1 \beta^{6,7}$. The increase of gingival IL- $1 \beta$ levels is in line with the study of Aral and co-workers (2015), that showed higher IL-1 $\beta$ in the ligature model of $\mathrm{PD}^{60}$. The over-expression of TNF $\alpha$ and IL- $1 \beta$ increases the damage of the periodontal tissue and alveolar bone loss by stimulating osteoclastogenesis and inhibiting the osteoblasts function ${ }^{6,7}$. The CSN electrical stimulation decreased the TNFa expression in the gingival tissue of rats, as well. It is possible that the lower expression of 
A
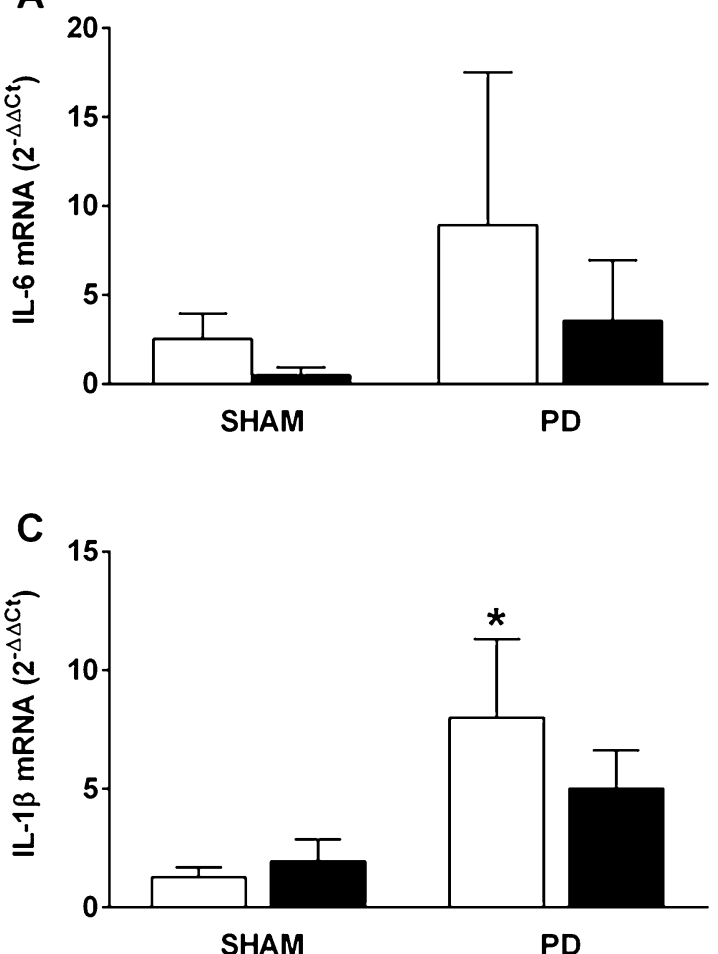

B
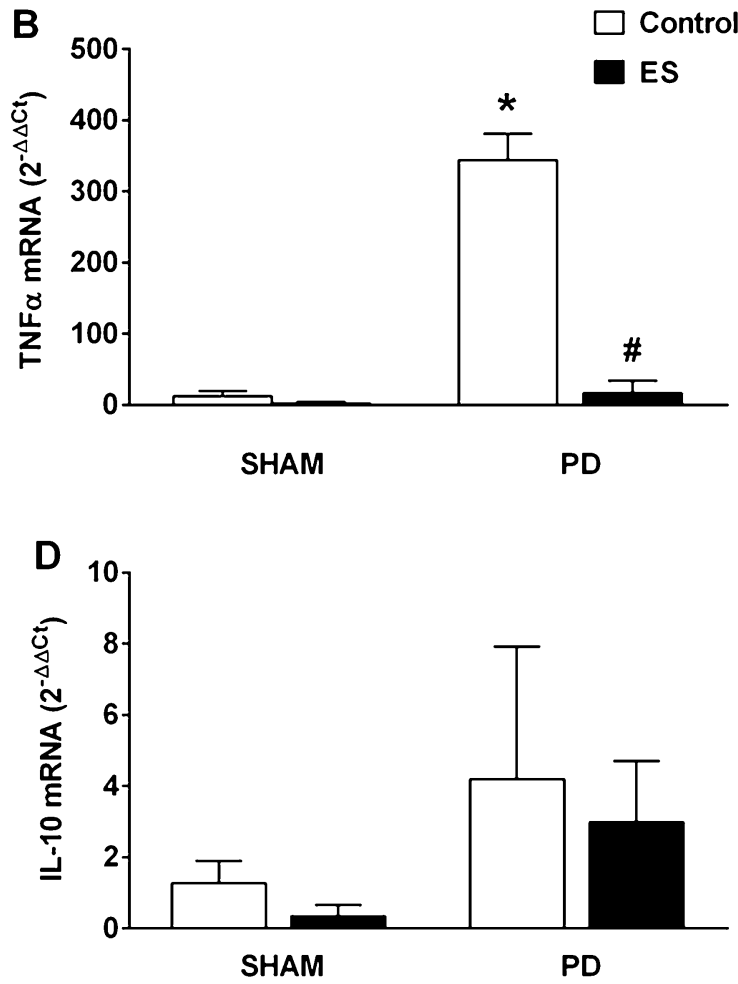

Figure 6. CSN stimulation decreases the expression of TNF $\alpha$ mRNA expression in gingival tissues. Expression of IL-6 (A), TNF $\alpha(B)$, IL-1 $\beta$ (C) and IL-10 (D) mRNA in gingival tissue of SHAM rats with $(n=3)$ and without $(n=3)$ CSN stimulation and of PD rats with $(n=4)$ and without $(n=3)$ CSN stimulation. Gene expression values are in relation to the SHAM group without stimulation of the $\operatorname{CSN}\left(2^{-\Delta \Delta C t}\right)$, which was normalized by GAPDH. Bars graphs represent the mean \pm standard error. ${ }^{\star} P<0.05$ versus SHAM + Control; $\# P<0.05$, versus $\mathrm{DP}+$ Control. CSN, carotid sinus nerve; ES, electrical stimulation; PD, periodontal disease; SHAM, fictitious ligation.

TNFa contributed to the reduction of bone loss in PD rats under CSN activation. In fact, previous studies showed that TNFa antagonist inhibits osteoclast formation, inflammatory response, and bone loss in experimental periodontitis ${ }^{61-63}$.

Baroreceptors are mechanoreceptors that monitor the arterial pressure and heart rate from the aortic arch, carotid sinuses and major blood vessels ${ }^{28}$. In the periodontal ligament, there is also mechanoreceptors which respond to strength application ${ }^{64}$. Besides, it has been suggested that the periodontal sensory innervation may interact with immunocompetent cells to assist their migration to inflamed areas of the periodontal ligament ${ }^{65}$. Periodontal mechanoreception is similar to baroreceptor function, and can be considered an important reflex mechanism ${ }^{66}$. The therapeutic method of electric activation of the baroreflex is described in the literature as Baroreflex Activation Therapy and has been used to treat some cardiovascular diseases, i.e. resistant hypertension and heart failure ${ }^{25-27}$. Our laboratory developed a technique to electrically stimulate the CSN in unanesthetized rats, providing simultaneous carotid baroreflex and chemoreflex activation without the undesirable effects of anesthesia ${ }^{30}$. In addition, both chemoreflex and baroreflex activation, through the CSN electrical stimulation, can also be used as an electroceutical approach to control the inflammation ${ }^{24}$. Despite that, little is known about the possible influence of the baroreflex and chemoreflex mechanisms, particularly their activation, on the hemodynamic parameters (MAP and HR) in PD. The findings in the present study indicated that CSN electrical stimulation promotes similar hypotensive responses in SHAM and PD rats. However, no changes were observed in HR due to the CSN stimulation in the SHAM or PD groups. Moreover, there was no difference between baseline arterial pressure or HR between rats with and without periodontitis. Therefore, these data are in line with previous studies that demonstrated that ligature-induced periodontitis did not affect arterial pressure in mice ${ }^{67}$, and also that the CSN electrical stimulation did not change HR in unanesthetized rats ${ }^{30}$.

Nevertheless, it is important to highlight that further studies are needed to elucidate: (1st) the mechanism involved in the baroreflex activation attenuating the PD development; (2nd) whether the chemoreflex stimulation decreased PD progress by the sympathetic or parasympathetic activation; (3rd) whether both baroreflex and chemoreflex are needed to control the PD progression; and (4th) whether the CSN stimulation would attenuate the PD development after its installation.

The current study had the limitation that concerns the use of antibiotics after periodontitis induction, that was administered to protect the animal of undesirable infection caused by the surgical procedure for implantation of the electrodes. Periodontitis was induced concomitantly with implant surgery to avoid another surgical stress. Moreover, the most important aspect of this particular protocol is that the development of periodontitis 
after the implantation of the electrodes and performance of the ligature combined with the antibiotic-without the electrical stimulation (control protocol) - was remarkable. In this sense, it was observed consistent results of alveolar bone loss, an increase of cytokines expression in the gingival tissue and plasma levels, and histopathological scores in the interdental (between the first and the second molar) region. Apropos, these results were similar to previous studies ${ }^{60,68,69}$ indicating that the protocol used in the current manuscript is straightforward, demonstrating the efficacy of the electrical stimulation of the carotid sinus nerve upon the physiopathological responses of periodontitis.

In conclusion, the present study demonstrated that the electrical stimulation of the CSN promotes a protective effect on PD development in unanesthetized rats. Moreover, the current findings provide new insights to understanding the link between baroreflex and chemoreflex activation on the modulation of periodontal bone loss.

Received: 18 August 2020; Accepted: 23 October 2020

Published online: 06 November 2020

\section{References}

1. Petersen, P. E. \& Baehni, P. C. Periodontal health and global public health. Periodontol 2000(60), 7-14. https://doi.org/10.111 1/j.1600-0757.2012.00452.x (2012).

2. Darveau, R. P. Periodontitis: a polymicrobial disruption of host homeostasis. Nat. Rev. Microbiol. 8, 481-490. https://doi. org/10.1038/nrmicro2337 (2010).

3. Garlet, G. P. Destructive and protective roles of cytokines in periodontitis: a re-appraisal from host defense and tissue destruction viewpoints. J. Dent. Res. 89, 1349-1363. https://doi.org/10.1177/0022034510376402 (2010).

4. Cekici, A., Kantarci, A., Hasturk, H. \& Van Dyke, T. E. Inflammatory and immune pathways in the pathogenesis of periodontal disease. Periodontol 2000(64), 57-80. https://doi.org/10.1111/prd.12002 (2014).

5. Kindle, L., Rothe, L., Kriss, M., Osdoby, P. \& Collin-Osdoby, P. Human microvascular endothelial cell activation by IL-1 and TNFalpha stimulates the adhesion and transendothelial migration of circulating human CD14+ monocytes that develop with RANKL into functional osteoclasts. J. Bone Miner Res. 21, 193-206. https://doi.org/10.1359/JBMR.051027 (2006).

6. Kwan Tat, S., Padrines, M., Théoleyre, S. \& Heymann, D Fortun. IL-6, RANKL, TNF-alpha/IL-1: interrelations in bone resorption pathophysiology. Cytokine Growth Factor Rev. 15, 49-60. https://doi.org/10.1016/j.cytogfr.2003.10.005 (2004).

7. Wajant, H., Pfizenmaier, K. \& Scheurich, P. Tumor necrosis factor signaling. Cell Death Differ. 10, 45-65. https://doi.org/10.1038/ sj.cdd.4401189 (2003).

8. Fonseca, J. E., Santos, M. J., Canhão, H. \& Choy, E. Interleukin-6 as a key player in systemic inflammation and joint destruction. Autoimmun Rev. 8, 538-542. https://doi.org/10.1016/j.autrev.2009.01.012 (2009).

9. Graves, D. T., Fine, D., Teng, Y. T., Van Dyke, T. E. \& Hajishengallis, G. The use of rodent models to investigate host-bacteria interactions related to periodontal diseases. J. Clin. Periodontol. 35, 89-105. https://doi.org/10.1111/j.1600-051X.2007.01172.x (2008).

10. Chenu, C. \& Marenzana, M. Sympathetic nervous system and bone remodeling. Joint Bone Spine 72, 481-483. https://doi. org/10.1016/j.jbspin.2005.10.007 (2005).

11. Eimar, H., Tamimi, I., Murshed, M. \& Tamimi, F. Cholinergic regulation of bone. J. Musculoskelet. Neuronal. Interact. 13, 124-132 (2013).

12. Elefteriou, F., Campbell, P. \& Ma, Y. Control of bone remodeling by the peripheral sympathetic nervous system. Calcif. Tissue Int. 94, 140-151. https://doi.org/10.1007/s00223-013-9752-4 (2014)

13. Bajayo, A. et al. Skeletal parasympathetic innervation communicates central IL-1 signals regulating bone mass accrual. Proc. Natl. Acad. Sci. USA 109, 15455-15460. https://doi.org/10.1073/pnas.1206061109 (2012).

14. Ordovas-Montanes, J. et al. The regulation of immunological processes by peripheral neurons in homeostasis and disease. Trends Immunol. 36, 578-604. https://doi.org/10.1016/j.it.2015.08.007 (2015).

15. Procaccini, C., Pucino, V., De Rosa, V., Marone, G. \& Matarese, G. Neuro-endocrine networks controlling immune system in health and disease. Front Immunol. 5, 143. https://doi.org/10.3389/fimmu.2014.00143 (2014).

16. Sternberg, E. M. et al. Inflammatory mediator-induced hypothalamic-pituitary-adrenal axis activation is defective in streptococcal cell wall arthritis-susceptible Lewis rats. Proc. Natl. Acad. Sci. U S A 86, 2374-2378. https://doi.org/10.1073/pnas.86.7.2374 (1989).

17. Tracey, K. J. The inflammatory reflex. Nature 420, 853-859. https://doi.org/10.1038/nature01321 (2002).

18. Martelli, D., Yao, S. T., McKinley, M. J. \& McAllen, R. M. Reflex control of inflammation by sympathetic nerves, not the vagus. J. Physiol. 592, 1677-1686. https://doi.org/10.1113/jphysiol.2013.268573 (2014).

19. Andersson, U. \& Tracey, K. J. Neural reflexes in inflammation and immunity. J. Exp. Med. 209, 1057-1068. https://doi.org/10.1084/ jem.20120571 (2012).

20. Tracey, K. J. Reflex control of immunity. Nat. Rev. Immunol. 9, 418-428. https://doi.org/10.1038/nri2566 (2009).

21. Tracey, K. J. Understanding immunity requires more than immunology. Nat. Immunol. 11, 561-564. https://doi.org/10.1038/ni071 $0-561$ (2010).

22. Bassi, G. S. et al. Baroreflex activation in conscious rats modulates the joint inflammatory response via sympathetic function. Brain. Behav. Immun. 49, 140-147. https://doi.org/10.1016/j.bbi.2015.05.002 (2015).

23. Brognara, F. et al. Baroreflex stimulation attenuates central but not peripheral inflammation in conscious endotoxemic rats. Brain Res. 1682, 54-60. https://doi.org/10.1016/j.brainres.2018.01.003 (2018).

24. Santos-Almeida, F. M. et al. Carotid sinus nerve electrical stimulation in conscious rats attenuates systemic inflammation via chemoreceptor activation. Sci. Rep. 7, 6265. https://doi.org/10.1038/s41598-017-06703-0 (2017).

25. Bisognano, J. D. et al. Baroreflex activation therapy lowers blood pressure in patients with resistant hypertension: results from the double-blind, randomized, placebo-controlled rheos pivotal trial. J. Am. Coll. Cardiol. 58, 765-773. https://doi.org/10.1016/j. jacc.2011.06.008 (2011).

26. de Leeuw, P. W. et al. Sustained reduction of blood pressure with baroreceptor activation therapy: results of the 6-year open followup. Hypertension 69, 836-843. https://doi.org/10.1161/HYPERTENSIONAHA.117.09086 (2017).

27. Doumas, M., Faselis, C., Tsioufis, C. \& Papademetriou, V. Carotid baroreceptor activation for the treatment of resistant hypertension and heart failure. Curr. Hypertens. Rep. 14, 238-246. https://doi.org/10.1007/s11906-012-0258-7 (2012)

28. Chapleau, M. W., Hajduczok, G. \& Abboud, F. M. Mechanisms of resetting of arterial baroreceptors: an overview. Am. J. Med. Sci. 295, 327-334. https://doi.org/10.1097/00000441-198804000-00019 (1988).

29. Franchini, K. G. \& Krieger, E. M. Cardiovascular responses of conscious rats to carotid body chemoreceptor stimulation by intravenous KCN. J. Auton. Nerv. Syst. 42, 63-69. https://doi.org/10.1016/0165-1838(93)90342-r (1993).

30. Katayama, P. L. et al. Role of chemoreceptor activation in hemodynamic responses to electrical stimulation of the carotid sinus in conscious rats. Hypertension 66, 598-603. https://doi.org/10.1161/HYPERTENSIONAHA.115.05316 (2015).

31. Nazir, M. A. Prevalence of periodontal disease, its association with systemic diseases and prevention. Int. J. Health Sci. (Qassim) 11, 72-80 (2017). 
32. Muñoz Aguilera, E. et al. Periodontitis is associated with hypertension: a systematic review and meta-analysis. Cardiovasc Res. 116, 28-39. https://doi.org/10.1093/cvr/cvz201 (2020).

33. Gorska, R. et al. Correlation between the state of periodontal tissues and selected risk factors for periodontitis and myocardial infarction. Adv. Clin. Exper. Med. 26, 505-514. https://doi.org/10.17219/acem/74652 (2017).

34. Leira, Y. et al. Association between periodontitis and ischemic stroke: a systematic review and meta-analysis. Eur. J. Epidemiol. 32, 43-53. https://doi.org/10.1007/s10654-016-0170-6 (2017).

35. Chistiakov, D. A., Orekhov, A. N. \& Bobryshev, Y. V. Links between atherosclerotic and periodontal disease. Exp. Mol. Pathol. 100 220-235. https://doi.org/10.1016/j.yexmp.2016.01.006 (2016)

36. National Research Council. Committee for the Update of the Guide for the Care and Use of Laboratory Animals Guide for the Care and Use of Laboratory Animals (National Academies Press, Washington, D.C., 2011). https://doi.org/10.17226/12910.

37. Furlaneto, F. A. et al. Effects of locally administered tiludronic acid on experimental periodontitis in rats. J. Periodontol. 85, 1291-1301. https://doi.org/10.1902/jop.2014.130581 (2014).

38. Nunes, N. L. T. et al. Effects of local administration of tiludronic acid on experimental periodontitis in diabetic rats. J. Periodontol. 89, 105-116. https://doi.org/10.1902/jop.2017.170228 (2018).

39. Leitão, R. F. et al. Nitric oxide synthase inhibition prevents alveolar bone resorption in experimental periodontitis in rats. J. Periodontol. 76, 956-96s3. https://doi.org/10.1902/jop.2005.76.6.956 (2005).

40. Mar, J. C. et al. Data-driven normalization strategies for high-throughput quantitative RT-PCR. BMC Bioinf. 10, 110. https://doi. org/10.1186/1471-2105-10-110 (2009).

41. Schmittgen, T. D. \& Livak, K. J. Analyzing real-time PCR data by the comparative C(T) method. Nat. Protoc. 3, 1101-1108. https ://doi.org/10.1038/nprot.2008.73 (2008).

42. Singh, I. J., Herskovits, M. S., Chiego, D. J. \& Klein, R. M. Modulation of osteoblastic activity by sensory and autonomic innervation of bone. Prog. Clin. Biol. Res. 101, 535-551 (1982).

43. Ladizesky, M. et al. Effect of unilateral superior cervical ganglionectomy on mandibular bone in rats. Neuro Endocrinol. Lett. 24 314-320 (2003)

44. Ladizesky, M. G., Cutrera, R. A., Boggio, V., Mautalen, C. \& Cardinali, D. P. Effect of unilateral superior cervical ganglionectomy on bone mineral content and density of rat's mandible. J. Auton Nerv. Syst. 78, 113-116. https://doi.org/10.1016/s0165-1838(99)00067 $-3(2000)$.

45. Breivik, T., Gundersen, Y., Opstad, P. K. \& Fonnum, F. Chemical sympathectomy inhibits periodontal disease in Fischer 344 rats. J. Periodontal. Res. 40, 325-330. https://doi.org/10.1111/j.1600-0765.2005.00803.x (2005).

46. Okada, Y. et al. Blockade of sympathetic b-receptors inhibits Porphyromonas gingivalis-induced alveolar bone loss in an experimental rat periodontitis model. Arch. Oral. Biol. 55, 502-508. https://doi.org/10.1016/j.archoralbio.2010.04.002 (2010).

47. Shi, Y. et al. Signaling through the M(3) muscarinic receptor favors bone mass accrual by decreasing sympathetic activity. Cell Metab. 11, 231-238. https://doi.org/10.1016/j.cmet.2010.01.005 (2010).

48. Pavlov, V. A. \& Tracey, K. J. Neural regulators of innate immune responses and inflammation. Cell Mol. Life Sci. 61, 2322-2331. https://doi.org/10.1007/s00018-004-4102-3 (2004)

49. Arredondo, J. et al. Muscarinic acetylcholine receptors regulating cell cycle progression are expressed in human gingival keratinocytes. J. Periodontal. Res. 38, 79-89. https://doi.org/10.1034/j.1600-0765.2003.01006.x (2003).

50. Nguyen, V. T. et al. Choline acetyltransferase, acetylcholinesterase, and nicotinic acetylcholine receptors of human gingival and esophageal epithelia. J. Dent. Res. 79, 939-949. https://doi.org/10.1177/00220345000790040901 (2000).

51. Zoheir, N., Lappin, D. F. \& Nile, C. J. Acetylcholine and the alpha 7 nicotinic receptor: a potential therapeutic target for the treatment of periodontal disease?. Inflamm. Res. 61, 915-926. https://doi.org/10.1007/s00011-012-0513-z (2012).

52. Bencherif, M., Lippiello, P. M., Lucas, R. \& Marrero, M. B. Alpha7 nicotinic receptors as novel therapeutic targets for inflammationbased diseases. Cell Mol. Life Sci. 68, 931-949. https://doi.org/10.1007/s00018-010-0525-1 (2011).

53. Li, C. H. \& Amar, S. Morphometric, histomorphometric, and microcomputed tomographic analysis of periodontal inflammatory lesions in a murine model. J. Periodontol. 78, 1120-1128. https://doi.org/10.1902/jop.2007.060320 (2007).

54. Silva, N. et al. Host response mechanisms in periodontal diseases. J. Appl. Oral. Sci. 23, 329-355. https://doi.org/10.1590/1678775720140259 (2015).

55. Loos, B. G., Craandijk, J., Hoek, F. J., Wertheim-van Dillen, P. M. E. \& van der Velden, U. Elevation of systemic markers related to cardiovascular disease in the peripheral blood of periodontitis patients. J. Periodontol. 71, 1528-1534. https://doi.org/10.1902/ jop.2000.71.10.1528 (2000).

56. Hasturk, H. \& Kantarci, A. Activation and resolution of periodontal inflammation and its systemic impact. Periodontol 2000(69), 255-273. https://doi.org/10.1111/prd.12105 (2015).

57. Bonato, C. F., do-Amaral, C. C. F., Belini, L. \& Salzedas, L. M. P. \& Oliveira, S. H. P. Hypertension favors the inflammatory process in rats with experimentally induced periodontitis. J. Period. Res. 47, 783-792. https://doi.org/10.1111/j.1600-0765.2012.01496.x (2012)

58. Ridker, P. M., Rifai, N., Stampfer, M. J. \& Hennekens, C. H. Plasma concentration of interleukin-6 and the risk of future myocardial infarction among apparently healthy men. Circulation 101, 1767-1772. https://doi.org/10.1161/01.cir.101.15.1767 (2000).

59. Loos, B. G., Craandijk, J., Hoek, F. J., Wertheim-van Dillen, P. M. \& van der Velden, U. Elevation of systemic markers related to cardiovascular diseases in the peripheral blood of periodontitis patients. J. Periodontol. 71, 1528-1534. https://doi.org/10.1902/ jop.2000.71.10.1528 (2000)

60. Aral, K. et al. Therapeutic effects of systemic vitamin $\mathrm{k} 2$ and vitamin $\mathrm{d} 3$ on gingival inflammation and alveolar bone in rats with experimentally induced periodontitis. J. Periodontol. 86, 666-673. https://doi.org/10.1902/jop.2015.140467 (2015).

61. Assuma, R., Oates, T., Cochran, D., Amar, S. \& Graves, D. T. IL-1 and TNF antagonists inhibit the inflammatory response and bone loss in experimental periodontitis. J. Immunol. 160, 403-409 (1998).

62. Graves, D. T. et al. Interleukin-1 and tumor necrosis factor antagonists inhibit the progression of inflammatory cell infiltration toward alveolar bone in experimental periodontitis. J. Periodontol. 69, 1419-1425. https://doi.org/10.1902/jop.1998.69.12.1419 (1998).

63. Kim, J. H. et al. Tumor necrosis factor- $\alpha$ antagonist diminishes osteocytic RANKL and sclerostin expression in diabetes rats with periodontitis. PLOS ONE 12, e0189702. https://doi.org/10.1371/journal.pone.0189702 (2017).

64. Beertsen, W., McCulloch, C. A. \& Sodek, J. The periodontal ligament: a unique, multifunctional connective tissue. Periodontol 2000(13), 20-40. https://doi.org/10.1111/j.1600-0757.1997.tb00094.x (1997).

65. Vandevska-Radunovic, V., Kvinnsland, S. \& Jonsson, R. Delayed recruitment of immunocompetent cells in denervated rat periodontal ligament following experimental tooth movement. J. Dent. Res. 78, 1214-1220. https://doi.org/10.1177/002203459907800 60401 (1999).

66. Sims, M. R. Electron-microscopic affiliations of oxytalan fibres, nerves and the microvascular bed in the mouse periodontal ligament. Arch. Oral. Biol. 28, 1017-1024. https://doi.org/10.1016/0003-9969(83)90056-0 (1983).

67. Ribeiro, A. B. et al. Cardiovascular and Autonomic Dysfunction in Murine Ligature-Induced Periodontitis. Sci. Rep. 10, 6891. https://doi.org/10.1038/s41598-020-63953-1 (2020).

68. Messora, M. R. et al. Rosuvastatin promotes benefits on induced periodontitis in hypertensive rats. J. Periodontal Res. 52, 734-744. https://doi.org/10.1111/jre.12442 (2017). 
69. Vieira, G. H. A. et al. Sub-antimicrobial doses of doxycycline decreased bone loss related to ligature-induced periodontitis in hypertensive rats. Arch. Oral Biol. 101, 77. https://doi.org/10.1016/j.archoralbio.2019.03.011 (2019).

\section{Acknowledgements}

The authors thank the Fundação de Amparo à Pesquisa do Estado de São Paulo [(FAPESP) Process \#2013/205497]. A.B.R. holds a Postdoctoral Scholarship from FAPESP (Process \#2018/10455-9) and F.B. held a PhD Scholarship from FAPESP (Process \#2017/05163-6) and now receives a PhD Scholarship from Programa de Excelência Acadêmica/Coordenação de Aperfeiçoamento de Pessoal de Nível Superior [(PROEX/CAPES) \#88887.505419/2020-00]. The authors also thank the Conselho Nacional de Desenvolvimento Científico (CNPq) and Fundação de Apoio ao Ensino, Pesquisa e Assistência do Hospital das Clínicas da Faculdade de Medicina de Ribeirão Preto (FAEPA). The authors thank Simone Gomes Ferreira and Rubens Fernando de Mello for their technical support with the micro-computed tomography and histological studies, respectively.

\section{Author contributions}

A.B.R. contributed with the experiments, data acquisition, analysis of the results and participated in editing the manuscript. F.B. contributed to the experiments, data interpretation and revising the manuscript. J.F.S. performed the analysis of cytokine by RT-PCR and data interpretation. J.A.C. worked as a surgical technician. P.G.F. contributed to the conception of the work. R.C.T. contributed revising it for intellectual content. H.C.S contributed with conception, supervision, and writing the manuscript. All authors reviewed, read the final manuscript and approved the submission.

\section{Competing interests}

The authors declare no competing interests.

\section{Additional information}

Correspondence and requests for materials should be addressed to H.C.S.

Reprints and permissions information is available at www.nature.com/reprints.

Publisher's note Springer Nature remains neutral with regard to jurisdictional claims in published maps and institutional affiliations.

(c) (i) Open Access This article is licensed under a Creative Commons Attribution 4.0 International License, which permits use, sharing, adaptation, distribution and reproduction in any medium or format, as long as you give appropriate credit to the original author(s) and the source, provide a link to the Creative Commons licence, and indicate if changes were made. The images or other third party material in this article are included in the article's Creative Commons licence, unless indicated otherwise in a credit line to the material. If material is not included in the article's Creative Commons licence and your intended use is not permitted by statutory regulation or exceeds the permitted use, you will need to obtain permission directly from the copyright holder. To view a copy of this licence, visit http://creativecommons.org/licenses/by/4.0/.

(C) The Author(s) 2020 
Anexo B - Artigos Aceitos para Publicação 


\title{
Autonomic innervation of the carotid body as a determinant of its sensitivity: implications for cardiovascular physiology and pathology
}

\author{
Fernanda Brognara $\mathbb{C}^{1,2 \dagger}{ }^{1,}$, Igor S.A. Felippe ${ }^{10}{ }^{1 \dagger}$, Helio C. Salgado ${ }^{2}$, and \\ Julian F.R. Paton ${ }^{1 *}$
}

${ }^{1}$ Department of Physiology, Faculty of Medical and Health Sciences, University of Auckland, 85 Park Road, Grafton Auckland 1023, New Zealand; and ${ }^{2}$ Department of Physiology, Ribeirão Preto Medical School, University of São Paulo, Ribeirão Preto, São Paulo, Brazil

Received 18 February 2020; revised 1 July 2020; editorial decision 16 July 2020; accepted 18 August 2020

\begin{abstract}
The motivation for this review comes from the emerging complexity of the autonomic innervation of the carotid body (CB) and its putative role in regulating chemoreceptor sensitivity. With the carotid bodies as a potential therapeutic target for numerous cardiorespiratory and metabolic diseases, an understanding of the neural control of its circulation is most relevant. Since nerve fibres track blood vessels and receive autonomic innervation, we initiate our review by describing the origins of arterial feed to the $C B$ and its unique vascular architecture and blood flow. Arterial feed(s) vary amongst species and, unequivocally, the arterial blood supply is relatively high to this organ. The vasculature appears to form separate circuits inside the $C B$ with one having arterial venous anastomoses. Both sympathetic and parasympathetic nerves are present with postganglionic neurons located within the $\mathrm{CB}$ or close to it in the form of paraganglia. Their role in arterial vascular resistance control is described as is how CB blood flow relates to carotid sinus afferent activity. We discuss non-vascular targets of autonomic nerves, their possible role in controlling glomus cell activity, and how certain transmitters may relate to function. We propose that the autonomic nerves sub-serving the $C B$ provide a rapid mechanism to tune the gain of peripheral chemoreflex sensitivity based on alterations in blood flow and oxygen delivery, and might provide future therapeutic targets. However, there remain a number of unknowns regarding these mechanisms that require further research that is discussed.

Keywords Carotid body • Glomus cell • Vasculature - Autonomic innervation • Chemoreflex sensitivity
\end{abstract}

\section{Introduction}

The carotid body $(\mathrm{CB})$ has been highlighted as a potential therapeutic target for the treatment of cardiovascular diseases, including hypertension, heart failure, and breathing disturbances. ${ }^{1-7}$ Recent studies have suggested that in some cardiovascular disorders, the carotid bodies generate aberrant hyperreflexia and tonicity. Via reflex circuitry this tone powers the generation of excessive sympathetic activity, which is associated with the development and maintenance of disease, and contributes to end-organ damage. ${ }^{2,5,7,8}$ The mechanisms by which hyperreflexia and aberrant tone are generated are not fully understood but include: upregulated expression of $\mathrm{P} 2 \mathrm{X} 3$ purinoceptor, ${ }^{2}$ reduced carbon monoxide levels, ${ }^{9,10}$ high levels of hydrogen sulfide and reactive oxygen species, ${ }^{9,10}$ up-regulated proinflammatory cytokines (inflammatory mediators), and cytokine receptors in the $\mathrm{CB}^{11}$ There may also be changes in the expression of ion channels or activity of intracellular calcium and second messenger systems within glomus cells that regulate their excitability. ${ }^{12-14}$

Experimentally, one way to ascertain the role of carotid bodies in cardiorespiratory disease is to denervate or remove them. These manoeuvres reduce arterial pressure and sympathetic tone in spontaneously hypertensive rats and hypertensive patients. ${ }^{15-17}$ In addition, in animals with heart failure, removal of carotid bodies improved autonomic imbalance and cardiac pump function as well as resolving the breathing disturbances. ${ }^{18,19}$ In chronic heart failure, it has been proposed that the reduced cardiac output decreases blood supply to the $C B$ that causes

* Corresponding author. Tel: +64 9923 2052, E-mail: j.paton@auckland.ac.nz

$\dagger$ The first two authors contributed equally to the study.

Published on behalf of the European Society of Cardiology. All rights reserved. @ The Author(s) 2020. For permissions, please email: journals.permissions@oup.com. 
their sensitization and tonicity. ${ }^{7,20,21}$ In addition, hypoperfusion of the $C B$ in heart failure may be related to changes in the activity of a mechanoactivated transcription factor, called Kruppel-like factor 2. ${ }^{7,21,22}$ Studies in humans and rats have highlighted the regulatory role of the CB for glucose homeostasis. Indeed, hypoglycaemia has been shown to: (i) increase ventilation ${ }^{23-27}$ and (ii) increase $\mathrm{CO}_{2}$ sensitivity through adrenaline release. ${ }^{28,29}$ Together, these effects may avert acidosis in diseases like diabetes.

Removal of carotid bodies in patients with cardiovascular and respiratory disease, as a therapeutic approach, may have deleterious consequences. This is based on the facts that many patients have comorbidities and that the $\mathrm{CB}$ is a multi-modal receptor with at least 20 known physiological functions including: respiratory, ${ }^{30,31}$ cardiac/vascu$\operatorname{lar}^{32,33}$ neurohumoral regulation, ${ }^{25,34,35}$ and behavioural. ${ }^{6}$ Thus, its removal will likely disrupt numerous homeostatic functions thereby increasing susceptibility to side-effects. This outcome was exemplified in a recent study where nocturnal oxygen desaturations worsened in patients with heart failure and sleep apnoea. ${ }^{36}$ Thus, understanding the changes that occur within the $\mathrm{CB}$ in pathological states and the emerging mechanisms underpinning aberrant hyperreflexia and tonicity become essential if one is to attempt to pharmacologically antagonize these pathological conditions in humans. Given that, the CB is sensitive to blood flow and that reductions in cardiac output appear to trigger sensitization in heart failure, ${ }^{20}$ we have considered the mechanisms controlling blood flow to the $C B$ and whether this knowledge might provide novel targets that allow therapeutic manipulation of its sensitivity and tonicity.

Between the 1930s and 1980s, studies on CB vascularization and its autonomic innervation were described in numerous non-rodent species. Since then, few studies have been performed confirming these findings or adding additional information about the functional control of the circulation within the $C B$. This may reflect the relatively small size of the $\mathrm{CB}$ when transitioning from dogs and cats to rats and mice; notably, there is a dearth of data in the mouse. Therefore, the aim of the current review is to understand the role of the autonomic innervation of the $C B$ and how it might affect its sensitivity through. We survey much of the existing historical literature as well as more recent findings about the $C B$ vasculature and its neural innervation emphasizing its neurohumoral control in different species, including human in health and disease conditions.

\section{The origin of arterial blood supply to the $C B$ in different species}

The $\mathrm{CB}$ is considered to be one of the most densely vascularized organs in the body. ${ }^{37}$ The origin of the arterial blood supply to the CB varies between species, and within the same species (Table 1 and Figure 1). The pioneering study from Schaper ${ }^{38}$ did not find a common arterial blood supply to the $C B$ in human, cat, sheep, rabbit, and calf. He described that the $C B$ in humans received its supply from a small artery with its origin at the bifurcation of the common carotid artery. ${ }^{38}$ In contrast, in other species (cat, sheep, rabbit, and calf) he described that the arterial feed originated from several distinct branches from the carotid arteries (see below for details). In the next sections, the CB blood supply will be described for each species.

\subsection{Human}

In humans, the origin of CB blood supply was found to come from a small artery called the 'glomic artery' which was found to have numerous origins across individuals (Table 1 and Figure $1 A$ ). These included the bifurcation of the common carotid artery, ${ }^{39}$ the external carotid, internal carotid, ascending pharyngeal or vertebral arteries, or even the thyrocervical trunk - a branch of the subclavian artery. ${ }^{40-42}$ Studies have shown that the origin of these arteries may be associated with ethnicity. ${ }^{42,44}$ Muthoka et al. ${ }^{42}$ compared the source of arterial blood supply to the $C B$ in Kenyan vs. British cohorts and observed that the arterial blood supply was sourced from the carotid bifurcation in $88 \%$ of the British and $51.4 \%$ of the Kenyan population. In addition, while arterial origins from ascending pharyngeal, external, and internal carotid arteries made up only $12 \%$ of the cases in the British population, almost $50 \%$ of the Kenyan's demonstrated these feeds. ${ }^{39,42}$ Thus, it is clear that there is a huge variety in the origin of the CB blood supply in humans, and this difference might be related to ethnicity. However, to the best of our knowledge, it is unknown whether this anatomical divergence would be associated with different physiological and/or pathophysiological functions.

\subsection{Monkey}

In monkeys (Macaca fascicularis), the CB is situated between the occipital artery and the medial portion of the internal carotid artery. ${ }^{46}$ The morphometric study of the $\mathrm{CB}$ from two female cynomologus monkeys conducted by Hansen ${ }^{46}$ did not describe where the blood supply of the $C B$ originated. However, considering the position of the $C B$ in the monkey, it is reasoned that the blood supply originates from one or more of the following arteries: occipital, external carotid, and/or internal carotid (Table 1 and Figure 1B).

\subsection{Sheep and goat}

In these species, glomus tissue is not found in a single compact 'body' but scattered along the main arteries in the neck. ${ }^{48}$ However, main clumps of glomus tissue are supplied by a branch of the occipital artery ${ }^{48,49}$ as the internal carotid artery is small, becoming non-patent in these species (Table 1 and Figure 10). ${ }^{64}$

\subsection{Dog, cat, and rabbit}

The blood supply of the canine $\mathrm{CB}$ originates from a small artery branching off either the proximal part of the occipital artery or the external carotid artery ${ }^{50,65,66}$ or ascending pharyngeal artery (Table 1 and Figure 1D). ${ }^{50}$ In cats, Davis and Story ${ }^{51}$ indicated that its blood supply originated from the root of either the occipital or pharyngeal arteries; this was confirmed by Chungcharoen et al..$^{50}$ and Seidl ${ }^{52}$ who also described the external carotid artery as an additional possibility (Table 1 and Figure $1 E$ ). In the rabbit, Chungcharoen et al. ${ }^{50}$ found the $C B$ feeder artery arose from either the external or internal carotid arteries, or from the bifurcation of the common carotid artery (Table 1 and Figure 1F).

\subsection{Guinea pig}

Kondo ${ }^{67}$ revealed that the $C B$ of guinea pig was located close to the origin of ascending pharyngeal artery, but its blood supply was not described. Despite this, it is probable that the blood supply to the $C B$ comes from the ascending pharyngeal artery in guinea pig (Table 1 and Figure $1 G$. This species does not have internal carotid arteries. ${ }^{67}$

\subsection{Rat}

In the rat, McDonald and Larue ${ }^{58}$ described that the blood supply to the $\mathrm{CB}$ arises from a single artery called the ' $\mathrm{CB}$ artery', which originates 
Table I Possible origins of carotid body blood supply in different species

\begin{tabular}{|c|c|c|c|}
\hline Species & Origin & Carotid body: size/weight & Reference (s) \\
\hline Human & $\begin{array}{l}\text { Carotid bifurcation } \\
\text { External carotid artery } \\
\text { Internal carotid artery } \\
\text { Ascending pharyngeal artery } \\
\text { Vertebral artery } \\
\text { Thyrocervical trunk }\end{array}$ & $1.5-7 \mathrm{~mm} / 12-18 \mathrm{mg}$ & $\begin{array}{l}\text { Heath et al. }{ }^{39} \\
\text { Sarrat-Torres et al. }{ }^{40} \\
\text { Ozay et al. }{ }^{41} \\
\text { Muthoka et al. }{ }^{42} \\
\text { Heath et al. }{ }^{43} \\
\text { Khan et al. }{ }^{44} \\
\text { Nguyen et al. }{ }^{45}\end{array}$ \\
\hline Monkey & Not known & $0.8-1.3 \mathrm{~mm} /$ not known & $\begin{array}{l}\text { Hansen }^{46} \\
\text { Clarke et al. }^{47}\end{array}$ \\
\hline Sheep and goat & Occipital artery & $1.1 \mathrm{~mm} / 10 \mathrm{mg}$ & $\begin{array}{l}\text { Sadik et al. }{ }^{48} \\
\text { Najafi et al. }{ }^{49}\end{array}$ \\
\hline Dog & $\begin{array}{l}\text { Occipital artery } \\
\text { Ascending pharyngeal artery } \\
\text { External carotid artery } \\
\text { A muscle branch of the external ca- } \\
\text { rotid artery }\end{array}$ & $1-3 \mathrm{~mm} /$ not known & Chungcharoen et al. ${ }^{50}$ \\
\hline Cat & $\begin{array}{l}\text { Occipito-ascending pharyngeal trunk } \\
\text { Occipital artery } \\
\text { Ascending pharyngeal artery } \\
\text { External carotid artery }\end{array}$ & $0.45-1.2 \mathrm{~mm} / 2 \mathrm{mg}$ & $\begin{array}{l}\text { Davis and Story }{ }^{51} \\
\text { Chungcharoen et al. } \\
\text { Seidl }^{52} \\
\text { Clarke et al. } \\
\text { Jones } \\
\text { J4 }\end{array}$ \\
\hline Rabbit & $\begin{array}{l}\text { External carotid artery } \\
\text { Internal carotid artery or carotid } \\
\text { bifurcation }\end{array}$ & $0.8-1.9 \mathrm{~mm} /$ not known & $\begin{array}{l}\text { Chungcharoen et al. }{ }^{50} \\
\text { Clarke and de Burgh Daly } \\
\text { Eken et al. } .^{56}\end{array}$ \\
\hline Guinea pig & Not known & $0.5 \mathrm{~mm} / 0.08 \mathrm{mg}$ & $\begin{array}{l}\text { Clarke and de Burgh Daly }{ }^{55} \\
\text { Docio et al. } .^{57}\end{array}$ \\
\hline Rat & $\begin{array}{l}\text { External carotid artery } \\
\text { Occipital artery }\end{array}$ & $0.4-0.8 \mathrm{~mm} / 0.06 \mathrm{mg}$ & $\begin{array}{l}\text { McDonald and } \text { Larue }^{58} \\
\text { Habeck et al. } \\
\text { Unur and Aycan }^{60} \\
\text { Hess }^{61} \\
\text { Clarke and de Burgh Daly } \\
\text { Clarke et al. } \\
\text { McDonald }\end{array}$ \\
\hline Mouse & Not known & $0.4 \mathrm{~mm} /$ not known & Clarke and de Burgh Daly ${ }^{55}$ \\
\hline
\end{tabular}

from either the external carotid artery or the occipital artery (Table 1 and Figure $1 \mathrm{H}$ ); this was confirmed subsequently. ${ }^{59,60}$

\subsection{Mouse}

To the best of our knowledge, the vascularization of the mouse $C B$ has not been fully described. However, since the $\mathrm{CB}$ of mouse is located very close to the superior cervical ganglion (SCG) lying between external and internal carotid arteries, ${ }^{68,69}$ we suggest its blood supply comes from either the external carotid artery or occipital artery as described in rats (Table 1 and Figure 11

\section{Specializations of the intra-CB vascularization and microvascularization}

Of all species, vascularization of the $C B$ was studied comprehensively in the rat. Based on this and the density of current studies on $C B$ carried out in the rat, our discussion in this specific section, will be based exclusively on this species.

McDonald and Larue ${ }^{58}$ thoroughly described the ultrastructure and connections of blood vessels of the rat $\mathrm{CB}$. According to their work, the $C B$ artery enters the $C B$, immediately divides into three or four firstorder branches, and then, into at least five second-order branches. ${ }^{58}$ Of these secondary branches, about three branches-which are composed of continuous non-fenestrated endothelium with one or two layers of smooth muscle and a thin adventitial layer-supply the CB while the others go to adjacent structures, such as the carotid sinus nerve (CSN), vagus nerve, SCG, and nodose ganglion. ${ }^{58}$ The arterioles supplying the glomus cells originate from the third- and fourth-order branches of the CB artery, have a diameter $<15 \mu \mathrm{m}$, and at their distal end generate a capillary network. ${ }^{58,70}$ Clarke et al., ${ }^{47}$ described the small vessels (i.e. capillaries) comprised $\sim 50-60 \%$ of all vascular component of the CB. In Long-Evans rats, the microvascularization of the $C B$ is composed of 


\section{A Human}

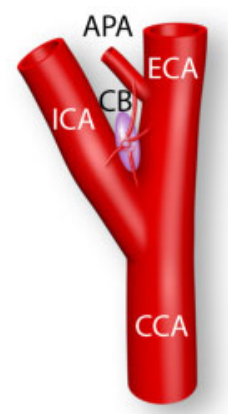

D Dog

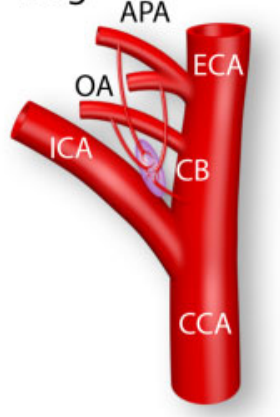

G Guinea pig

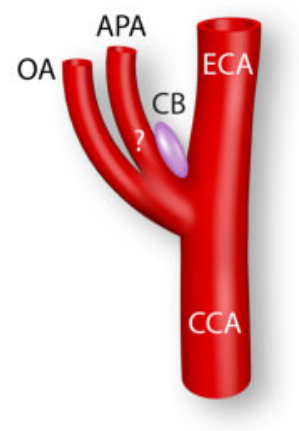

B Monkey

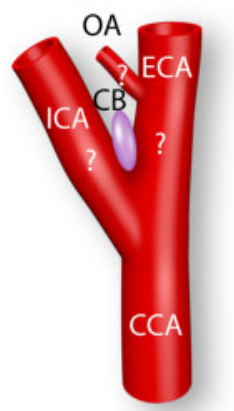

E Cat

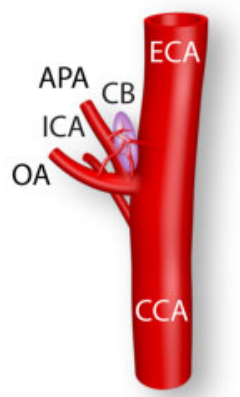

H Rat

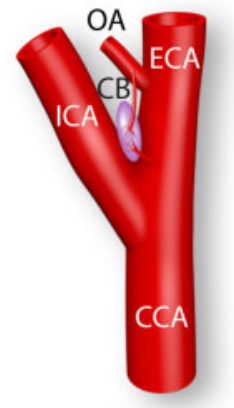

C Sheep and goat

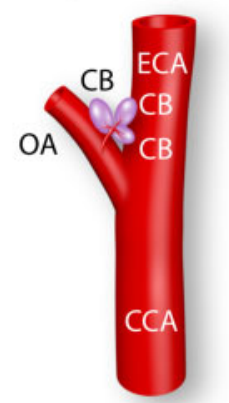

F Rabbit

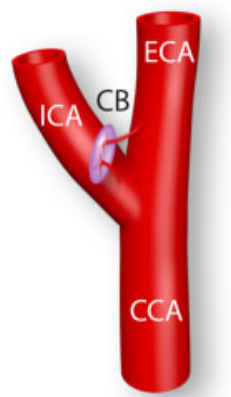

I Mouse

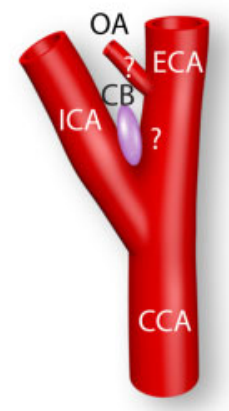

Figure I Species variation of the origin of CB blood supply. Schematic representation of the origin of CB blood supply in human $(A)$, monkey (B), sheep and goat $(C), \operatorname{dog}(D)$, cat $(E)$, rabbit $(F)$, guinea pig $(G)$, rat $(H)$, and mouse $(I)$. APA, ascending pharyngeal artery; $C B$, carotid body; CCA, common carotid artery; ECA, external carotid artery; ICA, internal carotid artery; OA, occipital artery. Data from Refs. ${ }^{39-42,48-52,58-60,67}$

distinct capillaries classified as Types I and II (Figure 2)..$^{58,70}$ Type I capillaries are large (14-20 $\mu \mathrm{m}$ of diameter) and supply clusters of glomus cells forming intimate curved contacts around single glomus cells. They are connected to many collecting venules by channels, which are narrower than the capillaries themselves, and have numerous fenestrations, few caveolae and are only partially covered by pericytes. In contrast, Type II capillaries are smaller ( $\sim 7 \mu \mathrm{m}$ of diameter), do not supply glomus cell clusters, have both straight and curved segments and are covered by pericytes at their arterial end and endothelial fenestrations at their venous end. ${ }^{58,70}$ They provide an alternate route for blood flow through the $\mathrm{CB} .^{58}$ Both types of capillaries are preceded by precapillary sphincters, which in are composed of a complete layer of smooth muscle cells or pericytes, that contribute to controlling the blood flow from arterioles into capillary branches within the CB. Numerous arteriovenous anasto- moses in the interior of the $\mathrm{CB}$ were found where arterioles connect directly to venules, ${ }^{58}$ but their function remains unknown.

The capillaries are connected to venules at both the outer surface of the $C B$ and within its interior. Some venules from the CB connect to either the internal or external jugular vein forming a $C B$ venous plexus that contributes to its drainage. In addition, caudal and rostral projecting veins from the CB connect to the pharyngeal vein that drains into the external jugular vein via the pharyngeal plexus and the posterior facial vein. Finally, ventral veins join the internal jugular vein. ${ }^{58}$ Therefore, arterioles and venules are the most important compartments for regulating total blood flow. This occurs via the presence of the aforementioned precapillary sphincters in terminal arterioles and narrowing channels at connecting points of arterial vessels with venules. Altogether, total blood flow through the $C B$ is regulated by sphincters at the arterial and venous vessels. 


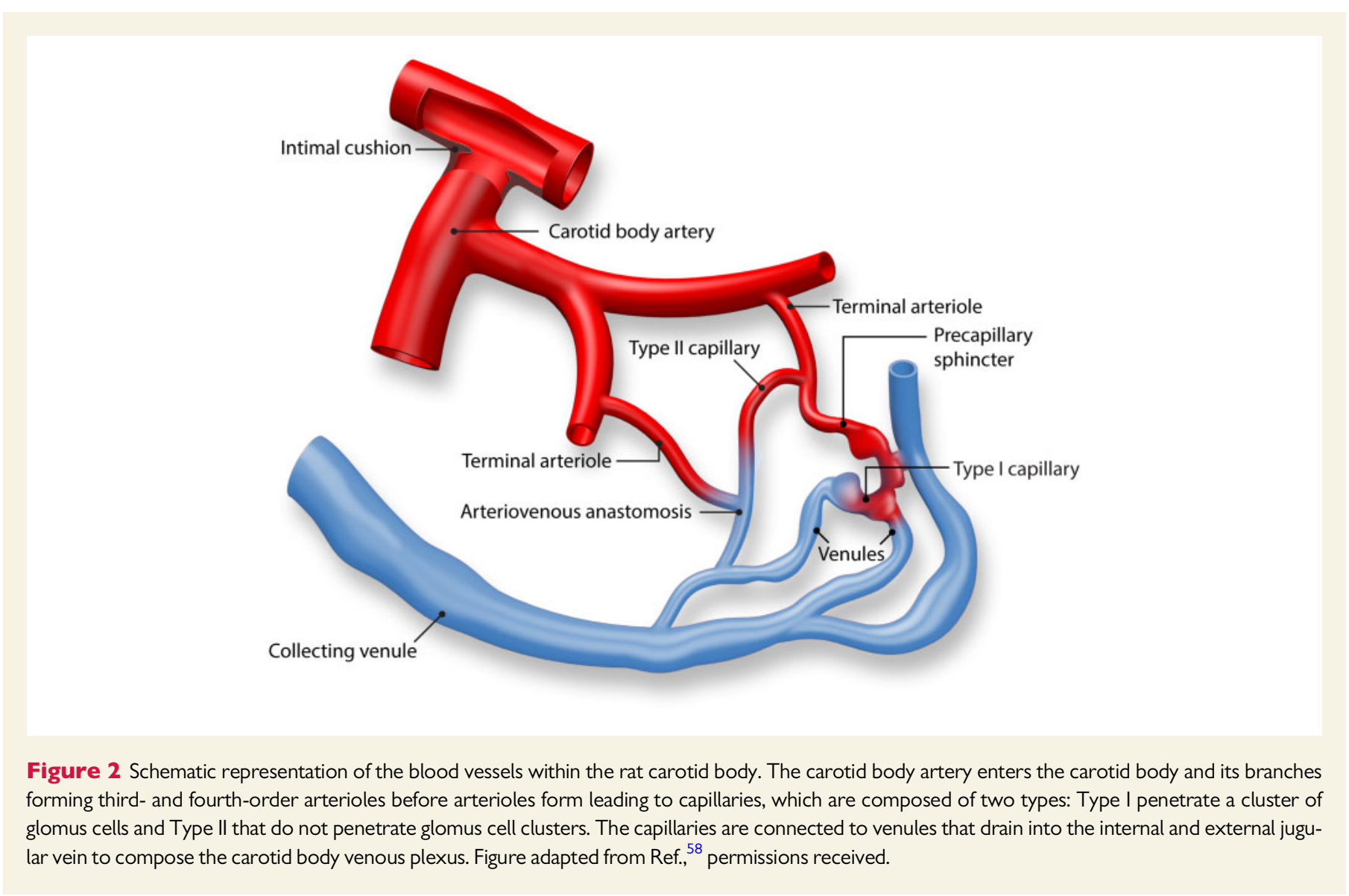

\section{The remarkable blood flow of the CB}

In addition to the precapillary sphincters, another structure contributes to the control of blood flow within the CB known as the 'intimal cushion' (Figure 2). The intimal cushion is formed by circumferential smooth muscle cells, collagenous fibres, basal and elastic laminae, and also by components of the extracellular matrix. ${ }^{58}$ It is found at the origin of the $C B$ artery and can reduce the diameter of this artery by $>50 \%$, and this is most likely mediated through its autonomic innervation. ${ }^{58,71}$ Nevertheless, despite this structure being found in rats, studies in humans do not report its presence. ${ }^{72}$

Relative to human brain $(\sim 50 \mathrm{~mL} / \mathrm{min} / 100 \mathrm{~g})^{73,74}$ and heart $(\sim 80 \mathrm{~mL} /$ $\mathrm{min} / 100 \mathrm{~g}),{ }^{75-77}$ the $\mathrm{CB}$ has a relatively large blood flow compared to other highly metabolically active organs in the body, and the same is observed in other species, for instance, in cats. ${ }^{37}$ In cats, the total CB blood flow (venous outflow) was reported to be $1417-2000 \mathrm{~mL} / \mathrm{min} /$ $100 \mathrm{~g},{ }^{37,78}$ while in rabbits it is $700-1203 \mathrm{~mL} / \mathrm{min} / 100 \mathrm{~g}$. ${ }^{20,79}$ Clarke et $a .^{47}$ reported that in rats and non-human primates, the $C B$ tissuespecific blood flow (blood flow measurement based on the wet weight of the dissected organ) is $104 \mathrm{~mL} / \mathrm{min} / 100 \mathrm{~g}$ and $31 \mathrm{~mL} / \mathrm{min} / 100 \mathrm{~g}$, respectively.

In disease states, there is evidence that blood flow to the CB is diminished. With impaired cardiac output in heart failure, blood flow to the $\mathrm{CB}$ is reduced, and this diminution is associated with an increase in peripheral chemoreflex sensitivity and a hyperreflexic sympathetic response. ${ }^{7,20,21}$ Ding et al. ${ }^{20}$ showed that, in addition to the reduction in the carotid blood flow, chronic heart failure and carotid artery occlusion similarly decreased neural nitric oxide synthase (NOS) expression and nitric oxide (NO) levels in the $\mathrm{CB}$, which might explain the raised reflex sensitivity, given the inhibitory role of $\mathrm{NO}$ in the $\mathrm{CB} .{ }^{9,10}$ In addition, angiotensin II type 1 receptor protein expression and angiotensin II concentration were both elevated in the $\mathrm{CB}$ of heart failure rabbits, ${ }^{20}$ which may induce vasoconstriction. Furthermore, it has been suggested that the decrease in CB blood flow is associated with a reduction in expression of Kruppel-like Factor 2, which is induced by endothelial cell shear stress and associated with reduced $\mathrm{NO}$ bioavailability, elevated inflammation, and angiotensin metabolism. ${ }^{7,21,22,80}$ Kruppel-like Factor 2 expression was decreased in chronic heart failure and sensitized $\mathrm{CB}$ function by: (i) decreasing endothelial NOS expression thereby reducing NO bioavailability; (ii) increasing angiotensin-converting enzyme 1 expression, which increases angiotensin II levels, consequently enhancing the renin-angiotensin system activity within the CB; and (iii) triggers inflammation since the Kruppel-like Factor 2 has anti-inflammatory function and inflammation has been associated with $C B$ sensitization. ${ }^{7,21,81-83}$ Whether there is also expression of adherence molecules by the $C B$ endothelium trapping leukocytes, as was seen in the brainstem microvasculature of spontaneously hypertensive rats, ${ }^{84,85}$ remains a possibility to be confirmed.

It is known that the bifurcation of the common carotid arteries is prone to developing atherosclerosis due to several factors which include the turbulence, the flow velocity changes and the artery wall stress among others. ${ }^{86-88}$ The pioneering study of Lowe et al. ${ }^{89}$ suggested that the progressive carotid atherosclerosis compresses the CB blood supply through the glomic arteries. ${ }^{89}$ These authors ${ }^{89}$ showed a progressive loss of glomic tissue in the $C B$ as the carotid bifurcation arteries 
(external, internal, and common) became increasingly stenosed with age. More recent studies also demonstrated damage to the $C B$ damage with carotid artery stenosis. ${ }^{90,91}$ Matturri et al., ${ }^{90}$ studied elderly patients who died from cerebral vascular disorders and had carotid artery obstruction; these patients presented atrophy and fibrosis of the $C B$ associated with a focal decrease of $C B$ vascularization. ${ }^{90}$ Thus, severe damage of the $C B$ and a reduction of the $\mathrm{CB}$ blood supply are characters of carotid artery stenosis. It is known that the ischemia of the $C B$ increases peripheral chemoreflex sensitivity, ${ }^{20}$ which causes significant mortality and morbidity in several diseases. ${ }^{92,93}$ In addition, patients with asymptomatic carotid artery stenosis have increased chemoreflex sensitivity. ${ }^{94}$ Further, carotid artery revascularization following endarterectomy reduced chemoreflex sensitivity in patients with arteriosclerotic carotid stenosis. ${ }^{95}$ Compared with stenting, endarterectomy was more effective in reversing chemoreceptor function in these patients. ${ }^{95}$

Of note, given that in humans common carotid artery blood flow is reduced on standing compared with the supine position ${ }^{96-98}$ this may provide a stimulus to the $C B$ to increase its activity. Thus, changes in blood flow to the $C B$ clearly affect its sensitization. This prompts the question regarding autonomic innervation of $C B$ vasculature and whether changes in autonomic vasomotor nerve discharge can alter $\mathrm{CB}$ reflex sensitivity and tonicity.

\section{Autonomic innervation of the CB and control of blood flow}

Given the increased sympathetic vasomotor tone in hypertension, the question arises whether this is also increased in the sympathetic nerves innervating the $\mathrm{CB}$ arterioles and, if so, does this decrease its blood flow to a level sufficient to activate glomus cells. If so, this could trigger a systemic increase in sympathetically mediated vasoconstriction and hypertension, and possibly further vasoconstriction in the $C B$ via a positive amplification feedback loop. To understand better this possibility, it is crucial to comprehend the autonomic innervation of $\mathrm{CB}$ vasculature and whether this is altered in disease states.

Autonomic innervation of the $C B$ includes innervation of three structures: (i) all segments of the vascular bed-arterioles, capillaries, precapillary sphincters, intimal cushion, arteriovenous anastomoses, venules, and small venules-(Figure 2); (ii) type A glomus cells; and (iii) sympathetic and parasympathetic ganglion neurones located circumferentially within the $C B .^{71,99}$ It is well described that within the $C B$, one or two glomus cells are located alongside glial-like cells commonly adjacent to a capillary. ${ }^{100}$ Furthermore, electron microscopy studies have identified two subpopulations of glomus cells (Type A and Type B) based on the diameter of their dense-core vesicles: Type $A$ glomus cells contain larger dense-core vesicles than Type B. Type A glomus cells are the only cells that receive either afferent or efferent nervous innervation and are more abundant than Type B cells (Figure 3). ${ }^{101}$

Autonomic innervation of the capillaries is not completely understood. However, McDonald ${ }^{71}$ discusses that they could be involved with vasomotor changes via direct effects on the extensive pericytes that exist on $\mathrm{CB}$ capillaries, or indirectly via actions on glomus cells. Nevertheless, according to the author, ${ }^{71}$ they could also take up amines inflowing into the $C B$ via the circulation.

\subsection{Sympathetic innervation}

The CB receives sympathetic postganglionic fibres from the SCG via the ganglioglomerular nerve (GGN). ${ }^{100}$ The postganglionic sympathetic neurons exclusively innervate blood vessels. ${ }^{71}$ Some of these sympathetic postganglionic cells are located outside the SCG either along the GGN or within the $C B$ itself. ${ }^{100}$ They receive inputs from preganglionic neurons ascending via the cervical sympathetic trunk (CST). ${ }^{99}$ Similar to chromaffin cells within the adrenal medulla, the $\mathrm{CB}$ also receives preganglionic sympathetic innervation from the CST that directly innervates some glomus cells (Figure 4A). ${ }^{99}$

In cats, Eyzaguirre and Uchizono ${ }^{108}$ reported that some sympathetic fibres originating from the SCG course within the CSN to innervate the $\mathrm{CB}$. The authors described a thick nerve dividing into two branches, in which one of them pierced the glomerular capsule that surrounds the $\mathrm{CB}$, whereas the other branch bypassed the $\mathrm{CB}$ and joined the $\mathrm{CSN}$ caudally. In rats, a similar description was conveyed by McDonald. ${ }^{102} \mathrm{He}$ described that a small branch of the CSN joined the sympathetic nerve that emerges from the SCG and alongside the GGN comprises the external carotid nerve. According to McDonald, ${ }^{102}$ this nerve emerged from the lateral aspect of the superior cervical ganglion, wrapped around the carotid sinus in a dorsal to ventral trajectory, passed just dorsal to the sinus nerve [where they connected], and then joined the sympathetic nerves on the external carotid artery (Supplementary material online, Figure S1A). The author emphasized that at the convergence between the CSN and the sympathetic nerve was used as a thoroughfare for baroreceptor terminals to innervate the carotid sinus region. However, this anatomical description does not rule out the idea that postganglionic sympathetic neurons course to the rostral pole of the $\mathrm{CB}$ via the CSN as described by Eyzaguirre and Uchizono. ${ }^{108}$ Whether the function of these nerves relative to the sympathetic fibres originating from the SCG differs, remains to be elucidated.

In cats, Biscoe and Sampson ${ }^{103}$ reported two extra-cranial postganglionic branches from the SCG connecting the internal carotid nerve with the glossopharyngeal nerve (GPN). From these branches, postganglionic sympathetic neurons make a loop and return to the CB via the CSN (Supplementary material online, Figure S1). The authors recorded from the central end of fibres peeled from the CSN cut close to the CB that demonstrated rhythmic activity modulated by respiration. The spontaneous rhythmic activity of these postganglionic sympathetic fibres was abolished when the extra-cranial postganglionic branches from the SCG were cut. Therefore, in cats, postganglionic sympathetic fibres from the SCG join the CSN at two locations: caudal portion of the CSN and the GPN (Figure 4Aand Supplementary material online, Figure S1B).

\subsection{Parasympathetic innervation}

This occurs via the CSN and a branch of the vagus nerve. The preganglionic neurons synapse with autonomic ganglion cells either just outside or inside the $\mathrm{CB}$. Some authors refer to the set of these ganglionic cells as the carotid ganglion ${ }^{109}$ and argue that they innervate blood vessels exclusively (for review see Daly, ${ }^{100}$ p37 and McDonald and Mitchell ${ }^{99}$ ), whereas other authors do not accept this assumption and suggest they could also innervate glomus cells. ${ }^{110}$ Biscoe et al. ${ }^{111}$ reported that nerve endings found to synapse with some glomus cells are efferent neurons with soma located in the brainstem; this suggests a direct preganglionic parasympathetic innervation. Retrograde labelling revealed preganglionic parasympathetic cell bodies at two nuclei: the nucleus parvocellularis reticularis and the retro nucleus ambiguus (Figure 4B). ${ }^{104}$ However, lately, the importance of preganglionic parasympathetic innervation has 


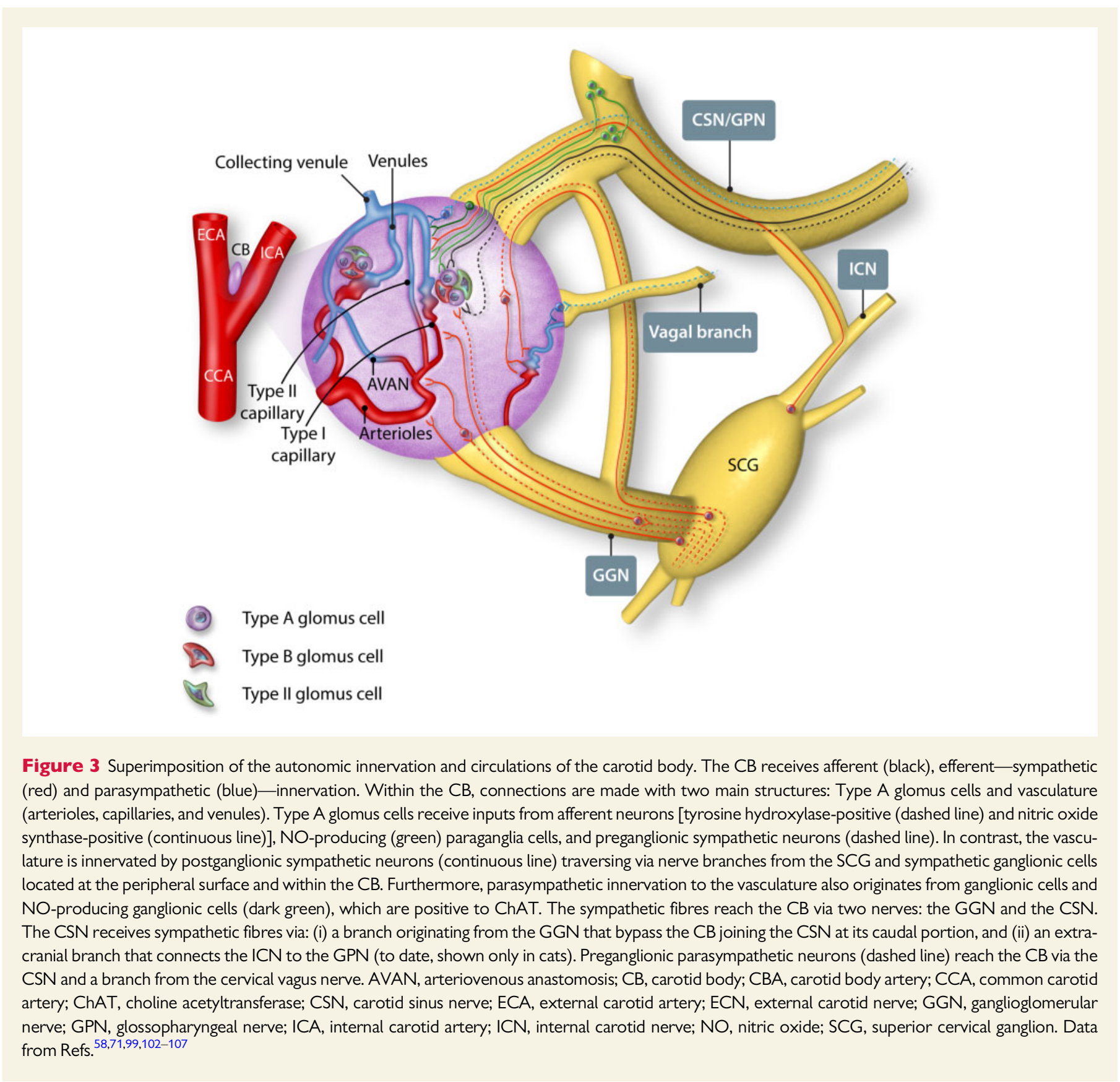

been questioned, especially with the report of putative innervation of paraganglia neurons present within both the GPN and CSN. ${ }^{115}$ A summary of the parasympathetic innervation of the $C B$ is depicted in Figure 3.

\section{Autonomic influences on CB chemoreceptors: vascular, non-vascular, or both?}

The function of sympathetic and parasympathetic innervation on $C B$ afferent discharge has been studied in non-rodent species ${ }^{100,106,114,115}$ (for review see de Burgh Daly, ${ }^{100}$ p85-88) and is described next for each limb of the autonomic nervous system.

\subsection{Sympathetic responses}

McDonald and Mitchell ${ }^{99}$ reported that preganglionic sympathetic connections of glomus cells represented only $1 \%$ of all connections; therefore, we can speculate that not all glomus cells are innervated and the bulk of effect of sympathetic activation to the $C B$ is most likely mediated via a vascular effect. Floyd and $\mathrm{Neil}^{116}$ were the first authors to evaluate the effects of sympathetic innervation on peripheral arterial chemoreceptor afferent activity. They electrically stimulated the CST in anaesthetized cats and reported an increase in chemoreceptor afferent discharge. Thereafter, Daly et al. ${ }^{78}$ reproduced this finding and also showed an associated reduced $\mathrm{CB}$ blood flow and vasoconstriction with cervical sympathetic stimulation. Two decades later, McDonald and Mitchell ${ }^{99}$ demonstrated preganglionic sympathetic innervation to some glomus cells and proposed that sympathetic innervation might have two distinct effects: (i) an excitatory effect on CB afferent discharge caused by vasoconstriction and reduced blood flow; and (ii) an inhibitory response 


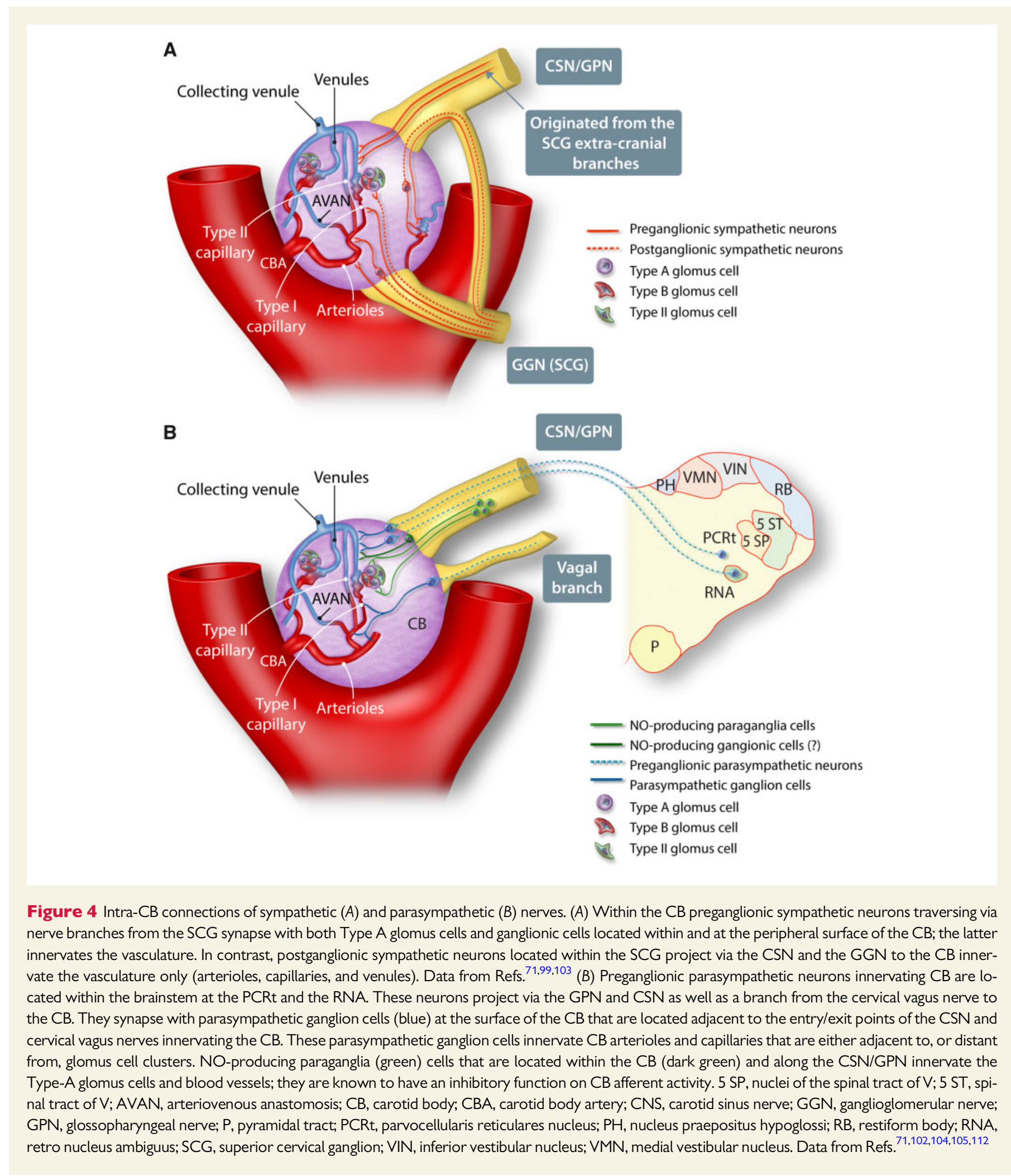

mediated by an evoked release of dopamine via the innervation of glomus cells. Dopamine acting on $\mathrm{D}_{2}$ receptors is well known to exert an inhibitory effect upon both chemoreceptors discharge and the hypoxic ventilatory response. ${ }^{117,118}$ Pharmacological studies have shown that injecting cholinergic nicotinic agonists increase the release of norepinephrine (NE) in the CB. ${ }^{119}$ It was suggested that nicotinic receptors
(nAChR) are located in specific NE-containing glomus cells. ${ }^{119}$ However, according to the study of McDonald and Mitchell, ${ }^{99}$ the only chemoreceptors which are immunoreactive for dopamine beta-hydroxylase (i.e. able to produce NE) are the Type $B$ glomus cells, and these receive neither afferent nor efferent innervation. One possibility is that Type A glomus cells are excited via preganglionic sympathetic fibres and 
simultaneously depolarize Type B cells via gap junction connections. ${ }^{99}$ Another source of NE via $n A C h R$ activation is released from sympathetic postganglionic cells located within the CB (Figure 5). ${ }^{99}$

Regarding the excitatory effect of the sympathetic innervation of the $\mathrm{CB}, \mathrm{O}^{\prime}$ Regan ${ }^{120}$ suggested two mechanisms: the first mediated by the release of NE acting on vascular $\alpha_{1}$-adrenergic receptors and the second produced by co-release of neuropeptides. In fact, postganglionic sympathetic neurons in the $C B$ are known to co-release neuropeptide $Y$ (NPY) with NE, and this one is able to produce vasoconstriction in other vascular beds. ${ }^{119,121,122}$ In cats, intra-carotid injection of NPY was able to produce activation of hyperpnoea proving its ability to stimulate chemoreceptors ${ }^{123}$; however, whether or not glomus cells express NPY receptors is yet to be determined. Additionally, non-adrenergic neurons of sympathetic origin release vasoactive intestinal peptide (VIP). ${ }^{109}$ VIP was demonstrated to activate afferent sensory fibres in the $C B$ of cats and are known to produce vasodilation. ${ }^{119,124}$ In the CB, NE causes vasoconstriction via $\alpha_{1}$-adrenoreceptors located on vascular smooth muscle. ${ }^{125}$ Acting via $\alpha_{2}$-adrenoreceptors located on glomus cells, NE inhibits chemoreceptors decreasing their sensitivity. ${ }^{119,126,127}$ The $\alpha_{2}$-adrenoreceptors were also found on sympathetic endings where they modulate the

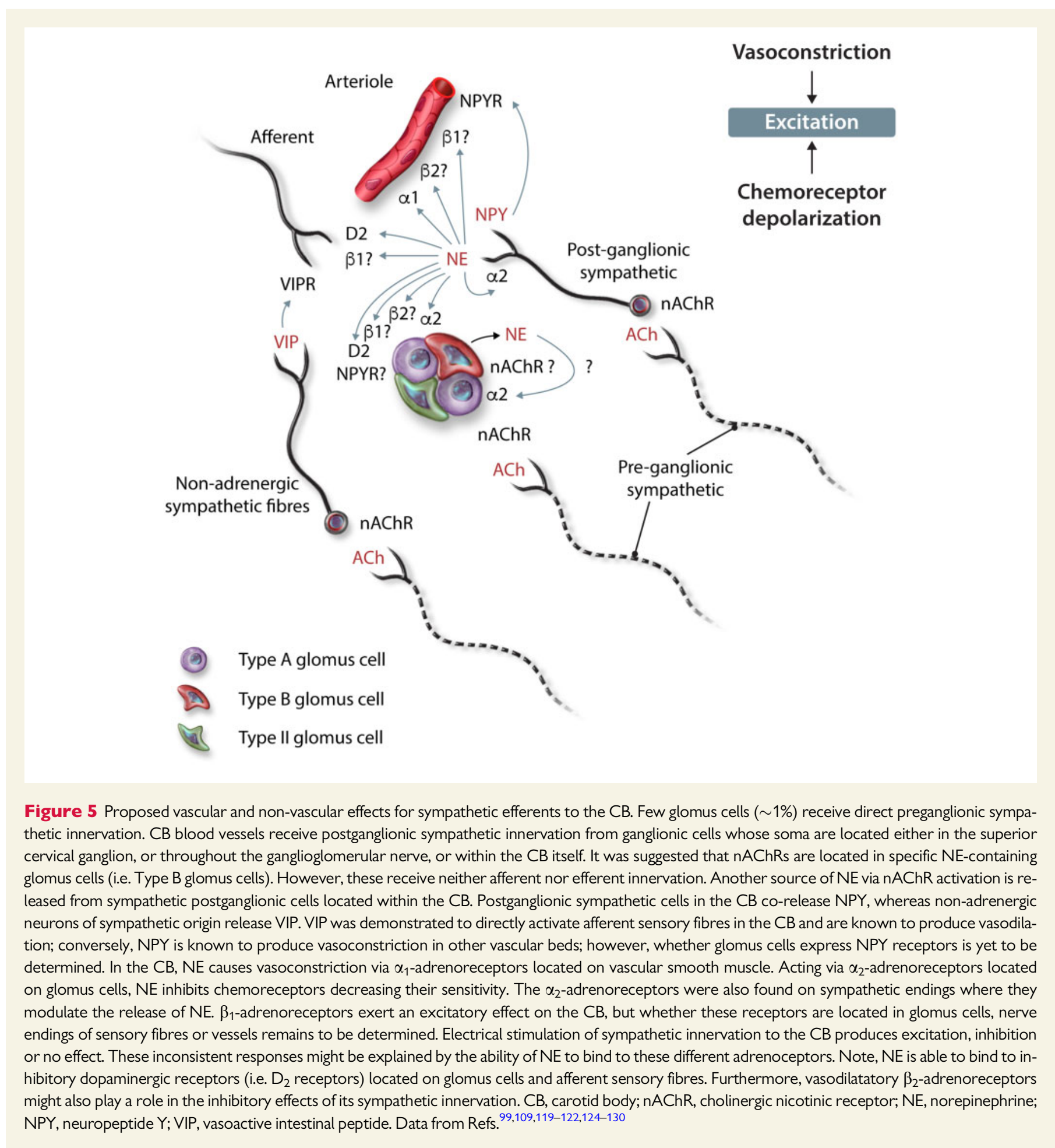


release of NE. ${ }^{126}$ Folgering et al. ${ }^{128}$ demonstrated excitatory effect on CSN discharge mediated via $\beta_{1}$-adrenoreceptors, but whether these receptors are located in glomus cells, nerve endings of sensory fibres or vessels are still to be determined. O'Regan ${ }^{120}$ demonstrated that electrical stimulation of sympathetic innervation to the $C B$ is able to produce excitation, inhibition, or no effect. These inconsistent responses might be explained by the ability of NE to bind to these different adrenoceptors. It is worth note that NE is able to bind, in some degree, $D_{2}$ receptors located in glomus cells and afferent sensory fibres. ${ }^{129,130}$ Furthermore, vasodilatatory $\beta_{2}$-adrenoreceptors might also play a role in inhibitory effects of sympathetic (Figure 5).

\subsection{Parasympathetic responses}

The influence of the CSN innervation, which contains parasympathetic pre-ganglionic and paraganglia neurons, on $\mathrm{CB}$ chemoreceptor activity was investigated in vivo. ${ }^{104,105,113,131}$ Measuring CB blood flow in cats, Neil and O'Regan ${ }^{131}$ showed that stimulation of the CSN decreased chemoreceptor discharge and produced a concomitant increase in $\mathrm{CB}$ blood flow. Following intra-arterial injection of atropine close to the $C B$, the effect on the blood flow was abolished, but the inhibitory effect on chemoreceptor activity persisted. The authors came to the conclusion that the CSN-mediated inhibitory effect was due to a non-vascular effect. Later, McCloskey ${ }^{132}$ criticized these findings due to lack of precautions to avoid pseudo-inhibition by antidromic depression of afferent discharge. Moreover, in contrast to Neil and O'Regan, ${ }^{131}$ Goodman ${ }^{133}$ found an inhibitory effect of CSN stimulation on chemoreceptors discharge that was abolished by close intra-arterial injection of atropine concluding that the CSN inhibitory effect was vasomotor in origin. Using different techniques, the same conclusion was reached by Belmonte and Eyzaguirre ${ }^{134}$ and McCloskey. ${ }^{132}$ The latter study tested two hypotheses: stimulating the efferent nerves to the $C B$ will change chemoreceptors discharge via either (i) changes in blood flow or (ii) direct effects on glomus cells. The author used stagnant asphyxia to stimulate the chemoreceptors, which arrests blood flow. It was argued that if the effect of efferent innervation was mediated via glomus cells, then stimulating the CSN during stagnant asphyxia (when there is no blood flow) would continue to reduce chemoreceptor discharge. On the other hand, if the effect of CSN activity was mediated through changes in blood flow, then stimulating the CSN would generate no effect with the stagnant asphyxia protocol. The latter was the case. Therefore, the author claimed to prove that when there is no flow, there are no efferent effects; said differently, CSN-mediated modulation of CB afferent discharge is mediated via changes of its vascular resistance. An important caveat of this study, though, is the fact that McCloskey did not measure the CB blood flow itself. Furthermore, as thoroughly described by Jones ${ }^{54}$ in his review of O'Regan's legacy, O'Regan ${ }^{135}$ elegantly eradicated any concerns with antidromic pseudo-inhibition and proved the existence of non-vascular effects via activation of CSN efferent without electricity, demonstrating its inhibitory effect in the complete absence of blood flow.

Acker and O'Regan ${ }^{136}$ electrically stimulated the CST and CSN and measured the $\mathrm{CB}$ total blood flow, local tissue blood flow, and $\mathrm{PO}_{2}$ from within the $C B$ in cats. The $C B$ total blood flow was quantified via collection of the venous outflow from the transverse pharyngeal vein; the authors weighed the blood over periods of time to calculate the flow rates in $\mu \mathrm{L} / \mathrm{min}$. On the other hand, local tissue blood flow within the $C B$ was measured in an indirect qualitative manner (hydrogen washout technique). The authors pierced the CB with two electrodes: with one electrode a small quantity of hydrogen gas was generated via electrolysis using constant current; the second electrode measured the hydrogen concentration in its immediate vicinity. Thus, changes of blood flow in the vicinity of the tip of the hydrogen-sensing electrode caused a greater or lesser dissipation of hydrogen. After confirming the chemoreceptor stimulatory (via sympathetic CST stimulation) and inhibitory (via parasympathetic CSN stimulation) effects on chemosensory afferent discharge, the authors administrated phentolamine (an $\alpha_{1}$-adrenoreceptor antagonist) via close intra-arterial injection to block the effects of sympathetic stimulation. They observed that electrical stimulation of CST and CSN changed the chemoreceptors discharge with alterations of total blood flow; however, no variations on local tissue blood flow and glomeral $\mathrm{PO}_{2}$ were seen. After phentolamine, changes in total blood flow following CST stimulation were abolished, but the effects on chemoreceptors discharge were attenuated only. The authors concluded that a possible non-vascular mechanism was involved. Of course, these findings do not rule out the possibility that other vasoactive neurotransmitters are being co-released with NE from sympathetic fibres, in which phentolamine would not antagonize. Modern imaging approaches could be useful to improve this information. Therefore, the evidence is inconsistent as to whether changes in blood flow consequent of autonomic nerve stimulation can affect $C B$ afferent activity. Notably, there is a dearth of data regarding whether the sensitivity of chemoreflex evoked end-organ responses are affected by activation of autonomic nerves destined for the $\mathrm{CB}$.

\subsubsection{New players in the CSN efferent}

McDonald and Mitchell ${ }^{99,137}$ believe that electrical stimulation of the CSN leads to inhibition of CB chemoreceptors due to antidromic stimulation of afferent neurons forming 'reciprocal synapses' with glomus cells and release dopamine to depress their activity. This opposes the idea that stimulation of the CSN activates parasympathetic efferent fibres to enhance sensitivity. It is argued that $\sim 95 \%$ of the afferent neurons that innervate the CB are located in the petrosal ganglion; $4 \%$ of petrosal ganglion neurons are immunoreactive for tyrosine hydroxylase; and $90 \%$ of these tyrosine hydroxylase positive neurons originate from the $\mathrm{CB} .{ }^{109,138}$ These neurons could be the source of the dopaminergic 'reciprocal synapses' proposed by McDonald and Mitchell. ${ }^{99,137}$ We anticipate that $C B$ afferents would operate in a similar way to that described for other sensory afferent fibres. ${ }^{139}$ Peripheral afferents display significant arborization which could lead to depolarization at branch points where these peripheral afferent collaterals would send antidromic spikes back towards glomus cells. A second possibility is that the after-depolarization in petrosal ganglion neurones might generate an antidromic action potential. Both mechanisms would affect the sensitivity of the afferent ending as well as trigger transmitter release from the afferent terminal ending as has been described for muscle afferents which act to modulate their own excitability. ${ }^{140}$ However, no functional data for such a mechanism exists for the $C B$, but that does not rule out that it may exist. On the other hand, an antidromic mechanism may not be the only way to achieve afferent sensitivity control. If dopamine is released from afferent terminals, this could be mediated by intracellular events triggered once the terminals are depolarized rather than orthodromic spikes generating antidromic ones. Also, if dopamine is released from afferent terminals, we do not know whether they will act on auto-receptors or will travel towards glomus cells (i.e. retrograde synaptic signalling). ${ }^{141,142}$ If we consider that both blood flow and reciprocal afferent synaptic connections play a role in modulating $\mathrm{CB}$ sensitivity, it is possible that both authors are correct. For example, in Neil and O'Regan work, ${ }^{131}$ atropine would block the effect on blood flow but not the release of dopamine from 


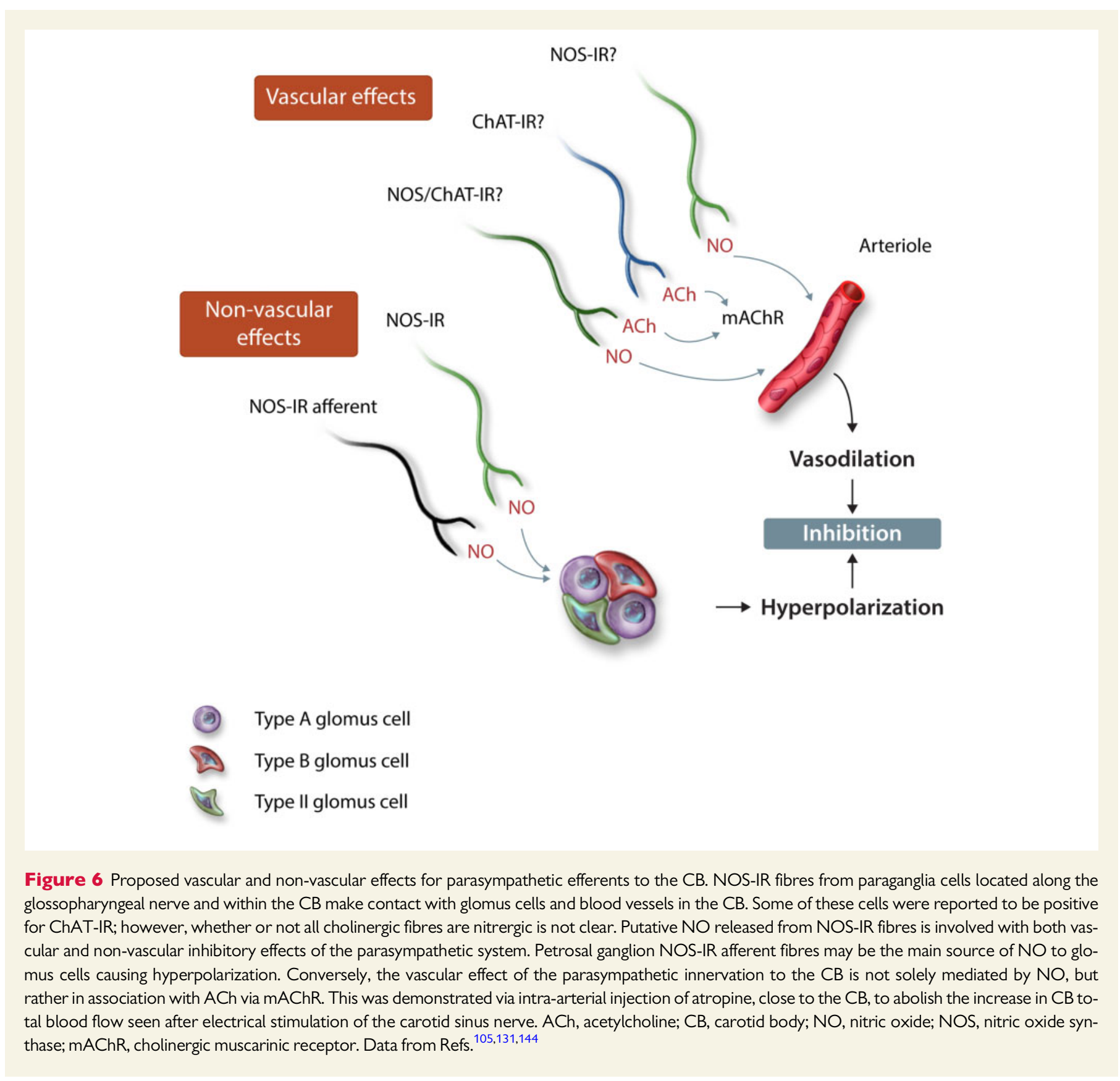

reciprocal afferent connections. However, dopamine is not the only modulatory neurotransmitters proposed to be released from CSN efferent and sensory connections.

Wang et al. ${ }^{143}$ demonstrated nitrergic fibres within the CSN and nitrergic varicosities juxtaposed to both blood vessels and glomus cells. Thus, stimulation of the CSN might also activate these nitrergic fibres and inhibit the $\mathrm{CB}$; such an effect would not be blocked by atropine and may explain Neil and O'Regan ${ }^{113,131}$ findings. Indeed, NO-mediated inhibition of $\mathrm{CB}$ could be explained by either an action on glomus cells or the vasculature causing vasodilatation and increasing blood flow (Figure 6). Wang et al. ${ }^{143}$ addressed that most of the NOS-positive fibres that connect with glomus cells are sensory from the petrosal ganglion, whereas the ones innervating the vessels are autonomic. Additionally, they also reported that these cells are positive for choline acetyltransferase (ChAT); however, whether or not all cholinergic fibres are nitrergic is not known. All told, there is evidence suggesting that CSN innervation of the CB depresses chemoreception and improves blood flow, and can neuromodulate glomus cell activity (Figure 6). ${ }^{136}$ However, to what extent and under what conditions $\mathrm{NO}$ and acetylcholine acts on the $\mathrm{CB}$ and whether the reductions in chemoreceptor afferent discharge are mediated by increases in blood flow to the $C B$ is unclear.

An additional complexity is that paraganglia neurons residing in close proximity to blood vessels within the CSN/GPN are $\mathrm{O}_{2}$ sensitive and activated by hypoxia. ${ }^{145,146}$ With $\mathrm{P} 2 \mathrm{X} 2$ and $\mathrm{P} 2 \mathrm{X} 3$ purinoceptors present on these cells ${ }^{107}$ one possibility is that adenosine triphosphate (ATP) released from erythrocytes within the CB during hypoxia could activate these $\mathrm{NO}$ producing paraganglia neurons providing a negative feedback loop to $\mathrm{CB} .{ }^{105,107}$ Whether this has a functional effect on afferent discharge or reflex response magnitudes remains to be investigated. 
Table 2 Molecular pathways involved in the different functions of the carotid body

\begin{tabular}{|c|c|c|c|c|c|c|}
\hline $\begin{array}{l}\text { Molecular } \\
\text { pathway }\end{array}$ & $\begin{array}{l}\text { Physiological } \\
\text { functionality }\end{array}$ & Where? & $\begin{array}{l}\text { Physiological } \\
\text { effect on } \\
\text { excitability }\end{array}$ & $\begin{array}{l}\text { What happens } \\
\text { in disease } \\
\text { state? }\end{array}$ & $\begin{array}{l}\text { Associated } \\
\text { disease (s) }\end{array}$ & Reference (s) \\
\hline NOS/NO & Inhibits glomus cells & $\begin{array}{c}\text { Varicosities fibres in- } \\
\text { nervating glomus } \\
\text { cells }\end{array}$ & $\downarrow$ & Down-regulation & $\begin{array}{c}\text { Hypertension and } \\
\text { heart failure }\end{array}$ & $\begin{array}{c}\text { Ding et al. }{ }^{20} \\
\text { Atanasova et al. }{ }^{148}\end{array}$ \\
\hline $\begin{array}{l}\text { Ang II and } \\
\text { AT1R }\end{array}$ & $\begin{array}{c}\text { Vasoconstriction and } \\
\downarrow \text { carotid body } \\
\text { blood flow }\end{array}$ & Vessels & $\uparrow$ & Up-regulation & Heart failure & Ding et al. ${ }^{20}$ \\
\hline KLF-2 & $\begin{array}{l}\uparrow N O \text { and } \\
\downarrow \text { inflammation }\end{array}$ & Endothelial cells & $\downarrow$ & Down-regulation & Hypertension & $\begin{array}{c}\text { Fledderus et al. }{ }^{83} \text {; } \\
\text { Iturriaga et al. }{ }^{82} \text {; } \\
\text { Li et al. }{ }^{81} \text {; Marcus } \\
\text { et al. }{ }^{21} \text {; Schultz et } \\
\text { al. }^{7}\end{array}$ \\
\hline $\mathrm{CO}$ & Inhibits glomus cells & $\begin{array}{l}\text { Red blood cells or } \\
\text { glomus cells? }\end{array}$ & $\downarrow$ & Reduced & $\begin{array}{c}\text { To be determined } \\
\text { the importance in } \\
\text { disease model }\end{array}$ & $\begin{array}{l}\text { Prabhakar and } \\
\qquad \text { Peers }^{10} \text {; } \\
\text { Prabhakar et al. }{ }^{9}\end{array}$ \\
\hline $\mathrm{H}_{2} \mathrm{~S}$ & $\begin{array}{c}\text { Inhibits Potassium } \\
\text { channels and } \\
\uparrow\left[\mathrm{Ca}^{2+}\right] \mathrm{i}\end{array}$ & Glomus cells & $\uparrow$ & Increased & $\begin{array}{c}\text { To be determined } \\
\text { the importance in } \\
\text { disease model }\end{array}$ & $\begin{array}{c}\text { Prabhakar and } \\
\text { Peers }{ }^{10} \text {; } \\
\text { Prabhakar et } \\
\text { al. }^{149}\end{array}$ \\
\hline$P_{2} X_{3}$ & $\begin{array}{c}\text { Convey glomus cells } \\
\text { sensory input to } \\
\text { brainstem nuclei }\end{array}$ & Sensory fibres & $\uparrow$ & Up-regulation & Hypertension & Pijacka et al. ${ }^{2}$ \\
\hline
\end{tabular}

\section{Clinical implications of dysfunctional CB autonomic innervation}

As discussed above, emerging evidence supports a causal relationship between CB dysfunction and cardiovascular diseases such as heart failure and hypertension (Table 2). ${ }^{18,150-155}$ Current data also suggest that this multi-modal receptor plays a role in the control of metabolism and glucose regulation, making it a potential target for diabetes. ${ }^{156,157}$ In such diseases, the CB leads to augmented sympathetic outflow that will contribute to target organ damage (heart failure), total peripheral resistance (hypertension), enhanced chemical loop gain (apnoea), and glucose intolerance (diabetes). Studies have demonstrated that targeting the CB (denervation/resection) has beneficial effects in heart failure, hypertension and for improving glucose regulation in both humans and animal models. $2,17,18,27,34,156,160-163$ CB hyperexcitability, which includes increased tonicity and hyperreflexia, is the apparent underlying mechanisms of dysfunction for the mentioned disease as demonstrated in spontaneously hypertensive rats, for instance. ${ }^{2}$ Thus, hereafter, we will discuss how such hyperexcitability might be developed.

Accordingly, in some diseases, the CB leads to augmented sympathetic outflow that will contribute to target organ damage (heart failure), total peripheral resistance (hypertension), enhanced chemical loop gain (apnoea), and glucose intolerance (diabetes). The mechanisms behind CB dysfunction and its apparent hyperexcitability include increased tonicity and hyperreflexia as demonstrated in spontaneously hypertensive rats, for example. ${ }^{2}$
As recently proposed, hypoperfusion of peripheral organs will stimulate intrinsic afferent nerves (e.g. small diameter and unmyelinated) to cause reflex changes resulting in an imbalance in autonomic activity and elevated arterial pressure in an attempt to improve tissue blood flow. ${ }^{164}$ As discussed above, in healthy animals autonomic innervation of the $C B$ modulates chemoreceptors discharge: the sympathetic nervous system increased, whereas the parasympathetic nervous system decreased chemo-afferent discharge. ${ }^{106,136}$ This might provide a rapid, dynamic, and reversible way to adjust chemo-afferent sensitivity under different physiological conditions. Although controversial, the modulatory effects of the autonomic system upon the $\mathrm{CB}$ may be directly related to changes in its blood flow. ${ }^{20,165}$ Given this together with persistently elevated sympathetic activity in cardiovascular disease, the question is raised as to whether hyperexcitability of the $C B$ results from an intense bombardment of sympathetic activity. This might also promote inflammation and vascular remodelling that further sensitizes the afferent output.

In pre-hypertensive spontaneously hypertensive rats, sympathetic overactivity is already present just after birth and takes the form of increased sympathetic-respiratory coupling. ${ }^{166}$ Consequently, it is conceivable to assume that a reduction of $\mathrm{CB}$ blood flow via sympathetically mediated vasoconstriction within the body will lead to hypoperfusion and localized ischaemia, which could be responsible for the increased tonicity and sensitivity of these peripheral chemoreceptors (Figure 7). The underlying mechanism involved with this increased tonicity and sensitivity is not completely known. However, we can speculate on some possibilities based on previous comparable studies in Wistar and spontaneously hypertensive rats. 


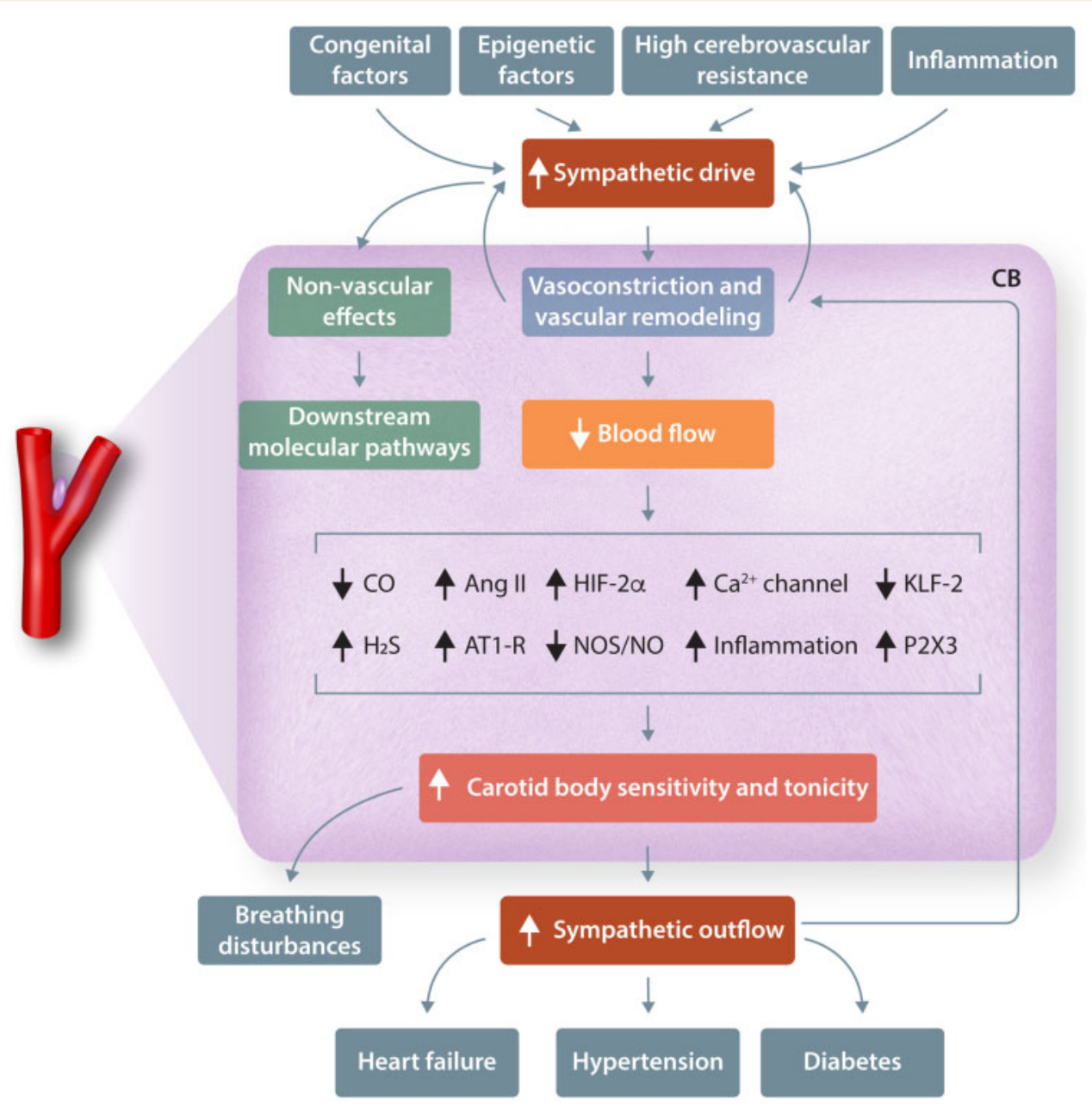

Figure 7 Schematic summary of some pathways associated with increased tonicity and sensitivity of the peripheral chemoreceptors. Congenital and/ or neurogenic remodelling of the vertebrobasilar arteries might lead to brainstem hypoperfusion, increasing sympathetic activity. A reduction of carotid body (CB) blood flow via sympathetically mediated vasoconstriction within the body will lead to hypoperfusion and localized ischemia, which could be responsible for the increased tonicity and sensitivity of these peripheral chemoreceptors and contribute to the development and maintenance of disease as heart failure, hypertension, apnoea, and diabetes. The mechanisms by which hyperreflexia and aberrant tone of the CB are generated include: reduced carbon monoxide levels (CO), decreased neural nitric oxide synthase (NOS) expression and nitric oxide (NO), increased angiotensin II type 1 receptor (AT1-R) protein expression and angiotensin II (Ang II) concentration, enhanced HIF-2 $\alpha$, high levels of hydrogen sulfide $\left(\mathrm{H}_{2} \mathrm{~S}\right)$, up-regulation of the $\alpha_{1 H} \mathrm{~T}$ type $\mathrm{Ca}^{2+}$ channels, up-regulated expression of $\mathrm{P} 2 \mathrm{X} 3$ purinoceptor, reduced Kruppel-like factor 2 (KLF-2) expression, up-regulated proinflammatory cytokines. The increased sympathetic drive also produces non-vascular effects which are involved with downstream molecular pathways. Data from Refs. ${ }^{7,9,10,14,20-22,80-83,167,168}$

\subsection{Mechanisms of excitability in organs cells that share similarities with the SCG and CB glomus cells}

Consideration is given to understanding mechanisms accounting for the elevated postganglionic sympathetic activity impinging on the $C B$ and whether this might offer a plausible strategy to therapeutically (and indirectly) modulate $C B$ sensitivity. In cultured rat adrenal chromaffin cells, signalling via brain-derived neurotrophic factor (BDNF) and its receptor tropomycin receptor kinase $B($ TrkB) were up-regulated during chronic hypoxia and this is dependent on hypoxia-inducible factor (HIF)- $2 \alpha^{167}$ Pharmacological activation of TrkB receptors from hypoxic cells compared to non-hypoxic ones led to greater membrane excitability, increased $\mathrm{Ca}^{2+}$-transients, and greater catecholamine secretion. Not only were more cells recruited for catecholamine release but also the quantal amount and frequency were increased. ${ }^{167}$ This is most likely mediated by a greater entry of extracellular $\mathrm{Ca}^{2+}$ via the up-regulation of the $\alpha_{1 \mathrm{H}}$ T-type $\mathrm{Ca}^{2+}$ channels during hypoxia that are activated at potentials close to resting membrane potential. ${ }^{169}$ Therefore, they will contribute to a low-threshold catecholamine discharge in response to mild depolarizations. ${ }^{167}$ It is interesting that Arias et al. ${ }^{170}$ demonstrated that neurotrophins, such as BDNF and nerve growth factor (NGF), are involved with the maintenance of ganglionic long-term potentiation (gLTP) in the SCG of rats. Such mechanisms may apply to the CB in cardiovascular disease and or to the SCG modulating effect; being therefore good targets to explore.

In the CB, the neurotrophins Ki-67, NGF, NT-3, and BDNF alongside their receptors (e.g. TrkB) were demonstrated to be up-regulated in 
glomus cells of spontaneously hypertensive rats relative to Wistar rats. ${ }^{171}$ Although speculative, we hypothesize that sympathetically mediated ischemia and chronic hypoxia within the CB would favour the formation of the HIF- $2 \alpha$ and downstream signalling. One outcome would be up-regulation of neurotrophins and their receptors such as BDNF and TrkB together with T-type $\mathrm{Ca}^{2+}$ channels such as observed in chromaffin cells. ${ }^{167}$ This would increase the membrane excitability of the glomus cells to low-intensity stimuli, therefore, increasing tonicity. In addition, the number of responding glomus cells recruited by stimuli, as well as the increased quantal amount and frequency of neurotransmitter (e.g. ATP) secreted during strong stimuli could also account for the hyperreflexia. Indeed, ATP, a major glomus cell transmitter, has been shown to play a major role in both CB tonicity and hyperreflexia. ${ }^{2}$

\subsection{CB mechanisms of hyperexcitability}

Long-term synaptic plasticity via neurotrophins is not the only possible molecular mechanism involved. In pre-hypertensive spontaneously hypertensive rats, overexpression of other receptors and channels have been demonstrated, for instance, the $\mathrm{P} 2 \mathrm{X} 3$ purinoceptor and the ionic channels: amiloride-sensitive acid-sensing sodium channel (ASIC3) and 2-pore domain acid-sensing $\mathrm{K}^{+}$channel (TASK1) that might be or not involved with a hypoxia-induced molecular transduction in glomus cells. ${ }^{2,8,172}$ CB sensitivity has also been shown to be elevated by inflammation and oxidative stress generation ${ }^{82,173,174}$ as well as reduced NOmediated efferent inhibition. ${ }^{148}$

As previously mentioned, the increased sympathetic-respiratory coupling is already present in young and pre-hypertensive spontaneously hypertensive rats (as is chemoreflex sensitivity and tonicity). ${ }^{2}$ We propose that an initiating step is sympathetic over activity that sensitizes the $C B$, which via a positive feedback loop based on CB hyperexcitability amplifies sympathetic outflow further. Previous studies have demonstrated remodelling of vertebrobasilar arteries, that supply blood flow to cardiorespiratory brainstem nuclei of pre-hypertensive spontaneously hypertensive rats. ${ }^{175}$ These changes lead to brainstem hypoperfusion, which in turn activated the Cushing response that may contribute to the development of hypertension via increased sympathetic activity. ${ }^{176,177}$ Remodelling of vertebrobasilar arteries might be congenital and/or neurogenic in origin. However, a more recent study does not support sympathetic activity as responsible for this vertebrobasilar artery remodelling ${ }^{178}$ but rather an immune response. ${ }^{179}$ Whether or not there is a congenital remodelling of $C B$ vasculature in hypertension or whether this is due to sympathetic hyperactivity or inflammation or their combination remains unknown.

In summary, unbalanced autonomic activity innervating the $\mathrm{CB}$ may be involved with its hyperexcitability due to a reduction in blood flow, leading to downstream genomic variation. Through sensitization of the $C B$, these changes will further enforce the development of hypertension, including elevations of sympathetic tone furthering the problem of $C B$ hypoperfusion. There appear to be a host of possible new therapeutic targets that include reducing the sympathetic drive to the $C B$ via autonomic denervation, pharmacological targets (e.g. P2X3, TrkB, ASIC3, TASK1), or sophisticated approaches, such as Optogenetics to control $\mathrm{CB}$ hyperreflexia in conditions of hypertension and heart failure. Selective targeting of the $C B$ is one of the main issues. Endothelial glycocalyx is composed by proteoglycans and glycoproteins connected to different carbohydrate chains. ${ }^{180}$ It is possible that the glycocalyx protein content of different vascular beds in different organs is unique, therefore, making it targetable via systemic delivery of drug/s. Whether the vasculature of the $C B$ has a unique expression of recognition proteins within its glycocalyx is unknown but if it did it would allow targeted immunomodulatory therapy. Although this is horizontal speculation, it does deserve exploration especially given the unique nature of the circulation of this organ.

\subsection{Chemoreceptors and COVID-19}

Hyperexcitability of $\mathrm{CB}$ chemoreceptors is not the only clinical dysfunction we should consider. The inability of this organ to properly tackle hypoxaemia might generate severe consequences for patients. During the current pandemic outbreak of the novel 2019 coronavirus (COVID19) caused by the virus SARS-CoV-2, some patients were reported to present what is called 'silent hypoxia.' ${ }^{181}$ In this condition, oxygen saturation $\left(\mathrm{SpO}_{2}\right)$ as low as $60 \%$ were described but, remarkably, without loss of consciousness or any classical signs of hypoxia which are anxiety, confusion, and restlessness; instead, the patients remain calm. ${ }^{182}$ We currently discussed ${ }^{112}$ that coronavirus neurotoxicity — evidenced by the loss of taste- could also be interfering with the ability of CB chemoreceptors to sense hypoxaemia since both afferent modalities are mediated by the petrosal ganglia.

\section{Conclusions}

This review summarizes current information about $C B$ vascularization in different species, its autonomic innervation, and clinical implications of its dysfunction. We provide insights into how autonomic mechanisms may control $\mathrm{CB}$ sensitivity and conclude that there is no consistent origin of the arterial feed to the $C B$, either between or within a species. It is clear that many questions remain to be answered about the function of both the sympathetic and parasympathetic innervation of the CB. For example: is the sympathetic innervation to the glomus cells preganglionic and/ or postganglionic? Does the same fibre innervate arterioles and glomus cells or are there distinct fibres? Are the NO-producing paraganglia cells and the parasympathetic ganglion cells the same or distinct populations, and do they all receive inputs from the brainstem preganglionic neurons? Finally, can an autonomically mediated change in blood flow within the $\mathrm{CB}$ alter glomus cell-petrosal ganglion excitability? We believe resolving these questions will further our understanding of the physiological function of the $C B$ and, consequently, help reveal pathological mechanisms that may be therapeutically targeted to treat numerous diseases.

\section{Supplementary material}

Supplementary material is available at Cardiovascular Research online.

\section{Acknowledgements}

The Health Research Council of New Zealand and The São Paulo Research Foundation (FAPESP) are acknowledged.

Conflict of interest: The authors declare that there is no conflict of interest.

\section{Funding}

This work was supported by The Health Research Council of New Zealand (Programme grant 19/687) and The São Paulo Research Foundation [FAPESP (\#2013/20549-7) and (\#2017/05163-6 and \#2018/16953-0 to F.B.)]. I.S.A.F. is funded by the University of Auckland post-graduate scholarship scheme. 


\section{References}

1. Fujii K, Saku K, Kishi T, Oga Y, Tohyama T, Nishikawa T, Sakamoto T, Ikeda M, Ide $\mathrm{T}$, Tsutsui $\mathrm{H}$, Sunagawa K. Carotid body denervation markedly improves survival in rats with hypertensive heart failure. Am J Hypertens 2017;30:791-798.

2. Pijacka W, Moraes DJA, Ratcliffe LEK, Nightingale AK, Hart EC, Da Silva MP, Machado BH, McBryde FD, Abdala AP, Ford AP, Paton JFR. Purinergic receptors in the carotid body as a new drug target for controlling hypertension. Nat Med 2016; 22:1151-1159.

3. Del Rio R, Andrade DC, Lucero C, Arias P, Iturriaga R. Carotid body ablation abrogates hypertension and autonomic alterations induced by intermittent hypoxia in rats. Hypertension 2016;68:436-445.

4. Del Rio R. The carotid body and its relevance in pathophysiology. Exp Physiol 2015; 100:121-123.

5. Paton JFR, Ratcliffe L, Hering D, Wolf J, Sobotka PA, Narkiewicz K. Revelations about carotid body function through its pathological role in resistant hypertension. Curr Hypertens Rep 2013;15:273-280.

6. Zera T, Moraes DJA, da Silva MP, Fisher JP, Paton JFR. The logic of carotid body connectivity to the brain. Physiology 2019;34:264-282.

7. Schultz HD, Marcus NJ, Del Rio R. Mechanisms of carotid body chemoreflex dysfunction during heart failure. Exp Physiol 2015;100:124-129.

8. Tan ZY, Lu Y, Whiteis CA, Simms AE, Paton JFR, Chapleau MW, Abboud FM. Chemoreceptor hypersensitivity, sympathetic excitation, and overexpression of ASIC and TASK channels before the onset of hypertension in SHR. Circ Res 2010; 106:536-545.

9. Prabhakar NR, Peng Y-J, Yuan G, Nanduri J. Reactive oxygen radicals and gaseous transmitters in carotid body activation by intermittent hypoxia. Cell Tissue Res 2018; 372:427-431.

10. Prabhakar NR, Peers C. Gasotransmitter regulation of ion channels: a key step in $\mathrm{O}_{2}$ sensing by the carotid body. Physiology 2014;29:49-57.

11. Fung ML. Pathogenic roles of the carotid body inflammation in sleep apnea. Mediat Inflamm 2014;2014:1-10.

12. Kemp PJ, Williams SEJ, Mason HS, Wootton P, lles DE, Riccardi D, Peers C. Functional proteomics of BK potassium channels: defining the acute oxygen sensor. Novartis Found Symp 2006;272:141-151; discussion 151-156, 214-217.

13. Pandit J], Winter V, Bayliss R, Buckler KJ. Differential Effects of Halothane and Isoflurane on Carotid Body Glomus Cell Intracellular Ca2+ and Background K+ Channel Responses to Hypoxia. New York, NY: Springer; 2010. p205-208.

14. Evans AM, Hardie DG, Galione A, Peers C, Kumar P, Wyatt CN. AMP-activated protein kinase couples mitochondrial inhibition by hypoxia to cell-specific $\mathrm{Ca} 2+$ signalling mechanisms in oxygen-sensing cells. Novartis Found Symp 2006;272:234-252; discussion 252-258, 274-279.

15. Abdala AP, McBryde FD, Marina N, Hendy EB, Engelman ZJ, Fudim M, Sobotka PA Gourine AV, Paton JFR. Hypertension is critically dependent on the carotid body input in the spontaneously hypertensive rat. J Physiol 2012;590:4269-4277.

16. Nakayama K. Surgical removal of the carotid body for bronchial asthma. ANZ J Surg 1962;31:214-221.

17. Narkiewicz K, Ratcliffe LEK, Hart EC, Briant LJB, Chrostowska M, Wolf J, Szyndler A, Hering D, Abdala AP, Manghat N, Burchell AE, Durant C, Lobo MD, Sobotka PA, Patel NK, Leiter JC, Engelman ZJ, Nightingale AK, Paton JFR. Unilateral carotid body resection in resistant hypertension: a safety and feasibility trial. JACC Basic Transl Sci 2016;1:313-324.

18. Marcus NJ, Del Rio R, Schultz EP, Xia X-H, Schultz HD. Carotid body denervation improves autonomic and cardiac function and attenuates disordered breathing in congestive heart failure. J Physiol 2014;592:391-408.

19. Schultz HD, Marcus NJ, Del Rio R. Role of the Carotid Body Chemoreflex in the Pathophysiology of Heart Failure: A Perspective from Animal Studies. Cham: Springer; 2015. p167-185.

20. Ding Y, Li Y-L, Schultz HD. Role of blood flow in carotid body chemoreflex function in heart failure. J Physiol 2011;589:245-258.

21. Marcus NJ, Del Rio R, Ding Y, Schultz HD. KLF2 mediates enhanced chemoreflex sensitivity, disordered breathing and autonomic dysregulation in heart failure. I Physiol 2018;596:3171-3185.

22. Schultz HD, Marcus NJ. Heart Failure and Carotid Body Chemoreception. Dordrecht: Springer; 2012. p387-395.

23. Kumar P, Prabhakar NR. Peripheral chemoreceptors: function and plasticity of the carotid body. Compr Physiol 2012;2:141-219.

24. Bin-Jaliah I, Maskell PD, Kumar P. Carbon dioxide sensitivity during hypoglycaemiainduced, elevated metabolism in the anaesthetized rat. J Physiol 2005;563:883-893.

25. Bin-Jaliah I, Maskell PD, Kumar P. Indirect sensing of insulin-induced hypoglycaemia by the carotid body in the rat. J Physiol 2004;556:255-266.

26. Limberg JK, Taylor JL, Mozer MT, Dube S, Basu A, Basu R, Rizza RA, Curry TB, Joyner MJ, Wehrwein EA. Effect of bilateral carotid body resection on cardiac baroreflex control of blood pressure during hypoglycemia. Hypertens 2015;65: 1365-1371.
27. Wehrwein EA, Limberg JK, Taylor JL, Dube S, Basu A, Basu R, Rizza RA, Curry TB, Joyner MJ. Effect of bilateral carotid body resection on the counterregulatory response to hypoglycaemia in humans. Exp Physiol 2015;100:69-78.

28. Thompson EL, Ray CJ, Holmes AP, Pye RL, Wyatt CN, Coney AM, Kumar P. Adrenaline release evokes hyperpnoea and an increase in ventilatory $\mathrm{CO} 2$ sensitivity during hypoglycaemia: a role for the carotid body. J Physiol 2016;594:4439-4452.

29. Maskell PD, Rusius CJ, Whitehead KJ, Kumar P. Adrenaline increases carotid body $\mathrm{CO}_{2}$ sensitivity: an in vivo study. In: Hayashida $\mathrm{Y}$, Gonzalez $\mathrm{C}$, and Kondo $\mathrm{H}$, eds. Advances in Experimental Medicine and Biology. Boston, MA: Springer US; 2006. p245-250.

30. Lahiri S, DeLaney RG. Stimulus interaction in the responses of carotid body chemoreceptor single afferent fibers. Respir Physiol 1975;24:249-266.

31. Hodges MR, Forster HV. Respiratory neuroplasticity following carotid body denervation: central and peripheral adaptations. Neural Regen Res 2012;7:1073-1079.

32. Daly M de B, Scott MJ. The cardiovascular responses to stimulation of the carotid body chemoreceptors in the dog. J Physiol 1963;165:179-197.

33. Lugliani R, Whipp BJ, Wasserman K. A role for the carotid body in cardiovascular control in man. Chest 1973;63:744-750.

34. Pardal R, López-Barneo J. Low glucose-sensing cells in the carotid body. Nat Neurosci 2002;5:197-198.

35. López-Barneo J. Oxygen and glucose sensing by carotid body glomus cells. Curr Opin Neurobiol 2003;13:493-499.

36. Niewinski $P$, Janczak $D$, Rucinski $A$, Tubek $S$, Engelman ZJ, Piesiak $P$, Jazwiec $P$, Banasiak W, Fudim M, Sobotka PA, Javaheri S, Hart ECJ, Paton JFR, Ponikowski P. Carotid body resection for sympathetic modulation in systolic heart failure: results from first-in-man study. Eur J Heart Fail 2017;19:391-400.

37. Barnett S, Mulligan E, Wagerle LC, Lahiri S. Measurement of carotid body blood flow in cats by use of radioactive microspheres. J Appl Physiol 1988;65:2484-2489.

38. Schaper A. Beiträge zur Histologie der Glandula carotica. Archiv Für Mikrosk Anat 1892;40:287-320.

39. Heath D, Path FRC. View from beneath-pathology in focus. A new look at the carotid bodies. J Laryngol Otol 1989;103:803-805.

40. Sarrat-Torres MA, Torres A, Whyte J, Baena S, Cisneros A, Sarrat R. Structure, location, function and pathological features of the human carotid body. Eur J Anat 2006;10:1-5.

41. Ozay B, Kurc E, Orhan G, Yucel O, Senay S, Tasdemir M, Gorur A, Aykut Aka S. Surgery of carotid body tumour: 14 cases in 7 years. Acta Chir Belg 2008;108: 107-111.

42. Muthoka JM, Hassanali J, Mandela P, Ogeng'o JA, Malek AA. Position and blood supply of the carotid body in a Kenyan population. Int J Morphol 2011;29:65-69.

43. Heath D, Edwards C, Harris P. Post-mortem size and structure of the human carotid body. Thorax 1970;25:129-140.

44. Khan Q, Heath D, Smith P. Anatomical variations in human carotid bodies. J Clin Pathol 1988;41:1196-1199.

45. Nguyen RP, Shah LM, Quigley EP, Harnsberger HR, Wiggins RH. Carotid body detection on CT angiography. AJNR Am J Neuroradiol 2011;32:1096-1099.

46. Hansen JT. Ultrastructure of the primate carotid body: a morphometric study of the glomus cells and nerve endings in the monkey (Macaca fascicularis). J Neurocytol 1985;14:13-32

47. Clarke JA, Daly D. B, Ead HW, Kreclovi G. A morphological study of the size of the vascular compartment of the carotid body in a non-human primate (Cercopithecus ethiopus), and a comparison with the cat and rat. Acta Anatomica 1993;147:240-247.

48. Sadik AH, Al-Shaikhly AK, Khamas WA. Anatomic location of the carotid body and carotid sinus in sheep and goats. Small Rumin Res 1993;12:371-377.

49. Najafi G, Soltanalinejad F, Hasanzadeh H. A preliminary anatomical study on carotid body of Makouei sheep. Vet Res Forum 2013;4:129-131.

50. Chungcharoen D, de Burgh Daly M, Schweitzer A. The blood supply of the carotid body in cats, dogs and rabbits. J Physiol 1952;117:347-358.

51. Davis DD, Story HE. The Carotid Circulation in the Domestic Cat. Chicago: Field Museum of Natural History; 1943.

52. Seidl E. On the variability of form and vascularization of the cat carotid body. Anat Embryol 1976;149:79-86.

53. Clarke JA, de Burgh Daly M, Ead HW. Dimensions and volume of the carotid body in the adult cat, and their relation to the specific blood flow through the organ. Acta Anatomica 1986;126:84-86.

54. Jones JFX. Retrospective view of the carotid body research of Ronan G. O'Regan. Exp Physiol 2004;89:39-43.

55. Clarke JA, de Burgh Daly M. A comparative study of the distribution of carotid body type-I cells and periadventitial type-I cells in the carotid bifurcation regions of the rabbit, rat, guinea-pig and mouse. Cell Tissue Res 1981;220:753-772.

56. Eken E. A morphological study on the carotid body of the Angora rabbit. Anatomy 2008;2:49-54.

57. Docio I, Olea E, Prieto-LLoret J, Gallego-Martin T, Obeso A, Gomez-Niño A, Rocher A. Guinea pig as a model to study the carotid body mediated chronic intermittent hypoxia effects. Front Physiol 2018;9:694.

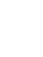


58. McDonald DM, Larue DT. The ultrastructure and connections of blood vessels supplying the rat carotid body and carotid sinus. J Neurocytol 1983;12:117-153.

59. Habeck JO, Honig A, Huckstorf C, Pfeiffer C. Arteriovenous anastomoses at the carotid bodies of rats. Anat Anz 1984;156:209-215.

60. Unur E, Aycan K. Arteries of the carotid body in rats. Anatom Histol Embryol 1999; 28:167-169.

61. Hess A. The significance of the ultrastructure of the rat carotid body in structure and function of chemoreceptors. In: MJ Purves, ed. The Peripheral Arterial Chemoreceptors. London: Cambridge University Press; 1975. p51-73.

62. Clarke JA, Daly M de B, Marshall JM, Ead HW, Hennessy EM. Quantitative studies of the vasculature of the carotid body in the chronically hypoxic rat. Braz J Med Biol Res 2000:33:331-340.

63. McDonald DM. Peripheral chemoreceptors: structure-function relations of the carotid body. In: T Hornbein, ed. The Regulation of Breathing (Lung Biology in Health and Disease). New York: Dekker; 1981. p105-319.

64. Baldwin BA. The anatomy of the arterial supply to the cranial regions of the sheep and ox. Am J Anat 1964:115:101-117.

65. Comroe JH, Schmidt CF. The part played by reflexes from the carotid body in the chemical regulation of respiration in the dog. Am J Physiol 1937;121:75-97.

66. Winder CV. Experimental consideration of vertebral artery-carotid artery anastomoses. Am J Physiol 1933;106:28-34.

67. Kondo $\mathrm{H}$. An electron microscopic study on innervation of the carotid body of guinea pig. J Ultrastruct Res 1971;37:544-562.

68. Shirahata M, Kostuk EW, Pichard LE. Carotid chemoreceptor development in mice. Respir Physiol Neurobiol 2013;185:20-29.

69. López-Barneo J, Pardal R, Ortega-Sáenz P, Durán R, Villadiego J, Toledo-Aral JJ. The neurogenic niche in the carotid body and its applicability to antiparkinsonian cell therapy. J Neural Transm 2009;116:975-982.

70. McDonald DM, Haskell A. Morphology of connections between arterioles and capillaries in the rat carotid body analysed by reconstructing serial sections. In: D Pallot, ed. Peripheral Arterial Chemoreceptors: Proceedings of the VII International Meeting. London: Croom Helm Limited; 1983. p195-206.

71. McDonald DM. A morphometric analysis of blood vessels and perivascular nerves in the rat carotid body. I Neurocytol 1983;12:155-199.

72. Heath D, Edwards C. The glomic arteries. Cardiovasc Res 1971;5:303-312

73. Kety SS, Schmidt CF. The nitrous oxide method for the quantitative determination of cerebral blood ow in man: theory, procedure and normal values. I Clin Invest 1948;27:476-483.

74. Lassen NA. Normal average value of cerebral blood flow in younger adults is 50 $\mathrm{ml} / 100 \mathrm{~g} / \mathrm{min}$. J Cereb Blood Flow Metab 1985;5:347-349.

75. White CW, Wilson RF, Marcus ML. Methods of measuring myocardial blood flow in humans. Prog Cardiovasc Dis 1988;31:79-94.

76. Wyss CA, Koepfli P, Fretz G, Seebauer M, Schirlo C, Kaufmann PA. Influence of altitude exposure on coronary flow reserve. Circulation 2003;108:1202-1207.

77. Duncker DJ, Bache RJ. Regulation of coronary blood flow during exercise. Physiol Rev 2008;88:1009-1086

78. Daly M de B, Lambertsen CJ, Schweitzer A. Observations on the volume of blood flow and oxygen utilization of the carotid body in the cat. J Physiol 1954;125:67-89.

79. McCloskey DI, Torrance RW. Autoregulation of blood flow in the carotid body Respir Physiol 1971;13:23-35.

80. Dekker RJ, van Thienen JV, Rohlena J, de Jager SC, Elderkamp YW, Seppen J, de Vries CJM, Biessen EAL, van Berkel TJC, Pannekoek H, Horrevoets AJG. Endothelia KLF2 links local arterial shear stress levels to the expression of vascular toneregulating genes. Am J Pathol 2005;167:609-618.

81. Li Y-L, Xia X-H, Zheng H, Gao L, Li Y-F, Liu D, Patel KP, Wang W, Schultz HD. Angiotensin II enhances carotid body chemoreflex control of sympathetic outflow in chronic heart failure rabbits. Cardiovasc Res 2006; 71:129-138.

82. Iturriaga R, Moya EA, Del Rio R. Inflammation and oxidative stress during intermittent hypoxia: the impact on chemoreception. Exp Physiol 2015;100:149-155.

83. Fledderus JO, Boon RA, Volger OL, Hurttila $H$, Ylä-Herttuala S, Pannekoek $H$ Levonen A-L, Horrevoets AJG. KLF2 primes the antioxidant transcription factor Nrf2 for activation in endothelial cells. Arteriosd Thromb Vasc Biol 2008;28 1339-1346.

84. Waki H, Liu B, Miyake M, Katahira K, Murphy D, Kasparov S, Paton JFR. Junctional adhesion molecule-1 is upregulated in spontaneously hypertensive rats: evidence for a prohypertensive role within the brain stem. Hypertens 2007;49:1321-1327.

85. Xu H, Oliveira-Sales EB, McBride F, Liu B, Hewinson J, Toward M, Hendy EB, Graham D, Dominiczak AF, Giannotta M, Waki H, Ascione R, Paton JFR, Kasparov S. Upregulation of junctional adhesion molecule-A is a putative prognostic marker of hypertension. Cardiovasc Res 2012;96:552-560.

86. Keele CA. Pathological changes in the carotid sinus and their relation to hypertension. QJM 1933;2:213-220.

87. Zarins CK, Giddens DP, Bharadvaj BK, Sottiurai VS, Mabon RF, Glagov S. Carotid bifurcation atherosclerosis. Quantitative correlation of plaque localization with flow velocity profiles and wall shear stress. Circ Res 1983;53:502-514.

88. Samuel KC. Atherosclerosis and occlusion of the internal carotid artery. J Pathol Bacteriol 1956;71:391-401.
89. Lowe P, Heath D, Smith P. Relation between histological age-changes in the carotid body and atherosclerosis in the carotid arteries. I Laryngol Otol 1987;101: 1271-1275.

90. Matturri L, Lavezzi AM, Silvestri F, Grana DR, Bussari R, Rossi L, Milei J. Severe carotid barochemoreceptor involvement in stroke. Int / Cardiol 2005;98:439-445.

91. Milei J, Lavezzi AM, Bruni B, Grana DR, Azzato F, Matturri L. Carotid barochemoreceptor pathological findings regarding carotid plaque status and aging. Can J Cardiol 2009:25:e6-e12.

92. Schmidt H, Francis DP, Rauchhaus M, Werdan K, Piepoli MF. Chemo- and ergoreflexes in health, disease and ageing. Int / Cardiol 2005;98:369-378.

93. Hering D, Zdrojewski Z, Król E, Kara T, Kucharska W, Somers VK, Rutkowski B, Narkiewicz K. Tonic chemoreflex activation contributes to the elevated muscle sympathetic nerve activity in patients with chronic renal failure. J Hypertens 2007;25 157-161

94. Rupprecht S, Hoyer D, Hagemann G, Witte OW, Schwab M. Central sleep apnea indicates autonomic dysfunction in asymptomatic carotid stenosis: a potential marker of cerebrovascular and cardiovascular risk. Sleep 2010;33:327-333.

95. Rupprecht S, Finn S, Ehrhardt J, Hoyer D, Mayer T, Zanow J, Guenther A, Schwab M. Autonomic outcome is better after endarterectomy than after stenting in patients with asymptomatic carotid stenosis. J Vasc Surg 2016;64:975-984.

96. Alperin N, Lee SH, Sivaramakrishnan A, Hushek SG. Quantifying the effect of posture on intracranial physiology in humans by MRI flow studies. J Magn Reson Imaging 2005;22:591-596.

97. Sato K, Fisher JP, Seifert T, Overgaard M, Secher NH, Ogoh S. Blood flow in internal carotid and vertebral arteries during orthostatic stress. Exp Physiol 2012;97: $1272-1280$

98. Tindall GT, Craddock A, Greenfield JC. Effects of the sitting position on blood flow in the internal carotid artery of man during general anesthesia. J Neurosurg 1967;26:383-389.

99. McDonald DM, Mitchell RA. The innervation of glomus cells, ganglion cells and blood vessels in the rat carotid body: a quantitative ultrastructural analysis. J Neurocytol 1975;4:177-230.

100. de Burgh Daly M. Peripheral Arterial Chemoreceptors and Respiratory-Cardiovascular Integration, 1st edn. Clarendon Press, Oxford, UK; 1997.

101. Chen I-L, Yates RD. Two types of glomus cell in the rat carotid body as revealed by $\alpha$-bungarotoxin binding. J Neurocytol 1984;13:281-302.

102. McDonald DM. Morphology of the rat carotid sinus nerve. I. Course, connections, dimensions and ultrastructure. J Neurocytol 1983;12:345-372.

103. Biscoe TJ, Sampson SR. Rhythmical and non-rhythmical spontaneous activity recorded from the central cut end of the sinus nerve. J Physiol 1968:196:327-338.

104. Berger AJ. The distribution of the cat's carotid sinus nerve afferent and efferent cell bodies using the horseradish peroxidase technique. Brain Res 1980;190:309-320.

105. Campanucci VA, Nurse CA. Autonomic innervation of the carotid body: role in ef ferent inhibition. Respir Physiol Neurobiol 2007;157:83-92.

107. Campanucci VA, Dookhoo L, Vollmer C, Nurse CA. Modulation of the carotid body sensory discharge by NO: an up-dated hypothesis. Respir Physiol Neurobiol 2012;184:149-157.

108. Eyzaguirre C, Uchizono K. Observations on the fibre content of nerves reachin the carotid body of the cat. J Physiol 1961;159:268-281.

109. Ichikawa H. Innervation of the carotid body: immunohistochemical, denervation, and retrograde tracing studies. Microsc Res Tech 2002;59:188-195.

110. O'Regan RG. Control of carotid body chemoreceptors by autonomic nerves. Ir Med Sci 1977;146:199-205.

111. Biscoe T], Lall A, Sampson SR. On the nerve endings associated with the carotid body glomus cells of the cat. J Physiol 1969;200:131P-132P.

112. Prabhakar NR, Kumar GK, Chang Ho Chang Agani FH, Haxhiu MA. Nitric oxide in the sensory function of the carotid body. Brain Res 1993;625:16-22.

113. Neil E, O'Regan RG. Efferent and afferent impulse activity recorded from few-fibre preparations of otherwise intact sinus and aortic nerves. J Physiol 1971;215:33-47.

106. Eyzaguirre C, Lewin J. The effect of sympathetic stimulation on carotid nerve activity. J Physiol 1961;159:251-267.

114. Biscoe TJ, Purves MJ. Factors affecting the cat carotid chemoreceptor and cervical sympathetic activity with special reference to passive hind-limb movements. J Physio 1967:190:425-441.

115. Sampson SR, Biscoe TJ. Efferent control of the carotid body chemoreceptor Experientia 1970;26:261-262.

116. Floyd WF, Neil $E$. The influence of the sympathetic innervation of the carotid bifurcation on chemoceptor and baroceptor activity in the cat. Arch Int Pharmacodyn Ther 1952;91:230-239.

117. Niewinski P, Tubek S, Banasiak W, Paton JFR, Ponikowski P. Consequences of peripheral chemoreflex inhibition with low-dose dopamine in humans. J Physiol 2014, 592:1295-1308.

118. Monteiro TC, Batuca JR, Obeso A, González C, Monteiro EC. Carotid body function in aged rats: responses to hypoxia, ischemia, dopamine, and adenosine. Age (Omaha) 2011;33:337-350.

119. Gonzalez C, Almaraz L, Obeso A, Rigual R. Carotid body chemoreceptors: from natural stimuli to sensory discharges. Physiol Rev 1994:74:829-898.

120. O'Regan RG. Responses of carotid body chemosensory activity and blood flow to stimulation of sympathetic nerves in the cat. J Physiol 1981;315:81-98. 
121. Lundberg JM, Änggård A, Pernow J, Hökfelt T. Neuropeptide Y-, substance P- and VIP-immunoreactive nerves in cat spleen in relation to autonomic vascular and volume control. Cell Tissue Res 1985;239:9-18.

122. Lundberg JM, Tatemoto K. Pancreatic polypeptide family (APP, BPP, NPY and PYY) in relation to sympathetic vasoconstriction resistant to $\alpha$-adrenoceptor blockade. Acta Physiol Scand 1982;116:393-402.

123. Potter EK, McCloskey DI. Excitation of carotid body chemoreceptors by neuropeptide-Y. Respir Physiol 1987;67:357-365.

124. McQueen DS, Ribeiro JA. Effects of $\beta$-endorphin, vasoactive intestinal polypeptide and cholecystokinin octapeptide on cat carotid chemoreceptor activity. Exp Physiol 1981;66:273-284.

125. O'Regan RG. Carotid chemoreceptor responses to sympathetic excitation [proceedings]. J Physiol 1976;263:267P-268P.

126. Almaraz L, Pérez-García MT, Goméz-Niño A, González C. Mechanisms of a2-adrenoceptor-mediated inhibition in rabbit carotid body. Am J Physiol Cell Physiol 1997;272(2 Pt 1): C628-37.

127. Nakatani H, Kim C, Sakamoto A. Low-dose dexmedetomidine facilitates the carotid body response to low oxygen tension in vitro via $\alpha 2$-adrenergic receptor activation in rabbits. Eur J Anaesthesiol 2012;29:570-576.

128. Folgering $\mathrm{H}$, Ponte J, Sadig T. Adrenergic mechanisms and chemoreception in the carotid body of the cat and rabbit. J Physiol 1982;325:1-21.

129. Llados F, Zapata P. Effects of adrenoceptor stimulating and blocking agents on carotid body chemosensory inhibition. J Physiol 1978;274:501-509.

130. Lei S. Cross interaction of dopaminergic and adrenergic systems in neural modulation. Int J Physiol Pathophysiol Pharmacol 2014;6:137-142.

131. Neil E, O'Regan RG. The effects of electrical stimulation of the distal end of the cut sinus and aortic nerves on peripheral arterial chemoreceptor activity in the cat. | Physiol 1971;215:15-32

132. McCloskey DI. Mechanisms of autonomic control of carotid chemoreceptor activity. Respir Physiol 1975;25:53-61.

133. Goodman NW. Efferent control of arterial chemoreceptors mediated by glossopharyngeal fibres and artifacts introduced by stimulation techniques. J Physiol 1973;230: 295-311.

134. Belmonte C, Eyzaguirre C. Efferent influences on carotid body chemoreceptors. J Neurophysiol 1974:37:1131-1143.

135. O'Regan RG. Efferent control of chemoreceptors. In: AS Paintal, ed. Morphology and Mechanisms of Chemoreceptors. New Delhi: Navchetan Press Ltd; 1976. p229-247.

136. Acker H, O'Regan RG. The effects of stimulation of autonomic nerves on carotid body blood flow in the cat. J Physiol 1981;315:99-110.

137. McDonald DM, Mitchell RA. The neural pathway involved in "efferent inhibition" of chemoreceptors in the cat carotid body. J Comp Neurol 1981;201:457-476.

138. Katz DM, Black IB. Expression and regulation of catecholaminergic traits in primary sensory neurons: relationship to target innervation in vivo. J Neurosci 1986;6: 983-989.

139. Sorkin LS, Eddinger KA, Woller SA, Yaksh TL. Origins of antidromic activity in sensory afferent fibers and neurogenic inflammation. Semin Immunopathol 2018;40: 237-247.

140. Bewick GS. Synaptic-like vesicles and candidate transduction channels in mechanosensory terminals. J Anat 2015;227:194-213.

141. Tao HW, Poo M. Retrograde signaling at central synapses. Proc Natl Acad Sci U S A 2001;98:11009-11015.

142. Gerdeman GL. Endocannabinoids at the synapse: retrograde signaling and presynaptic plasticity in the brain. In: Köfalvi Y, ed. Cannabinoids and the Brain. Boston, MA: Springer US; 2008. p203-236.

143. Wang Z-Z, Stensaas LJ, Bredt DS, Dinger B, Fidone SJ. Localization and actions of nitric oxide in the cat carotid body. Neuroscience 1994;60:275-286.

144. Wang Z-Z, Bredt DS, Fidone SJ, Stensaas LJ. Neurons synthesizing nitric oxide innervate the mammalian carotid body. J Comp Neurol 1993;336:419-432.

145. Campanucci VA, Fearon IM, Nurse CA. A novel O2-sensing mechanism in rat glossopharyngeal neurones mediated by a halothane-inhibitable background $\mathrm{K}+$ conductance. J Physiol 2003;548:731-743.

146. Campanucci VA, Nurse CA. Biophysical characterization of whole-cell currents in $\mathrm{O}_{2}$-sensitive neurons from the rat glossopharyngeal nerve. Neuroscience 2005;132: 437-451.

147. Campanucci VA. Expression of multiple P2X receptors by glossopharyngeal neurons projecting to rat carotid body $\mathrm{O}_{2}$-chemoreceptors: role in nitric oxidemediated efferent inhibition. J Neurosci 2006;26:9482-9493.

148. Atanasova DY, Dandov AD, Dimitrov ND, Lazarov NE. Histochemical and immunohistochemical localization of nitrergic structures in the carotid body of spontaneously hypertensive rats. Acta Histochem 2020;122:151500.

149. Peng Y-J, Makarenko VV, Gridina A, Chupikova I, Zhang X, Kumar GK, Fox AP, Prabhakar NR. H2S mediates carotid body response to hypoxia but not anoxia. Respir Physiol Neurobiol 2019;259:75-85.

150. Habeck JO. Peripheral arterial chemoreceptors and hypertension. J Auton Nerv Syst 1991:34:1-7.
151. Ponikowski P, Chua TP, Anker SD, Francis DP, Doehner W, Banasiak W, PooleWilson PA, Piepoli MF, Coats AJS. Peripheral chemoreceptor hypersensitivity an ominous sign in patients with chronic heart failure. Circulation 2001;104:544-549.

152. Niewiński P, Janczak D, Rucinski A, Jazwiec P, Sobotka PA, Engelman ZJ, Fudim M, Tubek S, Jankowska EA, Banasiak W, Hart ECJ, Paton JFR, Ponikowski P. Carotid body removal for treatment of chronic systolic heart failure. Int J Cardiol 2013;168: 2506-2509.

153. Schultz HD, Li YL, Ding Y. Arterial chemoreceptors and sympathetic nerve activity: implications for hypertension and heart failure. Hypertension 2007;50:6-13.

154. Paton JFR, Sobotka PA, Fudim M, Engelman ZJ, Hart EC], McBryde FD, Abdala AP, Marina N, Gourine AV, Lobo M, Patel N, Burchell A, Ratcliffe L, Nightingale A. The carotid body as a therapeutic target for the treatment of sympathetically mediated diseases. Hypertension 2013;61:5-13.

155. Toledo C, Andrade DC, Lucero C, Schultz HD, Marcus N, Retamal M, Madrid C, Rio R. Del Contribution of peripheral and central chemoreceptors to sympathoexcitation in heart failure. J Physiol 2017;595:43-51.

156. Joyner MJ, Limberg JK, Wehrwein EA, Johnson BD. Role of the carotid body chemoreceptors in glucose homeostasis and thermoregulation in humans. J Physiol 2018; 596:3079-3085.

157. Koyama Y, Coker RH, Stone EE, Lacy DB, Jabbour K, Williams PE, Wasserman DH. Evidence that carotid bodies play an important role in glucoregulation in vivo. Diabetes 2000;49:1434-1442.

158. Shirahata M, Tang W-Y, Shin M-K, Polotsky VY. Is the carotid body a metabolic monitor? Adv Exp Med Biol 2015;860:153-159.

159. Kumar P, Bin-Jaliah I. Adequate stimuli of the carotid body: more than an oxygen sensor? Respir Physiol Neurobiol 2007;157:12-21.

160. Newhouse LP, Joyner MJ, Curry TB, Laurenti MC, Man CD, Cobelli C, Vella A Limberg JK. Three hours of intermittent hypoxia increases circulating glucose levels in healthy adults. Physiol Rep 2017;5:e13106.

161. Rafacho A, Gonçalves-Neto LM, Ferreira FBD, Protzek AOP, Boschero AC, Nunes $E A$, Zoccal DB. Glucose homoeostasis in rats exposed to acute intermittent hypoxia. Acta Physiol 2013;209:77-89.

162. Vera-Cruz P, Guerreiro F, Ribeiro MJ, Guarino MP, Conde SV. Hyperbaric Oxygen Therapy Improves Glucose Homeostasis in Type 2 Diabetes Patients: A Likely Involvement of the Carotid Bodies. Cham: Springer; 2015. p221-225.

163. McBryde FD, Abdala AP, Hendy EB, Pijacka W, Marvar P, Moraes DJA, Sobotka PA, Paton JFR. The carotid body as a putative therapeutic target for the treatment of neurogenic hypertension. Nat Commun 2013;4:11.

164. Koeners MP, Lewis KE, Ford AP, Paton JF. Hypertension: a problem of organ blood flow supply-demand mismatch. Futur Cardiol 2016;12:339-349.

165. Acker H, O'Regan RG. Autonomic nervous influences upon total flow, local flow, tissue PO2 and chemosensory activity of the cat carotid body [proceedings]. | Physiol 1979;295:95-96.

166. Simms AE, Paton JFR, Pickering AE, Allen AM. Amplified respiratory-sympathetic coupling in the spontaneously hypertensive rat: does it contribute to hypertension? J Physiol 2009;587:597-610.

167. Scott AL, Zhang M, Nurse CA. Enhanced BDNF signalling following chronic hypoxia potentiates catecholamine release from cultured rat adrenal chromaffin cells. J Physiol 2015;593:3281-3299.

168. Wang Y, Li G, Liang S, Zhang A, Xu C, Gao Y, Zhang C, Wan F. Role of P2X3 receptor in myocardial ischemia injury and nociceptive sensory transmission. Auton Neurosci 2008;139:30-37.

169. Carabelli V, Marcantoni A, Comunanza V, de Luca A, Díaz J, Borges R, Carbone E. Chronic hypoxia up-regulates alpha1H T-type channels and low-threshold catecholamine secretion in rat chromaffin cells. J Physiol 2007;584:149-165.

170. Arias ER, Valle-Leija P, Morales MA, Cifuentes F. Differential contribution of BDNF and NGF to long-term potentiation in the superior cervical ganglion of the rat. Neuropharmacology 2014;81:206-214.

171. Atanasova DY, Lazarov NE. Expression of neurotrophic factors and their receptors in the carotid body of spontaneously hypertensive rats. Respir Physiol Neurobiol 2014:202:6-15.

172. Ford AP, Undem BJ, Birder LA, Grundy D, Pijacka W, Paton JFR. P2X3 receptors and sensitization of autonomic reflexes. Auton Neurosci 2015;191:16-24.

173. Oyarce MP, Iturriaga R. Contribution of oxidative stress and inflammation to the neurogenic hypertension induced by intermittent hypoxia. Front Physiol Frontiers 2018;9:893.

174. Schulz E, Gori T, Münzel T. Oxidative stress and endothelial dysfunction in hypertension. Hypertens Res 2011;34:665-673.

175. Cates MJ, Steed PW, Abdala APL, Langton PD, Paton JFR. Elevated vertebrobasilar artery resistance in neonatal spontaneously hypertensive rats. J Appl Physiol 2011; 111:149-156.

176. Marina N, Ang R, Machhada A, Kasymov V, Karagiannis A, Hosford PS, Mosienko V, Teschemacher AG, Vihko P, Paton JFR, Kasparov S, Gourine AV. Brainstem hypoxia contributes to the development of hypertension in the spontaneously hypertensive rat. Hypertension 2015;65:775-783. 
177. Warnert EAH, Rodrigues JCL, Burchell AE, Neumann S, Ratcliffe LEK, Manghat NE, Harris AD, Adams Z, Nightingale AK, Wise RG, Paton JFR, Hart EC. Is high blood pressure self-protection for the brain? Circ Res 2016;119:e140-e151.

178. Roloff EVL, Walas D, Moraes DJA, Kasparov S, Paton JFR. Differences in autonomic innervation to the vertebrobasilar arteries in spontaneously hypertensive and Wistar rats. J Physiol 2018;596:3505-3529.

179. Walas D, Nowicki-Osuch K, Alibhai D, Roloff E von L, Coghill J, Waterfall C, Paton JFR. Inflammatory pathways are central to posterior cerebrovascular artery remodelling prior to the onset of congenital hypertension. J Cereb Blood Flow Metab 2019; 39:1803-1817.
180. Reitsma S, Slaaf DW, Vink H, van Zandvoort MAMJ, Oude Egbrink MGA. The endothelial glycocalyx: composition, functions, and visualization. Pflugers Arch 2007;454 345-359.

181. Ottestad W, Seim M, Mæhlen JO. COVID-19 with silent hypoxemia. Tidsskr nor Laegeforen 2020;140:1-3.

182. Paton JF, Felippe I, Paterson DJ, Donnelly J. What should we add to the intensivists mask to relieve "hypoxic happiness" in COVID-19 patients? Physiol Soc 2020; https://www.physoc.org/blog/hypoxic-happiness-covid19/?fbclid=lwAR35v4_QhUbc FSBarGYtzPB408SsGcpFjcO26KmmgsXA66nOapQNvmdMJlw (1 September 2020 date last accessed). 
Anexo C-Manuscritos 


\section{PHYSIOLOGICAL SYMPATHETIC ACTIVATION IN SYSTEMIC INFLAMMATION: THE ROLE OF BAROREFLEX AND CHEMOREFLEX}

Fernanda Brognara ${ }^{1}$, Jaci Airton Castania ${ }^{1}$, Alexandre Kanashiro ${ }^{2}$, Daniel Penteado Martins $\operatorname{Dias}^{3}$, Helio Cesar Salgado ${ }^{*}$.

${ }^{1}$ Department of Physiology, Ribeirão Preto Medical School, University of São Paulo, Ribeirão Preto, SP, Brazil.

${ }^{2}$ Department of Neuroscience and Behavior, Ribeirão Preto Medical School, University of São Paulo, Ribeirão Preto, SP, Brazil.

${ }^{3}$ Barão de Mauá University Center, Ribeirão Preto, SP, Brazil.

Short title: Reflex Sympathetic Activation

\section{*Corresponding Author:}

Helio C. Salgado, M.D., Ph.D.

E-mail: hcsalgado@fmrp.usp.br

Department of Physiology

Ribeirão Preto Medical School - University of São Paulo

Av. Bandeirantes, 3900; 14049-900, Ribeirão Preto, SP, Brazil

Phone: +55-16-33153201 


\section{Abstract}

Aim: Baroreflex and chemoreflex act through the autonomic nervous system, which is involved with the neural regulation of inflammation. The present study reports the effects of physiological sympathetic activation in unanesthetized endotoxemic rats; as well the influence of the baroreceptors and peripheral chemoreceptors, in the cardiovascular and systemic inflammatory responses. Methods: Systemic inflammation was induced by lipopolysaccharide (LPS) administration in male Wistar Hannover rats. Bilateral carotid occlusion (BCO), a physiological approach involving the baroreflex and chemoreflex mechanisms, was applied to activate the sympathetic nervous system reflexively; while selective surgical denervation of the baroreceptors or chemoreceptors was performed, in some animals, to deactivate these important mechanosensitive and chemical sensors, respectively. The arterial pressure was recorded under $360 \mathrm{~min}$, in unanesthetized rats, and serial blood samples were collected to analyze the plasma cytokines levels. Results: BCO elicited the reflex activation of the sympathetic nervous system, providing the following outcomes: (I) increased the power of the low-frequency band in the spectrum of the systolic arterial pressure during the $\mathrm{BCO}$ period; (II) reduced the levels of pro-inflammatory cytokines in plasma, including the tumoral necrosis factor (TNF) and the interleukin (IL)-1 $\beta$; (III) increased the plasma levels of anti-inflammatory cytokine IL-10, $90 \mathrm{~min}$ after LPS administration. Moreover, either baroreceptor or chemoreceptor denervation, by itself, decreased the LPS-induced cytokines release. Conclusions: These results show, for the first time, that physiological reflex activation of the sympathetic circuit decreases the inflammatory response in endotoxemic rats, and suggest a novel function for the baroreceptors as immunosensors during the systemic inflammation.

Keywords: baroreceptors; bilateral carotid occlusion; chemoreceptors; inflammation; neuroimmune interactions; sympathetic activation. 


\section{Introduction}

The interaction between the central nervous system and the immune system has been studied since the 19 th century ${ }^{1}$. Of note, this interaction plays a fundamental role in the regulation of inflammation, via activation of neuroendocrine circuits including hypothalamicpituitary-adrenal axis ${ }^{2,3}$, "cholinergic anti-inflammatory pathway" 4,5, and "splanchnic antiinflammatory pathway" ${ }^{6}$. Most of these studies have emphasized the regulatory role of the autonomic nervous system (sympathetic and parasympathetic branches) in the inflammatory response applying some procedures that did not trigger a real physiological reflex activation (for instance, electrical stimulation or surgical denervation) ${ }^{6-9}$. Nevertheless, the body has physiological reflex mechanisms to activate, or deactivate, either systems (sympathetic and/or parasympathetic). Among these mechanisms are: (I) the baroreflex, which provides the moment-to-moment control of arterial pressure mediated primarily by the arterial baroreceptors; and (II) the chemoreflex, which keeps the cardiorespiratory homeostasis in response to changes in blood gases concentrations (such as oxygen or carbon dioxide) due to the presence of the peripheral chemoreceptors. Therefore, a methodological approach that activates the autonomic nervous system reflexively, under a reliable physiological context, would be more appropriate for investigating the importance of the nervous system during an immune challenge.

Thus, the bilateral carotid occlusion (BCO) is one of the techniques used to elicit global reflex activation of the sympathetic nervous system in both, unanesthetized ${ }^{10-13}$ and anesthetized animals ${ }^{14,15}$. Of note, when the common carotids arteries are occluded temporarily, there is a significant reduction in the arterial pressure and blood flow inside the carotid sinus region, culminating with the deactivation of the carotid baroreceptors. This inactivation of the carotid baroreceptors induces an increase in sympathetic activity to the blood vessels (increasing the global peripheral resistance), combined with a concomitant 
reduction in cardiac parasympathetic activity, determining the increase in arterial pressure 16,17. In addition, there is the activation of the carotid chemoreceptors, due to the hypoxia caused by the reduction of blood flow into the carotid sinus, contributing to the increase in sympathetic activity ${ }^{16,17}$.

Because the $\mathrm{BCO}$ is a methodological approach that promotes reflex sympathetic activation and has been used successfully in unanesthetized animals; this approach is considered a very special tool that would assist the study of the influence of the autonomic nervous system, particularly of its sympathetic branch, in the control of systemic inflammation. Furthermore, taking into account that the baroreceptors and the chemoreceptors are involved in the pressor response to $\mathrm{BCO}$, it is also necessary to examine the individual participation of these receptors during an inflammatory process. Thus, the present study aimed to investigate in unanesthetized endotoxemic rats: (I) the effect of BCOinduced sympathetic reflex activation; (II) the importance of either, the baroreflex and the chemoreflex in this procedure; and (III) the influence of the baroreceptors and the peripheral chemoreceptors, through their surgical denervation, in the systemic inflammatory response induced by lipopolysaccharide (LPS) administration.

\section{Results}

\subsection{Hemodynamic and Autonomic Responses to Bilateral Carotid Occlusion}

BCO promoted an increase in systolic, diastolic and mean arterial pressure (Fig. 1A$\mathrm{C})$, in intact animals and those with the chemoreceptors (CHEMO-X) or the baroreceptors (BARO-X) surgically removed, indicating an increase in peripheral resistance due to the augmented sympathetic activity. However, the hypertensive response to $\mathrm{BCO}$ was smaller in the CHEMO-X than the intact and BARO-X animals (mean arterial pressure: Intact, $\Delta 61 \pm 3$ 
mmHg; BARO-X, $\Delta 61 \pm 3 \mathrm{mmHg}$; CHEMO-X, $\Delta 47 \pm 3 \mathrm{mmHg}$ ), indicating the importance of the integrity of the chemoreceptors for the peak of hypertensive response during $\mathrm{BCO}$, as previously described ${ }^{16}$. In addition, while $\mathrm{BCO}$ did not change the heart rate of intact and BARO-X animals, it did promote bradycardia in the CHEMO-X subjects (Fig. 1D), indicating a reflex response involving the aortic baroreceptors activating the parasympathetic function upon the heart.

It is worth mentioning that the increase in sympathetic activity for the vessels, resulting from the $\mathrm{BCO}$ maneuver, was in line with the increase of the power of the lowfrequency (LF) band in the spectrum of the systolic arterial pressure during the BCO period (Fig. 2), in both intact and denervated animals (BARO-X and CHEMO-X).

\subsection{Time Course of Hemodynamic and Autonomic Responses}

The analysis of the hemodynamic parameters from animals with baroreceptor denervation showed higher mean arterial pressure higher than the intact rats under basal conditions (Fig. 3A). Regarding the other periods evaluated over time, no difference was observed in the mean arterial pressure among groups at each time frame evaluated (Fig. 3BE). Concerning the heart rate under basal conditions, the subjects with baroreceptor denervation exhibited higher levels of heart rate than intact - an outcome already described in the literature ${ }^{18,19}$ - and chemoreceptor denervated animals (Fig. 3F). Over time, the rats that received LPS showed an increase in heart rate compared to the animals that received saline, starting from 180 min after LPS administration (Fig. 3H). Moreover, this response was similar at 180, 270 and 360 min after LPS injection (Fig. 3H-J). In addition, this tachycardia was maintained until the end of the protocol $(360 \mathrm{~min})$ in the animals exhibiting endotoxemia (Fig. 3J). 
The analysis of heart rate variability did not reveal any difference in the power of the LF band in the spectrum of the cardiac interval between the groups evaluated over time (Fig. 4A-E). The same was observed for the LF/HF ratio over time (Fig. 4K-O). Regarding the power of the high-frequency $(\mathrm{HF})$ band, a reduction in this parameter was observed in the basal period in the animals with selective denervation of baroreceptors compared to the intact control rats (Fig. 4F). The group with selective denervation of the chemoreceptors also showed already lower values of the power of the HF band under the basal period (Fig. 4F). However, the group with selective denervation of the chemoreceptors associated with BCO showed an increase in the HF band compared to the BARO-X+BCO+LPS group under basal and 90 min (Fig. 4F and G). Over time, all groups that received LPS showed a reduction of the power of the HF band compared to the saline group, as displayed at $270 \mathrm{~min}$ and $360 \mathrm{~min}$ (Fig. 4I and J).

\subsection{Bilateral Carotid Occlusion Reduced Systemic Inflammation}

$\mathrm{BCO}$ reduced the plasma levels of TNF and IL-1 $\beta$ in both, the intact and those animals with selective denervation of the baroreceptors or the chemoreceptors, 90 min after LPS administration (Fig. 5A and C and Table 1). For IL-1 $\beta$, this effect was maintained until $180 \mathrm{~min}$ after LPS administration in intact, and up to $270 \mathrm{~min}$ in denervated (BARO-X and CHEMO-X) rats (Table 1). In addition, BCO increased the levels of IL-10 in the plasma of intact animals and those with surgical denervation of the chemoreceptors 90 min and up to 180 min, respectively (Fig. 5D and Table 1). In other words, the anti-inflammatory cytokine levels increased in plasma when the carotid baroreceptors were deactivated. In addition, the BCO did not change the plasma levels of IL-10 at 90 min in the BARO-X animals (Fig. 5D

and Table 1), but increased them at 180 min compared to the LPS group (Table 1). BCO reduced IL-6 plasma levels only in the CHEMO-X subjects 90 and 180 min after LPS 
administration (Fig. 5B and Table 1). However, BCO was not effective in reducing the plasma IL-6 in intact animals and those with BARO-X at any of the evaluated time frames (Fig. 5B and Table 1).

\subsection{Denervation of the Baroreceptors or Chemoreceptors Modulates Systemic}

\section{Inflammatory Response}

Surprisingly, the surgical denervation of the aortic and carotid baroreceptors, by itself, attenuated the release of TNF, IL-6, and IL-1 $\beta$ into the plasma 90 min after LPS administration (Fig. 5A-C and Table 1). This effect remained until $180 \mathrm{~min}$ after triggering the immune challenge for IL-6, and until $270 \mathrm{~min}$ for IL-1 $\beta$ (Table 1). The same outcome was observed in animals that underwent selective denervation of the chemoreceptors (Fig. 5A-C and Table 1), suggesting a possible communication among both baroreceptors and chemoreceptors modulating the immune system. Considering the plasma levels of IL-10, compared to the LPS group, the selective denervation of the baroreceptors stimulated its release already under the basal period (Table 1); and maintained the same response 90 min after the administration of LPS (Fig. 5D; Table 1), and also in the other periods evaluated (Table 1). On the other hand, no difference was observed in IL-10 plasma levels in any time frame periods in the CHEMO-X+LPS group compared to the LPS group (Table 1).

\subsection{Correlation of Sympathetic Modulation and Cytokines Levels Release}

Negative correlations between the sympathetic modulation and TNF (Fig. 6A), IL-1 $\beta$ (Fig. 6B) and IL-10 (Fig. 6D) plasma levels were found. These results can be interpreted as follows, i.e., the higher the reflex sympathetic modulation, the lower is the cytokine release in unanesthetized endotoxemic rats. By contrast, no correlation was found between the sympathetic modulation and IL-6 plasma level (Fig. 6C). 


\section{Discussion}

The present study shows for the first time that a reflex physiological activation of the sympathetic nervous system reduces the systemic LPS-induced inflammatory response. In addition, we also demonstrated that surgical denervation of the aortic and carotid baroreceptors, as well as of the peripheral chemoreceptors, by themselves, decreases the plasma cytokines levels in endotoxemic rats.

Previous studies involving the role of the individual sympathetic and parasympathetic branches controlling the inflammatory response displayed questionable procedures, i.e., they did not trigger a real physiological reflex activation, because they used a less physiological approach (for instance, electrical stimulation or surgical denervation) ${ }^{6-9,20-22}$. Therefore, taking into account that the body uses mechanisms fine regulatory mechanisms to preserve the homeostasis, it is understood that a method that activates or deactivates, the sympathetic or the parasympathetic branch, such as the bilateral carotid occlusion in the conscious state, would be more appropriate for investigating the role of physiological reflex controlling the inflammatory responses.

The $\mathrm{BCO}$ technique promotes a reduction of the arterial pressure and the blood flowing into the carotid sinus region; culminating, therefore, in the deactivation of the carotid baroreceptors and activation of the peripheral chemoreceptors. These responses determinate the increase in sympathetic activity, particularly upon the arterioles (increasing the global peripheral resistance), with a concomitant reduction in parasympathetic activity to the heart, increasing the arterial pressure ${ }^{16,17}$. The data obtained in the present study are in line with the literature because all animals submitted to BCO showed a significant increase in the arterial pressure and the power of the LF band of the systolic arterial pressure variability during the BCO period. Because the power of the LF band of the systolic arterial pressure variability is 
related to the peripheral resistance from blood vessels ${ }^{23}$, this data confirms that this methodological approach - BCO - in fact, promoted an increase in peripheral resistance due to increased sympathetic activity to the resistance vessels, in both intact and denervated (baroreceptor or chemoreceptor) rats. Overall, concerning the intact animals, this sympathetic activation could be attributed to the deactivation of the carotid baroreceptors combined with the activation of the peripheral chemoreceptors. With respect to the baroreceptor denervated animals, the increase in sympathetic activity is attributed to the activation of the chemoreceptors. In contrast, in rats with denervation of these sensors - chemoreceptors - this increase is probably due to the inactivation of the carotid baroreceptors. Of note, the increase in arterial pressure combined with tachycardia observed in animals with baroreceptor denervation, under basal condition, is in line with previous reports from the literature ${ }^{18,19}$.

In the present study, rats with intact or denervated baroreceptors did not show a change in heart rate; however, those animals with denervated chemoreceptors exhibited bradycardia during $\mathrm{BCO}$. In fact, the increase in arterial pressure due to the $\mathrm{BCO}$ triggers the activation of the aortic baroreceptors, promoting an increase of parasympathetic activity to the heart, and attenuation of the sympathetic activity to the resistance vessels and heart as well, in order to restore the arterial pressure to basal levels. Thus, the reduction in heart rate in the animals without the chemoreceptors could be explained by the activation of the aortic baroreceptors during the increase in arterial pressure following the $\mathrm{BCO}$, contributing to the increase in parasympathetic activity to the heart. It is also essential to highlight that the heart rate response to $\mathrm{BCO}$ depends on the species involved. While dogs showed tachycardia or no change in heart rate ${ }^{24,25}$, rabbits exhibited a slight tachycardia ${ }^{26}$, and mice, a reduction in heart rate ${ }^{11}$.

Plasma cytokines evaluation showed that the sympathetic activation elicited by BCO decreased pro-inflammatory plasma cytokines (TNF and IL-1 $\beta$ ) and increased the anti- 
inflammatory cytokine (IL-10); contributing to the control of the systemic inflammatory response. Moreover, a negative correlation was found between the sympathetic modulation (assessed by the power of the LF band of SAP variability) and cytokine production; suggesting that the higher sympathetic modulation to the resistance vessels during the $\mathrm{BCO}$, determined a lower cytokine release induced by LPS. Thus, considering that BCO results in a significant increase of global sympathetic activity ${ }^{16,17}$, and given that the spleen (known as the main source of cytokines) is innervated by the sympathetic system, we suggest that $\mathrm{BCO}$ can stimulate the celiac ganglion inhibiting the release of pro-inflammatory cytokines by the splenic macrophages (Fig. 7) ${ }^{4,22}$. This hypothesis is in line with the proposed "splanchnic anti-inflammatory pathway" as well as the "cholinergic anti-inflammatory pathway" 6,27.

As observed in the current study, the absence of the carotid chemoreceptors decreased the cytokine release into the plasma. Regarding the role of the chemoreceptors in the inflammatory response, several studies have shown that glomus cells of the carotid body have receptors for pro-inflammatory cytokines (TNF, IL-6, and IL-1), expressing Toll-like receptor 4, responsible for the LPS recognition ${ }^{28-34}$. Moreover, the administration of LPS increased the expression of $\mathrm{TNF}$ and $\mathrm{TNF}$ receptor in the carotid body, increasing the immune response ${ }^{29,30}$. Thus, these findings in the literature suggest an immunosensory function of the carotid body as a peripheral sensor for the presence of immunogenic agents from the blood ${ }^{30}$.

Additionally, the present study showed that baroreceptor absence decreased antiinflammatory cytokines release in endotoxemic rats. A recent study showed that sinoaortic denervation attenuated the release of plasma IL- 6 and IL-10 in endotoxemic rats ${ }^{35}$. However, since sinoaortic denervation includes the removal of the carotid chemoreceptors ${ }^{36-39}$, it is possible that the response observed in the aforementioned study occurred due to the absence of the chemoreceptors, but not due to the absence of the baroreceptors. It is known that both 
Toll-like receptor 4 and cytokine receptors are expressed in neurons and the nodose ganglion 40-44. Therefore, it is conceivable that LPS and peripheral cytokines could also inform the brain about a peripheral inflammatory response via baroreceptor nerve endings.

The $\mathrm{BCO}$ increased the release of IL-6 in rats with baroreceptors denervation particularly. Of note, when the $\mathrm{BCO}$ was carried out in the absence of the baroreceptors, only the chemoreceptors were activated. Thus, this finding suggests that chemoreflex activation increases the release of IL-6. This notion is in line with a previous study conducted in healthy volunteers who presented an increase in the IL-6 release from the carotid bodies, due to their activation by hypoxia ${ }^{33}$.

Over time, the administration of LPS decreased the power of the HF band, but not LF band, in the cardiac interval spectrum. Likewise, none of the maneuvers used in the present study (BCO, BARO-X or CHEMO-X) changed the power of the LF band in the spectrum of the cardiac interval over time. Of note, the groups with baroreceptor denervation already showed a decrease in the power of the HF band of the cardiac interval spectrum in the baseline period, confirming a reduction in the vagal modulation when the aortic and carotid baroreceptors are absent. Corroborating previous studies $35,45,46$, our data indicate that during systemic inflammation, the absence of the aortic and carotid baroreceptors, or the peripheral chemoreceptors, does not significantly affect the sympathetic modulation to the heart, but decreases the vagal modulation.

It is essential to highlight that the heart rate variability and the systolic arterial pressure variability analysis are useful tools for understanding the autonomic modulation to the heart and vessels in a number of situations ${ }^{23,47,48}$. Moreover, the assessment of the autonomic balance under clinical and experimental studies is an important analytical tool in different clinical conditions, including infectious and autoimmune diseases ${ }^{49,50}$. Furthermore, the heart rate variability parameters are used for the diagnosis and monitoring of patients with 
sepsis ${ }^{51,52}$. Of note, this non-invasive approach does not promote additional stress and hemodynamic alterations in the animals.

In conclusion, these results show, for the first time in the literature, that the reflex physiological activation of the sympathetic circuit decreases the inflammatory response in endotoxemic rats. In addition, the data indicate that baroreceptors (aortic and carotid) and peripheral chemoreceptors contribute to the development of the systemic inflammatory response induced by LPS since their absence attenuates the release of pro-inflammatory cytokines.

\section{Material and Methods}

\subsection{Experimental Animals}

Male Wistar-Hannover rats (250-320 g) obtained from the Main Animal Facility of the University of São Paulo (Campus of Ribeirão Preto; Ribeirão Preto, SP, Brazil) were used. The animals were maintained in individual cages under controlled temperature $\left(22{ }^{\circ} \mathrm{C}\right)$, constant 12 hours light-dark cycle, with free access to water and food. All procedures were reviewed and approved by the Committee of Ethics in Animal Research of the Ribeirão Preto Medical School - University of São Paulo (Protocol \# 194/2016).

\subsection{Manufacturing of the Pneumatic Cuffs}

Pneumatic cuffs were made following the technique described by Maio et al. ${ }^{53}$. Briefly, both tips of the $0.5 \mathrm{~cm}$ long polyethylene tube (PE-320) were dilated by heating and then cut along its longitudinal axis. A hole was made in the center of the opposite wall of the previous PE-320, using a 16G 11/2 hypodermic needle $(40 \times 16 \mathrm{~mm})$. Another $10 \mathrm{~cm}$ long polyethylene (PE-50) tube also has one of its ends dilated by heating, and then, with the aid 
of a mandrel inside the PE-50 tube, it receives a latex membrane that was tied by a cotton thread. When inflated with air or water, this membrane becomes a balloon. The membrane attached to the PE-50 tube was inserted into the hole in the PE-320 tube, completing the construction of the pneumatic cuff (Fig. 8A-C).

\subsection{Experimental Groups}

Before submitting to surgical procedures, the rats were divided into seven experimental groups:

I) Saline ( $\mathbf{n}=\mathbf{9})$ : fictitious surgery and saline administration.

II) LPS $(\mathbf{n}=\mathbf{8})$ : bilateral implantation of the pneumatic cuffs, without $\mathrm{BCO}$, with the administration of LPS.

III) BCO + LPS (n= 8): bilateral implantation of the pneumatic cuffs and, BCO during 20s, with the administration of LPS.

IV) BARO-X + LPS $(\mathbf{n}=\mathbf{7})$ : selective denervation of the aortic and carotid baroreceptors, bilateral implantation of the pneumatic cuffs, without BCO, with the administration of LPS.

V) BARO-X + BCO + LPS $(\mathbf{n}=\mathbf{9})$ : selective denervation of the aortic and carotid baroreceptors, bilateral implantation of the pneumatic cuffs and BCO during 20s, with the administration of LPS.

VI) CHEMO-X + LPS ( $(\mathbf{n}=7)$ : selective denervation of the carotid chemoreceptors, bilateral implantation of the pneumatic cuffs, without BCO, with the administration of LPS.

VII) CHEMO-X + BCO + LPS $(\mathbf{n}=9)$ : selective denervation of the carotid chemoreceptors, bilateral implantation of the pneumatic cuffs and BCO during 20 s, with the administration of LPS.

\subsection{Surgical Procedures}


The animals were anesthetized with a mixture of Ketamine and Xylazine $(50 \mathrm{mg} / \mathrm{kg}$ and $10 \mathrm{mg} / \mathrm{kg}$, i.p.) and then submitted to the surgical procedure for cannulation of the left femoral artery and vein for arterial pressure recording and LPS (or saline) administration, respectively. Briefly, polyethylene tubes (PE-50 soldered to PE-10 polyethylene tube; Intramedic, Clay Adams, Parsippany, NJ, USA) were implanted into the femoral artery and vein and pulled up through a subcutaneous track to the rat's neck and exteriorized in the nape. The catheter inserted into the femoral artery was filled with $100 \mathrm{IU} / \mathrm{mL}$ heparin in saline. In the same surgery, except for the saline group, all other animals had pneumatic cuffs implanted, bilaterally, around the common carotid arteries. For this prodecure, it was carried out an anterior median cervicotomy, while the sternohyoid and sternocleidomastoid muscles were identified and retracted, exposing the common carotid artery and the carotid sinus. To implant the pneumatic cuffs, the common carotid arteries were carefully isolated, and the pneumatic cuffs fixed around them with cotton threads. The catheters for filling the balloons were exteriorized and fixed on the back of the neck, as well as the vascular catheters. The surgical incisions were properly sutured and, immediately after the surgery, an analgesic was administered (tramadol hydrochloride, $2 \mathrm{mg} / \mathrm{kg}$, s.c.).

Concerning the groups IV and $\mathrm{V}$, in the same surgery for the pneumatic cuff implantation, the rats were submitted to procedures for baroreceptor denervation. This approach was undertaken to prevent the attenuation of the sympathetic activity by the baroreceptors, during the elevation of the arterial pressure resulting from the $\mathrm{BCO}$; and also, to eliminate a possible influence of the baroreflex in the anti-inflammatory response caused by sympathetic activation. For this purpose, the denervation of the aortic and carotid baroreceptors was performed bilaterally. The carotid baroreceptor denervation was performed according to the technique described by Castania et al. ${ }^{54}$. Briefly, the common carotid region and the carotid bifurcation were exposed. Next to the glossopharyngeal nerve, two branches 
were identified, usually separated by a small artery. With the aid of a magnifying glass, one of these branches, which carries the afferent fibers of the carotid baroreceptors, was carefully sectioned. The aortic baroreceptors denervation, on the other hand, was carried out following the technique described by Krieger ${ }^{37}$, in which the superior laryngeal nerve and the superior cervical ganglion were isolated and sectioned. The cervical sympathetic trunk was also sectioned caudally to the superior cervical ganglion, which was dissected and removed. The procedure was performed on both sides. On the other hand, groups VI and VII were submitted to the denervation of the carotid chemoreceptors to study their influences in the inflammatory response during the $\mathrm{BCO}$. The technique was also performed bilaterally, following the method described by Franchini and Krieger ${ }^{36}$. For this procedure, the common carotid artery and its bifurcation were exposed. With the aid of a magnifying glass, the carotid body was identified, and the carotid body artery was carefully isolated and sectioned distally to the ligature.

\subsection{Arterial Pressure Recording}

After recovering from the surgery, which took $24 \mathrm{~h}$, the unanesthetized rats were connected to the arterial pressure recording system. Briefly, the arterial catheter was connected to a pressure transducer (MLT844; ADInstruments, Bella Vista, Australia) and the signal was amplified (ML224; ADInstruments, Bella Vista, Australia) and sampled at $2 \mathrm{kHz}$ by an IBM/PC computer (Core 2 Duo, $2.2 \mathrm{GHz}, 4$ GB RAM) attached to an analog-to-digital interface (PowerLab, ADInstruments, Bella Vista, Australia). The experiment was conducted with the animals moving freely in their own cage, and the silence was maintained to minimize environmental stress. Arterial pressure recordings were processed with computer software (LabChart 7.0, ADInstruments, Bella Vista, Australia) capable of detecting inflection points and generate mean arterial pressure, systolic arterial pressure, diastolic 
arterial pressure, and heart rate beat-by-beat time series. In the case of groups with BCO, the two catheters for filling the balloons were connected to a syringe with water through a personalized $\mathrm{Y}$-shaped polyethylene tubing to perform the occlusion simultaneously on both sides. A blood sample was collected with heparin under basal conditions from all subjects.

Following the basal recording of pulsatile arterial pressure during $30 \mathrm{~min}$, both common carotid arteries were occluded during $20 \mathrm{~s}$ decreasing the blood flow above the carotid region (Fig. 8E-F). Next, the balloons were deflated to re-establish the blood flow. Immediately after the end of the occlusion, LPS [0.06 mg/kg (i.v.); Escherichia coli - 0111: B4 purified by phenol extraction; Sigma-Aldrich, St. Louis, MO, USA] was administered (Fig. 8F). For the other groups, not submitted to BCO, saline or LPS was administered immediately after the end of the basal recordings. Arterial pressure was recorded continuously during 360 min after the administration of LPS, or saline, in all groups (Fig. 8 F). During this period, serial blood samples ( $250 \mu \mathrm{L}$ per sample) were taken at 90, 180, 270, and 360 min after the administration of LPS, or saline, through the catheter placed into the left femoral artery (Fig. 8F). Blood samples were collected with heparin and kept on ice until centrifuged at $4{ }^{\circ} \mathrm{C}$ during $15 \mathrm{~min}$ at $5000 \mathrm{rpm}$. Then, the plasma was collected and stored at $80{ }^{\circ} \mathrm{C}$ until processing. In the groups with denervation (baroreceptor or chemoreceptor), at the end of the last blood collection, tests were performed with phenylephrine $(2 \mu \mathrm{g}$ in $0.1 \mathrm{~mL}$, i.v.) and potassium cyanide ( $40 \mu \mathrm{g}$ in $0.1 \mathrm{~mL}$, i.v.) to confirm the correct denervation of each animal. Subjects that were not adequately denervated were not included in the work.

\subsection{Heart Rate and Systolic Arterial Pressure Variability Analysis}

Beat-by-beat time series with systolic arterial pressure and cardiac interval values were extracted from periods of approximately $10 \mathrm{~min}$ for each moment (basal, 90, 180, 270 and 360 min after LPS or saline) from pulsatile arterial pressure tracings. For the analysis 
during the $\mathrm{BCO}$ period, data points from the first 60 seconds, after $\mathrm{BCO}$ was initiated, were used. The time series were analyzed in the frequency domain by means of spectral analysis using an open-access custom computer software (CardioSeries v2.7, www.danielpenteado.com). Briefly, the beat-by-beat time series were resampled using cubic spline interpolation $(10 \mathrm{~Hz})$, and the interpolated series were split into half-overlapping sequential segments of 512 data points. All segments were visually inspected by a wellexperienced researcher looking for transients that could affect the calculation of the power spectral density. To ensure that visual inspection of the time series was properly performed, a Hanning window was used to diminish side effects and the spectrum was calculated for all segments using a direct Fast Fourier Transform (FFT) algorithm for discrete time series. Finally, all spectra were visually inspected for abnormalities and were integrated into low(LF: $0.20-0.75 \mathrm{~Hz}$ ) and high-frequency (HF: 0.75-3.00 Hz) bands. Results are expressed in absolute $\left(\mathrm{ms}^{2}\right.$ and $\left.\mathrm{mmHg}^{2}\right)$ and normalized (nu) units. LF/HF ratio was also calculated.

\subsection{Cytokine Measurements}

Plasma levels of cytokines (TNF, IL-1 $\beta$, IL-6, and IL-10) were measured by the immune-enzymatic ELISA method using Duo set kits from R\&D Systems (Minneapolis, MN, USA) according to the manufacturer's instructions.

\subsection{Statistical Analysis}

The results are presented as mean \pm standard error of the mean (SEM). The hemodynamic and cardiocirculatory variability parameters were analyzed by two-way analysis of variance (ANOVA) for repeated measurements followed by the Tukey post-test when indicated, and by one-way ANOVA followed by the Tukey post-test when indicated. The data obtained from plasma were analyzed by one-way ANOVA, followed by the 
Student-Newman-Keuls post-test, when indicated, and also by the two-way ANOVA for repeated measures followed by the Student-Newman-Keuls post-test. Interrelations between systolic arterial pressure variability and cytokines levels were examined by Pearson's correlation. Differences were considered statistically significant if $\mathrm{P}<0.05$. Statistical analysis was performed using SigmaPlot 12.0 software (Systat Software, San Jose, CA, USA) and GraphPad Prism 6.0 software (GraphPad Software, San Diego, CA, USA).

\section{Acknowledgements}

Supported by The São Paulo Research Foundation (FAPESP) process \#2013/20549-7 and \#2017/05163-6 and by The Academic Excellence Program (PROEX) from Coordination for the Improvement of Higher Education Personnel (CAPES) process \#88887.505419/202000.

\section{Conflict of Interest}

The authors declare no conflict of interest.

\section{References}

1 Salomonsen CJ, Madsen T. Influence de quelques poisons sur le pouvoir antitoxiquen du sang. Comt Rend Acad Sci. 1898;125:1229-33.

2 Hench PS, Kendall EC, Slocumb CH, Polley HF. The effect of a hormone of the adrenal cortex (17-hydroxy-11-dehydrocorticosterone: compound E) and of pituitary adrenocortical hormone in arthritis: preliminary report. Ann Rheum Dis. 1949;8(2):97104.

3 Selye H. Stress and disease. Science. 1955;122(3171):625-631.

4 Rosas-Ballina M, Tracey KJ. The neurology of the immune system: neural reflexes regulate immunity. Neuron. 2009;64(1):28-32.

5 Tracey KJ. The inflammatory reflex. Nature. 2002;420(6917):853-859. 
6 Martelli D, Yao ST, McKinley MJ, McAllen RM. Reflex control of inflammation by sympathetic nerves, not the vagus. The Journal of physiology. 2014;592(7):1677-86.

7 Bassi GS, Brognara F, Castania JA et al. Baroreflex activation in conscious rats modulates the joint inflammatory response via sympathetic function. Brain Behav Immun. 2015. doi:10.1016/j.bbi.2015.05.002.

8 Borovikova LV, Ivanova $\mathrm{S}$, Zhang $\mathrm{M}$ et al. Vagus nerve stimulation attenuates the systemic inflammatory response to endotoxin. Nature. 2000;405(6785):458-462.

9 Brognara F, Castania JA, Dias DPM et al. Baroreflex stimulation attenuates central but not peripheral inflammation in conscious endotoxemic rats. Brain Research. 2018;1682:54-60.

10 DiCarlo SE, Stahl LK, Hasser EM, Bishop VS. The role of vasopressin in the pressor response to bilateral carotid occlusion. J Auton Nerv Syst. 1989;27(1):1-10.

11 Lataro RM, Castania JA, Chapleau MW, Salgado HC, Fazan R Jr. Baroreceptor and chemoreceptor contributions to the hypertensive response to bilateral carotid occlusion in conscious mice. Am J Physiol Heart Circ Physiol. 2010;299(6):H1990-1995.

12 Parra RS, Mendes LAF, Fazan R, Salgado HC. Pressure response to carotid occlusion in diabetic rats: Effect of insulin therapy. Diabetes Research and Clinical Practice. 2005;68(1):12-17.

13 Salgado HC, Salgado MC, Krieger EM. Cardiovascular reflexes in conscious sodiumdepleted rats. Braz J Med Biol Res. 1986;19(2):319-325.

14 Reison DS, Oliver JA, Sciacca RR, Cannon PJ. Release of norepinephrine from sympathetic nerve efferents by bilateral carotid occlusion. Am J Physiol. 1983;245(4):H635-639.

15 Wang HH, Chai CY, Kuo JS, Wang SC. Participation of cardiac and peripheral sympathetics in carotid occlusion response. Am J Physiol. 1970;218(6):1548-1554.

16 Bedran-de-castro MT, Moreira ED, Krjeger EM. Reflex and Central Components of Carotid Occlusion in Conscious Rats Effect of Lesion of the Medial Forebrain Bundle. Hypertension . 1986;8(4).http://insights.ovid.com/hypertension/hype/1986/04/001/reflexcentral-components-carotid-occlusion/11/00004268 (accessed 23 Dec2016).

17 Krieger EM. CAROTID OCCLUSION IN THE RAT: CIRCULATORY AND RESPIRATORY EFFECTS. Acta Physiol Lat Am. 1963;13:350-357.

18 Fazan Júnior R, Machado BH, Salgado HC. Hemodynamic responses to acute aortic coarctation in conscious sinoaortic denervated rats. Braz $J$ Med Biol Res. 1997;30(10):1249-1255.

19 Vasques E, Krieger E. Regulatory, integrative and comparative physiology sequence of tachycardia following baroreceptor denervation in the rat. Oxford University Press, Oxford, England. 1980;(Arterial Baroreceptors and Hypertension):413-417. 
20 Abe $\mathrm{C}$, Inoue $\mathrm{T}$, Inglis $\mathrm{MA}$ et al. $\mathrm{C} 1$ neurons mediate a stress-induced anti-inflammatory reflex in mice. Nat Neurosci. 2017;20(5):700-707.

21 Koopman FA, Chavan SS, Miljko S et al. Vagus nerve stimulation inhibits cytokine production and attenuates disease severity in rheumatoid arthritis. Proc Natl Acad Sci USA. 2016;113(29):8284-8289.

22 Vida G, Peña G, Deitch EA, Ulloa L. $\alpha 7$-cholinergic receptor mediates vagal induction of splenic norepinephrine. J Immunol. 2011;186(7):4340-4346.

23 Julien C. The enigma of Mayer waves: Facts and models. Cardiovasc Res. 2006;70(1):12-21.

24 Kirby DA, Vatner SF. Enhanced responsiveness to carotid baroreceptor unloading in conscious dogs during development of perinephritic hypertension. Circ Res. 1987;61(5):678-686.

25 Vatner SF, Manders WT. Depressed responsiveness of the carotid sinus reflex in conscious newborn animals. Am J Physiol. 1979;237(1):H40-43.

26 Kumagai K, Reid IA. Losartan inhibits sympathetic and cardiovascular responses to carotid occlusion. Hypertension. 1994;23(6 Pt 2):827-831.

27 Rosas-Ballina M, Ochani M, Parrish WR et al. Splenic nerve is required for cholinergic antiinflammatory pathway control of TNF in endotoxemia. Proceedings of the National Academy of Sciences of the United States of America. 2008;105(31):11008-13.

28 Fernandez R, Nardocci G, Navarro C, Reyes EP, Acuña-Castillo C, Cortes PP. Neural reflex regulation of systemic inflammation: Potential new targets for sepsis therapy. Frontiers in Physiology. 2014;5:1-9.

29 Fernández R, Nardocci G, Simon F et al. Lipopolysaccharide signaling in the carotid chemoreceptor pathway of rats with sepsis syndrome. Respiratory Physiology and Neurobiology. 2011;175(3):336-348.

30 Fung ML. Pathogenic roles of the carotid body inflammation in sleep apnea. Mediators Inflamm. 2014;2014:354279.

31 Lam S-Y, Tipoe GL, Liong EC, Fung M-L. Chronic hypoxia upregulates the expression and function of proinflammatory cytokines in the rat carotid body. Histochem Cell Biol. 2008;130(3):549-559.

32 Wang X, Wang B-R, Duan X-L et al. Strong expression of interleukin-1 receptor type I in the rat carotid body. J Histochem Cytochem. 2002;50(12):1677-1684.

33 Kåhlin J, Mkrtchian S, Ebberyd A et al. The human carotid body releases acetylcholine, ATP and cytokines during hypoxia. Experimental physiology. 2014;8:1-23.

34 Mkrtchian S, Kåhlin J, Ebberyd A et al. The human carotid body transcriptome with focus on oxygen sensing and inflammation--a comparative analysis. $J$ Physiol (Lond). 2012;590(16):3807-3819. 
35 Amorim MR, de Deus JL, Pereira CA et al. Baroreceptor denervation reduces inflammatory status but worsens cardiovascular collapse during systemic inflammation. Sci Rep. 2020;10(1):6990.

36 Franchini KG, Krieger EM. Carotid chemoreceptors influence arterial pressure in intact and aortic-denervated rats. Am J Physiol. 1992;262(4 Pt 2):R677-683.

37 Krieger EM. Neurogenic hypertension in the rat. Circ Res. 1964;15:511-521.

38 Silva EF, Sera CTN, Mourão AA et al. Involvement of sinoaortic afferents in renal sympathoinhibition and vasodilation induced by acute hypernatremia. Clin Exp Pharmacol Physiol. 2015;42(11):1135-1141.

39 Zhang ZQ, Barrès C, Julien C. Involvement of vasodilator mechanisms in arterial pressure lability after sino-aortic baroreceptor denervation in rat. $J$ Physiol (Lond). 1995;482 ( Pt 2):435-448.

40 Chavan SS, Pavlov VA, Tracey KJ. Mechanisms and Therapeutic Relevance of Neuroimmune Communication. Immunity. 2017;46(6):927-942.

41 de Lartigue G, Barbier de la Serre C, Espero E, Lee J, Raybould HE. Diet-induced obesity leads to the development of leptin resistance in vagal afferent neurons. Am J Physiol Endocrinol Metab. 2011;301(1):E187-195.

42 Hosoi T, Okuma Y, Matsuda T, Nomura Y. Novel pathway for LPS-induced afferent vagus nerve activation: possible role of nodose ganglion. Auton Neurosci. 2005;120(12):104-107.

$43 \mathrm{Li} \mathrm{M}$, Shi J, Tang J-R et al. Effects of complete Freund's adjuvant on immunohistochemical distribution of IL-1beta and IL-1R I in neurons and glia cells of dorsal root ganglion. Acta Pharmacol Sin. 2005;26(2):192-198.

44 Ma F, Zhang L, Westlund KN. Reactive oxygen species mediate TNFR1 increase after TRPV1 activation in mouse DRG neurons. Mol Pain. 2009;5:31.

45 Brognara F, Castania JA, Dias DPM, Kanashiro A, Salgado HC. Time Course of Hemodynamic Responses to Different Doses of Lipopolysaccharide in Unanesthetized Male Rats. Front Physiol. 2019;10. doi:10.3389/fphys.2019.00771.

46 Amorim MR, de Deus JL, Cazuza RA et al. Neuroinflammation in the NTS is associated with changes in cardiovascular reflexes during systemic inflammation. Journal of Neuroinflammation. 2019;16(1):125.

47 Cygankiewicz I, Zareba W. Heart rate variability. Handb Clin Neurol. 2013;117:379393.

48 ChuDuc H, NguyenPhan K, NguyenViet D. A Review of Heart Rate Variability and its Applications. APCBEE Procedia. 2013;7:80-85.

49 Pongratz G, Straub RH. Role of peripheral nerve fibres in acute and chronic inflammation in arthritis. Nat Rev Rheumatol. 2013;9(2):117-126. 
50 Zubcevic J, Jun JY, Kim S et al. Altered inflammatory response is associated with an impaired autonomic input to the bone marrow in the spontaneously hypertensive rat. Hypertension. 2014;63(3):542-550.

51 Bohanon FJ, Mrazek AA, Shabana MT et al. Heart rate variability analysis is more sensitive at identifying neonatal sepsis than conventional vital signs. Am J Surg. 2015;210(4):661-667.

52 Bravi A, Green G, Longtin A, Seely AJE. Monitoring and Identification of Sepsis Development through a Composite Measure of Heart Rate Variability. PLOS ONE. 2012;7(9):e45666.

53 Maio A, Moreira ED, Salgado HC, Krieger EM. Cardiovascular responses of conscious rats due to arterial occlusion. Brazilian Journal of Medical and Biological Research. $1981 ; 14: 115$.

54 Castania JA, Katayama PL, Brognara F, Moraes DJA, Sabino JPJ, Salgado HC. Selective denervation of the aortic and carotid baroreceptors in rats. Exp Physiol. 2019;104(9):1335-1342. 
Table 1. Time course of plasma cytokines.

\begin{tabular}{|c|c|c|c|c|c|c|c|}
\hline & $\begin{array}{l}\text { Saline } \\
(n=9)\end{array}$ & $\begin{array}{c}\text { LPS } \\
(n=8)\end{array}$ & $\begin{array}{c}\text { BCO+LPS } \\
(n=8)\end{array}$ & $\begin{array}{c}\text { BARO-X+ } \\
\text { LPS } \\
(\mathbf{n}=7)\end{array}$ & $\begin{array}{c}\text { BARO-X+ } \\
\text { BCO+LPS } \\
\quad(n=9)\end{array}$ & $\begin{array}{c}\text { CHEMO-X+ } \\
\text { LPS } \\
(n=7)\end{array}$ & $\begin{array}{c}\text { CHEMO-X+ } \\
\text { BCO+LPS } \\
(n=9)\end{array}$ \\
\hline \multicolumn{8}{|l|}{$\begin{array}{c}\text { TNF } \\
(\mathrm{pg} / \mathrm{mL})\end{array}$} \\
\hline $0 \mathrm{~min}$ & $503 \pm 89$ & $183 \pm 60^{*}$ & $145 \pm 32 *$ & $290 \pm 60$ & $359 \pm 63$ & $160 \pm 41^{*}$ & $177 \pm 32 *$ \\
\hline $90 \mathrm{~min}$ & $207 \pm 66$ & $1831 \pm 290 *$ & $1326 \pm 180^{* \#}$ & $671 \pm 72 * \#_{\dagger}$ & $873 \pm 96^{* \# \dagger}$ & $442 \pm 75^{* \#+\$ \S}$ & $889 \pm 146^{* \# \dagger \dagger}$ \\
\hline $180 \mathrm{~min}$ & $117 \pm 36$ & $275 \pm 40$ & $206 \pm 19$ & $222 \pm 15$ & $299 \pm 21$ & $69 \pm 9$ & $213 \pm 22$ \\
\hline $270 \mathrm{~min}$ & $105 \pm 25$ & $120 \pm 18$ & $100 \pm 8$ & $114 \pm 18$ & $226 \pm 18$ & $30 \pm 7$ & $121 \pm 8$ \\
\hline $360 \mathrm{~min}$ & $89 \pm 20$ & $99 \pm 12$ & $76 \pm 5$ & $92 \pm 14$ & $181 \pm 12$ & $24 \pm 8$ & $97 \pm 9$ \\
\hline \multicolumn{8}{|l|}{$\begin{array}{c}\text { IL-6 } \\
(\mathrm{pg} / \mathrm{mL})\end{array}$} \\
\hline $0 \mathrm{~min}$ & $0 \pm 0$ & $0 \pm 0$ & $0 \pm 0$ & $0 \pm 0$ & $0 \pm 0$ & $0 \pm 0$ & $0 \pm 0$ \\
\hline $90 \mathrm{~min}$ & $0 \pm 0$ & $8389 \pm 1480 *$ & $8546 \pm 1560 *$ & $2684 \pm 225^{* \# \dagger}$ & $10120 \pm 502^{* \#+\$}$ & $3398 \pm 533^{* \#} \uparrow \S$ & $4810 \pm 587^{* \#+\$ \$ \ddagger}$ \\
\hline $180 \mathrm{~min}$ & $0 \pm 0$ & $2977 \pm 588^{*}$ & $3048 \pm 1191^{*}$ & $252 \pm 92^{\#} \dagger$ & $3888 \pm 695 * \$$ & $0 \pm 0^{\#} \uparrow \S$ & $398 \pm 49^{\#} \dagger \S$ \\
\hline $270 \min$ & $0 \pm 0$ & $14 \pm 12$ & $22 \pm 19$ & $0 \pm 0$ & $0 \pm 0$ & $0 \pm 0$ & $0 \pm 0$ \\
\hline $360 \mathrm{~min}$ & $0 \pm 0$ & $0 \pm 0$ & $0 \pm 0$ & $0 \pm 0$ & $0 \pm 0$ & $0 \pm 0$ & $0 \pm 0$ \\
\hline \multicolumn{8}{|l|}{ 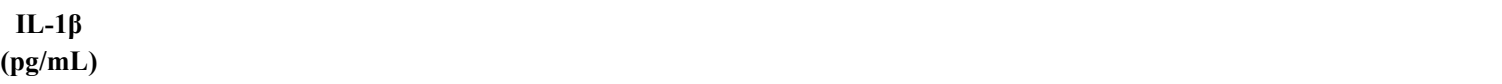 } \\
\hline $0 \mathrm{~min}$ & $0 \pm 0$ & $10 \pm 9$ & $3 \pm 3$ & $0 \pm 0$ & $12 \pm 11$ & $21 \pm 18$ & $0 \pm 0$ \\
\hline $90 \mathrm{~min}$ & $0 \pm 0$ & $212 \pm 35^{*}$ & $104 \pm 39^{* \#}$ & $0 \pm 0^{\#} \dagger$ & $12 \pm 11^{\#} \dagger$ & $7 \pm 3^{\#} \dagger$ & $19 \pm 11^{\# \dagger}$ \\
\hline $180 \mathrm{~min}$ & $2 \pm 1$ & $178 \pm 26^{*}$ & $116 \pm 50^{* \#}$ & $18 \pm 12^{\#} \dagger$ & $0 \pm 0^{\#} \dagger$ & $4 \pm 2^{\#} \dagger$ & $19 \pm 11^{\#} \dagger$ \\
\hline $270 \mathrm{~min}$ & $0 \pm 0$ & $82 \pm 18^{*}$ & $47 \pm 20$ & $0 \pm 0^{\#}$ & $23 \pm 14^{\#}$ & $0 \pm 0^{\#}$ & $8 \pm 5^{\#}$ \\
\hline $360 \min$ & $0 \pm 0$ & $39 \pm 35$ & $11 \pm 7$ & $0 \pm 0$ & $2 \pm 1$ & $0 \pm 0$ & $3 \pm 2$ \\
\hline \multicolumn{8}{|l|}{$\begin{array}{c}\text { IL-10 } \\
(\mathrm{pg} / \mathrm{mL})\end{array}$} \\
\hline $0 \mathrm{~min}$ & $543 \pm 29$ & $181 \pm 31^{*}$ & $286 \pm 70^{*}$ & $505 \pm 78^{\#}$ & $440 \pm 82^{\#}$ & $245 \pm 65^{*}$ & $513 \pm 75^{\#} \dagger t$ \\
\hline $90 \mathrm{~min}$ & $287 \pm 34$ & $410 \pm 55$ & $730 \pm 66^{* \#}$ & $819 \pm 33^{* \#}$ & $546 \pm 63 * \uparrow \$$ & $245 \pm 86 \dagger^{\$} \S$ & $1057 \pm 88^{* \#+\$ \S \dagger}$ \\
\hline $180 \mathrm{~min}$ & $198 \pm 18$ & $474 \pm 51^{*}$ & $523 \pm 56^{*}$ & $989 \pm 173 * \#+$ & $730 \pm 70 * *_{\dagger}$ & $307 \pm 94^{\$} \S$ & $900 \pm 108 * \#+\ddagger$ \\
\hline $270 \mathrm{~min}$ & $105 \pm 12$ & $229 \pm 38$ & $295 \pm 39$ & $539 \pm 49^{* \#+}$ & $328 \pm 40 * \$ \ddagger$ & $14 \pm 13 \uparrow \$$ & $349 \pm 48 * \$ \ddagger$ \\
\hline $360 \mathrm{~min}$ & $43 \pm 11$ & $122 \pm 31$ & $137 \pm 13$ & $415 \pm 50 * *_{\dagger}$ & $222 \pm 42^{\$}$ & $0 \pm 0^{\$}$ & $188 \pm 29^{\$}$ \\
\hline
\end{tabular}

Data are expressed as mean \pm SEM. TNF: tumor necrosis factor; IL-6: interleukin 6; IL-1 $\beta$ : interleukin 1 $\beta$; IL-10: interleukin $10{ }^{*} \mathrm{p}<0.05$ vs. Saline at the same moment; $\# \mathrm{p}<0.05$ vs. LPS at the same moment; $\uparrow \mathrm{p}<0.05$ vs. BCO + LPS at the same moment; $\$ \mathrm{p}<0.05$ vs. BARO-X+LPS at the same moment; $\S p<0.05$ vs. BARO-X+BCO+LPS at the same moment; $\ddagger \mathrm{p}<0.05$ vs. CHEMO- 
$\mathrm{X}+\mathrm{LPS}$ at the moment. BARO-X: denervation of baroreceptors; BCO: bilateral carotid occlusion; CHEMO-X: denervation of chemoreceptors; LPS: lipopolysaccharide.

\section{Legends to Figures}

Figure 1. Hemodynamic responses from intact, and surgically denervated animals under basal and during the peak response to bilateral carotid occlusion (BCO). SAP: systolic arterial pressure (A); DAP: diastolic arterial pressure (B); MAP: mean arterial pressure (C); HR: heart rate (D). Periods: basal (white bars) and BCO peak response (gray bars). Bars represent mean \pm SEM. $* \mathrm{p}<0.05$.

Figure 2. Autonomic response to bilateral carotid occlusion (BCO) in intact animals and with denervation of baroreceptors (BARO-X) or chemoreceptors (CHEMO-X). Periods: basal (white bars) and BCO period (gray bars). LF-SAP: low-frequency band of the systolic arterial pressure. Bars represent mean \pm SEM. ${ }^{*} p<0.05$.

Figure 3. Time course of hemodynamic responses. Mean arterial pressure (MAP) at basal (A), $90 \mathrm{~min}(\mathrm{~B}), 180 \mathrm{~min}(\mathrm{C}), 270 \mathrm{~min}(\mathrm{D})$ and $360 \mathrm{~min}(\mathrm{E})$; and heart rate (HR) at basal (F), $90 \min (\mathrm{G}), 180 \mathrm{~min}(\mathrm{H}), 270 \mathrm{~min}(\mathrm{I})$ and $360 \mathrm{~min}(\mathrm{~J})$. BARO-X: denervation of baroreceptors; BCO: bilateral carotid occlusion; CHEMO-X: denervation of chemoreceptors; LPS: lipopolysaccharide. Bars represent mean \pm SEM. * $\mathrm{p}<0.05$.

Figure 4. Time course of heart rate variability. The parameters evaluated were: lowfrequency band (LF; panels A, B, C, D and E), high-frequency band (HF; panels F, G, H, I and $\mathrm{J}$ ), and $\mathrm{LF} / \mathrm{HF}$ ratio (panels $\mathrm{K}, \mathrm{L}, \mathrm{M}, \mathrm{N}$ and $\mathrm{O}$ ) the spectrum of the cardiac interval at 
different times: baseline, $90 \mathrm{~min}, 180 \mathrm{~min}, 270 \mathrm{~min}$ and $360 \mathrm{~min}$ after LPS or saline. BARO$\mathrm{X}$ : denervation of baroreceptors; $\mathrm{BCO}$ : bilateral carotid occlusion; CHEMO-X: denervation of chemoreceptors; LPS: lipopolysaccharide. Bars represent mean \pm SEM. ${ }^{*} \mathrm{p}<0.05$.

Figure 5. Plasma cytokine levels 90 minutes after saline or LPS administration. Plasma levels of TNF (A), IL-6 (B), IL-1 $\beta$ (C) and IL-10 (D) 90 min after administration of LPS or saline. BARO-X: denervation of baroreceptors; BCO: bilateral carotid occlusion; CHEMOX: denervation of chemoreceptors; LPS: lipopolysaccharide; n.d.: not detected. Bars represent mean \pm SEM. $* \mathrm{p}<0.05$

Figure 6. Correlation of systolic arterial pressure variability and cytokines levels release. Pearson's correlation between the power of the low-frequency band of the systolic arterial pressure (LF-SAP) during the BCO period and the cytokines plasma levels [TNF (A), IL-1 (B), IL-6 (C), and IL-10 (D)] at 90 min after the administration of LPS. BARO-X: denervation of baroreceptors; BCO: bilateral carotid occlusion; CHEMO-X: denervation of chemoreceptors; LPS: lipopolysaccharide.

Figure 7. Reflex sympathetic activation decreases pro-inflammatory cytokine release. The diagram shows how the baroreceptors and chemoreceptors act to reduce proinflammatory cytokine release during bilateral carotid occlusion $(\mathrm{BCO})$ following an immune challenge induced by LPS. During BCO, the carotid chemoreceptors are activated and, at the same time, the carotid baroreceptors are deactivated. Thus, the inhibitory influence of the baroreceptors on the sympathetic nervous system is impaired, and simultaneously, neurons from the rostral ventrolateral medulla (RVLM) are stimulated by the chemoreceptors activation, determining a significant increase of sympathetic activity. Accordingly, the 
sympathetic innervation of the spleen is stimulated inhibiting the cytokine production by the splenic macrophages. The diagram also highlights that baroreceptors and chemoreceptors would be activated by pro-inflammatory cytokines released from immune cells. CG: celiac ganglion; CVLM: caudal ventrolateral medulla; DMN: Dorsal motor nucleus of the vagus; IML: intermediolateral cell column; LPS: lipopolysaccharide; NA: nucleus ambiguous; NG: nodose ganglion; NTS: nucleus tractus solitarius; PG: petrosal ganglion; SG: sympathetic ganglion.

Figure 8. The pneumatic cuff, a schematic representation of the method used, and the experimental protocol. A: lateral view of the pneumatic cuff; B: pneumatic cuff with the balloon without inflation; C: pneumatic cuff filled with water inflating the balloon. $\mathrm{D}$ : schematic representation at the basal period, when there was no occlusion of the common carotid artery (normal blood flow). E: schematic representation during the carotid occlusion. The balloon inside the pneumatic cuff was inflated with water using a syringe with an unsharpened needle connected to the polyethylene tube. Note that the blood flow, as well as the diameter of the internal and external carotid arteries, are reduced in the region above the occlusion site, deactivating the carotid baroreceptors. F: the timeline of the experimental protocol used in the present study. 
Figure 1

BCO

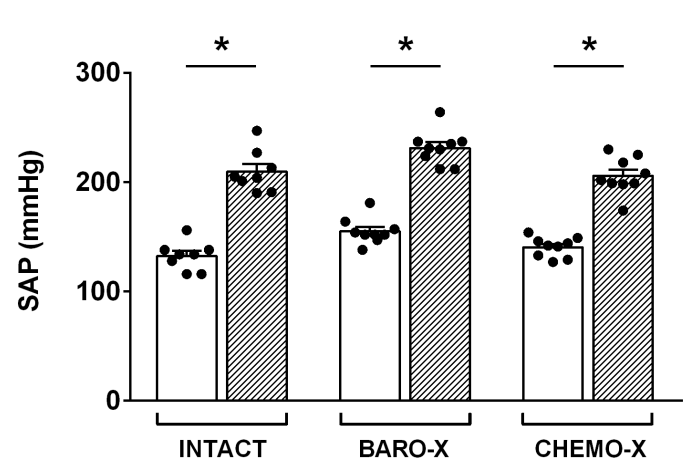

A

C

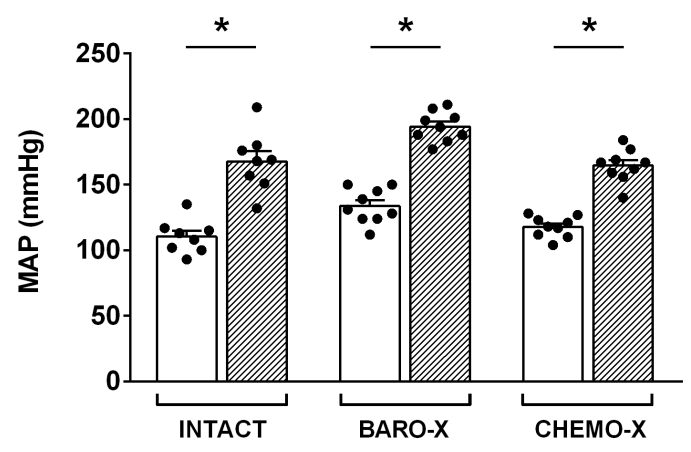

B

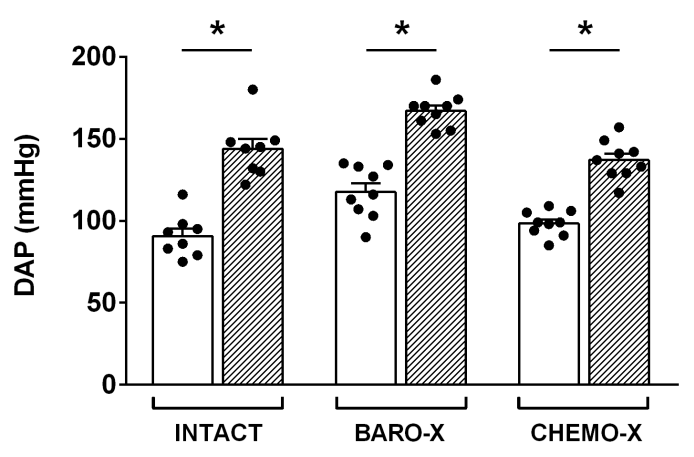

D

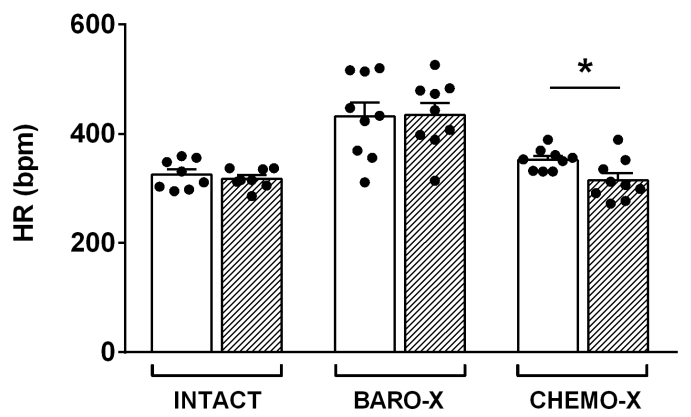


Figure 2

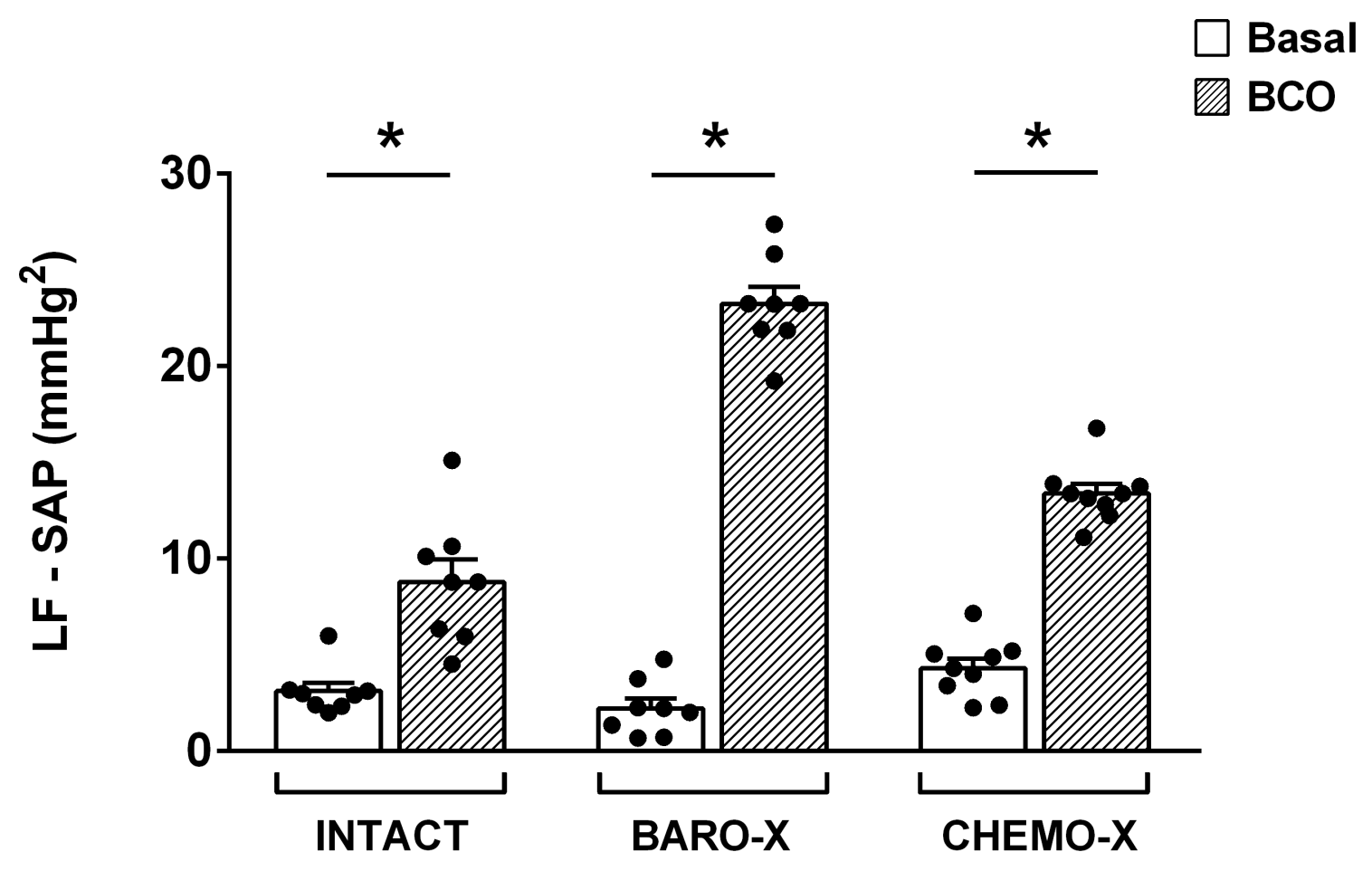


Figure 3

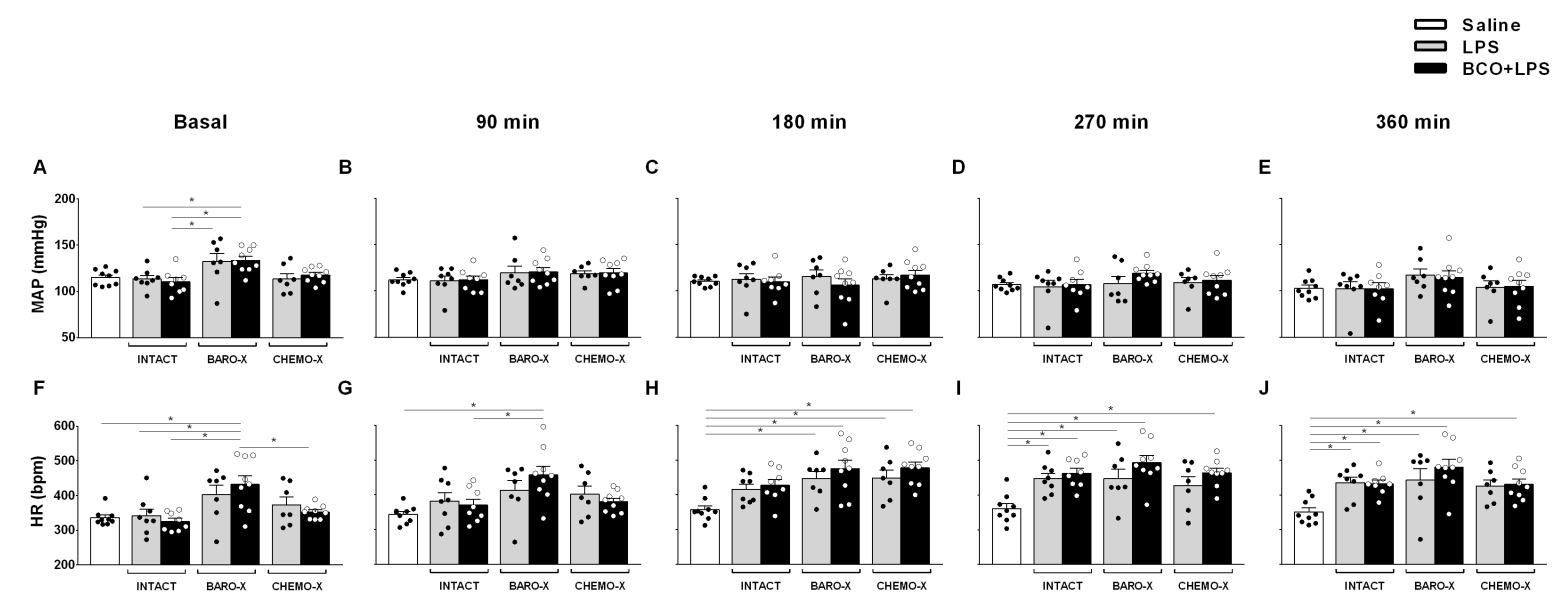


Figure 4

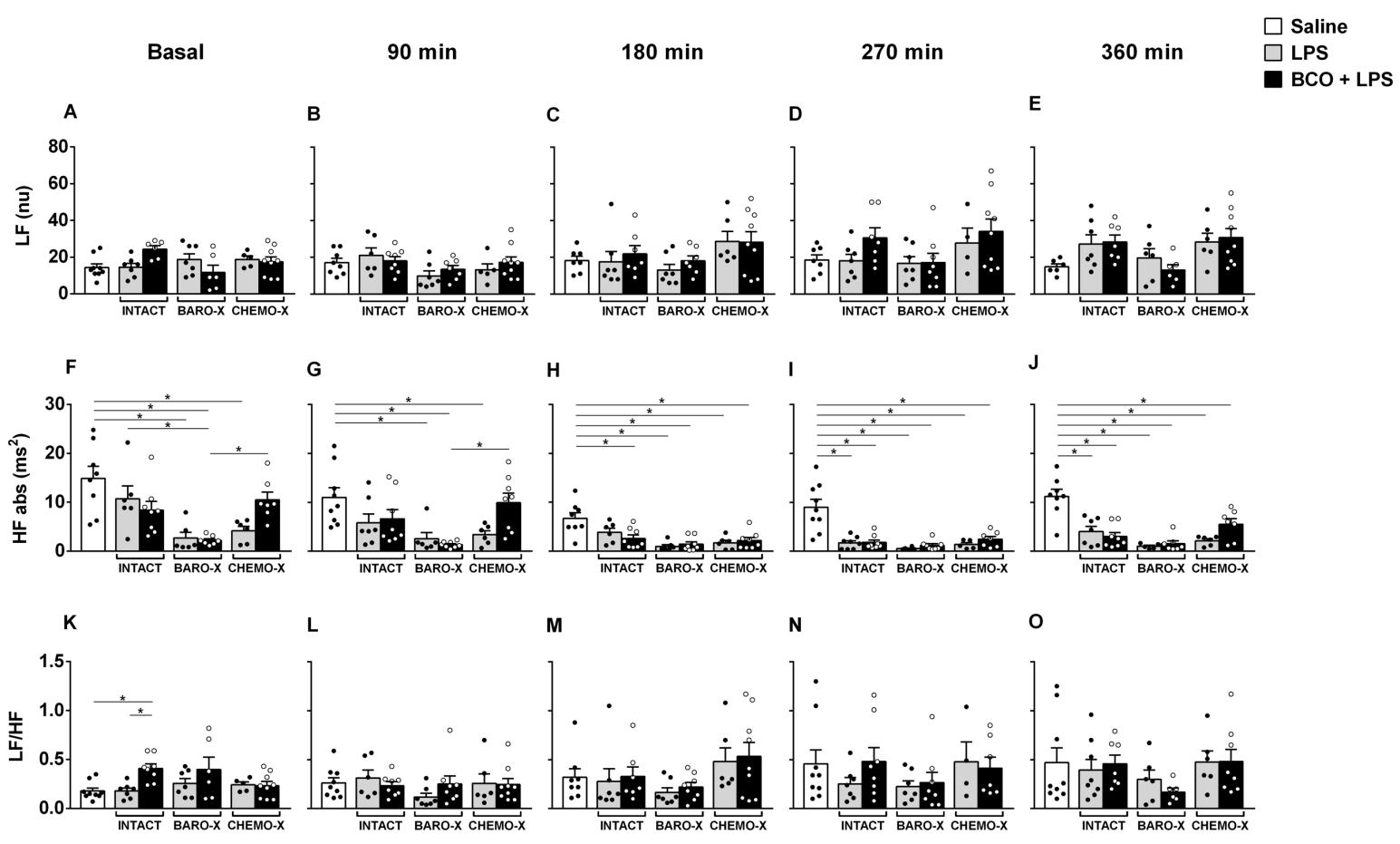


Figure 5

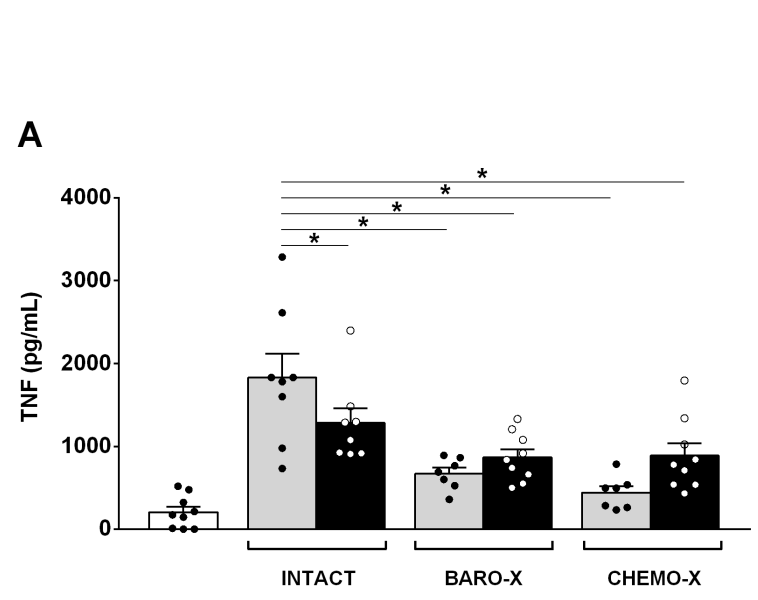

C

$\square$ Saline

BCO+LPS

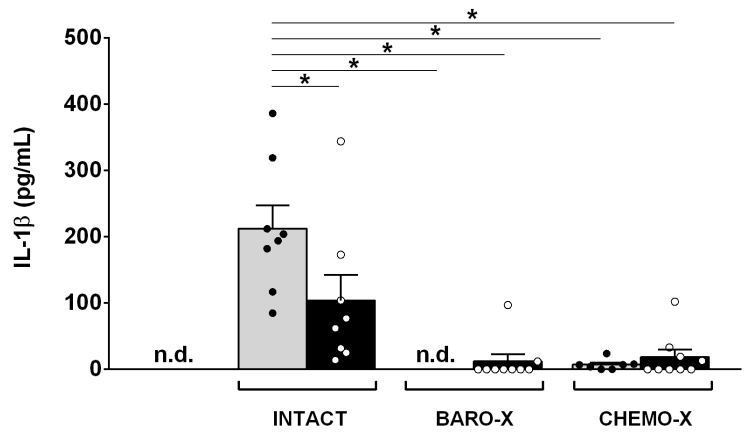

B

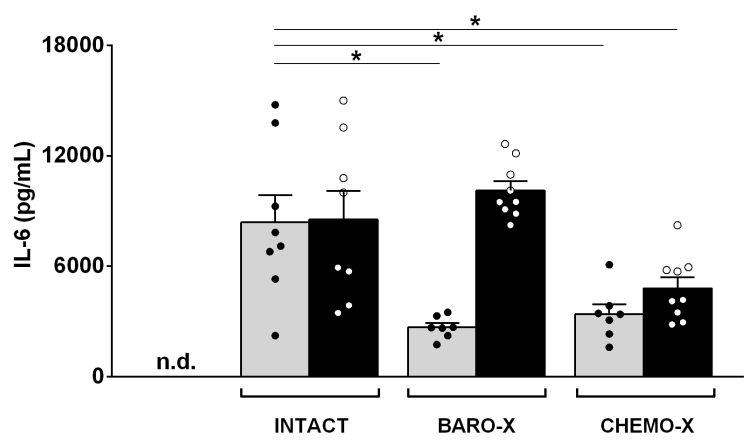

D

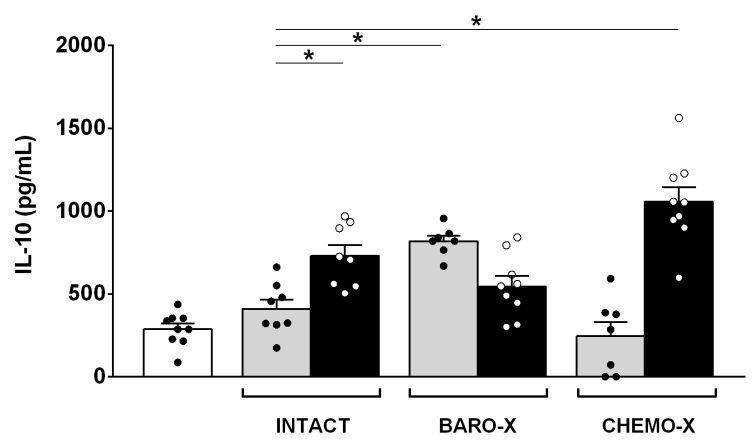


Figure 6
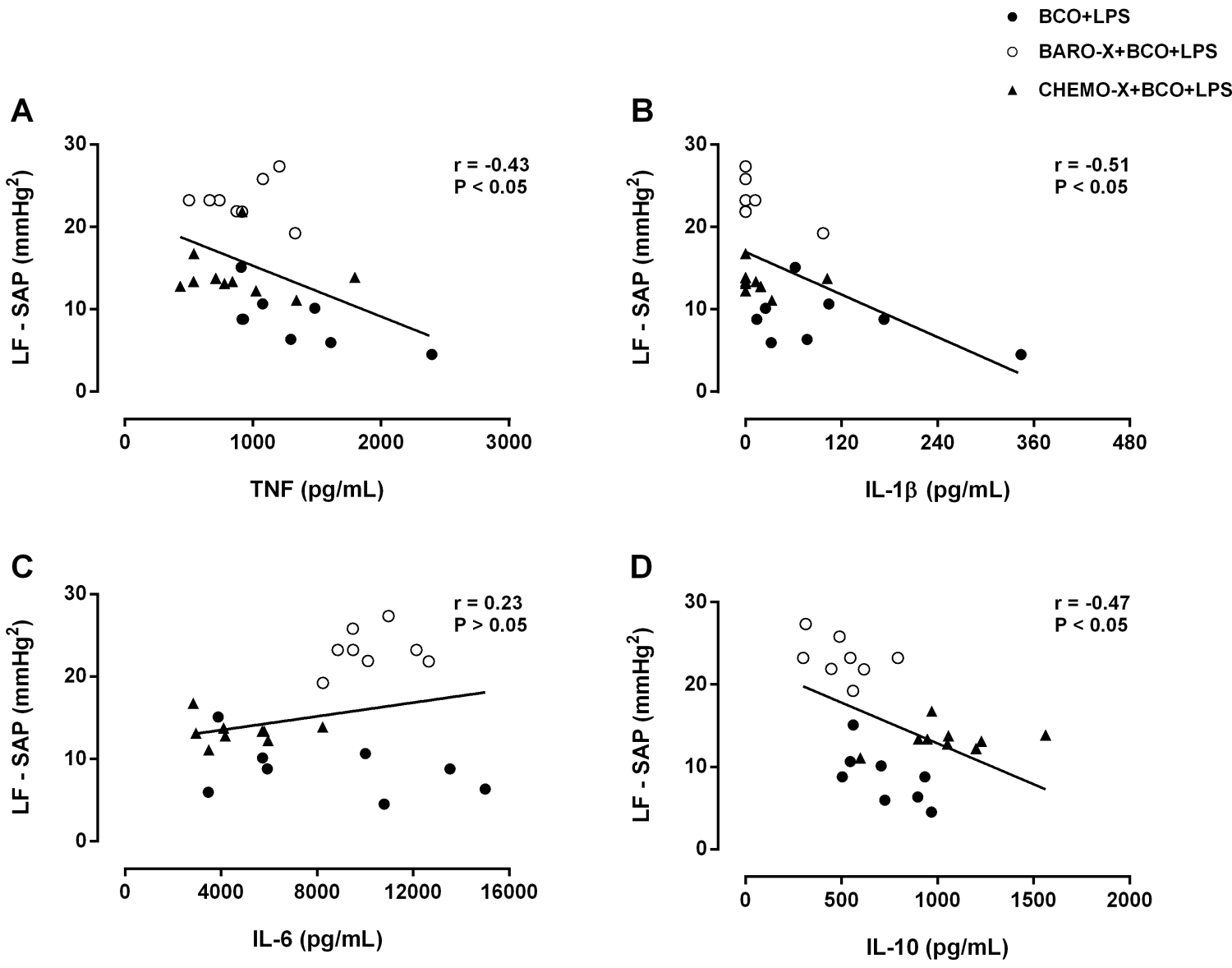
Figure 7

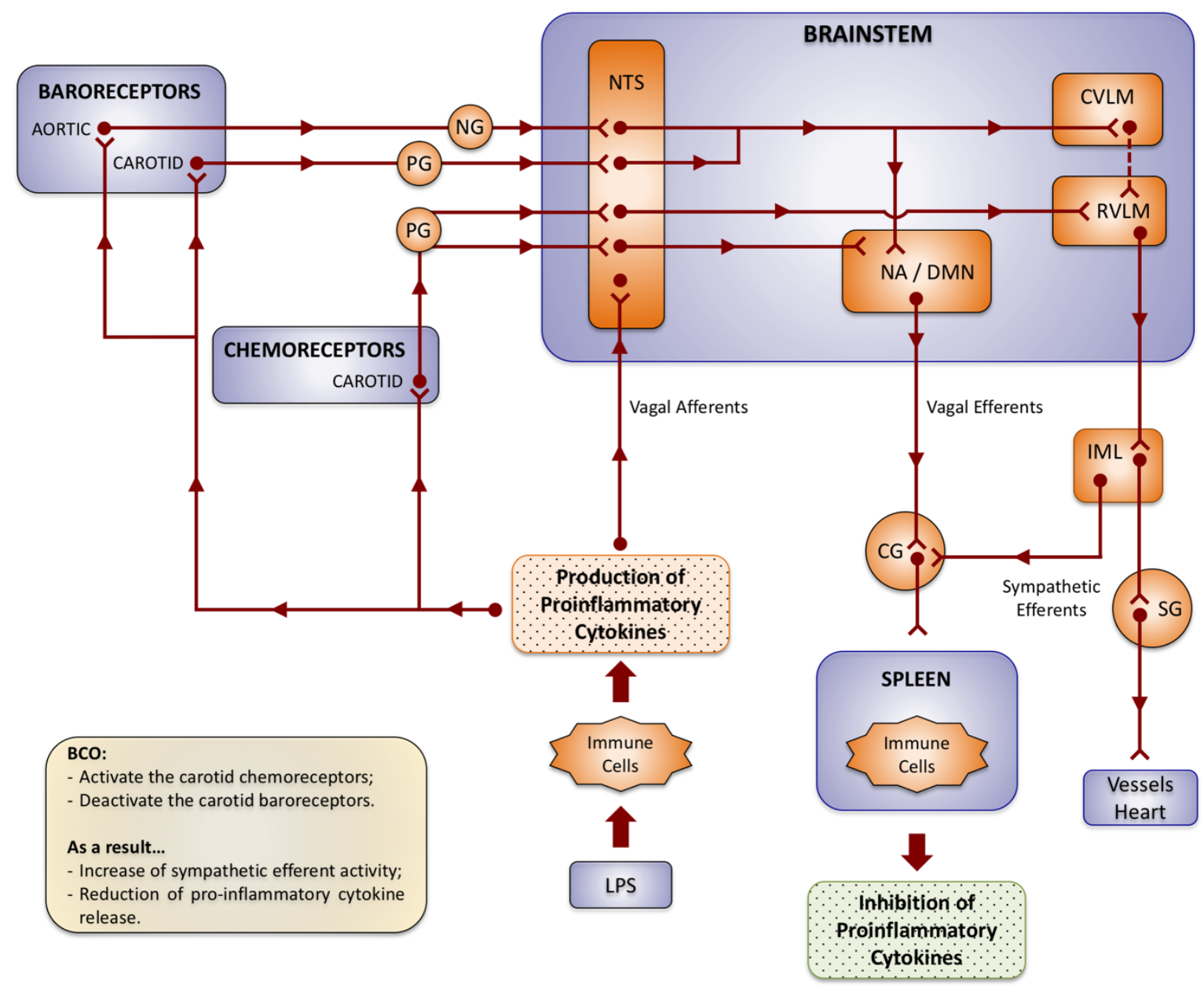


Figure 8

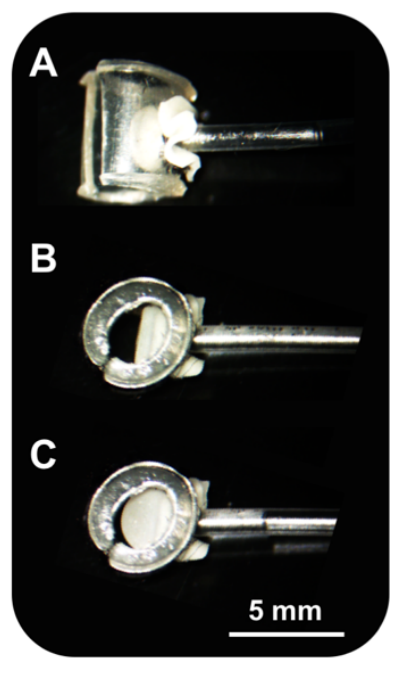

D

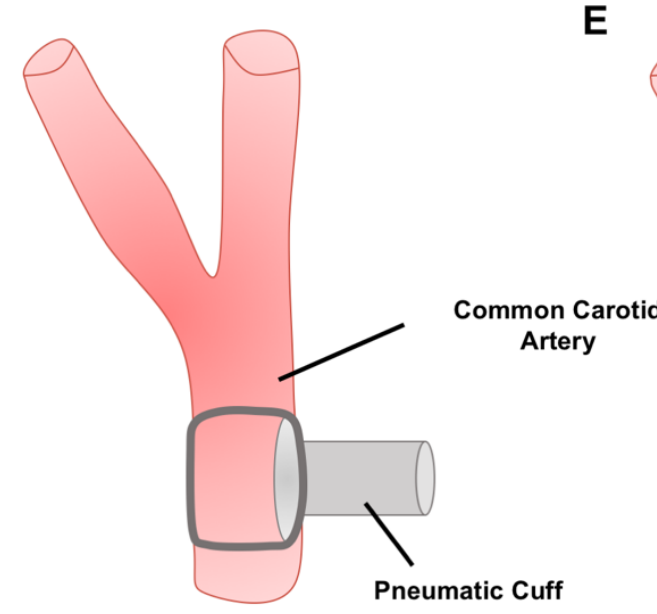

E

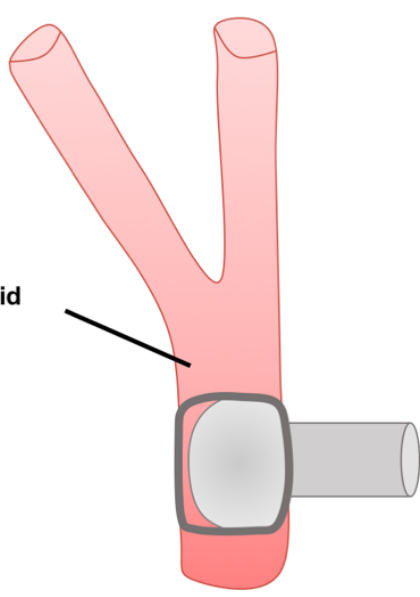

$\mathbf{F}$

\section{Continuous Pulsatile Arterial Pressure Recording}

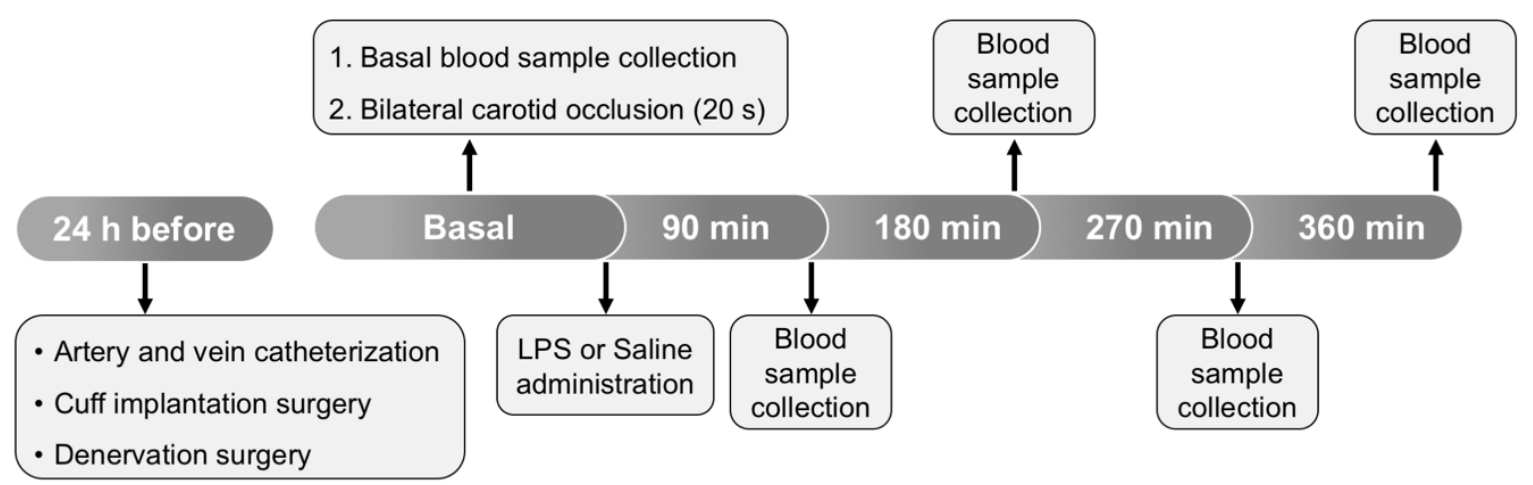




\section{THE BEZOLD-JARISCH REFLEX ACTIVATION REDUCES CYTOKINES}

RELEASE IN ENDOTOXEMIC RATS

Fernanda Brognara ${ }^{a}$, Jaci Airton Castania ${ }^{a}$, Aline Barbosa Ribeiro ${ }^{a}$, Nilton Nascimento Santos-Junior ${ }^{b}$, Helio Cesar Salgado ${ }^{*}$.

aDepartment of Physiology, Ribeirão Preto Medical School, University of São Paulo, Ribeirão Preto, SP, Brazil.

bMinas Gerais State University, Passos, MG, Brazil.

Running title: Bezold-Jarisch Reflex Modulates Inflammation

${ }^{*}$ Corresponding Author:

Helio C. Salgado, M.D., Ph.D.

E-mail: hcsalgado@fmrp.usp.br

Department of Physiology

Ribeirão Preto Medical School - University of São Paulo Av. Bandeirantes, 3900; 14049-900, Ribeirão Preto, SP, Brazil Phone: +55-16-33153201 


\begin{abstract}
We have described that the baroreflex activation displays anti-inflammatory proprieties. Analogously to the baroreflex, the Bezold-Jarisch reflex also promotes parasympathetic activation with simultaneous inhibition of the sympathetic nervous system. Thus, the present study aimed to evaluate whether the Bezold-Jarisch reflex activation would also have the ability to reduce inflammation. We used lipopolysaccharide injection to induce the systemic inflammation in Wistar Hannover rats, and phenylbiguanide administration to activate the Bezold-Jarisch reflex. The spleen, heart, hypothalamus, and a blood sample were collected to determine the levels of cytokines. Phenylbiguanide reduced arterial pressure and heart rate, immediately after its administration, confirming the activation of the Bezold-Jarisch reflex. Moreover, phenylbiguanide decreased TNF- $\alpha$ levels in the plasma and IL-6 levels in the spleen. However, phenylbiguanide did not change the cytokines evaluated in the heart or hypothalamus. These findings indicate, for the first time, that although limited, the Bezold-Jarisch reflex exhibits an anti-inflammatory modulation.
\end{abstract}

Keywords: Bezold-Jarisch reflex, parasympathetic activation, sympathetic inhibition, phenylbiguanide, inflammation, rats. 


\section{Introduction}

Several studies highlighted the role of the parasympathetic system to control the inflammation in numerous inflammatory diseases [1]. More recently, the baroreflex was identified as a modulator of the inflammatory response [2,3], in addition to its typical function of regulating the arterial pressure [4]. When activated, the baroreflex results in a neural response that comprises parasympathetic activation and sympathetic activity inhibition contributing to arterial pressure homeostasis [4]. Thus, the anti-inflammatory role played by the baroreflex activation is probably associated with its influence in both branches - sympathetic and parasympathetic - of the autonomic nervous system.

The Bezold-Jarisch reflex is a cardiopulmonary reflex in which the parasympathetic innervation of the cardiopulmonary region is crucial to regulate heart rate, systemic vasomotor tone, and respiration - when activated promotes bradycardia, hypotension, and apnea [5]. In experimental studies, the Bezold-Jarisch reflex is activated by some pharmacological agents, including a selective serotonergic 5-HT3 receptor agonist, the phenylbiguanide (PBG) [6,7]. Analogously to the baroreflex, the Bezold-Jarisch reflex also promotes parasympathetic activation with concomitant inhibition of the sympathetic nervous system. In addition, the baroreflex and the Bezold-Jarisch reflex share a common central pathway in the brainstem [810].

Taking into account that the baroreflex activation has anti-inflammatory proprieties, it is reasonable to expect that the Bezold-Jarisch reflex would also have the similar ability since both reflexes share the same central pathway and analogous efferent autonomic response. Therefore, this study aimed to evaluate if the BezoldJarisch reflex activation can control the systemic inflammatory response in rats.

\section{Materials and methods}

\subsection{Experimental animals}

Male Wistar Hannover rats (250 - $300 \mathrm{~g}$ ) from the Main Animal Facility of the University of São Paulo (Campus of Ribeirão Preto; Ribeirão Preto, SP, Brazil) were used to perform the study. The animals were kept under constant light-dark cycle (12 $\mathrm{h})$, and controlled temperature $\left(23^{\circ} \mathrm{C}\right)$ with free access to water and food. The 
experimental protocol of the present study was evaluated and approved by the Committee of Ethics in Animal Research from the Ribeirão Preto Medical School University of São Paulo (protocol \# 161/2016).

\subsection{Surgical procedures}

A cocktail of ketamine and xylazine (50 mg/kg and $10 \mathrm{mg} / \mathrm{kg}$, i.p.) was used to anesthetize the animals to perform the surgical procedures of catheterization. The left femoral artery and vein were catheterized with polyethylene tubing (PE-50 soldered to PE-10 polyethylene tube; Intramedic, Clay Adams, Parsippany, NJ, USA) for arterial pressure recording and PBG or saline (vehicle) administration, respectively. Furthermore, a catheter (PE-50 polyethylene tube; Intramedic, Clay Adams, Parsippany, NJ, USA) was inserted into the abdominal cavity for the administration of LPS from Escherichia coli 0111:B4 (Sigma-Aldrich, St. Louis, MO, USA) or saline (vehicle). The catheters were pulled up through a subcutaneous track to the animal's neck and exteriorized on the nape, and surgical incisions were sutured. Analgesic (tramadol hydrochloride: $2 \mathrm{mg} / \mathrm{kg}$, s.c.) was administered to avoid pain.

\subsection{Experimental protocol}

Forty-eight hours after the surgical procedures, the rats were assigned into four groups:

I) Sal + Sal: saline administration (i.v.) followed by saline injection (i.p.).

II) PBG + Sal: phenylbiguanide administration (i.v.) followed by saline injection (i.p.).

III) Sal + LPS: saline administration (i.v.) followed by LPS injection (i.p.).

IV) PBG + LPS: phenylbiguanide administration (i.v.) followed by LPS injection (i.p.).

With the animal unanesthetized, the experimental protocol consisted of basal recordings of pulsatile arterial pressure, followed by the administration of PBG (5 $\mu \mathrm{g} / \mathrm{kg}$, i.v.) - to promote the Bezold-Jarisch reflex activation - or saline (control). Five minutes later, the LPS (5 mg/kg, i.p.) was administered - to induce systemic inflammation - or saline (as control) was injected. The arterial pressure was recorded 
until completing 90 min after LPS or saline injection. Next, the arterial pressure recording was suspended, and a blood sample was collected through the catheter from the femoral artery with heparin. Then, the rats were killed by decapitation for quick collection of samples from the spleen, the heart and the whole hypothalamus, that were immediately frozen in liquid nitrogen. Blood samples were kept on ice until centrifugation at $3500 \mathrm{rpm}$ for $15 \mathrm{~min}$ at $4^{\circ} \mathrm{C}$. The plasma was then collected, and all biological material was stored at $-80^{\circ} \mathrm{C}$.

\subsection{Arterial pressure recording and analysis}

The pulsatile arterial pressure was recorded using a pressure transducer (MLT844; ADInstruments, Bella Vista, Australia), an amplifier (ML224; ADInstruments, Bella Vista, Australia), and an analog-to-digital interface (PowerLab, ADInstruments, Bella Vista, Australia). The experiment was conducted with the animals moving freely in their cage. The analysis of the mean arterial pressure and heart rate was carried out using computer software (LabChart 7.0, ADInstruments, Bella Vista, Australia).

\subsection{Cytokine measurements}

On the day of the assay, the tissue samples were homogenized in $0.5 \mathrm{~mL}$ of PBS using a homogenizer (Polytron-PT-3100, Evisa, Kinematica, Luzern, Switzerland) and then centrifuged at $1000 \mathrm{rpm}$ for $10 \mathrm{~min}$ at $4{ }^{\circ} \mathrm{C}$. The plasma and tissue supernatant samples were used to measure the cytokine (TNF- $\alpha$, IL-1 $1 \beta, I L-6$, and IL-10) levels by an immunoenzymatic method (ELISA) using Duo set kits from R\&D Systems (Minneapolis, MN, USA) according to the manufacturer's instructions.

\subsection{Statistical analysis}

The analysis of the hemodynamic data was carried out using two-way analysis of variance (ANOVA) for repeated measures, followed by Student-Newman- Keuls post hoc test. The analysis of inflammatory mediators was carried out using one-way ANOVA, followed by the same post hoc test mentioned. Differences were considered statistically significant if $P<0.05$. Statistical analysis was performed using the 
SigmaPlot 12.0 software (Systat Software, San Jose, CA, USA), and the results are presented as mean \pm standard error of the mean.

\section{Results and discussion}

\subsection{Hemodynamic response to phenylbiguanide}

Saline administration did not change arterial pressure or heart rate (Fig. 1A and B). However, immediately after PBG administration, a reduction in arterial pressure (Fig. 1A) and abrupt bradycardia (Fig. 1B) were observed. Classically, the BezoldJarisch reflex activation promotes hypotension and bradycardia [5]. The reflex vasodilation of the Bezold-Jarisch reflex is, in fact, because of the inhibition of the sympathetic vasoconstrictor tone [6], which is considered to be comprehensive [11]. This sympathetic inhibition due to the Bezold-Jarisch reflex activation was demonstrated in the lumbar [9,12], splanchnic [12], splenic [13] and renal nerves $[6,13]$. On the other hand, the bradycardia in Bezold-Jarisch reflex is predominantly due to parasympathetic activation [9]. Both responses were clearly observed in the present study, indicated that the administration of PBG promoted conspicuous parasympathetic activation and sympathetic inhibition, validating the activation of the Bezold-Jarisch reflex in the chosen model.

\subsection{Time course of arterial pressure and heart rate}

No changes in arterial pressure were observed over time in any of the groups studied (Fig. 1C). That is, the injection of LPS or PBG did not promote alterations in arterial pressure over $90 \mathrm{~min}$. However, the administration of LPS increased the heart rate 60 and 90 min later, compared to baseline and also compared to control groups, which received saline (Fig. 1D). In addition, PBG did not reduce the mean arterial pressure and heart rate over time (Fig. 1C and D).

The tachycardia observed after LPS administration in the present study is in line with the literature [14]. Regarding the arterial pressure response, some studies reported that, over time, LPS reduced the arterial pressure [15]. On the other hand, other reports described a hypertensive response [14], or even no changes in the 
arterial pressure [3]. Thus, the effects of LPS in the arterial pressure are quite variable in rats, definitely involving many factors, such as gender, strain, quality and dose of the LPS, level of anesthesia, among others.

\subsection{Phenylbiguanide reduced the TNF level in plasma and the IL-6 level in spleen}

The administration of saline associated, or not, with PBG did not modify the plasma cytokine levels (Fig. 2A-D). Instead, the administration of LPS increased all the cytokines evaluated in plasma, $90 \mathrm{~min}$ after its injection (Fig. 2A-D). The administration of PBG associated with LPS reduced the release of TNF- $\alpha$ in plasma (Fig. 2A). However, PBG administration did not prevent the increase of the other cytokines induced by LPS (Fig. 2B-D). The analysis of tissue cytokines showed that LPS administration increased most of the cytokines analyzed in the spleen (Fig. 2E$\mathrm{H}$ ), heart (Fig. 2I-L) and hypothalamus (Fig. 2N-P). Moreover, in the spleen, the administration of PBG attenuated the IL-6 release induced by LPS (Fig. 2F) but did not decrease the levels of the other cytokines induced by LPS (Fig. 2E, G and H). In the heart and hypothalamus, the administration of PBG, associated with LPS, did not reduce the release of any cytokine evaluated in the present study (Fig. 2I-P). Undetected levels of TNF- $\alpha$ were observed in the hypothalamus (Fig. 2M).

The central activation pathways for the Bezold-Jarisch reflex consists of the same paths as the baroreflex [8-10]. Taking into account that previous reports from our laboratory demonstrated that the stimulation of the baroreflex promoted antiinflammatory effects in rats [2,3], it was expected that the activation of the BezoldJarisch reflex would also produce the same result. Our findings showed that the activation of the Bezold-Jarisch reflex attenuated the cytokine release induced by systemic inflammation in unanesthetized rats. However, the anti-inflammatory effects of the activation of the Bezold-Jarisch reflex were not the same as those shown for the baroreflex activation. Brognara et al. [3] demonstrated that baroreflex activation reduced the levels of TNF, IL-6, IL1 $\beta$ and IL-10 in the hypothalamus of endotoxemic rats, without changing the levels of the same cytokines in plasma, spleen or heart. In the current study, the Bezold-Jarisch reflex did not decrease the inflammation in the hypothalamus or the heart but reduced the concentrations of TNF- $\alpha$ in the plasma and 
IL-6 in the spleen. These data indicate that: (I) although limited to some cytokines and territories, the Bezold-Jarisch reflex exhibited systemic anti-inflammatory modulation; and (II) that parasympathetic activation and sympathetic inhibition promoted by the Bezold-Jarisch reflex, have different anti-inflammatory properties than those resulting from baroreflex stimulation.

It is noteworthy that the study by Brognara et al. [3] was also conducted in unanesthetized rats submitted to the induction of systemic inflammation through the administration of LPS, as in the present study. However, an important factor may justify the differences observed in the anti-inflammatory effect promoted by each reflex: the method chosen to activate the parasympathetic and inhibit the sympathetic nervous system. In the experiments from Brognara et al. [3], the baroreflex was activated through electrical stimulation of the aortic depressor nerve, that is, a neurostimulation approach was used. In the current study, a pharmacological method was chosen to trigger the Bezold-Jarisch reflex. Thus, although the efferent autonomic response was practically the same for both reflexes, resulting in parasympathetic activation and concomitant sympathetic inhibition, the different afferent approaches used to activate these reflexes appeared to interfere with the effector inflammatory response.

In the current study, the anti-inflammatory effect of the Bezold-Jarisch reflex was selective for TNF- $\alpha$ in plasma and IL- 6 in the spleen. It is possible that the action of the Bezold-Jarisch reflex on the other cytokines in plasma (IL-6, IL-1 $\beta$, and IL-10) and the spleen (TNF- $\alpha, \mathrm{IL}-1 \beta$ and IL-10) may have a different time course, occurring later, or even earlier. That is, the anti-inflammatory effect produced by the parasympathetic activation and sympathetic inhibition due to the Bezold-Jarisch reflex stimulation would require more, or less, than ninety minutes to be effective. Thus, it would be interesting to further study the time course of cytokines in different tissues, during the development of the systemic inflammatory response in unanesthetized rats.

\section{Conclusions}

In conclusion, this is the first study describing that the Bezold-Jarisch reflex possesses an anti-inflammatory role in rats. In other words, like the baroreflex, the Bezold-Jarisch reflex can also control the release of TNF- $\alpha$ in plasma and IL-6 in the 
spleen in unanesthetized rats, when systemic inflammation was elicited by LPS. Thus, the study of the Bezold-Jarisch reflex activation, in different inflammatory diseases, would be useful for proposing new therapeutic strategies to treat the inflammation under diverse conditions.

\section{Acknowledgements}

This work was supported by The São Paulo Research Foundation (FAPESP) (process \#2013/20549-7; \#2017/05163-6; \#2018/20939-3; \#2018/10455-9) and by The Academic Excellence Program (PROEX) from Coordination for the Improvement of Higher Education Personnel (CAPES) (process \#88887.505419/2020-00).

\section{Competing interests}

The authors declare no conflict of interest.

\section{Author contributions}

Fernanda Brognara: Conceptualization, Formal analysis; Investigation; Funding acquisition; Methodology; Visualization; Writing - original draft. Jaci A. Castania: Data curation; Investigation; Resources. Aline B. Ribeiro: Funding acquisition; Investigation. Nilton N. Santos-Junior: Funding acquisition; Investigation; Writing - review \& editing. Helio C. Salgado: Conceptualization, Funding acquisition; Project administration; Supervision; Writing - review \& editing. All the authors revised and approved the final version of the manuscript before submission.

\section{References}

[1] V.A. Pavlov, S.S. Chavan, K.J. Tracey, Bioelectronic Medicine: From Preclinical Studies on the Inflammatory Reflex to New Approaches in Disease Diagnosis and Treatment, Cold Spring Harb Perspect Med. 10 (2020). https://doi.org/10.1101/cshperspect.a034140. 
[2] G.S. Bassi, F. Brognara, J.A. Castania, J. Talbot, T.M. Cunha, F.Q. Cunha, L. Ulloa, A. Kanashiro, D.P.M. Dias, H.C. Salgado, Baroreflex activation in conscious rats modulates the joint inflammatory response via sympathetic function, Brain Behav. Immun. (2015). https://doi.org/10.1016/j.bbi.2015.05.002.

[3] F. Brognara, J.A. Castania, D.P.M. Dias, A.H. Lopes, R. Fazan Jr., A. Kanashiro, L. Ulloa, H.C. Salgado, Baroreflex stimulation attenuates central but not peripheral inflammation in conscious endotoxemic rats, Brain Research. 1682 (2018) 54-60. https://doi.org/10.1016/j.brainres.2018.01.003.

[4] E.M. Krieger, H.C. Salgado, L.C. Michelini, Resetting of the baroreceptors, Int Rev Physiol. 26 (1982) 119-146.

[5] D.M. Aviado, D. Guevara Aviado, The Bezold-Jarisch reflex. A historical perspective of cardiopulmonary reflexes, Ann. N. Y. Acad. Sci. 940 (2001) 4858.

[6] L.B. Bell, K.P. O'Hagan, P.S. Clifford, Cardiac but not pulmonary receptors mediate depressor response to IV phenyl biguanide in conscious rabbits, Am. J. Physiol. 264

R1050-1057. https://doi.org/10.1152/ajpregu.1993.264.6.R1050.

[7] F.C. Silva, F.A. Paiva, F.C. Müller-Ribeiro, H.M.A. Caldeira, M.A.P. Fontes, R.C.A. de Menezes, K.R. Casali, G.H. Fortes, E. Tobaldini, M. Solbiati, N. Montano, V.J. Dias Da Silva, D.A. Chianca, Chronic Treatment with Ivabradine Does Not Affect Cardiovascular Autonomic Control in Rats, Front Physiol. 7 (2016) 305. https://doi.org/10.3389/fphys.2016.00305.

[8] K. Kashihara, Roles of arterial baroreceptor reflex during bezold-jarisch reflex., $\begin{array}{lllll}\text { Current } & \text { Cardiology } & \text { Reviews. } & 5\end{array}$ https://doi.org/10.2174/157340309789317805.

[9] A.J. Verberne, P.G. Guyenet, Medullary pathway of the Bezold-Jarisch reflex in the rat, Am. J. Physiol. 263 (1992) R1195-1202. https://doi.org/10.1152/ajpregu.1992.263.6.R1195.

[10] A.J. Verberne, R.L. Stornetta, P.G. Guyenet, Properties of C1 and other ventrolateral medullary neurones with hypothalamic projections in the rat, J. Physiol. (Lond.). 517 ( Pt 2) (1999) 477-494. https://doi.org/10.1111/j.14697793.1999.0477t.x. 
[11] A.J.M. Verberne, M. Saita, D.M. Sartor, Chemical stimulation of vagal afferent neurons and sympathetic vasomotor tone, Brain Research Reviews. 41 (2003) 288-305. https://doi.org/10.1016/S0165-0173(02)00269-2.

[12] D.M. Sartor, A.J.M. Verberne, The sympathoinhibitory effects of systemic cholecystokinin are dependent on neurons in the caudal ventrolateral medulla in the rat, Am. J. Physiol. Regul. Integr. Comp. Physiol. 291 (2006) R1390-1398. https://doi.org/10.1152/ajpregu.00314.2006.

[13] L.C. Weaver, H.K. Fry, R.L. Meckler, Differential renal and splenic nerve responses to vagal and spinal afferent inputs, Am. J. Physiol. 246 (1984) R7887. https://doi.org/10.1152/ajpregu.1984.246.1.R78.

[14] F. Brognara, J.A. Castania, D.P.M. Dias, A. Kanashiro, H.C. Salgado, Time Course of Hemodynamic Responses to Different Doses of Lipopolysaccharide in Unanesthetized Male Rats, Front. Physiol. 10 (2019). https://doi.org/10.3389/fphys.2019.00771.

[15] M.Y. Sallam, S.M. El-Gowilly, H.M. El-Gowelli, M.A. El-Lakany, M.M. El-Mas, Additive counteraction by $\alpha 7$ and $\alpha 4 \beta 2-n A C h R s$ of the hypotension and cardiac sympathovagal imbalance evoked by endotoxemia in male rats, Eur. J. Pharmacol. 834 (2018) 36-44. https://doi.org/10.1016/j.ejphar.2018.07.008.

\section{Figure legends}

Figure 1. Hemodynamic response to phenylbiguanide and LPS. Bar graphs show the mean arterial pressure (MAP, A) and heart rate (HR, B) at baseline (white bars) and after administration (gray bars) of phenylbiguanide (PBG) or saline. Interrupted lines show the MAP (C) and HR (D) at baseline (time zero), 30, 60 and 90 min after the administration of LPS or saline from the different groups. LPS: lipopolysaccharide; PBG: phenylbiguanide; Sal: saline. Panels $A$ and $B:{ }^{*} P<0.05$. Panel $D$ : ${ }^{*} P<0.05$ vs. 0 min; \# P $<0.05$ vs. 30 min. Two-way ANOVA with Student-Newman-Keuls post hoc test. 
Figure 2. The administration of phenylbiguanide decreased the release of TNF$\alpha$ induced by LPS in plasma and IL- 6 in the spleen. Bar graphs show the levels of TNF- $\alpha$, IL-6, IL-1 $\beta$ and IL-10 in plasma (A, B, C and D), spleen ( $E, F, G$ and $H$ ), heart $(\mathrm{I}, \mathrm{J}, \mathrm{K}$ and $\mathrm{L})$ and hypothalamus $(\mathrm{M}, \mathrm{N}, \mathrm{O}$ and $\mathrm{P}) 90 \mathrm{~min}$ after the administration of LPS or saline in the different groups. IL-6: interleukin 6; IL-1 $\beta$ : interleukin $1 \beta$; IL-10: interleukin 10; LPS: lipopolysaccharide; n.d.: not detected; PBG: phenylbiguanide; Sal: saline; TNF- $\alpha$ : tumor necrosis factor alpha. ${ }^{*} \mathrm{P}<0.05$ vs. Sal + Sal group; \# $\mathrm{P}<$ 0.05 vs. Sal + LPS group. One-way ANOVA with Student-Newman-Keuls post hoc test. The number in parentheses represents the $n$ of each group. 
Figure 1

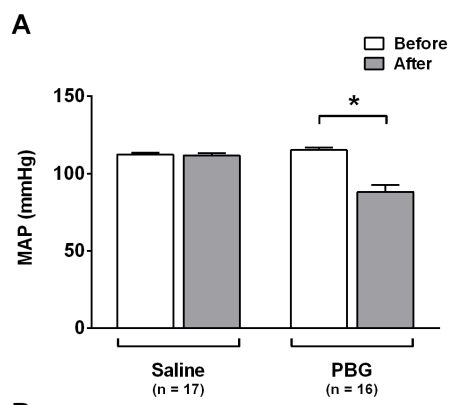

C
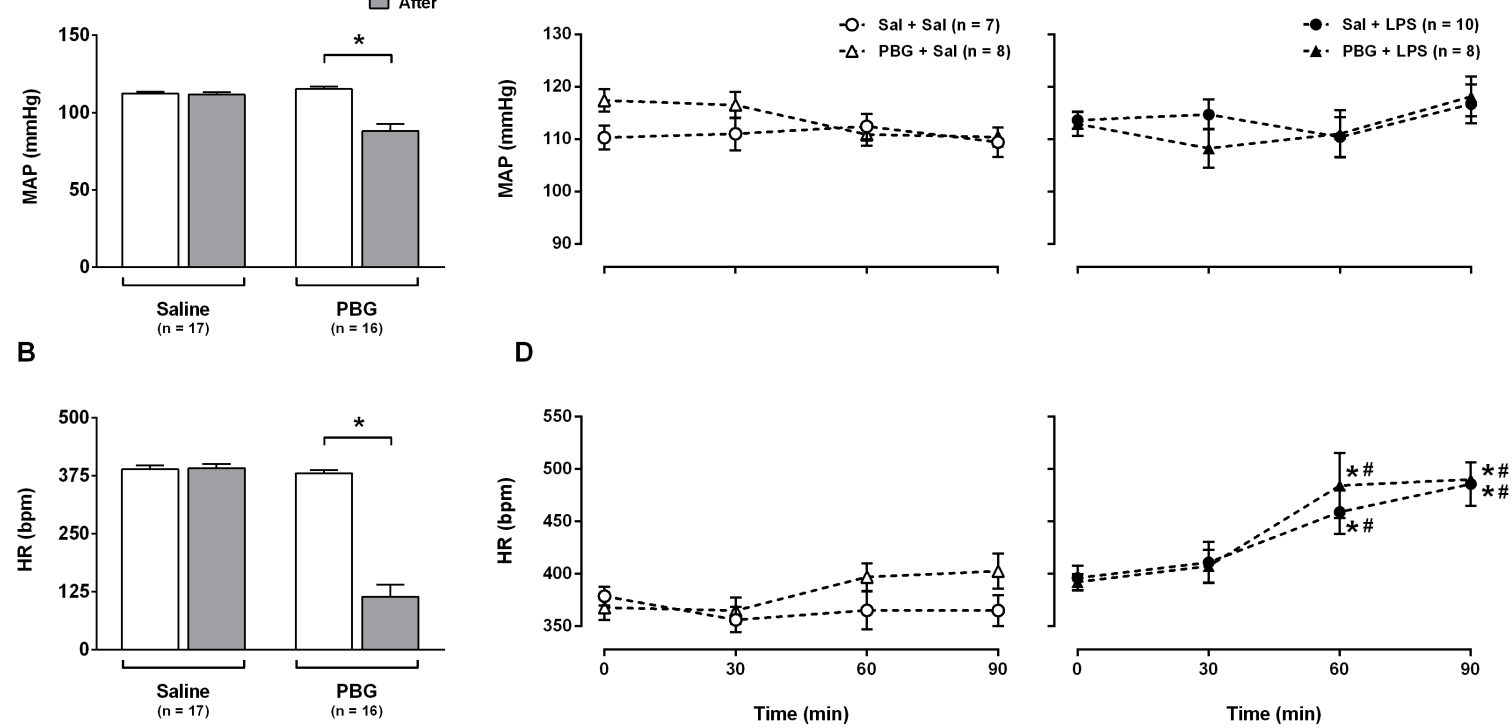
Figure 2

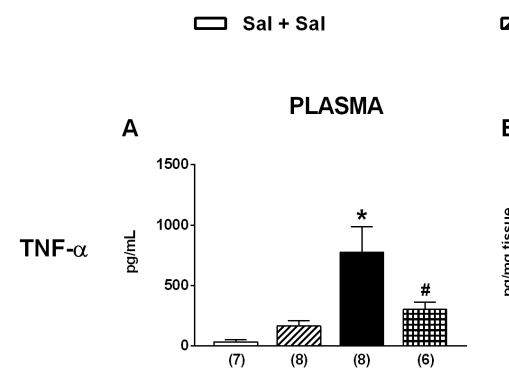

20 PBG + Sal

- Sal + LPS

m $\mathrm{PBG}+\mathrm{LPS}$
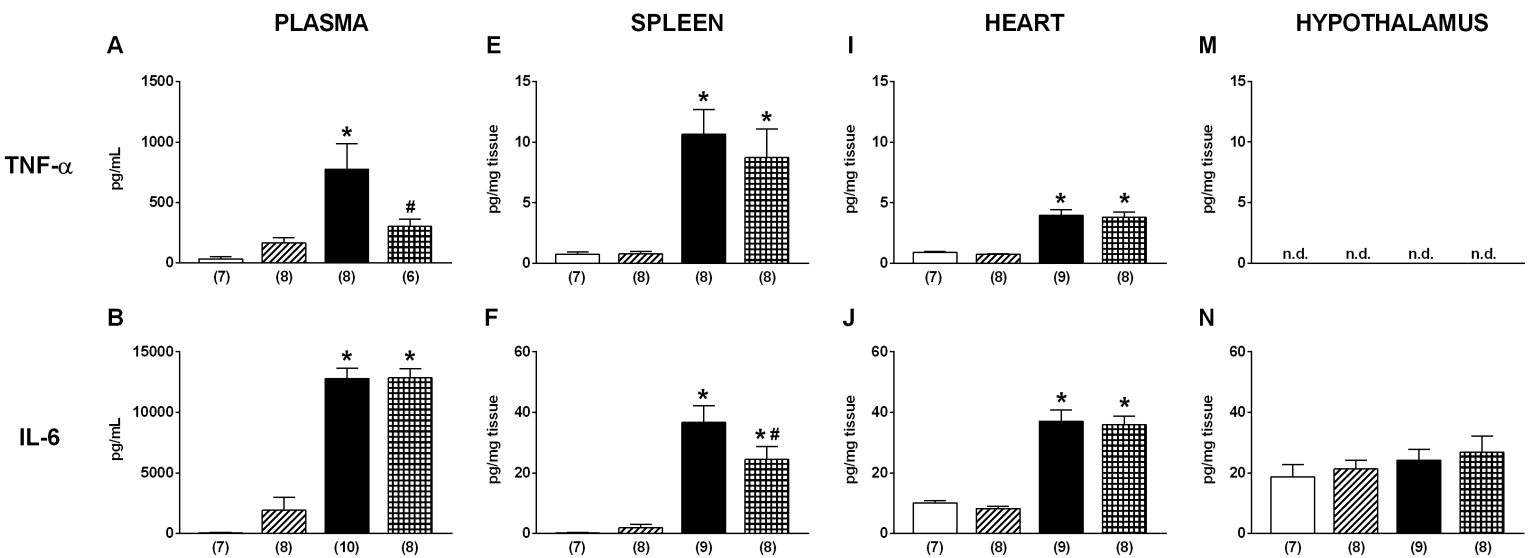

C

G

K
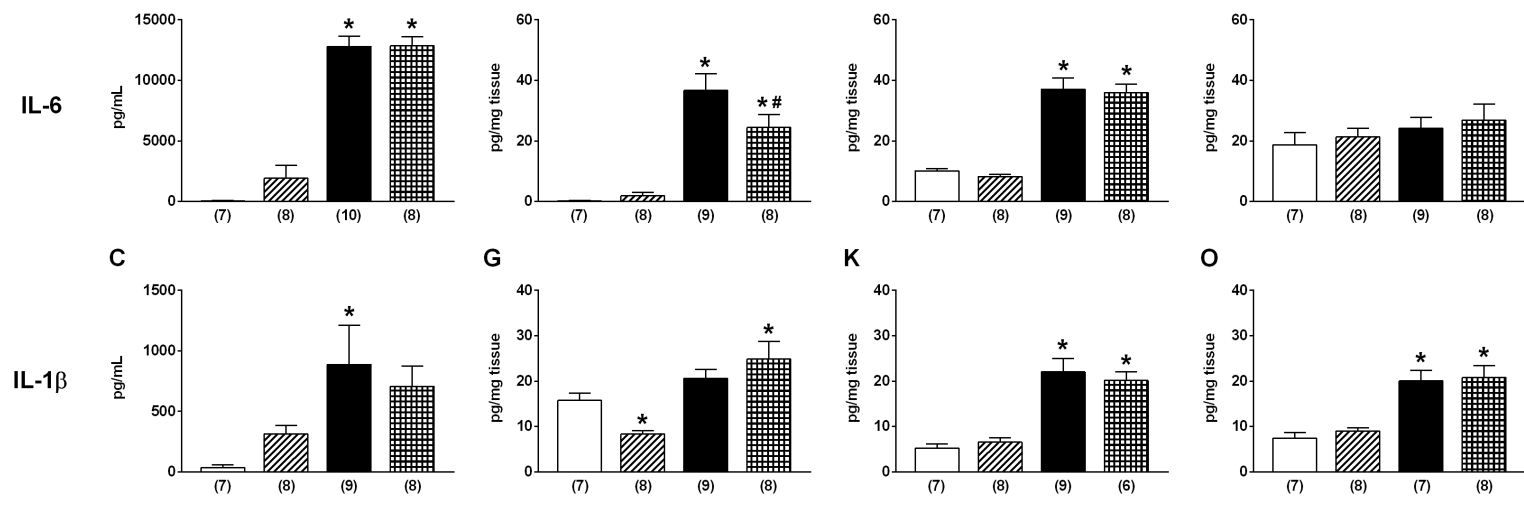

H
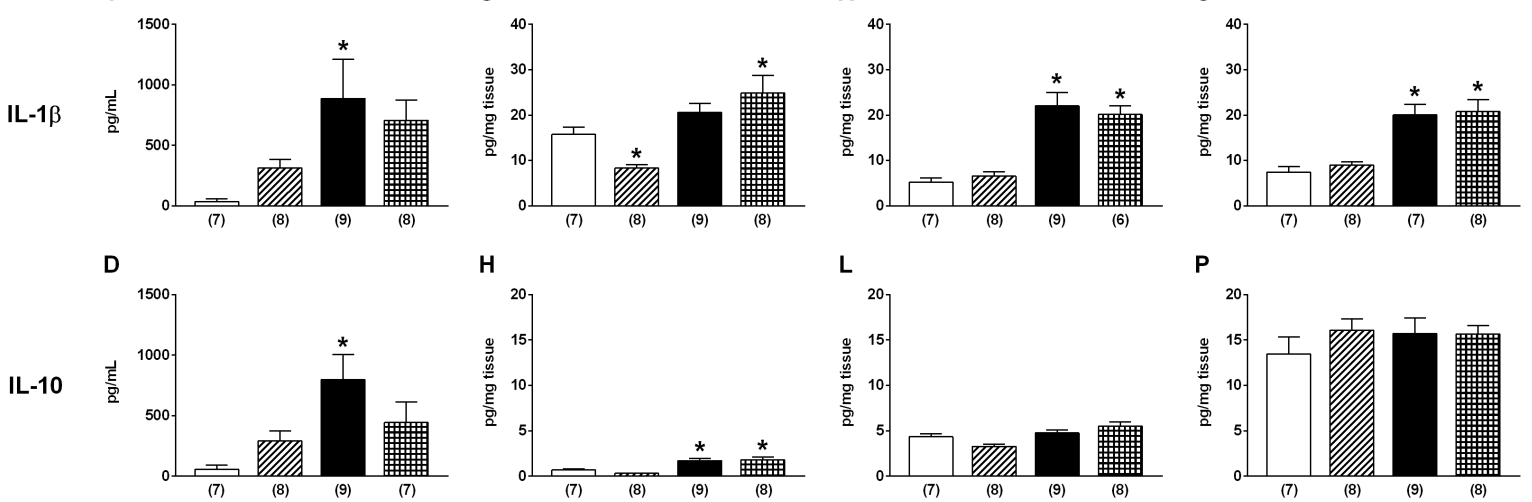


\section{Benefits of pharmacological and electrical cholinergic stimulation in hypertension and heart failure}

Gisele L. Cavalcante ${ }^{1,2 @}$, Fernanda Brognara ${ }^{3 @}$, Lucas Vaz de C. Oliveira ${ }^{1}$, Renata M. Lataro ${ }^{4}$, Marina de T. Durand ${ }^{5}$, Aldeidia P. de Oliveira $^{6}$, Antônio Cláudio L. da Nóbrega ${ }^{7}$, Helio C. Salgado $^{3}$, João Paulo J. Sabino ${ }^{1 *}$

${ }^{1}$ Graduate Program in Pharmaceutical Sciences, Department of Biophysics and Physiology, Federal University of Piaui, Teresina, PI, Brazil. ${ }^{2}$ Department of Pharmacology, Ribeirão Preto Medical School, University of São Paulo, Ribeirão Preto, SP, Brazil. ${ }^{3}$ Department of Physiology, Ribeirão Preto Medical School, University of São Paulo, Ribeirão Preto, SP, Brazil. ${ }^{4}$ Department of Physiological Sciences, Center of Biological Sciences, Federal University of Santa Catarina, Florianópolis, SC, Brazil. ${ }^{5}$ Medical School of University of Ribeirão Preto, Ribeirão Preto, SP, Brazil. ${ }^{6}$ Graduate Program in Pharmacology, Department of Biophysics and Physiology, Federal University of Piaui, Teresina, PI, Brazil, ${ }^{7}$ Department of Physiology and Pharmacology, Fluminense Federal University, Niterói, RJ, Brazil.

@ These authors have contributed equally to this work.

Short title: Benefits of cholinergic stimulation.

${ }^{*}$ Corresponding author:

João Paulo Jacob Sabino, M.D., Ph.D.

e-mail: jacobsabino@gmail.com

Department of Biophysics and Physiology, Federal University of Piaui, Teresina, PI, Brazil Avenida Nossa Senhora de Fátima s/n, CEP: 64049550 


\begin{abstract}
Systemic arterial hypertension and heart failure are cardiovascular diseases that affect millions of individuals worldwide. They are characterized by a change in the autonomic nervous system balance, highlighted by an increase in sympathetic activity associated with a decrease in parasympathetic activity. Most therapeutic approaches seek to treat these diseases by medications that attenuate sympathetic activity. However, there is a growing number of studies demonstrating that the improvement of parasympathetic function, by means of pharmacological or electrical stimulation, can be an effective tool for the treatment of these cardiovascular diseases. Therefore, this review aims to describe the advances reported by experimental and clinical studies that addressed the potential of cholinergic stimulation to prevent autonomic and cardiovascular imbalance in hypertension and heart failure. Overall, the published data reviewed demonstrate that the use of central or peripheral acetylcholinesterase inhibitors is efficient to improve the autonomic imbalance and hemodynamic changes observed in heart failure and hypertension. Of note, the baroreflex and the vagus nerve activation have been shown to be safe and effective approaches to be used as an alternative treatment for these cardiovascular diseases. In conclusion, pharmacological and electrical stimulation of the parasympathetic nervous system has the potential to be used as a therapeutic tool for the treatment of hypertension and heart failure, deserving to be more explored in the clinical setting.
\end{abstract}

Keywords: Anticholinesterases; Cholinergic Stimulation; Electrical Stimulation; Parasympathetic Nervous System; Sympathetic Nervous System. 


\section{INTRODUCTION}

Systemic arterial hypertension (SAH) has a high prevalence and is associated with high morbidity and mortality in the global population. According to the latest World Health Organization data from 2015, the incidence of SAH in adults (18 years of age or older) was $24 \%$ and $20 \%$ in men and women, respectively ${ }^{1}$. In 1975 , a total of 594 million people were diagnosed with SAH in the low and middle-income countries, while in 2015 this number increased to 1.13 billion of people, indicating a dramatic increase of $\mathrm{SAH}$ in the last four decades $^{2}$. In 2035 , it is expected that more than 130 million adults in the US population $(45.1 \%)$ will have some form of cardiovascular disease ${ }^{3}$. This outcome represents an approximate cost of $\$ 1.1$ trillion, with direct medical costs reaching $\$ 748.7$ billion, and estimated indirect costs of $\$ 368$ billion ${ }^{3}$. Furthermore, SAH is a significant risk factor for the onset of other serious cardiovascular diseases, such as acute myocardial infarction (MI), coronary disease, coronary artery aneurysms, heart failure (HF) and chronic kidney disease ${ }^{4,5}$. Besides, at least $45 \%$ of heart disease deaths and $51 \%$ of stroke deaths were related to $\mathrm{SAH}^{6,7}$. Therefore, $\mathrm{SAH}$ is considered a major public health problem.

In addition to the high arterial pressure, other physiological alterations are also observed in $\mathrm{SAH}$, such as autonomic dysfunction, which is characterized by an increase in the sympathetic and a decrease in the parasympathetic activity. This autonomic imbalance contributes to the increase in arterial pressure and the derangement of other physiological functions ${ }^{8,9}$. SAH also promotes several changes in the cardiac structure and function, for example, left ventricular (LV) hypertrophy, and left atrial hypertrophy, LV systolic and diastolic dysfunction ${ }^{10}$, as well as reduction of LV ejection fraction ${ }^{5}$. An increase in the levels of circulating catecholamines ${ }^{8,9,11}$, heart rate $(\mathrm{HR})$, peripheral resistance ${ }^{12,13}$, reduction of the total HR variability, and baroreflex dysfunction are also observed in patients with $\mathrm{SAH}^{14}$.

HF is another severe cardiovascular disease very prevalent worldwide, and it is associated with the progression of SAH. A previous study has shown that $\mathrm{SAH}$ induces $\mathrm{HF}$ in $59 \%$ of female and $39 \%$ of male patients ${ }^{15}$. Besides that, the risk of developing HF is greater when the patient with SAH presents MI, diabetes, LV hypertrophy, or valvular heart disease 
15. It is estimated that the HF affects about 23 million people worldwide, with incidence and prevalence rates reaching epidemic proportions. This outcome is demonstrated by the considerable increase in the number of hospitalizations and deaths attributed to HF, besides the growing expenditure on the care of these patients ${ }^{16}$. The prevalence is approximately $1-$ $2 \%$ of the adult population in developed countries, which is above $10 \%$ in individuals over 70 years of age, and also HF has a mortality rate close to $12 \%$ amongst African-American individuals ${ }^{17}$. HF is cardiovascular morbidity in which the heart cannot pump enough blood to all organs of the body ${ }^{18}$ and, in addition to hemodynamic dysfunction, is also characterized by activation of the immune system and autonomic system dysfunction ${ }^{19,20}$. In HF, both innate and adaptative immune systems are activated, resulting in the recruitment of several immune cells and an increase in the circulating levels of pro-inflammatory cytokines and myocardial inflammation ${ }^{20}$. Similarly to $\mathrm{SAH}$, the autonomic dysfunction observed in $\mathrm{HF}$ is due to increase of the sympathetic and reduction of the parasympathetic activities ${ }^{21}$ related to changes in the cardiorespiratory reflexes ${ }^{22}$. The sympathetic hyperactivity in HF also results in greater activation of the efferent renal sympathetic nerves, which causes an increase on renal renin release and, consequently, sodium retention, hypervolemia, and reduced renal blood flow ${ }^{6}$. Moreover, renal sympathetic activation rises the levels of circulating angiotensin II, which reaches the central nervous system and leads to an increase in the sympathetic tone ${ }^{23}$. Besides, there is an additional increase in norepinephrine release by the sympathetic nerve terminals due to activation of AT1 angiotensin II receptors in the pre-synaptic terminal of sympathetic neurons, harming the cardiovascular homeostasis ${ }^{24}$.

Before 1950, there were no effective medications for the treatment of SAH, so most of the hypertensive patients progressed to secondary complications, mainly $\mathrm{HF}^{25}$. At that time, the only effective treatment was broad bilateral sympathectomy, indicated for patients with malignant SAH or HF; however, the approach had limited effectiveness, since hypertension returned within a few years after surgery ${ }^{25}$. In 1952, based on the results from surgical sympathectomy, hexamethonium, and other drugs that performed an efficient pharmacological sympathectomy came up, but they exhibited a number of adverse effects ${ }^{25}$. 
Since then, studies involving pharmacological treatments of SAH progressed enormously, allowing the development of thiazide diuretics (1958), potassium-sparing diuretics (1957), beta-blockers (propranolol, 1973), alpha-2 adrenergic receptor agonists acting centrally (clonidine, the 1970s), alpha-1 adrenergic receptor blocker (prazosin, 1975), angiotensinconverting enzyme inhibitors (captopril, 1977), calcium channel blockers (verapamil, 1977), angiotensin II receptor blocker (losartan, 1982), renin inhibitors (aliskiren, 2000) ${ }^{26}$. After the development of these antihypertensive drugs, the appropriate treatment of SAH reduced the risk of MI by 15 to $25 \%$, the risk of stroke by $35-40 \%$, and HF by $64 \%{ }^{18}$. Nevertheless, some patients are still resistant to these medications, and the antihypertensive effects are not achieved.

On the other hand, it was also proposed that parasympathetic stimulation is able to inhibit the sympathetic impulse, since the release of acetylcholine acts on muscarinic receptors situated in the sympathetic pre-synaptic nerve endings, inhibiting the release of norepinephrine ${ }^{27}$. Accordingly, based on the possible cardioprotective role played by the parasympathetic nervous system, studies have explored the beneficial effects of cholinergic activation in cardiovascular diseases. Therefore, this review aims to highlight the advances in experimental and clinical studies of cholinergic stimulation (pharmacological and electrical) as a promising tool for the treatment of SAH and HF.

\section{PHARMACOLOGICAL STIMULATION OF THE PARASYMPATHETIC NERVOUS SYSTEM}

\subsection{Acetylcholinesterase Inhibitors in Systemic Arterial Hypertension}

In the heart, the parasympathetic neurotransmission is mediated through the release of acetylcholine (ACh), which binds to type 2 muscarinic receptors in the sinoatrial and atrioventricular node, causing reduction of the $\mathrm{HR}$ and atrial contractility ${ }^{28}$. Activation of type

2 muscarinic receptors stimulates the inhibitory $G$ proteins, which reduce the cardiac pacemaker activity by hindering calcium channels opening and increasing potassium 
membrane permeability ${ }^{29,30}$. The main reason for using the acetylcholinesterase inhibitors is to prevent the hydrolysis of ACh at the cholinergic nerve endings, prolonging its availability; and, consequently, increasing the efficiency of cholinergic transmission ${ }^{31}$.

Previous studies that stimulated the cholinergic system by means of the administration of acetylcholinesterase inhibitors, e.g. pyridostigmine and donepezil, have shown promising results with a significant improvement in the autonomic and cardiovascular parameters in experimental models of cardiovascular diseases ${ }^{32-35}$. Pyridostigmine bromide is an anticholinesterase agent, consisting of a quaternary amine that does not cross the blood-brain barrier; therefore, it does act, specifically in the peripheral synaptic clefts, increasing the bioavailability of ACh in these synaptic clefts ${ }^{31}$. Donepezil, which consists of a tertiary amine, is also an anticholinesterase agent, but with the capacity of crossing the blood-brain barrier ${ }^{31}$. This drug is particularly known as the most commonly used member of the class of acetylcholinesterase inhibitors for the treatment of Alzheimer's disease ${ }^{36}$. Interestingly, studies from patients with Alzheimer's disease have demonstrated that those using the acetylcholinesterase inhibitors had a lower risk of $\mathrm{Ml}$ and cardiovascular mortality when compared to non-users of this class of drugs ${ }^{37,38}$.

Experimental studies using spontaneously hypertensive rats (SHR) have demonstrated that pharmacological chronic cholinergic stimulation by means of pyridostigmine administration ( $25 \mathrm{mg} / \mathrm{kg} /$ day, during 14 days) in drinking water attenuated the increase of $\mathrm{HR}$, arterial pressure and the reduction of the parasympathetic tone ${ }^{66}$. Lataro and colleagues ${ }^{67}$ also showed that long-term administration of pyridostigmine $(1.5 \mathrm{mg} / \mathrm{kg} / \mathrm{day}$, during 16 weeks) to SHR attenuated the vascular reactivity dysfunction, by reducing reactive oxygen species generation and increasing nitric oxide (NO) bioavailability. Accordingly, the use of pyridostigmine can act by means of several different mechanisms, reducing the cardiovascular alterations observed in the SHR.

In order to explore both peripheral and central effects of an anticholinesterase in SAH, Lataro and colleagues also compared the effects of pyridostigmine $(1.5 \mathrm{mg} / \mathrm{kg} / \mathrm{day})$ versus donepezil (1.4 mg/kg/day) in SHR, both given during 16 weeks ${ }^{68}$. It was observed an 
improvement in the cardiac vagal tone and prevention of cardiac remodeling under both treatments ${ }^{68}$. Of note, only donepezil attenuated the development of SAH in SHR, suggesting that this antihypertensive effect cannot be attributed solely to a direct improvement of the cardiac parasympathetic tone. Recently, Cavalcante and colleagues investigated the role of these anticholinesterase agents in L-NAME hypertensive rats ${ }^{69}$. Oral treatment of either donepezil (1.4 mg/kg/day) or pyridostigmine (22 mg/kg/day), during 12 days, were effective in preventing the increase in arterial pressure, cardiac sympathetic tone and chemoreflex sensitivity, as well as the attenuation of the baroreflex, parasympathetic tone and gastric motility ${ }^{69}$. However, only donepezil administration prevented the increase in the sympathetic tone to blood vessels ${ }^{69}$. The differences of the results observed in the study of Cavalcante and colleagues ${ }^{69}$ versus Lataro and colleagues ${ }^{68}$ could be related to the experimental model investigated (L-NAME vs SHR), method of drug administration (gavage vs osmotic minipumps), and the dose of pyridostigmine (22 vs $1.5 \mathrm{mg} / \mathrm{kg} /$ day). Thus, higher doses of pyridostigmine may have blocked the action of non-neuronal acetylcholinesterase produced in other locations, such as the endothelium or lymphocytes, which may have potentiated the hemodynamic changes ${ }^{70}$. Therefore, these data reinforce that acetylcholinesterase inhibition could be used as a pharmacological tool to increase parasympathetic function and, consequently, prevent the adverse effects on the cardiovascular, digestive and autonomic systems, observed in SAH.

From the inflammatory point of view, it is essential to highlight that donepezil treatment also promoted an anti-inflammatory effect in SHR ${ }^{68}$, which may have influenced the attenuation of the SAH. Since the central inflammatory process is involved in the development of $\mathrm{SAH}$ and is correlated with alterations in the cardiovascular autonomic modulation, it is likely that the reduction of this process is a potential mechanism involved in cholinergic activation 71. Thus, these data suggest that anticholinesterase agents can reduce inflammation, being a preventive approach for patients at increased cardiovascular risk.

Clinical studies about the effects of acetylcholinesterase inhibitors in hypertensive patients are quite limited in the literature, compared to the experimental studies. Arad and 
colleagues ${ }^{72}$ evaluated eight hypertensive patients under regular treatment with beta-blockers combined with pyridostigmine (30 mg, 3 times per day, during 2 days). No differences were found between the pyridostigmine and placebo groups concerning $H R$, arterial pressure, PR interval or plasma catecholamines during regular daily activity ${ }^{72}$. However, during the bicycle ergometer exercise pyridostigmine reduced diastolic arterial pressure, indicating a reduction in peripheral vascular resistance due to parasympathetic stimulation ${ }^{72}$. Sandroni and colleagues ${ }^{73}$ examined the effects of pyridostigmine [30-60 mg, 2-3 times (gradual increase) during around 19 months] in subjects with neurogenic orthostatic hypertension. These authors described that 17 of 20 patients related moderate to marked improvement of the orthostatic symptoms with pyridostigmine treatment ${ }^{73}$. Therefore, these preliminary clinical data demonstrated that pyridostigmine might have promising results for the treatment of SAH. Nevertheless, further studies in hypertensive subjects are needed to better explore the benefits of acetylcholinesterase inhibitors treatment.

\subsection{Acetylcholinesterase Inhibitors in Heart Failure}

Similarly to the studies in animals and patients with $\mathrm{SAH}$, pharmacological cholinergic stimulation has shown promising results in HF subjects. A recent review has thoroughtly explored this issue from cell to patients reports, discussing the potential mechanisms involved in the effects of acetylcholinesterase inhibitors. Here, we are going to retrospectively examine the studies which performed pharmacological cholinergic stimulation in animals and patients with MI or HF.

Earlier studies in healthy volunteers demonstrated that a single dose of $30 \mathrm{mg}$ or 45 mg of pyridostigmine bromide promoted $28 \%$ reduction in serum cholinesterase activity, decreased resting HR and the QTc dispersion and improved ventricular function ${ }^{39-41}$. These data have encouraged further researches on pharmacological cholinergic stimulation in order to elucidate the benefits of parasympathetic activation in coronary artery disease and HF. In this sense, Castro and colleagues ${ }^{42}$ studied the effects of pyridostigmine on electrocardiographic variables and during cardiopulmonary treadmill exercise test in patients 
with stable coronary artery disease. The findings indicated that pyridostigmine caused bradycardia, improved exercise peak tolerance, inhibited the chronotropic response to submaximal exercise, protected against exercise-induced myocardial ischemia and reduced the QT interval in the first minute of active recovery, without causing significant side effects in those patients ${ }^{42,44,45}$. In addition, Nóbrega and colleagues ${ }^{46}$ demonstrated that cholinergic stimulation with pyridostigmine $(45 \mathrm{mg})$ two hours before a standard mental stress task prevented impaired myocardial function during mental stress in patients with coronary artery disease ${ }^{46}$.

In elderly patients with chronic HF, Androne and colleagues ${ }^{43}$ demonstrated that pyridostigmine improved the recovery of HR within one minute after physical exercise, suggesting that pyridostigmine increased the parasympathetic function of chronic HF patients. Subsequently, Serra and colleagues ${ }^{47}$ conducted a study with 32 patients with chronic HF who underwent 3 cardiopulmonary treadmill exercise test on different days. These authors observed that pyridostigmine led to an improvement in the hemodynamic profile during dynamic exercise in patients with $\mathrm{HF}^{47}$. Thus, these sets of studies in patients who have coronary artery disease and HF indicated that pyridostigmine is efficient in improving heart performance during situations of physical exercise and mental stress.

Experimental studies have also evaluated the benefits of donepezil and pyridostigmine in different heart failure models. Handa and colleagues ${ }^{32}$ observed that donepezil (5 $\mathrm{mg} / \mathrm{kg} /$ day, for 4 weeks), prevented cardiac dysfunction and remodeling in mice with HF ${ }^{32}$. Okazaki and colleagues ${ }^{34}$ also demonstrated that donepezil $(5 \mathrm{mg} / \mathrm{kg} / \mathrm{day}$ ) reduced biventricular weight, improved ventricular function and ameliorated parasympathetic function at night time of HF rats. Recently, Li and colleagues ${ }^{48}$ showed that central microinfusion of donepezil for 6 weeks in HF rats markedly improved the survival rate, prevented cardiac remodeling, and reduced plasma catecholamines, cerebral natriuretic peptide and angiotensin II ${ }^{48}$.

Similar to donepezil, pyridostigmine has also shown promising effects in experimental models of cardiac pumping failure. In myocardial infarcted rats, pyridostigmine administration 
(dissolved in drinking water $0.14 \mathrm{mg} / \mathrm{mL}$, during 11 days) improved cardiac contractility and attenuated the size of myocardial infarcted area, as well reestablished the mean arterial pressure, baroreflex sensitivity and autonomic control ${ }^{49}$. Additionally, Lataro and colleagues ${ }^{33}$ observed that pyridostigmine administration $(21 \mathrm{mg} / \mathrm{kg} /$ day, dissolved in drinking water 0.14 $\mathrm{mg} / \mathrm{ml}$, during 4 weeks) decreased plasma acetylcholinesterase activity in $42 \%$ and simultaneously prevented the autonomic imbalance commonly observed in $\mathrm{HF}$, improved cardiac function (systolic volume, ejection fraction, cardiac output and LV contractility), attenuated cardiomyocyte hypertrophy and reduced collagen deposition in the non-infarcted ventricle of $\mathrm{HF}$ rats ${ }^{33}$. These findings indicated that pyridostigmine administration to rats improved not only the cardiac structure but also the autonomic cardiovascular function in the early stage of MI (11 days $)^{49}$, as well as in established HF (4 weeks) ${ }^{33}$.

The benefits of pyridostigmine in HF rats were also evaluated in the later stage of HF ${ }^{35}$. Sabino and colleagues ${ }^{35}$ demonstrated that pyridostigmine improved baroreflex sensitivity, cardiac parasympathetic tone, intrinsic pacemaker frequency and autonomic cardiovascular variability in HF rats after 6 to 7 weeks of MI. Nevertheless, in this study, pyridostigmine was unable to prevent the arterial pressure reduction and to improve the cardiac function (measured by contractility indices and LV relaxation) ${ }^{35}$. Since the dose of pyridostigmine was the same in the aformetionated studies, the difference reported between the findings can be explained by the advanced stage of the disease in the animals with 7-weeks of HF.

Sabino and colleagues ${ }^{50}$ also investigated the effect of pyridostigmine involving the central and peripheral chemoreflex sensitivity of HF rats. Both stimuli, hypoxia $\left(10 \% \mathrm{O}_{2}\right)$ and hypercapnia ( $5 \%$ or $\left.10 \% \mathrm{CO}_{2}\right)$ induced greater pulmonary ventilation and respiratory rate in HF rats, indicating that the sensitivity of peripheral and central chemoreceptors was increased in $\mathrm{HF}$ rats ${ }^{50}$. However, the cholinergic stimulation, by means of pyridostigmine administration, was effective in reducing the increase in pulmonary ventilation during hypoxia; but its effect was negligible during hypercapnia since it did prevent only the increase of the respiratory rate in HF subjects. To explain these results, the authors suggested that pyridostigmine was able to increase the parasympathetic drive to the carotid body; and, consequently, attenuated the 
ventilatory response to hypoxia ${ }^{50}$. This hypothesis is based on the study by Fidone and Sato ${ }^{51}$, which demonstrated that parasympathetic stimulation of nerve fibers from the carotid body caused an attenuation of the sensitivity of the chemoreflex. Besides, it has already been demonstrated that the dose of pyridostigmine used in the study of the chemoreflex sensitivity evaluation ${ }^{50}$ is efficient for promoting an increase of the parasympathetic tone in rats with $\mathrm{HF}$ 33,35. Therefore, these findings indicate that part of the improvement of the autonomic control, after pyridostigmine administration, could be due to the attenuation of chemoreflex sensitivity, which is increased during $\mathrm{HF}^{50}$.

Later on, Santos-Almeida and colleagues evaluated the effect of pyridostigmine administration $\left(0.25 \mathrm{mg} / \mathrm{kg}\right.$; i.v.) during the first 4 hours after acute $\mathrm{Ml}$ in rats ${ }^{52}$. Pyridostigmine did not reverse the arterial pressure decrease caused by the $\mathrm{MI}$, but it was effective in preventing the associated tachycardia ${ }^{52}$. In addition, pyridostigmine reduced arrhythmias in infarcted rats and prevented QT prolongation and connexin 43 reduction in the LV ${ }^{52}$. The maintenance of connexin 43 levels and, consequently, the stability of cardiomyocyte components promoted by pyridostigmine administration in HF rats, could be related to the reduction of the arrhythmias observed in the treated animals ${ }^{52}$. Besides that, the antiarrhythmic function of anticholinesterase does not appear to require the bradycardic effect induced by pyridostigmine. This statement is based on the observation that significant bradycardia occurs only in the first 2 hours after MI, while the antiarrhythmic effect persisted during the 4 hours of the experimental protocol ${ }^{52}$.

The effects of pyridostigmine were also examined by Durand and colleagues in mice submitted to small $\mathrm{MI}^{56}$. The administration of $3 \mathrm{mg} / \mathrm{kg} /$ day of pyridostigmine, during 4 weeks (mini osmotic pump), prevented the tachycardia and autonomic changes caused by MI in mice. Moreover, the cholinergic approach counteracted the decrease in vagal tone and the sympathetic overactivity one week after Ml and produced a greater increase in the vagal tone in the fourth week compared to before $\mathrm{MI}^{56}$. Another study ${ }^{57}$ in mice investigated the effect of pyridostigmine ( $3 \mathrm{mg} / \mathrm{kg} / \mathrm{day})$ on the hemodynamic responses and nychthemeral oscillations of mean arterial pressure and HR before and one week after the induction of MI. 
Infarcted animals showed a decrease in arterial pressure and an increase in HR, whereas the administration of pyridostigmine prevented these alterations ${ }^{57}$. Moreover, the nychthemeral oscillations of mean arterial pressure and HR were not affected by pyridostigmine after the MI ${ }^{57}$, suggesting that the use of pyridostigmine may be a safe pharmacological therapy capable of improving hemodynamic and autonomic variables in experimental models of $\mathrm{Ml}$ and $\mathrm{HF}^{57}$.

It is essential to highlight that the number of reports showing the relationship between cardiovascular diseases and inflammation ${ }^{58-60}$ is increasing in the literature, leading the researchers to evaluate whether the improvement in cardiac and autonomic function, after cholinergic stimulation, was accompanied by attenuation of inflammatory processes. Thus, Bezerra and colleagues ${ }^{61}$ analyzed the anti-inflammatory effects of the pharmacological cholinergic stimulation by pyridostigmine during the proliferative phase of cardiac repair. It was observed that pyridostigmine administration after $\mathrm{Ml}$ increased parasympathetic modulation, reduced the oxidation of proteins (carbonyl) and the concentration of anti-inflammatory markers (IL-1 $\beta$, IL-6, TNF- $\alpha$ and IL-10), preventing oxidative stress ${ }^{61}$. Also, there is evidence that administration of pyridostigmine reduced the heart inflammation in $\mathrm{Ml}$, attenuating the heart dysfunction ${ }^{64,65}$. Rats treated with pyridostigmine showed higher anti-inflammatory cell recruitment (activated fibroblasts, monocytes/macrophages and cardiomyocytes) and reduced inflammatory cytokines expression (IFN- $\gamma$, IL-6, and IL-1 $\beta)^{64}$. These results indicated that increased ACh availability might activate the alpha-7 nicotinic receptor of the cholinergic anti-inflammatory reflex arc ${ }^{64}$. Additionally, Feriani and colleagues ${ }^{62,63}$ reported that the association of physical exercise with pyridostigmine might promote an additional benefit on autonomic cardiovascular modulation, systemic inflammatory profile ${ }^{62}$ and skeletal muscle function ${ }^{63}$.

\subsection{Perspectives of Clinical Application}

To the best of our knowledge, no clinical study evaluated the chronic effects of anticholinesterase treatment in HF or SAH patients. This is probably because of some side effects associated with the acute use of high doses of pyridostigmine $(>180 \mathrm{mg})^{74}$. The 
currently available data suggest that adverse reactions are related to muscarinic and/or nicotinic receptor activation, due to the increase in acetylcholine concentration in the synaptic cleft after administration of high doses of anticholinesterases ${ }^{74}$. The side effects induced by muscarinic receptors activation included nausea, vomiting, diarrhea, abdominal cramps, miosis, severe sweating, increased digestive sounds, peristalsis, salivation, and bronchial secretions; while the activation of the nicotinic receptors may cause muscle cramps, fasciculations, and weakness as adverse effects ${ }^{74}$.

On the other hand, low doses of pyridostigmine $(30-180 \mathrm{mg})$ may cause mild, transient and tolerable cholinergic symptoms. Preliminary data showed that $25 \%$ of patients presented abdominal symptoms, and $10 \%$ reported muscle symptoms that usually lasted 1 to 2 hours ${ }^{75}$. In addition, reactions were uncommon and not accompanied by symptoms on the central nervous system, dismissing any medical intervention ${ }^{75}$. Therefore, altogether, there is reasonable evidence that the treatment with anticholinesterases drugs is safe for patients and may represent an effective pharmacological alternative for the treatment of HF and SAH soon.

\section{ELECTRICAL STIMULATION OF THE PARASYMPATHETIC NERVOUS SYSTEM}

\subsection{Baroreflex Activation in Systemic Arterial Hypertension}

Despite the pharmacological treatment, some hypertensive patients are classified as resistant hypertensive. According to a Scientific Statement from the American Heart Association, "resistant hypertension is defined as the blood pressure of a hypertensive patient that remains elevated above goal despite the concurrent use of 3 antihypertensive agents of different classes, commonly including a long-acting calcium channel blocker, a blocker of the renin-angiotensin system (angiotensin-converting enzyme inhibitor or angiotensin receptor blocker), and a diuretic" ${ }^{76}$. Of note, patients with white-coat effect, antihypertensive medication nonadherence, and with imprecision arterial pressure measurement are excluded from the resistant hypertension diagnosis ${ }^{76}$. A recent meta-analysis, including data from more than 3 million hypertensive patients, showed that the prevalence of resistant hypertension, in 
this population, is around $10 \%{ }^{77}$. In addition, resistant hypertensive individuals have $25 \%$ more risk to develop the end-stage renal disease, $23 \%$ more chance to have a cerebrovascular accident, and an increase in $6 \%$ of the risk of mortality than patients with arterial pressure controlled by medicines ${ }^{78}$. Therefore, taking into account the high prevalence of SAH in the world population, the elevated number of resistant hypertensive patients, and the increased risk to present other diseases, it was reasonable to search for new treatments to reduce the clinical impact of the uncontrolled arterial pressure.

One alternative treatment proposed to control resistant hypertension was the carotid sinus nerve electrical stimulation. In the late 1950s, Warner ${ }^{79}$ showed that the electrical stimulation of the carotid sinus nerve reduced the arterial pressure in normotensive dogs. Later on, Griffith and Schwartz ${ }^{80}$ demonstrated the hypotensive effect of the carotid sinus nerve stimulation in hypertensive dogs. After that, in 1967, this approach was used in hypertensive patients; and a platinum bipolar electrode was implanted on the carotid sinus nerve in eleven subjects, but only eight of them were available for follow-up ${ }^{81}$. The carotid sinus nerve stimulation period ranged from five to thirty months, and six patients had a decrease in arterial pressure without the use of medication ${ }^{81}$. Thus, the electrical stimulation of the carotid sinus nerve started to be considered as a new treatment for clinical $\mathrm{SAH}^{82}$ and also for other cardiovascular diseases, for instance, angina pectoris ${ }^{83}$.

The electrical stimulation of the baroreceptors was also in focus in the 1960s as an alternative treatment for resistant hypertension. In 1964, Bilgutay and colleagues ${ }^{84}$ demonstrated that the electrical stimulation of the baroreceptors, using an implantable device called "Baropacer", was efficient to reduce the arterial pressure in different models of hypertension in dogs. The "Baropacer" was triggered by the R-waves collected by an electrode from the heart, and their impulses were intermittent with each systole, mimicking the natural discharge of the heart ${ }^{84}$. Two years later, Bilgutay and Lillehei tested the "Baropacer" in humans ${ }^{85}$, but with an improved version of the device. At this time, the electrodes were implanted around the walls of both carotid sinuses, and it was turned on or off by a magnetic switch just approaching to the region of the skin where the pulse generator had been implanted 
85. A white hypertensive man (40 years old) received the "Baropacer", and in association with the antihypertensive drugs, his arterial pressure was kept lower ${ }^{85}$.

However, despite the emergence of this promising electrical stimulation technique for the treatment of resistant hypertension, many side effects were reported in patients who have used this procedure (for instance, local discomfort due to the electrical current to adjacent structures and loss of nerve responsiveness after long-term stimulation) ${ }^{86}$. It was clear that the device needed technical improvement, but, due to the lack of available technology at that time, this approach was abandoned. Of note, in the 1980s, this electroceutical approach regained interest, and few studies were performed using the carotid sinus nerve stimulation in patients with SAH and angina ${ }^{87,88}$. Nevertheless, after that, these studies were not advanced clinically until the early 2000 s.

Although clinical studies using the electrical stimulation of the baroreflex to treat SAH have been discontinued at that time, experimental studies persisted in exploring these techniques in experimental hypertensive models. The electrical stimulation of the carotid sinus nerve and the electrical stimulation of the aortic depressor nerve were able to reduce the arterial pressure in anesthetized SHR and DOCA-salt hypertensive rats ${ }^{89,90}$. In addition, the hypotensive response due to electrical stimulation of the aortic depressor nerve was also described in unanesthetized SHR and L-NAME hypertensive rats ${ }^{91-93}$. In hypertensive dogs, it is essential to highlight the remarkable contribution of the experimental research conducted by Thomas E. Lohmeier and his research group ${ }^{94-102}$. After describing the effectiveness of the chronic baroreflex activation (electrodes implanted around the carotid sinus) to reduce the arterial pressure in normotensive dogs, Lohmeier and colleagues applied the same technique in hypertensive dogs induced by obesity ${ }^{101}$ and chronic infusion of angiotensin II ${ }^{103}$. The chronic baroreflex activation produced an antihypertensive response in both models of hypertension, but with less intensity in hypertensive dogs induced by angiotensin II ${ }^{101,103}$. These findings suggested that the activation of the renin-angiotensin-aldosterone system could attenuate the significant reduction of the arterial pressure during the baroreflex activation (see more details in the recent review ${ }^{104}$ ). 
Therefore, over time, several experimental studies emphasized the antihypertensive potential of electrical baroreflex stimulation as an alternative treatment for $\mathrm{SAH}$. Taking this notion into account, studies in hypertensive humans, using the baroreflex activation, were restarted in the last two decades. A new implantable device was created to solve some of the initial problems related to the 1960s device. The Rheos system (CVRx Inc., Minnesota, US) was the first-generation of the implantable devices developed for the treatment of resistant hypertension in humans. The new equipment was applied to several subjects and proved to be effective in controlling the arterial pressure in patients with resistant hypertension ${ }^{105-109}$. Moreover, evidence indicated that the decrease in arterial pressure, caused by the baroreflex electrical stimulation was, in fact, due to the inhibition of the sympathetic activity and, concomitantly, stimulation of the parasympathetic activity ${ }^{110,111}$. Between 2007 and 2009, a double-blind, randomized, placebo-controlled trial with 265 patients was conducted to evaluate the effect of baroreflex activation therapy on systolic arterial pressure in patients with resistant hypertension ${ }^{112}$. This study demonstrated that, in addition to reducing the arterial pressure, almost $5 \%$ of the patients had surgical complications and more than $9 \%$ had nerve injury, compromising the procedural safety ${ }^{112}$. Based on these findings, the Food and Drug Administration (FDA) did not approve the Rheos system to treat resistant hypertensive patients. Thus, the device to perform the electrical stimulation of the baroreflex in humans was improved once more; and the second-generation, the Barostim neo system, was presented in $2011^{113}$ and has been under investigation until nowadays ${ }^{114-118}$. In resistant hypertensive patients, this new device proved to be effective in reducing arterial pressure and keeping it low during three and six months. Besides, this new device is less invasive, reducing surgical complications, and the battery life was extended by using a unilateral electrode ${ }^{113}$. Several recent reviews have already compared and discussed the use of these devices, highlighting their advantages and limitations in the treatment of resistant hypertension ${ }^{104,118-124}$.

\subsubsection{Systemic Arterial Hypertension as an Inflammatory Disease and the Treatment with Baroreflex Stimulation}


Since the 1960s, studies have been conducted to demonstrate the role of the immune system in hypertension ${ }^{125-127}$. However, it was only in the last two decades that the study of this issue has substantially increased. Several experimental and clinical findings support the involvement of the innate and adaptative immune system in the development of hypertension and were already reported in some reviews ${ }^{128-131}$. As comprehensively approached and addressed in the review by Rodriguez-Iturbe and colleagues ${ }^{130}$, the increase in arterial pressure results from combined effects induced by inflammation, for instance, dysfunctional vascular relaxation, overactivity of the sympathetic nervous system, and impairment of pressure natriuresis response. Moreover, the hypothalamus inflammation is also related to the development and maintenance of hypertension ${ }^{132}$. Thus, it seems clear that some aspects involved in the genesis of SAH could be treated if the inflammation is controlled or prevented. However, the use of anti-inflammatory drugs in hypertensive patients must be viewed with caution, although it has been already tested ${ }^{133}$. Sympathetic hyperactivity in hypertensive subjects could cause immunosuppression by inhibiting naive T-lymphocytes in the spleen and lymph nodes ${ }^{134}$. Thus, the administration of anti-inflammatories, to treat $\mathrm{SAH}$, can worsen the patient's immunosuppression and favor the onset of other diseases.

Recently, Brognara and colleagues have described that, in addition to the antihypertensive effects, the baroreflex activation also exhibits anti-inflammatory proprieties 135,136. In endotoxemic rats, the electrical stimulation of the aortic depressor nerve reduced the levels of inflammatory cytokines in the hypothalamus, indicating a central anti-inflammatory effect of the baroreflex activation ${ }^{136}$. Taking into account that the inflammation of the hypothalamus is related to the development of $\mathrm{SAH}$, it is reasonable to suggest that baroreflex stimulation could treat SAH not only by its hypotensive effect but also by decreasing central inflammation. Nevertheless, further studies are needed to support this hypothesis in experimental models of SAH and even in clinical studies.

\subsection{Baroreflex Activation in Heart Failure}


In addition to the treatment of $\mathrm{SAH}$, the use of the baroreflex electrical stimulation has also focused on the treatment of HF, clinically and experimentally. Zucker and colleagues ${ }^{137}$ demonstrated that chronic electrical stimulation of the carotid sinus, using the Rheos system, increased survival and inhibited neurohormonal activation in chronic HF dogs. Moreover, Sabbah and colleagues ${ }^{138,139}$ showed that chronic electrical stimulation of the carotid sinus improved the LV systolic and diastolic function and LV remodeling in dogs with advanced HF. In unanesthetized HF rats, the electrical stimulation of the aortic depressor nerve was able to cause hypotension and bradycardia similar to control rats, indicating that this approach would also be useful to attenuate the HF ${ }^{140}$. Clinically, Gronda and colleagues ${ }^{141}$ reported the first study using the baroreflex activation therapy in eleven HF patients. Three and six months after starting the baroreflex electrical stimulation, the subjects had an improvement in the baroreflex sensitivity, quality of life, LV ejection fraction, and NYHA class ${ }^{141}$. Later on, other studies confirmed these benefits in severe HF patients with reduced ejection fraction ${ }^{142,143}$; and in the last year, the FDA approved the use of the Barostim neo system in HF patients ${ }^{144}$. Recent reviews have reported the safety and efficacy of the use of the baroreflex activation therapy in $\mathrm{HF}$ with reduced ejection fraction; however, in general, its also highlighted the relevance to perform more high-quality randomized clinical trials with long-term follow-up ${ }^{145,146}$.

\subsection{Vagus Nerve Stimulation in Heart Failure}

The vagus nerve electrical stimulation (VNS) has also been explored as a tool for the treatment of HF in experimental and clinical studies ${ }^{147}$. In 1991, the study conducted by Vanoli and colleagues ${ }^{148}$, in unanesthetized dogs, showed that VNS prevents ventricular fibrillation induced by the MI when performed very early, i.e., $15 \mathrm{~s}$ after the onset of coronary artery occlusion. Moreover, other studies from Sabbah's research group provided a significant contribution to the study of the VNS in HF dogs. In his studies, the VNS in HF dogs improved the LV function, LV remodeling, decreased pro-inflammatory cytokines in the plasma and LV tissue, normalized the expression of NO synthase (endothelial, inducible and neuronal) in LV tissue, and increased connexin 43 levels in LV tissue ${ }^{149-151}$. Later on, Zang and colleagues 
${ }^{152}$ described that the treatment with VNS increased the baroreflex sensitivity, HR variability, and decreased norepinephrine, angiotensin II and C-reactive protein levels in the plasma of HR dogs. These findings demonstrated an improvement of the cardiac autonomic control and attenuation of the development of HF.

The benefits of VNS in HF was also reported in rats. Li and colleagues ${ }^{153}$ showed that chronic VNS (6 weeks) in HF rats improved the survival rate (from $86 \%$ to $50 \%$ ) and promoted a reduction of $73 \%$ in the relative risk ratio of death. Besides, these authors demonstrated prevention of the cardiac remodeling, reduction of the LV end-diastolic pressure, and decrease of the plasma levels of norepinephrine and brain natriuretic peptide ${ }^{153}$. More recently, Zhou and colleagues ${ }^{154}$ reported that the transcutaneous VNS improved the diastolic cardiac dysfunction and attenuated the cardiac inflammation and fibrosis in HF rats with preserved ejection fraction, suggesting a novel non-invasive therapy to treat HF.

In humans, the first study evaluating the effects of the VNS in HF was conducted by Schwartz and colleagues in $2008{ }^{155}$. In this study ${ }^{155}$, eight male patients with severe HF received the electrode around the cervical vagus near to the carotid artery bifurcation, and the follow-up was conducted one, three and six months after started the electrical stimulation therapy. The chronic VNS reduced the NYHA class, improved the quality of life, the 6-minute walk test distance, decreased the pro-inflammatory plasma cytokine, and reduced the LV endsystolic volume in HF patients ${ }^{155}$. De Ferrari and colleagues ${ }^{156}$ also observed some of these benefits in HF subjects treated with chronic VNS, but some side-effects as pain in the implant region, voice alteration and cough were reported. Later on, in 2014 and 2015, two trials involving the VNS in HF patients were published ${ }^{157,158}$. These studies highlighted the safety, feasibility, and tolerability of this approach, and also showed an improvement in the NYHA class and the quality of life of HF subjects ${ }^{157,158}$. However, the increase in cardiac function was observed only in Premchand's study ${ }^{157}$. These divergent responses could be related to the patient demographic condition, the method used to perform the VNS, and the magnitude of the electrical stimulation response ${ }^{159}$. Therefore, the data obtained in HF patients using 
VNS therapy should be interpreted with caution, and randomized controlled trials are still needed to confirm the effectiveness of this technique in humans.

\subsection{Vagus Nerve Stimulation in Systemic Arterial Hypertension}

The VNS was also studied in experimental SAH. In salt-sensitive hypertensive rats, chronic VNS reduced the arterial pressure and the number of arrhythmic events, increased the conduction velocity of impulse propagation, and decreased the action potential duration ${ }^{160}$. Moreover, Annoni and Tolkacheva ${ }^{161}$ evaluated the effects of low-level intermittent VNS in unanesthetized hypertensive rats. Although VNS did not show acute changes in arterial pressure, HR, or heart contractility, it did show an increase in HR and arterial pressure variabilities during the stimulation period, suggesting an improvement in the autonomic control in hypertensive rats treated with VNS ${ }^{161}$. Recently, long-term effects of VNS were investigated in hypertensive rats, especially involving the arterial pressure. For this, Dahl salt-sensitive rats were subjected to high salt diet and implanted with a vagus nerve stimulator to perform the electrical stimulation during eight weeks ${ }^{162}$. The findings showed that chronic VNS during eight weeks improved in $78 \%$ the hypertensive rat's survival, attenuated arterial pressure, increased HR variability and heart weight without increase the fibrosis, and preserved autonomic balance ${ }^{162}$. Altogether, these data highlight the benefits of the VNS therapy in hypertensive rats, encouraging further studies in this issue to better understand the mechanisms behind these effects, contributing to the development of new therapeutic strategies for SAH.

\section{CONCLUSIONS}

In summary, experimental and clinical studies support that both pharmacological and electrical stimulation of the parasympathetic nervous system has the potential to be used as a new therapeutic strategy for the treatment of SAH and HF. The pharmacological approach mediated by cholinergic activation (use of anticholinesterases agents) has the advantage of not being invasive and seems to be quite efficient. In addition, the electrical stimulation has 
also been proven to be a safe and effective strategy, particularly in hypertensive patients who do not respond to the pharmacological therapy, and in advanced HF. Nevertheless, further studies are necessary to explore this potent therapeutic approach deeply, through experimental protocols that start the treatment when the disease is already established and even in clinical trials.

\section{ACKNOWLEDGEMENTS}

This work was supported by The São Paulo Research Foundation (FAPESP) [\#2013/20549-7 and \#2017/05163-6], National Council for Scientific and Technological Development (CNPq) [\#409109/2018-5] and Academic Excellence Program (PROEX) from Coordination for the Improvement of Higher Education Personnel (CAPES) [\#88887.505419/2020-00].

\section{CONFLICT OF INTEREST}

None declared.

\section{REFERENCES}

1 Zhou B, Bentham J, Di Cesare M et al. Worldwide trends in blood pressure from 1975 to 2015 : a pooled analysis of 1479 population-based measurement studies with $19 \cdot 1$ million participants. The Lancet. 2017;389(10064):37-55.

2 Zhou B, Bentham J, Di Cesare M et al. Worldwide trends in blood pressure from 1975 to 2015: a pooled analysis of 1479 population-based measurement studies with $19 \cdot 1$ million participants. The Lancet. 2017;389(10064):37-55.

3 Benjamin EJ, Virani SS, Callaway CW et al. Heart disease and stroke statistics - 2018 update: A report from the American Heart Association. 2018 doi:10.1161/CIR.0000000000000558.

4 Labarthe D, Dunbar S. Global cardiovascular health promotion and disease 
prevention: 2011 and beyond. Am Heart Assoc.

2012.https://www.ahajournals.org/doi/abs/10.1161/CIRCULATIONAHA.111.087726 (accessed 27 Mar2019).

5 Gosse P, Cremer A, Vircoulon M, Coulon P. Prognostic value of the extent of left ventricular hypertrophy and its evolution in the hypertensive patient. journals.Iww.com. 2012.https://journals.Iww.com/jhypertension/Fulltext/2012/12000/Prognostic_value_of _the_extent_of_left_ventricular.23.aspx?casa_token=51582djAkx4AAAAA:7LIpm_ND BVoxfXyEHstP6QPvPFNX4C90IxPYMzhK91h-dUf0jPSKfrscnGinBIafoaYifxE1TlayzdwNDIVC2bKDb4 (accessed 27 Mar2019).

6 Schultz HD, Li YL. Carotid body function in heart failure. Respiratory Physiology \& Neurobiology. 2007;157(1):171-185.

$7 \quad$ Zucker IH, Patel KP, Schultz HD. Neurohumoral Stimulation. Heart Failure Clinics. 2012;8(1):87-99.

8 Mancia G, Grassi G. The Autonomic Nervous System and Hypertension. Circulation Research. 2014;114(11):1804-1814.

9 Grassi G, Mark A, Esler M. The Sympathetic Nervous System Alterations in Human Hypertension. Circulation Research. 2015;116(6):976-990.

10 Georgiopoulou V V, Kalogeropoulos AP, Raggi P, Butler J. Prevention, diagnosis, and treatment of hypertensive heart disease. Cardiology clinics. 2010;28(4):675-91.

11 Grassi G, Seravalle G, Quarti-Trevano F. The 'neuroadrenergic hypothesis' in hypertension: Current evidence. Experimental Physiology. 2010;95(5):581-586.

12 Fisher JP, Fadel PJ. Therapeutic strategies for targeting excessive central sympathetic activation in human hypertension. Experimental Physiology. 2010;95(5):572-580.

13 Grassi G, Seravalle G, Quarti-Trevano F. The 'neuroadrenergic hypothesis' in 
hypertension: current evidence. Experimental Physiology. 2010;95(5):581-586.

14 Thayer, JF; Lane R. The role of vagal function in the risk for cardiovascular disease and mortality. Biological psychology.

2007.https://www.sciencedirect.com/science/article/pii/S0301051106001785 (accessed 25 Mar2019).

15 D Levy MGLRSVWBKKKH. The progression from hypertension to congestive heart failure. Journal of the American Medical Association. 1996;275(20):1557-62.

16 Bocchi EA, Braga FGM, Ferreira SMA et al. The 3rd Brazilian Guidelines for Chronic Heart Failure. Arquivos Brasileiros de Cardiologia. 2009;93(1 SUPPL. 1):1-71.

17 Nadar S. New classification for heart failure with mildly reduced ejection fraction: Greater clarity or more confusion? Sultan Qaboos University Medical Journal. 2017;17(1):e23-e26.

18 Flack JM, Nasser SA. Benefits of once-daily therapies in the treatment of hypertension. Vascular Health and Risk Management. 2011;7(1):777-787.

19 Jankowska EA, Ponikowski P, Piepoli MF, Banasiak W, Anker SD, Poole-Wilson PA. Autonomic imbalance and immune activation in chronic heart failure Pathophysiological links. Cardiovascular Research. 2006;70(3):434-445.

20 Adamo L, Rocha-Resende C, Prabhu SD, Mann DL. Reappraising the role of inflammation in heart failure. Nature Reviews Cardiology. 2020;17(5):269-285.

21 Lara A, Damasceno DD, Pires R et al. Dysautonomia Due to Reduced Cholinergic Neurotransmission Causes Cardiac Remodeling and Heart Failure. Molecular and Cellular Biology. 2010;30(7):1746-1756.

22 Despas F, Lambert E, Vaccaro A et al. Peripheral chemoreflex activation contributes to sympathetic baroreflex impairment in chronic heart failure. Journal of hypertension. 2012;30(4):753-60. 
23 Nautiyal M, Shaltout HA, De Lima DC, Do Nascimento K, Chappell MC, Diz DI. Central angiotensin-(1-7) improves vagal function independent of blood pressure in hypertensive (mRen2)27 rats. Hypertension. 2012;60(5):1257-1265.

24 Kar S, Gao L, Belatti DA, Curry PL, Zucker IH. Central Angiotensin (1-7) Enhances Baroreflex Gain in Conscious Rabbits With Heart Failure. Hypertension. 2011;58(4):627-634.

25 Luna RL. História da Cardiologia: Aspectos Históricos da Hipertensão no Brasil. Sociedade Brasileira de Cardiologia . 1999.http://publicacoes.cardiol.br/caminhos/03/ (accessed 21 Jul2020).

26 Laurent S. Antihypertensive drugs. Pharmacological Research. 2017;124:116-125.

27 Manabe N, Foldes FF, Töröcsik A, Nagashima H, Goldiner PL, Vizi ES. Presynaptic interaction between vagal and sympathetic innervation in the heart: modulation of acetylcholine and noradrenaline release. Journal of the Autonomic Nervous System. 1991;32(3):233-242.

28 Dhein S, van Koppen CJ, Brodde O-E. Muscarinic receptors in the Mammalian Heart. Pharmacological Research. 2001;44(3):161-182.

29 Kozasa $\mathrm{Y}$, Nakashima N, Ito M et al. HCN4 pacemaker channels attenuate the parasympathetic response and stabilize the spontaneous firing of the sinoatrial node. The Journal of Physiology. 2018;596(5):809-825.

30 Wickman KD, Iñiguez-Lluhi JA, Davenport PA et al. Recombinant G-protein $\beta \gamma$ subunits activate the muscarinic-gated atrial potassium channel. Nature. 1994;368(6468):255-257.

31 Taylor P. Anticholinesterase agents. in Hardman JG, Limbird LE, Gilman AG (Editors) Goodman and Gilman's :The Pharmacological Basis of Therapeutics NewYork: . $2011 ;: 175-192$. 
32 Handa T, Katare RG, Kakinuma Y et al. Anti-Alzheimer's Drug, Donepezil, Markedly Improves Long-Term Survival After Chronic Heart Failure in Mice. Journal of Cardiac Failure. 2009;15(9):805-811.

33 Lataro RM, Silva CAA, Fazan R et al. Increase in parasympathetic tone by pyridostigmine prevents ventricular dysfunction during the onset of heart failure. American Journal of Physiology-Regulatory, Integrative and Comparative Physiology. 2013;305(8):R908-R916.

34 Okazaki Y, Zheng C, Li M, Sugimachi M. Effect of the cholinesterase inhibitor donepezil on cardiac remodeling and autonomic balance in rats with heart failure. The Journal of Physiological Sciences. 2010;60(1):67-74.

35 Sabino JPJ, da Silva CAA, de Melo RF, Fazan R, Salgado HC. The treatment with pyridostigmine improves the cardiocirculatory function in rats with chronic heart failure. Autonomic Neuroscience. 2013;173(1-2):58-64.

36 Sugimoto H. Donepezil hydrochloride: A treatment drug for Alzheimer?s disease. The Chemical Record. 2001;1(1):63-73.

37 Kim JO, Lee SJ, Pyo JS. Effect of acetylcholinesterase inhibitors on post-stroke cognitive impairment and vascular dementia: A meta-analysis. PLoS ONE. 2020;15(2):e0227820.

38 Sato K, Urbano R, Yu C et al. The Effect of Donepezil Treatment on Cardiovascular Mortality. Clinical Pharmacology \& Therapeutics. 2010;88(3):335-338.

39 Nóbrega AC, Carvalho AC, Bastos BG. Resting and reflex heart rate responses during cholinergic stimulation with pyridostigmine in humans. Brazilian journal of medical and biological research $=$ Revista brasileira de pesquisas medicas e biologicas. 1996;29(11):1461-5.

40 Pontes PV de, Bastos BG, Romêo $F^{\circ}$ LJM, Mesquita ET, Nóbrega ACL da. Cholinergic stimulation with pyridostigmine, hemodynamic and echocardiographic 
analysis in healthy subjects. Arquivos Brasileiros de Cardiologia. 1999;72(3):297-306.

41 Castro RRT de, Serra SM, Nóbrega ACL da. Reduction of QTc interval dispersion. Potential mechanism of cardiac protection of pyridostigmine bromide. Arquivos Brasileiros de Cardiologia. 2000;75(3):210-213.

42 Castro RRT, Porphirio G, Serra SM, Nóbrega ACL. Cholinergic stimulation with pyridostigmine reduces the QTc interval in coronary artery disease. Brazilian Journal of Medical and Biological Research. 2002;35(6):685-689.

43 Androne AS, Hryniewicz K, Goldsmith R, Arwady A, Katz SD. Acetylcholinesterase inhibition with pyridostigmine improves heart rate recovery after maximal exercise in patients with chronic heart failure. Heart (British Cardiac Society). 2003;89(8):854-8.

44 Castro RRT, Porphirio G, Serra SM, Nóbrega ACL. Cholinergic stimulation with pyridostigmine protects against exercise induced myocardial ischaemia. Heart. 2004;90(10):1119-1123.

45 Castro RRT, Serra SM, Porphirio G, Mendes FSNS, Oliveira LPJ, Nóbrega ACL. Pyridostigmine reduces QTc interval during recovery from maximal exercise in ischemic heart disease. International Journal of Cardiology. 2006;107(1):138-139.

46 Nobrega ACL, Loures DL, Pontes P V., Sant'Anna ID, Mesquita ET. Cholinergic stimulation with pyridostigmine prevents the impairment in ventricular function during mental stress in coronary artery disease patients. International Journal of Cardiology. $2008 ; 125(3): 418-421$.

47 Serra SM, Costa RV, Teixeira De Castro RR, Xavier SS, Lucas Da Nóbrega AC. Cholinergic Stimulation Improves Autonomic and Hemodynamic Profile During Dynamic Exercise in Patients With Heart Failure. Journal of Cardiac Failure. 2009;15(2):124-129.

48 Li M, Zheng C, Kawada T, Inagaki M, Uemura K, Sugimachi M. Intracerebroventricular infusion of donepezil prevents cardiac remodeling and 
improves the prognosis of chronic heart failure rats. Journal of Physiological Sciences. 2020;70(1). doi:10.1186/s12576-020-00739-0.

49 De La Fuente RN, Rodrigues B, Moraes-Silva IC et al. Cholinergic stimulation with pyridostigmine improves autonomic function in infarcted rats. Clinical and Experimental Pharmacology and Physiology. 2013;40(9):610-616.

50 Sabino JPJ, da Silva CAA, Giusti H, Glass ML, Salgado HC, Fazan R. Parasympathetic activation by pyridostigmine on chemoreflex sensitivity in heartfailure rats. Autonomic Neuroscience: Basic and Clinical. 2013;179(1-2):43-48.

51 Fidone SJ, Sato A. Efferent inhibition and antidromic depression of chemoreceptor Afibers from the cat carotid body. Brain Research. 1970;22(2):181-193.

52 Santos-Almeida FM, Girão H, da Silva CAA, Salgado HC, Fazan R. Cholinergic stimulation with pyridostigmine protects myocardial infarcted rats against ischemicinduced arrhythmias and preserves connexin43 protein. American Journal of Physiology-Heart and Circulatory Physiology. 2015;308(2):H101-H107.

53 Ando M, Katare RG, Kakinuma Y et al. Efferent Vagal Nerve Stimulation Protects Heart Against Ischemia-Induced Arrhythmias by Preserving Connexin43 Protein. Circulation. 2005;112(2):164-170.

54 Pfeffer M, Pfeffer J, Fishbein M et al. Tamanho do infarto do miocárdio e função ventricular em ratos. Am Heart Assoc. 1979.https://www.ahajournals.org/doi/abs/10.1161/res.44.4.428047 (accessed 30 Mar2019).

55 Poelzing S, Rosenbaum DS. Altered connexin43 expression produces arrhythmia substrate in heart failure. American Journal of Physiology-Heart and Circulatory Physiology. 2004;287(4):H1762-H1770.

56 Durand MT, Becari C, de Oliveira $\mathrm{M}$ et al. Pyridostigmine restores cardiac autonomic balance after small myocardial infarction in mice. PloS one. 2014;9(8):e104476. 
57 Corrêa WG, Durand MT, Becari C et al. Pyridostigmine prevents haemodynamic alterations but does not affect their nycthemeral oscillations in infarcted mice. Autonomic Neuroscience. 2015;187:50-55.

58 Black PH, Garbutt LD. Stress, inflammation and cardiovascular disease. Journal of Psychosomatic Research. 2002;52(1):1-23.

Libby P, Ridker PM, Maseri A. Inflammation and atherosclerosis. Circulation. 2002;105(9):1135-1143.

60 Siti HN, Kamisah Y, Kamsiah J. The role of oxidative stress, antioxidants and vascular inflammation in cardiovascular disease (a review). Vascular Pharmacology. $2015 ; 71: 40-56$.

61 Bezerra OC, França CM, Rocha JA et al. Cholinergic Stimulation Improves Oxidative Stress and Inflammation in Experimental Myocardial Infarction. Scientific Reports. 2017;7(1). doi:10.1038/s41598-017-14021-8.

62 Feriani DJ, Souza GIH, Carrozzi NM et al. Impact of exercise training associated to pyridostigmine treatment on autonomic function and inflammatory profile after myocardial infarction in rats. International Journal of Cardiology. 2017;227:757-765.

63 Feriani DJ, Coelho-Júnior HJ, de Oliveira JCMF et al. Pyridostigmine improves the effects of resistance exercise training after myocardial infarction in rats. Frontiers in Physiology. 2018;9(FEB). doi:10.3389/fphys.2018.00053.

64 Barboza CA, Fukushima AR, Carrozzi N et al. Cholinergic Stimulation by Pyridostigmine Bromide Before Myocardial Infarction Prevent Cardiac and Autonomic Dysfunction. Scientific Reports. 2019;9(1). doi:10.1038/s41598-019-38841-y.

65 Rocha JA, Ribeiro SP, França CM et al. Increase in cholinergic modulation with pyridostigmine induces anti-inflammatory cell recruitment soon after acute myocardial infarction in rats. American Journal of Physiology - Regulatory Integrative and Comparative Physiology. 2016;310(8):R697-R706. 
66 Blanco JHD, Gastaldi AC, Gardim CB et al. Chronic cholinergic stimulation promotes changes in cardiovascular autonomic control in spontaneously hypertensive rats. Autonomic Neuroscience: Basic and Clinical. 2015;193:97-103.

67 Lataro RM, Silva MAB, Mestriner FL, Cau SBA, Tostes RCA, Salgado HC. Chronic Treatment With Acetylcholinesterase Inhibitors Attenuates Vascular Dysfunction in Spontaneously Hypertensive Rats. American Journal of Hypertension. 2019;32(6):579-587.

68 Lataro RM, Silva CAA, Tefé-Silva C, Prado CM, Salgado HC. Acetylcholinesterase inhibition attenuates the development of hypertension and inflammation in spontaneously hypertensive rats. American Journal of Hypertension. 2015;28(10):1201-1208.

69 Cavalcante GL, Ferreira FN, da Silva MTB et al. Acetylcholinesterase inhibition prevents alterations in cardiovascular autonomic control and gastric motility in LNAME-induced hypertensive rats. Life Sciences. 2020;256. doi:10.1016/j.Ifs.2020.117915.

70 Eglen RM. Muscarinic receptor subtypes in neuronal and non-neuronal cholinergic function. Autonomic and Autacoid Pharmacology. 2006;26(3):219-233.

71 Shi P, Diez-Freire C, Jun JY et al. Brain Microglial Cytokines in Neurogenic Hypertension. Hypertension. 2010;56(2):297-303.

72 Arad M, Roth A, Zelinger J, Zivner Z, Rabinowitz B, Atsmon J. Safety of pyridostigmine in hypertensive patients receiving beta blockers. The American Journal of Cardiology. 1992;69(5):518-522.

73 Sandroni P, Opfer-Gehrking TL, Singer W, Low PA. Pyridostigmine for treatment of neurogenic orthostatic hypertension: A follow-up survey study. Clinical Autonomic Research. 2005;15(1):51-53.

74 WILLIAMS JL. Human Response to Pyridostigmine Bromide. MACAULAY-BROWN 
INC FAIRBORN OH, 1984.

75 Medicine I of. Gulf War and Health. National Academies Press, 2000 doi:10.17226/9953.

76 Carey RM, Calhoun DA, Bakris GL et al. Resistant hypertension: Detection, evaluation, and management a scientific statement from the American Heart Association. Hypertension. 2018;72(5):E53-E90.

77 Noubiap JJ, Nansseu JR, Nyaga UF, Sime PS, Francis I, Bigna JJ. Global prevalence of resistant hypertension: A meta-analysis of data from 3.2 million patients. Heart. 2019;105(2):98-105.

78 Sim JJ, Bhandari SK, Shi J et al. Comparative risk of renal, cardiovascular, and mortality outcomes in controlled, uncontrolled resistant, and nonresistant hypertension. Kidney International. 2015;88(3):622-632.

79 WARNER HR. The frequency-dependent nature of blood pressure regulation by the carotid sinus studied with an electric analog. Circulation research. 1958;6(1):35-40.

80 Griffith L, Circulation SS-, 1963 undefined. ELECTRICAL STIMULATION OF CAROTID SINUS NERVE IN NORMOTENSIVE AND RENAL HYPERTENSIVE DOGS. Circulution. 1963;:28-730.

81 Schwartz SI, Griffith LSC, Neistadt A, Hagfors N. Chronic carotid sinus nerve stimulation in the treatment of essential hypertension. The American Journal of Surgery. 1967;114(1):5-15.

82 Tuckman J., Reich T., Lyon AF., Goodman B., Mendlowitz M., and Jacobson IH. Electrical stimulation of the sinus nerves in hypertensive patients: clinical evaluation and physiological studies. Hypertension. 1967;:16-23.

83 Braunwald E, Epstein SE, Glick G, Wechsler AS, Braunwald NS. Relief of angina pectoris by electrical stimulation of the carotid-sinus nerves. The New England journal 
of medicine. 1967;277(24):1278-1283.

84 Bilgutay AM, Wingrove RC, Simmons RL, Dahlstrom IJ, Lillehei CW. A new concept in the treatment of hypertension utilizing an implantable electronic device:“Baropacer”. Trans Am Soc Artif Intern Organs. 1964;10:387-395.

85 Bilgutay AM, Lillehei CW. Surgical treatment of hypertension with reference to baropacing. The American Journal of Cardiology. 1966;17(5):663-667.

86 Parsonnet V, Rothfeld EL, Raman K V., Myers GH. Electrical stimulation of the carotid sinus nerve. The Surgical clinics of North America. 1969;49(3):589-596.

87 Peters TK, Koralewski HE, Zerbst E. The principle of electrical carotid sinus nerve stimulation: A nerve pacemaker system for angina pectoris and hypertension therapy. Annals of Biomedical Engineering. 1980;8(4-6):445-458.

88 Zerbst E. Biomedical steps in the development of closed-loop nerve pacemaker systems in chronic carotid sinus nerve stimulation in hypertension and angina. Artif Organs (suppl). 1981;5:451-458.

89 Ohta H, Talman WT. Alteration of baroreceptor and chemoreceptor reflexes in spontaneously hypertensive rats. Clinical and Experimental Pharmacology and Physiology. 1995;22(s1):S60-S61.

90 Takeda K, Nakamura Y, Oguro M et al. Central Attenuation of Baroreflex Precedes the Development of Hypertension in DOCA - SALT-Treated Rats. American Journal of Hypertension. 1988;1(3_Pt_3):23S-25S.

91 Salgado HC, Barale ÁR, Castania JA, Machado BH, Chapleau MW, Fazan R. Baroreflex responses to electrical stimulation of aortic depressor nerve in conscious SHR. American Journal of Physiology-Heart and Circulatory Physiology. 2007;292(1):H593-H600.

92 Durand M de T, Castania JA, Fazan R, Salgado MCO, Salgado HC. Hemodynamic 
responses to aortic depressor nerve stimulation in conscious L-NAME-induced hypertensive rats. American journal of physiology Regulatory, integrative and comparative physiology. 2011;300(2):R418-27.

93 Durand MT, Mota AL, Barale AR, Castania JA, Fazan R, Salgado HC. Time course of the hemodynamic responses to aortic depressor nerve stimulation in conscious spontaneously hypertensive rats. Brazilian Journal of Medical and Biological Research. 2012;45(5):444-449.

94 Hildebrandt DA, Irwin ED, Lohmeier TE. Prolonged Baroreflex Activation Abolishes Salt-Induced Hypertension After Reductions in Kidney Mass. Hypertension (Dallas, Tex : 1979). 2016;68(6):1400-1406.

95 Clemmer JS, Pruett WA, Hester RL, lliescu R, Lohmeier TE. Role of the heart in blood pressure lowering during chronic baroreflex activation: insight from an in silico analysis. American Journal of Physiology-Heart and Circulatory Physiology. 2018;315(5):H1368-H1382.

96 Hildebrandt DA, Irwin ED, Cates AW, Lohmeier TE. Regulation of renin secretion and arterial pressure during prolonged baroreflex activation: influence of salt intake. Hypertension (Dallas, Tex: 1979). 2014;64(3):604-9.

97 Iliescu R, Tudorancea I, Irwin ED, Lohmeier TE. Chronic baroreflex activation restores spontaneous baroreflex control and variability of heart rate in obesity-induced hypertension. American Journal of Physiology-Heart and Circulatory Physiology. 2013;305(7):H1080-H1088.

98 Iliescu R, Irwin ED, Georgakopoulos D, Lohmeier TE. Renal responses to chronic suppression of central sympathetic outflow. Hypertension (Dallas, Tex : 1979). 2012;60(3):749-56.

99 Lohmeier TE, Iliescu R, Dwyer TM, Irwin ED, Cates AW, Rossing MA. Sustained suppression of sympathetic activity and arterial pressure during chronic activation of 
the carotid baroreflex. American Journal of Physiology-Heart and Circulatory Physiology. 2010;299(2):H402-H409.

100 Lohmeier TE, Hildebrandt DA, Dwyer TM et al. Prolonged activation of the baroreflex decreases arterial pressure even during chronic adrenergic blockade. Hypertension (Dallas, Tex : 1979). 2009;53(5):833-8.

101 Lohmeier TE, Hildebrandt DA, Dwyer TM et al. Renal denervation does not abolish sustained baroreflex-mediated reductions in arterial pressure. Hypertension (Dallas, Tex: 1979). 2007;49(2):373-9.

102 Lohmeier TE, Irwin ED, Rossing MA, Serdar DJ, Kieval RS. Prolonged Activation of the Baroreflex Produces Sustained Hypotension. In: Hypertension. Lippincott Williams \& Wilkins $\quad, 2004, \mathrm{pp}$ 306-311.

103 Lohmeier TE, Dwyer TM, Hildebrandt DA et al. Influence of prolonged baroreflex activation on arterial pressure in angiotensin hypertension. Hypertension (Dallas, Tex: 1979). 2005;46(5):1194-200.

104 Lohmeier TE, Hall JE. Device-Based Neuromodulation for Resistant Hypertension Therapy: Too Early for Prime Time? Circulation Research. 2019;124(7):1071-1093.

105 Tordoir JHM, Scheffers I, Schmidli J et al. An Implantable Carotid Sinus Baroreflex Activating System: Surgical Technique and Short-Term Outcome from a Multi-Center Feasibility Trial for the Treatment of Resistant Hypertension. European Journal of Vascular and Endovascular Surgery. 2007;33(4):414-421.

106 Schmidli J, Savolainen H, Eckstein F et al. Acute device-based blood pressure reduction: electrical activation of the carotid baroreflex in patients undergoing elective carotid surgery. Vascular. 2007;15(2):63-9.

107 Mohaupt MG, Schmidli J, Luft FC. Management of uncontrollable hypertension with a carotid sinus stimulation device. Hypertension. 2007;50(5):825-828. 
108 Scheffers IJM, Kroon AA, Schmidli J et al. Novel baroreflex activation therapy in resistant hypertension: Results of a European multi-center feasibility study. Journal of the American College of Cardiology. 2010;56(15):1254-1258.

109 Alnima T, De Leeuw PW, Kroon AA. Baroreflex Activation Therapy for the Treatment of Drug-Resistant Hypertension: New Developments. Cardiology Research and Practice. 2012;2012. doi:10.1155/2012/587194.

110 Heusser K, Tank J, Engeli S et al. Carotid Baroreceptor Stimulation, Sympathetic Activity, Baroreflex Function, and Blood Pressure in Hypertensive Patients. Hypertension. 2010;55(3):619-626.

111 Wustmann K, Kucera JP, Scheffers I et al. Effects of chronic baroreceptor stimulation on the autonomic cardiovascular regulation in patients with drug-resistant arterial hypertension. Hypertension (Dallas, Tex: 1979). 2009;54(3):530-6.

112 Bisognano JD, Bakris G, Nadim MK et al. Baroreflex Activation Therapy Lowers Blood Pressure in Patients With Resistant Hypertension. Journal of the American College of Cardiology. 2011;58(7):765-773.

113 Hoppe UC, Brandt MC, Wachter R et al. Minimally invasive system for baroreflex activation therapy chronically lowers blood pressure with pacemaker-like safety profile: Results from the Barostim neo trial. Journal of the American Society of Hypertension. 2012;6(4):270-276.

114 Heusser K, Thöne A, Lipp A et al. Efficacy of Electrical Baroreflex Activation Is Independent of Peripheral Chemoreceptor Modulation. Hypertension (Dallas, Tex: 1979). 2020;75(1):257-264.

115 Wallbach M, Born E, Kämpfer D et al. Long-term effects of baroreflex activation therapy: 2-year follow-up data of the BAT Neo system. Clinical Research in Cardiology. 2020;109(4):513-522.

116 Wallbach M, Böhning E, Lehnig L-Y et al. Safety profile of baroreflex activation 
therapy (NEO) in patients with resistant hypertension. Journal of Hypertension. 2018;36(8):1762-1769.

117 Gordin D, Fadl Elmula FEM, Andersson B et al. The effects of baroreflex activation therapy on blood pressure and sympathetic function in patients with refractory hypertension: the rationale and design of the Nordic BAT study ${ }^{*}$. Blood Pressure. 2017;26(5):294-302.

118 Wachter R, Halbach M, Bakris GL et al. An exploratory propensity score matched comparison of second-generation and first-generation baroreflex activation therapy systems. Journal of the American Society of Hypertension. 2017;11(2):81-91.

119 Lauder L, Azizi M, Kirtane AJ, Böhm M, Mahfoud F. Device-based therapies for arterial hypertension. Nature Reviews Cardiology. 2020;:1-15.

120 Gierthmuehlen M, Plachta DTT, Zentner J. Implant-Mediated Therapy of Arterial Hypertension. Current Hypertension Reports. 2020;22(2):1-9.

121 Seravalle G, Dell'Oro R, Grassi G. Baroreflex activation therapy systems: current status and future prospects. Expert Review of Medical Devices. 2019. doi:10.1080/17434440.2019.1697230.

122 Bolignano D, Coppolino G. Baroreflex stimulation for treating resistant hypertension: Ready for the prime-time? Reviews in Cardiovascular Medicine. 2018;19(3):89-95.

123 Jordan J. Device-Based Approaches for the Treatment of Arterial Hypertension. Current Hypertension Reports. 2017;19(7):1-8.

124 Gassler JP, Bisognano JD. Baroreflex activation therapy in hypertension. Journal of Human Hypertension. 2014;28(8):469-474.

125 Keir DA, Duffin J, Millar PJ, Floras JS. Simultaneous assessment of central and peripheral chemoreflex regulation of muscle sympathetic nerve activity and ventilation in healthy young men. Journal of Physiology. 2019;597(13):3281-3296. 
126 White FN, Grollman A. Autoimmune factors associated with infarction of the kidney. Nephron. 1964;204:93-102.

127 Okuda T GA. Passive transfer of autoimmune induced hypertension in the rat by Iymph node cells Title. Tex Rep Biol Med. 1967;25(2):267-264.

128 Singh JP, Kandala J, John Camm A. Non-pharmacological modulation of the autonomic tone to treat heart failure. European Heart Journal. 2014;35(2):77-85.

129 Solak Y, Afsar B, Vaziri ND et al. Hypertension as an autoimmune and inflammatory disease. Hypertension Research. 2016;39(8):567-573.

130 Rodriguez-Iturbe B, Pons H, Johnson RJ. Role of the immune system in hypertension. Physiological Reviews. 2017;97(3):1127-1164.

131 Miguel C De, Rudemiller N, Abais J. Inflamação e hipertensão: novos entendimentos e potenciais alvos terapêuticos. Hipertensão atual. 2015.https://link.springer.com/content/pdf/10.1007/s11906-014-0507-z.pdf (accessed 21 Jul2020).

132 Khor S, Cai D. Hypothalamic and inflammatory basis of hypertension. Clinical Science. 2017;131(3):211-223.

133 Herrera J, Ferrebuz A, MacGregor EG, Rodriguez-Iturbe B. Mycophenolate mofetil treatment improves hypertension in patients with psoriasis and rheumatoid arthritis. In: Journal of the American Society of Nephrology. J Am Soc Nephrol, 2006 doi:10.1681/ASN.2006080918.

134 Case AJ, Zimmerman MC. Sympathetic-mediated activation versus suppression of the immune system: Consequences for hypertension. Journal of Physiology. 2016;594(3):527-536.

135 Bassi GS, Brognara F, Castania JA et al. Baroreflex activation in conscious rats modulates the joint inflammatory response via sympathetic function. Brain, Behavior, 
and Immunity. 2015;49:140-147.

136 Brognara F, Castania JA, Dias DPM et al. Baroreflex stimulation attenuates central but not peripheral inflammation in conscious endotoxemic rats. Brain Research. 2018;1682:54-60.

137 Zucker IH, Hackley JF, Cornish KG et al. Chronic baroreceptor activation enhances survival in dogs with pacing-induced heart failure. Hypertension (Dallas, Tex: 1979). 2007;50(5):904-10.

138 Sabbah HN, Gupta RC, Imai M et al. Chronic electrical stimulation of the carotid sinus baroreflex improves left ventricular function and promotes reversal of ventricular remodeling in dogs with advanced heart failure. Circulation: Heart Failure. 2011;4(1):65-70.

139 Sabbah HN. Baroreflex activation for the treatment of heart failure. Current Cardiology Reports. 2012;14(3):326-333.

140 Pinto TOCT, Lataro RM, Castania JA et al. Electrical stimulation of the aortic depressor nerve in conscious rats overcomes the attenuation of the baroreflex in chronic heart failure. American Journal of Physiology-Regulatory, Integrative and Comparative Physiology. 2016;310(7):R612-R618.

141 Gronda E, Seravalle G, Brambilla G et al. Chronic baroreflex activation effects on sympathetic nerve traffic, baroreflex function, and cardiac haemodynamics in heart failure: A proof-of-concept study. European Journal of Heart Failure. 2014;16(9):977983.

142 Abraham WT, Zile MR, Weaver FA et al. Baroreflex Activation Therapy for the Treatment of Heart Failure With a ReducedEjection Fraction. JACC: Heart Failure. 2015;3(6):487-496.

143 Gronda E, Seravalle G, Trevano FQ et al. Long-term chronic baroreflex activation. Journal of Hypertension. 2015;33(8):1704-1708. 
144 U.S. Food and Drug Administration. Summary of Safety and Effectivness (SSED)Template SUMMARY OF SAFETY AND EFFECTIVENESS DATA (SSED). 2019https://www.accessdata.fda.gov/cdrh_docs/pdf18/P180050b.pdf (accessed 2 Jun2020).

145 Schmidt R, Rodrigues CG, Schmidt KH, Irigoyen MCC. Safety and efficacy of baroreflex activation therapy for heart failure with reduced ejection fraction: a rapid systematic review. ESC Heart Failure. 2020;7(1):3-14.

146 Mann JA, Abraham WT. Cardiac Contractility Modulation and Baroreflex Activation Therapy in Heart Failure Patients. Current Heart Failure Reports. 2019;16(1):38-46.

147 De Ferrari GM. Vagal stimulation in heart failure. Journal of Cardiovascular Translational Research. 2014;7(3):310-320.

148 Vanoli E, De Ferrari GM, Stramba-Badiale M, Hull SS, Foreman RD, Schwartz PJ. Vagal Stimulation and Prevention of Sudden Death in Conscious Dogs With a Healed Myocardial Infarction. 1991http://ahajournals.org (accessed 21 Jul2020).

149 Sabbah HN RSMSGRIIIMCUB-DTB-EO. Long-term therapy with neuroselective electric Vagus nerve stimulation improves LV function and attenuates global LV remodelling in dogs with chronic heart failure. European Journal of Heart Failure Supplements. 2005;4(1):166-167.

150 Rastogi S, Mishra S, Ilsar I, Zaretsky A, Sabbah H. Chronic therapy with electric Vagus nerve stimulation normalizes mRNA and protein expression of connexin-40,-43 and-45 in left ventricular myocardium of dogs with. 2007.https://www.ahajournals.org/doi/abs/10.1161/circ.116.suppl_16.II_218-a (accessed 21 Jul2020).

151 Sabbah HN, Ilsar I, Zaretsky A, Rastogi S, Wang M, Gupta RC. Vagus nerve stimulation in experimental heart failure. Heart Failure Reviews. 2011;16(2):171-178.

152 Zhang Y, Popović ZB, Bibevski S et al. Chronic vagus nerve stimulation improves 
autonomic control and attenuates systemic inflammation and heart failure progression in a canine high-rate pacing model. Circulation: Heart Failure. 2009;2(6):692-699.

153 Li M, Zheng C, Sato T, Kawada T, Sugimachi M, Sunagawa K. Vagal Nerve Stimulation Markedly Improves Long-Term Survival after Chronic Heart Failure in Rats. Circulation. 2004;109(1):120-124.

154 Zhou L, Filiberti A, Humphrey MB et al. Low-level transcutaneous vagus nerve stimulation attenuates cardiac remodelling in a rat model of heart failure with preserved ejection fraction. Experimental Physiology. 2019;104(1):28-38.

155 Schwartz PJ, De Ferrari GM, Sanzo A et al. Long term vagal stimulation in patients with advanced heart failure. First experience in man. European Journal of Heart Failure. 2008;10(9):884-891.

156 Ferrari G De, Sanzo A, Borggrefe M, Wolpert C. Chronic vagus nerve stimulation in patients with chronic heart failure is feasible and appears beneficial. Circulation. 2008;118:721-724.

157 Premchand RK, Sharma K, Mittal S et al. Autonomic regulation therapy via left or right cervical vagus nerve stimulation in patients with chronic heart failure: Results of the ANTHEM-HF trial. Journal of Cardiac Failure. 2014;20(11):808-816.

158 Zannad F, Ferrari G, Tuinenburg A. Chronic vagal stimulation for the treatment of low ejection fraction heart failure: results of the NEural Cardiac TherApy foR Heart Failure (NECTAR-HF) randomized. European heart. 2015;36:425-433.

159 Anand IS, Konstam MA, Klein HU et al. Comparison of symptomatic and functional responses to vagus nerve stimulation in ANTHEM-HF, INOVATE-HF, and NECTARHF. ESC Heart Failure. 2020;7(1):76-84.

160 Annoni EM, Xie X, Lee SW et al. Intermittent electrical stimulation of the right cervical vagus nerve in salt-sensitive hypertensive rats: effects on blood pressure, arrhythmias, and ventricular electrophysiology. Physiological Reports. 
2015;3(8):e12476.

161 Annoni EM, Tolkacheva EG. Acute cardiovascular and hemodynamic effects of vagus nerve stimulation in conscious hypertensive rats. In: Proceedings of the Annual International Conference of the IEEE Engineering in Medicine and Biology Society, EMBS. Institute of Electrical and Electronics Engineers Inc., 2018, pp 3685-3688.

162 Annoni EM, Van Helden D, Guo Y et al. Chronic low-level vagus nerve stimulation improves long-term survival in salt-sensitive hypertensive rats. Frontiers in Physiology. 2019;10(JAN). doi:10.3389/fphys.2019.00025. 